University of Rhode Island

DigitalCommons@URI

Open Access Master's Theses

1986

\title{
A MASTER PLAN UPDATE FOR MARSHFIELD, MASSACHUSETT'S 1986
}

Gary G. Ayrassian

University of Rhode Island

Peter D. Brown

University of Rhode Island

Gregory J. Guimond

University of Rhode Island

Pauline K. Zvonkovic

University of Rhode Island

Follow this and additional works at: https://digitalcommons.uri.edu/theses

\section{Recommended Citation}

Ayrassian, Gary G.; Brown, Peter D.; Guimond, Gregory J.; and Zvonkovic, Pauline K., "A MASTER PLAN UPDATE FOR MARSHFIELD, MASSACHUSETT'S 1986" (1986). Open Access Master's Theses. Paper 505. https://digitalcommons.uri.edu/theses/505

This Thesis is brought to you for free and open access by DigitalCommons@URI. It has been accepted for inclusion in Open Access Master's Theses by an authorized administrator of DigitalCommons@URI. For more information, please contact digitalcommons-group@uri.edu. 


\title{
A MASTER PLAN UPDATE FOR MARSHFIELD, MASSACHUSETTS 1986
}

\author{
BY \\ Gary G. Ayrassian \\ Peter D. Brown \\ Gregory J. Guimond \\ Pauline K. Zvonkovic
}

Submitted as a Master's Research Project in

Partial Fulfillment of the Requirements for the Degree and Master of Community Planning

UNIVERSITY OF RHODE ISLAND

1986 


\section{TABLE OF CONTENTS}

ACKNOWLEDGEMENTS

PAGE

LIST OF TABLES

i i i

LIST OF DIAGRAMS

$v$

LIST OF MAPS

vi

INTRODUCTI ON

CHAPTERS

1) NATURAL FEATURES

2) HISTORICAL BACKGROUND

3) LAND USE / ZONING

25

4) POPULAT I ON

5) HOUSING

6) TRANSPORTATION

78

7) ECONOMIC ANALYSIS

8) FINANCIAL ANALYSIS

121

9) PUBLIC FACILITIES / SERUICES

10) CONSERUATION / RECREATION

161

11) POLICIES \& RECOMMENDATIONS

APPENDICES

BI BLI OGRAPHY 


\title{
ACKNOWLEDGEMENTS
}

\author{
We acknowledge with thanks the assistance and cooperation \\ extended to us by various Marshfield Town officials and citizen \\ readers. We would also like to thank Paul Mission for his \\ contribution towards this project. \\ Finally, we would particularly like to thank the Marshfield \\ Planning Board for their cooperation.
}

Planning Board Members

William C. Finn, Chairman

Jean Horan, Secretary

Mathew Currie, Vice-Cha1rman

Leonard Ruszczyk, Treasurer

Dantel Arnold

Professional Readers

Calvin Cook, Town Planner Needham, Ma. Jean Christensen, Planner MAPC 


\section{LIST OF TABLES}

Table \#

Page

3.1 Land Use Study 27

3.2 Land Use In Marshfield, 1960-1985 30

3.3 Vacant Land Use By Zone, August, 1985

4.1 Population Increase 1950-1980 40

4.2 Population Distribution for Marshfield, 1950-1980 42

4.3 Population Projections 45

4.4 Elderly Population Projection by Sex 46

5.1 Housing Units (1ncluding Vacant and Seasonal Units) 50

5.2 Number of Year-Round Housing Units by Type of Structure

5.3 Subsidized Housing, Current and Proposed 55

5.4 Distribution of Permitted New Construction in Marshfield, 1980-1985

5.5 Distribution of Permitted Residential Additions and Alterations in Marshfield, 1980-1985

5.6 Median Sale Price of a Residential Unit by Tract, 1983-1984

5.7 Low and Moderate Income Households, 198064

5.8 Housing Demand in Marshfield by Age Group, 1986-2000 66

6.1 Daily Traffic Volumes 81

7.1 Employment by Major Sectors, $1980 \quad 92$

7.2 Trends in Employment by Major Sectors, 1970-1980 94

7.3 Number of Marshfield Residents Employed within
and outside the Town, 1980

7.4 Total Annual Payroll by Town, 1980-1983 97

7.5 Total Average Annual Payroll by Town, 1980-1983 98

7.6 Number of Persons Employed \& Unemployed In Marshfield, 1980 
7.7 Bas1c and Non-Basic Economic Sectors in Marshfield. 1982

7.8 Employment Projection, Scenario I 107

7.9 Employment Projection, Scenario II 110

7.10 Employment Projection, Scenario III 112

7.11 Comparison of Employment Projections 114

7.12 Relative Performance of Major Employment Sectors 118

8.1 Marshfield Tax Rates and Levies, 1960-1984 124

8.2 Town Receipts 126

$\begin{array}{lll}8.3 & \text { Town Expend1tures } & 128\end{array}$

9.1 Inventory of Existing Public School Facilities, 136

9.2 Student Population Profections 141

9.3 Marshfleld Well Capacity 153

9.4 Projected Water Consumption in Marshfield,
1990,2000 
LIST OF DIAGRAMS

Diagram \#

1.1 Hydrologic Circle

3.1 Requirements of Zoning

4.1 Marshfield Population Growth, 1920-1980

4.2 Marshifield Median Age, 1950-1980

5.1 Building Permits Issued, Single \& MultiFamily Units, 1970-1985

7.1 Trend Line Comparison of Employment Projections

8.1 Town Receipts and Expenditures, 1978-1984

10.1 Conservation Land Accumulated, 1961-1984

10.2 Land Use Changes, 1951,1971, and 1985
Page

9

37

41

41

53

115

130

170

171

v 


\section{LIST OF MAPS}

Map \#

Page

1.1 Location

1.2 Topography

1.3 General Soll Iimitations

1.4 Town Map

1.5 Groundwater Aquifer

1.6 Flood Hazard Areas

2.1 Travel Time from Marshfield

3.1 General Land Use, 1980

3.2 Zoning

5.1 Town of Marshfield by Tract

5.2 Location of Multi-Family Dwellings, 198560

5.3 Percentage of Low/Moderate Income Households, 198065

6.1 Public Transportation 83

$\begin{array}{lll}6.2 & \text { Road Improvements } & 87\end{array}$

6.3 Road Transportation Improvements 88

7.1 Surrounding Communities 89

7.2 Boston's Economic Influence on Marshfield 102

9.1 School Sites $\quad 135$

$\begin{array}{lll}9.2 & \text { Fire Stations } & 147\end{array}$

$\begin{array}{lll}9.3 & \text { Sewage Disposal } & 157\end{array}$

10.1 Conservation Acquisition Goal Areas 165

10.2 Isolated Lands Conservation Acquisition Goal Areas 167

10.3 Conservation, Quasi-Public and Town Owned Land, 1985169 
INTRODUCTION

This Master Plan $1 \mathrm{~s}$ an update of planning related information for the Marshfield Planning Board. The first stage of any planning study is the gathering of background information and data on which proposals are based. Throughout the past year, information was collected and anaylzed concerning the following: population, employment, natural features, land use, vacant land, schools, recreation, water and sewer systems, traffic circulation, administrative services and the town's fiscal status. This information was collected in order to assist the Town and its citizens in their decisions regarding the future growth of Marshfield.

The purpose of this Master Plan is to establish an updated guide for the continuing development of Marshfield. Thus this document is for everyone in Marshfield who is concerned with their community and its future. Marshfield is again at a crossroads, as the Town is facing difficult decisions concerning its future character. A debate has been going on over the last few years between those who advocate preservation of the Town's rural character and those who favor growth to strengthen the Town's economic base.

In addition the need to create more housing opportunities has become apparent to the Town's officials. Marshfield has a housing affordability problem and under the present federal administration, economic factors will dictate that the Town has to work on solutions with little help. One of the methods which 
Marshfield itself can employ at little cost is changing portions of the Town's Zoning By-Laws. However, this is only a single facet to the problem, which requires a multi-faceted approach.

This document promotes a balanced growth approach to the Town's future. Such an approach would provide the Town with the means to accommodate growth and development, while providing for the preservation of the Town's natural environment.

The benefits of such an approach are many; it will provide the Town's officials a rational framework on which to base their decisions regarding development as opposed to a case by case response to each development proposal. Developers would be given a clear indication of public policy on how the development should proceed, enabling the developer to save time and money. Thus local growth can occur in a rational and orderly fashion thereby minimizing the fiscal impacts sometimes associated with poorly planned developments. The Town and its various departments, boards and citizens groups must work together and forge a common approach to Marshfield's future development. It is hoped that this plan is used as a guide in that effort.

Essentially the Master Plan consists of the following sections; Natural Features, History, Land Use/Zoning, Demographics, Housing, Transportation, Economic Analysis, Financial Analysis, Public Services, Recreation, Conservation and a Public Policy Outline. 


\section{CHAPTER 1}

NATURAL FEATURES 


\section{NATURAL FEATURES}

\subsection{Overview}

One of the major factors in determining Marshfield's future development is the land itself. An example of this is its coastal wetlands or excessive slopes; these features limit the development capability of the town. The composition of the soil is another influence on development. Solls which are porous and possess good drainage are usually the first to be developed. Another important factor, which to date has not been fully realized, is the groundwater aquifer. Marshfield's drinking water supply depends on protection of the high pield and recharge areas. Development of commercial establishments, office buildings, residential apartments and condominiums have already occurred on an area above a potential high yield aquifer between Union and Furnace Street. With the lack of sewer Iines in this area, all storm runoff and human wastes are placed into this potential source of drinking water. Therefore it is strongly suggested that the town's natural environment, especially the ground water aquifer, should be given primary consideration in future land development decisions.

\subsection{Location}

Marshfield is located on the coastilne of Massachusetts Bay, 30 miles south of Boston and 12 miles north of Plymouth. The Town is in the northeast portion of Plymouth County. It is bounded by the Atlantic Ocean on the east, by the Town of Duxbury on the south, by the Towns of Pembroke and Norwell to the west and by

scituate on the north. Marshfield is comprised of approximately 29 square miles of which 22 percent is wetlands. (See MAP I.I) 

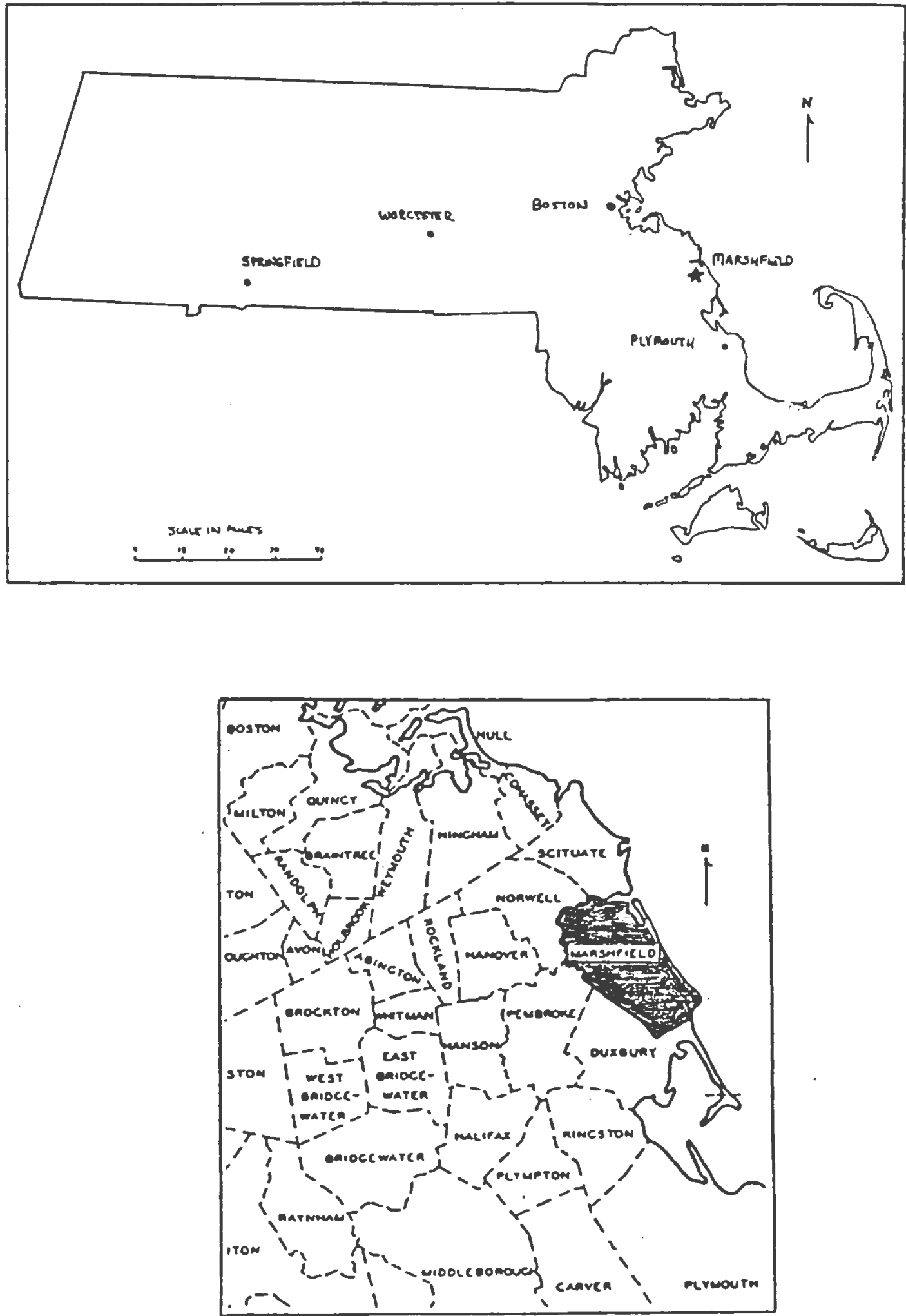

SOURCE: Department of Community Affairs

The Commonwealth of Massachusetts 


\subsection{Topography}

Topography is simply the shape of the land. Topographic features such as hills, valleys, ridges and plains influence development patterns. Marshfield does not have any severe topographical features which would create barriers to travel. The marsh itself serves as a recreational and scenic buffer between land uses. The topographic map is the means by which the features of the land can be 1llustrated. Topographic contour lines are superimposed over the Town base map to create the topographic map. Each contour line repesents a specific elevation or height. The topographic map used in this report was obtained from the 1960 Master Plan and uses a fifty foot contour interval. (See MAP 1.2)

Marshfield's topographic features were formed by glaciers during the past ice age. These glaciers scoured the surface of the town. Later as the ice receded it deposited till in a haphazard fashion. These deposits altered the pre-glacier features and are responsible for Marshfield's current topography, soll compositions and the creation of the present aquifer.

The northeastern section of the Town contains a number of small hills such as Holly, Telegraph and Ferry Hills. Carolina Hill, which is located in the north central area, is the highest in the Town. The Furnace Brook Valley separates Carolina Hill from the Marshfield Hills which are located in the northwestern section. South of Route 139 and separated by the South River are Mount skirgo and Pudding Hill. In the southwestern section of Marshfield there are two smaller heights, Gotham Hill and Black Mount. 


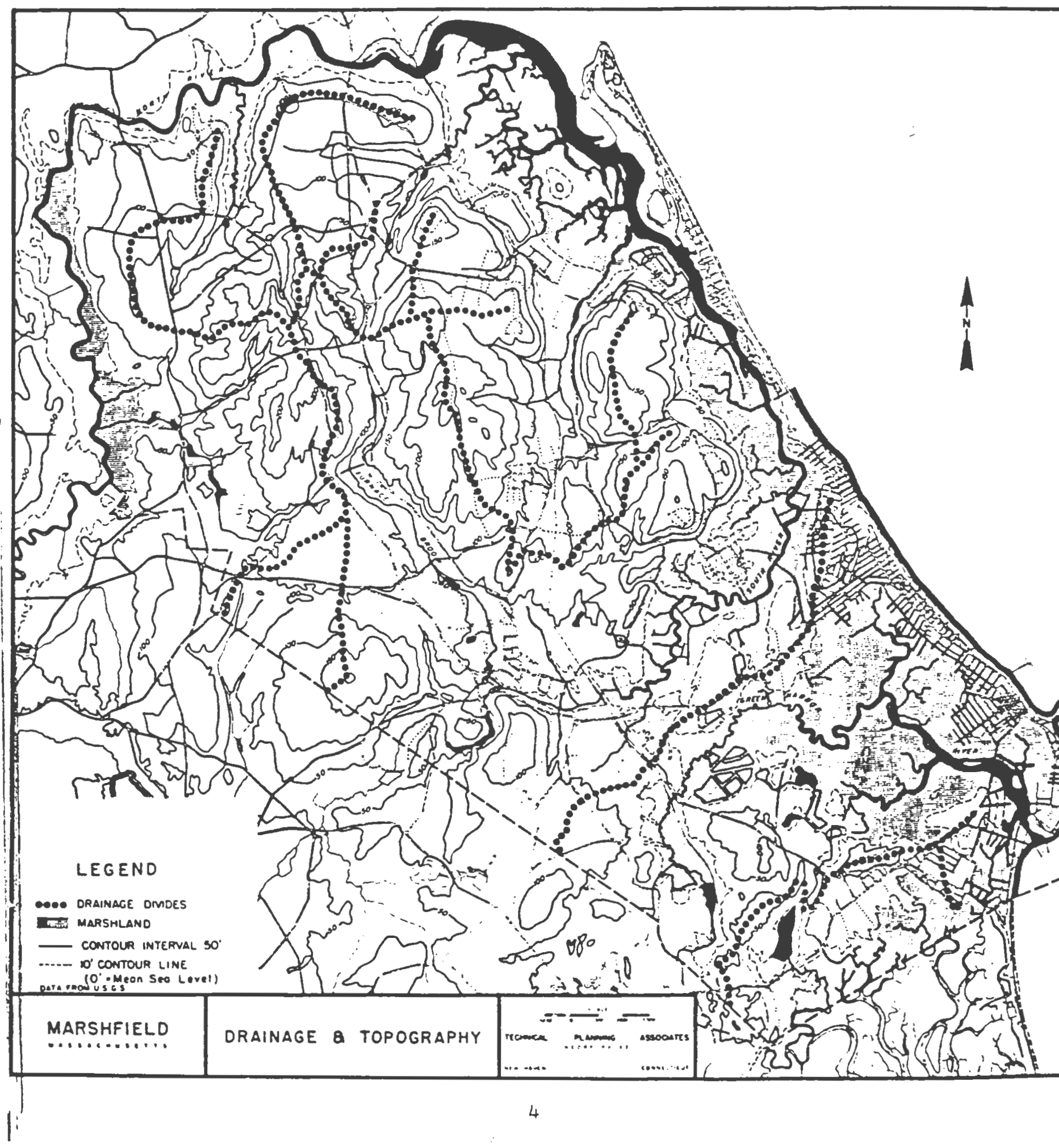


To the north of the Mount Skirgo border and to the east by Furnace Brook is a large flat plain. This large plain lies on top of a potential high pield aquifer. Therefore, while the topography lends itself to development, the aquifer below requires special considerations.

Marshfield also contains a unique man-made feature in the Green Harbor River Basin. The construction of a tidal gate and dike during the early 1870 s created a Polder. The result was a two square mile area of impounded fresh water wetlands.

1.4 Slope

Slope (in the simplest of terms) is the steepness of the land. The slope is an important site factor when determining the physical and economic feasibility of future development. In general, the more severe the slope, the difficulty and cost of development becomes greater.

The topographic map has been used to calculate and show the slope of the land. The closer the topographic contour lines are, the steeper the slope. Conversely, the greater the distance between the lines, the gentler the slope.

Slope is measured as the quotient of the change in vertical distance divided by the change in horizontal distance. The result of this division is known as the gradient. Thus a gradient of ten percent is one which rises one vertical foot for every ten horizontal feet.

For the purposes of this Master Plan the slope will be shown in three major classifications. 
0-7\% Gentle Slope: well suited for development. However, areas which are flat may be subject to ponding or pooling.

8-14\% Moderate slope: Residential development is possible but will require proper siting and construction controls.

$15 \%$ + Steep slope: Development is not recommended due to erosion and stability problems.

In Marshfield there are only a few small areas of steep slope in the northern end of the Town. Housing market conditions of the 1980s have allowed building on property previously considered to be steep. The results have often produced housing with spectacular views, however some have caused erosion problems during construction.

\subsection{Soils}

The inventory and analysis of solls is an extremely important component in the development decision process. Soll composition strongly influences the location of different land uses and dengity. Soll classifications are based on characteristics such as type, thickness and arrangement of layers. Soll containing similar characteristics are called a series. These series are named after the place where the type was first found and studied. Knowledge of the distinctive properties of different soil series allows for the predicting of its suitability on a general scale. An example is the Gloucester soil types which are moderately well-drained, and contain sandy loam solls which are usually 
accompanied by a high water table. A high water table could indicate that this soll type may be periodically saturated with water. This conditon would pose a problem for an on-site septic system (See APPENDIX A).

This Master Plan makes use of the 1969 Soil Survey prepared by the U.S. Soil Conservation Service and the two previous Master Plans for Marshfield. A generalized soil suitability map for the town from the 1969 survey is used as the base for this section. When evaluating developments for specific sites it is recommended that the developer should provide data from an on-site inspection. The general soils map provided (See MAP 1.3) breaks the information into three classifications which are as follows;

\author{
Class I : Slight Limitations \\ Class II : Moderate Limitations * \\ Class III: Severe Limitations $\star \star$ \\ * requires major design and construction measures \\ (public sewer) \\ *t Contains tidal marshes and wooded wetlands
}

Marshfield has a limitation on the extent that it can be developed due to the unsuitability of a large portion(22 percent) of the town. Another large portion of the Town contains class III solls, which would require sewer hook-up for a density of over two units per acre.

The Rexhame, Brant Rock and Green Harbor sections of this class II area have been serviced by public sewer. This sewer allows a higher density than otherwise could be supported. However, there are other areas of Town which are class III and 
$\operatorname{MAP} 1.3$

General Soil Iimitations

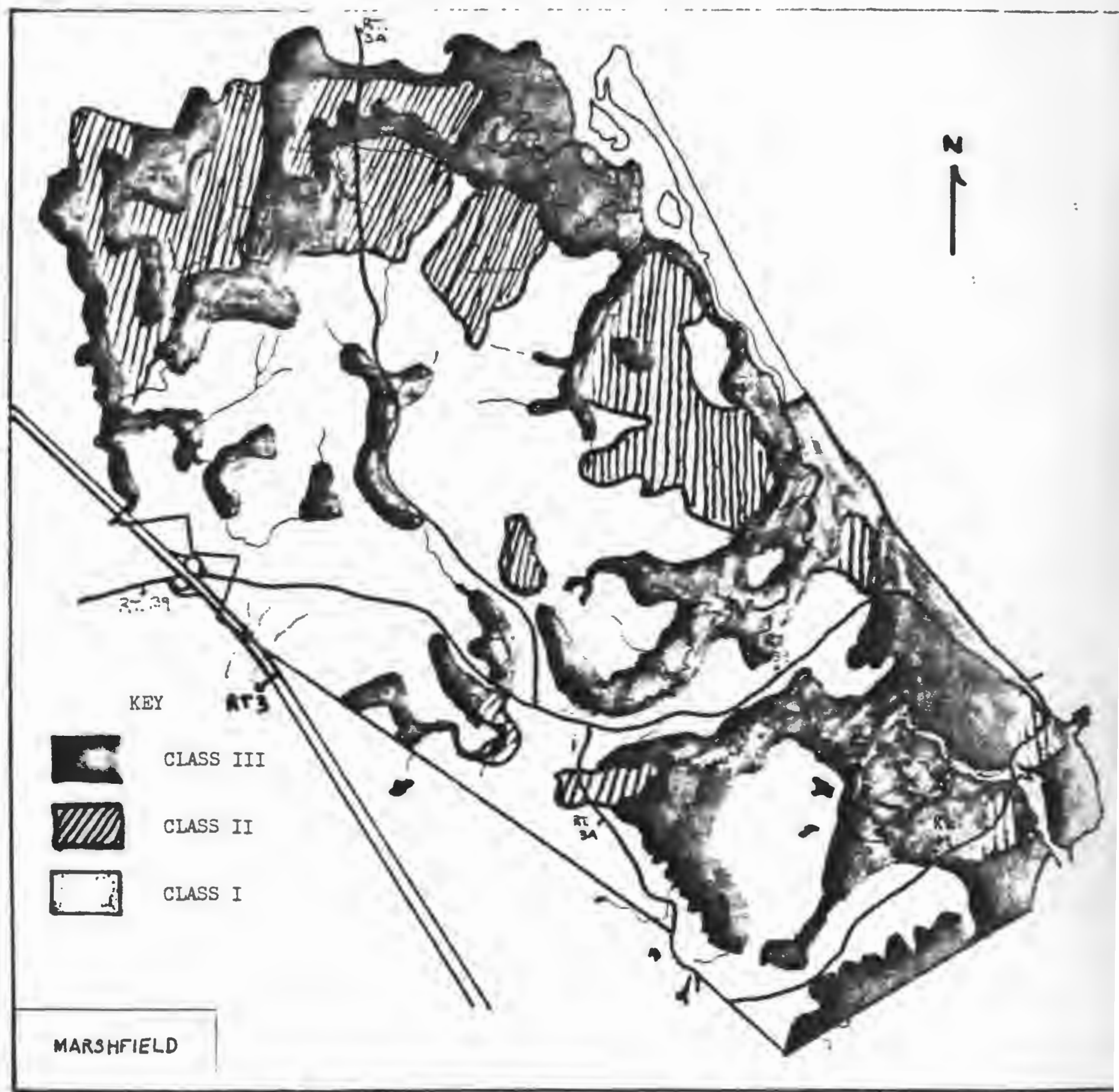

SOURCE: 1969 General Soll Map, U.S. Department of Agriculture Soll Conservation Service 
are not presently serviced and are not likely to be sewered in the foreseeable future. These areas would need special consideration if in the future the Town passes zoning changes that increase the present density. Any zoning change should require a limitation on the number of units by soil capabilities. A further requirement should be the provision for a second septic site on the property. The Town may wish to investigate common septic systems that have recently been used for residential cluster development in Needham. Massachusetts.

\subsection{Hydrology}

Hydrology refers to the various systems which involve water such as surface water/wetlands, floodplains and aquifer. Protection by identification and understanding is necessary to remove the danger of degradation of these water related systems (See DIAGRAM 1.1).

DIAGRAM 1.1

HYDROLOGIC CYCLE IN THE MARSHFIELD AREA

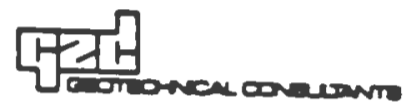

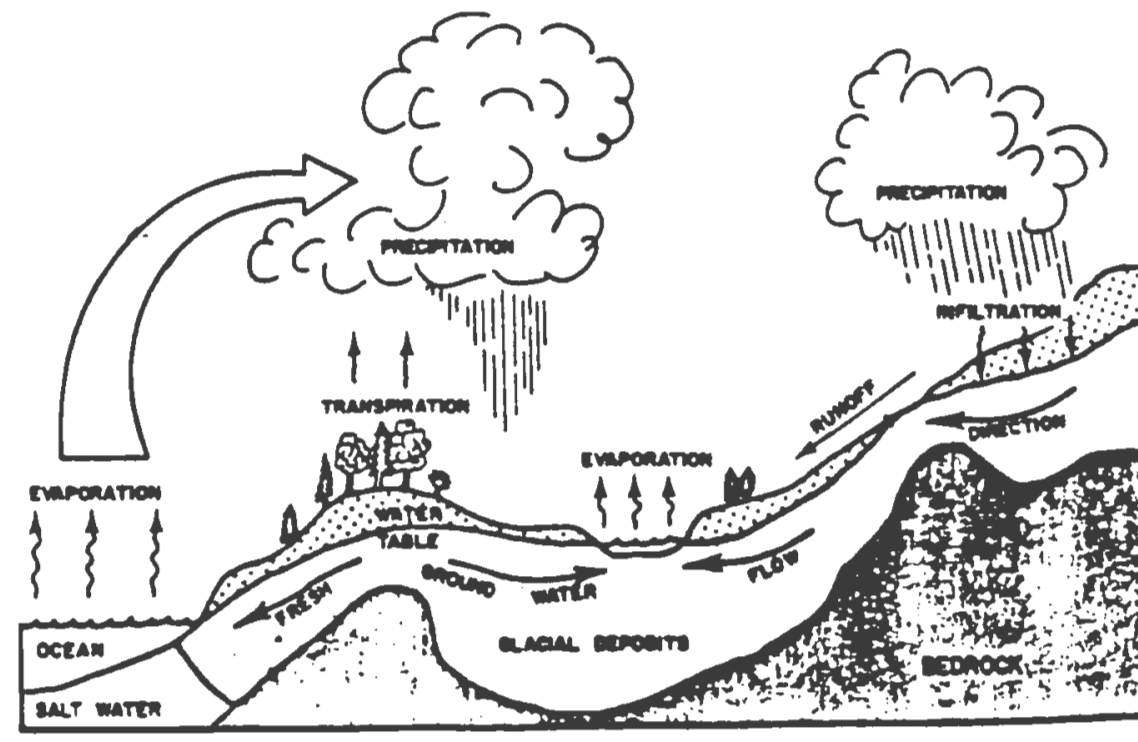




\subsubsection{Surface Water/Wetlands}

Surface water 1 s defined by visible water bodies. The Massachusetts Wetlands Protection Act (Mass.General Laws Chapter 131, Section 40) defines wetlands as "marshes, swamps, bog areas where groundwater,flowing or surface water or ice provide a significant part of the substrate for a plant community for at least five months of the year; emergent and submergent plant communities in inland waters; that portion of any bank which touches an inland water". The Wetlands Protection Act further defines coastal wetlands as any bank, marsh, swamp, meadow, flat, or other lowland subject to tidal action or coastal storm flowage. (See MAP 1.4)

Wetlands serve two principal functions: first, wetlands act as a sponge which absorb excess water during flooding. Second, and more 1mportant, the wetlands serve as a wildlife habitat and are critical in maintalning the ecological balance for fish and shellfish. In addition, surface waters and wetlands provide aesthetic and recreational amenities to Marshfield.

Marshfield has three rivers which flow through the Town and a number of smaller streams and brooks. The North River, which also serves as the Town's northern boundary, flows for a distance of eight miles from Route 3 to the new mouth at Fourth Cliff. The new mouth was created by a hurricane in 1898 which also closed the former mouth which presently serves as the Town Beach.

Within Marshfield the North River is tidal and is bordered by a narrow band of tidal marsh. A number of smaller streams and brooks flow into the North River from Marshfield. The most 


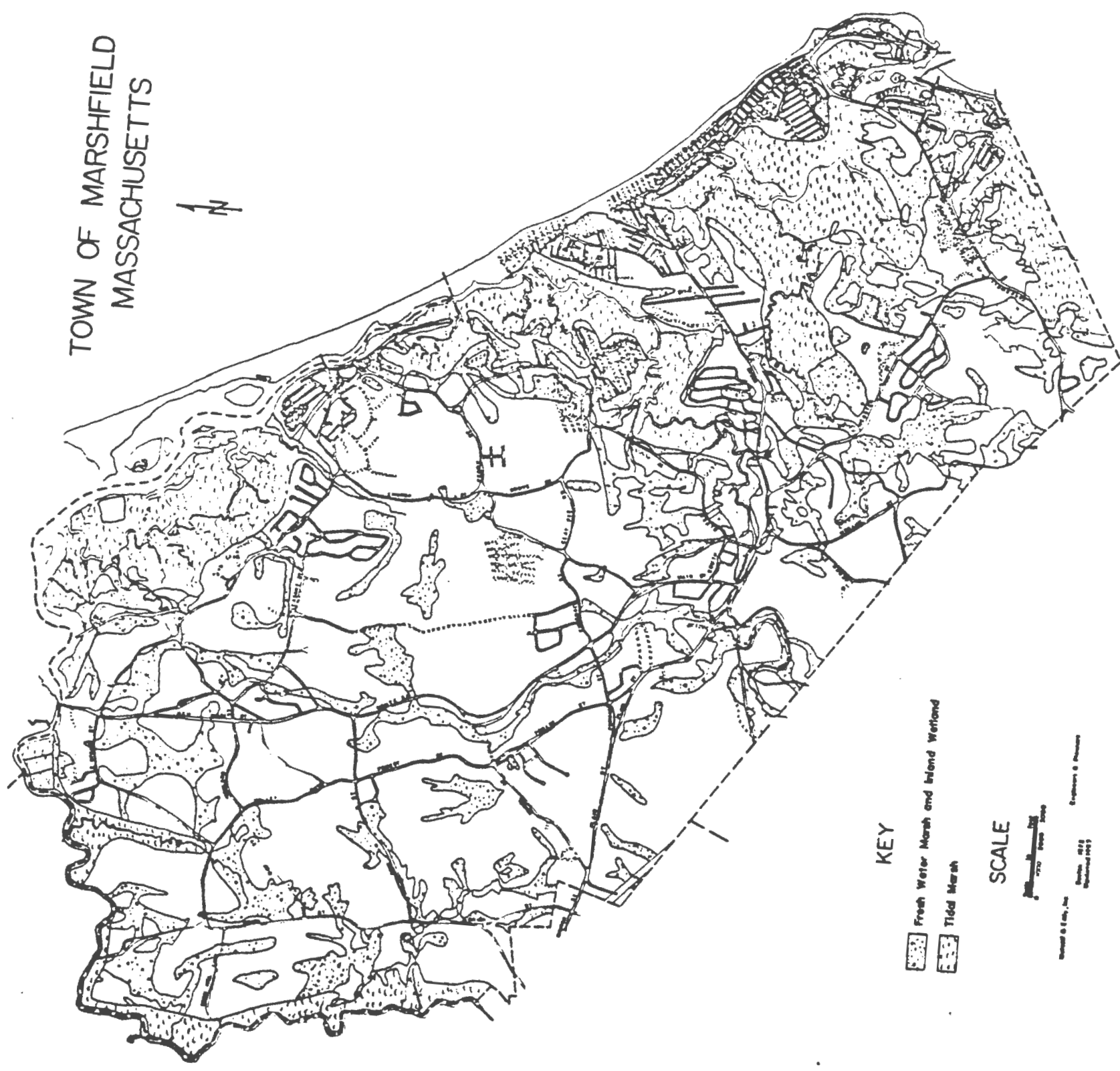


important of these is the Hannah Eames Brook which flows northeast from Route $3 A$ into a pond formed by Damon's Point Road. This brook is important due to the aquifer underneath which is a potential source of drinking water.

The South River enters Marshfield from Duxbury near Mount Skirgo and Jolns the North River near Fourth Cliff. The length of the South River in Marshfield is ten miles and contains a wide, supporting marsh. The important tributary to the south River is the Furnace Brook which flows south from the intersection of Pine and Main Streets. This brook lies above an important aquifer which supports a number of town wells.

The Green Harbor River enters into southern Marshfield from Duxbury along Route $3 \mathrm{~A}$ near the Town line and flows easterly into Green Harbor. This river mouth was once located near the present Town boundary with Duxbury. The majority of this river's length is no longer tidal due to the construction of the dike. The length of the River in Marshfield is approximately seven miles and contains extensive fresh water marsh. The area of the River near the Garretson Cranberry Bogs also has a potential high yield aquifer underneath.

The majority of the ponds in the Town are man made and date to the Colonial Period. These ponds were originally constructed to provide power for the Town's former mills. Although power is no longer attained from these water bodies, they together with the tidal marshes, still provide scenic beauty to the Town.

\subsubsection{Groundwater}

Groundwater is a supply of water which is stored below the surface of the ground. This storage zone is often a layer of 
water saturated soll also known as Glacial Outwash. The Outwash layer when resting on a natural bedrock depression acts like an underground lake. These deposits vary in depth, which have a great deal to do with the potential well yield. This well yield is measured in gallons per minute. The presence and abundance of groundwater is dependent on the soil composition and bedrock geology. The soil composition which is best for the purpose of groundwater retention is Glacial Outwash. These Outwash deposits were the results of streams formed by the melting Glaciers. Outwash deposits materials of finer texture and are well sorted in stratified layers. These layers form a zone of saturation in which a large volume of water can be stored between the grains of soil.

The groundwater itself is called an aquifer. The sandy soil through which the water percolates acts as a fllter which removes contaminants from the water. The areas which contain aquifer capabilities are important to protect from excessive development. High residential density, commercial, or industrial development should be discouraged from these areas unless public sewer hook up is available.

In Marshfield there are three areas which contain the highest yield potential. The first of these lies under the Hannah Eames Brook, which runs northeast from the cranberry bog across the street from Saint Christine's Church. Although there are currently no wells located in this area it is a potential source for the future. The second area runs south of Saint Christine's Church on the west side of Route $3 A$. This rather narrow band 
which runs underneath the Furnace Brook expands westward into the triangle formed by School. Furnace and Plain streets. It then continues southeast by Parsons Pond and into the South River Basin. This aquifer also includes the two smaller aquifers known as the Fairgrounds and Mount skirgo aquifers. These aquifers combined contains the majority of the town's present wells. The third highest yield aquifer lies underneath the Green Harbor River basin. Its best yield area is between the Garretson's Cranberry Bogs and the Green Harbor Golf Course. If the dike was ever removed this area would return to tidal action and thus be ruined as a drinking water source. (See MAP 1.5)

1.6.3. Flood Hazard Areas

In Marshfield, Flood Hazard Areas are defined in the Town's Zoning By-Laws as areas "...subject to periodic inundation which results in loss of life and property, health and safety hazards, disruption of commerce and governmental services...." . Flood Hazard areas, better known as Flood Plains, cover a large portion of the Town's coastal area and inland waterways. This of ten runs into conflict with the desirability of waterfront property. While construction methods are possible, the Town should discourage further development or density increase in the coastal areas of Marshfield. (See MAP 1.6) 
$\operatorname{MAP} 1.5$

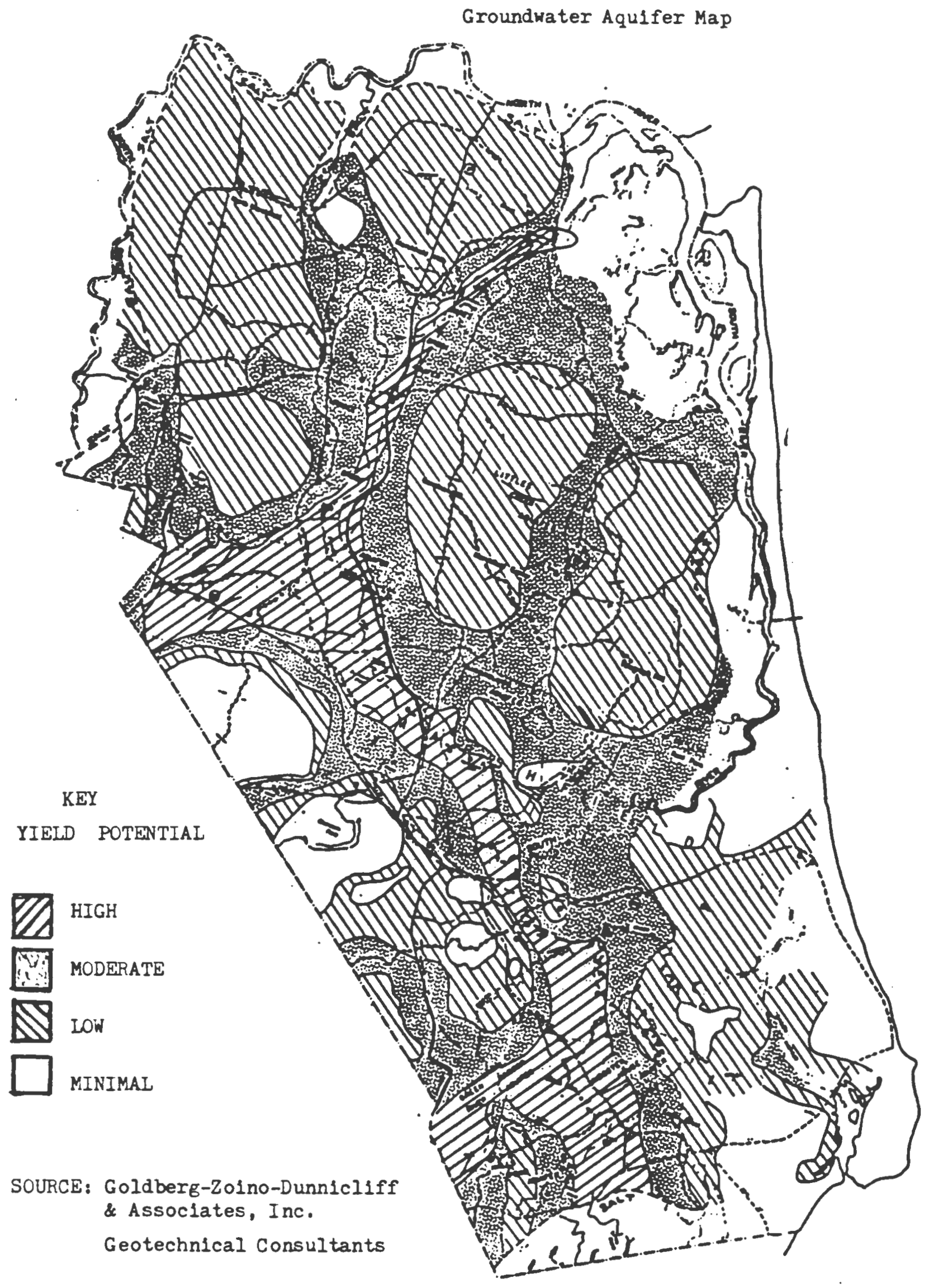


$\operatorname{MAP} 1.6$

Flood Hazard Areas

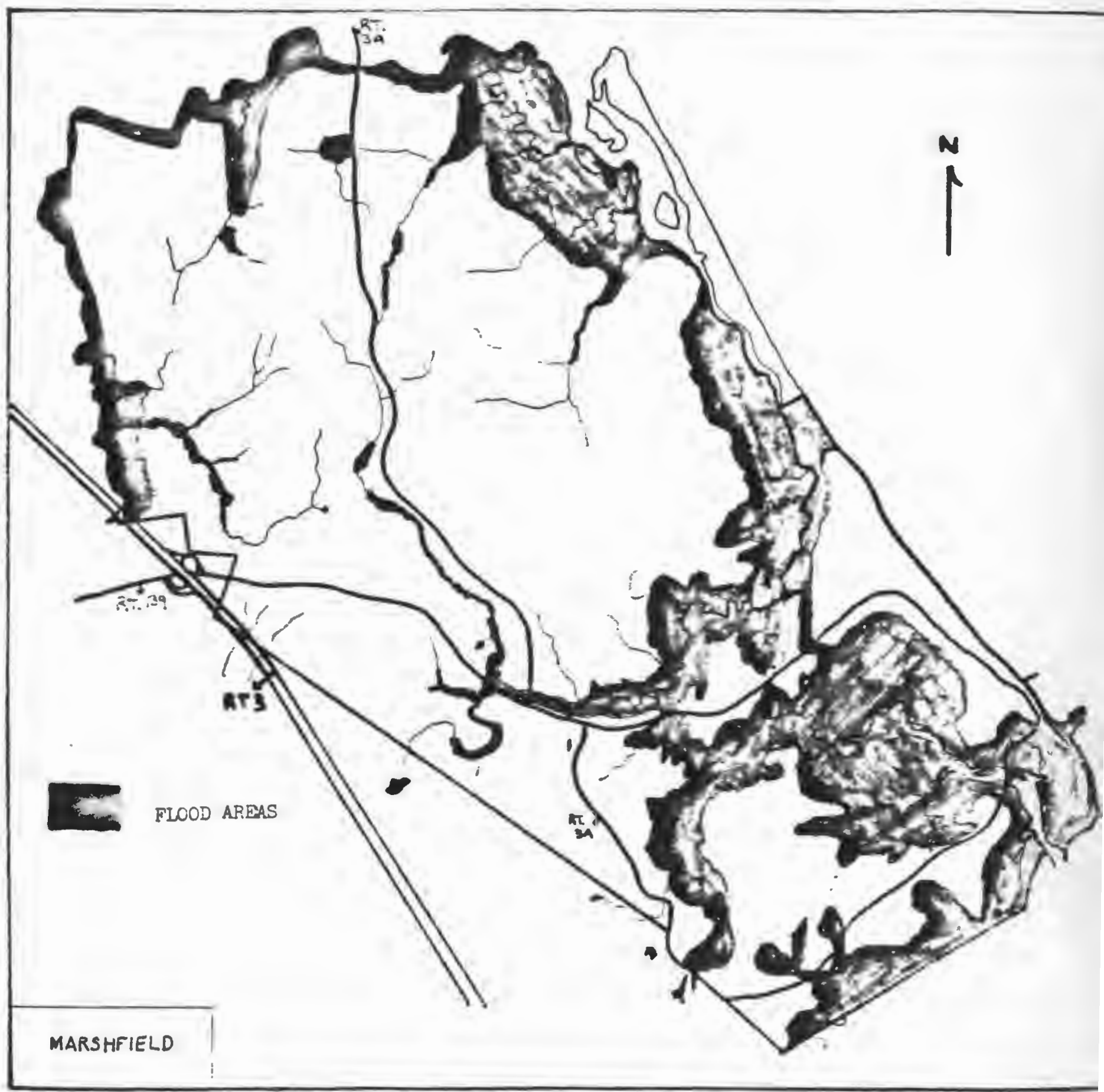

SCURCE: U.S. Department of Housing \& Urban Development Federal Insurance Administration Cctober, 1977 


\section{Footnotes}

1. Marshfield Vacant Land File. Thesis Study Group 1985

2. Marshfield's Changing Tides A History of Marshfield By The U.S. History/Bicentenial Class page 299

3. Town of Marshfield Massachusetts Conservation/Recreation = Open Space Plan $=1985$ page II-C -5

4. Marshfield 's Changing Tides A History Of Marshfield By The U.S. History/Bicentenial Class page 172 


\section{CHAPTER 2}

HISTORICAL BACKGROLND 


\section{HISTORICAL BACKGROUND}

\section{$\underline{2.1}$ Overview}

The area presently known as Marshfield has undergone a series of changes which have altered its appearance and use. In the years before the arrival of the English it was the summer residence of the Algonquin Indians who utilized the woods for hunting, the rivers for fishing and the fields for limited farming.

The primary occupation of the English settlers was farming and thus large areas of the land were cleared of trees and plowed. Due to the poor overland transportation network in this period, the rivers became the link to other areas. This dependence on water combined with the plentiful supply of lumber along the North River spurred the emergence of industry in Marshfield.

Improvements in transportation technology replaced the river packets with trains. The trains in turn were replaced with the improved state road system by the late 1930's. Beginning with the period of the railroad and continuing into the early 1950's, Marshfield returned to a small rural community with a large summertime influx.

This quiet community was dramatically altered by the construction of the Southeast Expressway and Route 3 to Cape Cod. This construction transformed Marshfield into a rapidly growing surburban community of Metropolitan Boston. Historical site locationg are listed in Appendix B. 
Marshfield was once the summer residence of the Wampanoag's, who were a tribe of the Algonquin Family. The area was then known as Missaucatuket. The Indian's thoughts and utilization of the land and its resources were quite different than the first settlers or the succeeding generations. The most important of these differences was the settler's ldea of private ownership of land.

The majority of this tribe of Indians died around 1614 due to an epidemic of small pox. It has been sald that this epidemic was conveyed by John Smith's crew during a venture along the Massachusetts Bay which included a trip into the North River. Thus, by the time the Pligrims expanded outward from Plymouth in search of better farm land, little remained of the Wampanoag tribe in the area but their paths and relics.

In the late 1620s, Marshfield was considered a prime farming location by the Pilgrims and eventual land was granted to Plymouth's prominent citizens. The first permanent settlement was recorded in the year 1632 as established by records in the First Church of Plymouth. During this time, Edward Winslow traveled to Marshfield and in 1636 received a grant of nearly one thousand acres of land. A rather colorful fiqure, Edward Winslow, among other accomplishments, would serve three times as governor of the colong.

During these early years the Town of Marshfield consisted of farmers. These farmers cleared a good deal of the Town's land and built stone walls to mark their property. Since farming is a land intensive use, the best lands were quickly divided up. A number of grist mills were soon built on Man-made ponds that 
provided supporting services to the farm industry.

While the transportation of supplies over land was extremely difficult and expensive throughout the colonial perlod, travel by water was easier and much less expensive. The town had two river inlets which helped to establish Marshfield as an important local commercial and transportation node. The first of these was the inlet for both the North and South Rivers; the second was the Green Harbor inlet.

The rich fishing banks off the coast combined with an abundance of hardwood stands along the North River helped create the ship building industry. Between 1650 and 1850 over one thousand ships were built along the North River. This activity developed a number of related industries which included nail making, sail manufacturing, small mills and eventually shoe making. After the Clvil War these small operations could not compete with the large developing mill towns elsewhere and gradually closed. Even the shipbullding operations disappeared as the slze of new ships grew larger than what the shallow river mouth could support.

Coinciding with the decline of industry, Marshfield saw the coming of the next transportation linkage system, the railroad. During this "quiet" period the Town returned to a summer resort area with a rather small year round population. Meanwhile the financially troubled Duxbury and Cohasset Railroad was quickly taken over by the 0ld Colony Railroad. In time, the old Colony Rallroad was overtaken by the New York, New Haven and Hartford Rallroad. The intent of the railroads was to promote further 
residential development of the suburban communities surrounding Boston. The railroad hoped that this residential development would increase commuter ridership to Boston by train. However, the branch line which transversed Marshfield had slow and infrequent service compared to other communities which were closer to Boston and were on mainlines. The travel time between Marshfield and Boston was close to one and one half hours due to the many stations along the way. Thus suburban rail commuters never settled in great numbers in Marshfield.

By the $1880 \mathrm{~s}$ industry in Marshfield had declined considerably so that there was little frelght traffic, meaning another source of revenue to the railroad was gone. This left the summer passenger traffic as the only profitable revenue source to the railroad. The beach-bound passengers increased in number for a few weeks each August with the annual town fair. During the fair the railroad maintained a special station and featured expanded passenger service.

The coming of the auto age, which was supported by state road construction, brought an increase in auto traffic on Route $3 A$. The resulting loss in summer passenger revenues forced the closing of the Marshfield and Duxbury sections of the rail line in May of 1939. Rall service to Boston did continue, however, for another twenty years just across the North River from Greenbush, Scituate.

Between the late 1880 s and up until the mid 1950 s Marshfield experienced relatively minor changes in permanent population. However, the beach areas swelled with an influx of summer residents during the summer months. In this period the majority 
of the summer cottages were constructed on small lots along the beach front. This high density on poor soil conditions led to septic problems which required the supplying of outside water to the housing sites. Until the mid 1920s, private water companies supplied water to Brant Rock, Ferry H1ll, and Fieldston. In 1927 the Town opened the Mount Skirgo Well and during the next few years the Town acquired control of the private water companies operating in Marshfield.

Marshfield remained a summer community until the late $1950 \mathrm{~s}$ with the construction of the Southeast Expressway. This new Iimited access highway, combined with social and economic factors of the Post Second World War, transformed Marshfield into its current state. The reduced travel time, rural atmosphere and lower land costs than the communities along the Route 128 belt made Marshfield an excellent location to raise children (See MAP 2.1).

During the early phase of the Town's population boom, the majority of the incoming residents either settled into newly constructed homes along existing roadways or in seasonal housing converted to year-round use. In the $1970 \mathrm{~s}$ and into the $1980 \mathrm{~s}$ the development has focused on the large tracts of undeveloped land. This shift will have an important impact on the rural character of the Town, as more wooded areas become urbanized.

Due to the siting of the Route 3 highway interchange in Pembroke, Route 139 replaced Route $3 \mathrm{~A}$ as the primary transportation linkage to, and entrance way into Marshfield. Earlier Marshfield depended on the rivers; as time passed 
this shifted to the rallroad which in turn was transferred to Route 3A. For the immedlate future the Town's future growth will depend on the accessibility to the Route 3 highway by way of Route 139.

As Marshfield heads into the 21 st century, development of the land presently zoned Industrial adjacent to Route 139, will be critical to the Town's future. This industrial zoned land is Important as a means for reducing the Town's dependence on residential property taxes. However, unplanned development without an improved road network will further strain Route 139.

$\operatorname{MAP} 2.1$

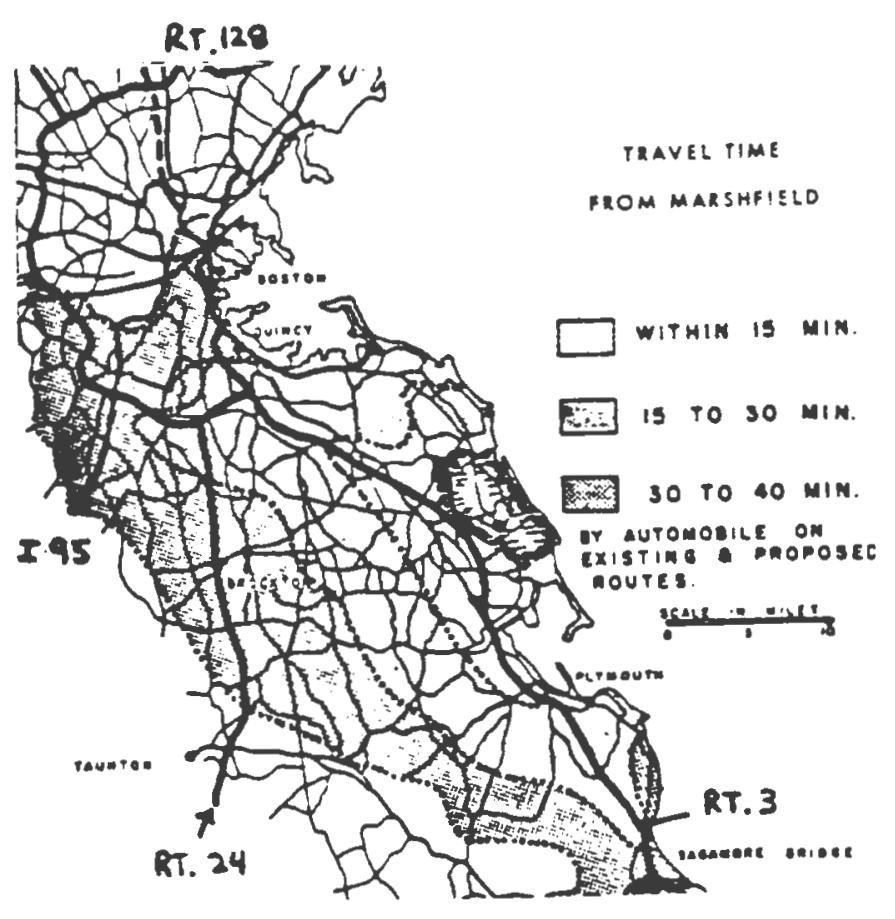




\section{Footnotes}

1. Marshfield The Autoblography of A Pilgrim Town; Marshfield Tercentenary Committee page 1

2. Marshfield Changing Tides A History of Marshfield By The U.S. History/Bicentenial Class

3. Ibid.:

4. Ibid.i

5. Marshileld The Autoblography of A Pilgrim Town; Marshfield Tercentenary Committee page 270

6. The New York, New Haven, and Hartford Railroad Company Timetables

7. Marshfield The Autobiography of A Pilarim Town; Marshfield Tercentenary Committee page 272

8. Ibid.: page 272 
CHAPTER 3

LAND USE / ZONING 
LAND USE AND ZONING

\section{$\underline{3.1}$ Overview}

Land use and zoning are locally controlled factors which have a direct impact on the future of Marshfield. Land use is the activity or usage that is actually on the property. Zoning is an ordinance which controls the use or uses on the property. Sometimes, the land use varies from what is permitted by zoning due to special permits, variances, or other exceptions.

Marshfield, in terms of land use, is steadily becoming urbanized. In 1950, approximately 10 percent of the land was built up. By 1985, this figure had risen to 35 percent. The continued urbanization of Marshfield will have an impact on the Town's rural character and the future land prices.

The affordability of housing in Marshfield, due in part to land use 1ssues, has become tied to the Town's proposed zoning changes. The present Zoning By-Laws have evolved over the last sixty years with the basic goal of preserving the natural and historical character of Marshfield. The zoning ordinance has to a large degree succeeded in this goal. However, this large lot zoning when combined with today's market conditions, has caused a housing affordability problem.

Building lot size and availability are two factors which have a direct impact on housing prices. The larger the minimum required lot, the higher the cost to the buyer. Also, as Marshfield continues to urbanize, subdivision parcels and building lots will become scarce. This scarcity will cause the land prices to rise. 
Currently it is hard to find a residential property priced under $\$ 100,000.00$. As a result, Marshfield is no longer a community where low to moderate income people particularly young couples, can afford to live. Changing the present zoning ordinance to allow for: attached housing, accessory apartments, or cluster subdivision, will assist in the goal of producing affordable housing (See APPENDIX C.1). However, any zoning changes should be analyzed to assess its impact on the community.

\subsection{Land Use}

In 1980 almost half (47\%) of Marshfield was classified as forest in a land use study of the Town. The urbanized land accounted for 28 percent of the total land. Single family residential was the predominant use (91\%). The remaining 9 percent of urbanized land was subdivided into commercial, industrial, transportation and other residentfal supporting services. (See TABLE 3.1)

Using the 1980 Land Use Map (See MAP 3.1), one can notice the large areas of forest land in the northwest and northcentral portions of Town. Most development is found along the roads in these areas. Almost all commercial activity in the Town is found along Route 139. The beach areas of Brant Rock, Green Harbor,etc; have the highest density and variation in land use.

The vacant parcel file (See APPENDIX C.2) indicates that as of 1985 the vacant land zoned for office construction was relatively low and not evenly distributed. Almost 83 percent of the total land zoned for office use in Marshfield is located near 
TABIE 3.1

METROPOLITAN AREA PLANNIHG COUNCIL LAND USE STUDY

\begin{tabular}{|c|c|c|c|c|c|c|}
\hline \multicolumn{2}{|c|}{ MARSHFIEDD } & 1951 & change, & $\begin{array}{c}\text { ACREAGE } \\
197 !\end{array}$ & change, & 1980 \\
\hline \multirow[t]{8}{*}{ URBAid } & Industrial (UI) & 14 & +11 & 25 & & 25 \\
\hline & Commercial (UC) & 40 & +109 & 149 & +31 & 180 \\
\hline & nse Residential (RI) & 297 & +400 & 6.97 & 138 & 735 \\
\hline & ium Residential (R2) & 874 & +925 & 1799 & -336 & 2135 \\
\hline & ght Residential (R3) & 871 & +800 & 1671 & 424 & 1845 \\
\hline & Transportation (UT) & 18 & $\$ 2$ & 80 & & 80 \\
\hline & Open and Public (UO) & 164 & -3 & 161 & +9 & 170 \\
\hline & URBAN TOTAL & 2278 & 2304 & 4582 & $\pi$ & 5170 \\
\hline \multirow[t]{4}{*}{ AGRI CULTURE } & ive Agriculture $(A C)$ & 283 & -Ps & 90 & & 90 \\
\hline & ive Agriculture (AP) & 1628 & $-1 / 83$ & 445 & & 445 \\
\hline & oody Perennials (WP) & 320 & -190 & 1301 & & 130 \\
\hline & AGRICULTURE TOTAL & 2231 & .1566 & 665 & & 665 \\
\hline OPE $:(C)$ & TOTAL & 262 & +4 & 266 & -71 & 195 \\
\hline ESREST(F) & TOTAL & 10844 & -1500 & 9344 & -556 & 8788 \\
\hline \multirow[t]{4}{*}{ WETLANIOS } & Water $(W)$ & & 1565 & $5 a 5$ & & 565 \\
\hline & Salt Wetlands (SW) & 2958 & $-5 \pi$ & 2380 & & 2380 \\
\hline & Fresh wetlands (FW) & 105 & 9198 & 303 & -3 & 300 \\
\hline & WETLANOS TOTAL & 3063 & $1 / 85$ & 32481 & -3 & 3245 \\
\hline \multirow[t]{4}{*}{ CUTECOP PECPEATION } & Participation (RP) & $6 x$ & 采 & 147 & $=88$ & 185 \\
\hline & Spectator (RS) & byes & sind & 91 & .9 & $\angle 00$ \\
\hline & Water Gased $\left(R^{\prime} N\right)$ & 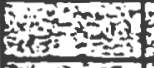 & $2=2+2$ & 55 & & 55 \\
\hline & RECPEDT:ON & & 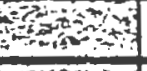 & 293 & +47 & 240 \\
\hline “: & TOTAL & tos & 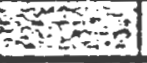 & 2691 & $\because 4$ & 255 \\
\hline$\therefore=5:=0 I S P O S \operatorname{LiL}(U 4)$ & $T O T A L$ & & $x+x=3$ & 11 & 9 & 20 \\
\hline
\end{tabular}


MAP 3.1

General Land Use 1980

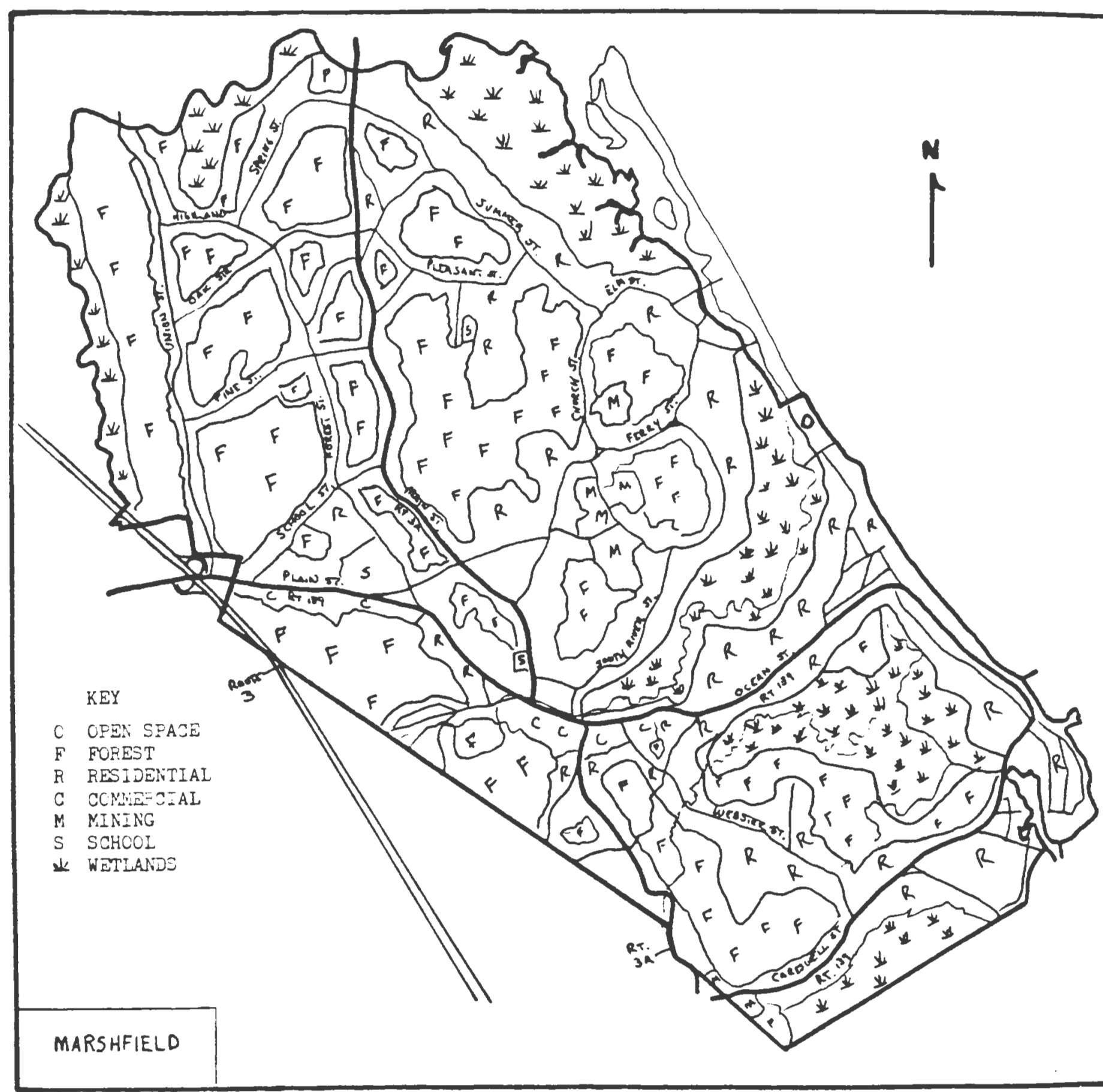

SOURCE: N.A.P.C. LAND USE MAF 1980 
the alrport. However tine Town's alrport $1 \mathrm{~s}$ about $4.5 \mathrm{~m} 11 \mathrm{~s}$ east of the Route 3 highway interchange. This means additional traffic would be generated through the Town Center along Route 139 if the vacant office is bullt up near the airport.

The market for office development, however, is clearly along Route 139 near the highway interchange in Pembroke. The recent office construction near the Town line was approved by special permits which are granted by the Board of Appeals. These special permits clearly show a need for a revamping of the Town's Zoning By-Laws to allow for office construction where the market would support it and where it would create less through traffic.

\subsubsection{Vacant Land File}

In the summer of 1985, utilizing Tax Assessor recorders a survey of vacant land in Marshfield was conducted. A file was created containing 11 categories of information about each parcel of land. This file contains only privately owned land that does not contain any structures. Thus, Town owned land and parcels owned by conservation or preservation groups have not been included.

This file is intended to be used by the Planning Board as an information source in review processes. The designated categories were determined by the Planning Board. These categories demonstrate the suitablity and development capabilities of each vacant parcel of land.

The following 1 s a delineation of the Vacant Land File categories:

As.Map-Lot: Assessor map lot number of each parcel. Location: Parcels street frontage. Owner of Rec: Owner of record as of $8-85$. 
Front: Frontage in feet on town accepted road.

Zon: Zoning as of 8-85.

Sew: If property has sewer line access.

Wat: If property has water line access.

FPA: If property is within the Flood Plain Area.

Access: The status of the road which the property has frontage on.

Area SF: Area of property in square feet.

The results of the main parcel file indicates that as of July, 1985 there were 1,955 vacant properties totaling 4,674 acres of land within Marshfield. This shows the drastic decline in the supply of developable land. Since 1973 the amount of undeveloped vacant land has dropped from $54 \%$ to $26 \%$ of the total 1and. This is a substantial reduction considering the fact that in the 13 years between 1960 and 1973, there was only a 5 percent loss in vacant land (See TABLE 3.2).

A complete copy of the Marshfield vacant land file, as of August, 1985, can be found in the append1x. A computer run of the parcel file, sorting by zoning classification, was also made. This breakdown by zoning shows the limited amount of vacant land remaining for office use (See TABLE 3.3 ).

TABLE 3.2

LAND USE IN MARSHFIELD (1960 - 1985)

\begin{tabular}{|c|c|c|c|c|c|}
\hline Use & 1960 & $*$ & 1973 & $q$ & 1985 \\
\hline Developed Land & 2,680 & 14 & 3,757 & 20 & 6,571 \\
\hline Town Owned Land & 825 & 4 & 1.223 & 7 & 2,995 \\
\hline $\begin{array}{l}\text { Marshlands, } \\
\text { Wetlands and } \\
\text { Surface Water }\end{array}$ & 4,120 & 22 & 3,511 & 19 & 4,118 \\
\hline Vacant & 11,005 & 59 & 10,140 & 54 & 4,947 \\
\hline $\begin{array}{l}\text { Total Acres } \\
\text { SOURCE: } 1985\end{array}$ & $\begin{array}{l}18,631 \\
\text { LAND F. }\end{array}$ & & 18,631 & & 18,631 \\
\hline
\end{tabular}


TABLE 3.3

Vacant Land By Zone (August, 1985)

\begin{tabular}{lcrr} 
Zone & \# of Parcels & Square Feet & Acres \\
I-1 & 33 & $9,875,128$ & 227 \\
OP & 4 & 396,092 & 9 \\
B-1 & 15 & 930,480 & 21 \\
B-2 & 29 & $3,328,421$ & 76 \\
B-3 & 27 & 414,281 & 9 \\
B-4 & 16 & 137,503 & 3 \\
R-1 & 683 & $131,259,227$ & 3013 \\
R-2 & 471 & $28,646,783$ & 658 \\
R-3 & 675 & $28,678,180$ & 658 \\
\hline Total & 1,955 & $203,673,263$ & 4,674
\end{tabular}

SOURCE: 1985 VACANT LAND FILE

The information contained in this inventory has been placed on a computer disk for the purpose of updating the information. Also, note that this parcel file contains a certain amount of error similar to the error factor involved in creating a map. Unlike a map, however, errors can easily be corrected.

\subsection{Zoning}

Zoning is the enactment of a law by public authority for the purpose of regulating the use of private land for the public good. The Zoning Districts are shown on the Town's Zoning Map (See MAP 3.2). The zoning ordinance or by-law specifies the permitted uses, heights, size of yards, off street parking and other prerequisites which are required in each district. Historically, the principal objective of the zoning document was to ensure the protection of private property by segregating incompatible uses. In Marshfield, the zoning ordinance also serves the additional purpose of preserving the Town's rural character and natural environment. 


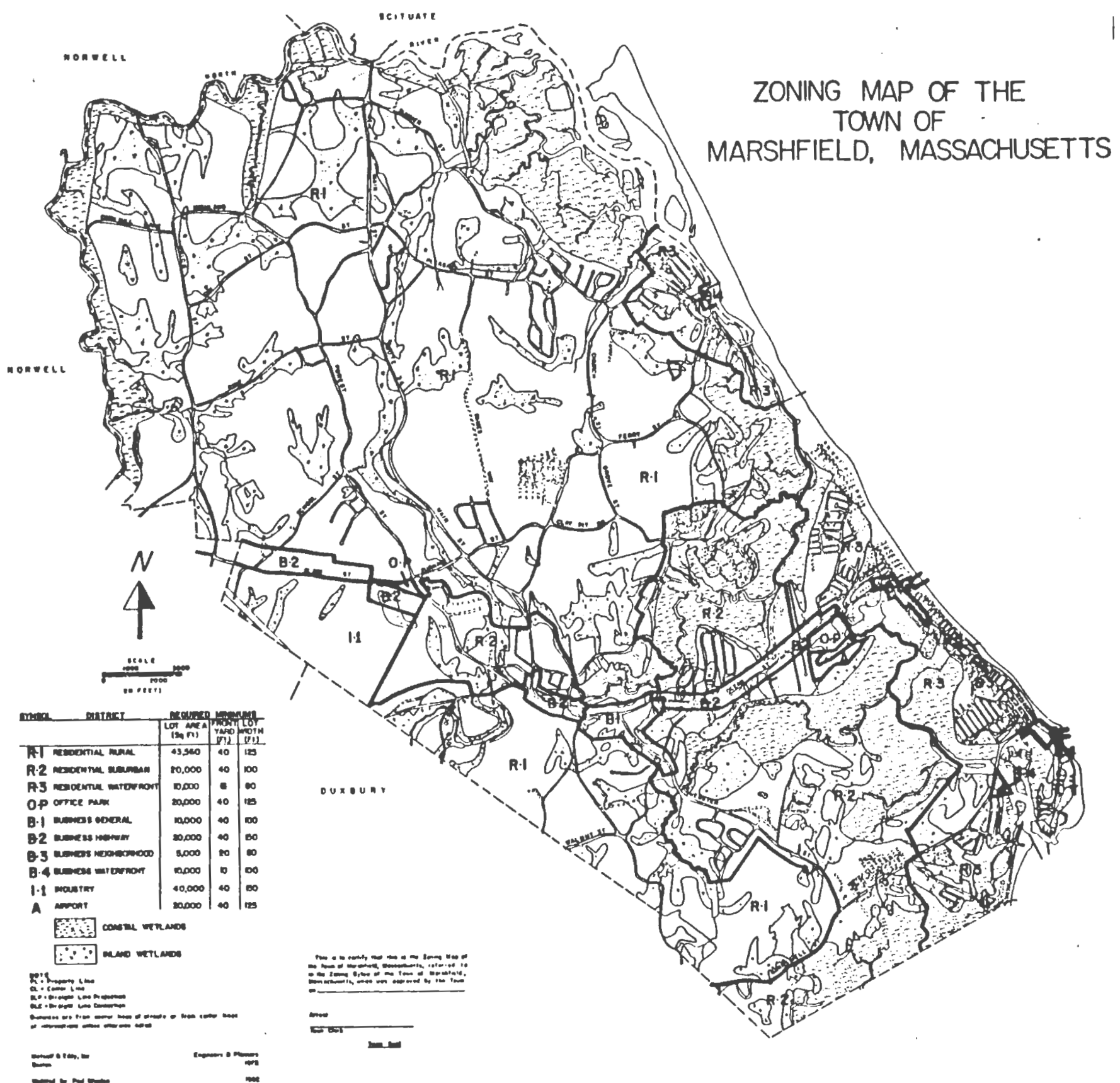


The first zoning ordinance in the United States was adopted by New York City in 1916. The major test on the legality of zoning came in 1926 with the favorable decision given by the U.S. Supreme Court in the Village of Euclid V. Ambler Realty Company. On June 1 of the same year, Marshfield approved its first zoning ordinance in a special Town meeting.

The only major change in recent years was during the early 1970's to allow for the construction of residential apartment in the (R-2) Highway Business District. The apartment construction boom which followed had several negative effects; First, there was the rapid reduction in the total acreage of vacant land zoned for Highway Business and second, there was a concentration of dwelling units just off Route 139. This increased the daily traffic volume and related problems on Route 139. Another problem was the undermining of the Town's rural character by this poorly planned construction. In 1973 apartment construction was removed from the zoning ordinance and recently a number of those apartments have been converted to condominiums.

Under current zoning, Marshfield is zoned largely for residential use. This residential use is broken down into three districts: (R-1) Rural, (R-2) Suburban, and (R-3) Waterfront. The (R-I) Rural district, the largest of the three, covers almost the entire northern end and smaller portions of the Town which border the northeastern sections of Duxbury. This district requires a minimum building lot of one acre $(43,560$ sq.ft.) and a minimum lot width and frontage of 125 feet. By requiring the lot width to be equal to the front, the Town precludes the pork-chop lot problem. A pork-chop lot is a parcel of land which has the 
required frontage that narrows for a distance and then expands to fit a house.

The (R-2) suburban district contains a good portion of the Green Harbor Basin with smaller areas to the west along Route 139 near the Industrial zoned land and surrounding the central area of the South River. This district requires a minimum lot just under a half acre $(20,000$ sq.ft.) and a width and frontage of 100 feet.

The (R-3) Waterfront district consists mainly of the Beachfront areas of Rexhame, Fleldston, Brant Rock and Green Harbor. A small additional area is located opposite of Humarock and contains a portion of the Holly Hill area. This district requires a lot of just under a quarter acre $(10,000)$ and a width of 80 feet.

The majority of the business zones are located of Route 139. The business district requires a lot size between 5,000 to 20,000 sq.ft. and $a$ width and frontage between 80 to 150 feet. There are two small office Park Districts in the Town. The first is located In the triangle formed by Furance, Plain (Route 139), and Forest streets. The second is located between Route 139 and the Town Alrport. The office park districts and the Airport zone require lots of $20,000 \mathrm{sq.ft.}$ and frontage and width requirements of 125 feet.

The Town's Industrial district is located south of Route 139 bordering both the Towns of Pembroke and Duxbury. As noted in this document, this area is, by and large, undeveloped and has a prime importance to Marshfield's future. This district currently 
requires a lot of just under an acre $(40,000$ sq.ft.) and a minimum frontage and width of 150 feet. This district's Use Regulations currently do not allow offlce development. Developers seeking to build offices go to the Board of Appeals. Under this condition the Planning Board can only advise the Board of Appeals .

\subsubsection{Impact Scenario}

A scenario was devised to get an 1dea of the possible traffic impact on Route 139 from the Industrial area. Utilizing the vacant land file and assessor maps, vacant parcels which had frontage on Town accepted streets were assembled and developed as part of the scenario. A bullding size of 120,000 square feet with three floors was used as a standard model. On site parking was required at a ratio of one space per 300 square feet. In this scenarlo the proposed access loop was not constructed, thus all traffic entered Route 139 between Forest street and the Town line. Twenty bulldings could be situated along Plain street following this criteria. The traffic volume along Route 139 would increase by 8,000 vehicles per day. This increase of 51 percent does not account for other growth factors, such as the projected population increase.

\subsubsection{Zoning Recommendations}

1) Amend the present residential zoning to allow for attached cluster subdivisions to help preserve the rural character of the Town while gaining more affordable housing units.

2) To transfer the Special Permit process for office construction from the Board of Appeals to the Planning Board. 
3) To establish an aquifer protection overlay district on the Zoning Map which would reduce the permitted density of the particular zoning district.

\subsection{Board of Appeals}

When zoning was concelved there was provisions included for cases of hardship. A hardship is an unnecessary condition which is caused by the particular physical surroundings, shape or topography of the property. The most common of these provisions is a variance to the zoning ordinance. A variance is intended to serve as a safety valve to protect the property owners against unfair treatment by the Town. This variance is granted by a separate panel known as the Board of Appeals. The Marshfield Board of Appeals consists of seven members who are appointed by the selectman.

\subsection{Subdivision Requlations}

Subdivision regulations are often confused with zoning. Generally, zoning deals with the locational factors of a structure or a use (See DIAGRAM 3.1). Subdivision regulations deal with the provision for, and design of, public facilities such as streets, sewers and the layout of the buildings on a site to ensure protection against flooding, erosion and other health and safety factors. Subdivision regulations also serve to assist in record keeping for transfers of title to land.

Besides the zoning and subdivision ordinances, there are several other laws which affect the use of land in Marshfield; they are as follows: 
1) Gravel Removal By-Law

2) Wetland Protection Act MGL Ch.131 Sec.40

3) Marshfield Wetland Protection By-Law

4) Coast Wetland Restriction MGL Ch. 130 Sec.105

5) North River Protection Order MGL ch.21 Sec. 17

6) Mass. Waterways Control MGL Ch. 91

7) Corp. of Army Engineers Wetland Permit Control

DIAGRAM 3.1

REQUIREMENTS OF ZONING

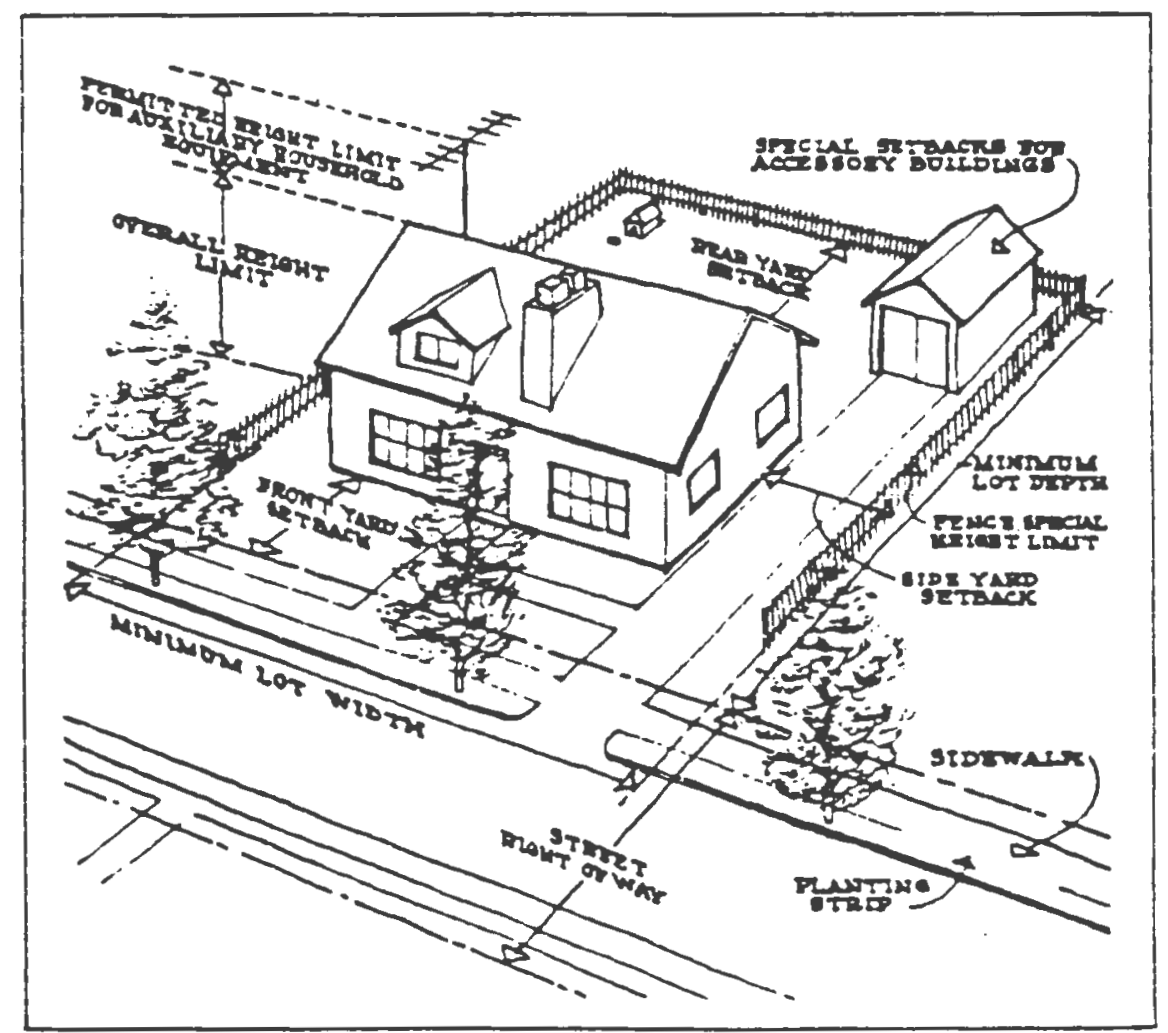




\section{Footnoteg}

1. Marshfield Vacant Land File, Thesis Study Group 1985

2. MAPC Land Use Study, 1980

3. Marshfield Zoning By-Laws

4. The Practice of Local Government Planning; page 416

5. Ibld.; page 417

6. Marshfield The Autobiography of A Pilgrim Town; Marshfield Tercentenary Committee page 298

7. The Language of Zoning; page 35

8. Town of Marshfield Masachusetts Conservation/Recreation $=$ Open Space Plan $=1985 ;$ page II-L-I 
CHAPTER 4

POPULATI ON 
POPULATION

\section{$\underline{4.1}$ Overview}

During the 1960's many of Massachusetts' central cities declined in populaton, with Boston and Springfield incurring the heaviest losses. In contrast, metropolitan areas around the central cities grew at a rate of about 19 percent per year. Small towns within the state also gained, averaging increases of 14 percent per year.

Similar trends occurred during the 1970's, as central cities continued to lose population but at more than twice the rate which occurred during the 1960's. Surrounding metro areas slowed in their growth rate dramatically, showing increases on average of 1.5 percent. Smaller clties and towns increased their population by over 19 percent during the same period. Thus, it is clear that living preferences of the population shifted to smaller towns and communities since the $1970^{\prime} \mathrm{s}$.

Although some communities showed marked population increases. the state's total population remained relatively stable during the $1970^{\prime} \mathrm{s}$

Overall. the population trends indicate three areas of substantial or continuing growth: Amherst and surrounding areas; south-east Massachusetts; the Cape and its surrounding areas. Plymouth and Bristol counties, in south eastern Massachusetts. together gained over 102.000 people in the past decade.

Residential growth has been strongest along Route 3 through Marshfield, Duxbury and Plymouth and the adjoining towns of Carver 
and Wareham. Together they account for over half of the growth in Plymouth County.

\subsection{Marshfield's Population Change}

Marshfield's Population has been increasing dramatically since the 1950's. (see DIAGRAM 4.1) The greatest ten year increase occurred between 1960 and 1970 (6.740 people to 15.223 people). From 1970 to 1980 . the population increased by 37.4 percent or 5.693 people. A community's population can change due to two factors, natural increase and migration. Natural increase is defined as the number of births in a community, less the number of deaths in that community for a given time period. Migration is the result of people moving into or out of a community. During this period migration accounted for an increase of 3.936 people and births exceeded deaths (natural increase) by 1.757 (see TABLE 4.1). The Town's Annual Report for 1984 estimates Marshfield's population to be 21.986 people.

TABLE 4.1

YEAR POPULATION INCREASE FROM I950 TO 1980

$1950-1960$

$1960-1970$

$1970-1980$

$$
\text { POP }
$$

NAT. INC

MIGR.

\% INC.

SOURCE: U.S Census and The Massachuetts Department of Health 

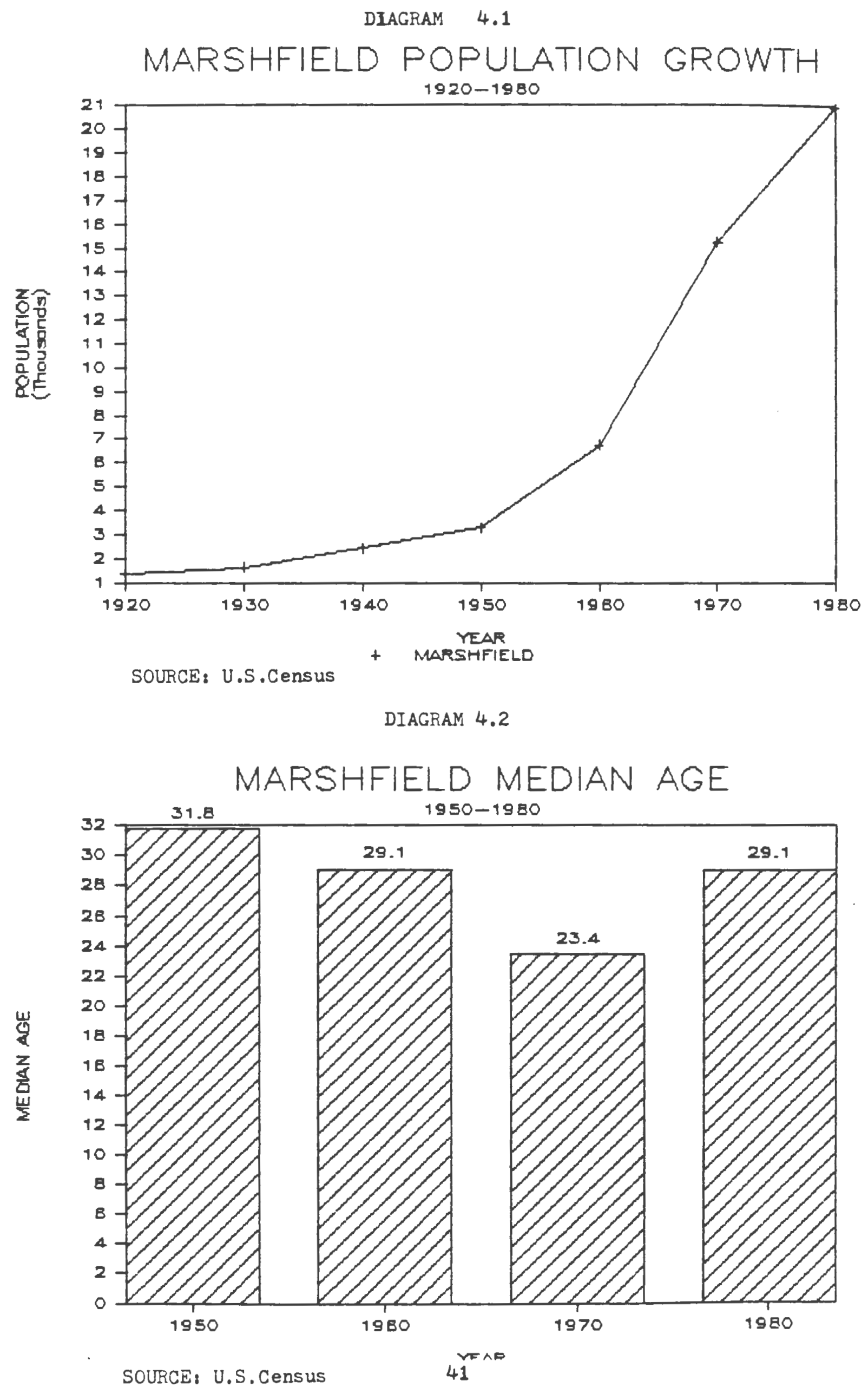


\subsection{Characteristics of the Population}

Prior to the 1970's the median age of Marshfield residents had been decreasing (see DIAGRAM 4.2). This was largely due to the number of young families which entered the town during this period. Between 1970 and 1980 this trend changed as is reflected in the rise in median age of the population. This rise was due to a slowing of the birth rate (reflected by a decrease in the $0-4$ population) as well as the marked increase in elderly population $(65+)$ ( see TABLE 4.2$)$.

TABLE 4.2

POPULATION DISTRIBUTION FOR MARSHFIELD FROM 1950 TO 1980

$\begin{array}{rrrrrc}\text { YEAR } & 0-4 & 5-19 & 20-64 & 65+ & \text { MEDIAN AGE } \\ 1950 & 349 & 847 & 1670 & 401 & 31.8 \\ 1960 & 869 & 1844 & 3333 & 702 & 29.1 \\ 1970 & 1829 & 5029 & 7346 & 1019 & 23.4 \\ 1980 & 1533 & 5950 & 11764 & 5506 & 29.1\end{array}$

SOURCE: 1973 Master Plan and the U.S. Census of Population 1950.1960 .1970 .1980

The population density in Marshfield, as stated in The Conservation Commission Report, varies from slightly more than one-half persons per acre in the northern $1 / 3$ of Town, (including North Marshfield and Marshfield Hills) to one person per acre in the central $1 / 3$ of the Town (including Standish, Marshfield Center, and Kent Park): and approximately two persons per acre in the Southern $1 / 3$ of the Town ( including Rexhame, Fieldston, Ocean Bluffs, Brant Rock, Green Harbor, Cedar Crest, and Black Mount). 
The highest population density occurs along Route 139 from the Pembroke line, east to the coast, then south and west to webster street. This high density is partly caused by the apartments, condominiums, and elderly housing in this area. Also, high population density is found along the coast. Fifty percent of the former summer beach cottage areas, from Scituate to Duxbury, are now used for year round housing. This results in higher year-round densities, as well as the increased density which occurs due to the influx of summer residents which number between 10,000 and 12.000 people annually.

Marshfield has had a history of requiring relatively large acreage for housing development (as demonstrated by $\mathrm{R}-2$ zoning). This has resulted in much of the town having low population densities.

The municipal sewer system whlch presently exists in the town serves only the beach area. Expansion of the system could allow for high residential density to occur in other areas of the town. However, expansion of the system seems unlikely due to budgeting constraints. For this reason, the present population density distribution is expected to remain constant in the future.

\subsection{Factors Affecting Future Population Growth}

The 1973 Master Plan attributed Marshfield's past population growth to a number of factors, the most significant being migration. Other factors include: 
1) Improved access provided by construction of Route 3 .

2) The availability of large tracts of vacant land.

3 ) The conversion of seasonal homes to year round occupancy.

4 ) The construction of apartments in commercial zones from 1968 through 1971.

Over the next 20 years migration, will continue to be the strongest factor affecting population growth in Marshfield. Specifically, the following conditions and situations will further influence growth, positively or negatively:

1) Zoning changes to allow for higher density housing. Such as changes which would allow for attached dwellings or accessory apartments.

2) Continued accessibility of Route 3 via Route 139.

3) The reestablishment of a commuter rail line to Greenbush, Scituate.

4) The present trend of low interest rates (under 10 percent) will continue, thus allowing for greater housing affordability..

5) The continued conversion of seasonal homes to year-round dwellings.

6) The availability of large tracts of developable land will start to diminish.

7) Expansion of the municipal sewer system will not occur.

\subsection{Population Forecasts}

This update of the 1973 Master Plan presents three population forecasts (see TABLE 4.3 ):

The first forecast was calculated by the Thesis Study Group using the cohort survival population projection technique (see APPENDIX D.1). The second forecast was obtained from the Massachusetts Area Planning Commission, (see APPENDIX D.2). The State of Massachusetts uses a series of factors such as trend analysis and location factors to calculate population forecasts. 
The third forecast was obtained from the Marshfield Master Plan of 1973. 5 The Plan states that a modified cohort survival projection technique was used to formulate population forecasts.

TABLE 4.3

POPULATION FORECASTS FOR MARSHFIELD MASSACHUETTS

YEAR lst FORECAST1 2nd FORECAST2 3rd FORECAST3

1970

15223

20916

27635

1990

35005

15223

20916

15223

23700

26047

2000

24300

Source: U.S. Census Bureau Population Statistics for 1970.1980

1 Cohort Survival Projection, as done by the Thesis Study Group.

2 State of Massachusetts, Metropolitan Area Planning Commission Population Projection Report.

31973 Marshfield Master Plan

The reason that the cohort survival technique is used in population forecasting is that it is considered to be one of the more or most accurate means of predicting future populations. This is mainly due to the fact that it takes into account migration when calculating the statistics. The reason that the results of the first and third forecasts differ is most likely due to changes in the survival rates.

Results of the first forecast showed that the 1980 total male population of 10.284 will increase to 13.595 by the year 1990 and to 17.313 by the year 2000 . The 1980 female population of 10.632 will increase to 14,040 by 1990 and to 17,692 by the year 2000 . 
Thus, the total population for 1990 is projected to be 27,635 . For the year 2000, the population is projected to reach 35,005. The state of Massachusetts. projects the Town's population to be 23,700 by the year 1990, and reach 24,300 by the year 2000 . The 1973 Master Plan estimates the 1990 population to reach 39.974. The 1973 Master Plan did not project the population to the year 2000 .

We believe that the population forecast done by the Thesis Study Group is the most probable forecast. This is due to the fact that we did not modify our figures to group the population into large subgroups. Also, we used the most current population figures as supplied by the census as well as the latest vital statistics available from the Massachusetts Department of Health to determine current birth and death rates.

Based on our forecast. the most significant finding is the change in the elderly population between 1990 and the year 2000. (see TABLE 4.4)

TABLE 4.4

$\begin{array}{lcc}\text { ELDERLY POPULATION PROJECTION FOR MARSHFIELD BY SEX } \\ \text { YEAR } & \text { MEN 65+ } & \\ & & \text { WOMEN } 65+ \\ 1980 & 665 & 996 \\ 1990 & 1020 & 1657 \\ 2000 & 1502 & 2478\end{array}$

SOURCE: Based on cohort survival projection as done by the Thesis Study Group, URI 1986 


\section{$\underline{4.8}$ Conclusion}

The population of the Town will ultimately be determined by the decisions that will be made, for example, in regards to zoning and infrastructure expansion. It is in the Town's best interest to judge how quickly to allow for development, keeping in mind the goals of the community. as growth should be controlled in order to allow for the continued quality of life that Marshfield's community presently enjoys. 


\section{Footnotes}

1. Inter1m Population Forecast 1980-2010 Data Analysis Program Technical Report 2; M.A.C.P.; Boston. Massachusetts; July 1981

2. Annual Report for The Town of Marshf1eld, 1984

3. Harrington and Reynolds; Town of Marshfield Massachusetts Conservation/Recreation - Open Space Plan - 1985: Conservation Commission, Recreation Commission; 1985

4. R-2 Zoning - Town of Marshfield Zoning By-Laws: April 30.1984 Suburban District Requiring building lots to be 20,000 sq. ft.

5. Marshfield Master Plan: Metcalf and Eddy.: Boston, Massachusetts: November. 1973

6. U.S. Census Bureau The Population for Massachusetts Regions and Towns: 1970 - 1980 
CHAPTER 5

HOUSING 
HOUSING

\subsection{Introduction}

Given the rapid growth of Marshfield over the last twentyfive years, there has been a corresponding growth in the number of dwelling units in the town. As Marshfield has easy access to Boston via Route 3 , the town has become increasingly desirable as a residential location.

This section of the Master Plan describes the Town's housing stock, then illustrates that because of the escalating demand for housing in the area, due to population growth, the price of housing has risen considerably in recent years. Rising housing prices have resulted in a housing affordability problem for Marshfield as there is a growing need to provide housing for low and moderate-income households. Since the major housing recommendation is the provision of affordable housing, most proposals are targeted to alleviating this problem.

\subsection{Housing stock}

The housing stock in Marshfield is predominately singlefamily detached houses. In the 1980 Census there were 8,610 housing units, of which 7,356 ( 85 percent) were single-family detached. Virtually all of the seasonal or migratory units are single-family detached $(1,456$ out of 1,475). See Table 5.1. Of the 7,135 year-round housing units in 1980, 6,838 were occupied;

this is broken down into 5,209 units or 76 percent occupied by homeowners and 1,629 units or 24 percent occupied by renters. See Table 5.2. 
Housing Units (including Vacant and Seasonal Units)

Number of Housing Units

Total Housing Units

8610

Total Year-Round Units

7135

Vacant and Seasonal Units

1475

Units in Single-Family Detached Structures 1456

Units in Single-Family Attached structures

Units in Two-Family Structures

Units in Structures of 3 or 4 Units

Units in Structures of 5 or more Units

Source: Housing in Marshfield Study, Abt Associates Inc. November, 1985.

\section{TABLE 5.2}

Number of Year-Round Housing Units by Type of Structure

\section{Units in Structure}

Total Year-Round:

Units in Single-Family Detached Structures

Units in Single-Family Attached Structures

Units in Two-Family structures

Units in Structures of 3 or 4 Units

Units in Structures of 5 or more Units

Total Occupled:

Units in Single-Family Detached Structures

Units in Single-Family Attached structures

Units in Two-Family structures

Units in Structures of 3 or 4 Units

Units in Structures of 5 or more Units

Renter Occupled:

Units in Single-Family Detached Structures

Units in Single-Family Attached Structures

Units in Two-Family structures

Units in Structures of 3 or 4 Units

Units in Structures of 5 or more Units
Number of Housing Units

7135

5900

72

88

86

989

6838

5691

72

82

86

907

1629

655

6

30

76

Source: Housing in Marshfield Study, Abt Associates Inc. November, 1985. 
Bullding permit approvals for new units lall single-family detached) from January 1980 through December 1985 amounted to 420 units, bringing to 7,555 the number of pear-round housing units. An undetermined number of seasonal units continue to be converted to year-round use.

The Town's rapid growth in population is also reflected in the relative newness of the housing stock. Of the year-round housing units, $(7,135$ in 1980 plus the 420 authorized through December 1985) over half (56 percent) were built since 1959. The condition of housing structures is therefore generally satisfactory.

The living environment may be adversely affected, however, by certain conditions in the area which result in the deterioration of living conditions. These conditions can include over-crowding of buildings, incompatible land uses, narrow streets, and noise/air pollution. Environmental deterioration is noticeable in the south-eastern quadrant of the Town as many of the summer resort cottages are located on narrow (in some cases unpaved) streets, have no sewerage or inadequate sewerage (some of these areas are subject to possible tidal flooding), and drainage problems.

As a result of the recent rapid growth of the Town's housing stock and soil constraints in the northern part of town, relatively few of the gear-round housing units are connected to the public sewer system ( 17 percent), which is limited to the south-eastern quadrant of the Town (see MAP 9.3). The remainder use a septic tank or cesspool system. Almost all of the Town ( 98 percent) is supplied by public water. 


\subsubsection{Accessory Apartments}

Estimating the number of "accessory apartments". (larger single-family dwellings which are modified to provide separate living quarters, usually for aging parents or young couples) is difficult, even though it is known that between 200 and 400 accessory apartments do exist in the Town. A more accurate number might come from the households that could benefit from an "accessory apartment" arrangement, forming independent living quarters as part of the same residence. The 1980 Census obtained data on the number of subfamilies living in the same housing unit as part of a larger household. The Census data indicated 109 such subfamilies in Marshfield some of which may be living in accessory apartments.

\subsubsection{Rental Housing}

Renters reside in most of the units situated in buildings of two or more units; most live in buildings of five or more units, although nearly half live in single-family detached dwellings (See TABLE 5.2). A majority of the apartment units in the Town were developed in the late 1960 s and early $1970 \mathrm{~s}$ along Route 139. of the 1.629 renter-occupied, year-round units in the 1980 Census, 993 were built between 1960 and 1974, and 117 were bullt between 1975 and 1980. Diagram 5.1 shows building permits authorized between 1970 and 1985. Between 1970 and 1974, permits were authorized for 853 multi-family units, all in structures of 5 or more units. The Zoning By-Law that had allowed this type of development was amended in 1973 to remove the provision for multi-family housing and has not been reinstated, since present 
DIAGRAM 5.1

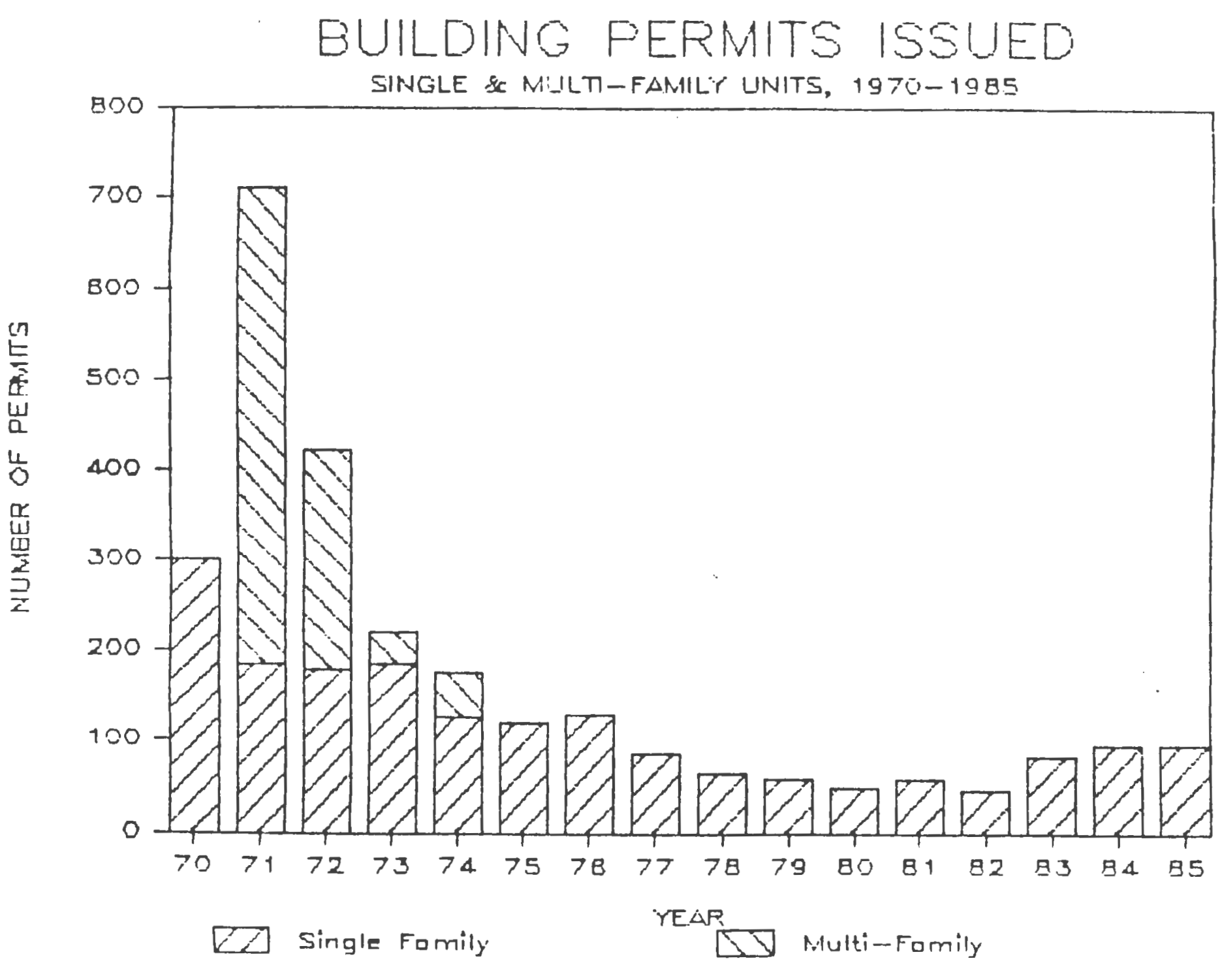

Source: Marshfield Building Department 
zoning permits only single-family detached construction, with the exception of special permit procedures for housing for the elderly.

Attempts have been made in recent years to modify the Zoning By-Law but have been rejected by Town Meeting, in reaction to the spurt of development in the early 1970s.

\subsubsection{Subsidized Housing}

Marshfield currently provides some form of subsidized housing for 229 households; of these, 101 are provided by the Marshfield Housing Authority. The South Shore Housing Development Corporation and the First Congregational Church also operate subsidized housing projects, mostly for the elderly, so that the total of all subsidized housing is 156 assisted units for elderly households, 71 family, and 2 handicapped households. See Table 5.3 for current and proposed projects. Proposed projects will accommodate an additional 28 family and 30 elderly households.

\subsubsection{Characterization of Housing Stock By Tract}

Marshfleld's housing stock is analyzed by reference to the four Census Tracts (See MAP 5.1). The Tracts correspond to the precinct numbering used in the Town.

Tract 1 (Census Tract 5061.02) -- North Marshfield, west of Main Street and north of Mount Skirgolold Oceans Streets, including Route 139; 
Subsidized Housing in Marshfield

Current and Proposed

Marshfield Housing Authority

Chapter 705 public housing

( 5 approved 1974, 5 in 1980)

Chapter 707 rental assistance

Tea Rock, Chapter 667 (1971)

Ryder School Congregate

(State funds approved 1984)

Webster/Parsonage (Section 202)

South Shore Housing Development

Corporation, Housing for

Independent Living (1981)

\section{Current}

10 family

27 familyt

64 elderly

30 elderly

Proposed

6 family
28 elderly and

2 handicapped $t \star$

Winslow Village (Section 236)

First Congregation Church (1971)

64 elderly

Section 8 Certificates (rental

housing assistance)

South Shore Housing

Development Corporation 34 familyt

Mariner Hill

State Street Development Co.

of Boston

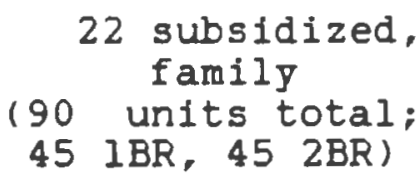

\section{6 elderly \\ 71 family \\ 2 handicapped}

Total 229 units
30 elderly

28 family

58 units

* Not counted for purposes of Chapter 774 by the state Executive office of Communities and Development.

$\star$ Counted as family housing by EOCD.

Source: Housing in Marshfield Study, Abt Associates Inc. November, 1985. 


\section{TOWN OF MARSHFIELD}

\section{BY TRACT}

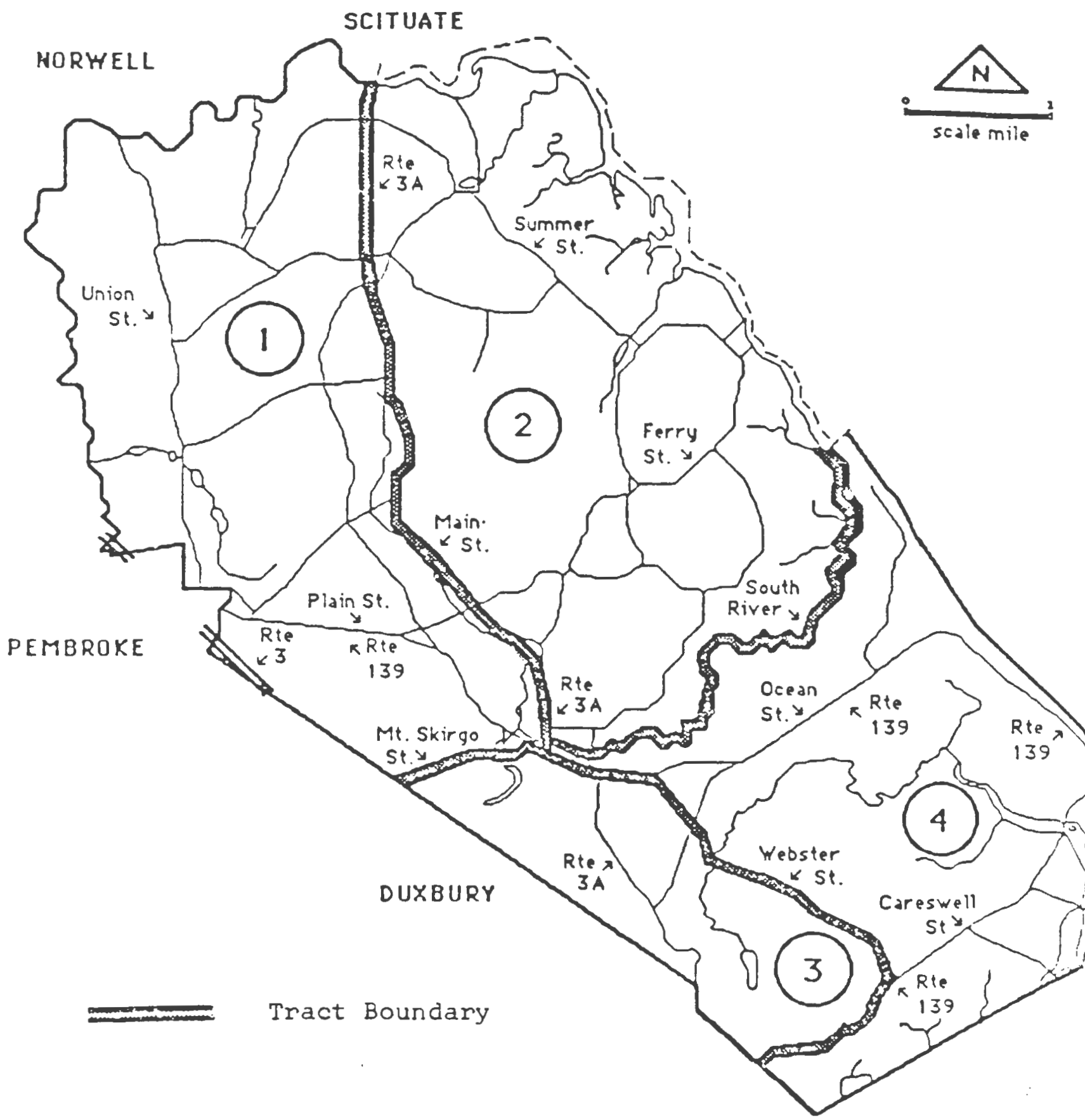

Source: Housing in Marshfield Study, Abt Associates Inc., 1985 
Tract 2 (Census Tract 5061.01) -- Northeast Marshfield, east of Main Street and north of the South River;

Tract 3 (Census Tract 5062.02) -- Town Center, south of Route 139 and bounded by Webster and Careswell Streets on the east;

Tract 4 (Census Tract 5062.01) -- Beach and Green Harbor area, Including the rest of Route 139.

Each of the areas has distinctive characteristics. Roughly 46 percent of the Town's housing stock is in the northern half, incorporating Tracts \#l (North Marshfield) and \#2 (Marshfield Hills, East). The balance is in the southern half, with Tract \#4 (Green Harbor/Beach) having about 44 percent, and Tract \#3 (Town Center, South) having 10 percent of the Town's housing. Since 1980, new construction of housing stock has favored the northern half of the Town by a 56:44 ratio (See TABLE 5.4).

The reverse is true concerning the distribution of alterations and additions with value in excess of $\$ 10,000$. Tract \#4 alone accounts for almost half of the total permits issued in recent years for alterations and additions (See TABLE 5.5). This reflects the older/newer bifurcation between housing in the southern and northern portions of Marshfield.

Tract \#4 incorporates the Green Harbor/Beach area of Marshfield. Its housing stock reflects the use of this area for summer residences with structures, typically small beach cottages, quite dense and close to the water areas. Although these beach cottages were initially constructed for only seasonal use, many owners are upgrading the structures to year-round use. The extent of this activity is illustrated by the large number of adition/alteration permits issued (See TABLE 5.5). As the 
TABLE 5.4

Distribution of Permitted New Construction in Marshfield, $1980-1985$.

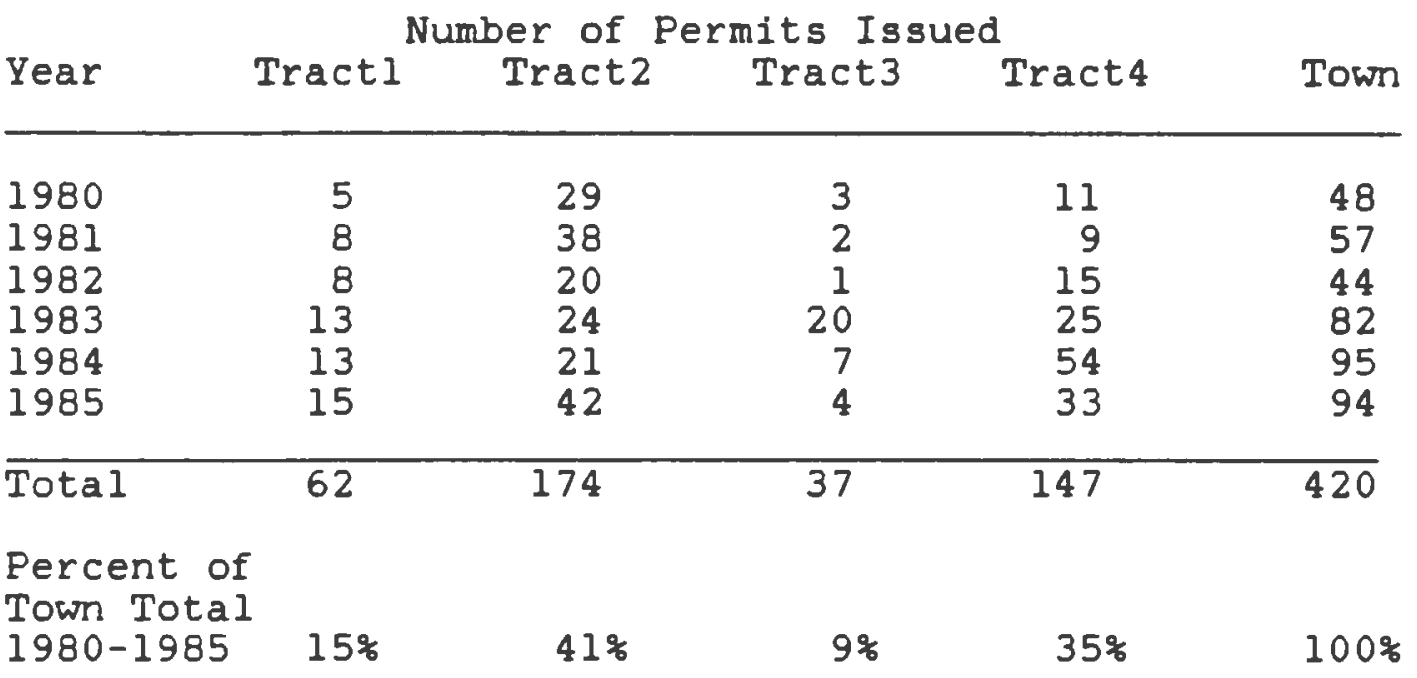

Note: All permits for Single Family Dwellings

Source: Marshfield Building Department

TABLE 5.5

Distribution of Permitted Residential Additions and Alterations in Marshfield, $1980-1985$.

Additions and Alterations

Year Tractl Tract2 Tract3 Tract4 Town

\begin{tabular}{lrrrrr}
\hline & 7 & 4 & 3 & 7 & 21 \\
1980 & 13 & 3 & 5 & 16 & 37 \\
1981 & 12 & 9 & 1 & 12 & 34 \\
1982 & 11 & 17 & 2 & 32 & 62 \\
1983 & 20 & 16 & 6 & 44 & 86 \\
1984 & 23 & 29 & 5 & 65 & 122 \\
1985 & 86 & 78 & 22 & 176 & 362 \\
\hline Total & & & & & \\
Percent of & & $21 \%$ & $6 \%$ & $49 \%$ & $100 \%$ \\
Town Total & & & & & \\
$1980-1985$ & $24 \%$ & & & &
\end{tabular}

Source: Marshfield Building Department 
number of new construction permits for this Tract is also high, this has been the most active area in Town for total building activity (new construction and additions/alterations) since 1980.

Tract \#3, Town Center South, is the smallest area in size and number of housing units. Housing development in this area is more recent than the Beach area, is more contemporary in nature and has larger lot sizes. This area has had the smallest amount of building activity compared to the other three Tracts during this decade, in elther new construction or rehabilitation, due in part to the zoning in this section of Town. Cost of land and its availability has also caused slow residential growth.

Tract \#2, Marshfield Hills East, is the most active area for new construction in the Town since 1980, with 41 percent of all new units (See TABLE 5.4). Along with Tract \#l, in the northern section of each, large "estate" housing can be found. Many of these homes date back to the early $19^{\text {th }}$ century.

Tract \#1, North Marshfield, has the highest value of new residential properties as records indicate that the average value of new construction has been the highest in this Tract. This section of Town is traversed by Route 139, and is also an area of multi-family housing development, with apartment complexes flanking commercial establishments; a situation also found in Tract \#4 (See MAP 5.2). Visually, this strip development along Route 139 is unique in the Town and does not characterize the rest of Tract \#1 and Tract \#4. 


\section{Location of Multi-Family Dwellings, 1985 Morshfield, MA}

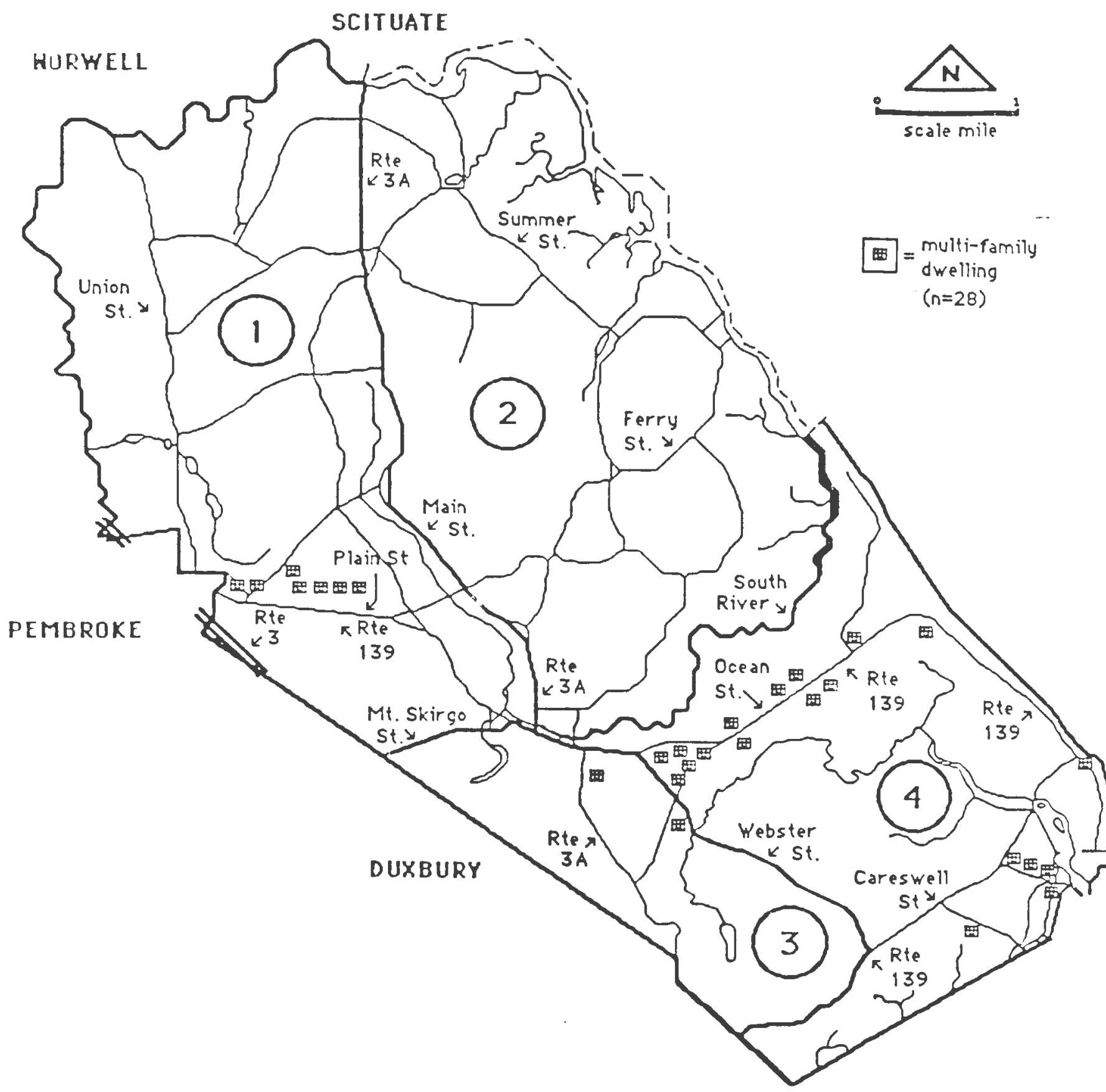

Source: Housing in Marshfield Study Abt Associates Inc., 1985 


\section{$\underline{5.3}$ Housing Costs}

Sale prices of houses and rent on rental properties have both risen significantly in recent months, giving rise to concern about the ability of those seeking housing to find it at an affordable cost.

Looking at new construction as an indicator of housing costs as indicated in bullding permits issued by the Town, the value of single-family houses has increased dramatically in recent years. Using the Census Tract boundaries again to designate the Town by area. Tract \#l as described above has had the largest increase in housing costs and has also had the highest historic values.

A rough measure that can be used to relate the cost of construction to sale price is to double the construction cost to allow for costs of land, construction and profit. Hence, given a town-wide average of $\$ 67,500$ for construction costs (for 1985), the current average cost of new housing would be $\$ 135,000$, with average costs in Tract \#1 nearing $\$ 200,000$.

Records from the Assessor's office show that median sale prices increased by over 20 percent in just two years, from $\$ 62,000$ in 1983 to $\$ 74,900$ in 1984. As shown in Table 5.6, Tract \#l had the highest median value $(\$ 112,000)$ for all sales and Tract \#4 the lowest $(\$ 63,500)$. Many apartment buildings are being converted to condomintums and this has provided lower priced housing as the median price for condominiums in 1984 was $\$ 42,500$. 
TABLE 5.6

Median Sale Price of a Residential Unit by Tract, $1983-1984$

Single Family

$\begin{aligned} & 1983 \text { - All Tracts } \\ & 1984 \text { - All Tracts } \\ & \text { - Tract } 1 \\ & \text { - Tract } 2 \\ & \text { - Tract } 3 \\ & \text { - Tract } 4\end{aligned}$

$\$ 62,000$

$\$ 74,900$

$\$ 112,000$

$\$ 96,900$

$\$ 95,000$

$\$ 63,500$
Condominium

$\$ 37,400$

$\$ 42,500$

$\$ 42,500$

Two-Family

Source: Marshfield Assessor's Office

Housing costs should be considered in the context of the local housing market of which Marshfield is a part. Based upon data provided by the Plymouth County Multiple Iisting Service, on 1985 sales in Plymouth County and in the Town of Marshfield, three bedroom houses sold at around $\$ 120,000$, the average single family house at $\$ 87,500$, while condominium units sold for about $\$ 47,000$.

Currently, an average three bedroom single family house is selling for $\$ 160,000$, whlle condominium prices are exceeding $\$ 100,000$. Rental rates currently range from $\$ 450-\$ 650$ a month for a unit in an apartment complex, and from \$700-\$1,000 for a single-family home, depending on the number of bedrooms.

\subsection{Housing Affordability and Demand}

Not everyone can afford to buy a home at today's prices so the municipality is faced with the task of meeting the housing needs of low and moderate-income households. To determine the 
number of such households in Marshfield, an income guideline can be utilized; for federal housing programs, an income level is used to define low and moderate-income households. The Department of Housing and Urban Development (HUD) defines a lower-income level as 80 percent of the median income for the area. In Marshfield's case this is the Boston metropolitan area. The 1980 income level for lower-income households, based on a family of four, was $\$ 15,500$ (in 1985 it was $\$ 25,850$ ) as established by the Boston Regional office of HUD.

Using 1980 Census data for Marshfield and the 80 percent of median income guideline, it is possible to calculate the number and percentage of households in each Census Tract which had incomes under the low and moderate-income level. These are tabulated in Table 5.7. Nearly one in three ( 31.2 percent) of all households in the Town were in this income category. The majority of such households are found in Tract \#4, specifically the Rexham Beach/Fieldston Beach/Ocean Bluff/Brant Rock area (see MAP 5.3).

Typically, housing assistance programs set a limit of 25 percent of income as a reasonable portion of income to cover housing costs. Taking 1980 census figures, the Housing In Marshfield Study determined that those households spending 25 percent or more for housing numbered 871 owner and 777 renter households. Based on the standards of the Executive Office of Communities and Development (EOCD), current preliminary unpublished figures show that as of 1985, Marshfield needed 656 subsidized family units and 161 subsidized elderly units. 
TABLE 5.7

Town of Marshfield

Low and Moderate Income Households, 1980

Low and Percent

Total Moderate Low and

Households Income Households Moderate

Tract 1 (North Marshfield)

Census Tract 5061.02

1,526

452

29.6

Tract 2 (Marshfield Hills, East)

Census Tract 5061.01

1,634

423

25.9

Tract 3 (Town Center South)

Census Tract 5062.02

Tract 4 (Green Harbor/Beach)

Census Tract 5062.01

3,029

1,108

36.6

MARSHFIELD Total

6.911

2,153

31.2

Source: Housing in Marshfield Study, Abt Associates Inc. November, 1985. 
Percentage of Low/Mod Income Households by Tract, 1980 Marshfield, MA

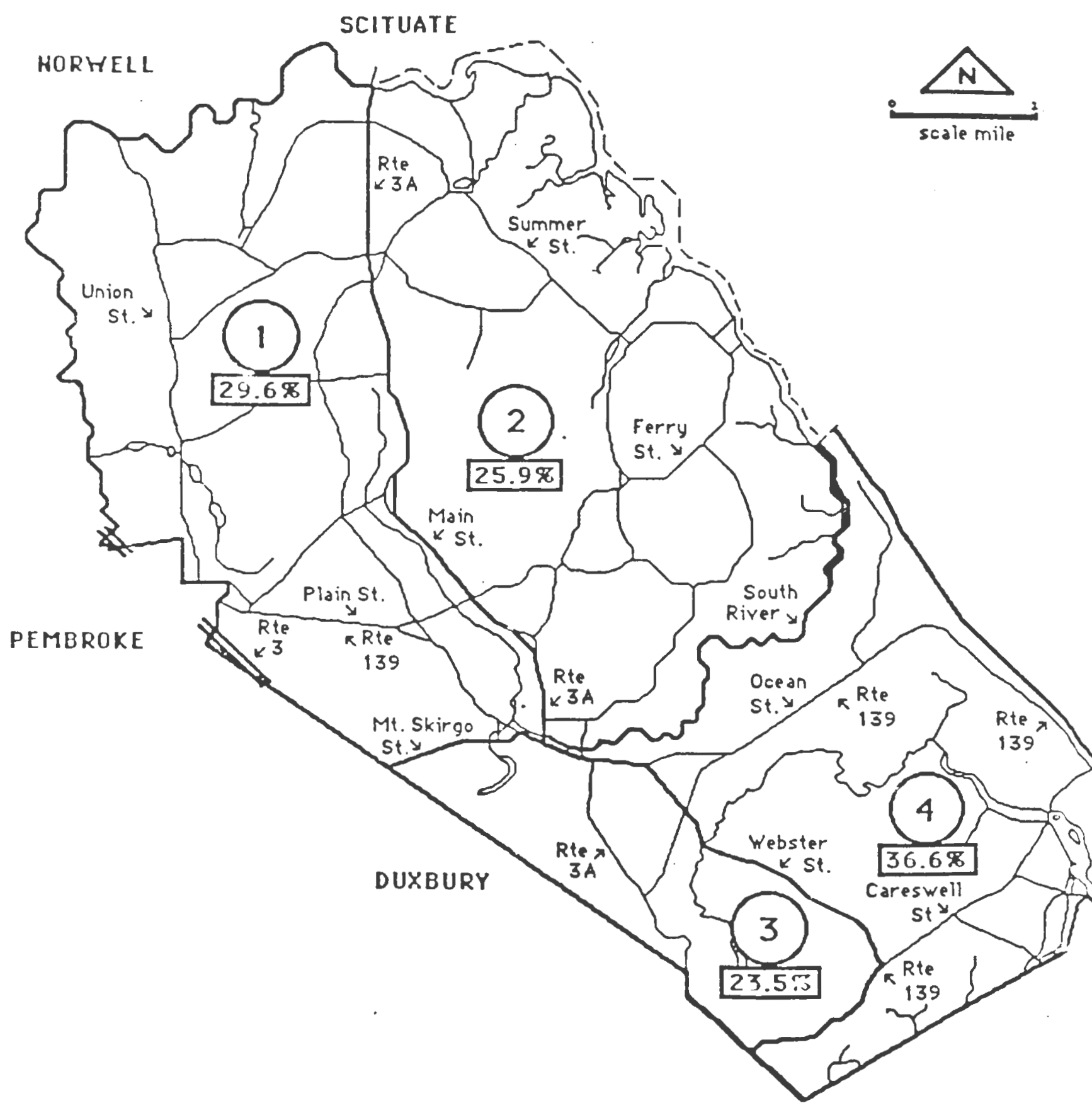

Source: Housing in Marshfield Study, Abt Associates Inc., 1985 


\subsubsection{Long Range Demand}

By the year 2000, the resident population of Marshfield is expected to be about 35,000 as projected in the Population section of the Master Plan. This represents an increase of 13,000 over the present population of about 22,000 . It is estimated that an additional 4,000 dwelling units will have to be built in the next 14 years to accommodate this growth. This means an average of about 285 housing units will need to be constructed annually.

Given today's housing costs and the projected age breakdown of the population in the year 2000, generalizations on housing type can be made. For example, the 20-29 age group and the over 65 age group have traditionally been apartment/condominium dwellers. Conversely, home buyers are generally persons 30 to 65. Assuming that these preferences and the present size of families remain relatively constant, the long-range housing demand of 4,000 units shown in Table 5.8 can be expected.

TABLE 5.8

Housing Demand in Marshfield by Age Group, 1986 - 2000

Age Group

$20-29$

$30-65$

65 and over
No. of New Units Needed

300
2,700
1,000
$-0 .-$
Total 4,000

Source: Calculations by Authors 


\subsection{State Requirements for Affordable Housing}

The Commonwealth of Massachusetts has adopted certain standards regarding the provision of subsidized housing. These are reflected in Chapter 774 and Executive Order 215 which ties state discretionary funds to the progress a town or municipality is making in addressing housing needs.

\subsubsection{Chapter $774=$ "Ant1-Snob Zoning Law"}

Under this law established in 1969, a limited dividend developer or non-profit (e.g. First Congregational Church) or public agency (e.g. Marshfield Housing Authority), seeking to build low and moderate income housing in a community can, subject to determination by the Housing Appeals Committee in the Executive Office of Communities and Development, override local ordinances which are shown to be unnecessarily restrictive. The Committee's decision to disregard local codes and ordinances is based partially on whether the existing supply of subsidized housing in the community meets certain specified guidelines. These guidelines stipulate that subsidized housing must be greater than either 10 percent of the total housing supply, or located on more than 1.5 percent of the total area of the commity less publicly-owned land. If either of the above maximum guidelines is not met, the community must then conform to an annual guideline requiring that 0.3 percent of its total area less public land be used for new subsidized housing.

The Chapter 774 threshold percentage for Marshfield, as of 1980, was 712 housing units. Given new housing development since 1980, the threshold figure for 1985 would be about 750 housing 
units. For purposes of Chapter 774, the Town currently has 168 units of subsidized housing, less than one-quarter the number required. These are the 10 Chapter 705 family units and the 64 elderly units at the Tea Rock development both operated by the Marshfield Housing Authority, the 30 elderly/handicapped units at the Webster/Parsonnage development, Housing for Independent Living, developed by the South Shore Community Development Corporation, and the 64 elderly units at the Winslow Hill development, developed by the First Congregational Church.

The 1973 Master Plan indicated that, as of 1970, the Chapter 774 test of 1.5 percent of land zoned residential, commercial, or industrial was 206 acres compared with 11 acres devoted to subsidized housing at that time. Subsequent zoning changes and development will not have altered these figures substantially. The Chapter 774 test of 0.3 percent of land area to be added annually to subsidized housing was 45 acres. As of 1980 , Marshfield had only 2.36 percent of units assisted.

\section{$\underline{5.5 .2}$ Executive order $\underline{215}$}

Introduced in 1982, the intent of the order is to accommodate the growing housing needs of the Commonwealth's population, as Massachusetts needs to add to its housing supply. In the review of local applications for state development assistance, the municipality's housing policies and practices are taken into consideration. It is the general policy of all state agencies not to award discretionary funds to cities or towns which have been determined to be unreasonably restrictive of new housing growth. 
Although Marshfield has not been subjected to a specific Executive office 215 review by EOCD to determine the Town's strategy in meeting its state obligation towards housing, it is possible that applications for Community Development Block Grant funds under the Massachusetts Small Cities Program or conservation grants could be affected at some point. Perhaps, the Town could take the initiative to outline its strategy on how it is approaching the problem of affordable housing in Marshfield. The Strategic Planning Program, recently formulated by the state, provides planning grant funds to towns and municipalities for affordable housing, and this support could be used for further development of affordable housing.

\subsubsection{Fair Housing Guidelines}

Development assistance is linked to the adoption of a Fair Housing Program, compliance being monitored by the Massachusetts Commission Against Discrimination (MCAD). A Fair Housing Program takes place in communities where there is underrepresentation or overconcentration of minorities and female-headed households. If an applicant for federal or state development assistance funds fails to meet its equal opportunity obligations, the Commission "shall .... recommend that the applicant be declared ineligible for ... funding."

According to the 1980 census, minorities comprised 1.7 percent of Marshfield's population, compared to 9.9 percent for the Boston metropolitan area. Even though the Town was requested to draw up a Fair Housing Program and has set up a fair housing committee, little action has been taken by the Town on its Fair 
Housing Program. The Town needs to formulate and implement a Falr Housing Program otherwise it will not avoid encumberances in Town requests for state and federal development assistance funds.

\subsection{Housing Problems}

After analyzing the housing inventory and the current trends in the real estate market, the following are perceived as housing problems in Marshfield.

1) Escalating prices of single family dwellings and rental units.

The rapid population growth has dictated an increased demand for housing units and prices have risen accordingly.

2) High cost of new housing construction for low- and moderate-income families is not something that can be readily controlled by the Town.

The Town has relatively little control over land prices (exclusive of zoning), mortgage rates, and costs of construction and materials.

3) Marshfield Housing Authority and non-profit groups are currently providing an insufficient amount of affordable housing.

The Marshfield Housing Authority operates on a limited budget and has found it very difficult to secure or provide affordable housing units.

4) Selection of future apartment/condominium sites will be difficult due to the lack of sewers.

It is preferable that extensive apartment developments are linked to a sewer system. As the sewer system in Marshfield is limited to the south-east portion of town, and as the Town does not have adequate funds to extend the present system, any possible future apartment/condominium sites are restricted. 


\subsection{Housing Recommendations}

Based on the problems noted above, the following housing recommendations are suggested:

1) Provision of affordable housing, especially to firsttime home buyers, to meet the growing housing needs of Marshfield.

2) Prevent the haphazard conversion of summer cottages to inadequate year-round dwellings.

3) Prevent the further deterioration of structures in the beach areas.

The major concern in regard to housing in Marshfield is the provision of affordable housing. Essentially, there are two ways in which the Town can alleviate the current shortage. One way concerns housing assistance programs; the second way is through development control alternatives.

\subsubsection{Housing Assistance Programs}

It is suggested that Marshfield extends its present level of participation in housing assistance programs. This would, as a policy of the Town, help relieve problems of housing affordability and help avoid the problems of Executive office 215 encumberances in development assistance funds. The following programs may be utilized by Marshfield:

I Rental Assistance Programs that provide income support. Assuming that eligible rental units are available and that state or federal subsidies are avallable, direct assistance for households in the existing rental housing stock has proven to be a very efficient use of subsidy f und $s$. 
(1) The Marshfield Housing Authority should expand 1ts participation in the state Chapter 707 rental assistance program.

(11) The Town should disclose the existence of help for eligible households through the south Shore Housing Development Corporation's administration of the parallel Section 8 Existing housing program.

(1ii) If possible, utilize the Massachusetts Housing Partnership program which is linked to EOCD.

II Property Tax Relief For Elderly Homeowners

Th1s action would improve affordabllity for low-income elderly households. Property tax "lost" could be recaptured at sale. However, such a program would ignore other needy households such as single parent households.

III Rehabilitation Programs

(i) Utilize federal Community Development Block Grants through the Massachusetts Small Cities Program.

(ii) Utilize the federal Rental Rehabilitation Program. An area eligible for this program is the Brant Rock area (specifically Block Group 2 of Census Tract 5062.01). Marshfield should make an application to EOCD to reserve an application of the subsidy funds available.

IV Development Programs For New Housing

Programs that could address the shortage of affordable housing are the SHARP program administered by EOCD in confunction with the Massachusetts Housing Finance Agency (MHFA), the TELLER program which provides for local housing authority financing of private rental housing, and the Home Loan Mortgage Program of MHFA. 
(1) The SHARP (State Housing Assistance for Rental Production) program reduces rental costs of new construction or rehabilitation through tax exempt bonds.

(11) The TELLER (Tax Exempt Local Loans to Encourage Rental Housingl program allows local housing authorities to issue tax bonds to finance new construction or rehabilitation of rental housing.

(11i) Tax Exempt bonds issued by MHFA is for acquisition and rehabilitation of one to four family buildings. The Home Mortgage Loan Program, as it applies to Marshfield, is limited to first-time homebuyers and priority is given to lower-income buyers.

\subsubsection{Development Control Alternatives}

Given that there is housing activity in the community and there is also strong interest in acquiring land for conservation, land prices for either use on developable parcels will increase as the competing interests bid against each other. The result is a further narrowing of the range of affordable housing alternatives, as higher land prices mean higher new housing prices. Also fewer new housing opportunities mean greater competition for existing housing, and consequently higher prices.

Marshfield's Zoning By-Law presently allows, by right, for only single-family detached residential development with special permits for cluster single-family detached and elderly housing. Previous initiatives to amend the By-Law to allow for other forms of residential use have been rejected at Town Meeting. A number of development control alternatives are presented below 
which Marshfield could consider. These may be divided into the following categories.

\section{Intensity}

This concerns the number of dwelling units on a given land area and/or the placement of those units on the land 1tself.

(1) Density Bonus - - It may be provided by reducing the lot size and/or increasing the number of units on a given lot. In the context of a policy encouraging affordable housing, providing density bonuses should be contigent on the bullder/developer assuring that the units are committed to the affordable housing target market. One mechanism that could be used is to commit units to the market at an affordable cost. For sales housing for example, (either new or condo conversion), some proportion of the total units (often 25 percent) are committed to be put on the market at a price no higher than 80 percent of median sales price in the defined market area.

(ii) Cluster - Development pattern in which residences are grouped or "clustered" through a density transfer, rather than spread evenly throughout a parcel as in conventional lot-bylot development. Its advantage is that it decreases land development costs, as less road and utility construction is needed, and these savings can be passed on to homebuyers.

(111) Zero Lot Line - A development approach in which a building is sited on one or more lot lines with no yard. This approach provides flexibility in site design, an important consideration when land avallable for development is scarce and/or environmentally constrained as is the case in Marshfield.

(iv) Planned Residential Development - This technique can be linked with density bonuses to provide affordable housing.

II Type

This concerns the type of housing uses permitted, which range from single famlly detached through multifamily, and also covers modifications to existing 
structures.

(1) Single-Family/Attached (New) - The number of units in the size of the building is the major concern. When used with intensity approaches, it is possible to require a diversity of types by setting proportional requirements for detached and attached, with internal distribution of number of units/bullding in the attached category. For example, it is possible to have a 100 unit development of 10 singlefamily/attached structures of 2 units each, 10 single-family/attached structures of 4 units each, and 5 single-family/attached structures of 8 units each.

(11) Multi-Family (New) - These structures offer the greatest density thus providing the opportunity for achieving affordable housing objectives.

(111) Accessory Apartments - Marshfleld has a number of large, older homes that are under-utilized and the potential exists for the conversion of homes into two or more units for occupancy by family members and/or special age groups such as newly formed households or the elderly.

\section{Review of Development Processes}

The granting of permits to build new housing and/or modify existing structures, provides an opportunity to control housing development to ensure there is an adequate supply of affordable housing.

(1) Seasonal Stock Conversion - As seasonal cottage properties have been converted to year-round, use there has been an accompanying increase in the sale price of these homes, with a resultant shrinkage of the affordable housing stock. Marshfield could create a grant and/or interestloan write-down fund itself. This would generate rehabilitation if used to write-down short-term rehabilitation loans.

(11) Alternative Development Scheme Requirement - The preparation of alternative development schemes enables regulatory review in the context of social and environmental goals such as affordable housing and open-space preservation as well as the traditional physical improvement review. General health and welfare/public interest rationales underpin such requirements. 
(11) Development By Special Permit - Most housing development proceeds under the traditional subdivision procedure. As a statutorily governed process, subdivision approval means that proposals which meet the Town's Rules and Regulations governing subdivision of land are granted approval by right. To the extent that particular development initiatives can be governed by special permit procedures, the Town's ablilty to achieve the recommendations suggested, is increased. One method is to make such development procedures as Planned Residential Development an optional overlay on existing zones, with review by special permit.

Some of the development control alternatives are discussed and fllustrated in the zoning section of the Master Plan.

Proposals for housing recommendation \#2 include:

1. Establish a code review committee. This committee would review the Town's codes and their enforcement procedures and recommend changes where appropriate.

2. Develop a rehabilitation code for the conversion of summer cottages to year-round dwellings and establish a "certificate of occupancy" permit to include on-site inspection.

Proposal for housing recommendation \#3:

1. Regular inspection of not only new construction, but existing dwellings in areas of potential blight/deterioration of living conditions to comply with the strict enforcement of the housing code.

Advantages of these proposals are that on a community basis the Town can promote and regulate a mixture of residential types by cost, density, and design in order to provide a housing choice for existing and prospective Marshfield residents. The Town will be more able to offer a diversity of choice of housing, and by establishing programs to eliminate substandard housing and preventing further deterioration of living conditions, the Town will be better equipped to meet its housing needs. 


\section{Footnotes}

1. Housing in Marshfield: Affordability Study and Development Control Options, Abt Associates Inc., Boston, Massachusetts, November, 1985, p. 7 .

2. Figure suggested by Planning Board at Zoning By-Law Review Committee Meeting, January 23, 1986.

3. Abt Associates Inc., op. cit. p. 24

4. Conversation with Century 21 broker, Marshfield Office, March $23,1986$.

5. Fair Housing Guidelines (301 Code of Massachusetts Regulations 50.19 - 7/1/79) Affirmative Action Regulations, Section 1.3 
CHAPTER 6

TRANSPORTATION 


\section{TRANSPORTATION}

\subsection{Present Trafic Pattern}

Since the opening of Route 3 in the early 1960s, Marshfield has become a "bedroom community" for Boston and the Route 128 belt. Route 3 is the primary north-south access for the entire south shore. Given the reduced travel time to Boston, Route 3 has been responsible for the rapid growth of the Town.

The regional traffic network, which Marshfield relies on consists of Route 3, for interregional travel, and Routes 139 and 3A. Route 139 serves as the east-west connector and provides direct access to Route 3. Route 3A historically was the primary north to south route in the Town. This changed with the opening of the limited access highway known as Route 3 . Most of the local roads within Marshfield were all developed during the colonial period. With the exception of some minor stretches, there have been no realignments of these early roadways. The improvements to the Towns roads has consisted of the asphalting of the surface to meet the requirements of automobile traffic.

The Town's road network serves two purposes: (1) it provides the means to travel from one location to another: and (2) it promotes access to adjacent properties. As the land along the road is developed and the local traffic flow increases, a conflict arises between the two aforementioned purposes. The frequency of curb cuts, combined with the heavy traffic flows, cause traffic delay and congestion along the roadways. Therefore, the road network must provide principle thoroughfares, with controlled access, so that traffic may move rapidly and without 
interference. Currently, Route 139 serves as the principal thoroughfare of the Town, however it lacks controlled access and needs major improvements to properly serve its function.

At present Marshfield's population is over 22,000 people. During the summer months it increases to a peak of 44,000 people over the July 4 th weekend. During the summer, travel along Route 139 and a section of Route 3A, which runs from South River to Moraine streets, becomes congested. As the Town's population is projected to increase to 35,000 people, this summer-time problem will become year-round.

\subsection{Local Steet Network}

The streets in Marshfield are functionally classified as followed :

Major Street: A street which, in the opinion of the Planning Board, is being used, or will be used as a thoroughfare between different portions of the Town and adjacent communities. An example of this would be Main Street (Route $3 A)$.

Secondary street: A street intercepting several collector streets and which, in the opinion of the Planning Board, may carry traffic from such collector streets to a major street or community facility, including the principal access streets or principal circulation streets of residential subdivisions, and including all streets, except those deslgnated as major streets, of a business or industrial subdivision. An example would be summer street.

Collector Street: A street which, in the opinion of the Planning Board, is being used or will be used primarily, to provide access to abutting lots, and which is not intended for use by through traffic. An example would be Winslow Cemetery Road. 


\subsubsection{Road Conditions}

A road survey of the major and secondary streets in the Town was conducted during March of 1986. This survey was concerned only with road surface conditions. The survey did not take into account other concerns such as traffic volume and road geometrics. Each of the streets was assigned a number ranging from 1 to 5. The value of 1 signified that the street was considered in excellent condition, requiring no immediate resurfacing. A value of 5 was assigned to streets considered to be in extremely poor condition, needing immediate repairs. This survey which 1 s located in the appendix, was used to create the proposed road resurfacing program.

\subsubsection{Road Resurfacing Program}

A number of the Town's secondary streets are falling into serlous disrepair. Using the road survey which we conducted in March, 1986, the following road resurfacing program is suggested.

First Year: Church and Ferry streets

Second Year: Pine and Union Streets

Third Year: School and Highland Streets

Fourth Year: Valley Path and Prospect Streets

These roads, in our view, will require a complete reconstruction. This program may need alteration to incorporate future water or sewer expansion or rehabilitation. While this is an expensive and time consuming task, we feel it is a necessary undertaking. The wear and tear on automobiles is justification alone. Also, if this problem is ignored, the future expenditures will dramatically increase as more roads fall into this category. The Town should devise such a program under an Overall Town Management Program for infrastructure improvement and maintenance. 


\subsection{Traffic Flow}

It can be seen from Table 6.1 that the average daily traffic volumes have increased substantially on Routes $3 A$ and 139 . The Route 139 Traffic study estimated the quality of travel between School and School streets to be level E at peak hour use. Level $E$ designation indicates delays caused by left hand turns or entering traffic. ( Designations range from A to F; an A grade indicates optimum conditions, while an F designation means a total failure of a section of road or an intersection.)

As the Town's population and automobile use continues to grow, and development continues to expand in the land zoned Industrial, Route 139's service level will continue to deteriorate.

$$
\text { TABLE } 6.1
$$

Dally Traffic Volumes

Location

Route 3A

South of Ocean St.

Route 139

Just West of Rt. 3A

Marshfield/Duxbury Line

$$
1970^{\prime} \mathrm{st}
$$$$
\text { ( } \mathrm{ADT} \text { ) }
$$$$
5,100
$$$$
14,900
$$$$
6,250
$$

6,250 $1980^{\prime} \mathrm{s} t \star$

( $A D T$ )

$$
7,700
$$

19,450

9,400

* Data from 1973 Master Plan, Metcalf \& Eddy. Inc. * Data from Massachusetts DPW

(ADT) Average Daily Traffic

\subsection{Public Transportation}

Marshfield is presently served by two bus routes for commuters to Boston. The Plymouth \& Brockton company presently operates these routes with public subsidies. The first route runs from Duxbury along Route 139 in Marshfield, and ends at 
South Station in Boston. The second route runs from the Marshfield High School to the Braintree M.B.T.A. red line station. These commuter routes are important in the overall state goal of reducing the automobile traffic on the highways.

The Town's present low density population cannot support an intra-town bus service. However, Marshfield currently operates a senior citizens shuttle throughout the Town.

\subsubsection{Public Transportation Recommendationg}

1) The Town should actively support the re-establishment of rail service to Boston from Greenbush, Scituate.

2) The train service should be constructed for speeds of at least 80 miles per hour.

3) Marshfield should actively pursue a M.B.T.A. bus route which utilized the old New Haven bus route or Route $3 \mathrm{~A}$. to serve the Proposed Greenbush Station. (See MAP 6.1)

4) Establishment of small parking lots along the bus route.

5) The Town should expand the senior citizens shuttle system to include all citizens.

\subsection{Circulation Problems}

There are three major circulation problems presently facing the town of Marshfield. These will be further accentuated in the future unless steps are taken to eliminate them. The three problems are:

1) Congestion of Route 139 which serves as the primary east to west roadway and the town link to Route 3 .

a) Marshfield is an auto dependent suburb.

b) The backbone of the town's network is Route 139.

c) Since the completion of Route 3 there has been a steady development of commercial activities in both Pembroke and Marshfield along Route 139 between the highway and Marshfield Center. 
MAP 6.1

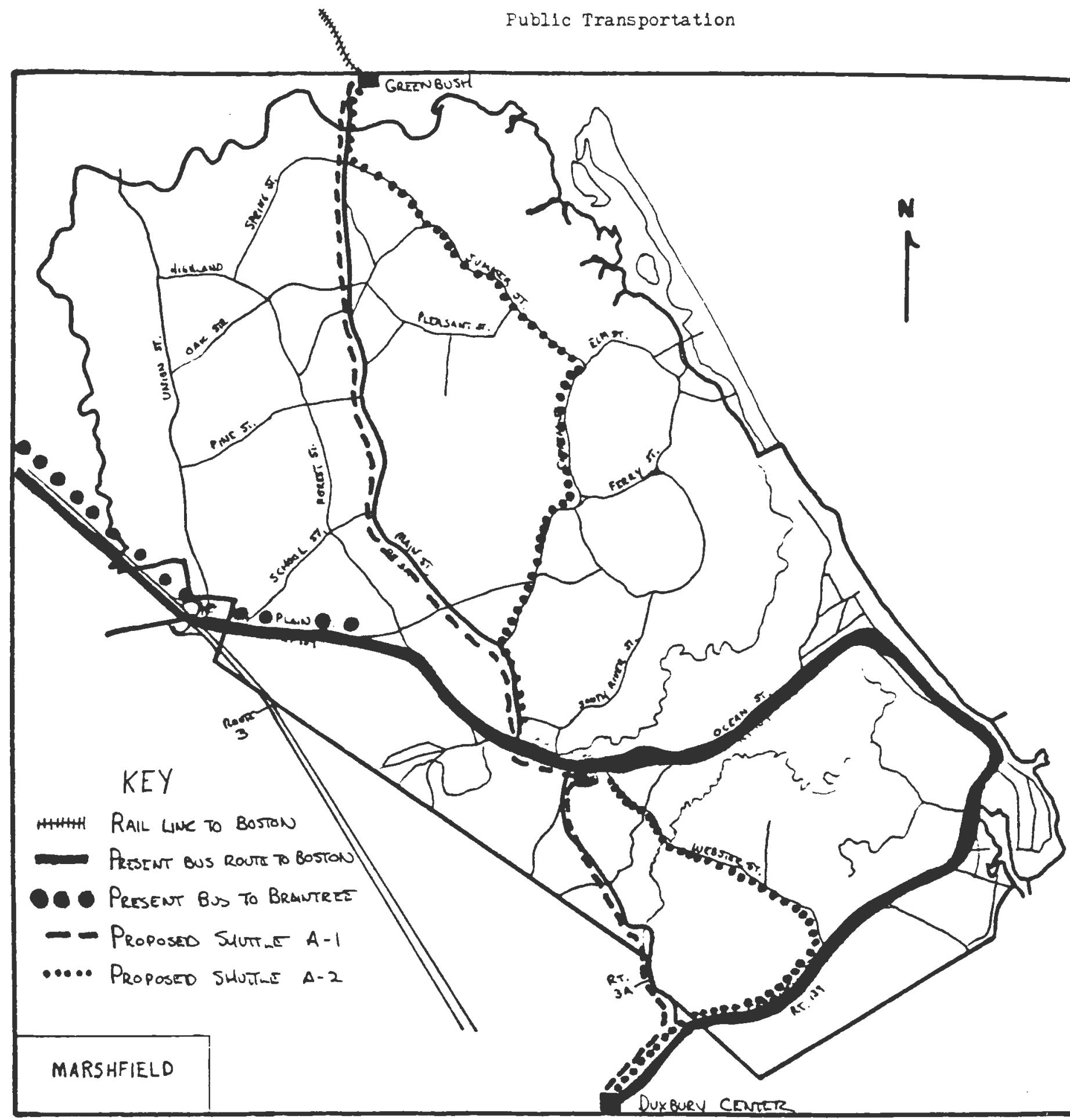


d) Marshfield's population rose dramatically with the completion of the Route 3 limited access highway. This directly reduced the travel time between Marshfield and Boston.

e) Full capacity of Route 139 is achieved during the summer months.

f) As the Towns' population continues to grow congestion will become a jear-round problem on Route 139.

g) Lack of space within Marshfield for a new interchange with Route 3.

h) Any new access road will have to run in or through sections of Pembroke or Duxbury.

1) Areas of environmental constraints exist on the border of Pembroke where a new access road could be built. These environmental concerns should be protected.

2) The limited north to south access of the northeastern section of the town with the Town's commercial center.

a) Majority of north to south traffic funnels into Route 3A between Ferry street and Route 139.

b) During summer months the intersection of Route 139 and Route $3 \mathrm{~A}$ is further congested.

c) The traffic congestion caused by the Marshfield Fair during August acts to isolate the northeastern section of the Town from the commercial center.

3) Poor pedestrian Safety along the Town's main roads.

a) Many of the main roads in Marshfield were developed from the pathways of colonial era. As a result, they are narrow and poorly laid out.

b) A strong desire by the Town's residents to keep the rural atmosphere, thereby resisting the widening of the roads to allow the placement of sidewalks.

c) The lack of proper lighting and sidewalks along the Town's roads presents a safety hazard to the pedestrian population. 
Recommendation 1

To provide the Town with a second east to west roadway that links the coastal areas to Route 3.

Proposal One

Develop a loop road into the industrial zone which would start at the intersection of Union, Oak and Plain ( Route 139) streets. The proposed road would run southeast connecting with Lone Street and Enterprise Drive, then turning northeast to connect with Route 139 at Furnace Street (See MAP 6.2).

\section{Advantage}

The loop would provide alternative frontage for future development in the Industrial Zone. This would reduce the need for additional curb cuts along Route 139. The loop road would provide access to presently land-locked parcels.

Proposal Two

Widen Plain Street (Route 139) to a four lane road with center stacking lanes for left hand turns, where required. The widening is proposed from the intersection of Union, Oak and Plain (Route 139) to the merge with Main Street (Route 3A). Also to install traffic lights at the intersections of Union and Furnace Streets with Route 139.

\section{Advantage}

The four lane roadway will accept future traffic volumes more efficiently. The stacking lanes for left hand turns would relieve blockage on through traffic lanes (See MAP 6.3). The installation of traffic lights at these intersections would provide the required gap time in traffic to permit entry onto Route 139.

\section{Recommendation $\underline{2}$}

To provide the Town with improved north to south access between the town center and the northeastern section of town.

Proposal one

To utilize the former old Colony Rallroad bed between south River and Ocean Streets as a new access road and to install a traffic light at the new four way intersection at Ocean street. 


\section{Advantage}

The new road would provide better access between the Town's commercial center and the northeastern section of Marshfield. This will also reduce the traffic volume on Routes $3 \mathrm{~A}$ and 139. The traffic light would increase the gap time in the Town center.

Proposal Two

To link Humarock and Rexhame with a new roadway and upgrade the intersection of Winslow street and Route 139 by providing a left-hand turn stacking lane.

Advantage

The new connecting road and upgrading of Winslow street would provide for better access from Humarock to Marshfield center. The proposed Improvements would also reduce the traffic volumes on Routes $3 \mathrm{~A}$ and 139. The proposed stacking lane would relieve blockage of the through lane.

\section{Recommendation $\underline{3}$}

To provide better pedestrian safety without destroying the Town's rural character.

\section{Proposal}

Utilizing Bituminous Concrete curbing and packed gravel along one side and providing a three foot paved and painted bikeway on the other side of collector streets.

Advantage

The gravel sidewalk and marked bikeway would provide improved safety for pedestrian and cyclists. The packed gravel would reduce the impervious surface area and preserve the rural character of the community. 


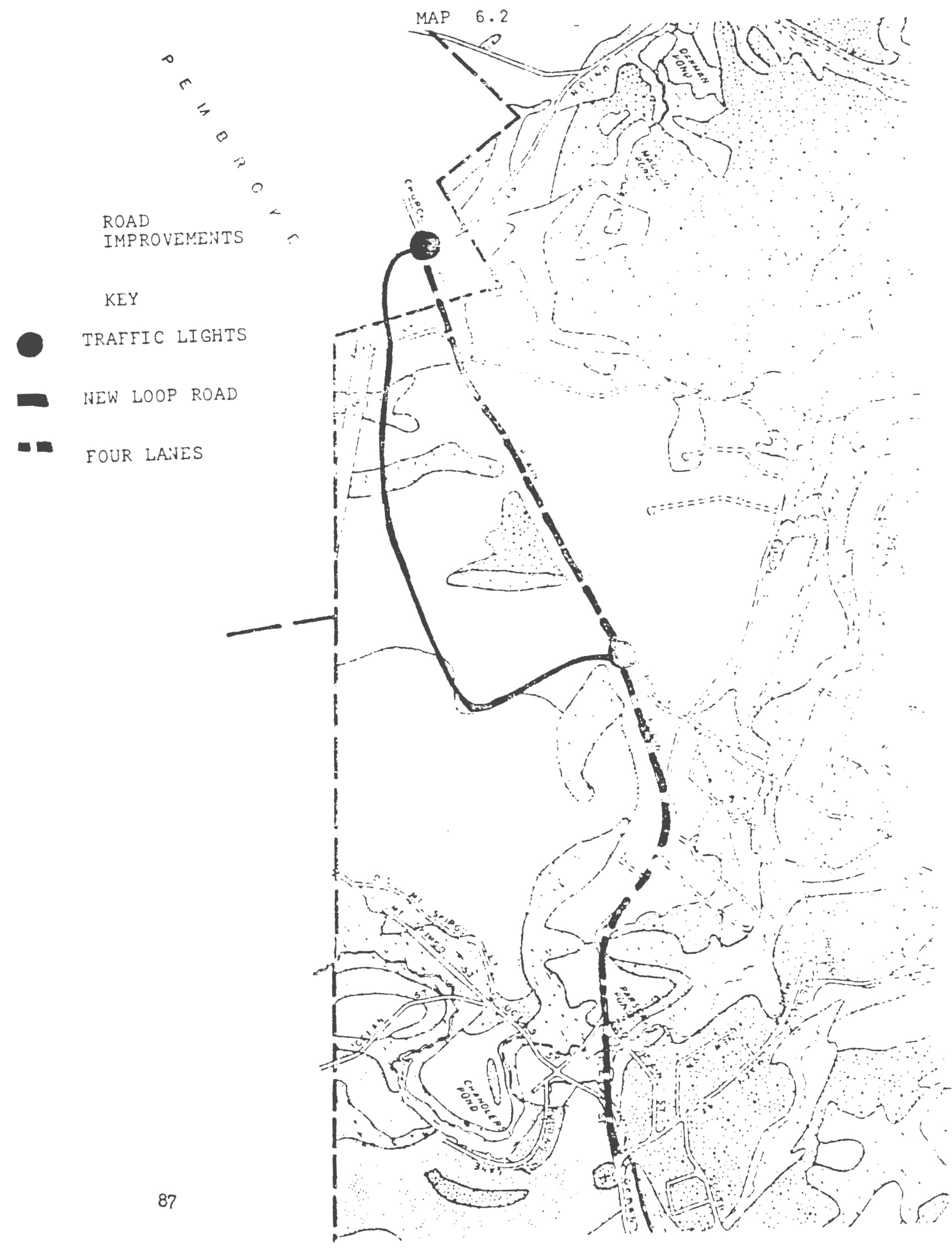


MAF 6.3

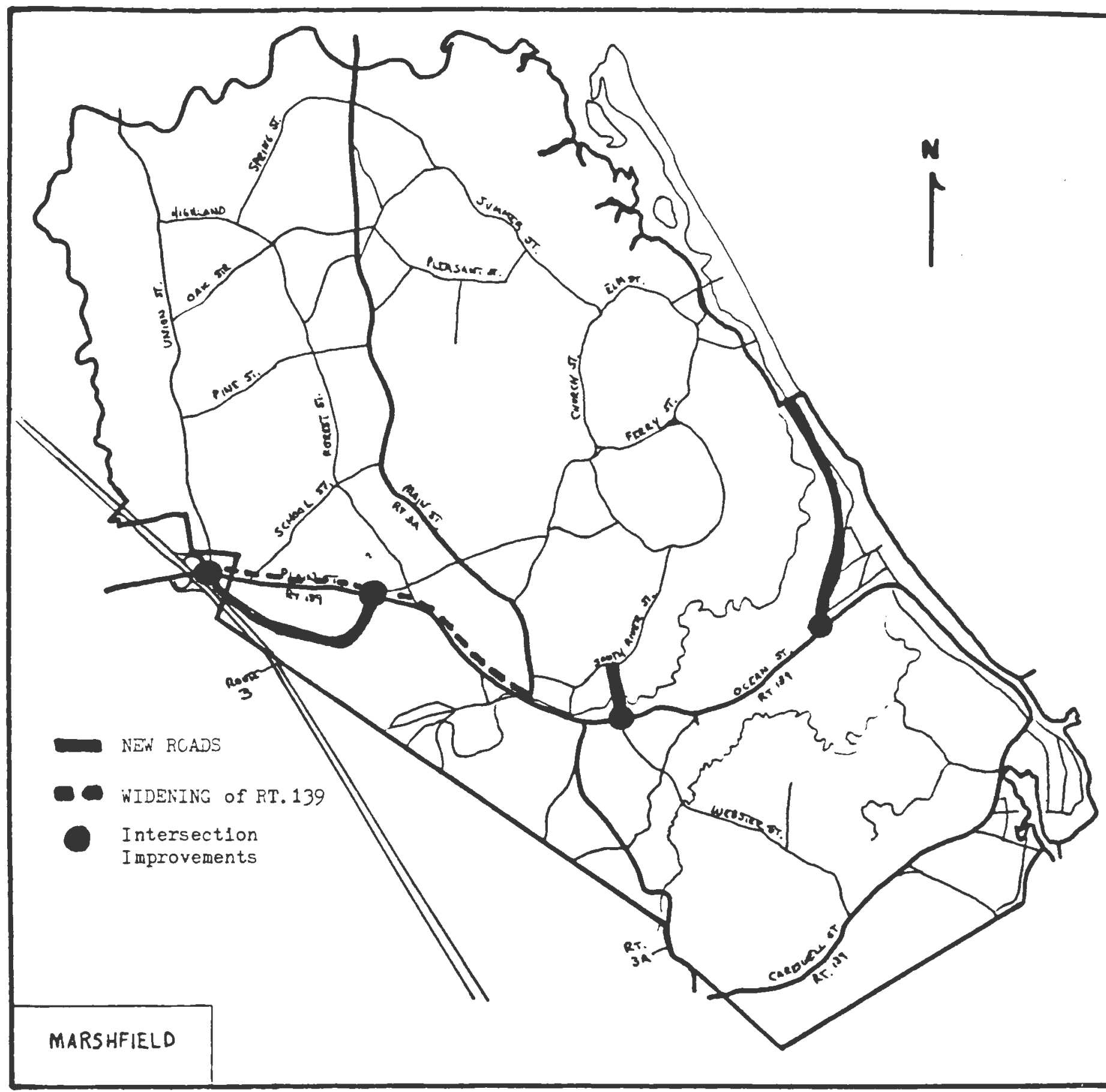




\section{CHAPTER 7}

ECONOMIC ANALYSIS 


\section{ECONOMIC BASE OF MARSHFIELD}

\subsection{Introduction}

The following section provides an analysis of Marshfield's economic base. Presently, Marshfield has no industrial base. although an industrial zone exists in the western portion of the Town. The one light industry which was located there, a sandpaper company, recently moved. Furthermore, commercial development in the Town has been expanding but at a modest rate in order to stay in line with the Town's rural character. In an overall perspective, Marshfield can be considered a bedroom community. In light of this, the following analysis will be primarily focused on Marshfield's past employment trends and future employment opportunities. First, an indepth study will provide an analysis of Marshfield's past employment trends in comparison to its four neighboring communities of scituate, Norwel1, Pembroke and Duxbury (see MAP 7.1). Secondly, two employment models will be utilized in order to study potential employment opportunities in Marshfield.

$\operatorname{MAP} 7.1$

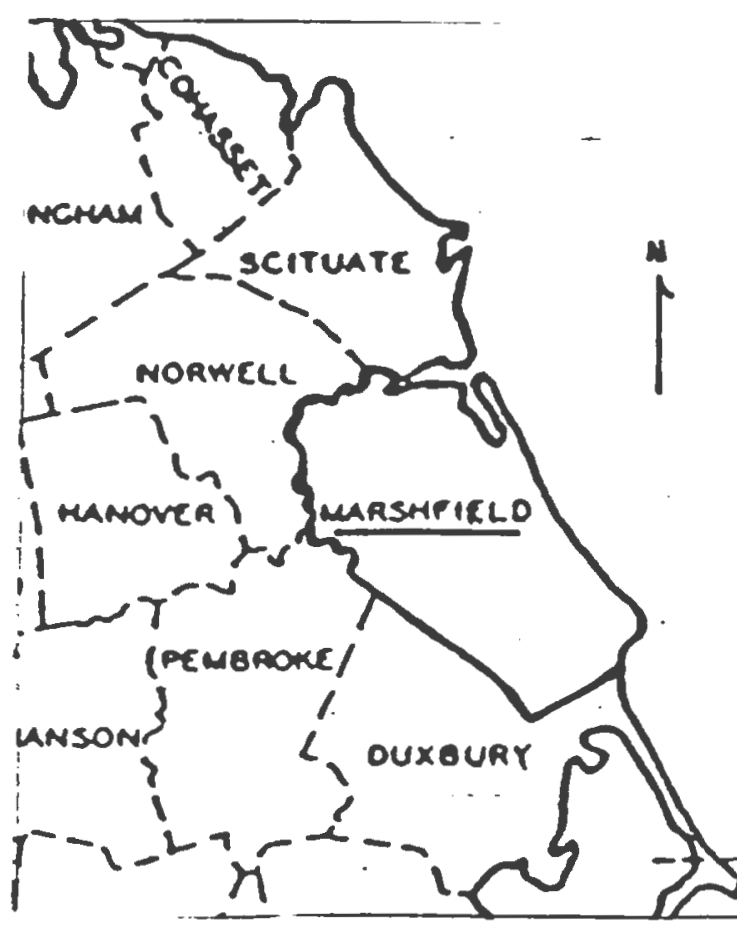




\subsection{Eackground}

From 1ts inception, Marshfield's fertile land and marshes were eagerly sought as farms and homesteads by early settlers. In the ligth century, shipbuilding on the North River and agriculture constituted the two primary sources of industrial employment. In years to follow, a number of Marshfield's residents opted to leave their local Town jobs and found employment in the shipyards of East Boston.

Today, Marshfield is a residential municipality in the Boston SMSA. In 1982, there was a total of 321 establishrents in the Town, as reported by the Massachusetts Division of Employment Security. These establishments employed an average of 28.5 persons and had an annual payroll of $\$ 34,988,600$. Of these local establishments, the retall trade sector employed the greatest proportion of persons at 40.3 percent. Government employment was second while the service sector placed third. From 1980 to 1983, the total number of establishments rose from 306 to 333 for an 8.8 percent increase. During the same period, total employment in Marshfield increased from 2,937 to 3,141 for an overall increase of 6.5 percent.

Marshfield has also become a popular summer resort; however, this has been declining with every year due to conversion of cottages to year-round housing. In the recent past, several cottages have been constructed along the coast. One of the more recent developments in Marshfield has been the attraction of year-round residents who commute to the Boston area for work. 


\subsection{Emplovment Trends}

The economic pattern of Marshfield has followed in line with general trends and developments of the majority of New England towns. The following is a synopsis of Marshfield's employment statistics in relation to its neighboring communities of Pembroke, Duxbury, scituate and Norwell. Table 7.1 compares the number and percentage of workers employed in the various sectors in 1980 in the town of Marshfield and its four surrounding communities.

In 1980, the majority of Marshfield's residents were employed in the service ( 36.9 percent), retall (19.3 percent) and manufacturing ( 17.2 percent) sectors. In analyzing the data, it is apparent to note that the percentage of Marshfield workers employed in agriculture, construction, mining, services and retail trade closely resembles the percentage of workers employed in those sectors in the four surrounding communities. However, of the five communities, Marshfield has the second highest percentage of residents employed in the manufacturing industry, second only to Pembroke. On the other hand, Marshfield has the second lowest percentage of residents employed in FIRE and the lowest percentage of residents employed in the wholesale trade. 
TABLE 7.1

EMELOYMENT BY MAJOR SECTORS

MARSHF IELD, FEMEROKE, DUXBURY, SCITUATE, MORHELL

$$
1980
$$

\section{Economic}

Sector

Town of Marshfield

Iown of Pesbroke

Tot. Eap $\%$ of Tot.

$\stackrel{0}{*}$

$90 \quad .9 \%$

$48 \quad .8 \%$

0

4.37

$7.3 \%$

1272

$21.1 \%$
Agricul ture

Minina

Construction

Hanufacturing

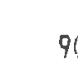

5

614

$6.3 \%$

1672

$17.2 \%$

Iransoortation/

utilities

Wholesale Trade

Retail Irade

Finance, Insur ance

Real Estate

Services

Total

$670 \quad 6.9 \%$

$358 \quad 3.7 \%$

$1879 \quad 19.34$

$839 \quad 8.6 \%$

$3585 \quad 36.9 \%$

$9712 \quad 99.8 \%$
Town of Duxbury

Tat. Enp $x$ of Tot.

81

$553 \quad 9.2 \%$

$264 \quad 4.4 \%$

$1239 \quad 20.6 \%$

$427 \quad 7.1 \%$

$1779 \quad 29.6 \%$

$6009 \quad 1004$
Town of Scituate

Town of Norwell

Tot. Emp Y. of Tot.

$\begin{array}{lr}93 & 1.1 \% \\ 0 & \\ 411 & 5.1 \% \\ 1319 & 16.7 \% \\ 468 & 5.8 \% \\ 383 & 4.7 \% \\ 1564 & 19.2 \% \\ 674 & 8.3 \% \\ & \\ 3214 & 39.6 \% \\ & \\ 8126 & 100 \%\end{array}$

Tot. Eno $\%$ of Tot.

$\begin{array}{rr}74 & 1.7 \% \\ 0 & - \\ 241 & 5.7 \% \\ 606 & 14.2 \% \\ 366 & 8.6 \% \\ 204 & 4.8 \% \\ 844 & 19.8 \% \\ 429 & 10.1 \% \\ & \\ 1490 & 35.0 \% \\ 4254 & 99.9 \%\end{array}$


In order to determine the trends in employment in each sector in Marshfield, a comparative analysis of the ten year period between 1970 and 1980 is conducted (TABLE 7.2). Again, Marshfield is compared to the four surrounding communities in order to put the statistics into perspective.

Marshfield experienced the second highest growth rate in employment in the agriculture/forestry \& fisheries sector, second only to Pembroke. In the construction sector, Marshfield again placed second with a 17 percent increase in employment and second only to Duxbury. In the manufacturing, finance, insurance and real estate (FIRE), and service sectors, Marshfield experienced the highest employment growth rates of all five communities with increases of 34.4 percent, 59.6 percent, and 52.8 percent respectively. In the transportation sector. Marshfield experienced the second lowest employment growth rate with a 40.6 percent increase. In the wholesale and retall trade sectors, Marshfield experienced healthy employment gains consistent with its neighboring communities. In summary, Marshfield experienced a significant increase in employment in each sector, except in mining, during the 1970-1980 period with an overall growth rate of 44.7 percent, second only to Duxbury. In examining 1980 employment statistics more closely, it can be concluded that Marshfield is a residential bedroom community. Table 7.3 illustrates Marshfield's total industrial employment by sector for 1980, including a breakdown of those who work in 


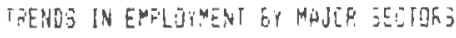
$1970-1980$

Enpiovient

Sector

Agri $i=u l t u r e$

M!ning

Cunstruction

\&

Marisfacturiag

Irdisigrationi

utriites

tholesale Trade

Petall irade

Finanze. Insuranca

Rexl Estate

jervices

Tot 31
Iron of Mareifield

Eas. 1789 Charige

$34 \quad 90+410.0 \%$

$19 \quad 5-72.3 \%$

$510 \quad 614+17.64$

$1099 \quad 1672+34.4 \%$

$395 \quad 370+10.54$

$234 \quad 358+34.76$

$10 \div 9 \quad 1879+45.32$

$339 \quad 639+57.5 \%$

$1093 \quad 3535 \quad+52.6 \%$

$5373 \quad 9712 \quad 44.7 \%$
Town of Pexbraine

1970 1980 Change

Eap. Emp.

$264845.8 \%$

$110-120.0 \%$

$457 \quad 437 \quad-4.4 \%$

$1142 \quad 1272 \quad+10.3$

$273 \quad 553+5.0 .7 \%$

$202 \quad 264+23.5 \%$

$374 \quad 1239 \quad+45.2 \%$

$230 \quad 427+46.24$

$1027 \quad 1779+42.22$

4047 bo019 32.7\%
Town of Duxbury

$\begin{array}{rrr}1970 & 1980 & \text { Change } \\ \text { Eap. } & \text { Eap. } & \\ 176 & d 1 & -58.7 \% \\ 0 & 0 & - \\ 183 & 325 & +43.4 \% \\ 5123 & 576 & +24.2 \% \\ 146 & 369 & +61.5 \%\end{array}$

$135 \quad 216 \quad+45.2 \%$

$422 \quad 769+45.2 \%$

$387 \quad 609+36.52$

692 201) +68.12

$26245683 \quad 48.4 \%$
Temn of Scituate

$\begin{array}{rrr}1770 & 1780 & \text { Chiange } \\ \text { Esp. } & \text { Eap. } & \\ 87 & 93 & 16.5 \% \\ 0 & 1) & - \\ 568 & 411 & -20.6 \% \\ 1009 & 1319 & 423.6 \% \\ 38 ! & 468 & 419.6 \%\end{array}$

$295 \quad 383+23.99$

$965 \quad 1564+58.3 \%$

$489 \quad 674 \quad+27.5 \%$

$227 i \quad 3214+29.2 \%$

$6111 \quad 8126 \quad 26.1 \%$
ThW of Vorweil

\begin{tabular}{|c|c|c|}
\hline 1970 & 1790 & Charge \\
\hline Enp. & Epo. & \\
\hline 197 & 74 & $-6.5 \%$ \\
\hline ) & i) & - \\
\hline 205 & $2^{4 !}$ & $+15.0 \%$ \\
\hline $57 \%$ & \pm 116 & $+5.9 \%$ \\
\hline 195 & 366 & $+47.5 \%$ \\
\hline $10 b$ & 204 & $+49.1 \%$ \\
\hline 40 & 894 & +56.74 \\
\hline $41 t$ & 429 & +3.17 \\
\hline 736 & 1190 & $+5 \% .74$ \\
\hline $234 !$ & 4254 & $33.3 \%$ \\
\hline
\end{tabular}


Marshfield and of those who commute to work outside Marshfield. The statistics reveal that nearly 80 percent of all employees in these sectors were employed outside of Marshfield.

TABLE 7.3

Number of Marshfield Residents Employed

Within and Outside the Town, 1980

Sector

Agriculture

Mining

Construction

Manufacturing

Transportation

Wh. / Ret. Trade

FIRE

Service

Total
Total

Employment
Inside Marshfield
Outside Marshfield

$\begin{array}{rrrrr}90 & 21 & 23.3 \% & 69 & 76.7 \% \\ 5 & 0 & - & 5 & 100.0 \% \\ 614 & 169 & 27.5 \% & 445 & 72.5 \% \\ 1672 & 130 & 7.8 \% & 1542 & 92.2 \% \\ 670 & 128 & 19.1 \% & 542 & 80.9 \% \\ 2237 & 1156 & 51.7 \% & 1081 & 48.3 \% \\ 839 & 133 & 15.9 \% & 706 & 84.1 \% \\ 3585 & 337 & 9.4 \% & 3248 & 90.6 \% \\ 9712 & & & 7638 & 78.6 \%\end{array}$

Source: Census of Population, 1970, 1980

According to the Division of Employment Security ${ }^{3}$, total annual payrolls for Marshfield increased from $\$ 30,973,700$ in 1980 to $\$ 40,239,700$ in 1983 with a net gain of $\$ 9,266,000$, or 23 percent. Average annual wages in Marshfield rose constantly between 1980 and 1983 from $\$ 10.546$ to $\$ 12,811$ (the 1980-1983 period is used because it provides the most recent information). Th1s resulted in a net gain of $\$ 2.265$ or 17.7 percent or an average rate of 4.42 percent during this period. Table 7.4 , illustrates the total annual payroll in Marshfield and 
1ts nelghboring communities. Table 7.5 1llustrates the trends in average annual payroll recelved by Marshfield residents and its four neighboring communities.

According to Table 7.4. Marshfield's overall growth in payroll was modest. In relative terms, the Town's total payroll increase between 1980 and 1983 was among the lowest of the five towns as denoted by the fact that Pembroke and Norwell both experienced far more rapid growth, while marshfield, Duxbury and Scituate experienced a less accelerated growth rate.

In examining the average annual payroll statistics in Table 7.5. of the five communities, Marshfield experienced the second highest total percentage increase between 1980 and 1983 at 17.7 percent, second only to Norwell. Marshfield was also second to Norwell in that its average annual wage growth was 5.9 percent as compared to 8.2 percent. However. Table 7.5 reveals that in 1983. the Town had the second lowest average annual payroll as compared to the State average, with Pembroke having the lowest.

In summary, it is interesting to note that while Marshfield experienced one of the lowest total payroll increases of the five communties between 1980 and 1983. it experienced the second highest increase in average annual payroll. This can be attributed to the fact that the employment rate slightly decreased during this period while wages increased thus raising the average payroll of the Town. Furthermore, it is interesting that even though Marshfield experienced the second highest average annual payroll increase between 1980 and 1983 , it still had the second lowest average annual payroll as compared to the 
THELE 7.4

TOTAL ANNLAL PAYFILL BY TOWN (thousands of dollars) $1980 i-1983$

\begin{tabular}{|c|c|c|c|c|c|}
\hline & Harshtield & Featroke & Duxtury & Scituate & Normel! \\
\hline 1780 & 309737000 & 11805100 & 17825700 & 29752700 & 25687100 \\
\hline 1981 & 32401200 & 15577000 & 19982400 & 322019300 & 28124800 \\
\hline $198:$ & 34988600 & 19135700 & 21686700 & 351998000 & 32411306 \\
\hline 1963 & 402347000 & 25511500 & 21282200 & 37575200 & 40405000 \\
\hline $193 i-1983$ & 9206000 & 13640800 & $345050 \mathrm{j}$ & 7622500 & 20177900 \\
\hline $1980-1983$ & $23.0 \%$ & $53.5 \%$ & 10.36 & 20.42 & $44.7 \%$ \\
\hline$\sqrt{11}$ & $7.7 \%$ & $17.8 \%$ & $5.4 \%$ & $0 . E \%$ & $14.9 \%$ \\
\hline al Gain & 3085607 & 4548533 & 1152160 & 2540833 & 6905967 \\
\hline
\end{tabular}

Source: Davision of Eaployent Securities 
TAELE 7.5

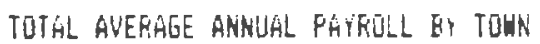

$1980 \dot{0}-1963$

$\begin{array}{cccccc} & \text { Marshifield } & \text { Penbrake } & \text { Duxbury } & \text { Scituate } & \text { Normeil } \\ 19801 & 10540 & 9120 & 12242 & 10729 & 11697 \\ 1981 & 11872 & 9603 & 12703 & 11807 & 12572 \\ 1992 & 12255 & 9477 & 13919 & 12598 & 13635 \\ 1965 & 12511 & 16650 & 14150 & 13054 & 15514\end{array}$

Total Gän

Total \& ba1n

Anrual is Ga1n

Average Annual Gain
226

$17.7 \mathrm{~h}$

$5.9 \%$

755
1530

14.4:

$4.8 \%$

512
1908

$13.5 \%$

$4.5 \%$

636
2325

17.26

5.72

775

3817

24.6:

$8.2 \%$

1272

Source: Divasion of Eaployeent Securities 
State figure. This indicates that scituate, Duxbury and Norwell all had higher average annual payrolls in 1980, 1981, and 1982 than Marshfield and therefore, even though Marshfield experienced a significant growth rate between 1980-1983, the realized increase still placed Marshfield only fourth overall relative to the state.

In 1980. the labor force in Marshfield numbered 10,270, an increase of 4.611 or 44.9 percent from 1970. Table 7.6 shows the number of persons who were employed and those unemployed in 1980. In comparing these statistics to the neighboring towns of Marshfield, it is apparent to note that Marshfield's employment statistics are not atypical. An encouraging note is that Marshfield had a relatively low unemployment rate.

TABLE 7.6

Number of Persons Employed \& Unemployed In Marshfield, 1980

\begin{tabular}{cccccc} 
Age & Total in Cohort & \multicolumn{2}{c}{ Employed } & \multicolumn{2}{c}{ Unemployed } \\
$16-19$ & 1524 & 797 & $52.3 \%$ & 96 & $6.3 \%$ \\
$20-24$ & 1565 & 1225 & $73.3 \%$ & 78 & $5.0 \%$ \\
$25-54$ & 8563 & 6567 & $76.7 \%$ & 252 & $2.9 \%$ \\
$55-64$ & 1623 & 961 & $59.2 \%$ & 77 & $4.7 \%$ \\
$65+$ & 1669 & 162 & $9.7 \%$ & 7 & $0.4 \%$ \\
Total & & & & & \\
& & & $94.6 \%$ & & $5.4 \%$
\end{tabular}

Source: Census of Population, 1980 
In placing Marshfield's more recent employment statistics into perspective, an analysis of the south Coastal service Delivery Area is conducted. The SCSDA is composed of 22 Massachusetts cities and towns, including Marshfield. The South Coastal SDA is contiguous on the north with the Boston SDA, on the west with the Metro South/West SDA and Brockton SDA, and on the south with the Bristol SDA. The 1984 annual average unemployment rate within the South Coastal SDA was 4.5 percent. This was three tenths of a percentage point lower than the state rate of 4.8 percent, and three percentage points lower than the national rate of 7.5 percent. In these terms, Marshfield had a 4.5 percent unemployment rate in 1984. Furthermore, while the unemployment rates in the South Coastal SDA ranged from a high of 7.2 percent to a low of 2.4 percent, Marshfield had an unemployment rate of 4.5 percent, which was also the same overall average for the SDA.

Data on the total number of south Coastal unemployment insurance claims paid to residents of the SDA was also investigated. The claimants are experienced workers who are involuntarily unemployed, mostly due to plant closing or layoffs. The data revealed that a total of 2,764 claims were paid to residents of the South Coastal SDA during December of 1984 . Marshfield accounted for 140 , or five percent, of these unemployment insurance claims. While UI claims decreased by 17.2 percent for the entire SCSDA area between December 1983 and 
December 1984, the number of such claims in Marshfield decreased by 15.7 percent (from 190 to 166 claims) during that same period. However, the percent change in the number of UI claims filed by Marshfield residents in comparison to its neighboring communities was the lowest during that period.

In light of Marshfield's past employment trends, the next logical step would be to place its economic base in a larger area. In order to examine the dynamics of Marshfield's economy, it is necessary to place it in context within a larger economic area to comprehend its status. A knowledge of the macro-economic structure and the function of a larger economy is a fundamental step in a land use planning analysis at the micro-economic level. The present and future of a large economy, in this instance, the Boston Metropolitan area, is controlled by the vitality of its income producing activities. Since most metropolitan areas, such as Boston, flourish because they serve and function as centers for the production and distribution of goods and services, fobs are created and employment opportunities (spin-offs) evolve both within the urban core and along its peripheral areas. Viewed in these terms, since a large economic area exerts such an influence over a region, it directly or indirectly influences the pattern of land development that occurs even in the hinterland areas of the metropolitan area. Towns outside the immediate Boston Metropolitan Area (see MAP 7.2) have felt, and still, feel the impact of its growth and expansion as evidenced by increased housing costs, land acquisition costs, and rising employment rates. 


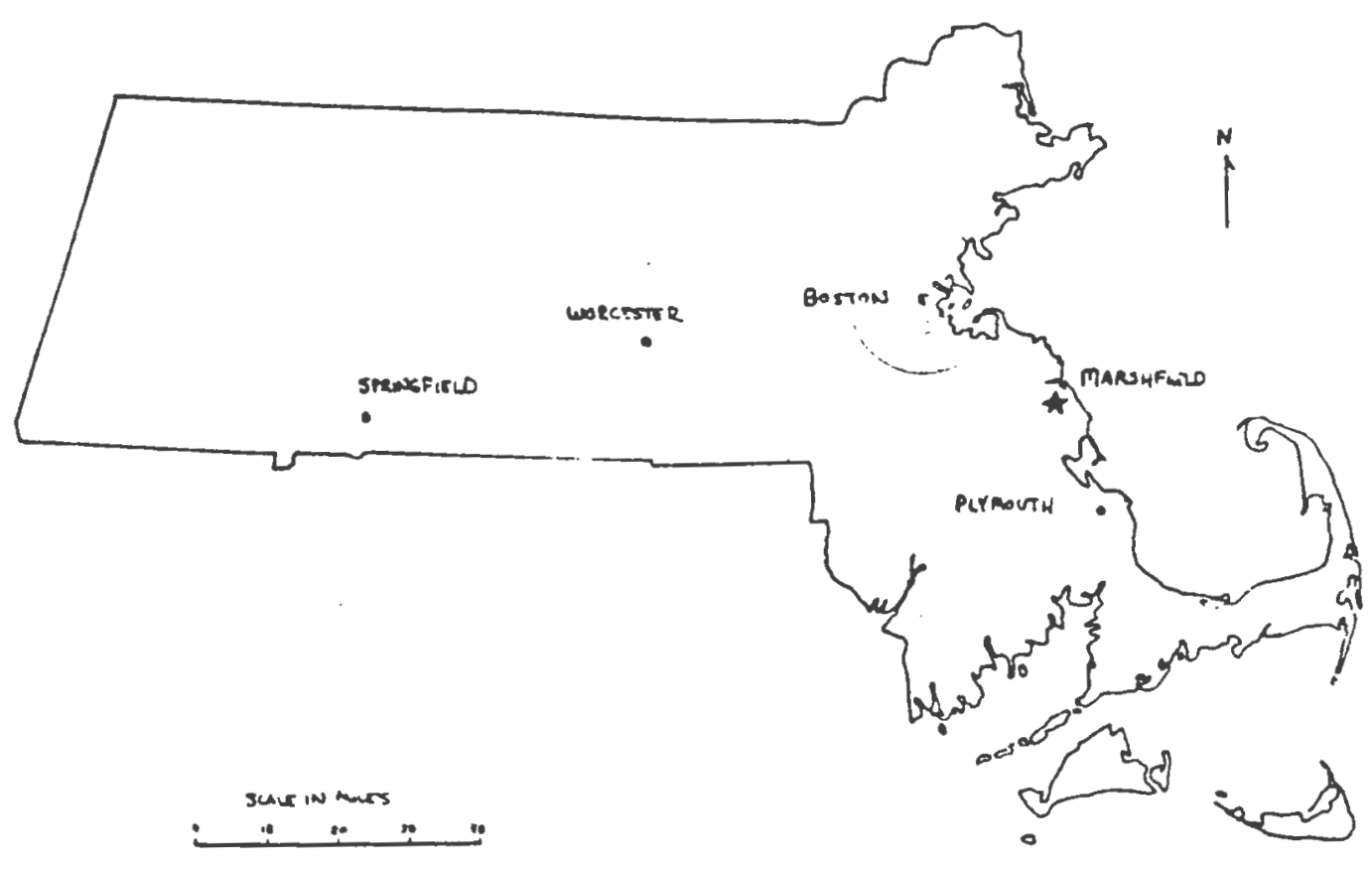

It is not only important to decipher how and why growth occurs but also to determine what the future holds. It is important to examine past economic and employment trends in order to project future scenarios. For example, to project valid forecasts, estimates of future land requirements for industrial uses would be based on manufacturing employment trends while future space needs for commercial uses depend on employment trends in wholesale and retail trade. Two approaches to studying Marshfield's economy are conducted to project employment opportunities. The first approach is economic-base analysis and the second approach is shift-share analysis.

\subsection{Economic Base Analysis}

Economic base analysis conceives the economy of a locality as formed by two all encompassing classes of productive activity. The first is "basic" activity which produces and distributes goods and services for the purpose of export to firms and 
individuals outside a defined localized economic area. The second is "non-basic" or "local" activity in which goods and services are consumed within the local economic area. The goal of this approach is to formulate a distinction between activity which brings new money (an infection) into the community (basic activity) as opposed to activity which only recirculates money which already exists there (non-basic activity).

It is in Marshfield's best interest, therefore, to strengthen and expand its "basic" activity which would act as a catalyst in generating growth in the total economy. As new money proceeds to enhance expansion in "basic" activity and provide the base for "non-basic" growth, it can create new jobs and improve living standards for those currently employed. The underlying premise is that a local or regional economy's growth depends on the expansion of its exports to other areas. In conducting this analysis, the regional economy which will be used to compare to Marshfield's economy will be Plymouth County. From this analysis, location quotients and the multiplier factor will determine the relative vitality of Marshfield's economy.

In examining the data, the findings are encouraging. As Table 7.7 reveals, using 1982 total employment statistics of the Town, the majority of Marshfield's economic sectors are "basic". The industries of agriculture/forestry \& fisheries, construction, transportation/utilities, FIRE, and services are all "basic". It would be in Marshfield's best interest to support and maintain the status of these industries. Of course, one must bear in mind 
that the remaining three industries should not be ignored at the expense of the other industries. The three "local" industries should also endeavor to increase their employment levels so as to rejuvenate their levels of productive activity.

TABLE 7.7

"Basic" and "Non-Basic" Economic Sectors In Marshfield, 1982

\begin{tabular}{lcc} 
Sector & $\begin{array}{l}\text { Location } \\
\text { Quotient }\end{array}$ & $\begin{array}{c}\text { Productive } \\
\text { Activity }\end{array}$ \\
\hline Agriculture & 2.02 & Basic \\
Mining & 0.66 & Local \\
Construction & 1.85 & Basic \\
Manufacturing & 0.73 & Local \\
Transportation & 1.28 & Basic \\
Wholesale/Retail & 0.66 & Local \\
FIRE & 1.79 & Basic \\
Services & 1.55 & Basic
\end{tabular}

Source: Thesis Group

In determining the growth factor potential for Marshfield, an employment multiplier is calculated. The result, again, is encouraging. The employment multiplier factor is 1.67. An interpretation of this statistic means that for every 10 "basic" jobs created, 6.7 new "local" jobs are generated. 


\subsection{Shiftshare Analysis}

This analysis, as well as the previous analysis, must be conducted by placing the Marshfield's economy within a larger economic entity. It is a technique which measures proportional changes to determine how a local market economy shares in the changes of a larger economy. In this analysis, Marshfield is again the local market economy and its interdependence will be examined against the State of Massachusetts. Three projections will be presented which forecast future employment levels in 19 2-digit SIC industries. The three forecasts are labelled "Constant Growth", "Stagnant State", and "Stagnant Local". A list of the 19 SIC sector (standard industrial classification) industries is provided for reference.

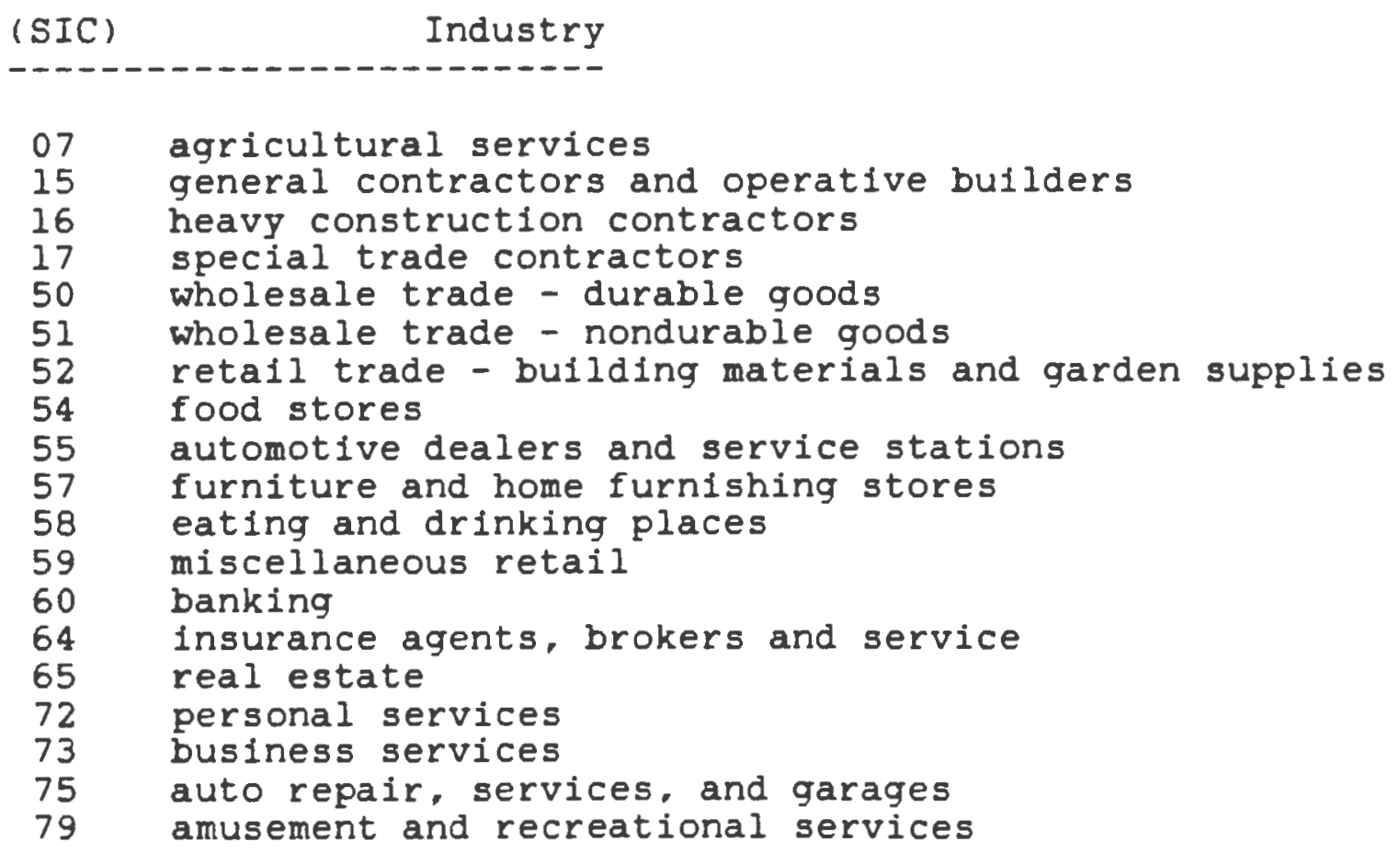




\subsubsection{Constant Growth}

The first projection. Scenario I, illustrated in Table 7.8, presumes that the economic trends of the 1976-1984 period will be repeated in the 1984-1992 period. Accordingly, the economic growth, proportional shift, and differential shift factors as calculated for the 1976-1984 period are summed, extrapolated into the future, and multiplied by 1984 sectoral employment levels. The resulting employment growth forecast, printed under "Forecast 1992", projects that Marshfield's employment levels will increase in all SIC sectors except for SIC 57 which is furniture and home furnishing stores. This projection discloses that by 1992 employment in these sectors will grow by 35 percent or 1,110 jobs.

It is estimated that the three highest projected employment opportunities will occur in the industries of special trade contractors (SIC 17) with 323 projected job opportunities, heavy construction contractors (SIC 16) with 139 projected job opportunities and eating and drinking places (SIC 58) with 201 projected job opportunities. Conversely, while employment in the auto repair and garage services (SIC 75) will experience an increase, it will realize the least growth with only 3 projected job opportunities. The column labelled "ForGrwth" illustrates the number of projected job opportunities in each SIC sector. 
TAE:E 7.8

SCERE:E! I

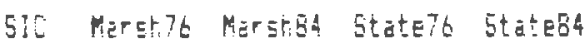

\begin{tabular}{|c|c|c|c|c|}
\hline 7 & 10 & 34 & 5750 & 9545 \\
\hline 5 & 4 & EI & i7c: & ZEE \\
\hline 10 & ! & 27 & 1003 & 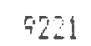 \\
\hline 9 & $\therefore$ & . & $4: 5$, & $58 \%$ \\
\hline
\end{tabular}

\begin{tabular}{|c|c|c|c|c|}
\hline 50 & 15 & $5:$ & QUEIt & ESE: \\
\hline $5:$ & $i$ & 44 & $55=47$ & $t 6: 2:$ \\
\hline 5 & $4:$ & $5 E$ & $12=0$ & $1 \leq 3$ \\
\hline 58 & $\because: \bar{E}$ & 274 & TE & Q7=? \\
\hline 55 & 19 & 146 & $4: 40$ & $4: 105$ \\
\hline 57 & :5 & 7 & 14775 & 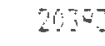 \\
\hline $5 E$ & 324 & 505 & $\therefore 15 E-2$ & $104=7$ \\
\hline 55 & $: 4 t$ & $19=$ & $50: 2$ & 729 \\
\hline$t$ & 17 & 45 & $44 \leq E:$ & $54=8$ \\
\hline 64 & $4 \bar{i}$ & 62 & 125 & 25 \\
\hline$t^{5}$ & 25 & $4:$ & 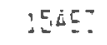 & tid \\
\hline $7 i$ & 45 & 77 & 2359 & $29 ! 7$ \\
\hline 7.5 & it & 53 & 6955 & IALCE: \\
\hline 75 & 72 & 35 & 17924 & 15107 \\
\hline 75 & 45 & 73 & $144 \div 9$ & 1ES5 \\
\hline & ك & 2367 & 764432 & 955809 \\
\hline
\end{tabular}

EeGrFatt Fropshit Uiffstit

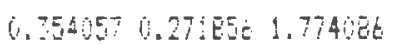

$0.354970 .26169: 0.107655$

$0.354557-6.645246 .629525$

0.3545070 .0763540 .905414

6.354520 .050452 .14851

$0.35457-0.165=0.647016$

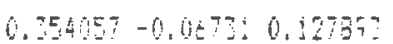

$0.35407-0.28780 .1666: 0$

C. $3545-0.212060 .0402$

$0.356 .578 .024 .14-0.94025$

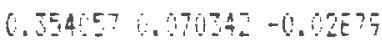

$6.354057-0.95226$ 0.017275

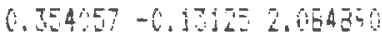

$0.3547500 .67540-0.35562$

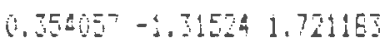

$0.354657-0.095240 .416057$

0.554570 .7460551 .212367

$0.354570 .018: 77-0.27848$

$0.354057-0.085010 .557782$

$0.35457,0.600000 \quad 0.182745$
$(6+H+1)$ For Gints

Forezest

1972

$\begin{array}{rrr}2.40000 & 52 & 116 \\ 0.723404 & 55 & 146 \\ 6.77593 & 139 & 161 \\ 1.339255 & 327 & 564\end{array}$

\begin{tabular}{|c|c|c|}
\hline 2.577733 & 154 & $1 E 7$ \\
\hline $0 . E S T S 3$ & 37 & $8:$ \\
\hline$\dot{0} .4: 463^{4}$ & 24 & $E 2$ \\
\hline $0.25 t 8 \mathrm{a}$ & 70 & 344 \\
\hline (1. 105060 & 15 & 161 \\
\hline$-0,5625$ & -4 & 3 \\
\hline 0.395504 & 201 & 705 \\
\hline 0.315068 & 60 & $25:$ \\
\hline 2.367692 & 95 & 142 \\
\hline $0.6 ? 3469$ & 55 & 137 \\
\hline $0.7 t$ & 73 & 77 \\
\hline 0.673513 & 52 & 127 \\
\hline 2.3125 & $1: 3$ & 176 \\
\hline 0.69375 & 3 & $3 E$ \\
\hline 0.622222 & 45 & $11 E$ \\
\hline
\end{tabular}

$0.536002 \quad 1110 \quad 3177$

NeV:

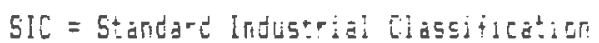

Suldre: Thesis Group

Marshte = 1570 Eajoyment in Marstifiejd in said sector

Marstes = 1964 Enolowert ir Marshifie in said sector

5tate7t = 1976 Eadowert in State in said sector

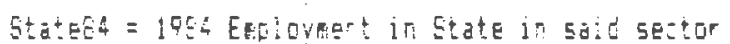

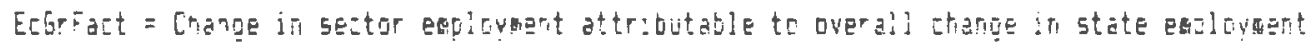

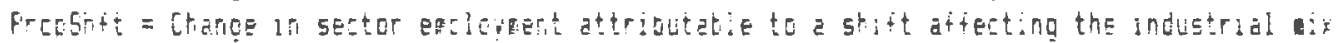

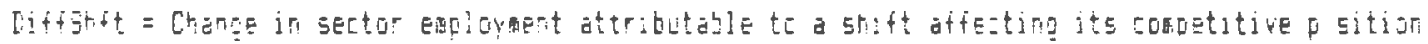

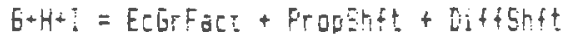

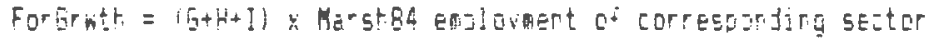

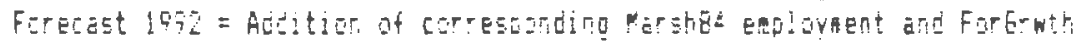




\subsubsection{Stagnant State}

The second projection, Scenario II, as illustrated in Table 7.9, presumes that total statewide employment will not increase between 1984-1992, but rather employment trends within individual sectors will remain constant. One should note that the column labelled "EcGrFact" in Table 7.11 is set to zero. The proportional and differential shift factors are entered as they were in the first scenario. The three factors are summed and then multiplied by current local employment to yield an estimate of projected sectoral growth.

According to this scenario, Marshfield's total employment is projected to increase by 378 jobs or 16.5 percent, an 18.5 percent lower growth rate than scenario 1 . Of the 19 industries, 14 are projected to increase in job opportunities while five are destined to decline. These five are food stores (SIC 54), automotive dealers and service stations (SIC 55), furniture and home furnishing stores (SIC 57), miscellaneous retail (SIC 59), and auto repair and garage service (SIC 75).

It is estimated that the three highest projected job opportunities will occur in the industries of special trade contractors (SIC 17) with 237 projected job opportunities, heavy construction contractors (SIC 16) with 131 projected job opportunities, and wholesale trade (SIC 51) with 115 projected job opportunities. On the other hand, employment in retail tradebuilding material/garden supplies (SIC 52) will realize the least 
growth with only 3 projected job opportunities. The column labelled "ForGrwth" 1llustrates the number of projected job opportunities in each SIC industry. 
THE:E 7.7

SEETFIC II

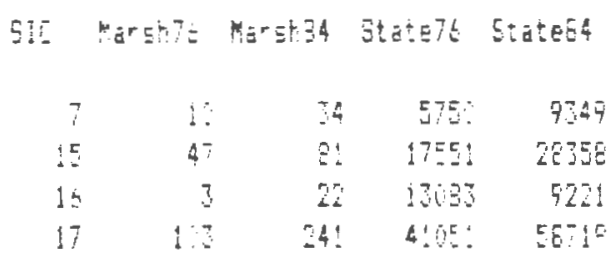

EcE.Fact Froostit Dit+5itit

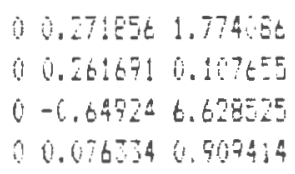

Forezest

1992

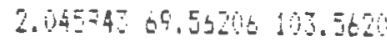

\begin{tabular}{|c|c|c|c|c|}
\hline$=0$ & $\vdots 5$ & 5 & $E A+Z t$ & ESE: \\
\hline$\therefore$ & 26 & 44 & $c_{1}=\bar{s}$ & that: \\
\hline 52 & $4 i$ & $5=$ & 367 & 120 \\
\hline 54 & $2 ! E$ & 274 & $76: 0 ?$ & ers: \\
\hline 5 & 15 & $14:$ & $4142 E$ & $4: 1=9$ \\
\hline 5.7 & it & 7 & 14775 & 20 \\
\hline 56 & 504 & 50 & 11502 & $1=47$ \\
\hline 5 & $14=$ & 172 & $5: 20$ & 72 \\
\hline E) & 15 & $4 j$ & $426=:$ & 5450 \\
\hline$=4$ & 47 & $\varepsilon_{-}$ & 12.80 & 25075 \\
\hline te & 25 & 44 & IEAE & bil \\
\hline 75 & $4=$ & $\overline{i i}$ & $25: 5 !$ & $25 ! 71$ \\
\hline 75 & it & 5 & t9E5E & JALG \\
\hline $7 E$ & 72 & I5 & 1394 & 4910 \\
\hline 79 & 45 & $i:$ & 14437 & IESIS \\
\hline & $1-45$ & 2067 & 7.445 & 955969 \\
\hline
\end{tabular}

0.36934729 .9171211349171

5.975796151 .5440153 .5440

$0.985790837 .5854 \quad 473.5254$
KEV:

Sir = Stariard Indistrial dassification

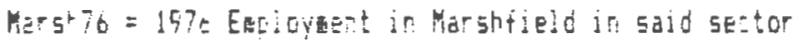

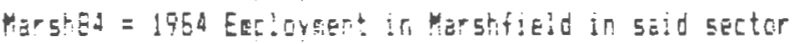

Etate76 = 197t Esoloyent ir State in said sector

Stategs = 1984 Explaveret in State in 5a:d sector

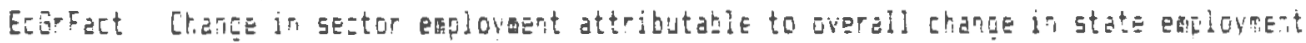

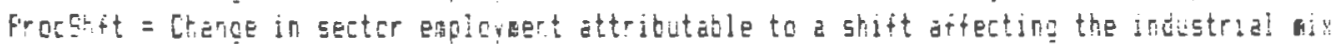

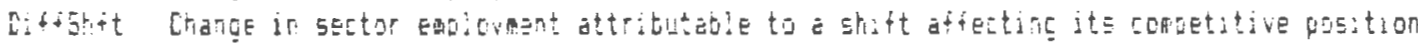

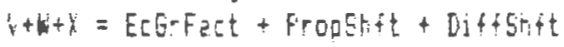

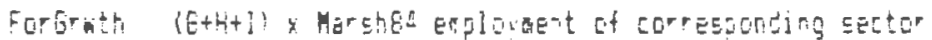

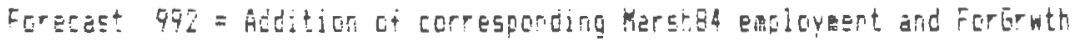

Sojrce: Thesis Goup

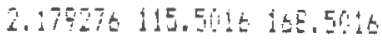

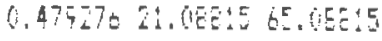

$0.0695775 .5474605: 34$ ?

$-0.09717-26.626=24-.2737$

$-0.24799-35.20-4109.79=5$

$-6.51652-6.415300 .50435$

$0.04154721 .10647525 . j 660$

$-0.3053-7.4859154 .54$

1.553t5 64.00631 127.006

$0.3194: 2$ 66.19:5! 10..1915

$6.45547 \quad 17.86: 4561.86: 45$

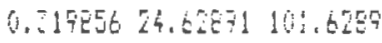

1. $956445103.795^{-3} 158.79^{\circ} 4$

$-0.20930-9.1107+25.88975$

0.26516519 .5760692 .5760 .

6. 185745377.73592444 .795 
7.5.3 Stagnant Local

In the third and final projection, scenario III, as illustrated in Table 7.10 , is based on the assumption of identical economic performance in both the state and Marshfield economies. According to this scenario, the differential shift factor for the individual Marshfield sectors are set at zero. The economic growth and proportional shift factors as calculated for the 1976-1984 period are summed, extrapolated into the future. and multilplied by 1984 sectoral employment levels. The resulting employment growth forecast, printed under "Forecast 1992" projects that Marshfield employment levels will increase in all SIC industries except for two: heavy construction contractors (SIC 16) and real estate (SIC 65).

This projection discloses that by 1992, employment in the remaining 17 industries will grow by 26.2 percent, or 732 jobs. While this forecast predicts a growth rate which is 8.8 percent less than scenario I. it does predict a growth rate which is 9.7 percent greater than Scenario II. It is estimated that the three highest projected employment opportunities will occur in the industries of special trade contractors (SIC 17) with 103 projected job opportunities, insurance agents, brokers and services (SIC 64) with 84 projected job opportunities, and business services (SIC 73) with 58 projected job opportunities. Conversely, furniture and home furnishing stores (SIC 57) will experience the least growth with only 2 projected job opportunities. The column labelled "ForGrwth" 1llustrates the number of projected fob opportunities in each SIC industry. 
TAELE 7.1\%:

SCERAEIS III

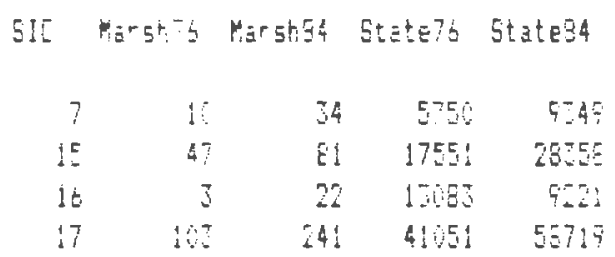

EegrFact Froesint: Diffsreft

$(k+L+1)$ Forerwit 1992

0.354570 .27165

$0.625: 1321.25105$ 55.2E:G5

$0.3542570 .26: 691$

0.61574645 .87561 130.8756

$0.35407-0.64924$

$-0.29517-6.45422 \leq 5.5 \% 57$

0.3569570 .076 .34

$0.430 .41103 .725 \div 344.724$

\begin{tabular}{|c|c|c|c|c|}
\hline 50 & 15 & 53 & $00-3 t$ & $E 581$ \\
\hline $5:$ & 24 & 44 & 55547 & $b t_{-}=Z 1$ \\
\hline E- & 43 & 53 & $12 t^{\top}$ & 16305 \\
\hline 54 & $\therefore: E$ & 274 & TEtos & 675:- \\
\hline 55 & $1: 2$ & $14:$ & $4: 25$ & $45: t 5$ \\
\hline 57 & 16 & 7 & 1479 & 20393 \\
\hline 56 & 54 & 56 & 115322 & 164791 \\
\hline 5 & $1^{2}=$ & .92 & $5=2$ & $72: 2$ \\
\hline 60 & 15 & $4:$ & $44 \leq=1$ & 5460 \\
\hline 64 & 45 & $8_{2}^{r_{1}}$ & :27YE & 25 \\
\hline$b=$ & $\therefore$ & 44 & $154=7$ & 011 \\
\hline $7 i$ & $4 t$ & 7 & $2 \div: 51$ & 25170 \\
\hline 75 & is & 53 & GFES & $\because 2681$ \\
\hline 75 & $\because=$ & $3 E$ & 1944 & 195] \\
\hline $7 \div$ & $4=$ & 73 & 14437 & \\
\hline & $\because 74=$ & $2 j t ?$ & $71.45=2$ & 950709 \\
\hline
\end{tabular}

0.545570 .07945

0.38500220 .4051273 .40512

$0.354057-0.168 .4$

0.1657158 .17146252 .17140

$0.354 .5:-0.0075:$

$0.25674016 .6365-74,699$

0.15027041 .17370315 .1739

1.642046 6.135610 102.135

$0.7763712 .645597 \quad 9.645577$

0.424399215 .5547 ?25.5547

0.29579455 .79256246 .7925

$0.222819 .5804705,5534$ ?

1. $3909784.35590165 .35=5$

-0. $50118-42.2920 \quad 1.707937$

0.25741519 .2517554 .85175

1.10013250 .30700111 .3070

0.37223413 .02025 4E.05252

0.26547915 .5961592 .54607

$0.5-4057$, G1E!

0.354057731 .85642796 .650

kevi:

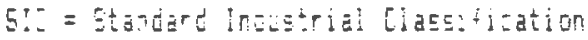

SOLEE: TheE:S GROHD

Herstit = $197 \mathrm{t}$ Eafloysent in harshideld in said sector

Marshat = 1984 Eacioverit ir Marshfieid in saic sector

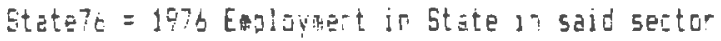

Statéc4 = 1984 Enc:ovnent. ir State in said sector

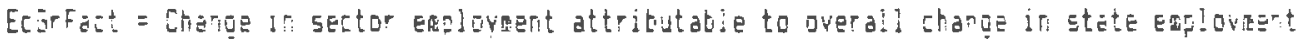

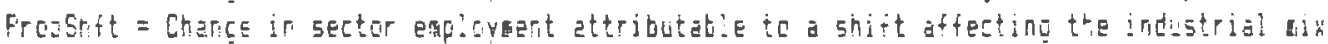

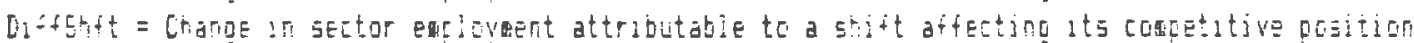

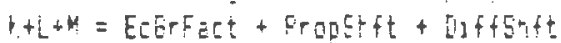

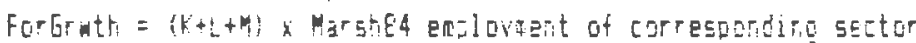

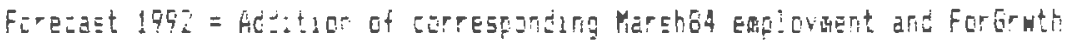




\subsection{Observations}

The following, Table 7.11 and Diagram 7.1, is a crosscomparison of the three scenarios. In 1984, the number of Marshfield residents who were employed in those various sectors numbered 2,067. According to the first scenario, the number of profected employment opportunities in those 19 SIC industries will increase by approximately 1.110 jobs by the year 1992. By contrast, if statewide employment does not continue to grow, but the relative compositions of Marshfield and the state economies remain constant, employment will increase by approximately 378 jobs by 1992. Finally, according to the third scenario, which projects no change in the relative performance of the Marshfield economy, employment in those industries will grow by approximately 732 jobs by 1992 .

It is felt that the scenario which will most likely evolve 1s scenario I. This assumption is based on the following. First of all, it is difficult to imagine that scenario II will take place because 1 t assumes that statewide employment will not grow and that the relative composition of the State's economy will remain constant; and in turn, this leveling-off effect will influence Marshfield's economy such that it too will become stagnant. However, Massachusetts has one of the lowest, if not the lowest, unemployment rates in the country today. Moreover, it is experiencing significant economic growth, especially in the hi-tech, office and service sectors. Therefore, with a booming economy and optimism still on the rise, scenario II is not likely 


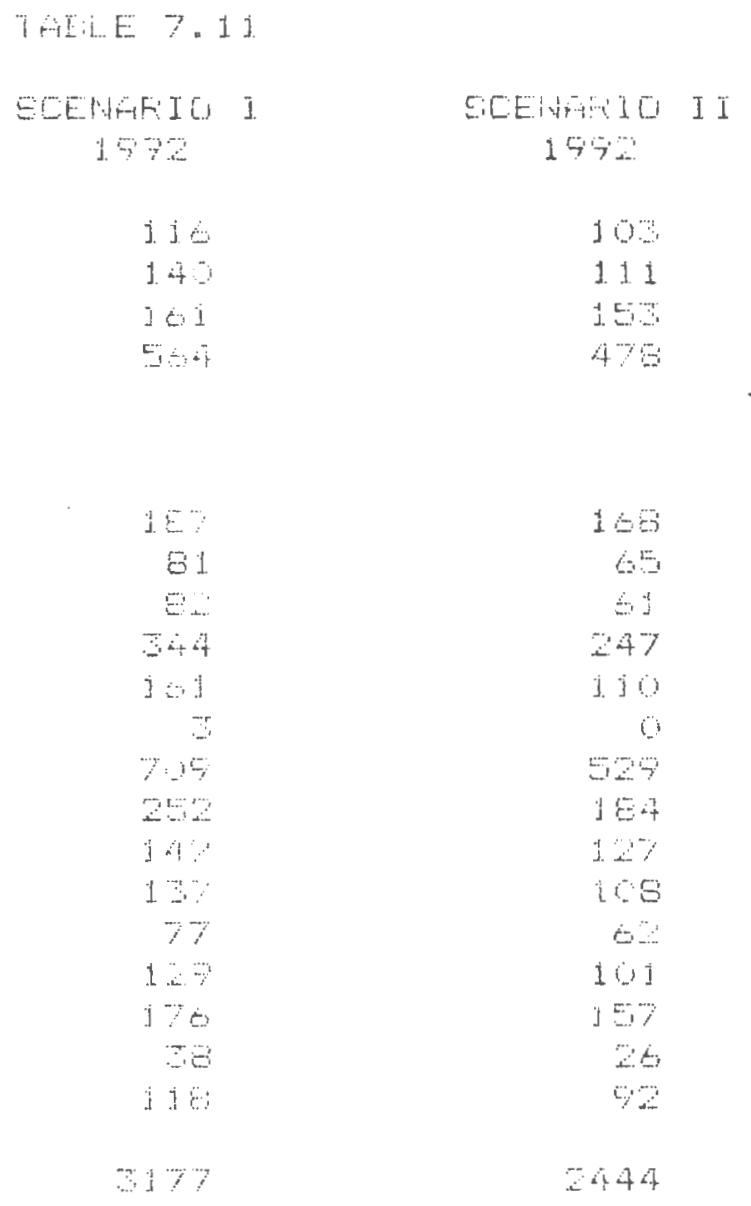

Source: Thesis Group 


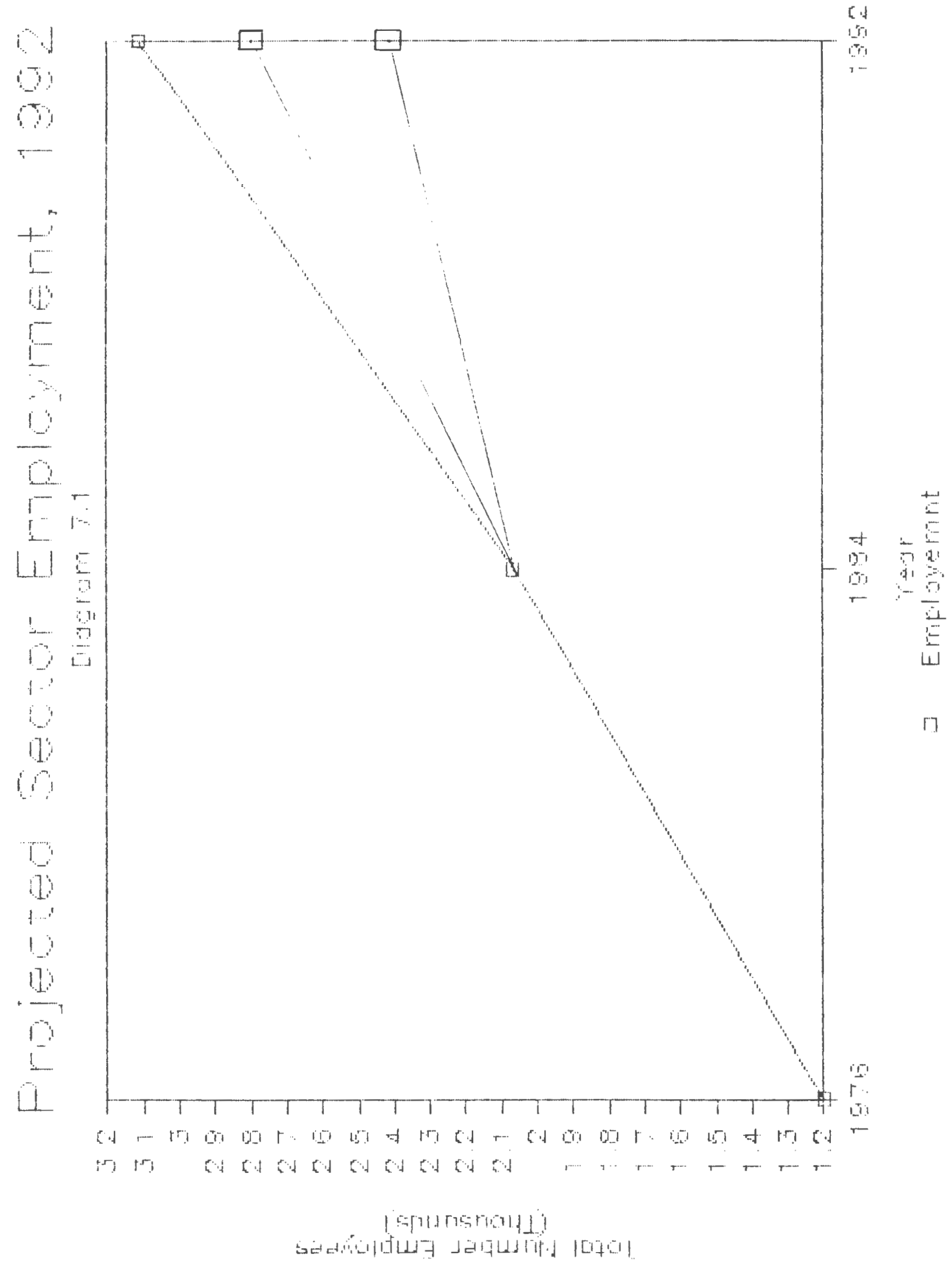


to occur. Secondly, it is felt that Scenario III will also not take place because it assumes that no change in the relative performance of Marshfield's economy will occur. However, considering that the chapter concerning demographics revealed that the population of Marshfield will continue to grow, the employment base of the Town will undoubtedly expand to serve the growing population. Furthermore, due to Marshfield's close proximity to Boston. Boston will continue to emit growth pressure on the Town, therefore inhibiting Marshfield's economic performance in becoming dormant and stagnant. Hence, it is felt that due to projected population growth in Marshfield, and its close proximity to an expanding Boston economy, Scenario $I$ is most likely to evolve. Moreover, Table 7.12 further substantiates that Scenario I is the most likely forecast. Table 7.12 points out that 15 of the 19 economic sectors in Marshfield are either "winners" (meaning such sectors at both the State level and in Marshfield are growing) or "mixed winners" (meaning such sectors are growing in their competitiveness more rapidy in Marshfield than at the State level), suggesting a relatively stable and healthy base.

The following analysis, as delineated in Table 7.12, illustrates those industries in Marshfield's economy which are considered either to be "winners", "mixed-winners", "losers" or "mixed-losers" today based on 1976-1984 statistics. First, the industries in the upper right-hand corner of Table 7.12 are termed "winners" because not only are such industries growing in 
the state economy, but more 1mportantly, local establishments in such sectors in Marshfield are growing faster than the statewide average. Secondly, it is encouraging that no industries are in the lower left-hand corner of Table 7.12 because such industries would be declining and therefore coined "losers". Such industries would be shrinking not only in the state economy, but would be shrinking even faster in Marshfield's economy than at the statewide average. Thirdly, industries in the upper left hand corner of Table 7.12 are coined "mixed-winners". This infers that industries at the state level are losing importance but that these same industries are growing in competitiveness locally in Marshfield. Finally, industries in the lower right hand corner are termed "mixed-losers". This infers that those industries are growing in importance throughout the remainder of the state, but are declining in competitiveness locally in Marshfield. 
IHELE $\% .12$

\begin{tabular}{|c|c|}
\hline 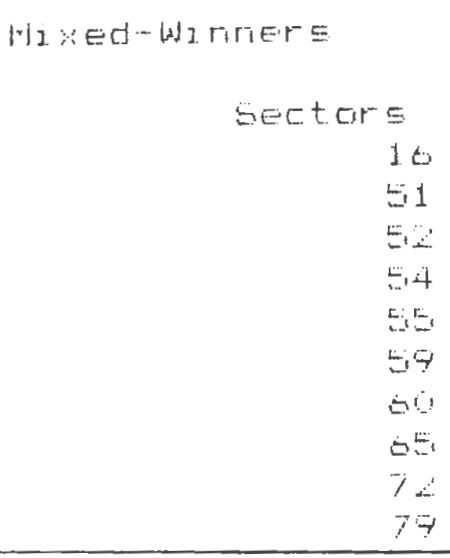 & $\begin{array}{r}\text { Sectors } \\
7 \\
15 \\
17 \\
50 \\
75\end{array}$ \\
\hline $\begin{array}{l}\text { Sectcors } \\
\text { WORE }\end{array}$ & $\begin{array}{l}\text { Mraed-Losers } \\
\text { Sector } \\
\\
57 \\
58 \\
54 \\
75\end{array}$ \\
\hline
\end{tabular}

Source: These 1 E Group 


\subsection{Recommendations}

1) Marshfield should seek to maintain and enhance its commercial center.
a) avoid commercial expansion into the industrial zone
b) allow provisions for the expansion of the General Business zone $(B-1)$
c) formulate a promotional package for the B-I zone

2) Promote secondary commercial node in the beach area.
a) utilize the Brant Rock Esplanade as the secondary commercial node
b) allow mixed use development in the Town pier vicinity
c) formulate a promotional package for the Brant Rock area

3) The Town should seek to expand its industrial base.

a) The Town must consider extending water and sewer lines to the industrial zone in order to attract potential industrial development

b) construction of the proposed industrial loop road

c) formulate a promotional package for the industrial zone 


\section{Footnotes}

1. Marshfield Monograph; October 1984; page 7

2. Marshfield Monograph: October 1984; page 7

3. Division of Employment Securities, 1980-1983; pages 28,32 , $33,133,134$

4. Division of Employment Securities, South Coastal Service Delivery Area: March 1985; pages 1, 8, 9, 11 
CHAPTER 8

FINANCIAL ANALYSIS 
FINANCIAL ANALYSIS

\subsection{Introduction}

In times of inflation and consequent strain on municipal budgets, elected officials and municipal department heads must be aware of the public costs associated with private development, major rezonings andor alternative land use plans. When projecting resident and school age children populations, attributable to development, the number of public employees who need to be hired, and the kinds of municipal facilities needed to serve a changing population, it is necessary to study the town's past financial activity in order to evaluate and/or determine the town's ability to provide funds needed for improvements and fund them in the most cost efficient manner. It is necessary to maintain a reasonable long-term balance by comparing fiscally beneficial decisions with those that are not.

\subsection{Tax Levp, Tax Rate, Per Capita Levy}

Communities, such as Marshfield, which have been experiencing constant growth for a number of years have been allocating an increased amount of funds towards community services. Basically, there are four reasons which can be attributed to increasing costs in the provision of municipal services. The most obvious is growth. Cost is a function of growth. As a municipality expands both physically and demographically, the provision of services must also be expanded in proportion in order to serve adequately the needs of the 
people. Secondly, the rising cost of service provision can be attributed to prevaliing economic forces such as inflation. Thirdly, the cost of services increases because they are inherently labor intensive. As wages increase for town employees, for example, to adjust to cost of living increases, this in turn raises the cost of providing municipal services. Public services can only be delivered by people and therefore. the cost of providing municipal services is greatly influenced by labor. Lastly, the provision of services is inelastic. A town has to provide a certain amount of municipal services in order to maintain its residential, educational, environmental and economic well-being. Since there is an obligation on the part of the town to provide public services, the cost of providing them can increase significantly the level of supply and/or efficiency can remain relatively constant.

As a community grows, the demand for land increases. This in turn causes an increase in land values. An ideal situation arises when a town's increased spending is offset by its increase in realized taxes which result from the increase in assessed value. However, more often than not, increased spending exceeds the growth rate in its tax base. This results in increases in the tax rates. Therefore, it is necessary to plan ahead in order to ensure that increased spending will increase in equal proportion with the growth in the taxable base. 
In Marshfield. Just as in most localities in the Boston Metropolitan area. land values and housing costs are spiraling upwards. Even with proposition $21 / 2$ imposing a limit on local taxes on real and personal property. Marshfield received slightly over $\$ 13,000,000$ in real estate and property taxes in 1984, the most the Town ever received up to that point in time. In examining Marshfield's tax base (see TABLE 8.1), one can note the trend which the tax rate has assumed over the past 26 years. Between 1965 and 1978 , the tax rate had increased by $\$ 60.00$, or a constant increase of $\$ 4.62$ per year. The tax rate in 1978 was the highest rate Marshfield residents had ever experienced. By 1981, the rate had fallen to $\$ 25.00$ per thousand, a 278 percent decrease from 1980. This sudden drop in the tax rate in the early part of the 1980 s is attributable to Proposition 2 1/2. Since then, the tax rate has remained virtually constant, except for 1984 when the rate dropped to $\$ 24.00$. Further examination of Marshfield's tax structure reveals that the tax levy had been steadily increasing from 1960 to 1979. During this period, the tax levy increased by $\$ 9,110,161$ for an average annual Increase of $\$ 479,482$. From 1980 to 1984 , the tax levy fluctuated without casting any apparent trend. In 1984, Marshfield realized its highest tax levy ever. Moreover, the statistics reveal that between 1960 and 1978 the per capita levy increased by 116 percent, indicating that the cost of municipal service provision has significantly risen. From 1970 to 1984, the per capita levy fluctuated every year; and again revealing no particular trend. By 1984, the per capita levy rose to $\$ 538$, the highest ever. 
TABLE B.1

Marshfield's Tax Rates \& Levies 1960-1984

$\begin{array}{llll}\text { Year } & \text { Tax Levy } & \text { Tax Rate } & \text { Per Capita } \\ 1960 & \$ 1,587,828 & \$ 73.50 & \$ 235.00 \\ 1965 & \$ 2,732,308 & \$ 36.00 & \$ 268.00 \\ 1968 & \$ 4,046,642 & \$ 47.00 & \$ 304.00 \\ 1969 & \$ 4,642,759 & \$ 51.00 & \$ 323.00 \\ 1970 & \$ 5,531,410 & \$ 59.00 & \$ 361.00 \\ 1971 & \$ 6,090,054 & \$ 62.00 & \$ 365.00 \\ 1972 & \$ 7,005,774 & \$ 67.00 & \$ 388.00 \\ 1973 & \$ 7,444,610 & \$ 66.50 & \$ 384.00 \\ 1978 & \$ 10,483,904 & \$ 96.00 & \$ 507.00 \\ 1979 & \$ 10,697,989 & \$ 91.00 & \$ 505.00 \\ 1980 & \$ 10,299,286 & \$ 94.50 & \$ 477.00 \\ 1981 & \$ 10,924,367 & \$ 25.00 & \$ 508.00 \\ 1982 & \$ 10,357,910 & \$ 25.00 & \$ 481.00 \\ 1983 & \$ 11,426,275 & \$ 25.00 & \$ 524.00 \\ 1984 & \$ 11,644,813 & \$ 24.00 & \$ 530.00\end{array}$

Source: Town Accountant's Records, Town Hall 


\subsection{Revenues}

Marshfield has a number of revenue sources. Its largest source has been generated from local property taxes which constituted between 20.6 percent and 39 percent of the total town income (local, state and federal funds) and between 55.4 percent and 65.78 percent of total local income alone during the period of 1978-1984. The Town's second largest source of revenue, as was the case between 1960 and 1973, was derived from state and county funds which accounted for 8.5 percent to 15.6 percent of the Town's total receipts. Federal funding is also an important revenue source. Although Marshfield's proportion of revenue sharing had decreased substantially between 1978 and 1984, it was still an important source of revenue. Table 8.2 provides a synopsis and comparison of Marshfield's receipts for 1978, 1980, 1982 and 1984.

\subsection{Expenditures}

Marshfield's expenditures for 1978, 1980, 1982 and 1984 are illustrated in Table 8.3. The categories with the largest operating expenditures have been Schools, the Department of Public Works, Protection of Persons and Property Recreation/Unclassified, along with General Expenditures. Relatively speaking, Veteran Services, Libraries, and Health and Sanitation have historically accounted for the least amount of expenditures during that period. 
TABLE 8.2

TUWH FELEIFTS 1976, $198 \mathrm{~A}, 1992.1984$

\begin{tabular}{|c|c|c|c|c|c|c|c|c|}
\hline Source: & 1978 & Fercent & 1980 & Ferceit & 1982 & Fercent & 1954 & Fercent \\
\hline Taxes & 1192755 & YE.t & $1: 724: 37$ & 20.1 & 11537367 & 26.7 & 13055790 & 34.2 \\
\hline $\begin{array}{l}\text { LiCETEES? } \\
\text { Persts: }\end{array}$ & 95596 & * & 80542 & $*$ & 155.58 & $*$ & 245068 & $*$ \\
\hline FITES & 17110 & $*$ & 38491 & $t$ & 35420 & 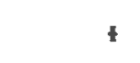 & 66.691 & t \\
\hline Feterál & $1259: 3$ & 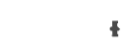 & 6701065 & $12 .:$ & 297142 & $*$ & 782328 & 2.3 \\
\hline $\begin{array}{l}\text { Etatel } \\
\text { County }\end{array}$ & $2747: 6 !$ & 9.0 & 5192279 & 5.1 & 446207 & 11.1 & 5202672 & 15.6 \\
\hline $\begin{array}{l}\text { Other bratts } \\
\text { Gifts }\end{array}$ & None & Hare & 3935 & 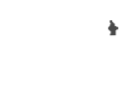 & $26: 70$ & + & 4130 & $t$ \\
\hline $\begin{array}{l}\text { Ctrier beretaj } \\
\text { Feverdu }\end{array}$ & 135 & 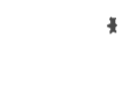 & $2 t o t$ & $\star$ & $3 E 2 t)$ & $*$ & 6725 & $t$ \\
\hline Excise Tak & 969775 & 3.2 & $1215: 4$ & 2.3 & 567179 & 1.3 & 437620 & 1.3 \\
\hline $\begin{array}{l}\text { Street f } \\
\text { Sewer }\end{array}$ & 24800 & 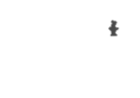 & $210 e^{2}$ & * & 220132 & * & 786137 & 2.4 \\
\hline Water & 800014 & 2.6 & 77258 & 1.4 & 83595 & 2.0 & 145713 & 4.4 \\
\hline $\begin{array}{l}\text { Geriera: } \\
\text { Governerit }\end{array}$ & $282 \pi i$ & 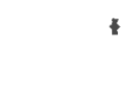 & 32450 & 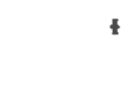 & 34105 & $\star$ & 59583 & * \\
\hline Departuental & 82962 & \pm & 42661 & $*$ & 69436 & $*$ & 66332 & $t$ \\
\hline Alrport & 565 & 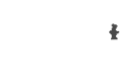 & 8155 & * & 11216 & $t$ & 13376 & 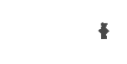 \\
\hline Uniclassified & MES & + & 2993 & 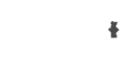 & 11675 & * & 33150 & $t$ \\
\hline Interest & gerato & $t$ & $54123:$ & * & 423673 & 1.0 & 627270 & 1.9 \\
\hline $\begin{array}{l}\text { Huncipal } \\
\text { Incebtedrose }\end{array}$ & $505=75$ & 16.5 & 12119000 & 21.3 & $68 \angle \mathrm{EEE} ?$ & 17 & 193250 & 5.8 \\
\hline Augency & 10003 & * & 24960 & $*$ & $35: 74$ & 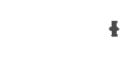 & 6183 & t \\
\hline Trust Furde & 12118 & $*$ & $57: 15$ & औ & $7344 t$ & 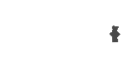 & 8.364 & t \\
\hline $\begin{array}{l}\text { Ceretery } \\
\text { Jourrial Entro }\end{array}$ & $10^{-50}$ & 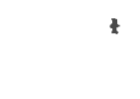 & 34110 & 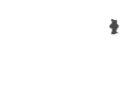 & $3 i 945$ & $*$ & 4441 & * \\
\hline $\begin{array}{l}\text { Total Fevolving } \\
\text { Furds }\end{array}$ & 313212 & 1.0 & $428: 72$ & $t$ & 465695 & 1.2 & 57352 & $\therefore .7$ \\
\hline
\end{tabular}




\begin{tabular}{|c|c|c|c|c|c|c|c|c|}
\hline $\begin{array}{l}\text { InUeEte-t } \\
\text { Mu-ides }\end{array}$ & None & None & Ile12000 & 20.4 & 8543870 & $2: 2$ & 1650000 & 4.5 \\
\hline $\begin{array}{l}\text { Pavroli } \\
\text { dectetione }\end{array}$ & $371922 \mathrm{t}$ & 12.2 & 4311405 & 7.6 & 4355112 & 16.6 & $5039 \div 72$ & $: 5.3$ \\
\hline $\begin{array}{l}\text { hieturds to } \\
\text { jesartre-ts }\end{array}$ & 10424 & * & 29083 & 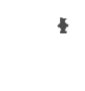 & 164554 & 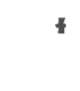 & $9000 \%$ & 1 \\
\hline Ither Fed Lide & 6 & $*$ & hore & NITE & Nöne & nüte & 48000 & 1.4 \\
\hline Feverue Er.zrire & 22475 & $\therefore 3$ & $15=8=45$ & $2 . E$ & 1047597 & 2.6 & 45650 & 1.4 \\
\hline Mis[ej] & $25=1757$ & 7.8 & hDIE & $y+E$ & Hore & MOTE & Nare & Nor:e \\
\hline TSt & $35954:$ & 59.5 & 56515756 & 59.0 & $4024 i 14=i$ & 95.4 & 3725710 & 95.7 \\
\hline
\end{tabular}


TABLE 8.3

TOKN EHFEKITURES 1978. 1964. 1982. 1954

\begin{tabular}{|c|c|c|c|c|c|c|c|c|}
\hline$E E_{L}+E:$ & 150 & FErzent & 1980 & Fercent & 1962 & Fercent & 1584 & Ferient \\
\hline $\begin{array}{l}\text { Gererai } \\
\text { Governatt }\end{array}$ & 51546 & 1.7 & 56515 & 4 & 588321 & 1.5 & 762162 & 2.5 \\
\hline $\begin{array}{l}\text { Fretestigr of } \\
\text { Fereates } \\
\text { frojerty }\end{array}$ & 2uting & 7.6 & 2553397 & 4.3 & 250145.24 & 6.5 & 24.01 is & 4.0 \\
\hline 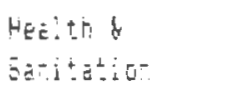 & $274: 7$ & + & 27855 & $\bullet$ & $27864 t$ & 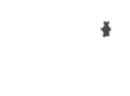 & 307013 & 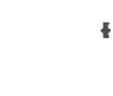 \\
\hline Veterad Servicee & REs: & 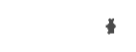 & $1: 7: 30$ & $*$ & 120417 & 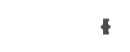 & B7t:? & 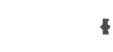 \\
\hline Stcocis & $8 i 6200$ & it. 5 & sidist & 15.4 & 8756670 & 2.7 & 10202640 & 31.7 \\
\hline L:DreFjes & $14: 52$ & $\ddagger$ & 16156 & $t$ & SUESO & $t$ & 151250 & \& \\
\hline 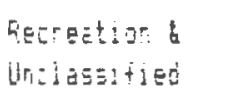 & $125=74$ & 4.6 & $147 \leq 20 !$ & 2.5 & 1472558 & $3 . E$ & 1722727 & $5 . ?$ \\
\hline $\begin{array}{l}\text { Legertront of } \\
\text { futide kerle }\end{array}$ & 1858435 & $6 . \therefore$ & 1743447 & 3.3 & $202153 E$ & 5.2 & 2375010 & 7.4 \\
\hline $\begin{array}{l}\text { Totei Interest } \\
\text { b Dett }\end{array}$ & 957048 & 7 & doente! & S.E & $144519 t$ & $\therefore .7$ & 155005 & 6.0 \\
\hline $\begin{array}{l}\text { Totai Geineral } \\
\text { Eroenditures }\end{array}$ & 11672454 & 37.9 & 32274750 & 54.4 & $1965 ? 524$ & 51.8 & 9168521 & 28.5 \\
\hline $\begin{array}{l}\text { Nor-RE UEUE } \\
\text { Accounts }\end{array}$ & 10504:1 & 3.4 & 8083465 & 13.6 & 457399 & 1.2 & $205065 ?$ & 6.4 \\
\hline $\begin{array}{l}\text { Total Fereriue } \\
\text { Shorirdo }\end{array}$ & $24 \div 448:$ & 8.1 & 1023510 & 2.7 & 1035000 & 2.7 & 42000 & 1.5 \\
\hline$M i s c \equiv l j a r z 0 i s$ & Nine & Norie & $456:$ & + & Nöte & Hone & None & None \\
\hline TETE & $30955: 53$ & 10 & $5726: 214$ & 95.5 & 38511427 & 99.7 & 322615 & 99.8 \\
\hline
\end{tabular}




\subsection{Observations}

Diagram 8.1 illustrates the trend which Marshfield's revenues and expenditures have assumed between 1978 and 1984 . The town's annual revenues and expenditures both were on the increase until they reached a peak in 1980; and since then, both have decreased dramatically. This decrease in revenues, and subsequently in Town expenditures, can be directly attributed to decreasing federal assistance under the Reagen Administration and to Proposition $21 / 2$.

It is projected that the Town's expenditures will begin to increase if policies/recommendations put forth in this document are implemented by the Town. Recommendations such as school expansion, expansion of fire facilities, and road construction and resurfacing are among some of the recommendations which will hike municipal expenditures. Conversely, as expenditures rise, revenues will remain relatively constant. However, revenues in fact, may decrease significantly if massive federal cuts in domestic spending continues. The cutbacks in federal assistance may be replaced by an increase in state and county contributions.

The bottom line is how will Marshfield finance the provision of future services and improvements. Proposition $21 / 2$ limits the Town's ability to increase the property tax to any great extent so as to finance any extensive projects in the immediate future. Projects would have to be phased out over a number of years in order to avold budgetary constraints. As Marshfield continues to grow, the Town will not be able to delay for any length of time the implementation of capital improvements and the expansion of its municipal services. 


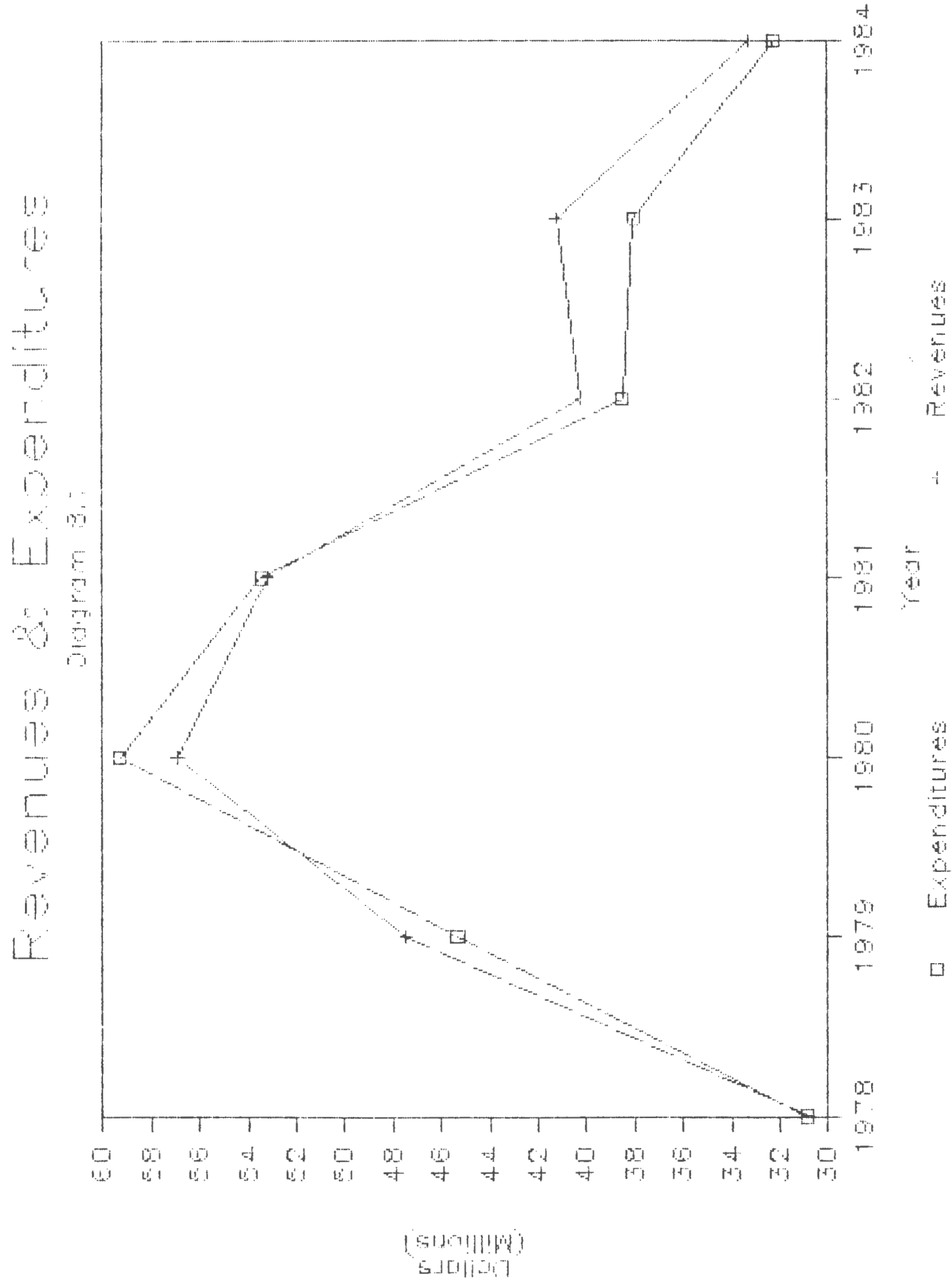




\section{Q.6 Recommendations}

Marshfield does not have the luxury of commanding a significant revenue surplus; and in light of this, the Town cannot pay for new or improved facilities through annual appropriations in the annual operating budget since most recommended public investments involve substantial outlays of funds. A careful financial analysis and the adoption of fiscal policies must be the framework upon which Marshfield should base any proposed public facility improvement and/or expansion. These policies in turn should address the implications identified in the financial analysis and should provide specific guidance to the budgeting and planning of the proposed improvements. The following is a list of policies and recommended financial tools which the Town can implement and utilize:

\section{Pol1cy Considerations}

1) the maximum amount of debt Marshfield is willing to assume

2) the extent of state and/or federal aid that will be given to Marshfield

$3)$ the types of projects or facilities which could pay for themselves through user fees

4 ) the forms of revenue mechanisms that will or will not be utilized

5) prioritize projects so that concurrent projects will not occur, if possible, in order to alleviate budgetary strains 


\section{Alternative Tools For Financing Improvements}

1) Reserve Funds - In reserve financing, funds are accumulated in advance for capital improvements and construction. The accumulation may result from surplus or earmarked operational revenues, funds in depreciation reserves, or the sale of capital assets.1

2) General Obligation Bonds - Some projects may be financed by general obligation bonds. Through this method, the taxing power of the Town is pledged to pay interest and principal to retire the debt. GOBs can be sold to finance permanent types of improvements such as schools, municipal buildings, parks and recreational facilities. 2

3) Revenue Bonds - Revenue bonds can be sold for projects, such as water and sewer systems, which produce revenues. Such bonds usually are not included in state imposed debt limits because they are not backed by the full faith and credit of the local jurisdiction, but are financed in the long run through service charges and fees. 3

4) Lease Purchase - A local government using the lease-purchase method prepares specifications for a needed public works project that is constructed by a private company or authority. The facility is then leased to the jurisdiction. At the end of the lease period, the title to the facility can be conveyed to the local government without any future payments. The rental over the years will have paid the total original cost plus the interest. 4

5) Special Assessments - Public works that benefit particular properties may be financed more equitably by special assessment; that is, they are financed by those who directly benefit. Local improvements often financed by this method include street paving, sanitary sewers, and water mains. 5

6) Authorities \& Special Districts - special districts may be created, usually to provide a single service such as schools, water, sewage treatment or parks. Sometimes these authorities are formed to avoid restrictive local government debt limits and also to finance facilities serving more than one jurisdiction. They may be financed through revenue bonds retired by user charges, although some authorities have the power to tax. 6 


\section{Footnotes}

1. David S. Arnold ed.: The Practice of Local Government Planning: International City Management Association; 1979 page 131

2. Ibid.; page 131

3. Ibid.; page 131

4. Ibid.; page 131

5. Ibid.; page 132

6. Ibid.; page 131 
CHAPTER 9

PUBLIC FACILITIES / SERUICES 
PUBLIC SERVICES

\subsection{Introduction}

This section provides an analysis of Marshfield's Public Service sector. The Public service sector includes the school system, police, fire, water and sewer services. Recommendations for each service sector are provided based on current and future community needs.

\subsection{Schools}

This section presents a study of the Marshfield Public School system. Included in this section are the general characteristics of the system, an assessment of the effects Proposition $21 / 2$ had on the system and an examination of present and future enrollments in the schools. Enrollment projections, as well as an assessment of room needs, are included.

\subsubsection{General Characteristics}

The boundaries of the Marshfield Public School System are coterminal with those of the town. School facilities (see TABLE 9.1 ) include one (1) Senior High School (grades 9 through 12), one Middle School (grade 6), one Middle School (grades 7 and 8), and four (4) Elementary Schools (grades kindergarten through 5).For locations refer to MAP 9.1 


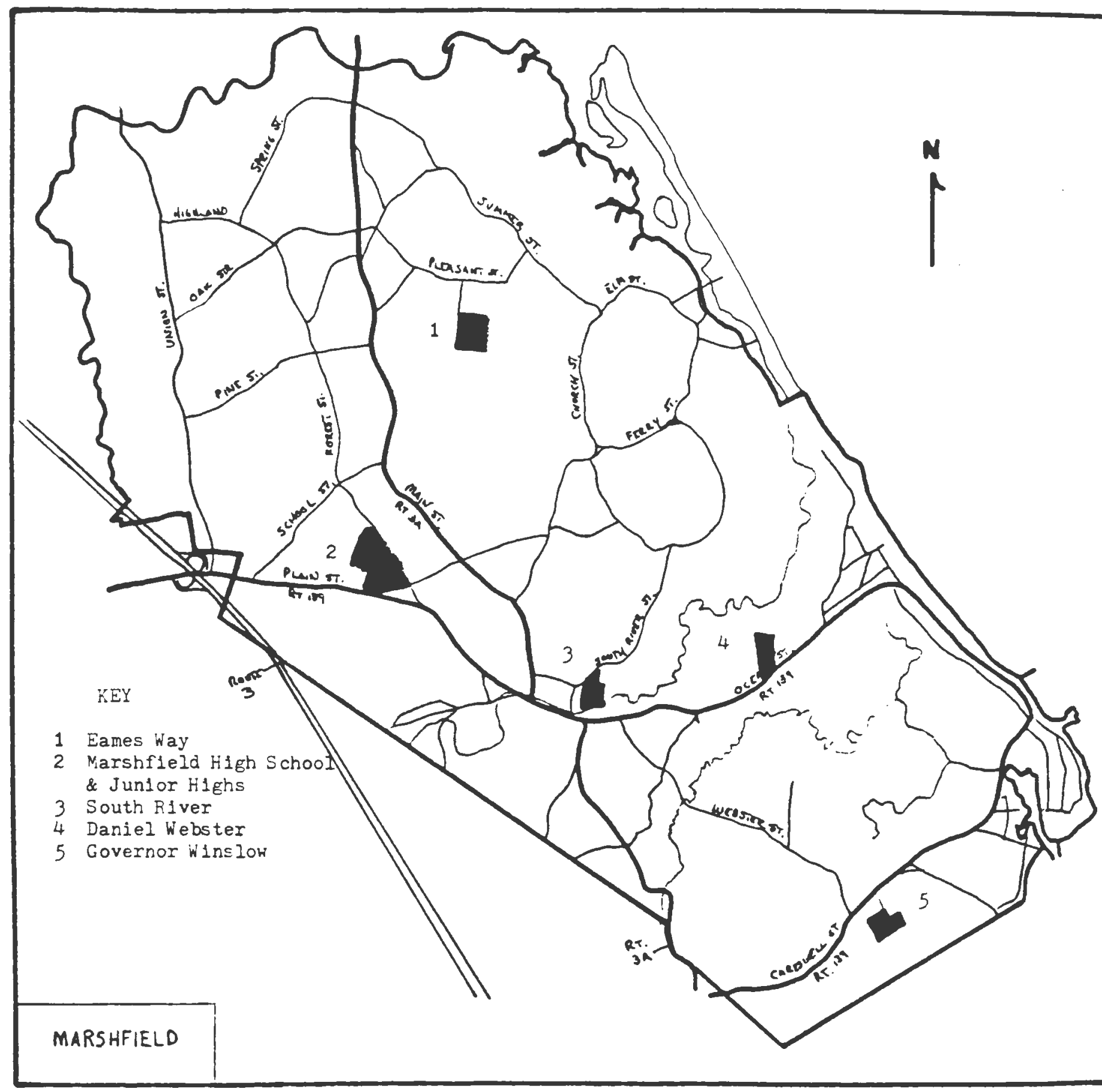

SOURCE: 1973 Master Flan, Metcalf \& Eddy 
TABLE 9.1

\section{INVENTORY OF EXISTING PUBLIC SCHOOL FACILITIES}

MARSHFIELD, MASSACHUSETTS, 1986

$\begin{array}{lcc}\text { GRADES } & \text { YEAR OF ORIGINAL } & \text { NUMBER OF } \\ \text { HOUSED } & \text { BUILDING OR ADDITION } & \text { STORIES }\end{array}$

Senior H.S

Martinson

Furnace Brook

Eames Way

South River

Daniel Webster

Gov. Winslow
$9-12$

$7-8$

6

$\mathrm{K}-5$

$\mathrm{K}-5$

$\mathrm{K}-5$

$\mathrm{K}-5$
1969

1965

1959

1961

1948

1965

1969
1973

1
1

1953

SOURCE: - Marshfield Master Plan; Metcalf and Eddy. Inc., Boston, Massachusetts; November 1973.

\subsubsection{District Boundaries}

1) Marshfield High School, grade 9-12, serves the entire town;

2) Martinson Junior High School, grade 7-8, serves the entire town;

3) Furnace Brook School, grade 6, serves the entire town;

4) Daniel Webster School, grade $k-5$, serves the district whose boundary begins at the intersection of Ocean and Webster streets. It includes all areas along Ocean street in an easterly direction to Fieldston. The boundary then turns south. whereby both sides of Ocean Street are included. The district ends at Colonial Road;

5) Eames Way School, grade k-5, serves the district whose boundary consists of all areas north of an Imaginary line running from the Pembroke line, down Plain and Furnace to 
Main, then running northeasterly to the function of Summer, Church and Elm Streets;

6) Governor Winslow school, grade k-5, serves the district whose boundary begins just south of Colonfal Road and consists of all areas south and west to the Duxbury line to include Black Mount Tarea and South on Webster Street;

7) South River School, grade $k-5$, serves the district whose boundary begins at the function of Summer. Church and Elm Street, and includes the Humarock section of Marshfield. In addition, all areas south to the South River and west to the Duxbury line, Including Webster street, but only to and including Whitford Circle, are in the district;

8) The School Administration Building is located at 76 South River Street.

\section{2 .3 Proposition $21 / 2$}

Proposition $21 / 2$ was passed in 1980. The effect of 1 ts passage, on the town in general and the school system in particular, was enormous. What follows is a reiteration of the effects Proposition 2 1/2 had on the school system. Information for this section was obtained from The Town's Annual Reports.

Upon ratification of the school budget for 1981, the Marshfield school system was forced to absorb 54 percent of the Town's revenue loss which resulted from the passage of $21 / 2$. An Increase in state aid helped soften some of the harshest cuts. 
St111, the school budget was decreased to $\$ 8,855,730.00$ or 47.74 percent of the Town's revenue.

The town budgeted $\$ 10.5$ million in 1980 for operation of the school system in 1981 . However, this figure was reduced by $\$ 2.19$ million dollars in 1981 . Fortunately, $\$ 570,236.00$ was reallocated to the school system in July and October of that year, reflecting a 25 percent reduction in the previous cuts. Despite reallocations, the school system still lost 84.5 positions. including 58.5 professional staff positions. These figures reflect a final reduction of 17 percent in staff positions, 18 percent in administrative positions. 51 percent in aid positions, 26 percent in custodial positions and 21 percent in clerical positions.

Core subject areas remained largely intact but offerings were affected by the elimination of some or all of the electives in art, business, english, foreign language, home economics, mathematics, music, physical education, science, and social studies at the high school level. There was a reduction of 25 percent to 50 percent in the art, music, and practical arts program at the middle school level, and an abandonment of the existing class size policy and a reduction of 25 percent in art and music programs, together with a 44 percent reduction in physical education at the elementary level. Throughout the system, library services were decreased by 50 percent or more. The guidance program was reduced by 50 percent in the middle schools and 20 percent in the high school and the administrative staff was reduced on all levels throughout the system. 
One school, Grace Ryder, was closed, while appropriate facilities within other schools were leased. Plant maintenance programs lincluding an estimated 1.5 million dollars in roof repairs) were postponed. Extra-curricular activities were reduced and nine coaching positions, as well as 9 th grade athletic teams, were dropped.

The school system was able to utilize federal funds enabling the high school to continue expansion of formal course work in computer science through the purchase of additional equipment and software. Also Title IV ${ }^{2}$ funds enabled new science texts to be purchased for grades 1 through 6 .

Initially, the schools' operating budget for 1982 , reflected 48.3 percent of the Town's revenue, or $\$ 9,624,905.00$. A second stage in budget development occurred during september of 1982 , when monies accruing from additional state aid were utilized to offset significant program and staff reductions in the following year's budget. The previous year's reductions amounted to better than a 20 percent reduction in the existing workforce. Change occurred through the reorganization plan for the middle grades. Furnace Brook school became a 6th grade school and Martinson School was turned 1nto a 7 th and 8 th grade Junior High School, saving approximately $\$ 130,000.00$ through staff reductions.

The school system was able to re-establish two half-time teaching positions at the elementary school level, a half-time counseling position at the junior high level, plus a full-time science/math teacher; and a half-time forelgn language position 
and a full-time administrative position at the high school level. Also at this time, $\$ 275.000 .00$ in additional state aid was obtained and a shuffling of resourses enabled some additional allocations. Upon the completion of both the initial and September phases, a $\$ 9,684,905.00$ fiscal budget reflected a net loss of 87.3 positions including 62.5 professional positions over a two year period.

The schools' operating budget was $\$ 10,085.997 .00$ for 1983 . reflecting 47.58 percent of the Town's allocation. The Superintendent of Schools, in assessing the situation, conceded that "I Inancial constraints continued to be a grave concern in planning for future achievement".

The educational system has had an estimated 21 percent reduction in personnel since 1981 . Initially reflecting a 53 percent to 47 percent division of revenues and expenses with the Town's government, the agreed upon 1984 budget included over $\$ 366.000 .00$ in reductions. During the fiscal year of 1984 , the school committee was able to allocate approximately $\$ 58,000.00$ for major improvements. The school system utilized 48.72 percent or $\$ 10,848,199.00$ of the Town's allocations.

Through creative fiscal management, the Marshfield School System has started to recover some of the initial losses which resulted from the passage of Proposition $21 / 2$. A number of necessary maintenance projects have been stalled due to a shortage of funds and this will be a major concern in the future. Eventually these projects may cost the Town even more if repairs 
are neglected too long. Along with the recommendations which follow later in this section, a maintenance program for the school system must be formulated.

\subsubsection{Present and Future Assessments}

In comparing the school's estimates of future school age population 3 to the population projections done by the Thesis Study Group (see TABLE 9.2), the school system has underestimated the future school age population for the Town.

TABLE 9.2

STUDENT POPULATION PROJECTIONS

GRADE STUDENTS AGE $\begin{gathered}\text { EXPECTED } \\ \text { POPULATION }\end{gathered}$

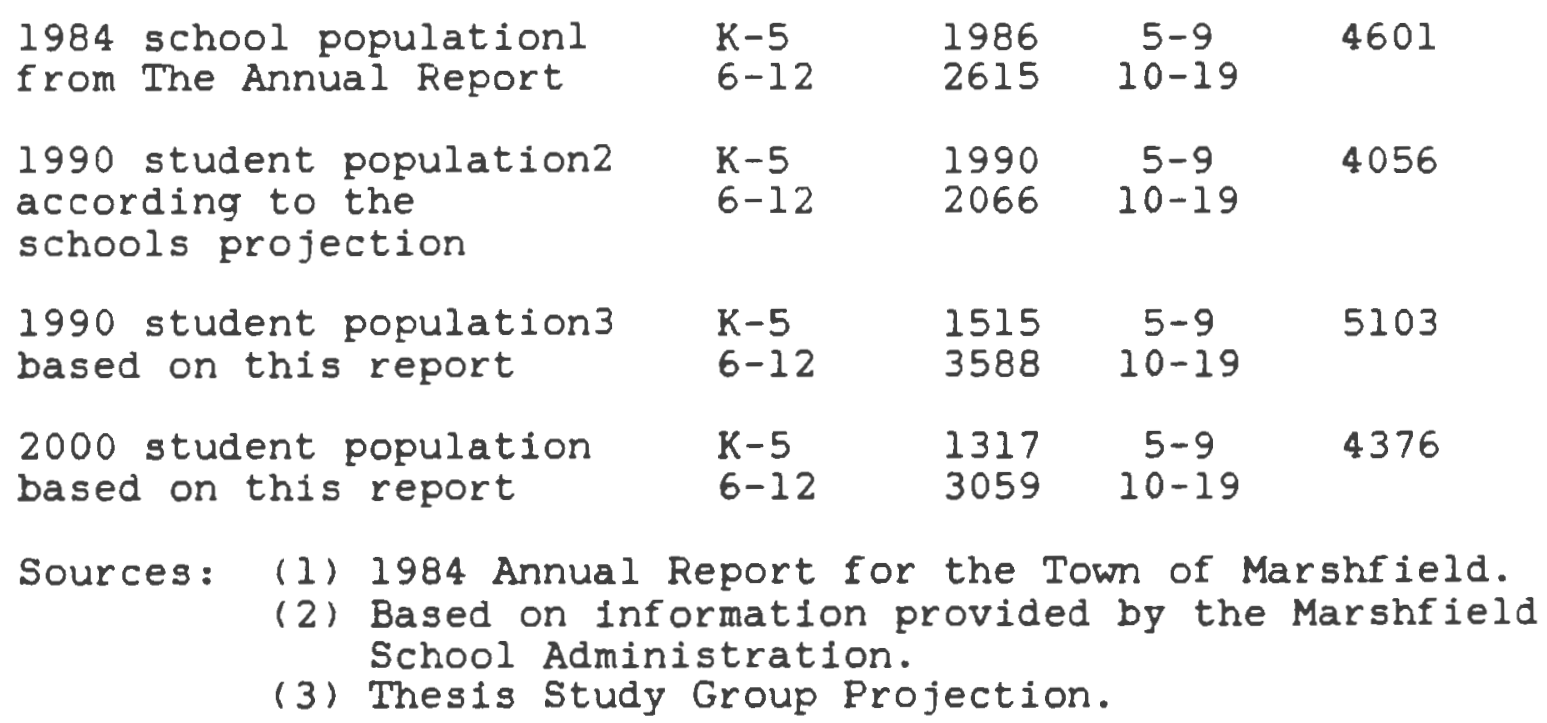

The school population, according to the Town's Annual Report for 1984 is 4.601. According to the school's projection (see APPENDIX E), the 1990 student population (school year 89-90) will 
decline to 4,059 (see TABLE 9.2). The total student population profection, as done by our group, is 5.103 for the year 1990 .

Looking more closely at our projection, the largest increase occurs in the 6 through 12 grade level (10-19 age group). An increase of 973 students is expected by 1990. This can be compared to the school systems estimate of a projected decrease of 526 students between 1984 and 1990. By the year 2000, our group estimates the total student population, grade $k$ through 12 (age 5-19 years old) will decline from 5103 to 4.376 .

How the projection relates to the current capacity of the school system is an important concern to the town. The present system has available to it 101 classrooms for Kindergarten through Grade 5 (see APPENDIX E). Of these classrooms, 18 are leased out by the school system, resulting in 83 classrooms currently available for instruction. At a student-teacher ratio of $25: 1$, the maximum number of students the system could accommodate is 2.075 (83 classroom X 25 students per room).

According to the school's projected room needs, the system will be able to provide the necessary classroom space for the Kindergarten through 5th grade level through the 1993-1994 school year. At that time there will be a shortage of 1 classroom (see APPENDIX E).

Based on our group estimate, there will not be such a shortage in class room space for the 5 through 9 age group. because the population is expected to decrease between 1990 and the year 2000. At some point, if there is found to be a shortage 
of class room space for this grade level, the school system will be able to meet the demand by changing the number of classroom leased out to other interests. Thus the school system is able to meet the future needs of the Kindergarten through Grade 5 student population, through to the year 2000 .

The current capacity of Furnace Brook School which houses only 6 th Grade students, is 350 . The total avallable classrooms in the buflding number 20, of which 6 are leased out. The current capacity of the Junior High School is 800 and the High School's capacity is 1750 students. Thus the total capacity of the Marshfield School System for Grades 6 through 12 is 2900.

Referring again to TABLE 9.2, for the age group 10 to 19 (grade 6 through 12 ) the 1990 population will reach 3.588 school children (study group estimate). The school system estimates the student population (grade 6 through 12) will be 2,066. This results in a difference of 1.522 students between the two projections. For the year 2000, the TABLE indicates that the population in the 6 through 12 grade level will be 3.059 . What the above estimates show is that the Town must plan to provide additional classroom space for students at this grade level by the year 1990 .

In addition to space provisions, the school system should also look towards expanding its' curriculum to include a vocational training program for high school students, for the following reason;

The distribution of 354 High School Graduates (Class of 1982) 
was as follows:

44 percent went on to a 4 year college;

5 percent to a 2 year college;

12 percent to work;

4 percent to other educational facilities:

35 percent to the military or not specified.

The estimated percentage of students going to work (12\%), combined with those going on to the military/not specified (35\%), totals 47 percent. This indicates that there may be a significant number of students entering the work force with only high school training. It may also indicate that a number of students may graduate and be unemployed. Vocational training may provide students with alternative educational options and/or advanced training, in order that they may enter the job market with additional skills.

In summation, due to Proposition $21 / 2^{\prime}$ s effects on the Town it is difficult to propose a major school building program because of the Town's budgetary constraints. Also, in light of the present federal legislation to curtail education funding, state educational aid may be reduced. It is therefore necessary for the Town to create a budgetary program aimed at ensuring that future education funds be available to meet future needs.

\subsubsection{Recommendations}

The 1973 Master Plan outlined two school facility building plans. The major difference in the two plans is based on;

1) A single High School Complex

2) Two Marshfield High Schools 
The plan outlined the following standards which should be maintained by the school system:

1) Kindergarten classes presently in double session will remain.

2) Classroom capacities should not exceed 25 students per class room.

3) Student / Teacher ratios maintained at 25:1

In addition to the above standards, the following recommendations are made:

Year 1986

1) A funding program established to provide funds for future maintenance of the school system.

Year 1990

1) leasing of school classrooms should be eliminated as needed, in order to provide room for expansion.

2) expansion of the present high school to accommodate an additional 1,900 students. The high school should expand its curriculum in order to be able to offer increased vocational training.

Year 2000

1) If demographic shifts prove correct, the conversion of one elementary school into a junior high school. 


\section{$\underline{9.3}$ Fire}

The following is an assessment of the current community service provided by the Marshfield Fire Departments6. Recommendations for future provisions for the department are made based on the most probable population projection (see Chapter 4).

\subsubsection{Personnel}

The current staff numbers 41 with the inclusion of lieutenants. In addition, the administrative staff consists of a Deputy Chief, the Chief, a clerk and a mechanic. The volunteer force currently number 15. (January 1986)

\section{$\underline{9.3 .2}$ Facilities}

At present Marshfield has three fire stations (see Map 9.2). Marshfield Hills - Equipment - 1 engine, 1 small aluminum boat, 1 back-up engine

The building is obsolete for modern equipment, and there exists severe space Iimitations.

Brant Rock - Equipment - 1 engine, 2 boats ( including 1 motorized rubber raft purchased in 1985) and 1 back-up engine.

The building is antiquated and space limitations are excessive.

Main Station (South River) - Equipment - I ladder truck, I engine, 2 brush fire trucks. I spare engine, 1 boat

The condition of the main station can be considered only fair for 
MAP 9.2

Fire Stations

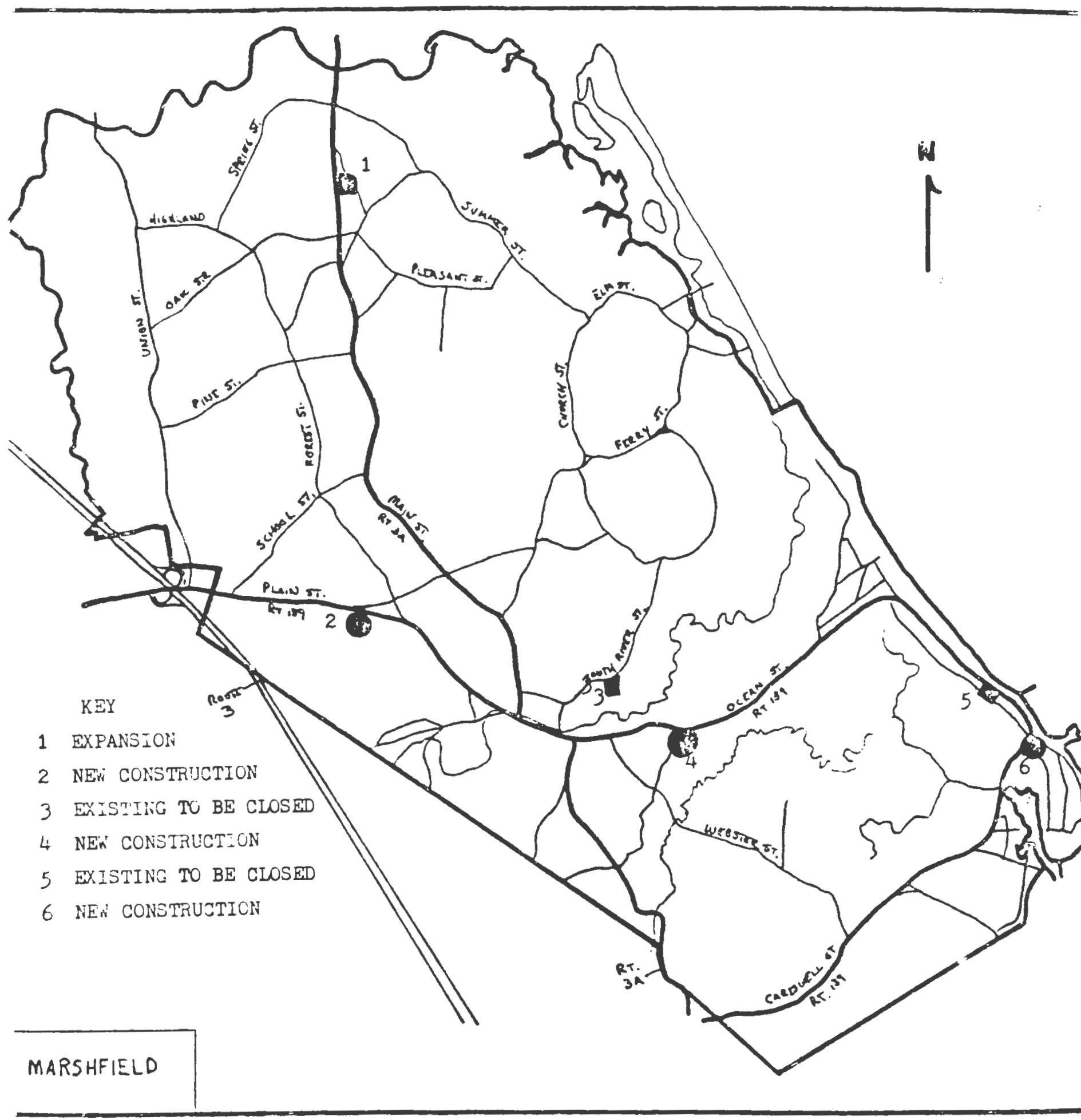


there are severe space limitations for proper maintenance work. Additionally, it should be noted that 50 percent of the total fire runs made by the department are directed toward the shore area. For the main station to respond, the fire delivery service route is down Route 139. Due to the location of the main station, response time is increased due to the congestion on Route 139, as well as the number of turns necessary for the trucks to make in order to access Route 139.

\subsubsection{Service Assessment}

At present, the Marshfield Fire Department is the third busiest department in Plymouth County. The department's equipment over the past few years has been upgraded by the initiation of a lease/purchase agreement. Under this agreement the town was able to obtain two new engines. In addition, a new brush truck was also obtained. Of the first line engines, one is currently in need of replacement. The fire chief, Fredrick P. Gibson, estimated that an engine and a ladder truck have a life expectancy of no more than 10 years. 5

\subsubsection{Recommendations}

There is a pressing need for the town to expand the current manpower of the fire department. An addition of one man per shift per station $1 \mathrm{~s}$ necessary in order to malntain and improve the 
efficlency of the department. In addition to this necessary increase in personnel, the following recommendations are made:

1) Add 2 ladder trucks.

2) Create an equipment replacement system so that engine and ladder trucks are replaced after 10 years of use.

3) Immediately replace the existing station on South River Street with an expanded facility on Route 139, pereferbly near the police station.

4) Replace, within the next two to five years, the Brant Rock station with a new structure along Route 139, near the new town pier access road. This station should be large enough to accommodate a ladder truck.

5) Develop a new station, within the next two to five years, located in the industrial zone with direct access to Route 139.

6) Immediately upgrade the Marshfield Hills Station or replace it with a station located along Route $3 \mathrm{~A}$.

9.4. Police

The following is an assessment of the current community service provided by the Marshfield Police Department. Recommendations for future provisions for the Department are made based on the most probable population projection (see Chapter 4).

\subsubsection{Personnel}

In 1975. Marshfield's Police Department operated with a staff of 57. As of 1985. its staff has been cut to 46 positions. In addition, there are 6 auxiliary policemen with police powers for emergency situations. Despite the cuts in manpower, currently the department operates well and there is no need for an increase in its' manpower. 


\subsubsection{Equipment}

At present, the department maintains four marked patrol cars and one supervisor vehicle. In addition, the department utilizes one four wheel drive vehicle for off-road and beach patrol use.

The current maintenance schedule serves the department well since three patrol cars are replaced on a yearly basis. This is necessary because each car averages 2,000 miles per week. The four wheel drive vehicle is replaced every third year.

\subsubsection{Facilities}

The renovation and expansion of police headquarters in 1976 Increased the square footage of the building and upgraded the facilities. At present, the building could accommodate a staff of 60 officers without further expansion.

The Lock-Up is more than adequate to suit the needs of the community. It provides for 8 adult male, 3 juvenile, and 2 female holding areas.

\section{4 .3 Recommendations}

The recommended number of patrolmen per 1000 people is two. It is necessary for the community to keep this in mind as its population expands. The maintenance of the safety of the town should always remain a top priority.

By the year 1990, a staff of 55 officers would be required by a population of 27,635 . By the year 2000, with a population of 35.005, staff requirements would reach 70 . The existing police 
headquarters are expected to be adequate unt1I the year 1995. At that time the Town may need to further expand Police headquarters and increase the number of staff positions due to the growth in the population. 


\subsection{Public Water Supply}

Marshfield's water system presently supplies essentially the entire population and virtually all of the developed areas of the Town. The Town depends entirely upon groundwater for its water supply. Sources of supply consist of eleven main wells which have a total capacity of 4,235 gallons per minute, an average of 385 gallons per minute (with the Furnace Brook 4 well having the highest average at $775 \mathrm{gpm}$ and the Mount Skirgo and South River Street wells having the two lowest at $200 \mathrm{gpm})$. There are also three intermittent wells which have a combined capacity of 1400 gallons per minute. A synopsis of Marshfield's well capacity is shown in Table 9.3. Marshfield also has three storage tanks. One is located on Pudding Hill, which was constructed in 1928 and has a capacity of 667,000 gallons. A second is located on Telegraph Hill, which was constructed in 1957 and has a capacity of 890.000 gallons. The third is located on Forest street, which was constructed in 1972 and has a capacity of 2.1 million gallons. Total storage capacity is 3.6 million gallons.

Based on the most recent statistics (April 1984), Marshfield's total yearly water consumption is $988,600,000$ gallons. Average daily consumption is $2,700.000$ with an estimated 98 gallons per capita consumption. In summer months. the peak daily use of water rises to an estimated 3.5 million to 5 million gallons per day. While peak hour demand (maximum day) can reach $9,800,000$ gallons, present maximum daily potential is 8.114,000 gallons (this includes main wells and intermittent wells). 
TAELE S.

MASGHF IELI WELL CAFAIITY

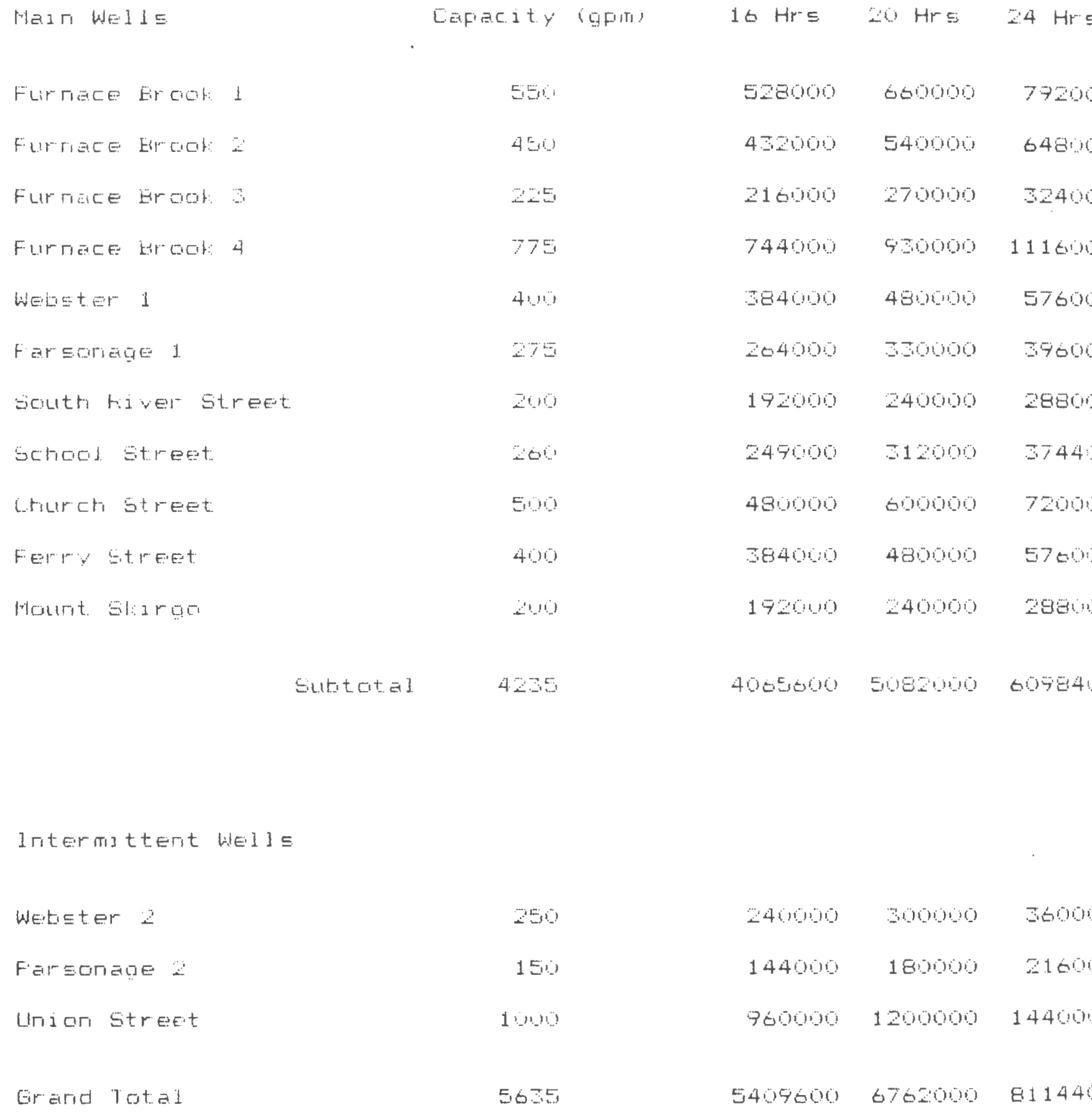

Source: Department of Futilic warl:s 
Table 9.4 1llustrates changes in water consumption overtime. Assuming that the per capita water consumption remains constant into the future, and using our population projections, annual water consumption is profected to increase by 18.5 percent in 1990 and by 37.2 percent in the year 2000 .

TABLE 9.4

Profected Water Consumption

In Marshfield, 1990, 2000

(In Gallons)

\begin{tabular}{|c|c|c|c|}
\hline Year & Population & Water Consumption & $\begin{array}{l}\text { Percent } \\
\text { Change }\end{array}$ \\
\hline 1984 & 21,980 & $988,600,000$ & \\
\hline 1990 & 27.635 & $1.213,272.000$ & $+18.5 \%$ \\
\hline 2000 & 35,005 & $1,572,760,000$ & $+37.2 \%$ \\
\hline
\end{tabular}

Based on 1984 figures, if all main wells (excluding intermittment wells) operated 24 hours a day, 2,225,916,000 gallons of water could potentially be pumped from the groundwater system. Hence, Marshfield's water supply is presently adequate. However, by the mid $1990 \mathrm{~s}$ and the year 2000, Marshfield's demand for water will be reaching the Town's capacity. It also should be kept in mind that these statistics on water consumption do not take into consideration the supply of water which 1 s exported to neighboring jurisdictions. 
Marshfield not oniy provides water to the entire Town, but also supplies water to three adjacent townships. The towns of Scituate, Duxbury and Pembroke are three customers which are supplied with water from Marshfield. Scituate receives an average of 89,300 gallons of water daily and $32,600,000$ gallons yearly. Duxbury recelves and average of 24,900 gallons of water daily and $9,100,00$ gallons yearly. Finally, Pembroke receives an average of 4,100 gallons of water dally and $1,500,000$ gallons yearly. In a combined total, Marshfield supplies the three towns with 118,000 gallons of water daily and 43,200,000 gallons on an annual basis.

Many towns, like Marshfield, which are located on the fringe of a metropolitan region, will be subject to growth pressure into the decades ahead: and there could be an acute water problem. However, Marshfield's large area and natural terrain, together with its relatively low density of development, place the Town in a better position to supply its water needs from within its own boundaries. There has been some activity by the Department of Public works to acquire land for potential new well sites. There is also a necessity to purchase real estate for a fourth water storage tank, as well as for new well installations.

Presently, there has been no activity in extending new water lines and there are no plans for the immediate future. However, there has been water line replacements. The cost of replacing 8 inch water lines ranges between $\$ 35.00$ and $\$ 40.00$ per foot; and 12 inch water replacement lines cost $\$ 45.00$ per foot. In 1984,1 
mile of 8 inch water lines was replaced with 12 inch water lines at a cost of $\$ 260,000$. In 1985, three-quarters of a mile of 12 inch water lines were replaced. In 1986, 2 miles of 12 inch water lines are proposed to be replaced at a cost of $\$ 480,000$.

\subsection{Recommendations}

1) An immediate activity of the Water Department and the Conservation Commission should be a study of potential water resources for future supply and acquisition of necessary land to assure their conservation.

2) Extension of pumping, storage, and distributing facilities should be carried out progressively as the Town grows.

3) It is also imperative that the mode of water user fees be changed. Presently, water billing and accountability is based on the number of fixtures in one's house. It is suggested that metering replace this present form of monitoring for two reasons. First of all, monitoring water usage by way of metering will give the Town a concise and accurate account of water consumption; and secondly, water billing will reflect actual use rather than an estimate.

\subsection{Sanitary Sewerage}

Today, the present system of public sewers existing in Marshfield is limited to the coastal beach area (See MAP 9.5). The present capacity of the sewerage treatment plant is 2.1 million gallons of sewerage per day. The present capacity of the plant adequately serves those who are connected to the system. As long as density under present zoning remains the same in the area, the plant will be adequate for some time. Furthermore, according to the Department of Public Works, there are no plans at present, nor any for the immediate future, to expand or replace sewer lines. Due to the Town's low density 
MAP 9.3

\section{SEWAGE DISPOSAL}

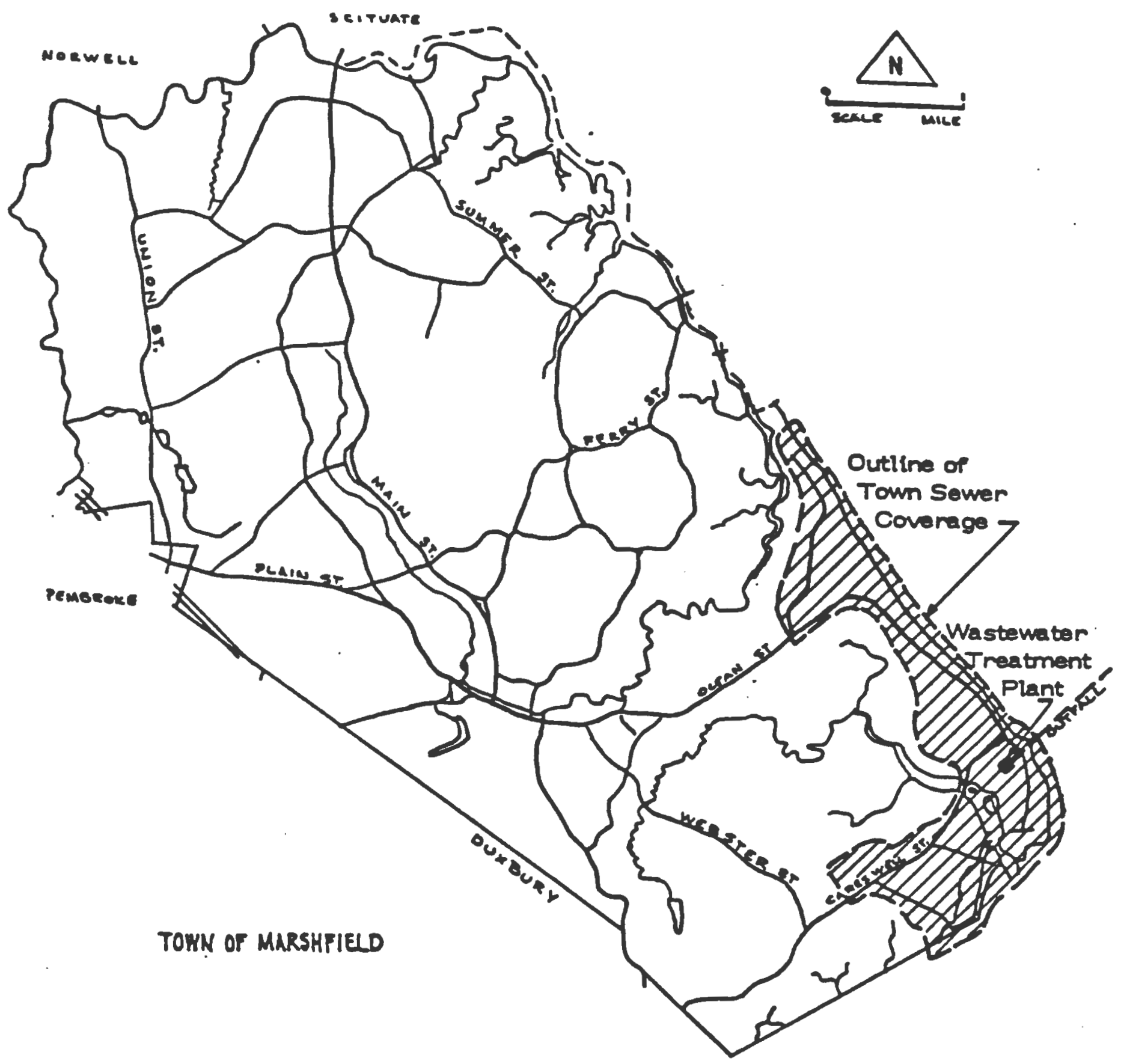

All sanitary waste is on site by septlc system except in the area having town sewer.

Source: Town of Marshfield, Conservation/Recreation-Open Space Plan- 1985 
development, an extensive public system of sanitary sewers would be uneconomical and unnecessary for at least the immediate future. Due to great cost, the installation of sewers throughout the town simply would not be feasible and cost efficient. Presently, user fees would in no way render such an undertaking self-sufficient. Also, there are no plans for extending sewer lines to the industrial zone which is located in the western portion of the Town. Considering the fact that only light industry is permitted to locate there, an on-site septic system would be sufficient to accommodate the future needs.

\subsection{Waste Disposal}

The Town dump site, which is located off of Grove Street, is adequate, but it will reach its maximum capacity soon. It is projected that the present dump site will reach the end of its life span by 1995 or the year 2000. However, according to the Department of Public Works, the likely avenue which the Town will take will be to extend the life of the present site by another 12 years. In order to accomplish this end, the Town would have to first partake in a permit application process. If the extension is permitted, the Town can either: (1) acquire more land from the adjoining area to expand the landfill, (2) be more selective in waste collection (i.e. such as not collecting certain items such as tires), (3) or utilize a shredder/baler machine which shreds garbage and packs it into hay-like bales. The latter two options can save space at the landfill, thus extending its use. 
However. this is fust one option. A second option the Town has is to acquire a new landfill site now (or at least begin the search for possible sites). Third, between now and 1995, perhaps the prevailing technology of the times will open new waste disposal options which the Town could consider. Lastly, the Town has the option of planning to participate, with other communities, in planning for a resource recovery facility. In years to come, waste disposal is going to be more of a regional issue and responsibility, rather than a local, one because waste disposal can be better coordinated (more centralized) at the regional level; and secondly, detriments to the environment relating to landfills can be avoided in the individual furisdictions. A resource recovery facility is a cleaner, economically feasible, and proves to be potentially less of a hazard to the environment than a landfill. The primary benefits of recycling are: (1) avoided disposal costs, (2) revenues from the sale of recyclables, and (3) significant reduction in potential groundwater pollution from landfills and air pollution from incineration. Resource recovery is a process that 1 s being given more attention by public officials in their search for solid waste management alternatives. Such technology has become a standard facet of Europe's waste management for over two decades. However, the plan for one community to become the recipient for a region is always accepted by all voters except those in the receiving community. Efforts for regional cooperation in such a project usually result in a stalemate. 
Since solid waste management is a major issue, it is recommended that closer cooperation among Town officials, Marshfield residents and state and regional officials be instituted in order to work together to aid the transition from landfilling to resource recovery. All options should be thoroughly examined and weighted in order to opt for the least environmentally detrimental and most cost-efficient alternative for both the short-run and the long-run. 


\section{Footnotes}

1. The Annual Report for The Town of Marshfield. $1979,1980,1981,1982,1983,1984$.

2. TITLE IV Funds, a federal program established to provide money for exemplary school programs, replaced by Chapter II.

3. School population projection and room needs projection provided by Dr. Paul McDonnell. Marshfield's Assistant Superintendent of Schools.

4. The Annual Report for The Town of Marshfield, 1984.

5. Based on an interview with Mr. Fredrick P. Gibson. Chief of The Marshfield Massachusetts Fire Department, January 21 , 1986

6. Based on an interview with Mr. William P. Sullivan, Chief of The Marshfield Massachusetts Police Department, January 21,1986 .

7. Center For Environmental Studies, Brown University; Recveling Strategy For R.I. Conclusions And Recommendations; Volume I: September 3.1985 
CHAPTER 10

CONSERUATION / RECREATION 
CONSERVATION/RECREATION

\subsection{Introduction}

With the increased public awareness of our environment, conservation and recreation are taking on added importance in the development of a community's comprehensive plan. Recreation and park programs and services are necessary and growing local government functions. More citizens are using their local parks and recreation facilities. As the number of hours devoted to one's job decreases and people are living longer, citizens look to their municipality to provide expanded leisure services and opportunities.

This section of the Master Plan serves two purposes:

1) to assess the existing conservation and recreational facilities, open space, and natural resources of the community; and

2) to propose plans and programs that will ensure the best use of the facilities and land for the present population and future generations of Marshfield.

\subsection{Inventory}

Marshfield is fortunate in having a number of excellent conservation and recreational facilities. Because of its shore location, the Town owns a large beach area at Rexhame and has use of beaches in Green Harbor and Brant Rock. Marshfield is also fortunate in having two natural harbors for small boats: Green Harbor and North River.

Passive pursuits such as bird-watching or fishing, and active pursuits such as soccer or tennis can be enjoyed by 
everyone in the community. Recreational programs are offered throughout the year to all different age groups.

A complete listing of existing conservation and recreational facilities can be found in Appendix $F$, which is reproduced from the Conservation/Recreation Open space Plan, 1985. Definitions of recreational facilities are also included in Appendix F.

It can be stated that no major problems or deficiences exist in regard to conservation and recreation in Marshfield. However, it is essential that programs and policies currently in place should be maintained so that Marshfield residents can enjoy their leisure time to its fullest potential.

Discussion now focuses specifically on conservation recommendations and proposals. This section concludes with recommendations and proposals for recreation.

\subsection{Conservation Recommendations}

We suggest the following conservation recommendations:

1) Protection of water resources in terms of quality and supply.

In a community of increasing population, water supply and recharge area protection is needed.

2) Safeguard areas of finite natural resources which are of unique environmental character such as beaches, marshes. and rivers.

Such areas are needed for their biological, aesthetic, and recreational values.

3) Continuation of land acquisition for the following five areas: 
i. Furnace Brook Watershed and Carolina Hill;

ii. Northwest Green area;

iii. Green Harbor Reclamation District;

iv. Marshland;

v. Significant isolated lands.

Open space land (passive) preservation is required throughout the entire community.

\section{(1) Furnace Brook Watershed and Carolina Hill}

To date, 855 acres of watershed have been acquired by the Town, representing 86 percent of the expressed goal. Areas in the recharge lands of Carolina Hill need to be protected as the wells in this area produce three quarters of the total water supply for the Town. Additional acquisition of 145 acres is needed to reach the goal of 1,000 acres. (See MAP 10.1). By acquiring the high ground on top of Carolina Hill, a water and land protection program started in 1971 would be completed.

\section{(ii) Northwest Green Area}

Thus far 484 acres of the current 600 acre goal (see MAP 10.1) have been acquired, which represents 81 percent of the goal. There should be a creation of a land corridor abutting the North River by acquiring parcels of land along the river. With the additional acquisition of 116 acres the goal of 600 acres would be completed.

\section{(111) Green Harbor Reclamation District}

The goal is to amass 800 acres of which 751 acres or 94 percent have been purchased. The remaining undeveloped acreage should be utilized to support wildlife. Preservation of Green 


\section{CONSERVATION ACQUISTTION GOAL AREAS}

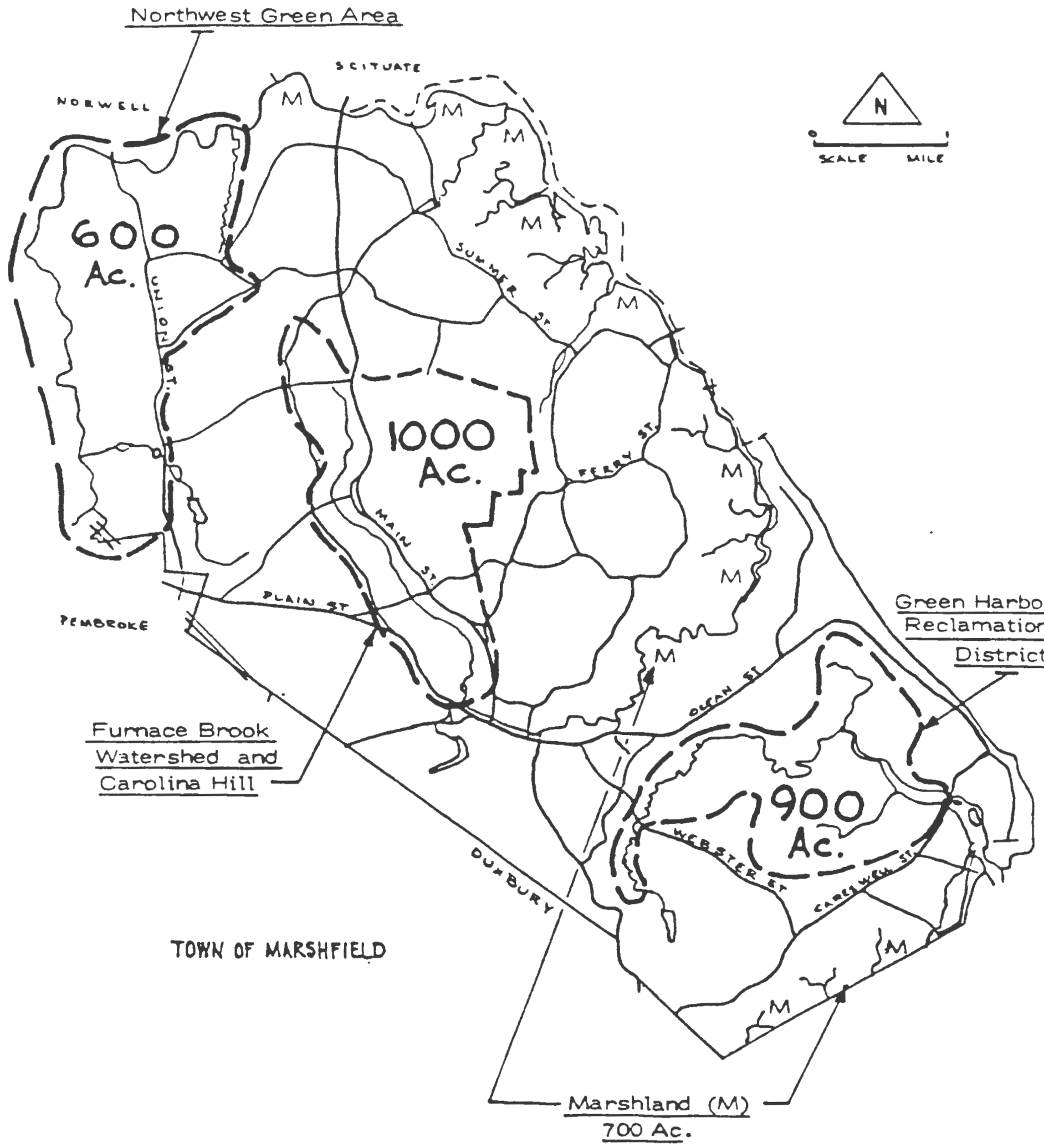

Source: Conservation/Recreation - Open Space Plan, 1985 
Harbor 13 mandatory for flood control. As the goal has been amended to 900 acres, (see MAP 10.1), 149 acres need to be acquired.

\section{(iv) Marshland}

At present, 229 acres (or 33 percent) of the 700 acre goal (see MAP 10.1) have been acquired. Coastal salt marshes should be preserved along the North and South Rivers, Green Harbor, Cut River, and Duxbury marsh as marshlands offer nutrient value and scenic beauty. This acquisition is lowest on the list of priorities, but the 471 acres needed to reach the goal of 700 acres should be acquired as land becomes avallable.

\section{(v) Significant Isolated Land}

Occasionally, additional land becomes available in areas other than the four listed above. In determining whether or not acquisition is made, the Conservation Commission considers the following criteria: importance to future water quality and supply, passive recreational potential, and protection of Marshfield's finite resources.

Several isolated sites (see MAP 10.2) meet these criteria and are listed as follows:

a) Tilden Island - a high drumlin in the middle of South River estuary. Acquire 24 acres.

b) Pine Island - a low upland spot on the edge of the South River estuary. Acquire four acres.

c) Chestnut Tree Grove - a 15 acre spot on the east slope of Holly Hill with rare growth of large fruit bearing 


\section{ISOLATED LANDS CONSERVATION ACQUISITION GOAL AREAS}

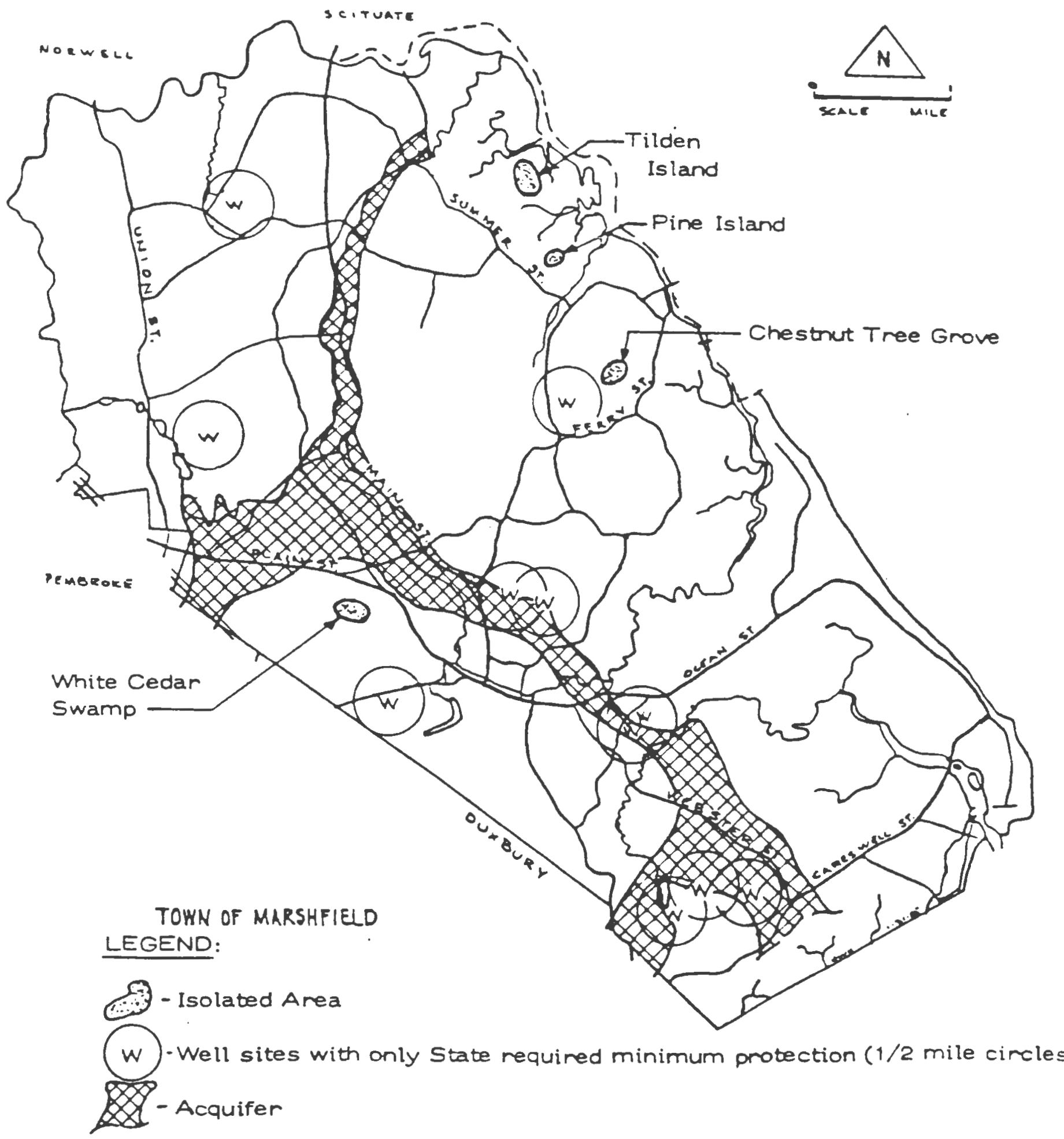

Source: Conservation/Recreation - Open Space Plan, 1985 
trees. Acquire 15 acres.

d) White Cedar Swamp - a 20 acre bog-like depression near Plain Street. The unique White Cedar stand is found in this spot. Acquire 20 acres.

e) Well sites - eleven well sites have been purchased and additional protection should be developed with acquisition of 11 acres.

f) Aquifer - this runs from north to south along the Furnace Brook and extends to Pembroke and Duxbury. An inclusive protection program should be designed to safeguard the entire aquifer.

In the four major areas, 881 acres are proposed for acquisition, of which 471 acres are salt marsh and 410 acres are in the other three areas. The 410 acres are further broken down into 130 acres of wetlands and 280 acres of upland. Conservation, quasi-public and other Town-owned land, and proposed conservation land is illustrated on Map 10.3.

Conservation land/open space, should, where it is feasible, be acquired in a linear parcel alignment. This would create a linear park linking present conservation properties and would protect the aquifer.

The acquisition of conservation land is now considered essential as seen in Diagrams 10.1 and 10.2. Diagram 10.1 1llustrates the positive steps the Town has taken to safeguard its heritage for the future with large acquisitions of land in the last twelve years. By 1984 total acquisitions amounted to 1.722 acres. Diagram 10.2 depicts land use changes in the Town 
MAP 10.3

\section{Conservation, Quasi-Public and Other Town} Owned Land--Owned/Proposed Marshfield, MA 1985

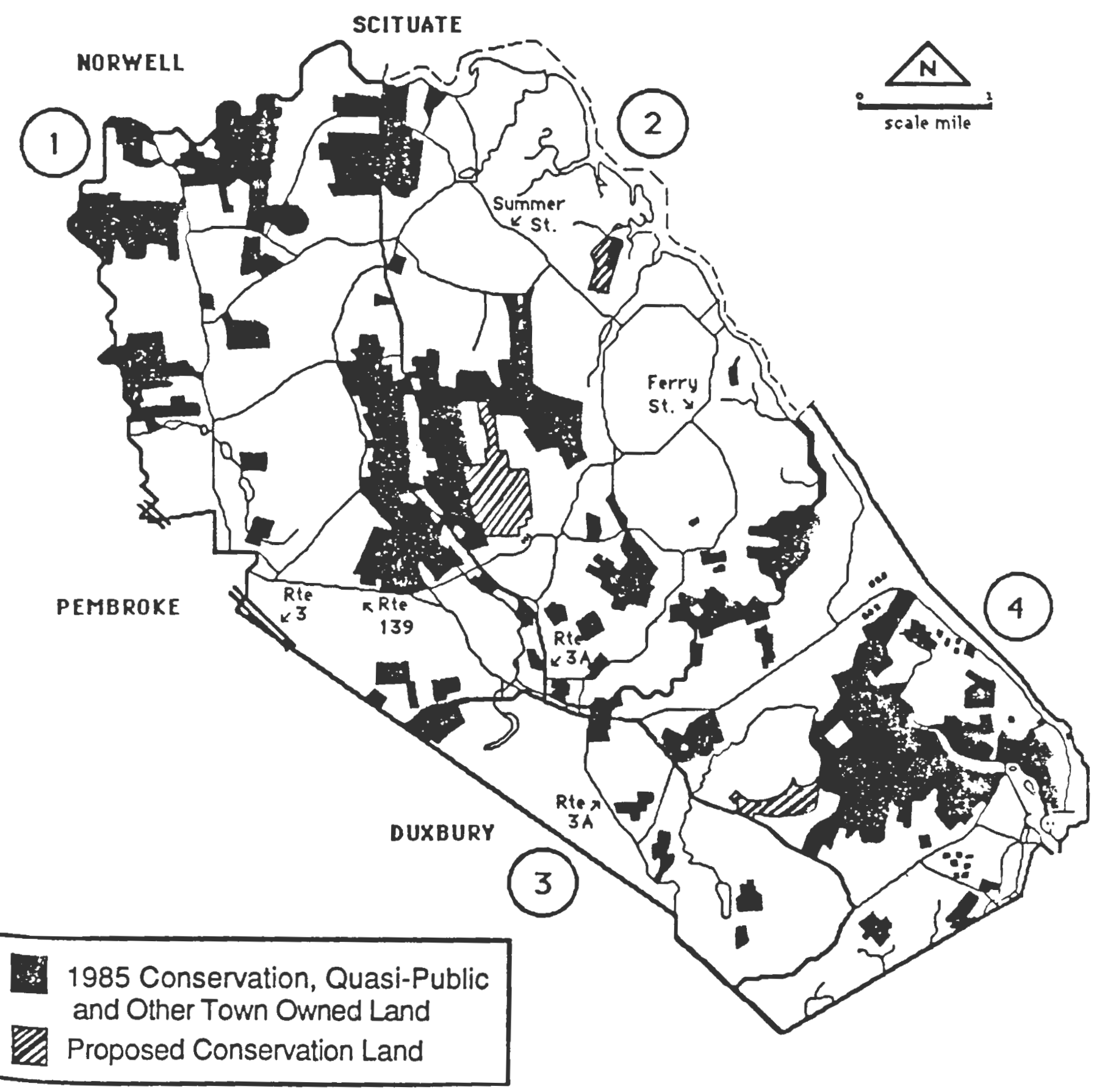

Source: Conservation/Recreation - Open Space Plan, 1985 
DIAGRAM 10.1

\section{CONSERYATION LAND ACGUMULATED $1981-1984$}

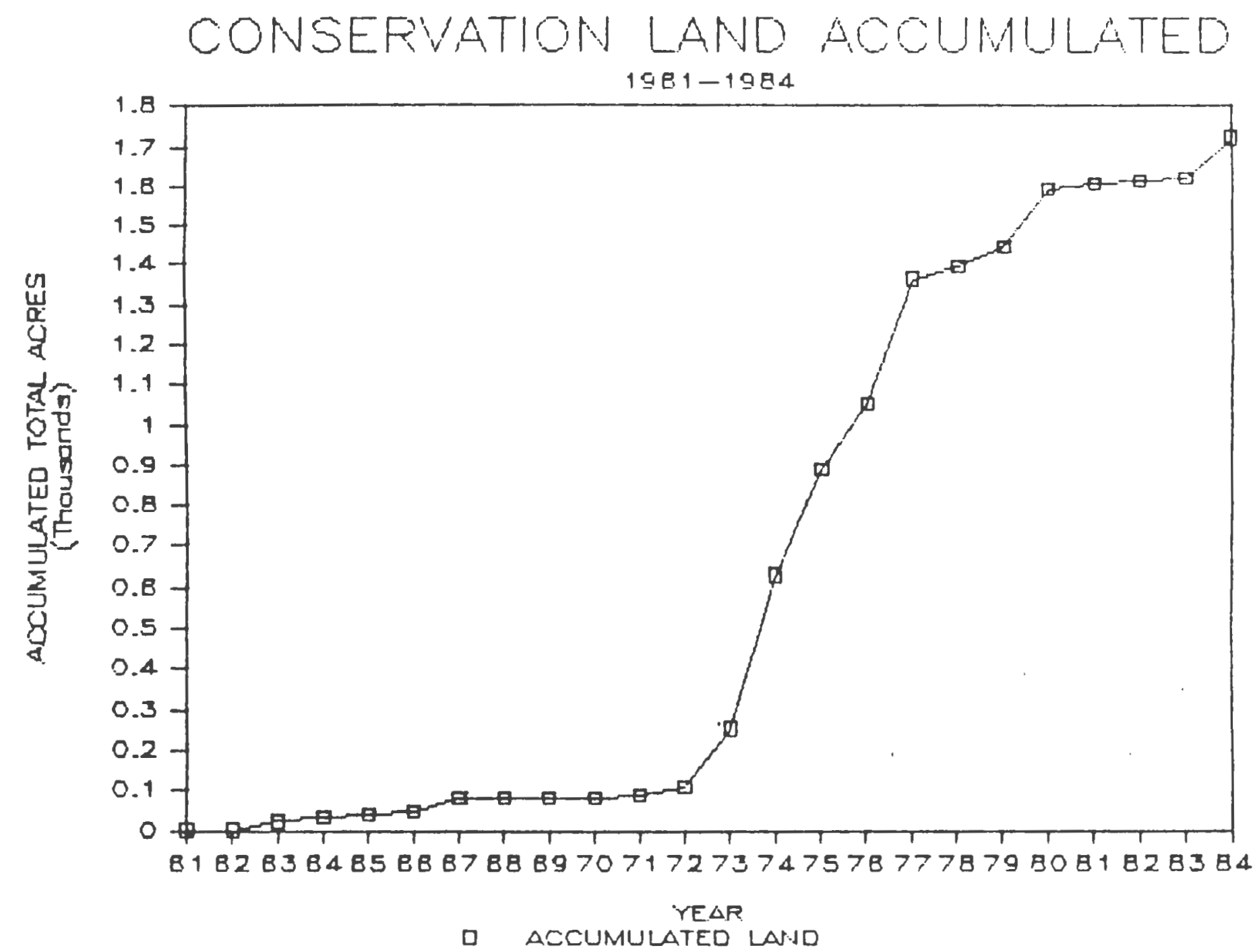

Source Conservation /Recreation - Open Space Plan, 1985 
DIAGRAM 10.2

$\stackrel{\sim}{\sim}$

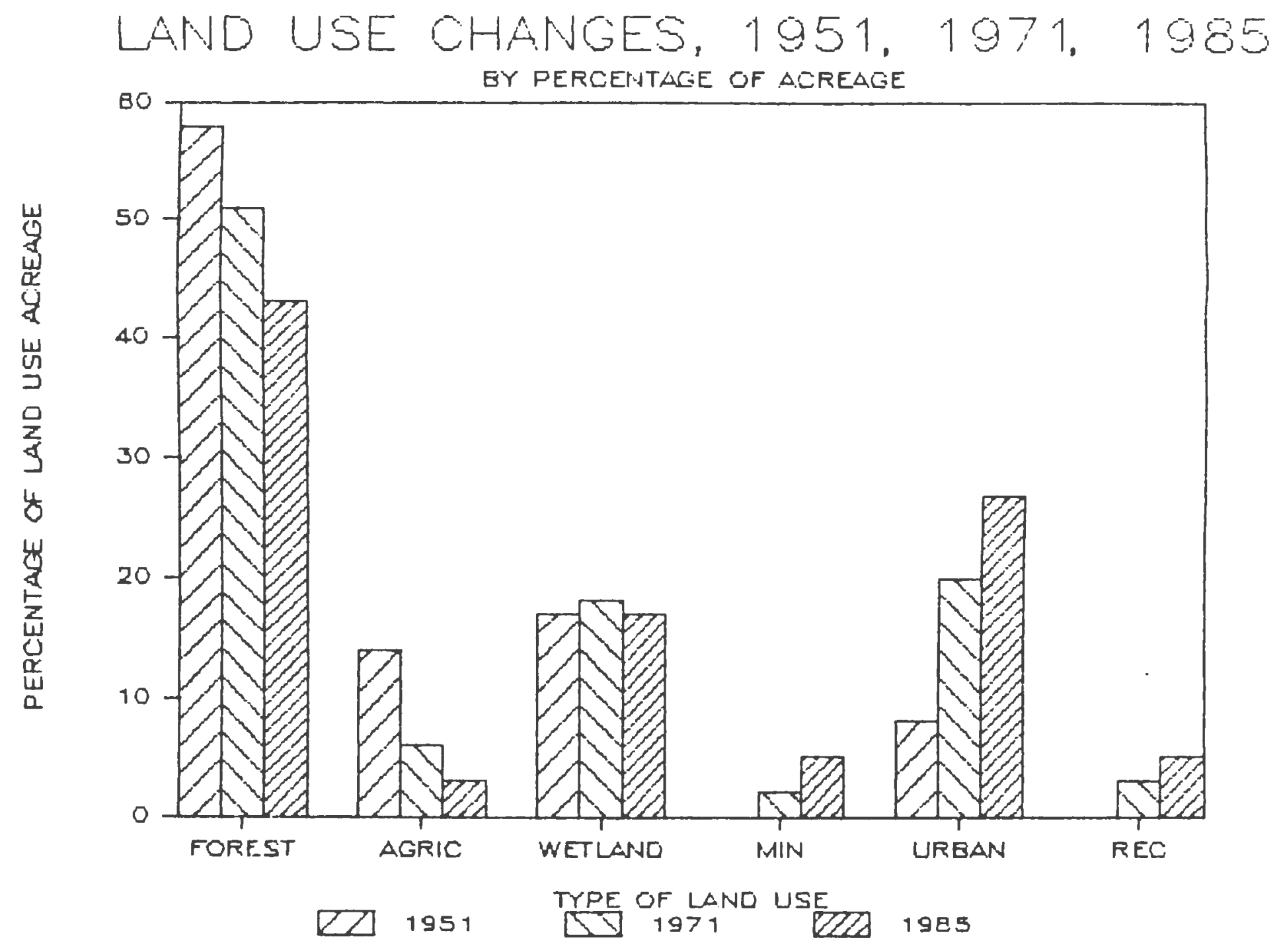

Source: Conservation/Recreation - Open Space Plan, 1985 
In the post second World War period. Between 1951 and 1985 Increasing development pressure resulted in a greater percentage of urban and associated land uses which had a detrimental effect on potential conservation areas such as forest land and agriculture/open land.

\subsection{Conservation Proposals}

The following proposals which we suggest, given adequate funding, can be realized within the next five years.

1) Acquire areas of conservation concern for open space. (Acquisition will depend on priority of area.) A program of acquisition might be as follows: Carolina Hill, Green Harbor Reclamation District, Aquifer, Isolated Land areas, Marshland, and Northwest Green Area.

2) Develop a forestry management plan.

3) Develop bike trails with the Recreation Commission.

4) Develop self-guiding nature trails at elementary schools and by the high school complex.

The advantages of these proposals will ensure conservation programs into the 1990s. Changes affected by these proposals will mean that Marshfiled's natural heritage will be preserved, thus allowing future generations to enfoy Marshfield's scenic beauty into the next century.

\subsection{Conservation Funding Sources}

To enable the above recommendations to be realized, a number of funding sources are required. Some major sources that have been and/or can be utilized are: 
Town of Marshfield: The town has shown its support of land acquisition, especially when it is fiscally able to afford such action, and has also worked in liason with the Massachusetts Audubon Society. Marshfield Rod and Gun Club, and other private organizations in acquiring large parcels and conservation restrictions.

Plymouth County Commissioners: A conservation land acquisition fund is available that the Town has used and will be using in the future.

Massachusetts Self-Help Program: This fund provides reimbursement funds for acquisition of land for conservation or passive recreation purposes. The Town has received 50 percent matching funds in the past totalling over $\$ 800,000$, but the current funding level of reimbursement may not exceed 80 percent of approved costs.

\section{Federal Land and Water Conservation Fund: Funds are} used for acquisition and/or development of conservation lands. The percentage of reimbursements is 50 percent.

Private Donations and Trusts: Donations of 1 and and of money have been and will continue to be sought. Trusts can also be used to acquire conservation land. Definition of a land trust can be found in Appendix F.

\subsection{Recreation Programs and 1984 Survey Results}

Recreational facilities are in high demand and existing facilities are experiencing extensive use. Recreational needs 
of the Town's residents are increasing as the population continues to grow. Needed funds and space are essential, and proper management is necessary to create additional recreational facilities, especially as the Town's population is projected to increase considerably by the end of the century.

The Recreation Commission promotes active and passive/indoor and outdoor leisure-time activities within the community, and encourages the development of adequate recreational facilities to meet community requirements. The Commission also promotes using town property, schools, playgrounds and conservation land for the recreational enjoyment of all ages, including senior citizens and the handicapped.

In a 1984 recreation survey. Town residents determined the needs of recreation services and programs. Beaches ranked the highest as an important recreational facility. A town indoor swimming pool and more playing fields were also desired.

\subsection{Recreation Recommendations}

After a review of the survey results and our own findings, we deem the following recreation recommendations as necessary:

1) To provide ample active and passive recreation opportunities for all age groups and both sexes in the entire community.

2) To provide organized, supervised recreation programs.

3) To maintain and improve the quality of recreational functions, facilities, and programs.

4) To promote awareness of open space, conservation land, and available recreation and public facilities. 


\subsection{Recreation Proposals}

As with conservation, the following proposals are earmarked to be enacted within the next five years:

1) Build an indoor swimming pool. (This could be built as part of the existing recreation center, or be built adjacent to the High Schooll.

2) Continue to develop a bicycle trail and to tie in the bicycle paths with those of the Towns of scituate. Pembroke, Duxbury, and Norwell for the development of a South Shore Bicycle Trail.

3) Build new facilities where needs arise such as a playground in the Ferry street section of Town, and lighted ballfields, soccer fields, and playgrounds at Wheelers' Pit.

4) Continue to develop and improve programs utilizing the schools, including the summer playground program.

5) Develop a comprehensive water safety and swimming program.

6) Continue to upgrade and equip the Town's parks and playgrounds.

7) Increase senior citizens' recreational programs and allow handicapped individuals more access to programs.

8) Renovate and expand the existing recreation center or build a new center.

Proper maintenance of recreational facilities is difficult because of their constant use. Limitations of funding for equipment repair, and the necessary manpower needed, make it difficult to provide a safe and quality recreational facility. New sources of funding are needed so that the Town can continue to provide first-rate recreational services. 


\subsection{Recreation Funding Sources}

Possible funding of recreational needs can come from the following sources:

Town of Marshfield: The Capital Improvement Program can provide some of the necessary funds for a major project such as an indoor swimming pool or recreation center.

Recreation Commission: The Commission should continue to generate revenues by ralsing funds through recreation dances, the Rexhame Beach snack bar proceeds, and the Recreation Card Program.

State and Federal funding: Projects can be funded for 50 percent reimbursement from the Land and Water Grant. Under the Federal Land and Water Conservation Fund, funds are used for acquisition and/or development of lands for outdoor recreation use such as ballfields.

Private Donations and Trusts: Private funds can be used to provide facilities such as a recreation center. An example is the Edwin Phillips Trust which is receptive to the Town's proposal to build a recreation facility for townspeople as well as handicapped residents of South Shore communities. 


\section{Footnotes}

1. Warren H. Harrington, and Paul Reynolds. Conservation/ Recreation Open Space Plan, 1985, Town of Marshfield Conservation Commission and Recreation Commission, p.VI-B-4.

2. "Phillips Trustees are receptive to spending money for rec center." Marshfield Mariner. January 29, 1986, pp.1-2. 
CHAPTER 11

POLICIES \& RECOMMENDATIONS 


\section{POLICIES \& RECOMMENDATIONS}

\subsection{INTRODUCTION}

The following section is a summation of policies and recommendations proposed in the previous chapters, and is intended to act as a set of guidelines which will enhance the Town's future development. A recommendation is a specific statement of a definite course of action designed to guide present and future decisions in a manner consistent with the policies which have been formulated.

\section{$\underline{11.2}$ LAND USE}

1) Land use decisions should serve to preserve and protect Marshfield's natural environment.
a) protection of groundwater aquifer
b) protection of the North, South, and Green Harbor Rivers, and adjacent marshlands
c) avoid concentrations of development in flood hazard areas
d) avoid high density development in areas of poor soil conditions
e) protection of the Town's historic sites

\subsection{ZONING}

1) The Planning Board should undertake a revision of its rules, regulations, and Zoning By-Laws.

a) amend present zoning to allow for attached cluster subdivision to help protect the Town's rural character

b) to transfer the Special Permit process for office construction form the Board of Appeals to the Planning Board 
c) to establish an aquifer protection district

d) to implement a new site plan review application

e) avoid the concentration of multi-family housing along Route 139

11.4 HOUSING

1) The Town should implement programs that address the affordable housing deficit to allow for a diversity of housing choice.

a) utilize housing assistance programs such as the SHARP and TELLER programs

b) utilize alternative development control

2) Prevent the haphazard conversion of summer cottages to inadequate year-round dwellings.

a) prevent the further deterioration of structures in the beach areas

b) establish a "certificate of occupancy" permit process

\subsection{TRANSPORTATION}

1) The Town should seek to expand its existing public transportation network.

a) the Town should actively support the reestablishment rail service to Boston from Greenbush, scituate

b) the train service should be constructed for speeds of at least 80 miles an hour

c) Marshfield should actively pursue an MBTA bus route which would utilize the old New Haven bus route, or Route $3 \mathrm{~A}$ 
d) establish small parking lots along the bus
route

e) the Town should alter the senior shuttle system to include other citizens

2) The Town should improve its vehicular circulation network.

a) develop a loop road into the industrial zone

b) widen Plain Street (Route 139) into a four lane road with center stacking lanes for left hand turns where required

c) utilize the former old Colony Railroad bed between South River and Ocean Streets as a new access road

d) link Humarock and Rexhame with a new roadway

3) The Town should provide improved pedestrian safety.

a) utilize bituminous concrete curbing and packed gravel along one side and provide a three foot paved and painted bikeway on the other side of collector streets

4) The Town should undertake a road resurfacing program.

a) devise a program under an Overall Town Management Program for infrastructure improvement and maintenance:

First Year - Church and Ferry streets

Second Year - Pine and Union Streets

Third Year - School and Highland Streets

Four Year - Valley Path and Prospect Streets

\subsection{ECONOMIC}

1) Marshfield should seek to maintain and enhance its commercial center.

a) avoid commercial expansion into the industrial zone 
b) allow provisions for the expansion of the General Business zone ( $\mathrm{B}-1$ )

c) formulate a promotional package for the B-1 zone

2) Promote secondary commercial node in the beach area.
a) utilize the Brant Rock Esplanade as a secondary commercial node
b) allow mixed use development in the Town pier vicinity
c) formulate a promotional package for the Brant Rock area

3) The Town should seek to expand its industrial base.
a) the Town must consider extending water and sewer lines to the industrial zone to attract potential industrial development
b) construct the proposed industrial loop road
c) formulate a promotional package for the industrial zone

\subsection{FINANCIAL}

1) The Town must adopt an overall financial management program.

a) the following projects should be prioritized in order to avoid further budgetary constraints; and these include:

- road resurfacing program

- fire station construction/rehab.

- school expansion

- recreation facilities

- conservation land acquisition

- acquisition of land for wells

- water metering

- proposed new road construction

- sewer expansion 


\subsection{PUBLIC FACILITIES}

Schools

1) The Town needs to establish a school maintenance program.

a) utilize financial maintenance techniques

2) Provide an adequate supply of classrooms.
a) reduce leasing as required
b) expand high school
c) convert one elementary school to a junior high school as required

3) The Town should support expansion of the school curriculum.
a) establishment of a vocational school
b) restore academic curriculum to pre- Proposition $21 / 2$ levels

Fire \& Police

1) The Town should seek to enhance public safety.
a) add two ladder trucks
b) create an equipment replacement system
c) replace the existing station on South River Street with an expanded facility on Route 139. preferably near the police station
d) replace within the next two to five years the Brant Rock station with a new structure along Route 139, near the new Town pier access road



e) construct a new station within the next two to five years in the industrial zone with direct access to Route 139
f) upgrade the Marshfield Hills station or replace it with a station located along Route 3A
g) based on our population projection, the Town will require 55 police officers by 1990 and 70 police officers by the year 2000
h) expansion of police headquarters to accommodate the increase in staff

Waste Disposal

1) The Town should pursue participation in a resource recovery facility.

a) locate the facility in the industrial zone

b) ensure that the site will have direct access to Route $3 \mathrm{~A}$

\subsection{CONSERVATION/RECREATION}

1) To ensure the protection of conservation land and finite natural resources.

a) continue to acquire land for the protection of water recharge areas to maintain future water quality and supply

b) maintain the preservation of Green Harbor for flood control and recreational opportunites

2) To maintain and improve the quality of recreational functions, facilties and programs.

a) develop bicycle, biking, and jogging trails 
b) continue to develop and improve programs utilizing the schools, including the school playground program

c) continue to upgrade and equip the Town's parks and playgrounds

d) increase senior citizens' recreational programs and allow handicapped individuals more access to programs

e) renovate and expand the existing recreational center or build a new center

f) build an indoor swimming pool

g) develop a comprehensive water safety and swimming program 
APPENDICES 
APPENDIX A

SEPTIC SYSTEMS AND GROUNDWATER 


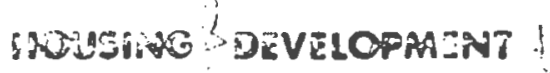

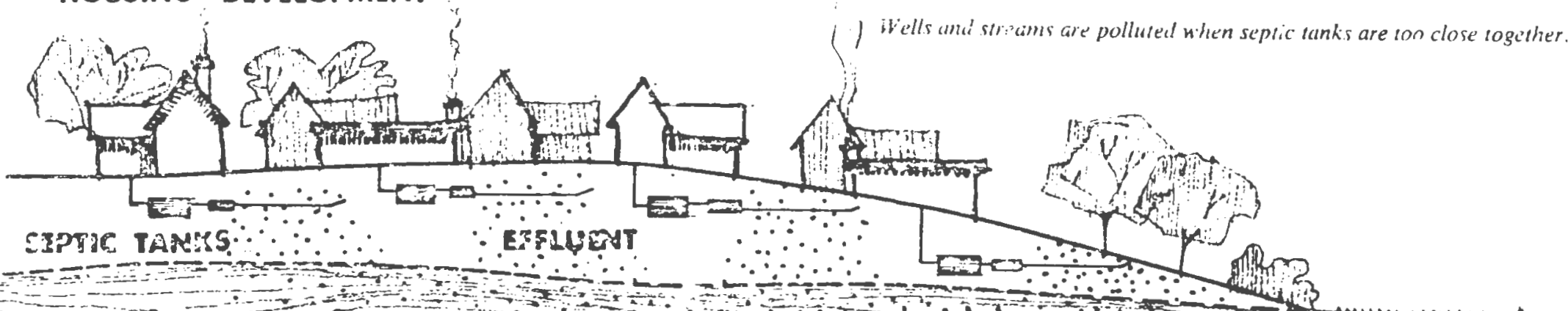

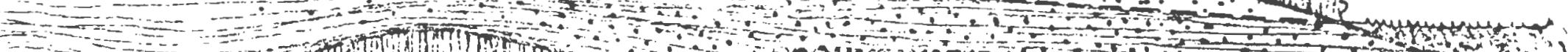
19Tin The (1)

\section{STPELE HCUSE}

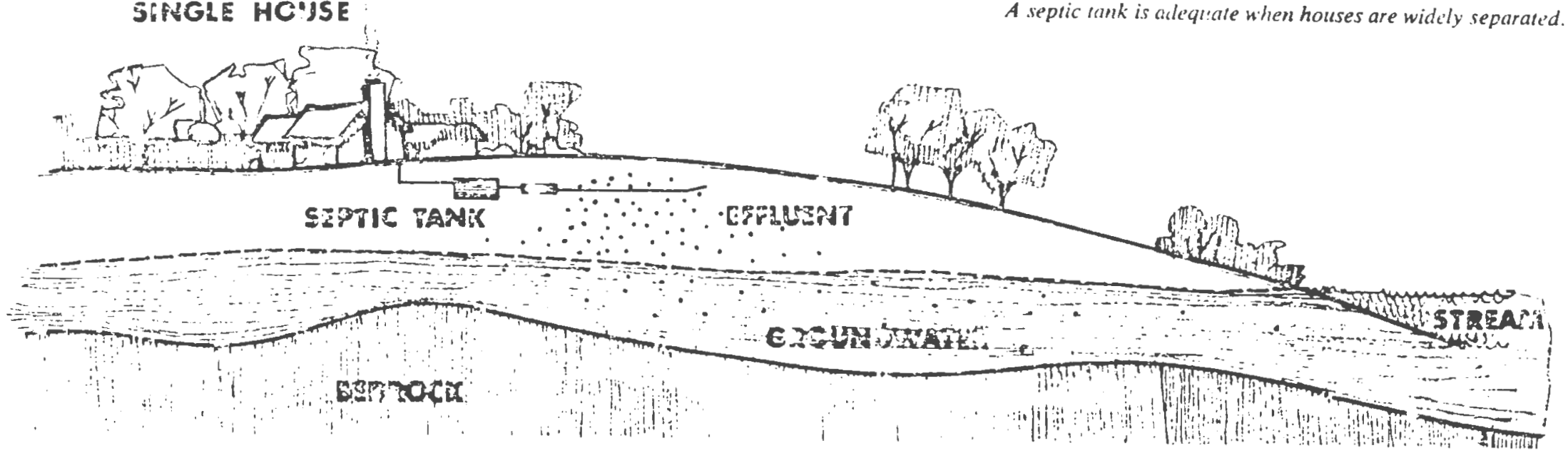


APPENDIX B

HISTORICAI SITES 
MAP 2.1

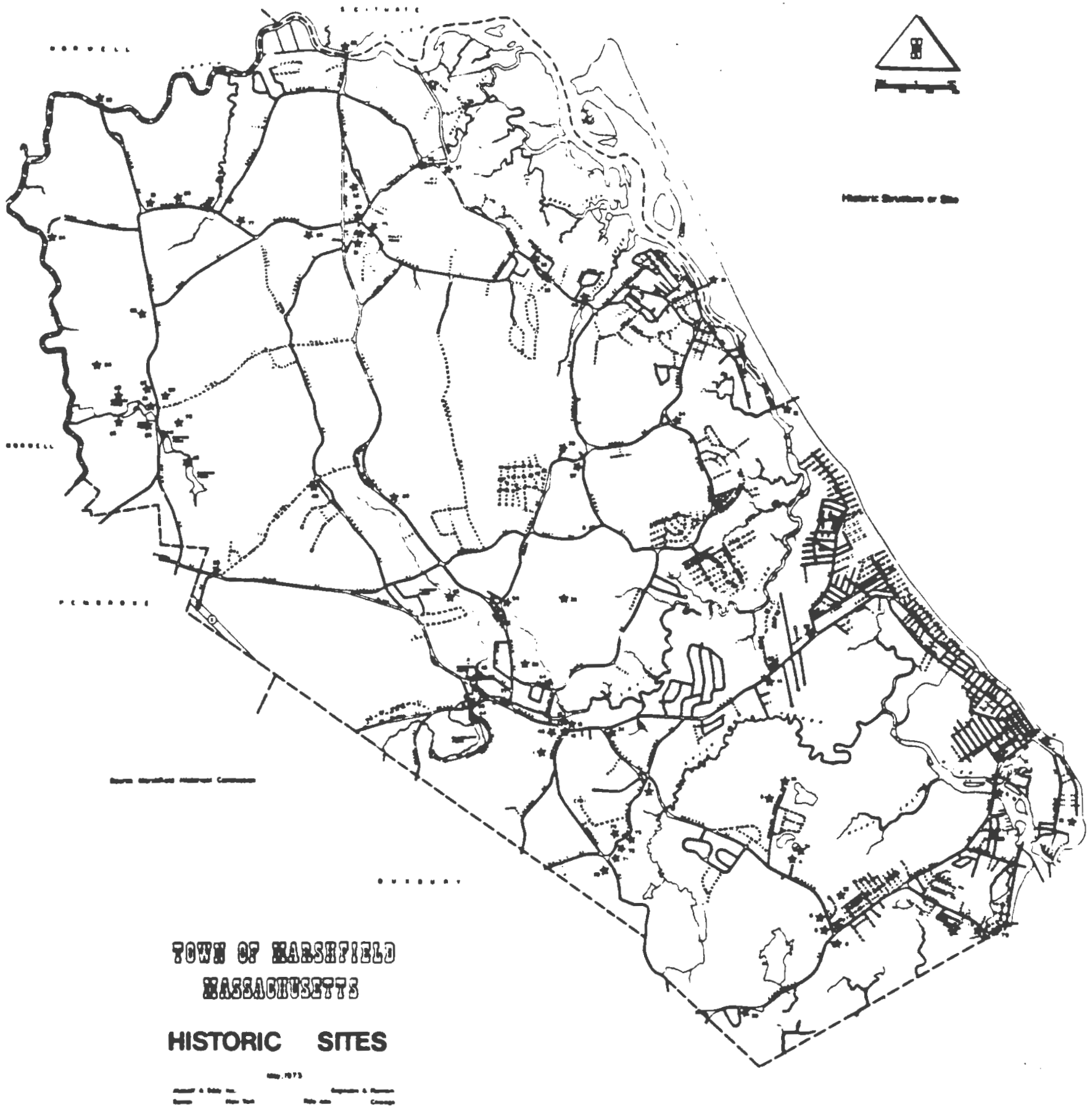




\section{APPFNDIX}

\section{HISTORIC SITES WITHIN TIE TOWN OF MARSHFIFLD*}

1. Tea Rock Hill - 851 Noraine Street on private froperty; rock has Lecn removed. (Site of burning of a collection of tea in December 1773.)

2. Silte of Old South School - private property (marker at corner of Webster and Parsonagre strcets indicated location of original school (1645) estahlished in the carliest days of public schooling in New Fngland.

3. Hinslow Cemetery - al eastern end of road by same name, off Webster Street. (Site of first burying ground, first church building, tomb for the R'inslows and strave of Daniel N'ebster.)

4. Sile of Daniel Nebster's Home - private ownership located off Webster Street; on a knoll which was part of the 1,500-acre estate that extended to Green Harbor.

5. Ninslou House - comer of Niebster and Carcswell strects; owned and maintained by a private organization, prescntly used as a museum and tourist point. (The I:istoric Ninslow House Association.)

6. (Iffice of Daniel D'ebster - moved to open ficld nurth of Winslow 'Youse. (Can be inspected by inicrested parties.)

7. Schoolhouse - corner of Webster and Careswell streets; used as headquarters for the Historic Commission.

8. Careswell - puorly delineated area somewhere near the Winslow School and identified as the site of the first house built hy Ellward Ninslow about 1636-1637. Thiree cellar holes explored in recent archacological probes indicate this may have been settled earlier than Plymouth.

9. Marker on Dytie Street - at bridge over Green Harbor river states that it is on the site of the Green Ilarbor Dike. (The history of the Dike reflects the furding in the 1870 's between those who wanted to develop the upland mearlows against those who wanted the harbor devcloped for fishing and boats.)

10. Site of Fessenden Tower Blackman's Point, Brant Rock - construction of radio transmitting station started in 1905. Four hundred foot tower on a three-foot base, which consisted of a metal ball set in ccment and glass insulators between layers of cement, sent a message to Scotland. In 1906 the first wircless

\footnotetext{
*Informution supplied by Marshficld Ilistoric Commision.
} 
transmission of a human voice was made from Fessenden station. Everything was dismantled at onset of World War II.

11. Sile of Brant Rock Life Saving Station - sturage of boats and needed equipment for volunteers who rescued shipwreck survivors from 1893 to 1947. (The building was demolished in 1967.)

12. Old mouth of the North and South Ricers - cloned by severe storm on November 27, 1898; presently is town line between Rexhame, Narshfirld-Humarock, Sciluate.

13. Canal - marker on houlder of Canal Street, faring north from small bridge explains that a water passage from Duxbury Bay to Green's llarbor was eut to facilitate conmunication with Plymouth. In 1636 the Gincral Court ordered that "a Cutl for boat passagre be mate at 18 foote wide and six foote deep."

14. Iilgrim Trail - a marker on Webster Strect denotes an old lndian trail used by early settlers as a fouipath belwern IMymuth and points north. (As best this conmitte could ascert ain. the entire length of the trail runs on private property.)

15. First Congregational Church - 19941 cean Street; land and structure owned by church membership. ((Original "gathering" of congregation in 1632; present luilding erected in I 8:38.)

I6. The Common or Training Green - triangle plot between Morainc, Occan and Centennial streets, presently owned by the Town of Marshfield.

17. Sile of Peregrine White House - off S. River Street; 200 acres and house stayed under ownership by the White family for six generations; presently owned by Dr. E. A. Brown.

18. Proclor Bourne Store - 2000 Ocean Street, currently owned by storekeeper on ground floor. Original building dated back to 1675 .

19. Sile of Ilite's Ferry - conveyance to Sciluate, at end of Sea Street.

20. Rosers Store - corner of Prospect and Summer strects, Yarshfield Ilitls (182?).

21. The Former Lnitarian Churrh Vain Street, Marshfield Mills (1818).

22. Lillle's Iridge - now Route 3 1 over the North River, formerly Dogactt's Ferry. The bridge was a toll bringe from 182.7-1867. 
23. Union Bridge - crossed the North River where Bisbec's Ferry loaded at North Marshfield. Bridge built in 1800 , toll removed in 1850 .

21. Gravelly Beach - former shipyard site at end of Corn Hill Lane, North Marshfield.

25. Hatch Mill - Union Strect, "Two Mile", one of the few remaining water-driven saw mills in New England.

26. Two .Mile - a strip of land along the North River to the west of Linion Strect. It was annexed by Marshfield in 1789 .

27. I'eterans Memorial Park - at intersection of Routes 139 and $3 \mathrm{~A}$ is now owned and maintained by a private organization. It is the site of a grist mill, later a fahric mill and still later, a wet wash.

23. Marshfield Fair Grounds - Main and South River strects, privately owned by charter to the Marshfield Agricultural and Iforticultural Society. The "grounds" include fairly large tracts of land to the north and east of the huildings. Since 1865 the site has been used only during scheduled Fair days and occasionally ofher groups are permitted very limited use, i. e., Firemen's Muster, Highway lepartment Clambake.

29. The Heurse IJouse - rescareh on site not very exp'icit. There is supposed to have lren a cluster of town buildings including an $\mathrm{Alms}$ House and Mecting House. Early records indicate that there was the earliest Town Ilall type structure in this general area.

30. Green Ilarbor Railroad Station Site

31. Cherry IIill, Site of W'ebster's Last Speech

32. Site of I'ebster's Horse Graves

33. Old Colony Railuay Bed

34. Narsh field Railroad Station Site

35. Marsh ficld Center Railroad Site

36. Seavieu Railroad Slation Site

37. Varshforld I'ills Railroad Stution Site 
38. Nalker Pond Nail Factory Site

39. Damon's Pond Mill Site

40. David Hatch Fullings Mill Sile

41. Jonathan Hatch Mill Site

42. Vagoun Box Board Viil Site

43. John Wlagoun Sau Mill Sile

44. Chandler Pond Crist Mill Site - Duxbury and Marshfirld Manufacturing Co.

45. Bonney's Iron Furnace

46. Little Pond Mill Sile

47. Brant Rock District-1800

48. Soulh District School 1851 - Ventress Library

49. Joyce District School

50. Two .Mile District School

51. Union District School Site

52. North District School Site

53. Litlle Town District School Site

54. Ferry District School Site

5.5. Factory District School Site

56. Zion's Mall - First Methodist Church Site

57. First Episc,ipal Clurch Sile

58. First Baptist Church Site 
5). Vorth Maptist Churrh Site.

60. Cirace Chapel

61. I'nion Churrh - Branl Rork

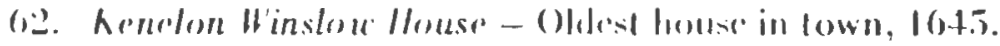

63. Thomas Bourne House - Mirl ITh Gionlury.

(o.t. Ilonland Ilouse

6.i. Liegers fiarrison /louse - 16.50

66. Viarmer Ben Ilatch - 1691 - Clift Store 1700's

67. Hatch House - Mirl I600)'s.

683. Ilatrh Ilomestead-1647

69. Two Mile Farm - 17th Cintury.

7). Jonathan Halch - 1651

71. Col. Anthony Thomas

72. I7.10 Thomas Ilouse.

73. Ningley House

74. The Carver Ilouse?

75. Clift Rogers Library

76. Congregational - Trinilarian Church

7i. Rogers House - Mid 16000s.

78. Jethro Taylor - 17th Century.

79. Cire'en's Fishing l'ost sile 


\author{
APPENDIX C.I \\ INFORMATION FROM AFFORDABLE SINGLE FAMILY HOUSING \\ APA/PAS REPORT \#385 \\ INFORMATION FROM "ATTACHED HOUSING" \\ BUILDERS MAGAZINE SEPTEMBER 1.1979
}

INFORMATION FROM PERFORMANCE ZONING

LANE KENDIG, APA 
III. B. CLUSTER DEVELOPMENT

1. Description

Cluster develspment is a land design technique for single-family subdivisions that calls for the developmant of lots smaller than those specified in a majority of a community's conventional zoning districts. Clustering respects a zoning district's permitted gross censity (number of cwellings per acre relative to the entire jevelopment site), but - by reducing lot size and limiting development to the most developable portion of the tract - increases a subiivision's net density (number of dwellings per acre relative to the deralopable area of a site).

Gencrally, there are two types of cluster development: one which specifies a degree of lot size reduction below the area reguired by a particular zoning district; and one which permits the clustering of attached units. In the first case, dwellings are arranged on lots smaller than trose tipically permitted in a conventional zo..ing district. The lots ere organizcd arourd courts, cul-de-sacs, or short loop streets. In the secord case, a cluster of ittached linits (duplexis, triplexes, and quadplexis) is arranged arou..3 parking ccmpounds or in private courts. Sone jurisdicions permit both categories within the same project. In these cases, there is orten a Iimit on the number of units which 
can be attached. The limit is based on a percentage of the total number of units permitted on the gross tract. Whatever the category of cluster development, developers are often raquired to reserve undeveloped land as common open space in exchange for permission to alter the configuration of the conventional subdivision.

\section{Advantages}

Clustering permits more efficient us of land resources tisan is otherwise possible under conventional subdivision regulations. In order to yield the gross density permitted in a zoning district, the traditional single-family subdivision must use all available land. Since such site constraints as poor soils or environmentally sensitive lands can limit the developable portion of a tract, developers often find themselves building to lower than permitted gross densities. With clustering, however, developers can locate homes on the nost buildable sections of a site and still achisve permitted gross densities in most cases.

Tra zanafits of clustering extend well beyond density consiceracions. Ey concentrating residenital units on a portion of a site, less land is disturbed in gradirg and clearing. As a result, site preparation costs are reduced on a per unit basis. Furthe=, the landforms and vegetation that disniaguish the site can be retained to set oif one 
group of clustered resilences from another and to provide a sense of privacy, thus increasing the marketability of the clustered homes. Minimal disruption of the land, particularly for streets, sidewalks, and driveways, can also kecp down the costs of either temporary or permanent sndimentation and erosion controls.

In addition to preserving much of the natural character of the site, clustering can permit savings in both the raw and improved land costs of new homes. Depending on local market conditions, the reduced per unit consumption of land can translate into lower per unit raw land prices. Further, with smaller lot sizes and proportionate decreases in linear front footages, the distances traversed by sewer and water lines are minimized, and street and sidewalk lengths arz necessarily reduced. Consequently, per unit charges for the installation and maintenance of public services can be expected to be lower for clustered dwellings than for homes in a conventional large-lot subdivision.

Arsther ajvarioge of clustering lice in its potantial for enazoy conservation from the perspective of both the entire subdivision and the individual dwolling. One-time energy expenditures for the construction and installation of public services for an entire subdivision are limiced by a cluster cojlopment's compact pattern. Where the individual hore is concerned, clustering affords the developer a 
measure of flexibility in siting the unit to take advantage of solar access and any natural features of the development site that cut energy consumption for heating and cooling.

\section{Housing Types}

Depending upon a community's regulatory framework, cluster development can accommodate a rarge of housing types. Traditionally, the single-family detached home has been the areferred choice among American households, although it is the most expensive type to own and operate because of its requi renents for land, streets anci sidewalks, and utility runs. The cluster concept, however, recognizes consumer uemand for the free standing rome and, by siting homes $\mathrm{cn}$ smaller lots, minimizes some of the costliest aspects of the detached unit. As an altarnative to the single-family detached home, cluster development can also acconmodate the zero lot-line house and the single-family attached unit, houses that are specifically intended to limit land consumption while ensuring an ideguate measure of privacy and exterior space for household activities. Thesc two house types are described in further devail in sections III. D and E.

4. Regulatory Framework

cluster development as a category of development most 
closely resembles the conventional single-family subdivision in that it respects a zoning district's use and density reguirements. The regulatory treatment accorded cluster development, however, varies from one comsunity to the next and can m-ke the approval process more or less expeditious. Local provisions most freguently categorize cluster either as a conventional subdivision requiring a public hearing prior to approval, a planned unit development, or a land use requizing a special exception.

Cluster is readily approved in jurisdictions that consider this development form largely identical to the conventional subdivisicn. In some comnunities, however, cluster is viewed as a variant of the conventional subdivision and is thus subject to a lengthier approval process. It is not uncommon, for example, for a cluster project to undergo staff review to determine if clustering is feasible. Other communities require a public hearing for a cluster proposal, though not for a conventional subdivision, or specify that a site plen accompany the preliminary subdivision plat. Clearly, given that cluster development serely alters the configuration of the traditional subdivision, it should be considered in alternate form of single-family subdivision devclopment whose approval requircmerts are ron more derranding and time-consuming than those imposed on the conventional subdivision. State laws delegating zoning powers to local jurisuictions often specify grounds on wich variations to conventicral zoning can be permitted. 
STIEET PAVERENT

Asphalt pavement

Minor Sireets; Cul-de-sacs

8" \$1.83/S.F.

Collectar/Subcollector

9"@\$2.05/S.F.

Toial Costs

Costs/DU

\section{CURBS \& GUTTER}

$\$ 10.50 /$ L.F.

Total Costs

Cosis/DU

STAEET TREES

$\$ 16.00$ 'L.F.

Total Costs

Costs/DU

RRADING/STREETS \& R.O.W.

R.O.W.

Collector/Sutcolleclor

So.14/S.F.

Minor Streets/Cul-de-sacs

$\$ 0.14 / S . F$.

STHEET EXCAYATICN

Totäl Strevis

(50.03/S.F.

r.:e grading. seed

civ. (C) \$0.15/S.F.

Total Costs

Costs:DU

DEIVEHAYS

Ccncrete pavement

(i) $\$ 2.25 /$ S.F.

Total Costs

Costs:Du
CONVENTIO:NAL

\begin{tabular}{lr}
492.330 S.F. & $\$ 900.964$ \\
345.640 S.F. & $\$ 708.562$ \\
\hline & $\$ 1.609 .526$ \\
& $\$ \quad 3.410$
\end{tabular}

48,208 L.F.

s 506,184

$5 \mathbf{5 0 6 . 1 8 4}$

s 1.07?

25.781 L.F. \$ $\quad$ \$ 412.496

$\begin{array}{rr}\$ & 412,496 \\ \$ & 874\end{array}$

512.378 S.F. \$ 71.133

B06.344 S.F. \& 112.338

837,270 S.F. \& 75.417

540.752 S.F. $\quad$ S 81,113

\$ 341,151

$5 \quad 723$

330.400 S.F. S 743.400

$\begin{array}{lr}\$ & 743.400 \\ \$ & 1.575\end{array}$
Cluster

311,300 J.F. \& $\$ 09,679$

214.270 S.F. \& 439,253

$\$ 1,008,932$

$\$ 2.135$
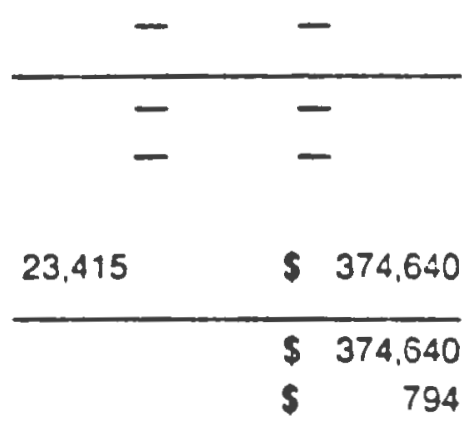

316,246 S.F. \$ $\quad 44.274$

575,008 S.F. \& 80,501

525,570 S.F. \& $\quad \$ 7.301$

265.684 S.F. $\$ 5 \div .853$

\$ 226.929

254,540 S.F. $\quad$ \$ 527,715

$\$ 527.715$

$\$ \quad 1.213$ 
20 acres wooded

(a) $\$ 4.650 /$ acre

117 acres open

(C) 1,200 /acre

Tutal Cost

Ceevou

CIEEVALKS

$56: 5 / L . F$.

CONVDU

\section{STORH SEWER}

15"@20.00.L.F.

18" (28.00/L.F.

21"@31.50/L.F.

24"@34.50:L.F.

27"@39.00/L.F.

30"@ 43.00/L.F.

33" @ 46.25'L.F.

36"@50.50/L.F.

42"@63.00/L.F.

Hearwalls@\$700 i.a.

Irilets (2) \$2,500 e?

(c) $\$ 2.800$ e3.

Mantioles@\$1.375

Riprap@ headwalls

\$320.c0/headwall

Grass swales

(@) $\$ 3.00 / L . F$.

\section{Total Cost}

Ccat/DU

WATER DISTAIBUTION

Firehydrant@\$1,300ea.

8"water@ 20.00/L.F.

6"water@18.00/L.F.

2"water@15.00/L.F.

I" service connection

@

Toisl Costs

cosidou

SARITARY SIWER

Manholes@1.000.00 ca.

8"pipe@20.00/L.F.

Gravel backfill@2.00/L.F.

6 " double =ervice

corr.ection (c) 21.00/LF.

double, Y connesiors 202.00

T, ij Cost

Cost/ou

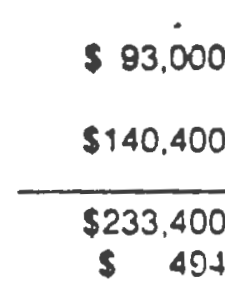

31,000 L.F.

5,300 L.F. 4,500 L.F. 1,400 L.F. 1,00OL.F. 600 L.F.

1,000 L.F. 1,000 L.F. 450 L.F. SCOL.F.

23 L.F.

75 L.F.

12 L.F. \$ $\$ 16,500$

23 L.F.

$\$ 209.250$

$\$ 443$

$\$ 137,800$

$\$ 126,000$

s 44.100

S 34,500

$\$ 23,400$

$\$ 43,000$

$\$ 46.250$

\$ 22.725

s 18,900

\$ 16,100

$\$ 187,500$

s 7.350

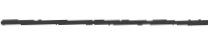

$\$ 724,135$

$\$ 1,534$

$\begin{array}{cc}21 & \$ 27.300 \\ \text { C,8:0 L.F. } & \$ 136.000 \\ 15,900 \text { L.F. } & \$ 286.200\end{array}$

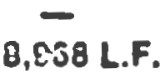

-

\$ 91,522

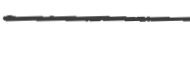

$\$ 541,42 ?$

\$ 1,147

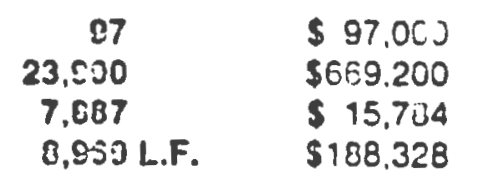

$\begin{array}{rr}27 & \$ 97.00 J \\ 23,800 & \$ 669.200 \\ 7,687 & \$ 15.704 \\ 8,959 \text { L.F. } & \$ 188,328\end{array}$

236
$=9,300$ L.F.

5 ccres wooded

118 ecres opon

\$ 23,250

$\$ 141.600$

$\$ 164.850$

S 349

$\$ 197,775$

$\$ \quad 419$

2,700 L.F. $\$ 70.200$

1,000 L.F. $\$ 28,000$

700 L.F. \$ 22,050

1,260 L.F. $\$ 43,470$

120 L.F. \$ 5.160

S00 L.F. \$ 13.875

800 L.F. $\$ 43.450$

EOL.F. \$ 3.780

13 L.F. \$ $\$ 9,100$

-

12 L.F. $\$ 16,500$

13L.F. \$ 4.160

5,000 L.F. $\quad \$ 15,000$

$\$ 411,345$

$\$ \quad 373$

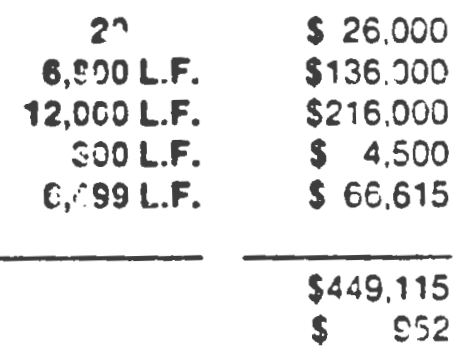

$\begin{array}{cc}00 & \$ 88,000 \\ \mathbf{2 1 , 0 0 0 \text { L.F. }} & \$ 513.200 \\ \mathbf{5 , 4 7 5 \text { L.F. }} & \$ 10.550 \\ \mathbf{6 , 6 9 9 \text { L.F. }} & \$ 135.479\end{array}$

$: 36$

\$ 19,352

$\$ 857,081$

S 1.839 


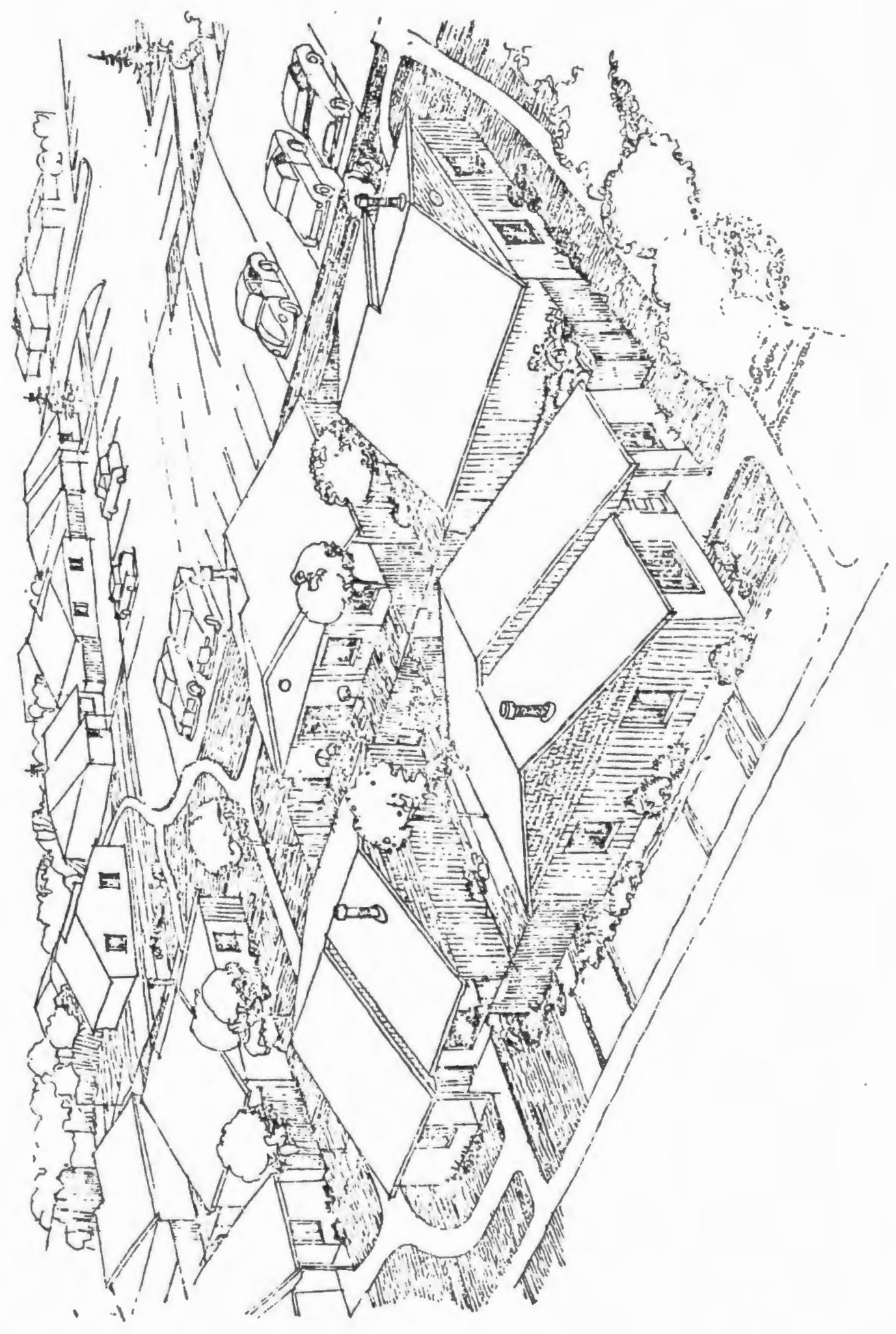




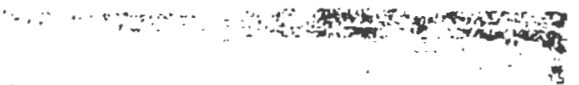

Figure 2. A comparison of Conventional (A) and Small-Lot (B) Slting of Dwelling Units.

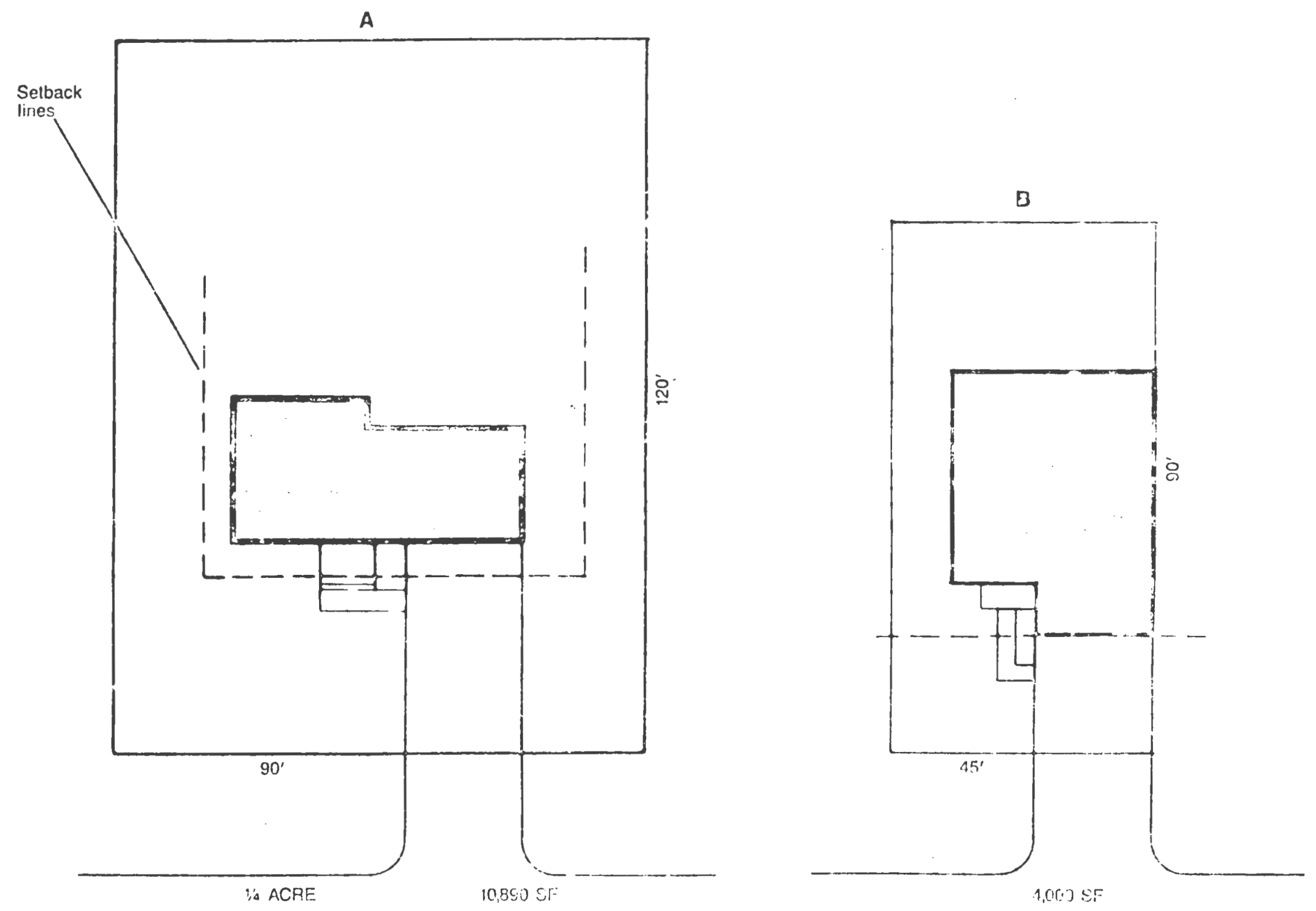

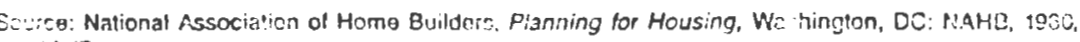


巣

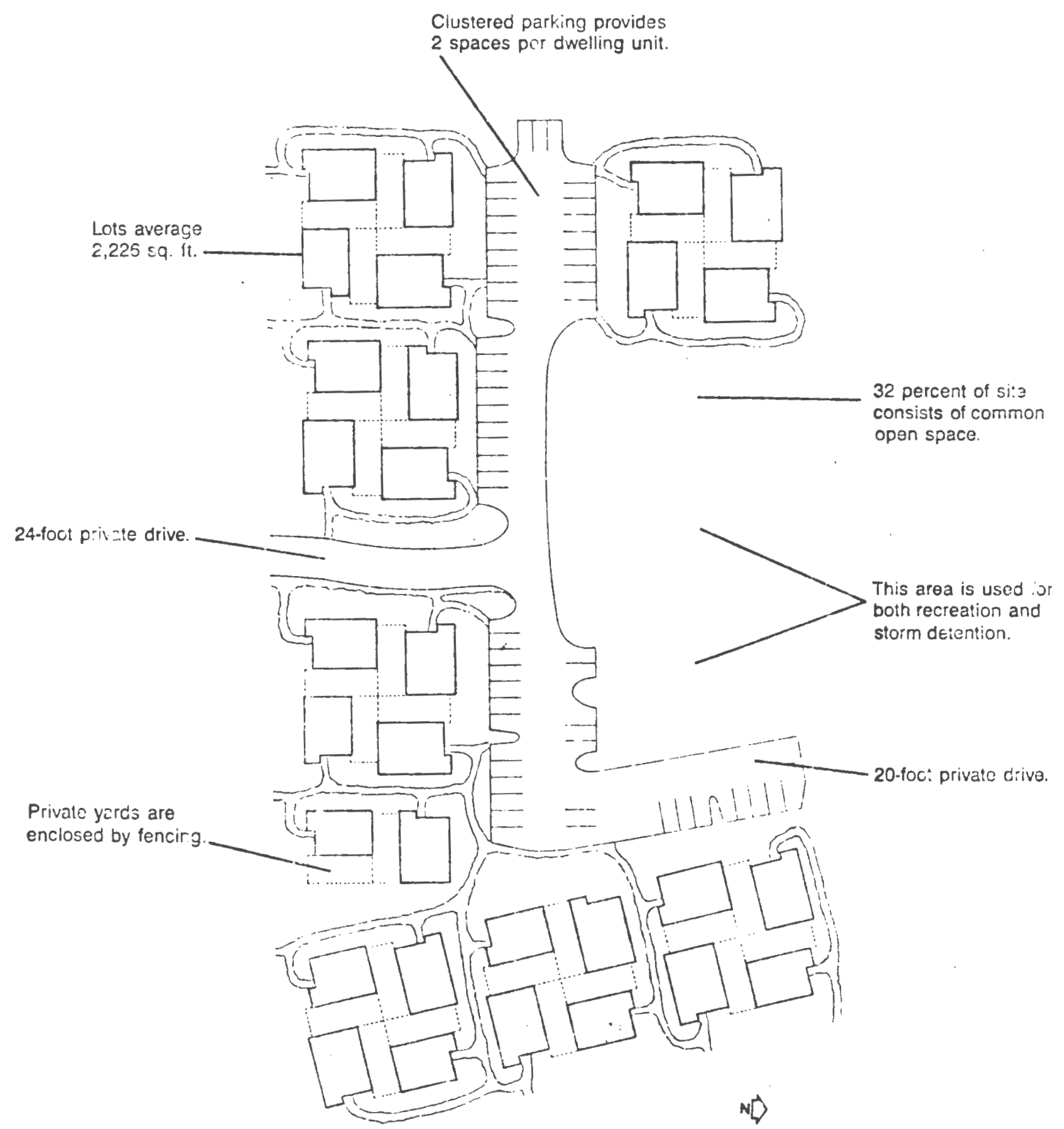


Figure 7. Floor Plans, Su rise Development, San Antonio, Texas.

\section{CHABET PHSARS}

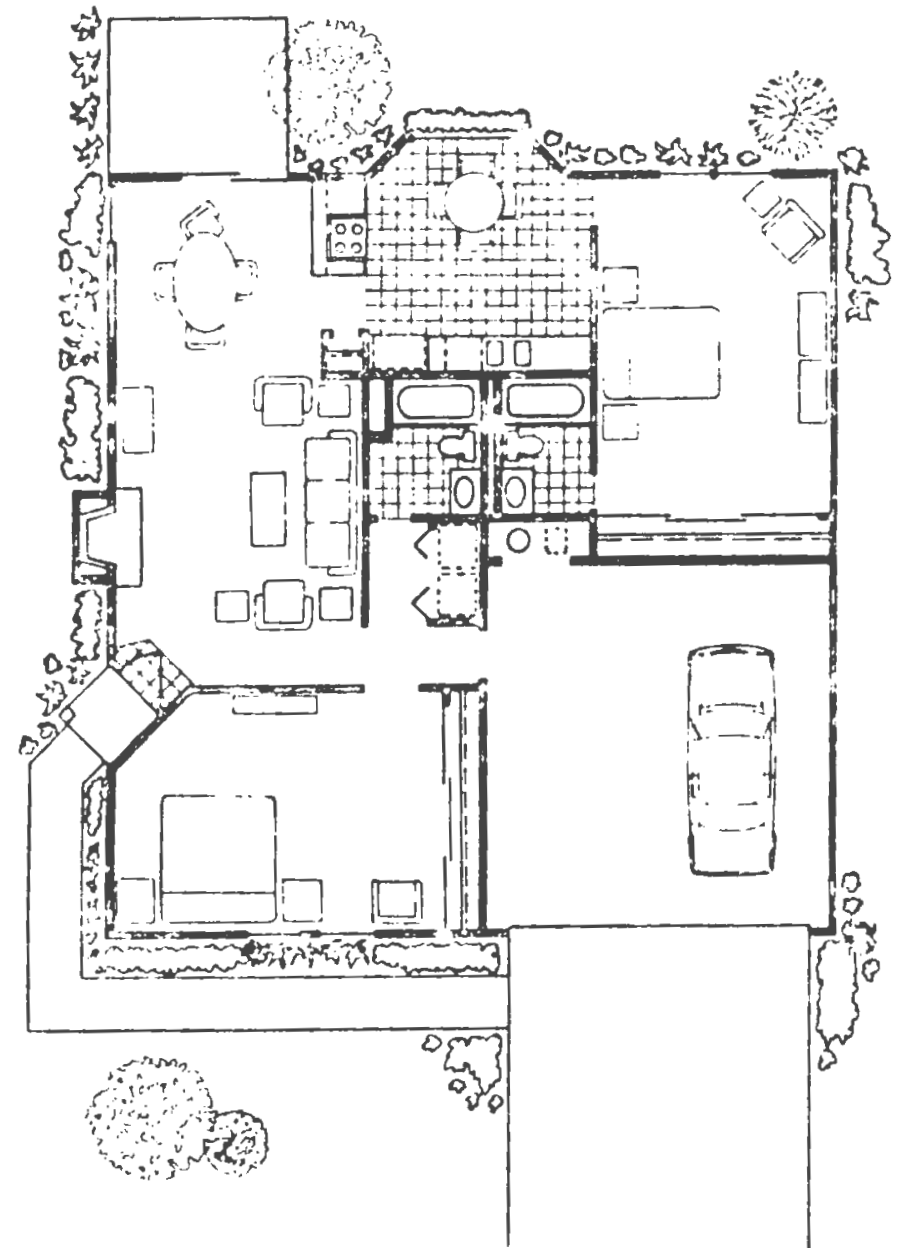

Living Area

1309 sq. ft.

Parking Area \& Storage

399 sq. ft.

Porch \& Fatio

96 sq. $t$.

1804 sq. ft.

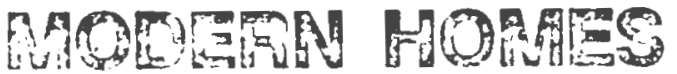

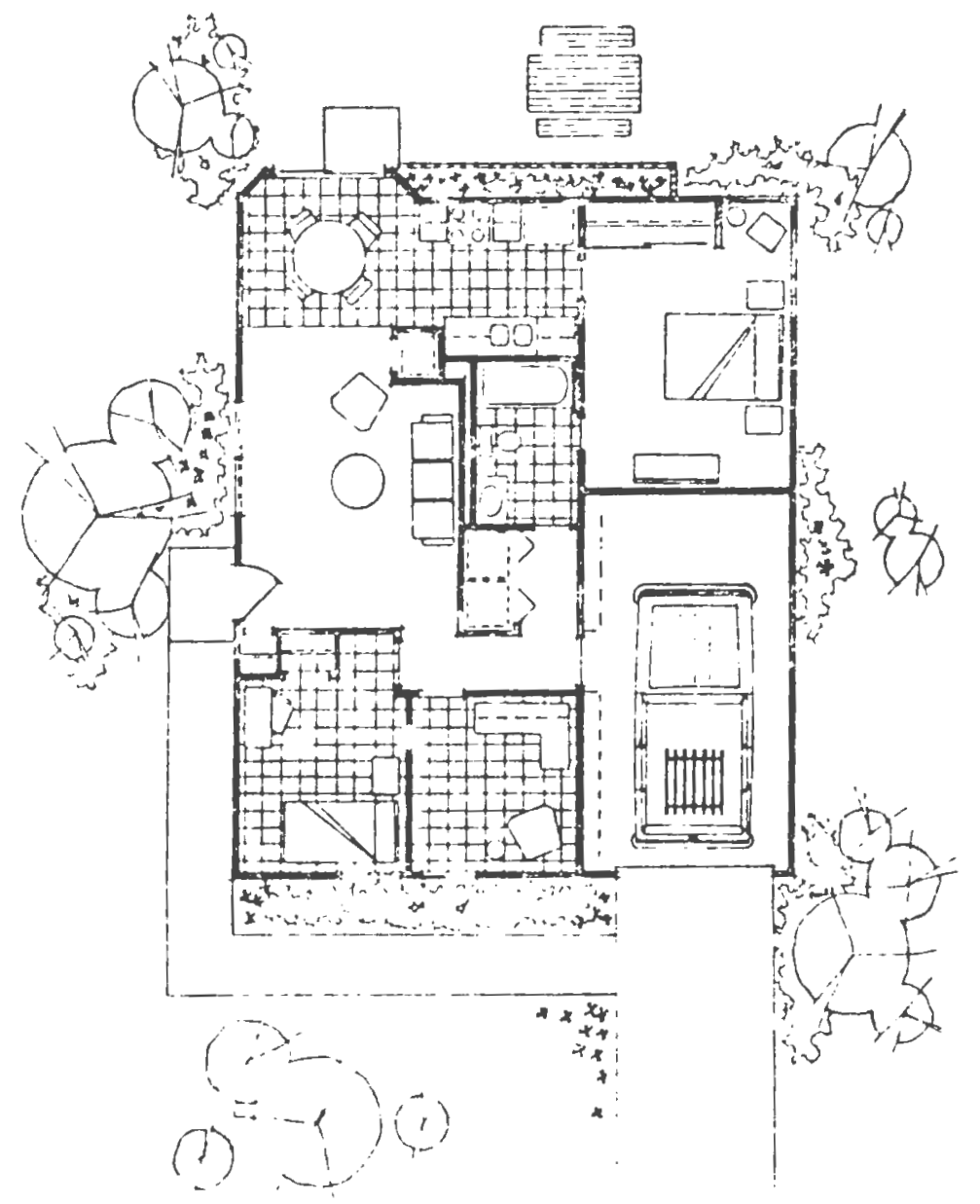

$\begin{array}{lr}\text { Living Area } & \text { 262 sq. ft. } \\ \text { Garage \& Storage } & 250 \text { sq. It. } \\ \text { Porch \& Fatio } & 30 \text { sq. It. } \\ \text { Total Area } & 1142 \text { sq. fl. }\end{array}$



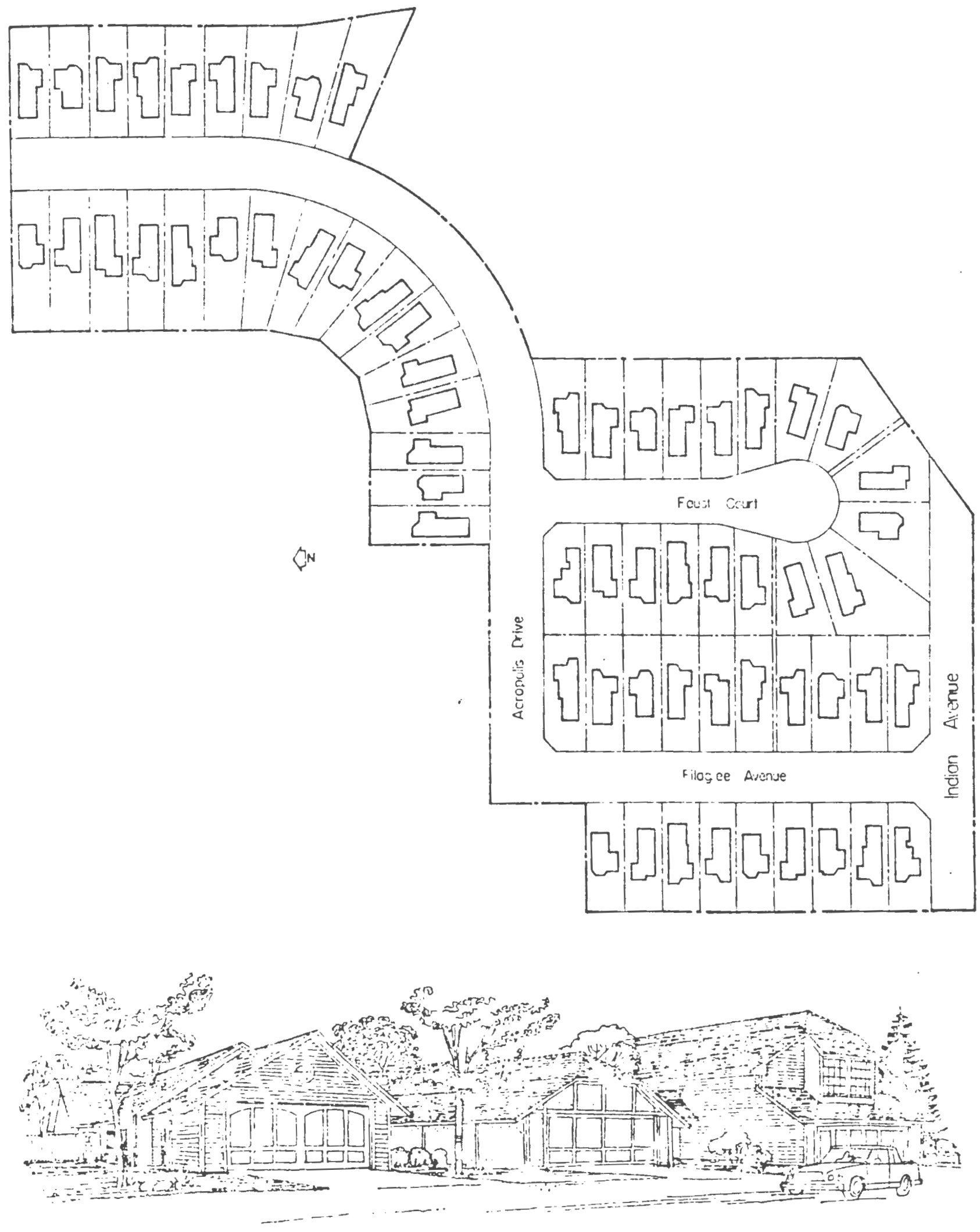

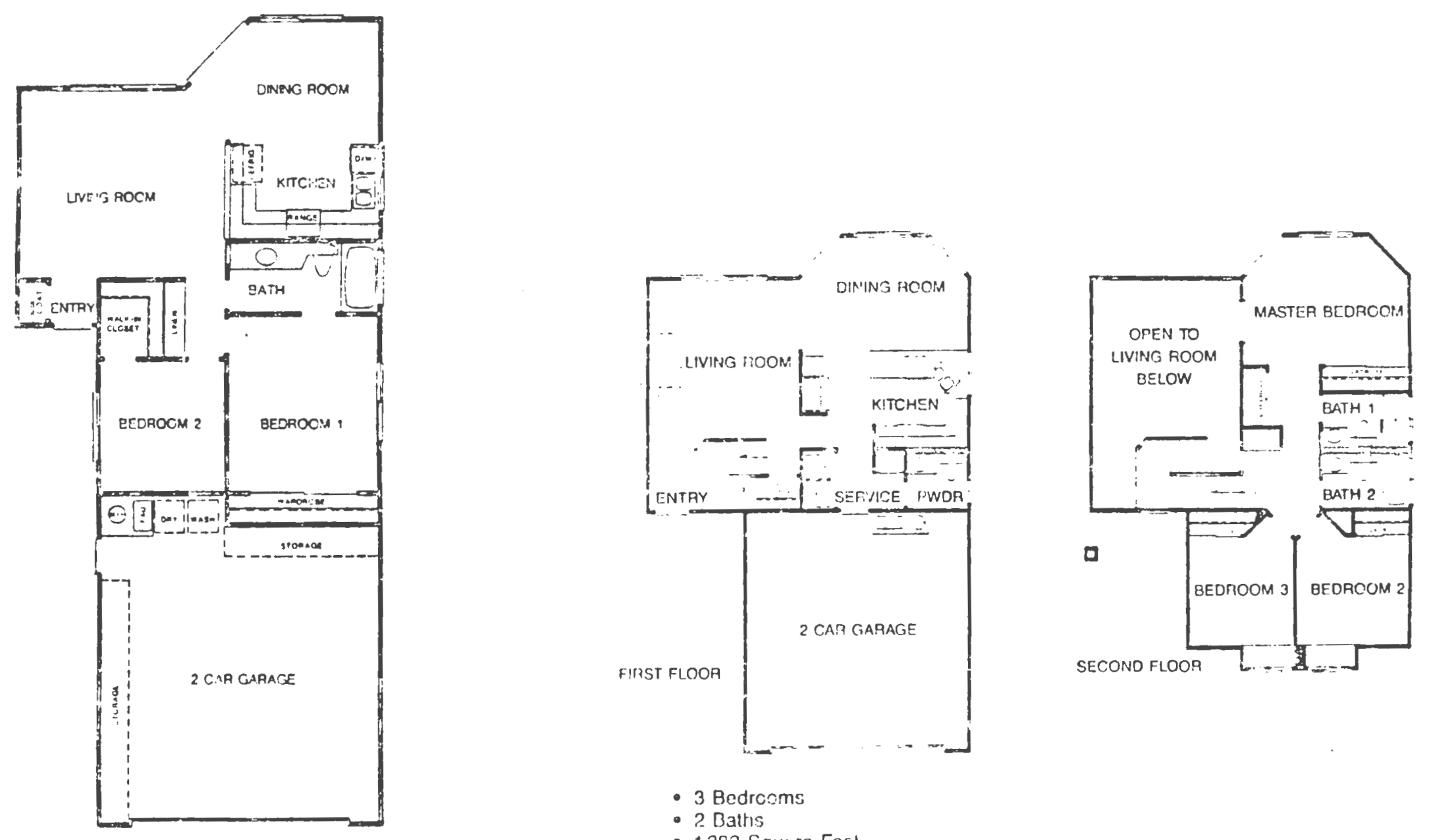

- 3 Bedrcoms

- 2 Baths

- 1,30? Szuare Foct

- 2 Bedrooms

- 1 bath

- 82: Square Feet 


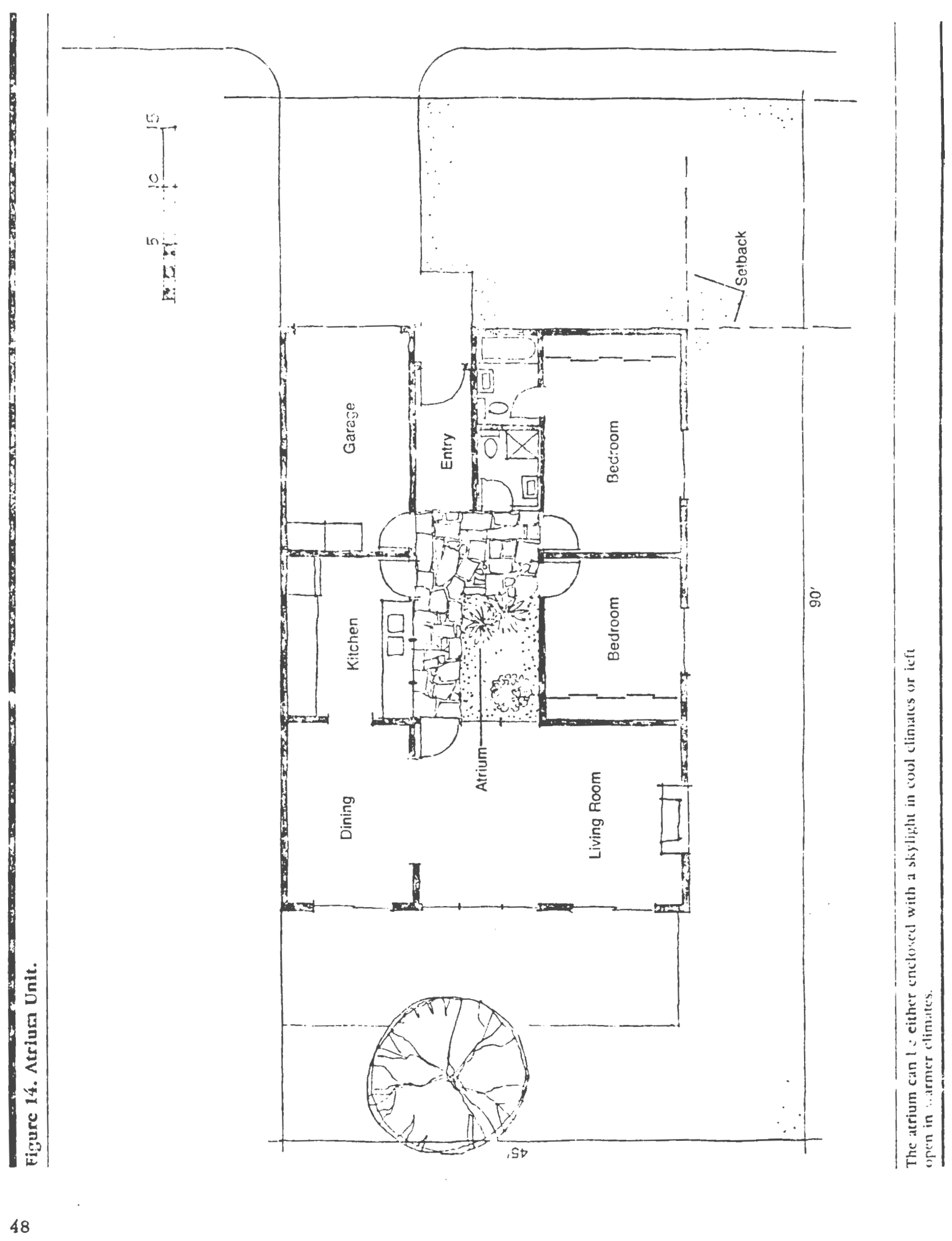




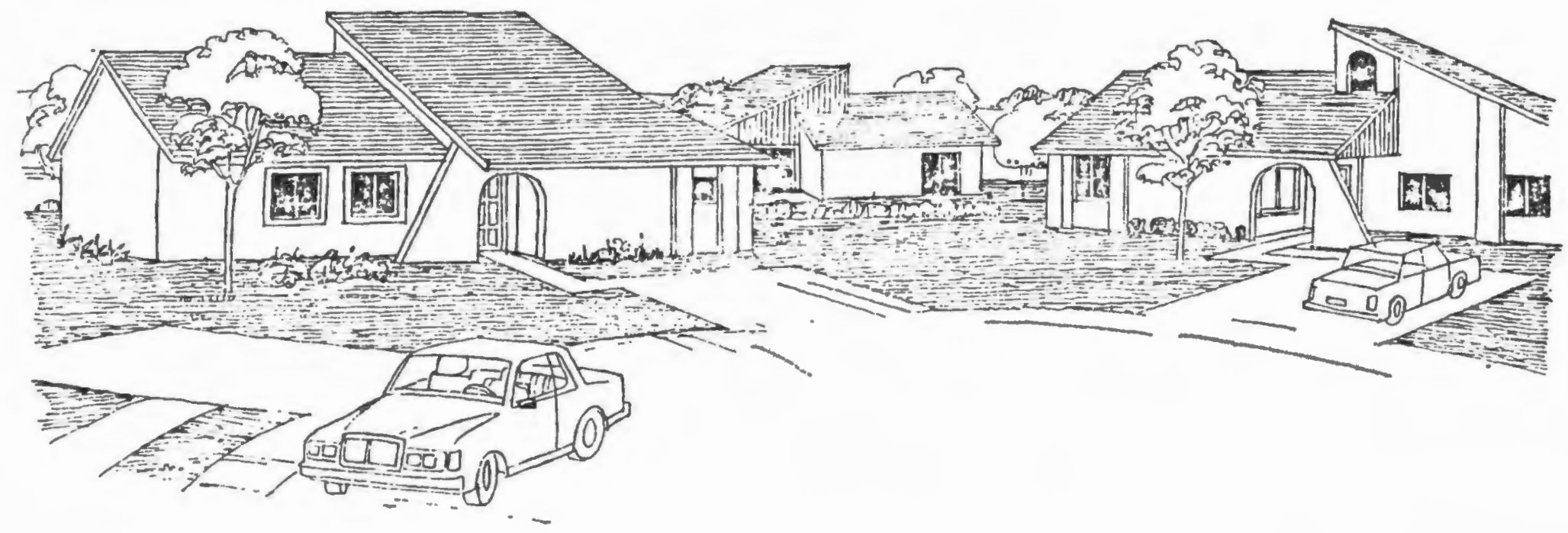




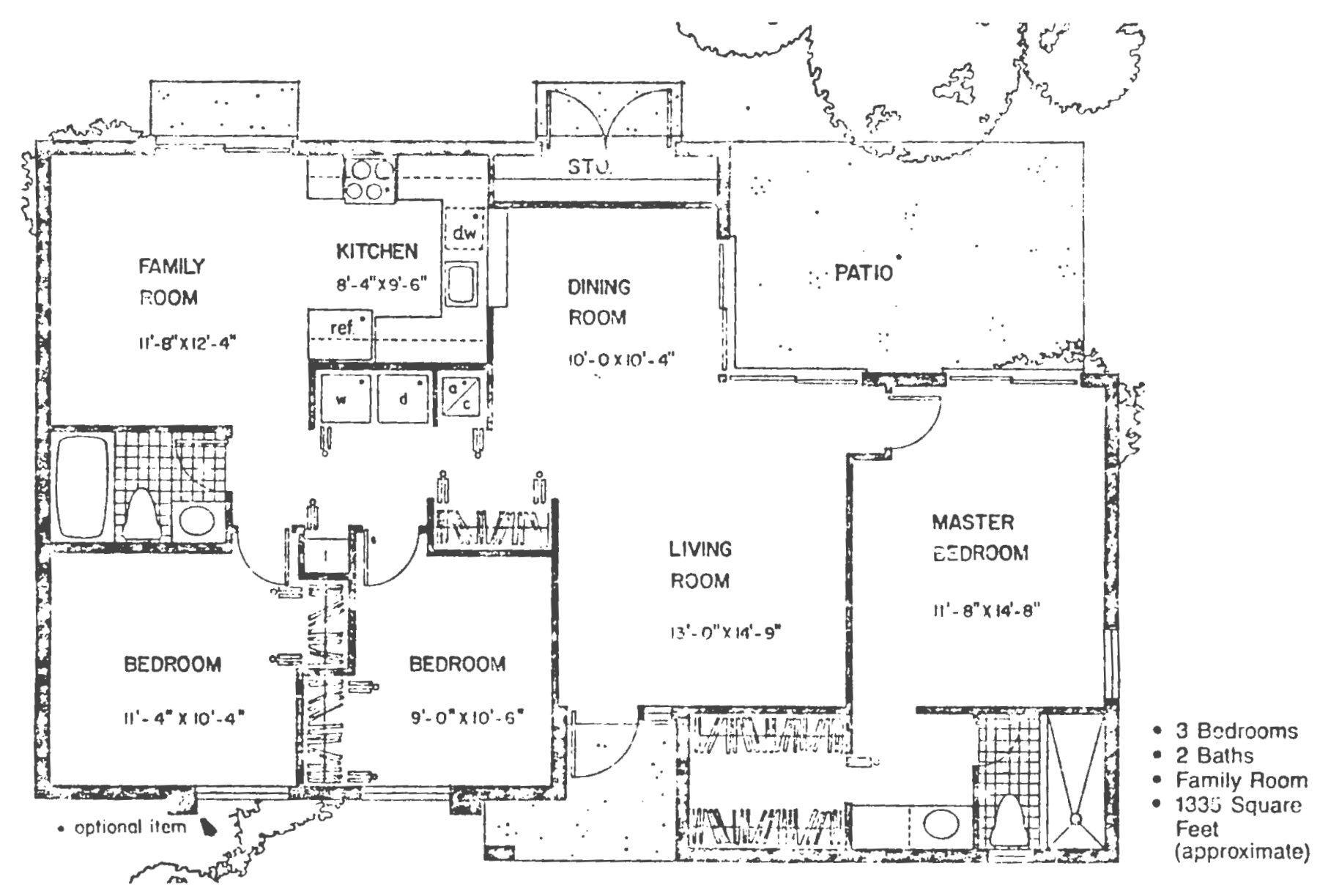




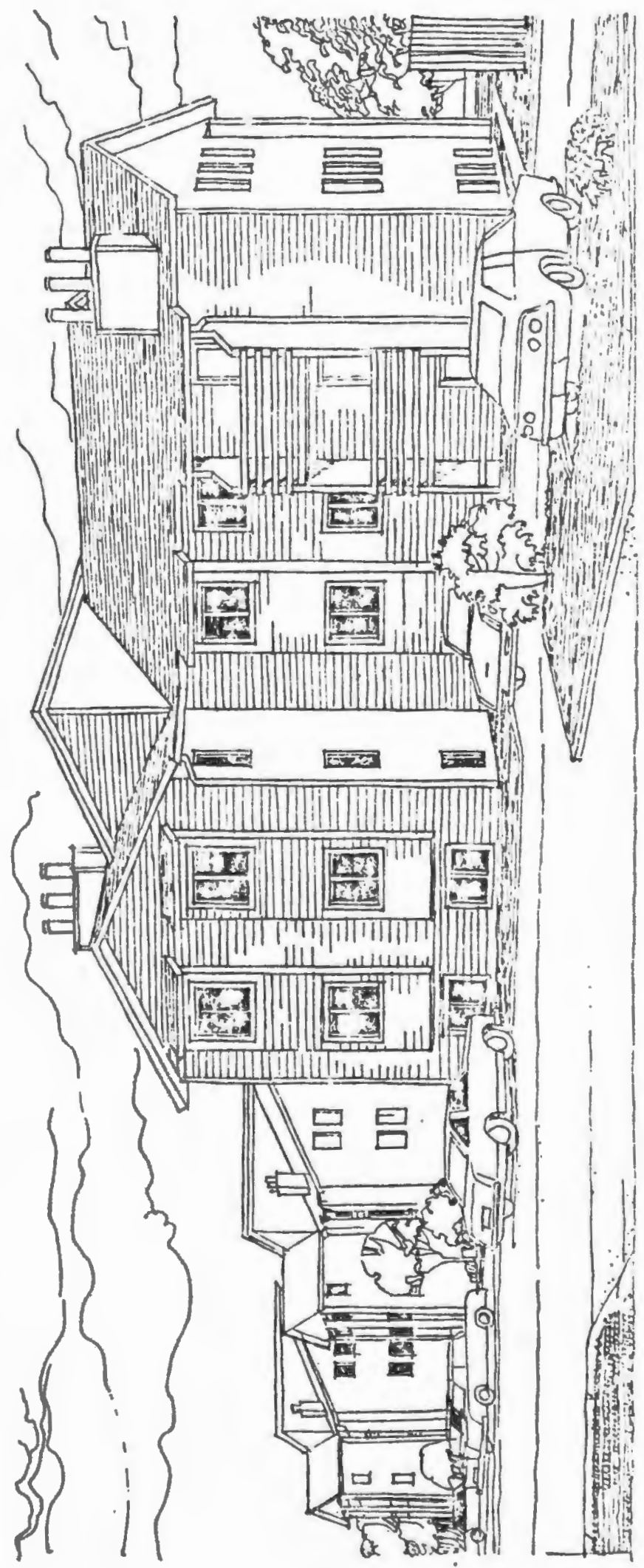




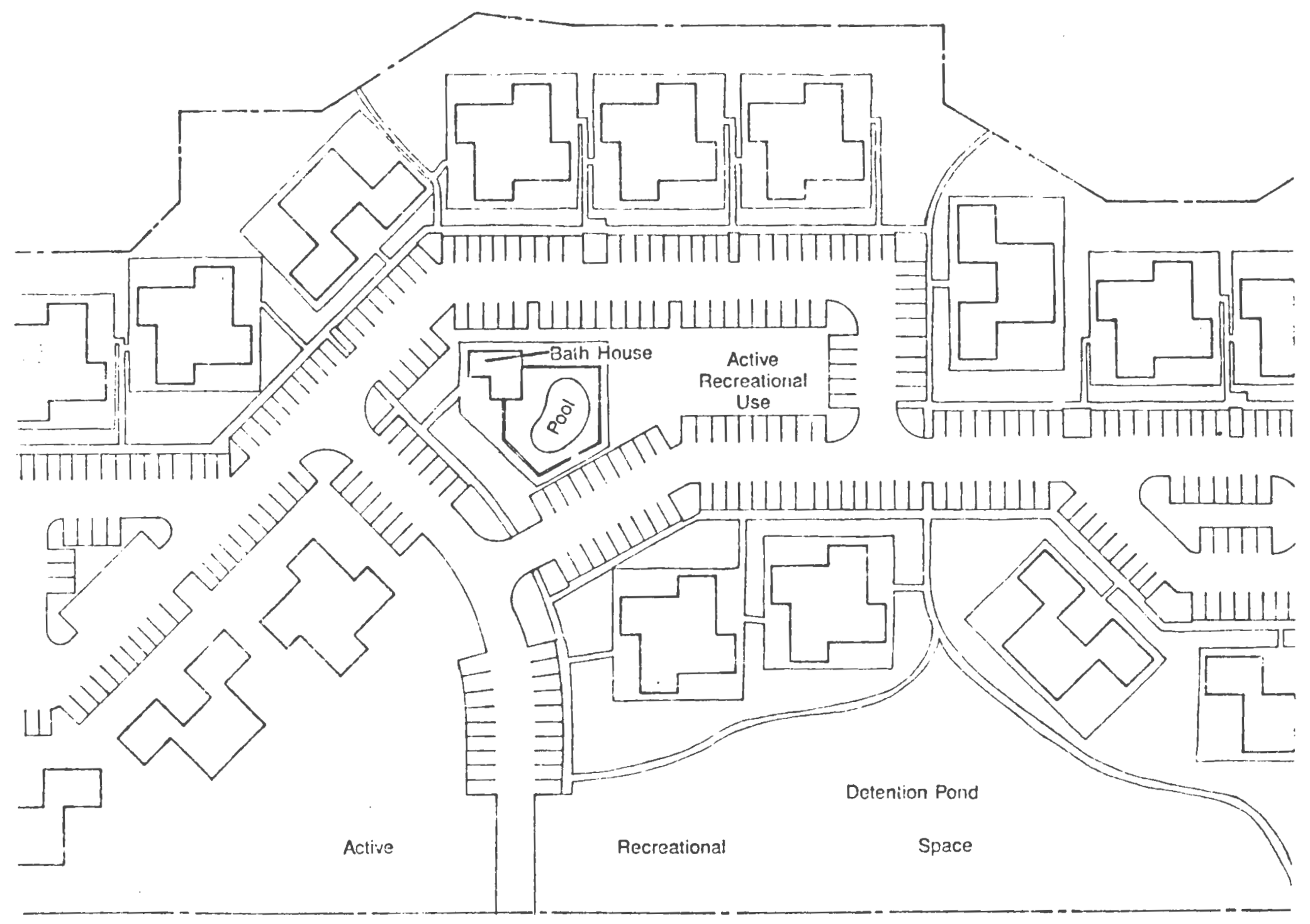




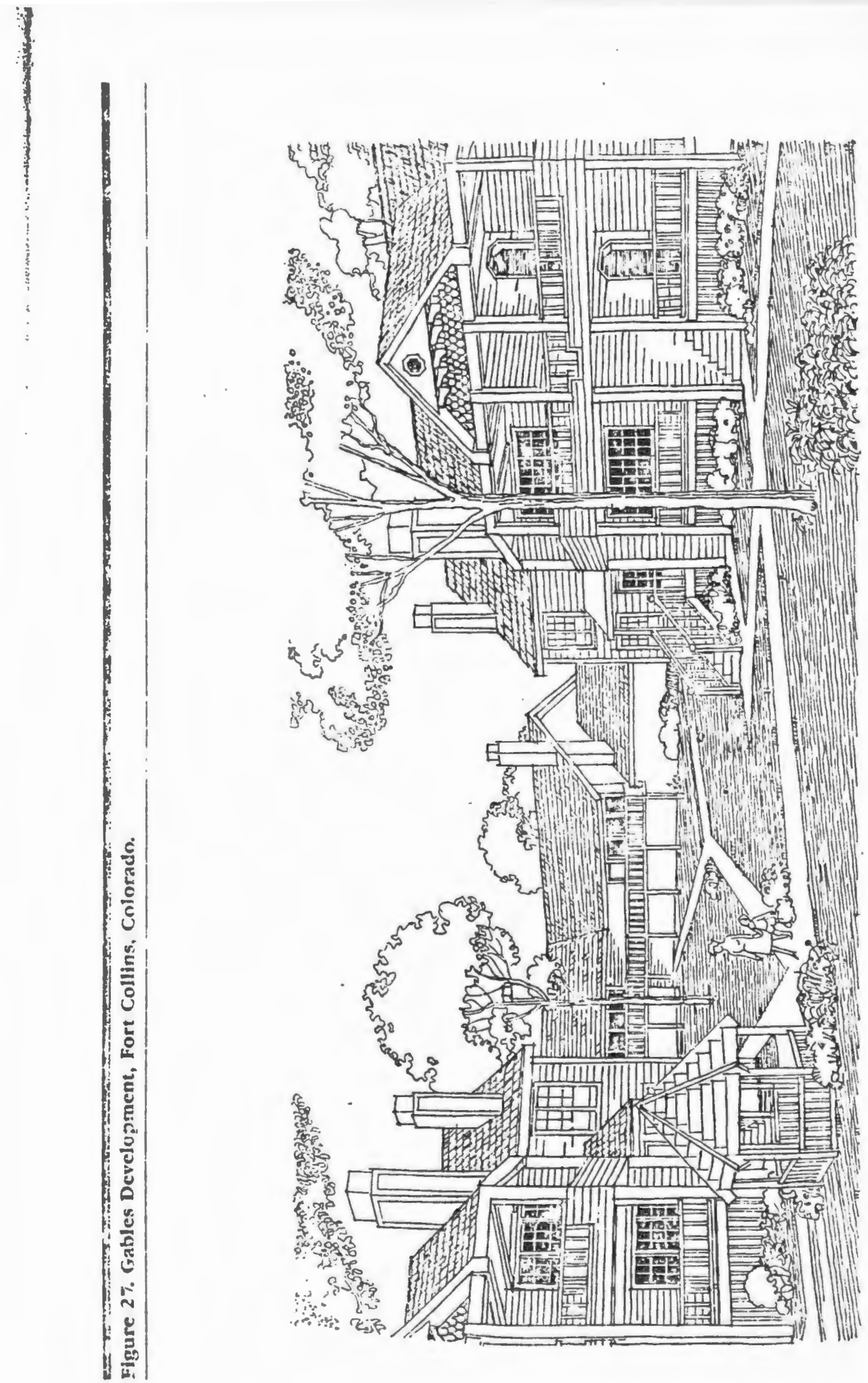




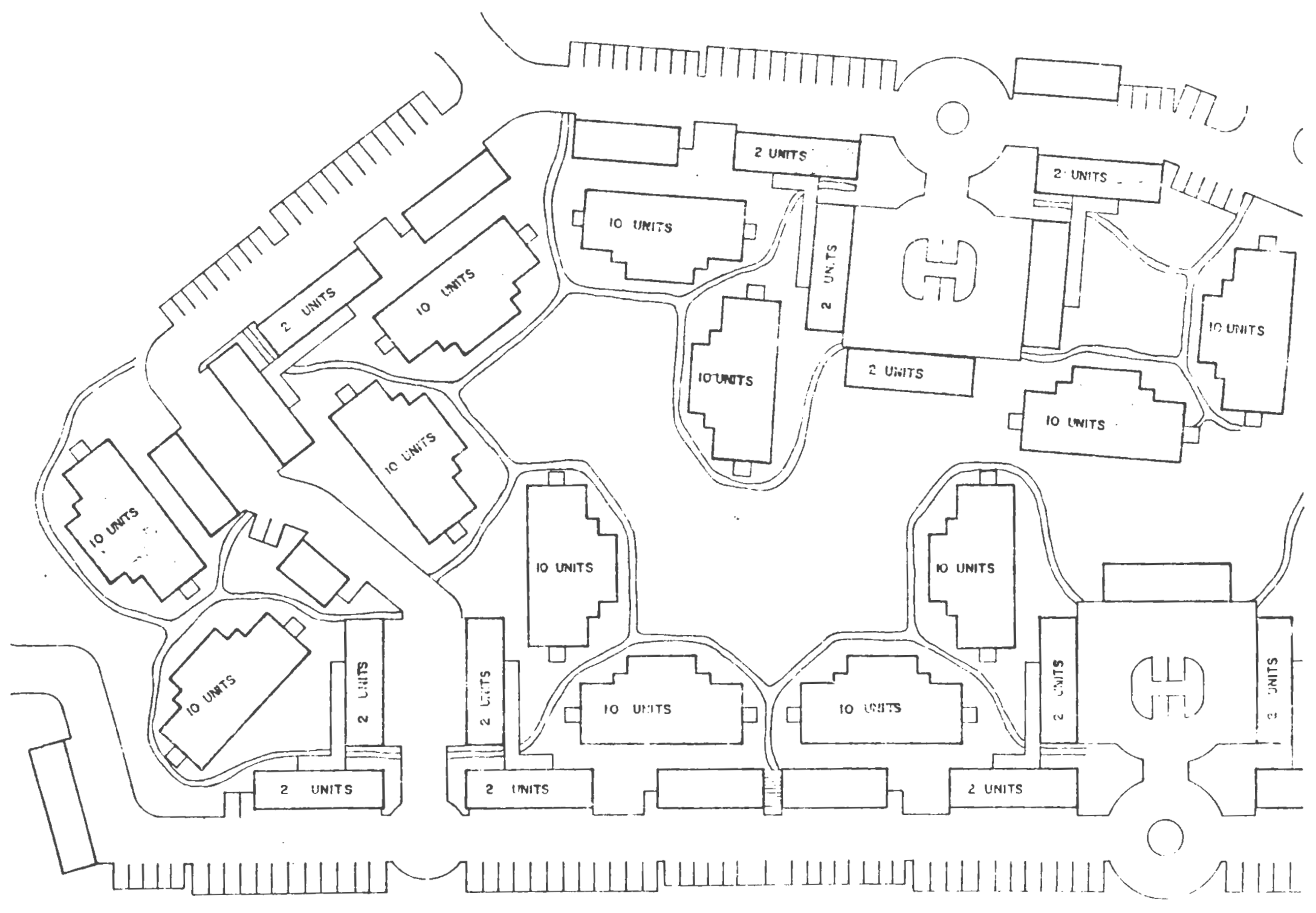




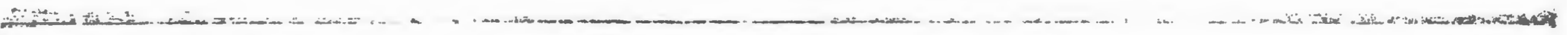
Figure 29. Carriage Ilouse, Gables Development, Fort Collins, Color:ado.

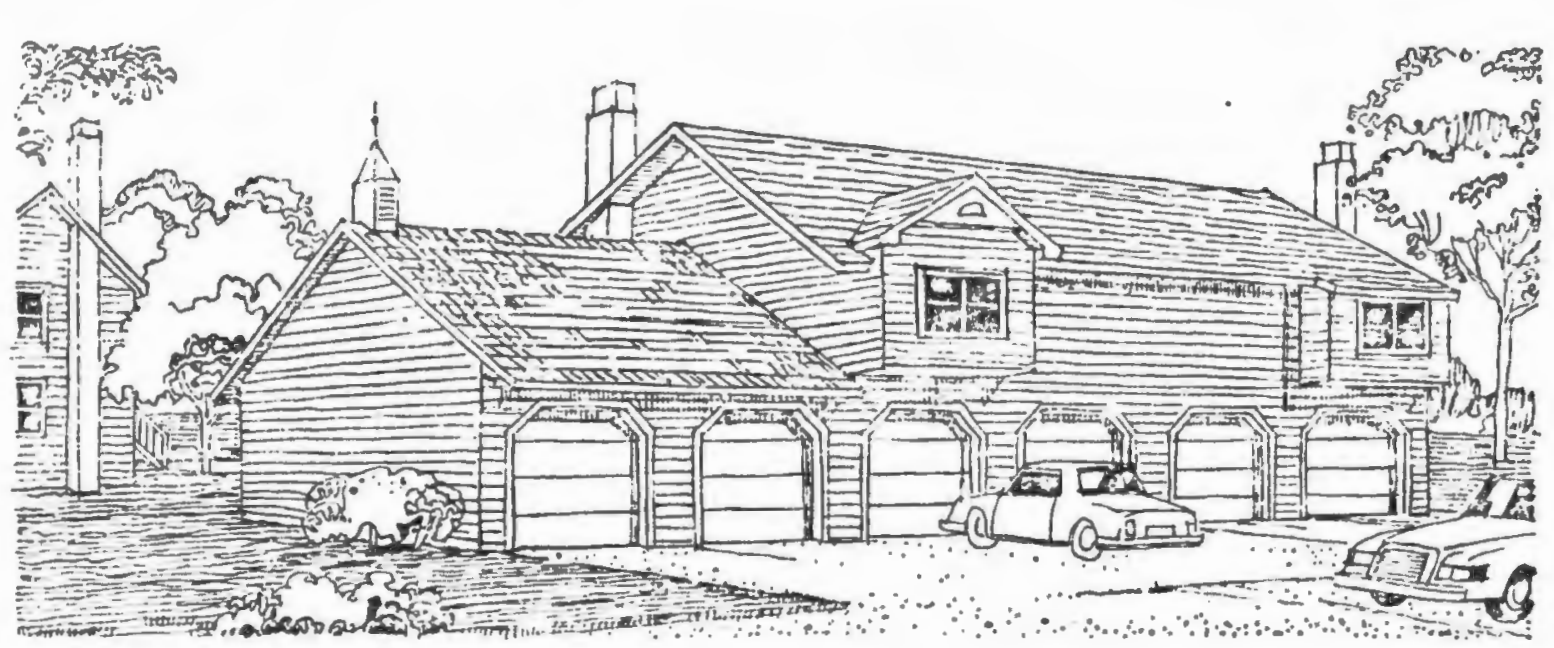

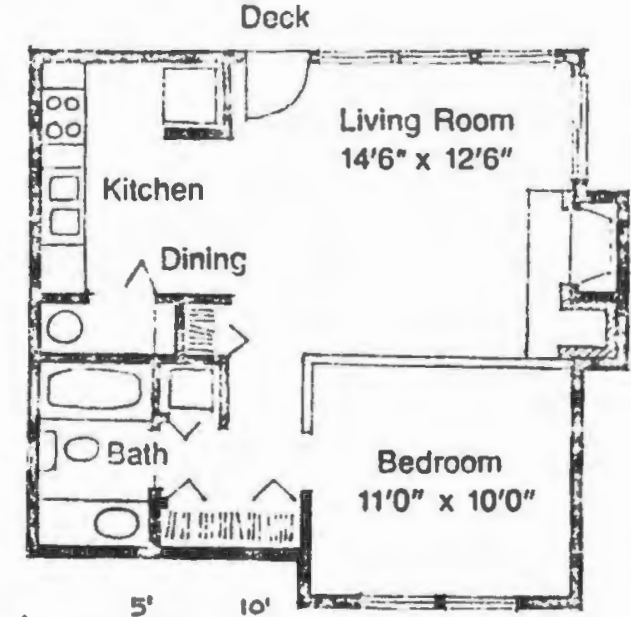

trof

1 Bedroom Above Garage 552 Square Feet 


\begin{tabular}{|c|c|c|c|c|}
\hline \multirow[b]{3}{*}{ Init Size (Sq. Ft.) } & \multicolumn{3}{|c|}{$\begin{array}{l}\text { WOODHAVEN COTTAGES } \\
\text { RIVERSIDE COUNTY, CALIFORI:IA }\end{array}$} & \multirow[b]{3}{*}{$\begin{array}{c}\text { Initial } \\
\text { Price Otferi }\end{array}$} \\
\hline & \multirow{2}{*}{$\begin{array}{l}\text { Site Arca: } \\
\text { Total Dwelling Unit: } \\
\text { Gross Density: } \\
\text { Housing Types: } \\
\text { Average Price: } \\
\text { Number } \\
\text { of Units } \\
\end{array}$} & \multicolumn{2}{|c|}{$\begin{array}{l}41 \text { acres } \\
256 \\
6.5 \text { units/acre (aproximate) } \\
\text { Singie-family de rched } \\
\$ 64,009\end{array}$} & \\
\hline & & Bedrooms & Bet'urooms & \\
\hline 805 & 39 & 1 or 2 & 1 & $\$ 49,950$ \\
\hline $800-2^{*}$ & 30 & i or 2 & 1 & 52,950 \\
\hline 1,01 & 56 & 2 or 3 & 2 & 62,950 \\
\hline 1.253 & 73 & 3 & 2 & $E 7,750$ \\
\hline 1,457 & 71 & 3 & 2 & 73,550 \\
\hline \multicolumn{4}{|c|}{$\begin{array}{l}\text { Jeveloper: Woodhaven Homes } \\
\text { Riverside, California }\end{array}$} & : \\
\hline
\end{tabular}

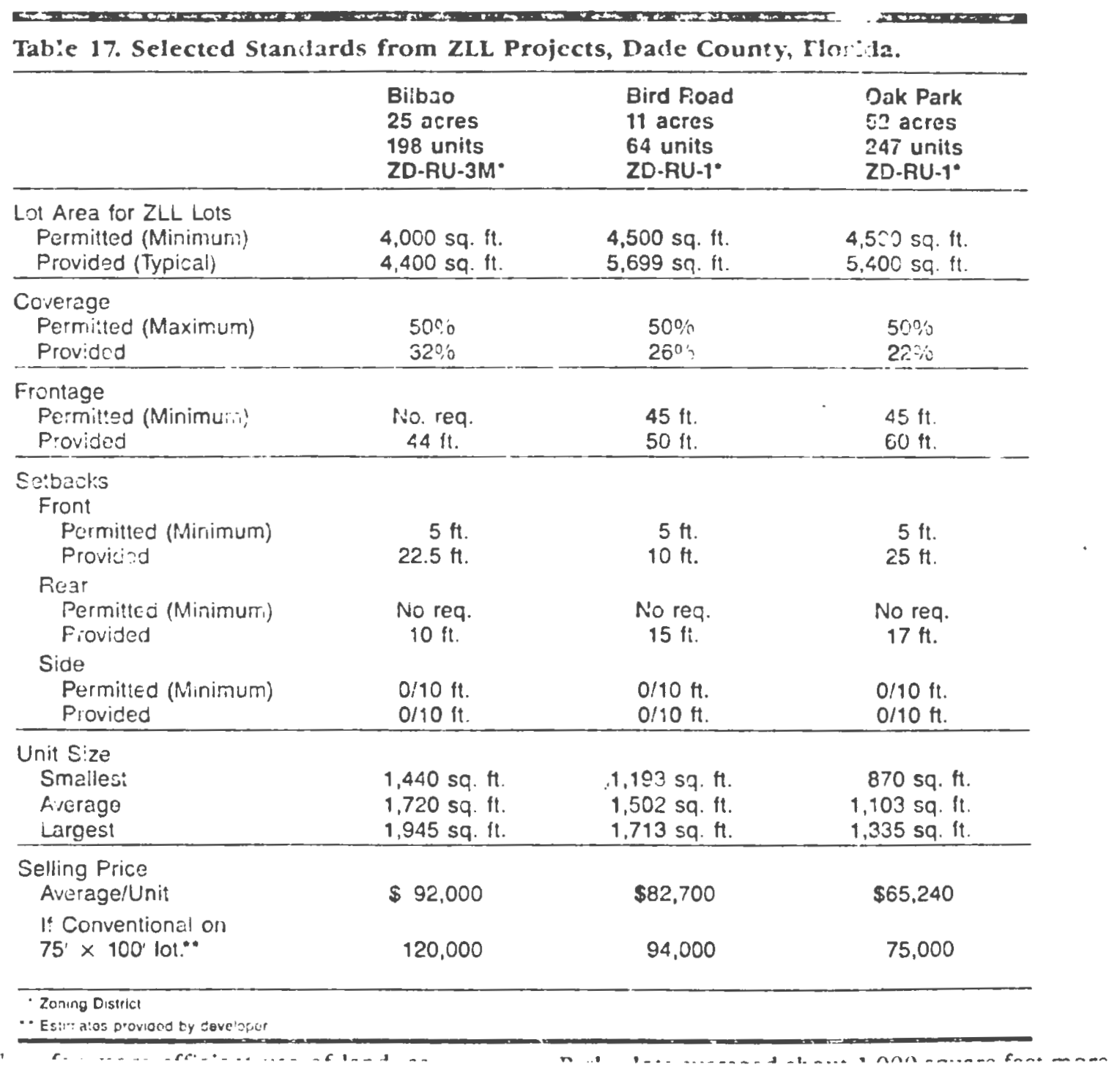




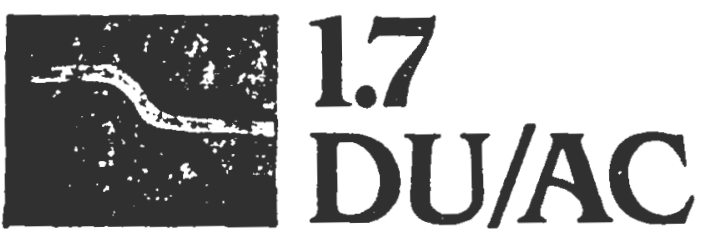

\section{Clustering saves a sités natural charm}

4 n elegant cluster development on a 2. beautifully wooded waterfront site: that vision of Treetops on Cape Cod would have stayed a dream if the neighbors hadn't been brought around.

Neil Glynn, vice president, marketing, The Green Co., explained that residents on nearby properties who initially opposed the development were powerfully articulate-environmental advocates who piesented rational arguments.

By "politicking" and compromisingand developing a stunningly attractive product (judging by sales)-the builder not only quelled opposition, according to Glynn, but made home buyers out of former no-growth advocates.

"We had to make a compromise," he said. "Originally we planned to build 90 units, and now the number is 62. But some of those who opposed the project became buyers, and a lot of them became friends."

The real success story of Treetops in Falmouth, Mass., is rapid sales. More units are presently sold than built, and 23 of the one- and two-story townhouses were sold in the first four months on the market.

This lowest-density project in this special report shares characteristic with over half of the 8 projects examined here: it's on the water. Most of the units look across Oyster Pond to Martha's Vineyard.

It's no accident that units are clustered. Difficult topography dictated high density housing. The project's overall density-1.7 du/ac- is deceivingly low because a large portion of the site was left as woodland; in the area where homes are built, density is much higher.

Originally, the siting concept "was to build the units around courtyards. But we found we weren't maximizing the views," Glynn said.

Instead, set-back clusters of three to five one- and two-story townhouses, all with basements, are set in rows (site

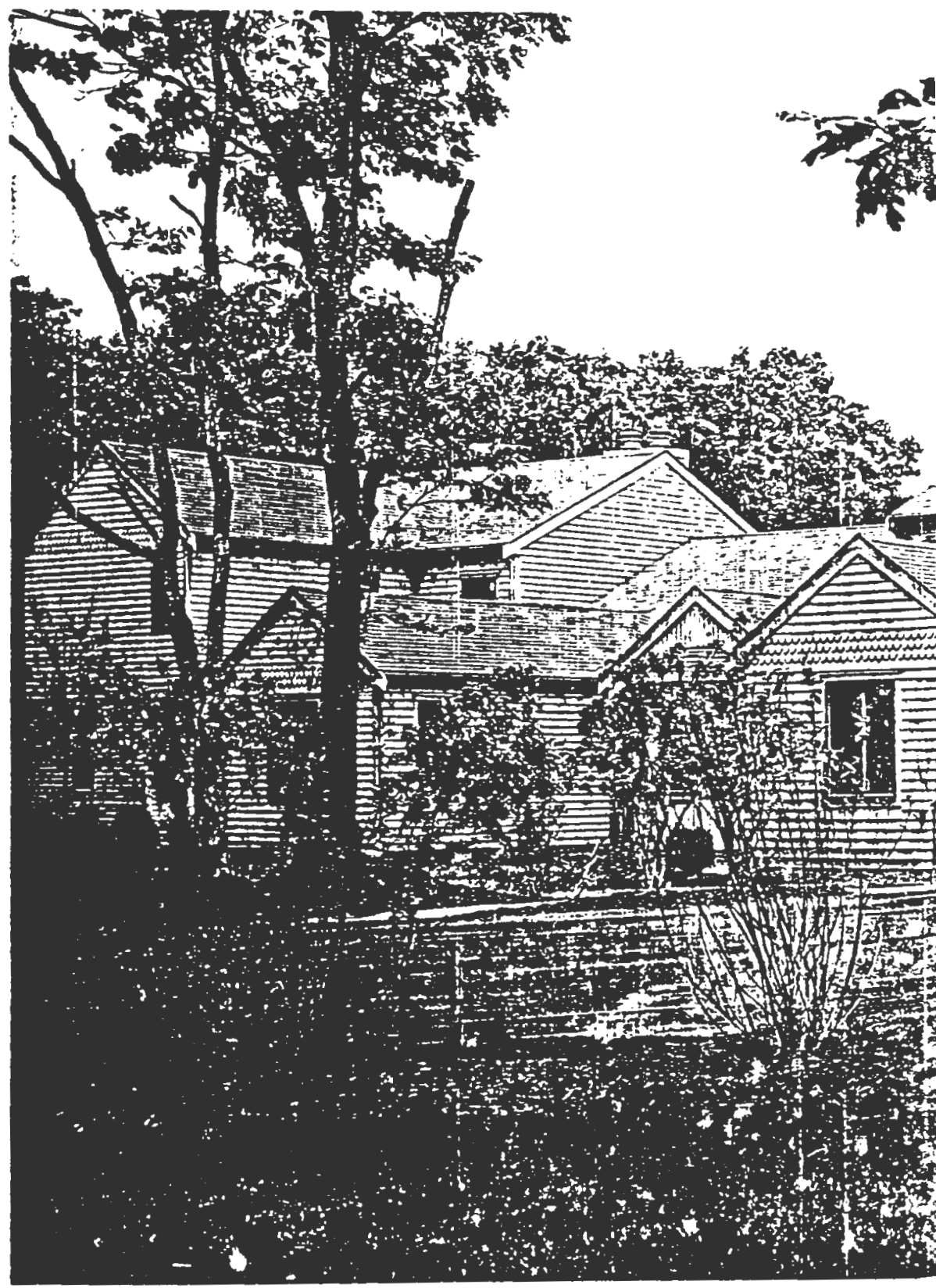


Photos: Foutdewileon studios

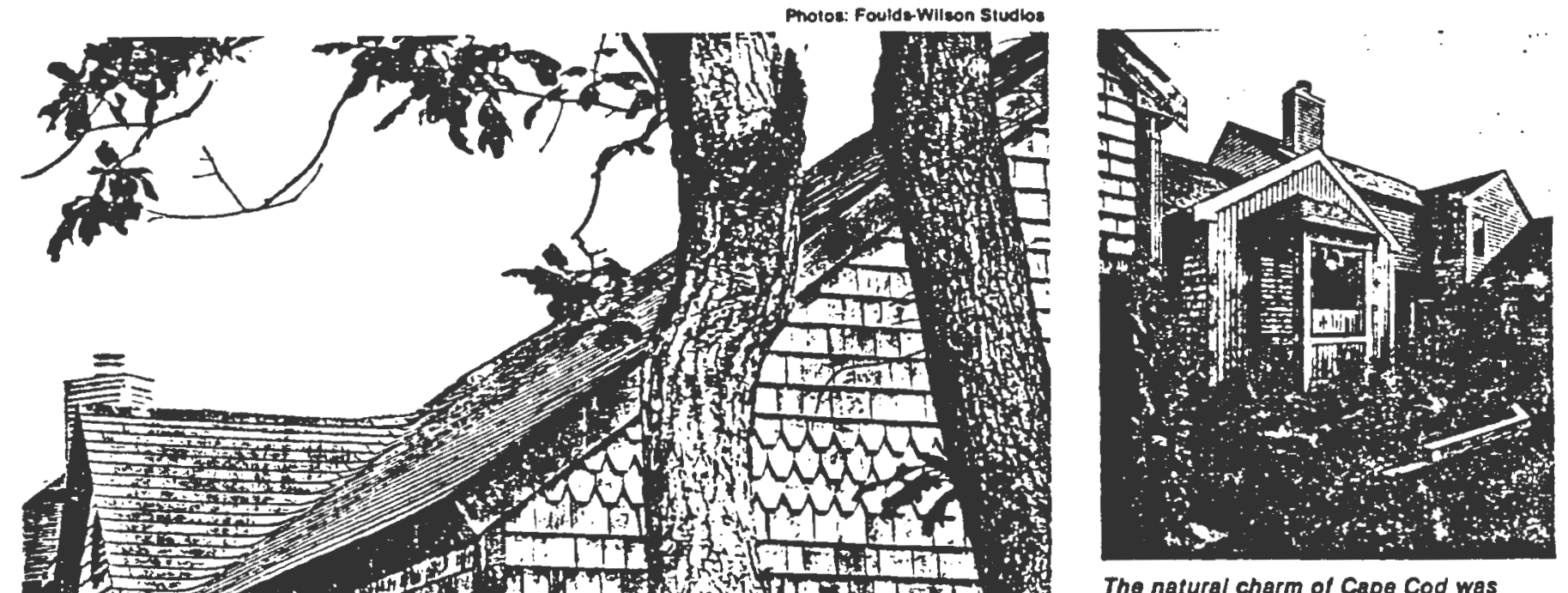

The natural charm of Cape Cod was retained at Treetops, a fast-selling townhouse condominlum community in Falmouth, Mass. The waterfront slte looks across a pond to Martha's Vineyard. The houses are in small clusters (photo lelt) that face Oyster Pond. Fireplaces and boxed windows (photo above) were among the features. that spurred sales. 


\section{View lots command premiums}

plan detail, page 59). The architect is Claude Miquelle Associates of Boston.

The 10 clusters are grouped by two paved roads-the "low road," betier than half the units, on the pond frontage at about 25 fet elevation; and the "high road," a second group at higher elevations, set back further from the pond and parallel to the first group.

Units are priced according to size and location. The smallest unit, a 1,450 square foot one-story with two bedrooms and two full baths, sells for as little as $\mathbf{5 0 , 0 0 0}$ in some locations; the largest, a 1,900 square foot twostory with three bedrooms and two-andone-half baths, sells for as high as $\$ 150,000$ in a prime site location.

The best seller so far has been an intermediately priced (starting at $\$ 100,000$ ) one-story two-bedroom with 1,650 square feet of living space. The big selling point, said Glynn, has been the 18 by 14 foot country kitchen with a Franklin stove. The kitchen opens out to a large deck and also has "poppedup" ceiling and European style custom cabinets (a feature which has proved popular in all kitchens in the development).

Middle-aged professionals and academics comprise the market, Glynn said.

Site amenities include two tennis courts, swimming pool and a clubhouse. Guest parking areas combined with garages in almost all units yield a parking ratio of two spaces per unit.

The biggest problem in building Treetops was finding a workable building plan on the very hilly site, which varied in elevation from 0 to 96 feet, Glynn said. After convincing zoning officials the site was unsuited for single-family detached horues, The Green Co. had the much tougher task of convincing neighboring experts that the building of Treetops would not upset the local ecological balance.
The deck of one unlt overlooks a pond with Martha's Vineyard in the background.

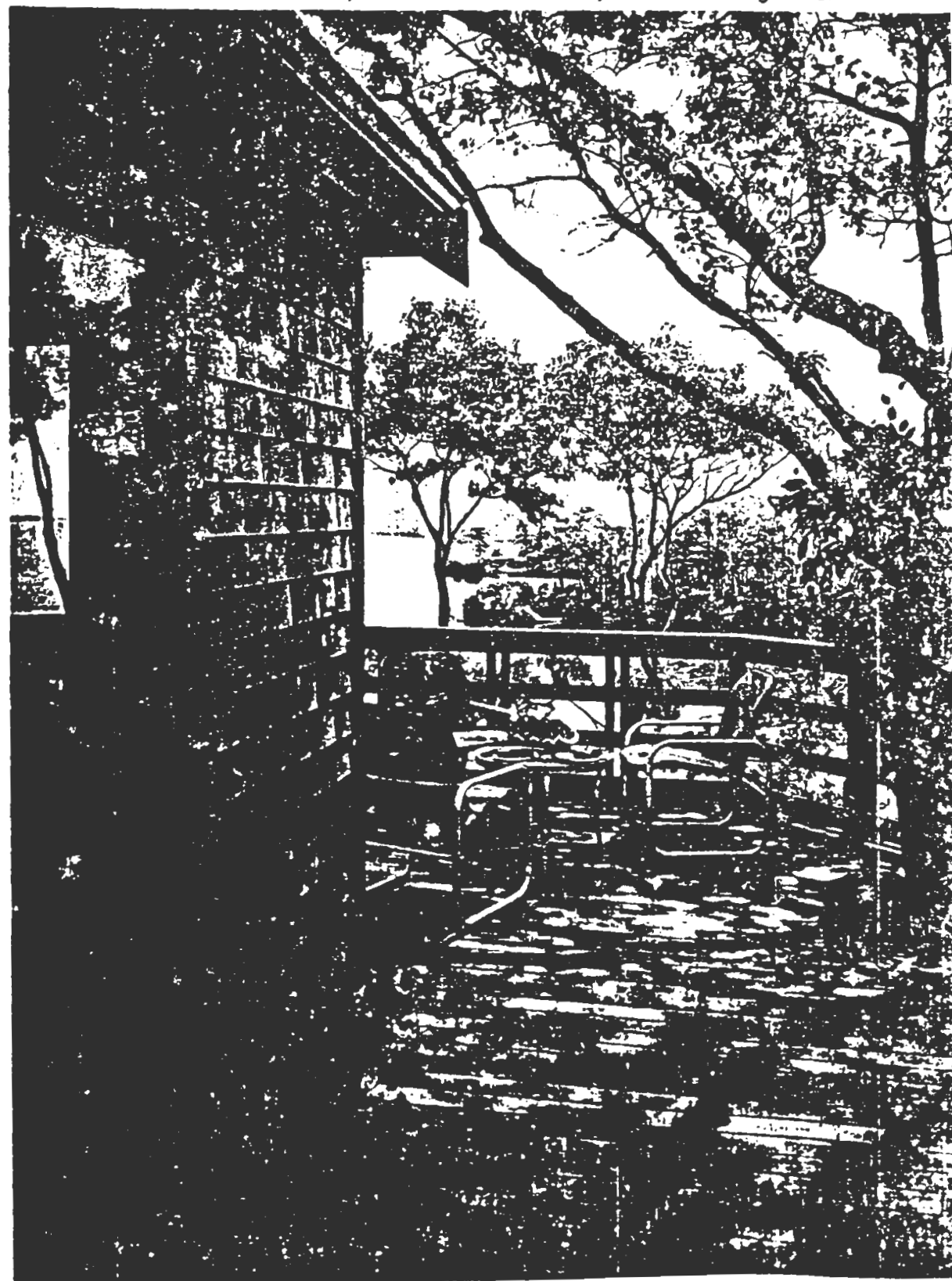



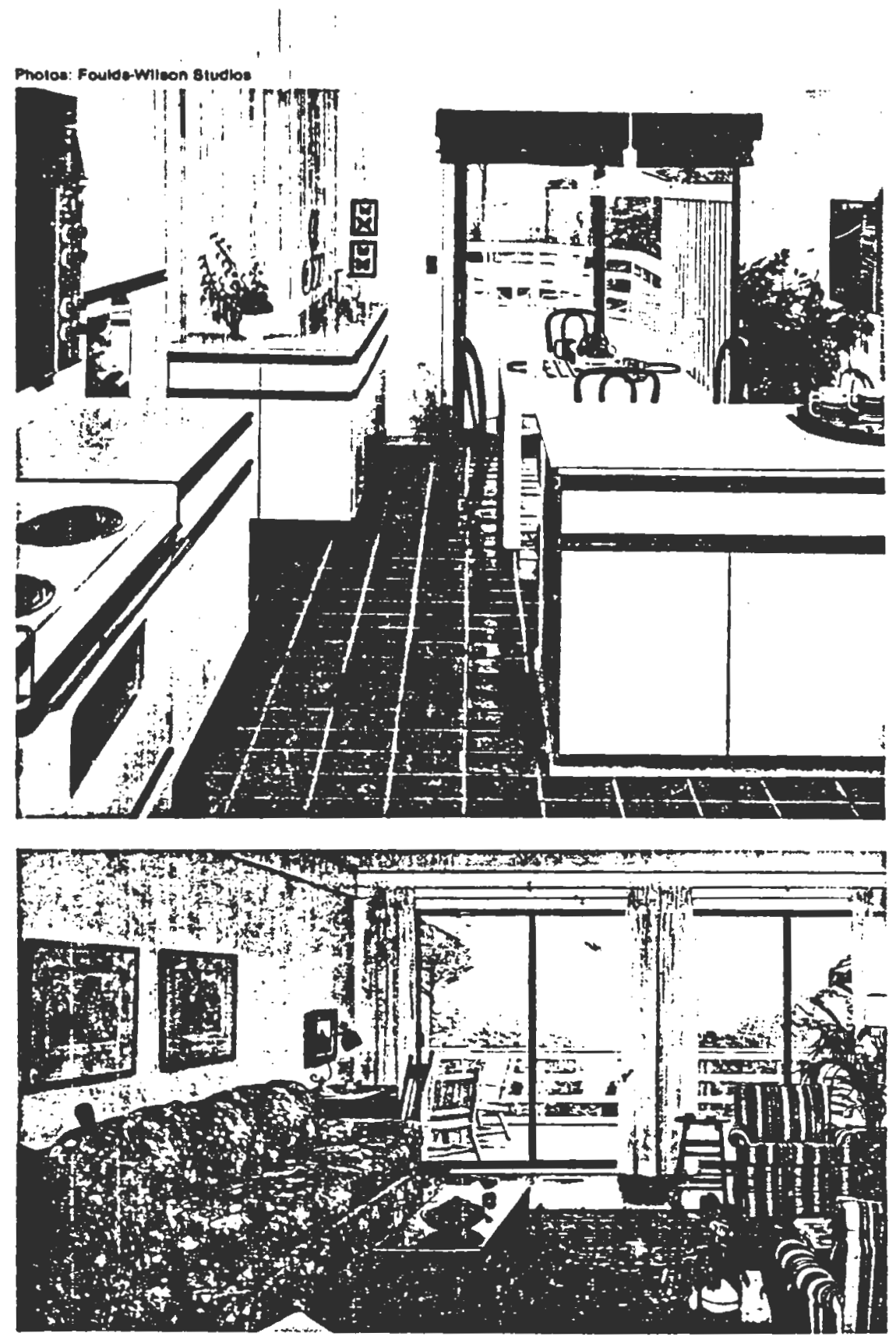

Furnished model shows living room opening to deck with water viow.

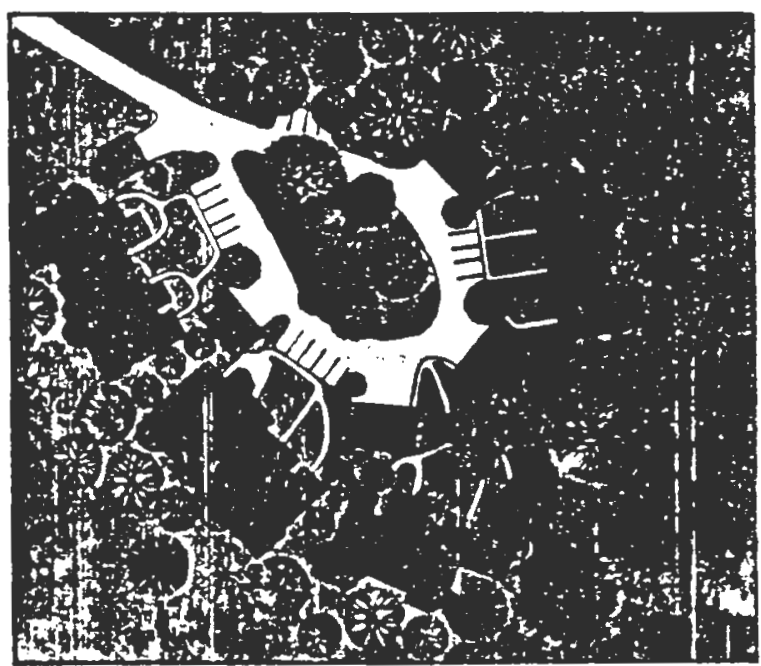

Slie delall Indicates straight-line

clustering, to afford maximum number of views. 


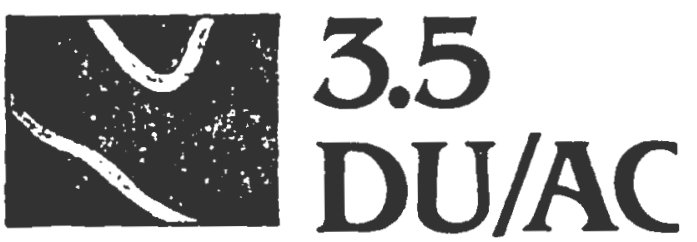

\section{Lodge-style units nestled on wooded site}

$\mathbf{T}$

ransplanting a successful classic architectural style, using natural materials, and secluding the units in small clusters in the woods were the secrets of the success of Gleneagles near Tampa.

Architect Eugene R. Smith, A.I.A., of Tampa, designed the units, and he and the builder, Gleneagles Associates, thought that most units would be sold as second homes. Instead, about 50 percent of them are used as primary residences.

The townhouses range in price from $\$ 69,300$ to $\$ 103,500$, with floor area going from 1,564 to 2,063 square feet. Smith designed three types of units: flats, one-floor plans with lofts above, and two-story townhouses.

The best selling unit has been the onestory. It has 1,564 square feet, two bedrooms and two baths. Smith noted that this unit was always an end unit, and, at $\$ 69,300$, the least expensive.

Another reason for its popularity was the multiple carpor attached 10 each cluster. The carport was closest to the end units. A covered walkway connects the carport to individual units and additional guest parking is provided, yielding a 2.2 parking ratio per unit.

The site is woodsy, and Smith took full advantage of $\mathrm{i}$.

"We maintained 60 percent of the site undisturbed and moved only 12 percent of the trees for construction," he said. "We wanted to maintain the feeling of a northern lodge, since a lot of our market was weal thy northerners."

To appeal to this market, heavy use of stone and wood created architectural "estate lodge vernacular," a far cry from typical Florida concrete block structures.

A peculiarity of Gleneagles is proximity to Innisbrook, a time-sharing reson and luxury country club which does not have full-time lodging facilities for all members. A membership is offered to Gleneagles home buyers.

Only 25 of the 150 units have been completed to date; the rest are currently under construction. The density of the first phase is 3.5. Completed in early 1977, hard costs were tallied at $\$ 27.50$ per square foot.

Selling price per square foot was between 545 and 549 , Smith said. The first group of houses sold out in 18 months.

Passive solar design included the placement of all living units 45 degrees off the east-west axis. Additional protection from direct sun is afforded by deep roof overhangs.

Elevations vary from 15 to 45 feet, creating a gently rolling wooded site. Internal roads run through the highest contours, and surface water runoff is handled through an existing pond.

Gleneagles, besides being an excellent example of density, is also this month's winner in the Builder's Choice Design Contest.

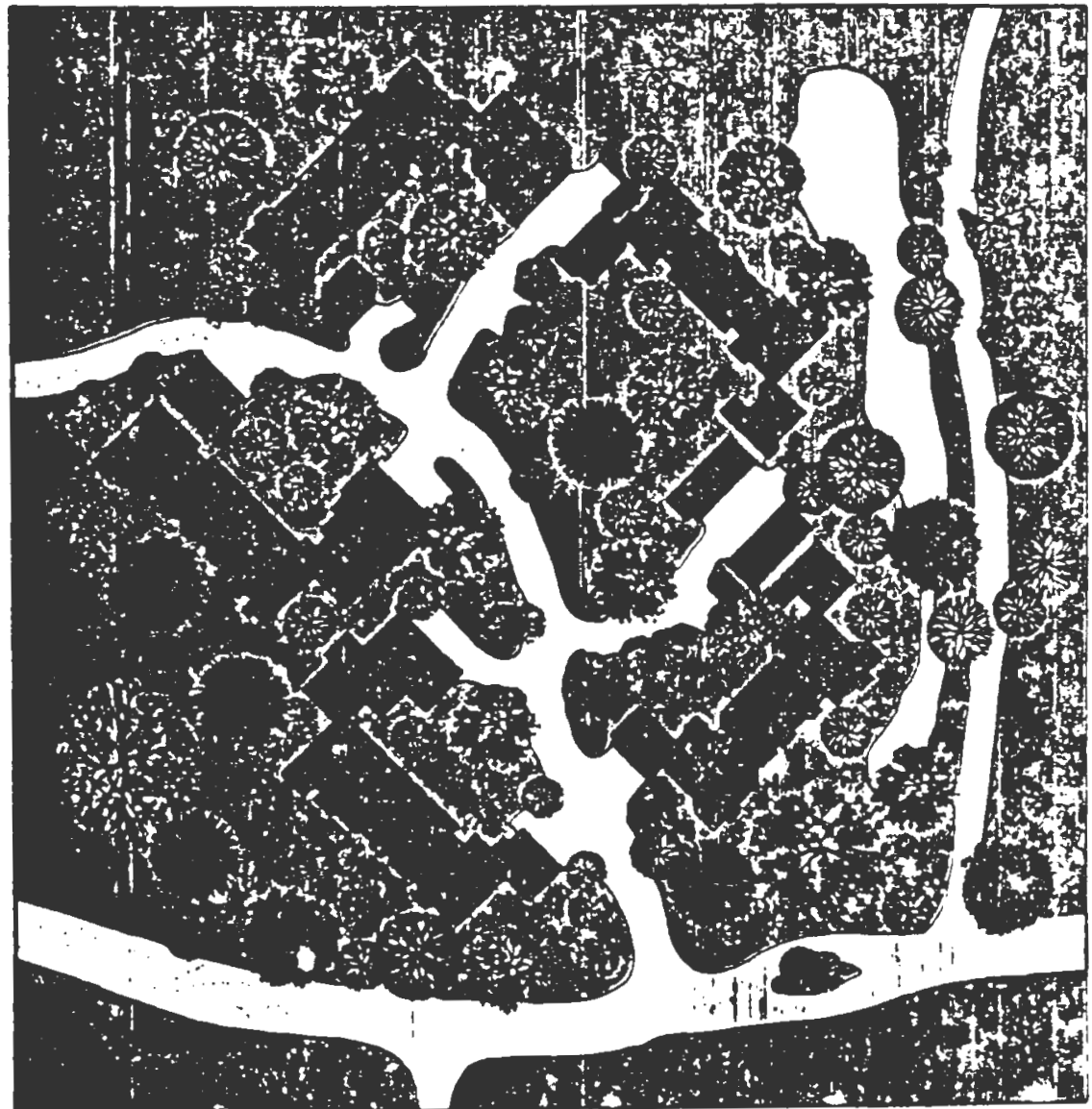

Saving trees was an Important ecologlcal-and selling-polnt in the slte design of Gleneagles. About 60 percent of the slte is given to open space. 
Deap roof overhangs are part of the passive solar design at the Tampa, Fla., prolect (photo rlght). An appealing woodsy atmosphere is created with natural follage and "estate lodge ver. nacular" archltectural style
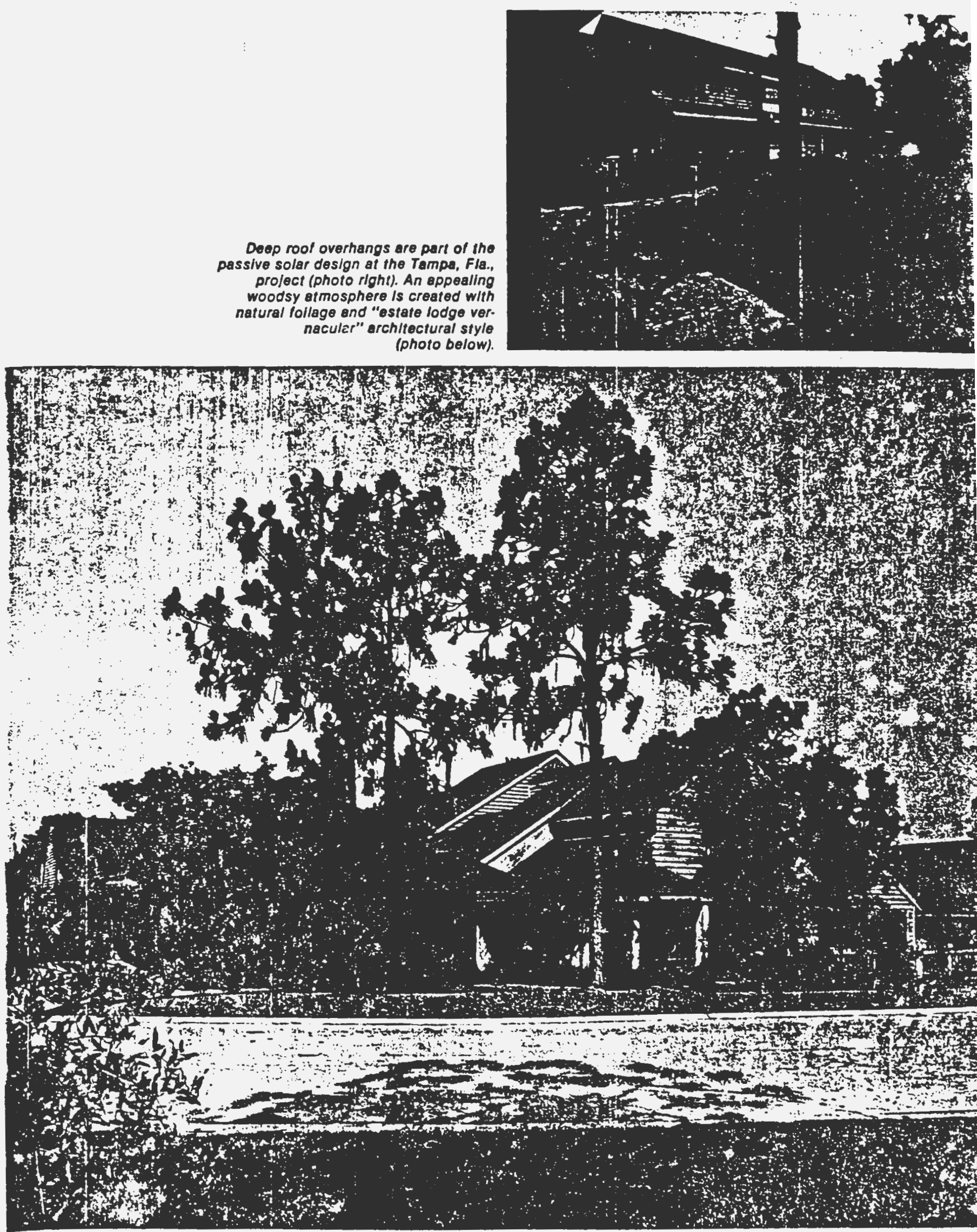


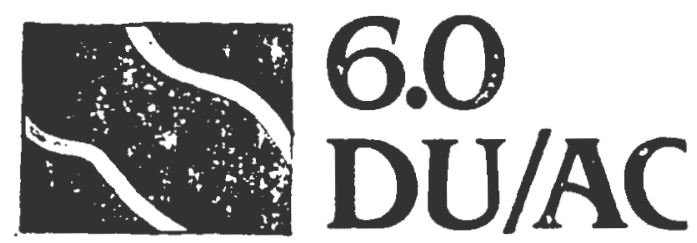

\section{Townhouses are the choice for hilltop site}

Commanding hilltop views and a - terrain that wouldn't have permitted large-lot homes almost dictated the design of Summit Ridge, a 161-unit townhouse project in Walnut Creek, a San Francisco suburb.

"I don't think you could hve even put 27 detached homes on the 27-acre site," said Roger Menard, president, Broadmoor Homes-North. In fact, the rolling hills caused architects FisherFriedman to design three versions of one model: a level entrance, an upentrance, and a down-entrance.

The prime site, overlooking hills east of San Francisco, brought high pricesindividual finished lots for the feesimple townhouses $\operatorname{ran} \$ 25,000$ apiece.

The units vary in price depending on view. Current prices for remaining units range from $\$ 130,000$ to $\$ 200,000$. The units have from 1,820 to 2,571 square feet.

When Broadmoor acquired the raw land in 1976, Fisher-Friedman had already made a preliminary site design, said Menard. Changes were made only in the interiors.

The density was achieved by terracing the site. The terraces permit a density of six units to the acre and preserve a feeling of openness. A system of wide winding roads and heavy wood accents worked against a cramped atmosphere.

The homes were marketed to a "very professional" clientele working in the Berkeley-Walnut Creek-Oakland area or in San Francisco. Average household income in the community is $\$ 70,000$, according to Menard.

Outdoor amenities on the site include a stvimming pool, a therapy pool and a recreation building with a fireplace.

Inside the units are at least two and often three skylights. All but one of the four models have wet bars and walk-in -losets in the master bedrooms.

Because of the extreme grade, the argest unit has three configurationsone for a flat lot, and two split-level
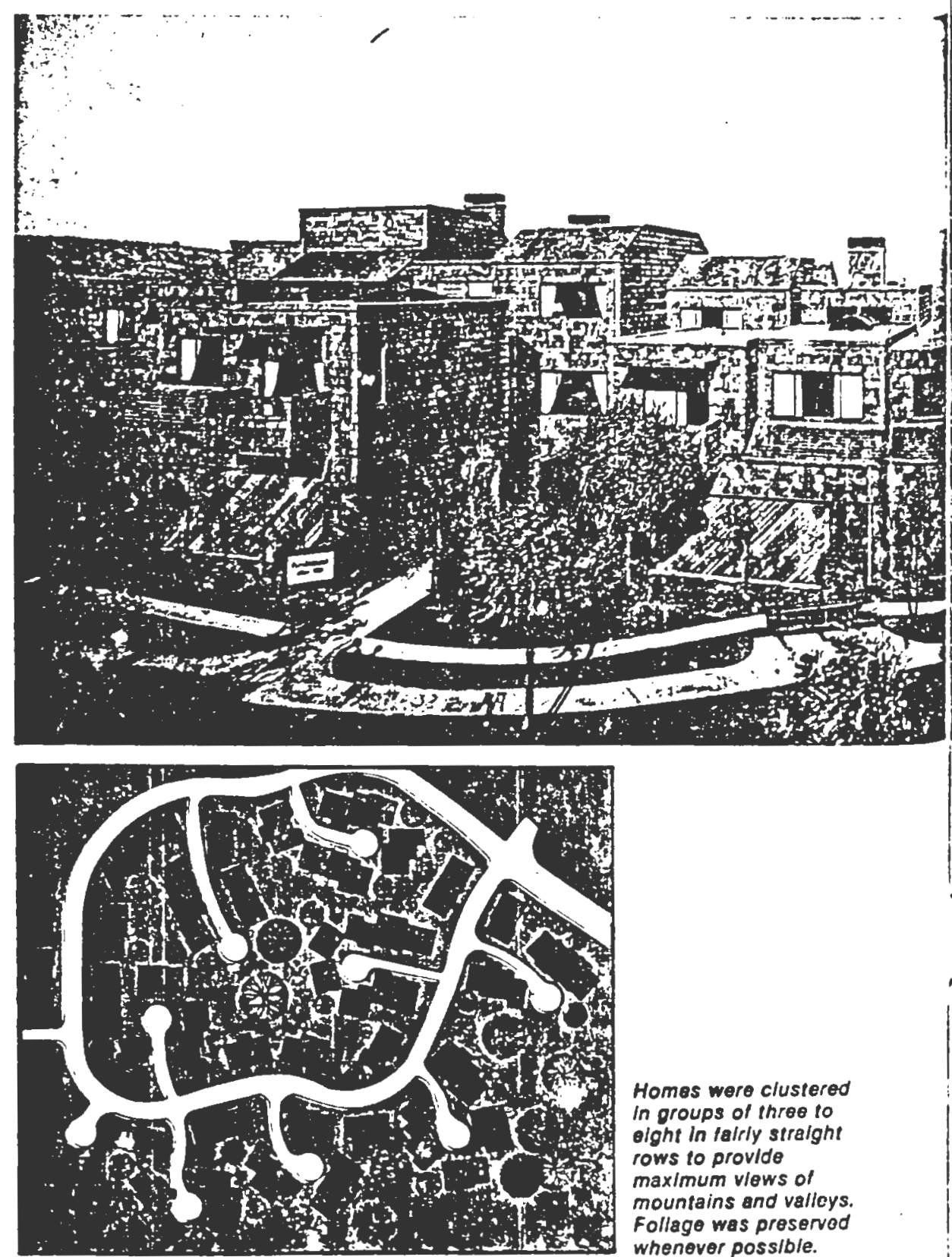

Homes were clustered In groups of three to olght in talriy straight rows to provlde maximum views of mountains and valleys. Follage was preservad whenover possible. 


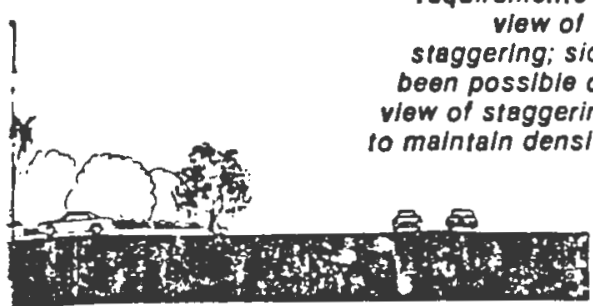

putting 22 units on the Aldea site. In order to fit everything on the site, the architect designed some units that are only 16 feet wide. Most units are 22 feet wide. The narrow units were placed furthest from the water.

There were other construction problems: height and minimum elevation regulations. Although Belleair Beach has no density requirements, 100-year flood plain regulations require a minimum 13 foot elevation from sea level.

Most builders use stilts in the area to meet flood plain requirements. Rather than build the units at Aldea on stiltsthat would have interrupted continuity between building and beach-Tibma built base units and flat slab patios on a raised 13-foot level (see section above), and sloped the site gradually down to sea level.

Local zoning doesn't allow three-story buildings or any structure exceeding 36 feet on the beach, he added. The only way townhouses over flats could get approval was by making the townhouses one-andone-half stories and calling the master suite upstairs a loft (see section above).

The lofts, in fact, were built into the frame of the roof. On the ocean side, the overhang was cut short to allow for an uncovered sundeck. Staggering of units kept privacy.

Amenities include a private beach, of course, and a swimming pool on each of the three sites. There is exterior parking on the back of each cluster. with a parking ratio of 2.2 spaces per unit.

Carr said that Tibma brothers has had success clùstering its products since 1971 and "definitely clustered homes work well in certain areas," but added, "we have not done a project like this that's not on the water."

Purchasers'were mainly professionals in early 40 s to mid-50s, Carr said.

Purchasers spent up to $\$ 20,000$ customizing homes with such items as imported Italian tile and special wood products, Carr said.

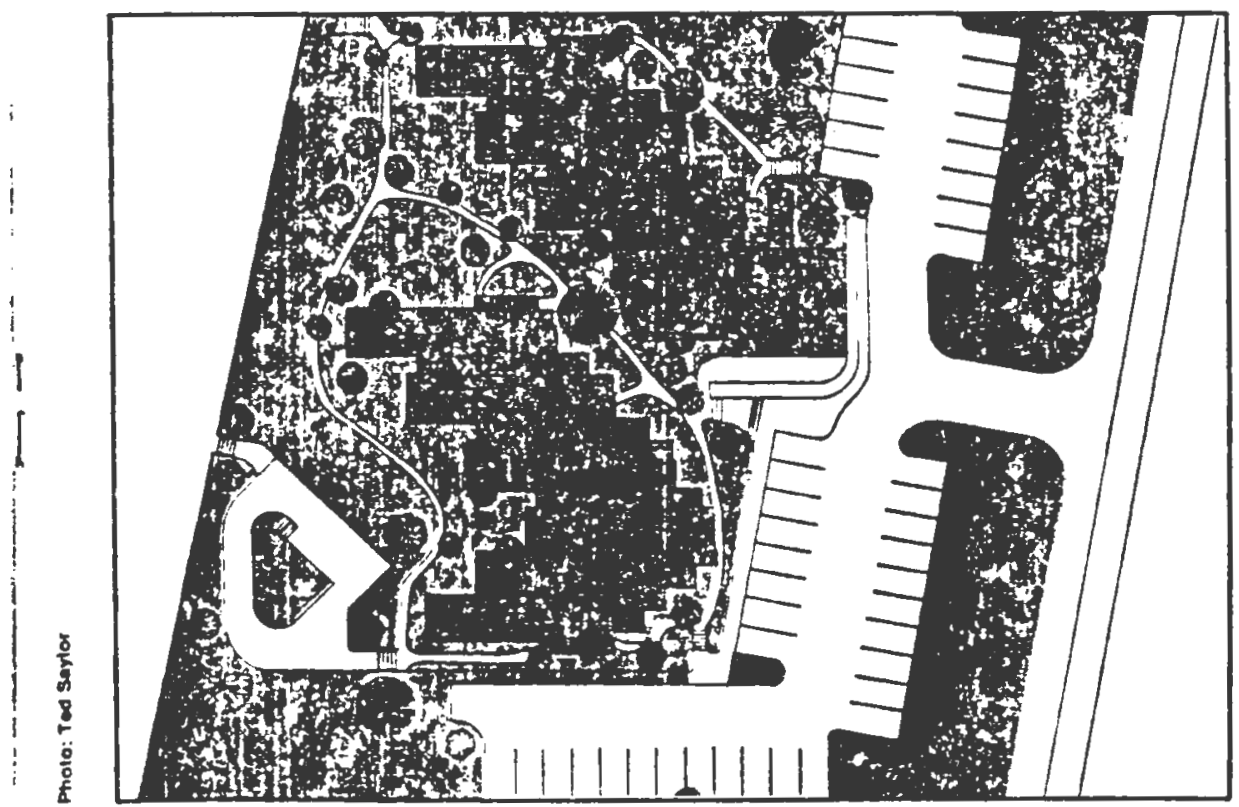




\section{All units have water views}

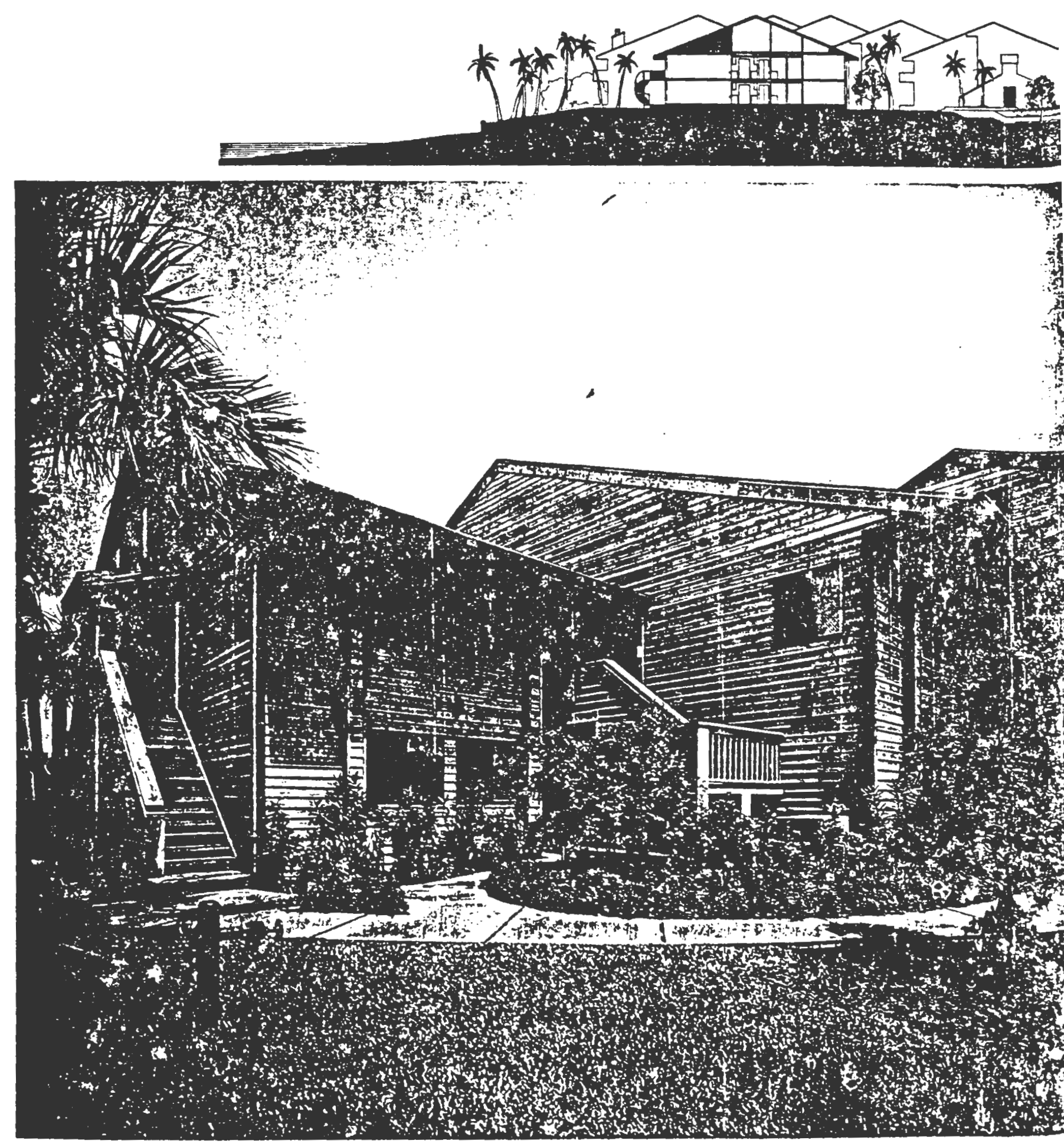


Master sulte (ohoto right) opens out into sundeck in upper units. Sulte is in lolt, and privacy wall follows roolline of townhouse. Concrele block construction is well masked by use of prebleached cedar furring strips (photo below). Splral stalr leads to upstalrs unlt, whlle llat below ope.7s to patlo directly on the beach.

$P$ rim rime oceanfront property on the orida coast is often too expenbuilding for well-heeled buyers. But if homes are attached, imaginative design is a must.

That's how Tibma Brothers Eevelopment and Construction Co. devised "attached custom homes" as the marketing thrust for Aldeal Sonrisa/LaConcha, luxury condominiums in Belleair Beach near Clearwater.

The one-and-one-half story townhouses stacked on flats sell at $\mathbf{\$ 9 6 . 7 0}$ a square foot. At $12.3 \mathrm{du} / \mathrm{ac}$, Tibma Brothers "utilized the property to the fullest, while remaining tasteful," said Al Carr, vice president, construction.

Three clusters were built in separate phases, each named differently. The staggered siting (site plan, page 69) gives each unit a side as well as a front view, with all units facing the Gulf of Mexico.

Units range in size from 1,400 to 2,800 square feet. Lower units are one bedroom, convertible to two; upper units are three bedroom, with the master bed in a Joft which opens to a Gulf-side sundeck. Current sales prices: $\$ 135,000$ to $\$ 250,000$.

All three phases are, for practical purposes, identical; this phase shown here is called Aldea. Aldea, with 22 units, was finished in winter 1977; Sonrisa, 14 units, was completed last September; and La Concha, the third phase, is scheduled for completion late this summer. It has eight units.

Architect Ernie Smith, AlA of The Design Advocates, Inc., Tampa, sajd that the staggered siting had several advantages:

- It allowed for maximum privacy;

- It gave more of a residential feel to the project than a row would have;

- It was the most efficient plan for a narrow, deep site.

Developers, Tibma Brothers and Milo Smith and Associates, insisted on
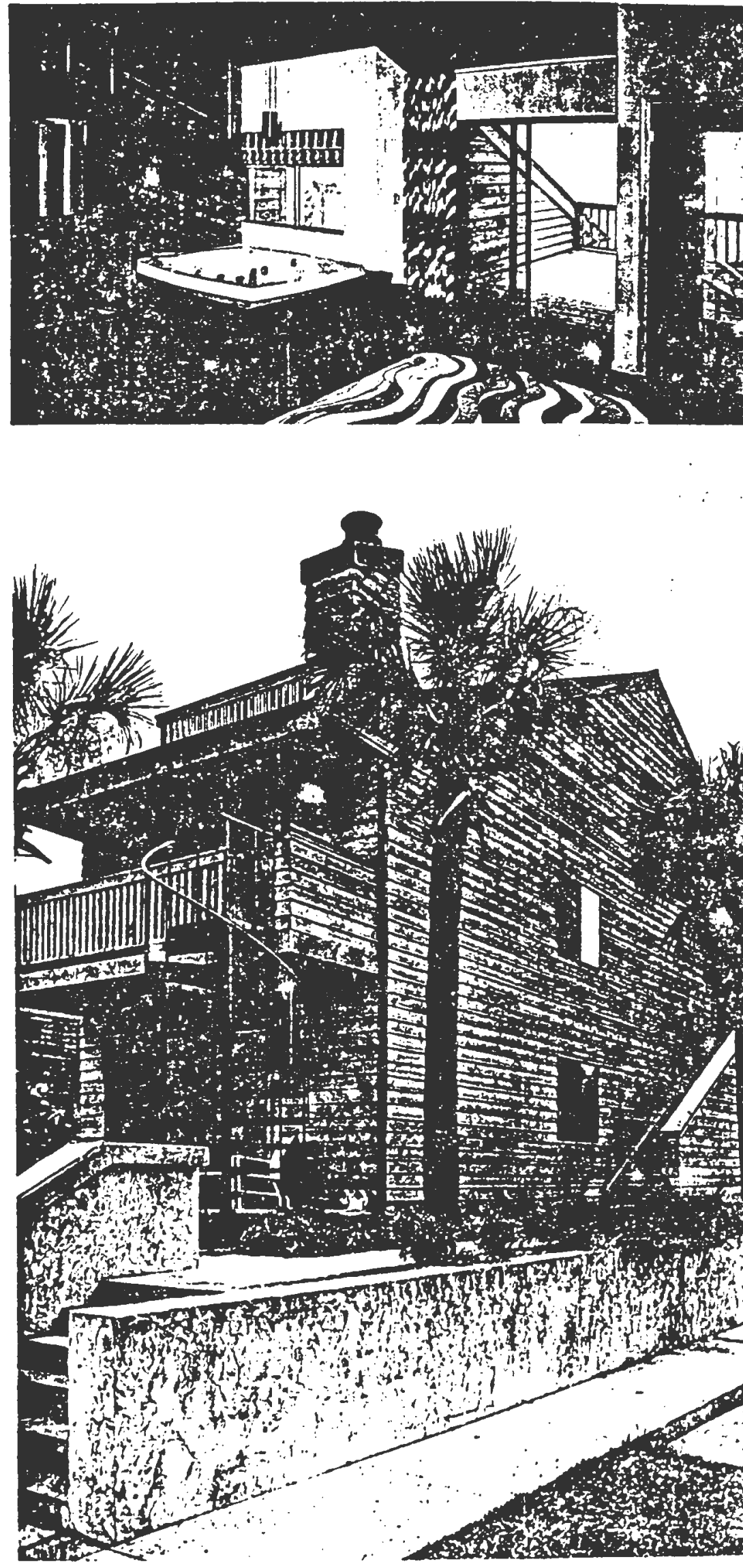

BUILDERUSEPTEMBER 1, 1979 


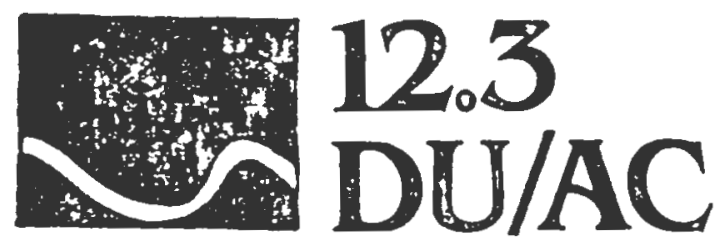

\section{Stacked units take advantage of seaside site}

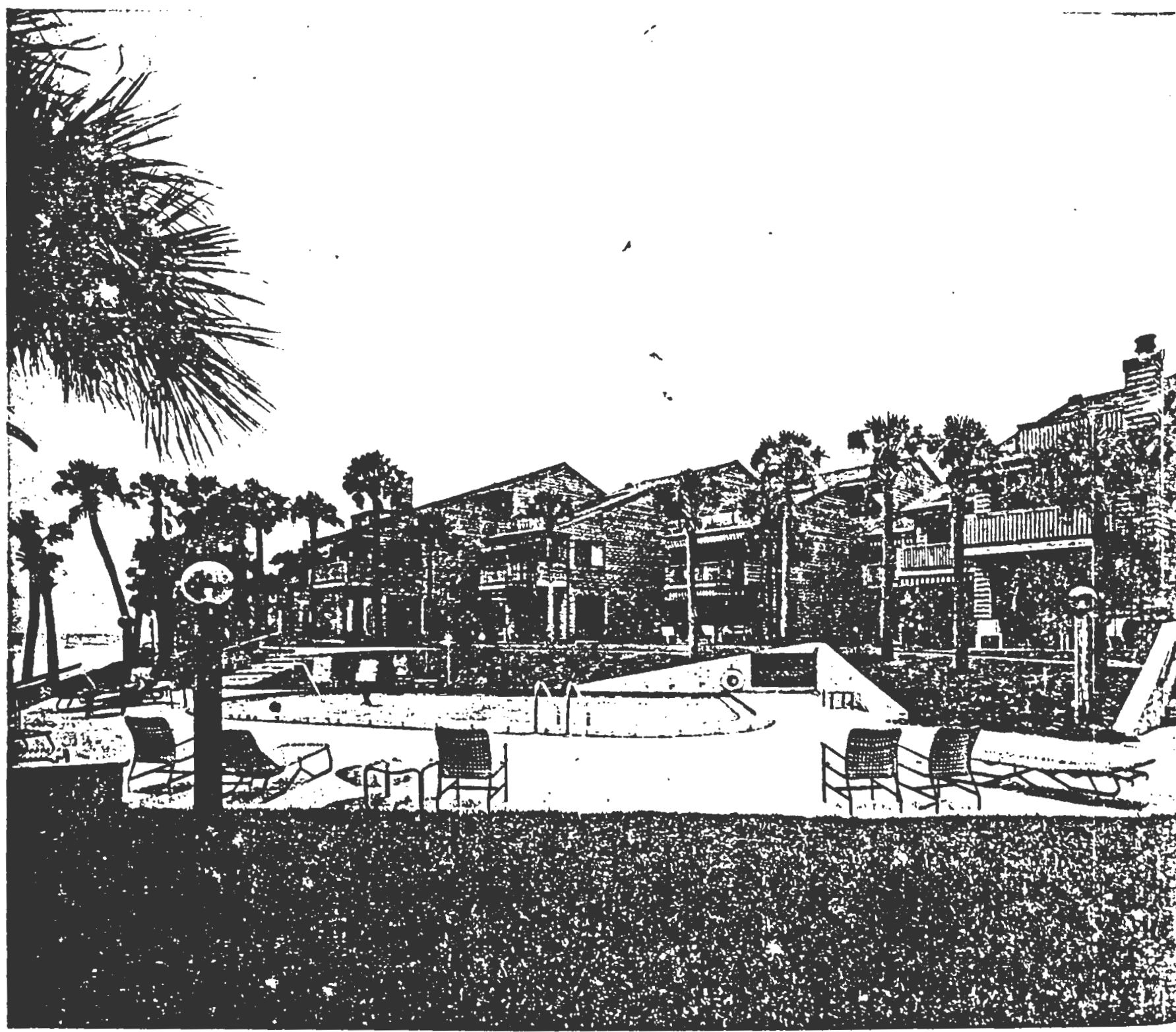

Aldea In Bellealr Beach. Fla., ollors residents the cholce of swimming in the pool or the Gull. Upstairs residents enloy sundecks fecing the water, whlle those llving in flats below walk right out to private beech, left. 
Devereaux: They "put the units up in the air" and they gave the attached units a single-family look.

Wood plays an important role in maintaining the nautical atmosphere of Chesapeake Landing, he added. Cedar siding creates a rustic feel, and heavy bolted wood, $8 \times 8$ posts and nominal 3 . inch planks on decks reinforce the marina atmosphere.

Units are placed so that living rooms and bedrooms open to decks that look out to the water and moored yachts.

The buyers at this project have been professional persons in their mid-40s, Parks said. Few have children. Income is generally $\$ 60,600$ to $\$ 80,000$.

Total cost of the project will be $\$ 6.3$ million, Parks said. Hard cost of construction, including sitework, is $\mathbf{\$ 4 2}$ per square foot, and present sales prices are $\$ 62$ per square foot. Parking ratio, including one garage per unit and guest parking lots, is two per unit.

Sales have been steady, Parks said, and staggering sales to move residents in immediately after units are completed "has been the key to this thing being a success."

"My maximum outstanding construction cost has been $\$ 1.8$ million, at any one time," Park said. The three clusters away from the waterfront are now completed, and the other two phases will begin construction in the near future.

Garages In townhouses facllitate placement of stairs to ralsed first story. which In turn gives project single-family

look, according to archltect Willlam Devereaux, Jr. AlA (pholo above). Yachts on sllps at the end of the slte are vis/ble through one unlt's living room ishoto right).
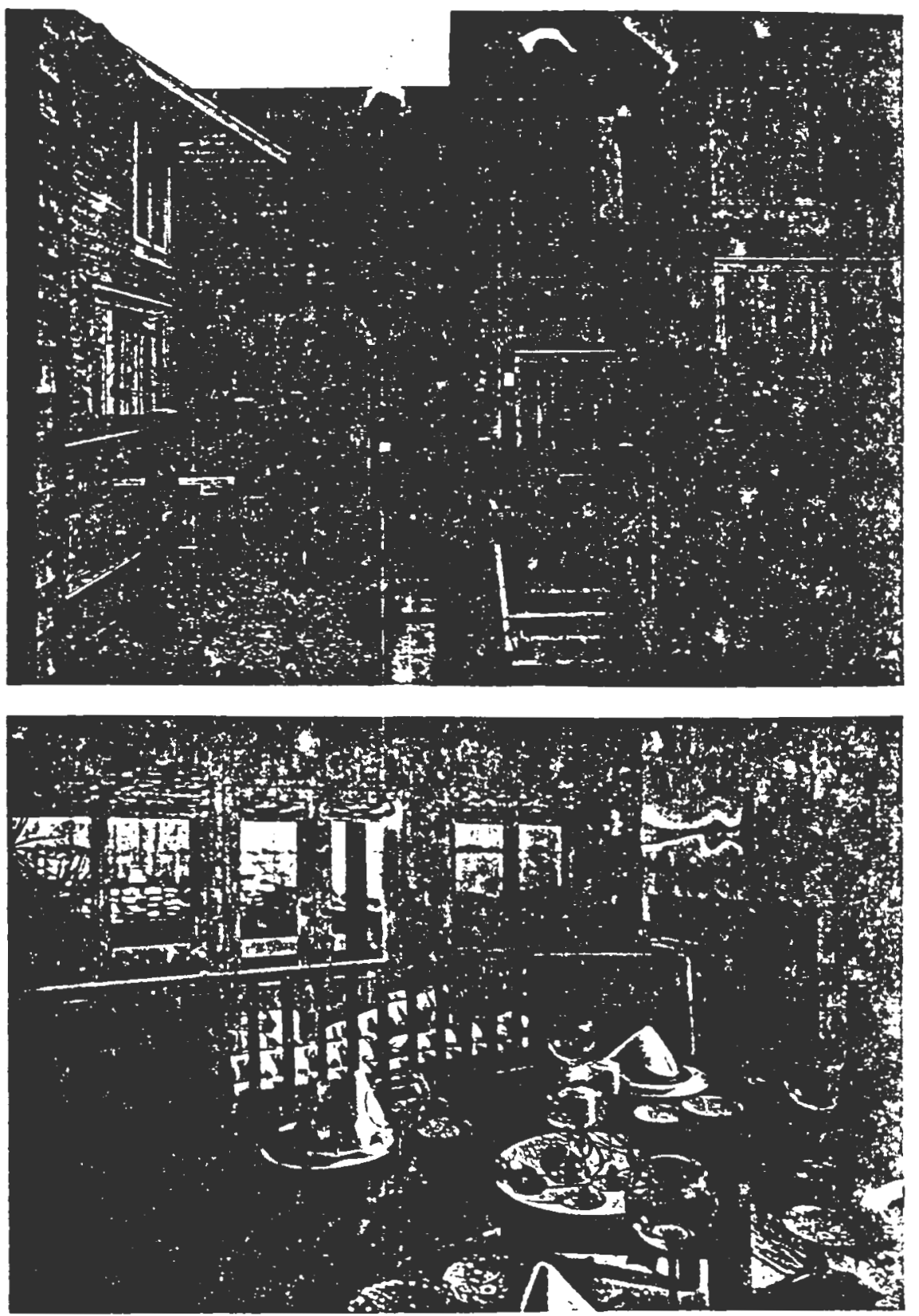


\section{0 DU/AC}

\section{Clustering creates a cozy village atmosphere}

7 oning and geography required builChesapeake Landing in L-shaped clusters of seven to 10 townhouses in Annapolis, Md.

Parks initially acquired the waterfront site where the Chesapeake Bay joins the Severn River in the early 1960 s and extended it into the water with pilings and fill to create the Maryland Capital Yacht Club (note boat slips on waterfront, site plan below).

The Yacht Club was incorporated in 1968, but when Bay Landing Development Co., Parks' firm, tried to build homes on the site, zoning snags emerged. A workable solution was found: replat the site into five flag lots (lots with direct access to roads), since Annapolis allows up to 10 attached units per lot. Homes were sited so all had views.

Once this problem was solved, the construction began.

"The major part of the draw was that the people with luxury boats would want luxury living to go with them." said Parks. One basic unit was designed by Berkus Group Architects of Washington, D.C. with several variations, to permit all units to have a water view.

The two-story-with-loft townhouses, ranging between 2,832 and 3,057 square feet, were built with wood rather than brick on exteriors "to create a Nantucket fishing village type of feel," said architect William J. Devereaux, Jr., AlA.

Prices on units currently being completed range from $\$ 165,000$ to $\$ 200,000$, with one specially enlarged

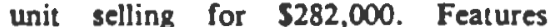
include: covered garage in every unit, decks with a view of the bay, three bedrooms, three-and-one-half baths, a recreation room on the garage level, and a breakfast area in the kitchen. All units have fireplaces in living rooms.

Garages served two functions, said

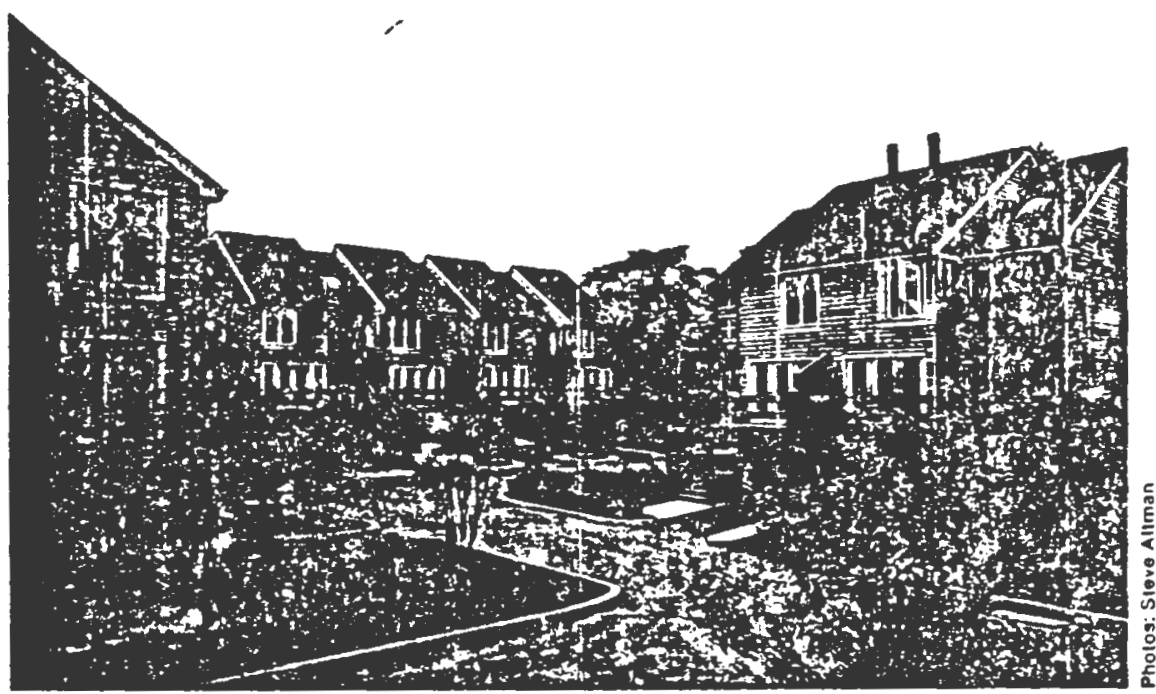

A nautlcal wood look was Important In distinguishlng Chesapeake Landing in the Eastport Section of Annapolls, Md.

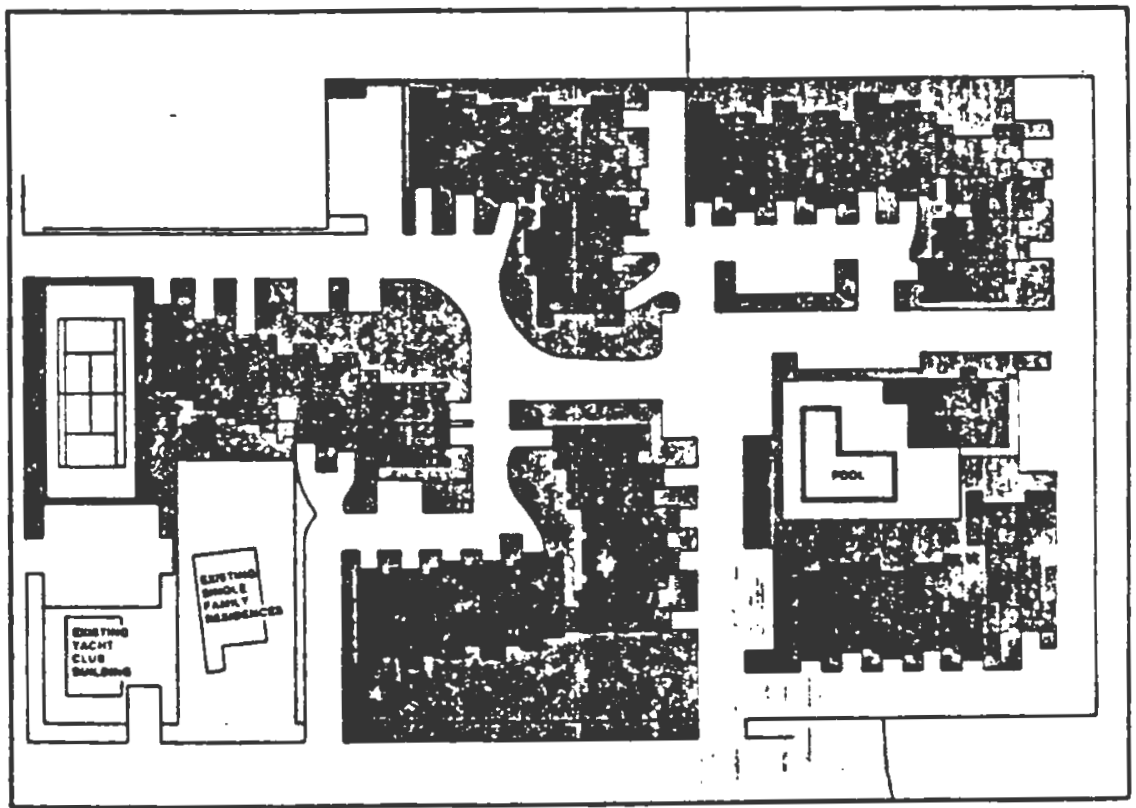

Slte plan shows how unlts are all orlented toward water. Ex/stlng yacht club, lower left, was bullt in 1968 by bullder Jerry Parks, and fownhouses followed 10 years later. 
Broadmoor Homes terraced the 27.acre site 10 provide greafer privacy at the exclusive Summit Ridge development (photo below). Site plan does not show the extreme variations in grade which made density the best possible land use.

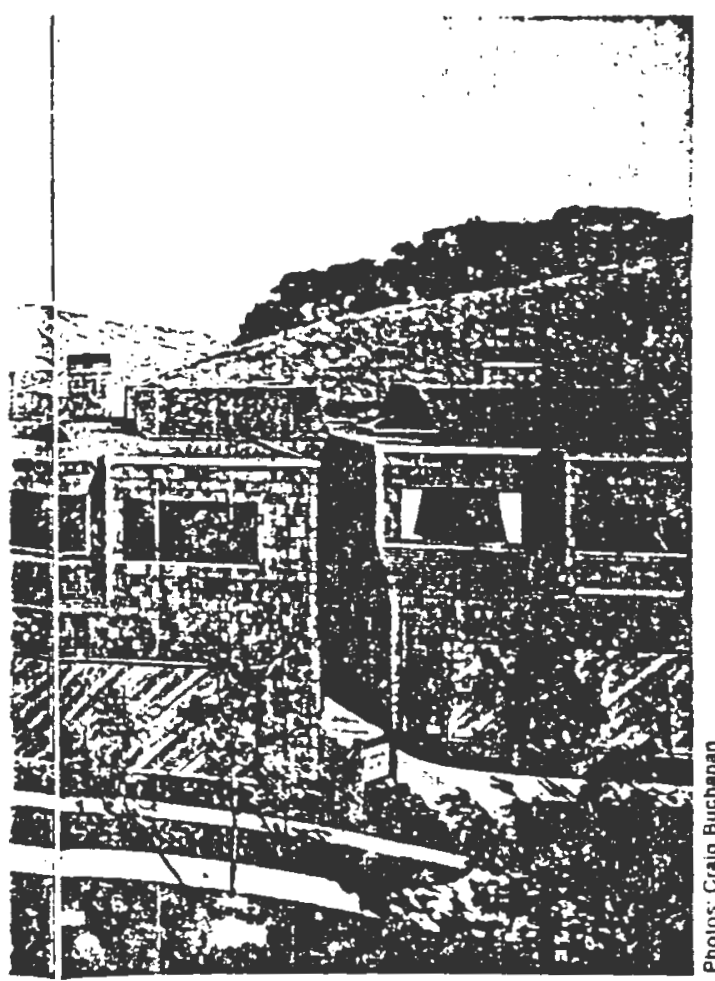

plans: one with an entrance going up and the other with an entrance going downstairs. However, the basic floorplan remains the same, at about 2,500 square feet.

The best selling unit, however, was the smallest unit, a two-story split level with three bedrooms, two-and-one-half baths, covering 1,820 square feet. Prices on this unit vary depending on location within the site, but the lowest price was about $\$ 110,000$.

Average lot size is between 55 and 60 feet by 30 feet, and lots fit the actual ground covered by the unit, noted Don Frederickson, vice president, project development. Hard costs in the curreni phase are $\$ 41$ a square foot. The project won the 1979 American Wood Council "Design for Better Living" award.
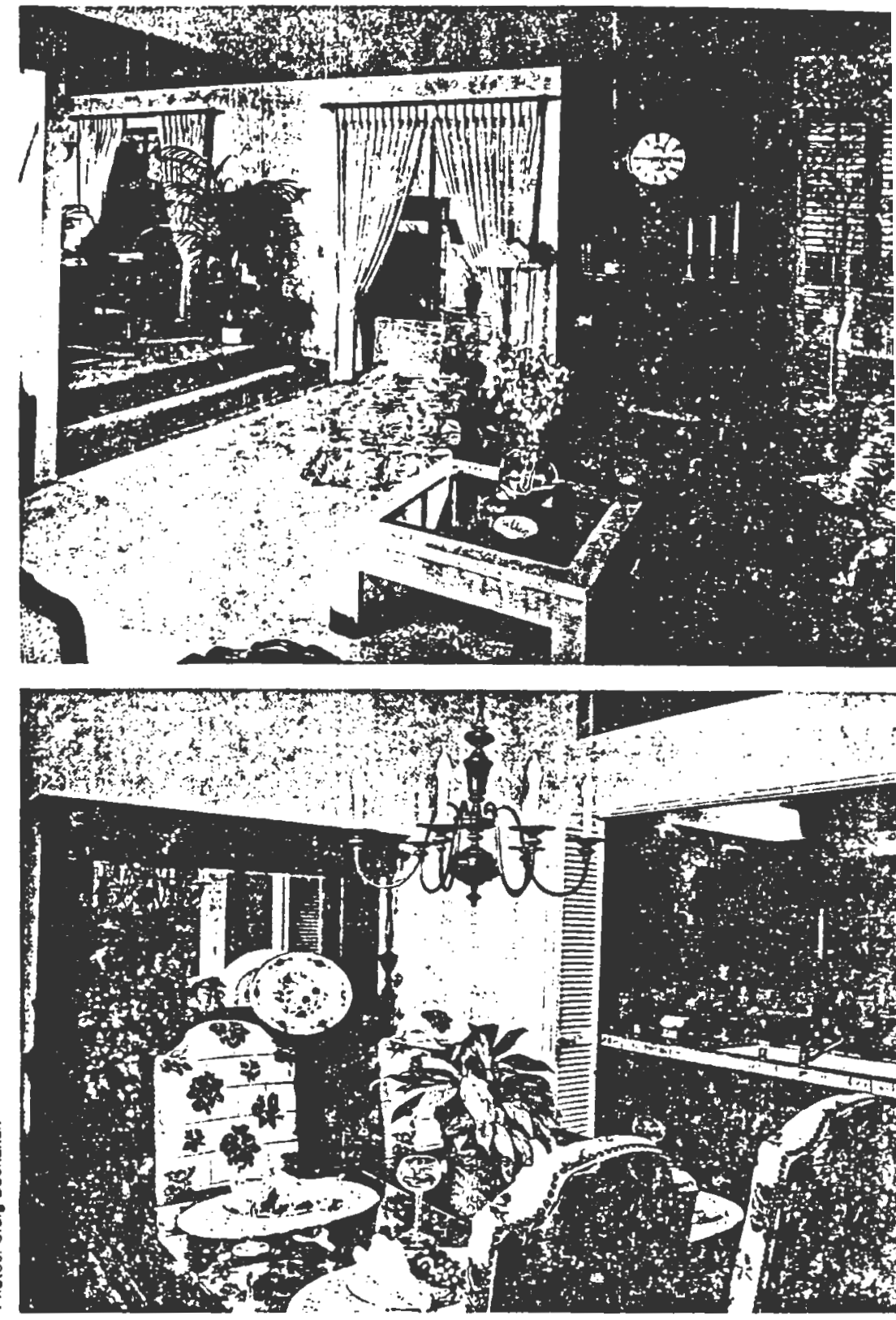

Elegance /s the watchword at Sum Ridge, where average household inco Is $\$ 70,000$, the developer sald. Multille plans and alry spatial arrangements, w skyllghts, were designed to appeal t sophisilcated, protessional resid (photos abor 


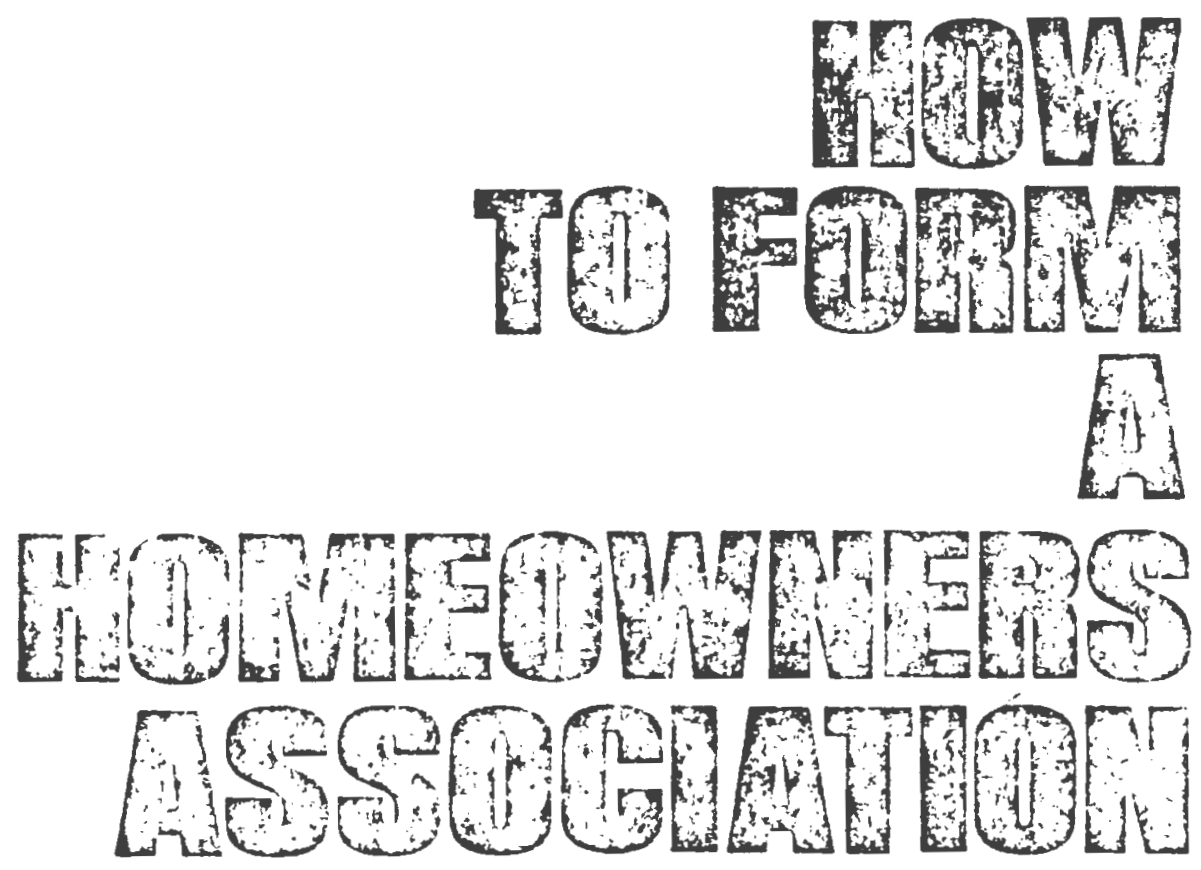

C. James Dowden, executive vice president, Community Associations Institute

\section{As the story on pages 54 to 75 shows, there is a trend to highor density residentlal development.}

But in achieveing these densities, builders are faced ivith the protlem of requiring some form of community association to share and maintain common areas; provide security, trash removal or other services; ard eniorce ccveriants to contiol architectural standards.

This roport discusses the growth of community associations during the past decade and tells ho:y experis solve-and builders can solve-second generation problems.
We real growth in development of condominium and homeowner associations has occurred over the last decide and a half. In the easly 1960s, there were barely 500 homeowner associations in planned residential developments and almost no condominiums. Today, there are more than 40,000 condominium and homcowner association communities, and they ar: growing at the rate of 3,000 to 4,000 associations each year.

While the basic form and cliaracter of condominium and homeowner association communities has not changed, the approach to their creation and operation has. Builders should benefit from this experience; there is no need to rcinvent the whel, no need to repeat the mistakes of the pioneers in this field.

\section{Projsct design conslderat!ons}

There is a much greater awareness today of the impact of design decisions on the capacity of the community association to operate and survive. It was not uncor.mon in early developments to ignore the consequences of design decisions on the long-term operating cost of maintaining facilities and amenities provided.

Large, mausoleum-like clubhouses, much larger than the capacity of the community to make use of; olympicsized swimming pools for 100 unit communities, basic building materials and designs that require careful maintenance and frequent attention; the absence of energy-conscious features, including common meters for all units; and the absence of what today are basic energy-conservation techniques are examples.

Builders today have found that each design decision regarding the exterior or common facilities has an impact on the financial capacity of the association. Increasingly, decisions are made in the direction of redusing maintenance to the minimum. Yes, amenities do help to sell, but larger amenities may hurt long term sales and resales because of thcir expense and burden.

Another consideration in design is the basic question of what entity will be responsible for maintenance of the major facilities. Where we project concept will permit, most association practitioners today prefer to see as many facilities as possible dedicated to public entities. Recent surveys of local electef and planning officials suggest that a number of association communities are petitioning for public acceptance of heretofore private streets. utility systems and outdoor recreational and open space areas. They are doing 
this to reduce maintenance and operating costs carried by the assuciati:?

If these iacilitics, particularly strecis, sidewalks and outdoor lighting, need not be held in private ownarstip by virtue of project design, then the developer is urged to didizate them to a public entity.

\section{Legal dccumonls}

Experience has led to signiffcant cuanges in legal documents. One importan: change has bcen the devclopment of more sophisticated state legislation dealing with ccndominium documentation. A number of statcs irave amended their statutes to require that condominium association documents provide protzction to the buyer.

Another significant change has been the recognition that the legal cocuments for a condominium or homeowner association project must be tailored to the specific project and that no model documents or standard forms can be effectively and safely used.

Experienced attorneys give great time and attention to project design, the site and the developer's scheme of development in order to assurc that the documents reflect the approach of a develoment. There have been too many examples in the past where "canned" documents have been used and have been found to be inadequate.

There has also been a trend away from spccificity and detail toward flexibility and latitude in documents. During the early days of PUD and condcrinium documentation, the inclination was to protect the developcr's interest and rights to the exclusion of the purchasers' and 10 impose restrictions designed to protect the new owners agains: the possibility that the association would run amuck. Extraordinary voting requirements were imposed to raise special assessments or to change documents, even when such changes were necessary.

There are very few, if any, true examples of a homcowner association or condominium associasion which has run anuck. Eut there are numerous examples of associations that have not been able to administer their affairs, or raise the funds to complete nccessary repairs, or continue operating services because of artificial limits on thcir right to do so.

Despite all of the inadequacies of laymen running community associations, in general they have done a decent job. No wonder. They have a great deal more at slake in making proper decisions than builders and developers have given them credit.

The builder and his attorney must rccognize lliat the association is being created not for a period of five years but for the full life of the conmunity. Documents must have the nexibility to respond to changing conditions over 10 , 15 or 25 ycars.

\section{Financlal manąoment}

In most jurisdictions and areas and to meet most Inding requirements, the builder must have an initial budget which establishes the buyers' assessment fee levels. This budget is based upon a reasonable estinate of the costs of operating the association and is funded during the early phases by the builder and the early purchasers.

As the number of buyers increases, the builder's share of this total expense diminishes.

Too often in the past, budgets have been deliberately or erroneously underestimated. Thus the carrying costs for the individual owner are significantly understated. In part, this has been bccause of the builder's inexperience with condominium operation and his failure to project those costs properly. At the same time, extraordinary increascs in operating costs and inflation have caused unbalanced budgets.

All too often, however, the budget has been underestimated to fit presumed market considerations. A number of court cases have typically found against the builder who deliberately and consciously misstated such fees.

No matter what the basis for the errors in budgut estimating, the builders must recognize that buyers are more sophisticated. They know it is necessary to check projected expenses and operating costs for the association and are looking specifically for the existence of a capital rescrves budget.

States and local governments are looking to this area as one of potential abuse and are establishing procedures to help protect prospective buyers. For example, California has enforced regulations requiring the establishment of reserve accounts by stopping sales until such accounts have been esiablished.

\section{Insurance}

Insurance has been one of th: slowest areas to respond to the innovation of common intcrest subdivisions. Initially, insurance of individual units and common elements of community association dcvelopments was through policies that applied to single family ownership or to rental units in

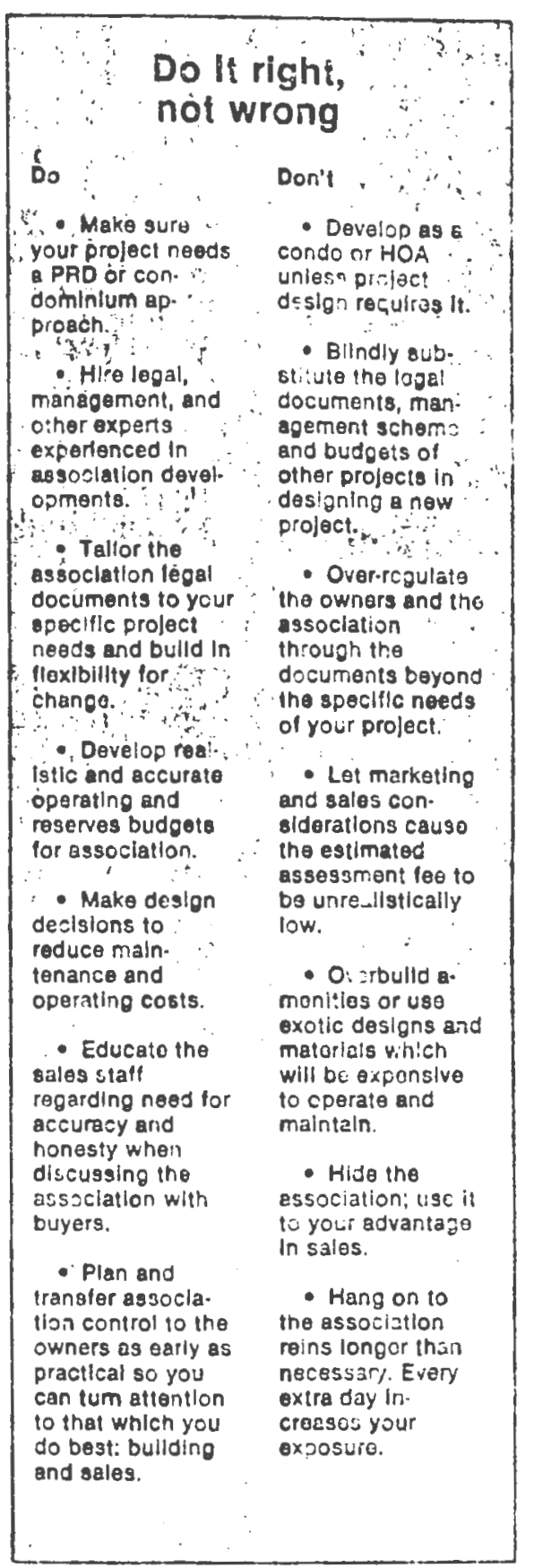

multifamily configurations. It was noi until the 1970 s that the insurance industry finally developed standaru condominium forms of insurance that provided coverage to individuals who owned rather than rented an apartment.

The common interest subdivision, involving complex and overlapping forms of ownership, prese:ts unique insurance challenges. For irsiance, lic association of owners needs insurance protection against the prospect of liability claims for incidents that misy occur on the common property. The policy must even protest itself against the possibility that individual onners of property will attempt to recove damages from the assoziation or froit 


\begin{tabular}{|c|c|c|c|c|c|}
\hline \multicolumn{6}{|c|}{ Association dovelopment procoss } \\
\hline $\begin{array}{l}\text { ASCCCIATION } \\
\text { PHASE: }\end{array}$ & \multicolumn{3}{|c|}{ Pro.Desion } & \multicolumn{2}{|c|}{ Dosign } \\
\hline $\begin{array}{l}\text { DEVEIOPISENT } \\
\text { PHAC .: }\end{array}$ & $\begin{array}{l}\text { Ctiolcs and } \\
\text { Evalustion of } \\
\text { Sito }\end{array}$ & $\begin{array}{c}\text { Dosign } \\
\text { Assossment }\end{array}$ & $\begin{array}{l}\text { Markot } \\
\text { Approsch }\end{array}$ & $\begin{array}{l}\text { Finencling the } \\
\text { Projoct }\end{array}$ & $\begin{array}{l}\text { Markoing tho } \\
\text { Proljet }\end{array}$ \\
\hline $\begin{array}{l}\text { ASGCEIATION. } \\
\text { RELATED } \\
\text { DECISIONS OR } \\
\text { ACTIVITIES }\end{array}$ & $\begin{array}{l}\text { Asscismcnt of } \\
\text { natural features of } \\
\text { barrieis, and of } \\
\text { common preporty. } \\
\text { Decisions about } \\
\text { clustcilng and land } \\
\text { conservallon. } \\
\text { Decisions about } \\
\text { housing typo. }\end{array}$ & $\begin{array}{l}\text { Selection of } \\
\text { common areas and } \\
\text { open space. } \\
\text { Determination of } \\
\text { common facillties. } \\
\text { Declsions about } \\
\text { major capltal items } \\
\text { requirlng long term } \\
\text { maintenance } \\
\text { Decisions about } \\
\text { whether to develop } \\
\text { all at once or in } \\
\text { phases. }\end{array}$ & $\begin{array}{l}\text { Acceftance of } \\
\text { design and projoct } \\
\text { by' market. } \\
\text { Exploration of } \\
\text { aiternative ap. } \\
\text { proaches to } \\
\text { ownership of } \\
\text { common property: } \\
\text { - assoclation } \\
\text { - loint ownership } \\
\text { prlvate club } \\
\text { - dedicatirn to } \\
\text { local en:iry } \\
\text { - fundod trust. } \\
\text { Decide on con- } \\
\text { dominlum or HOA } \\
\text { communlty. } \\
\text { Acceptance of } \\
\text { deslgn and } \\
\text { development by } \\
\text { munlcipal officlals. } \\
\text { Assemblè team of } \\
\text { talonts. } \\
\text { Initlate preparatlon } \\
\text { of associatlon legal } \\
\text { documents. }\end{array}$ & $\begin{array}{l}\text { Comp!oie the } \\
\text { preparation of the } \\
\text { legel documents. } \\
\text { Make sure the } \\
\text { projoct conforms } \\
\text { with rngulrements } \\
\text { of FNMA, FHLMC, } \\
\text { VA, FHA, and other } \\
\text { lending-related in- } \\
\text { stltutlons. } \\
\text { Prepare the initial } \\
\text { assoclatlon budget } \\
\text { and management } \\
\text { procedures. } \\
\text { Submit proliminary } \\
\text { assoclatlon mana- } \\
\text { gemont and sales } \\
\text { program to lender. }\end{array}$ & $\begin{array}{l}\text { Explain the } \\
\text { assoclation con- } \\
\text { cept as a sales } \\
\text { tool. } \\
\text { Inform the } \\
\text { salesforce about } \\
\text { the legal aspects of } \\
\text { selling a home with } \\
\text { an associatlon. } \\
\text { Prepare the home } \\
\text { buyer and } \\
\text { homeowner } \\
\text { brochures. }\end{array}$ \\
\hline
\end{tabular}

the cirectors of the association for allaged crrors in judgment in managing the association. In many respects, the association is and opcrates like a busizess and must have the same forms of insurance protection that busincsses must have.

In the property instrance area we now recognize that there is an interlocking relationship between the ce:erages of each individual owner and the coverage provided by the association. The association and the owners collectively necd to be assured that damaged property, even if owned by single individuals, will be restored to its original condition. Common areas and structures are now insured by a master policy for all of the property except the personal contents of each individual unit. This approach can result in significant cost savings to unit oviners.

Uniortunately, however, the Veterans f. dministration and the Federal Housing Acininistration have not recognized that there is 8 need for such $\Gamma^{\prime} \cdot \cdots$ in- surance programs and will not recognize or permit these approaches without 100 percent concurrence of the owncrs.

\section{Salos approach}

The greatest mistakes of the past seem to have occurred in the sales office. At times there have becn deliberate efforts to hide or obscure tue association, to ignore or to downplay the responsibilities and the restrictions imposed by the association, and to over-promise what would be delivered by the association or by the developer on the association's behalf.

Much of the adverse publicity that surrounded the early efforts of condominiums and PUD developers centered on their inability to deliver the project as promised by sales personnel. Much of the community association oriented litigation that has followed that period has centered in this area.

Who among us has not heard the lament."I never knew there was an association or that I had to pay an assessment!" More importantly, how often have we heard that, "he said they were going to build a swimming pool over there" or "he said I could have a dog, that nohody would mind." Each oi these are examples of the kinds of problems that will come back to haunt the buildar-probably in court-and will certainly present operating challenges to the association.

The builder today must have sales personnel who understand their responsibility (and the developer's legal exposure) for the statements they make or fail to make when offering condominium or PRD units for sale. There are specific state and local regulations regarding disclosure.

The builder must educate and train his sales personnel to handle these areas truthfully and accurately.

\section{Trenaltion of contrel}

In the earliest projects, documents provided that the builder would retain control of the board of directors of the 


\section{Learn the language}

Homoowners' Assoclatici (HOA). An eniliy that helds title to and manages and malnteins common properiy in a com. munily assoctatlon development. The $\mathrm{HOL}$ algo enferces coversents and rastrictlone. A purchaser of t...? estute In such a development ovins ils unit and underlying land and automatlcaliy becomes a member of the HOA.

Plannod Unlf Doxs?opmont (PUD) or Platica Resldentle: DG:sioptiont (PRD). Croginally assoziz:ed $n ! t h$ zoning of a planned prcicci alferen: fiom traditional c: conventicnai zon!ng. How a dosign philoscany that increases l'e duveloper's thexibllity to mix housing iypcs, cluste un: $:$, ard deve'op commen firlitities that may include nonres!dentlal lise 3 to servo the rislderitial units. A PUD or iffo may Include condom'nlums, cooferatives, nomeowner associulons and commercial or ciror lorms of uses.

Condominlum. Po: a type of housing. tut a fo:m of ownership whoraby an cisirer has flite to an excluslve area (or space or timo period) and a picicentage owncrship in cuminch arcas.

Community Assoclation. An association of ho.neowners charged with the responsibility of maimlain'ng or operating common faclitios and sorvices. An owner, by virtue of the pl chase of sorie form of teal estate whather In a condominlum a PUD, c. a cooperative housing devciopment, is requires to be a member.

Umbiella Assoclation. In a large-scale plenned unit development, an assoclation of all the owners in the entire project, with local cluster or condominlum asicoictions responsibio for smal! residential developments. These localized essociations are reponsible for maln. teriance and upkeep of lacillties within their communliy. The umbrella ascoclation is resporisible for maintainlng facllities used in common by all of the owners of the local assoclations.

Time-chering Condominlun. A con. dominium conceft found almost ex. clusivcly in resort or vacatior pioperty. in a tirnothising ccndomintum, the owner purchases ite rights of the excluclve tise of specilies periods of time ter a farticular ccndominlum unit. A con. dominitm w-ie.stare ualt is conveyca io Several purchasers as $t$ enants In commion with a regally exrocited agicsment supu - reg the the ce civneiv heve rights

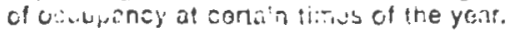

r.es?uentlal ceser:el:so. A form of ownership in which ar, Ir.diviuual pur. thisses stock in a non-r cotil corzoration that owis a recider lial fisjelig complex. By virtue of cuinership of the stoci, the InJivicual has a propriotan lease 10 8 specific unit within the complex. The coo; crative corporaticn owns alt of the froperty, has a mortgaze and pays all of the associated costs of debl service. mainiciance, improiement, and other. The is:dividual pays a monithly peyment for his share of the corforation's ox. penses.

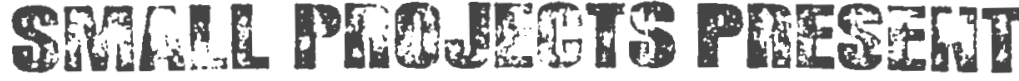

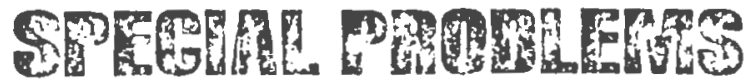

The size of condominium proj. acis has decreased from an average of 75 to 80 units in the early 1970 s to a recent average of 50 to 60 units.

There are two rcasons for this trend: First, in the early 1970s, when the cconomy turned down, largescalc do'elopers were left with uncompleted projects and unsold units. This stared a trend toward smaller projects or more phasing of large ones to keep in step with market demand. Second, with the larger, more attractive rental properties already converted, smaller projects are now being brought on the conversion market. There is also more new construction of smaller for-sale projects on the limited sites available in central cities. This has resulted in many condominium projects of 15 to 35 units.

These small projects present special problems for builders. One obvious problem is that there are fewer units over which the full cost of development can be spread and recovered. And the cost of development may actually be increased by the legal fees required for correct documentation of the condominium.

The reduced number of units also means that the monthly condominium fees must be carried by fewer owners and may of necessity be higher. This can be an important drawback in marketing a small condominium project to modcrate income prospects.

Condominium and homeowner associations, whether large or small, must have responsible leaders to run them. Drawing interested and experienced Icaders from 15 to 25 families in a small development is more difficult than finding them among the 100 to 150 families available in a larger project. The lack of leaders may present problems in the transitional phase of development.

A smaller condominium project will almost surcly present problems for its owners in ongoing management. Companies that specialize in condominium management in most communities are reluctant to take on smaller communities without a minimum fee that is too large an expense for a 5 nall number of owners. This means tliat small associations generally choose to manage themselve:. The lack of experience and professional guidance under these circumstances is a source of trouble.

As smaller projects are converted to condominiums, more and more inexperienced owners are entering the field. To reduce their costs, they refuse to use outside experts in drafting documents and devcloping management plans. Expcrienced condominium practitioners are afraid that these smz..er conversions will result in dissetisfied buyers and owners and will ultimately tarnisl] the image of condominium developers.

The builder who is bound to undertake a smaller project can guard against some of these problems by careful attention to his project design. Common areas should be kept to a minimum and constructed so that little, if any, maintenance is required. Outside services should be eliminated, if possible. Wherever possible maintenance should be the responsibility of the individual owners. For example, in a larger community the exterior maintenance of individual units and grounds might properly be the responsibility of the condominium assoviation. This practice would be dangerous for a smaller community and inevitably will lead to trouble.

Documents st.ould be writien to reduce the responsibilities of the board of directors, and the size of the board should be cut to not more than three members. This will guard against the potential loss of willingness to participate that will surely occur later on. If professional management is available, the bui!der should acquire it before turring th: association over to the oviners. A multi-year management plar should be provided to help guice ovirers through the early years of the association. 


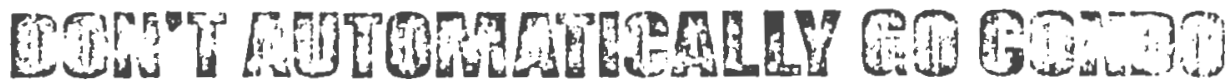

Fhe developer of higher density E' housing with open space has several alternatives for the management and maintcrance of the common area in the devclopmont.

First, he can attempt to dedicate the common land to a local goicrnment entity. This has the sales advantage of an apparent lower monthly carrying cost because there are no association fces or due's.

But if he does this, the community must meet the siandardz of the entity invoived. Strects, easements, parking and other restrictions must cunform to the jurisdiction's codes. And the dedi-ated common area must be avaisable to the public at large, which may connict with the developer's plans for privacy and security.

Moreover, local governments are tccoming less receptive to the dedication of open space because of drains on the tax dollar.

In another situation, where the common area is largely recreational, sunh as a golf course, a private club may be used to maint ain and operate the facilities. Here the burden of paying for the operation falls on those who clioose to be memoers and actually use the facilities. A frequent problem with this type of op:ration is the difficulty in maintaining the voluntary membership. A solution to the problem has ofien been to open membership in the club to the surrounding community, defeating the private club aspect of the cluster devclopment.

Most developers choose an automatic membership associationeither a condominium or a homeowners association (HOA) - to manage and maintain the common elements. Although they draw from the same membership, perform the same functions and have the same sources of financing and power, the two are different.

The basic difference is that the HOA owns the common p:operty while the condominium association simply administes it. Of the two, which is best?

As a gencral proposition, most builders and developers today as well as attorneys and property managers would agree that where possible, the HOA should be used for these reasons:

- The design, site plan, mixture of housing types and siyles, and ability to cluster units at higher densities is the same with an HOA as with a condominium.

- It is an easicr concept to explain to buyers because the buyer is purchasing a lot and home much as he does in a traditional real estate iransaction, he has less fear of the unknown.

- It is less subject to onerous statc and local laws and regulations. In every state condominiums are regulated. This is not true with HOAs in all but a few states.

- It is better understood by local planning and zoning agencies ard by financial institutions. Mosi lenders and sccondary market agencies impose more substanilal requirements and restrictions on the builder of a condominium than are imposed on a HOA development.

- It involves lower start-up costs, particularly legal costs.

Eecause the condominium form of ownership overlaps the $\mathrm{HCr}$, since it can be used in both horizontal and vertical developments, it is frequently chosen by builders who are unaware that an HOA would have been appropriate. The condominius:, where the owner has title to an exclusive area or space, must be used in vertical subdivisions.

Builders also have used the condominium form of ownerstip when local zoning preventzd sub. dividing a parcel into individual lots. Some have built single family detached homes on otherwise unsubdivisible land and sold them as condominiums. -ssociation until 75, 80 or even 90 percent of sales had been completed. It was felt that this control was necessary to protect the legitimate right of the builder to complete the project. This is the most stark e::ample of efforts to prevent the owners from running amuck.

In actual fact, most owners who want to Eovern the association do not want to west conirol from the builcer or to do him harm. If there are frotlems of construction or warranty issues, these problems are going to surface whether or not therc is an association and whether or nol the owners are orginized through the association of owners.

Tocay builders are providing for earlier transition to owner control of the association board, in scrre cases, as soon as 50 percen: of sales complcticn or even eariticr. This irend is based on the prir.ciple tha: the ovizers have an interest in protecting and preserving the rommunity and in enhancing its image-not detracting from it.

The builder, as the governing majority of the board, has conflicts of interest between his role as the developer and his role as the president of the association. $\mathrm{He}$ can protect himself against this exposure in only one way-by removing himself from that board.

In addition, during the last half of the development and sales pericil of a cornmunity, the builder is not interested in the meetings of the association for making decisions regarding suimming pool rules, hiring of landscape contractors or enforcing pest control provisions. $H C$ is interested in complciing sales and getting out of his development.

The most recent documents are beginning to include other ways to protect the developer's legitimate rigits during the devclopment process whilc at the same time providing earlier transition of control to ouners. These include a veto for the developer o:er certain kinds of board decisions or ad hoc advisory board; of owne s to make most decisions unless overridden by the developer-controlled board.

No longer is it proper or aprropriate for the builder to control the board up to the final sale or even to 80 or 90 percent of thc sales. Most recent state legislative requirements are hcading in the cirection of requiring transition at an earlier stage, and builders must recognize this trend and act accordingly.

This roport was prepared with the asgisionce of the Community Assoclatlons instituto (CAI). a nonprofit opgunization that deve'sps and distributes guldence ca horreowners assoclations. For ramborghlp or other in. formuton, wrlt CAl, 1832 M St., N.W.. Wasnington, D.C. 20036 


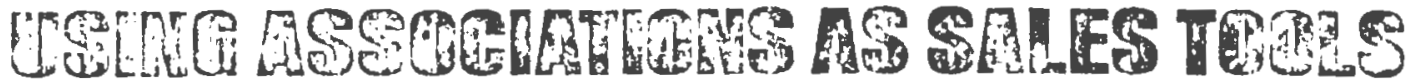

r. $n$ the early days of Planned Unit Development the advice to builders was to hide the community association under a basket. After all, the buyer in such a project would have to pay an additional fee, an assessment, for the assc:iation to manage its alfairs; and he would have to abide $b y$ rules and regulations that would te!l him how to behave and what he could and couldn't do with his property.

Today, all of these negative aspects about the community association have been reversed by experienced marleters. Instead of hidirg the association, they use it as a sales tool.

Herc are the features of the community association they promote:

S'ared facilitics. A basic feature of flanned devclopment is the preservation of open space that can be used in common by all of the members of the community. Buyers are no longer merely tenants in an apartment building or isolated house owners in a tract development. They belong to a self-noverning community.

Betler protection. With more and mora Amcricans turning to their home as an investment and hedge against inflation, the buyer in a development with a community association can feel even more reassured. One of the association's principal iunctions is 10 protect and enhance the propcriy held by the ccmmunity. The owners detcrmine, through their association, how much improvement and maintenance they desire. They fund that level of scrvice through the imposition of an assessment on themselves.

Long-tern prolection. The association not only protects the conmunity with its month to month mainterance and service programs, it also preserves the community's property through its long-term capit: I reserve budgct that provides for major repair or rchabilitation of facilities.

Every member of the sales : orce must be trained to understand the concepi and uenefits of the community association.

They must also know all of the elements of the master deed and bylaws of the community and be able to answer prospects' questions accurately. Those who don't understand the elements exactly are liable to cause legal problems for the builder as well as lose sales.

The sales force should be able to answer these basic questions.

- Who owns what property? What is common property? What does the buyer own?

- What are the restrictions on using the common property?

- What are the powers of the association and the responsibilitics

Transition process for single phase HOA community or condominium devolopmont

Polnt of Closings Committes Activity Commilteo Control Assaciation

Governanco

\begin{tabular}{|c|c|c|c|}
\hline $\begin{array}{l}\text { By } 25 \text { percent of } \\
\text { closings }\end{array}$ & $\begin{array}{l}\text { Newsletter } \\
\text { Welcoming } \\
\text { Recreation } \\
\text { Architectural } \\
\text { controls } \\
\text { Management } \\
\text { Budget } \\
\text { Insurance }\end{array}$ & $\begin{array}{l}\text { Developer controls, } \\
\text { owners chair } \\
\text { Developer controls } \\
\text { through board, } \\
\text { owners staff } \\
\text { Devolopor controls, } \\
\text { owners chair }\end{array}$ & $\begin{array}{l}\text { Developer controls } \\
\text { all seats on the } \\
\text { board ( } 5 \text { to } 7) \text {, and } \\
\text { he may elect one or } \\
\text { two carefully } \\
\text { selected owners }\end{array}$ \\
\hline $\begin{array}{l}\text { By } 50 \text { percent of } \\
\text { closings }\end{array}$ & $\begin{array}{l}\text { Maintenance } \\
\text { Newsletter } \\
\text { Welcoming } \\
\text { Recreation } \\
\text { Insurance } \\
\\
\text { Architectural } \\
\text { controls } \\
\text { Management } \\
\text { Budget }\end{array}$ & $\begin{array}{l}\text { Developer controls } \\
\text { Ihrough board, } \\
\text { owners staff } \\
\text { Owners control } \\
\text { Owners control, } \\
\text { with developer } \\
\text { involvement }\end{array}$ & $\begin{array}{l}\text { Transition board } \\
\text { with developer } \\
\text { controlling and } \\
\text { electlng additlonal } \\
\text { owners to the } \\
\text { board but still } \\
\text { retalning a majority }\end{array}$ \\
\hline
\end{tabular}

\begin{tabular}{|c|c|c|c|}
\hline $\begin{array}{l}\text { By } 75 \text { percent of } \\
\text { closings }\end{array}$ & $\begin{array}{l}\text { Maintenance } \\
\text { Newsletter } \\
\text { Welcoming } \\
\text { Recreation } \\
\text { Insurance } \\
\text { Architectural } \\
\text { controls } \\
\text { Management } \\
\text { Budget } \\
\text { Transition }\end{array}$ & $\begin{array}{l}\text { Joint committee of } \\
\text { developor and } \\
\text { owners } \\
\text { Owners control }\end{array}$ & $\begin{array}{l}\text { A transition board, } \\
\text { and depending on } \\
\text { the existing lezal } \\
\text { statutes, tho } \\
\text { developer shculd } \\
\text { shift to a minority } \\
\text { position. A mem. } \\
\text { bership meeing is } \\
\text { held to elect toard } \\
\text { membzrs arid to } \\
\text { effect the transfor } \\
\text { of control }\end{array}$ \\
\hline $\begin{array}{l}\text { By completion of } \\
\text { closings }\end{array}$ & $\begin{array}{l}\text { Maintenance } \\
\text { Newsletter } \\
\text { Welcoming } \\
\text { Recreation } \\
\text { Insurancc } \\
\text { Architectural } \\
\text { controls } \\
\text { Management } \\
\text { Budget }\end{array}$ & & $\begin{array}{l}\text { Compleis owner } \\
\text { control of board, } \\
\text { but developor may } \\
\text { be asked to } \\
\text { maintain liaison }\end{array}$ \\
\hline
\end{tabular}

of the owner?

- How are expenses allocaied?

- How and when will the builder turn over the management of the association to the owners?

- How is the associatio

Even though the provision of legal documents to prospects may be required to meet disclosure regulations, these materials must be explained to them by the sales force. If the buyer does not understand the association concept, it is not likely to work. 


\section{Housing Cost}

II is obvious that by permitling and encouraging all types of housing unils, performance zoning provides nore flexibility for the privale markel to provide housing for the lroadest sector of the market. $\Lambda$ significant cost reduction as compared to ronventional zoning is the elimination of the necessity for zoning changes to permit such a development ri mir. In many suburbas communitics the zoning change or annexation process may last a year. The costs are unnecessary; they do not provide a belier lot or larger house. Any such costs make altached housing types less competitive.
A second problem is the relationship of lot size and dwelling unit. When zoning was introduced in many suburban communities, homes were often scaled to fit on the respective lot sires while the lots had some spaciousness. Rising expectations as to the number of required rooms and size of a home have increased housing sizcs, anu in "lion has forced many lo opt 'or

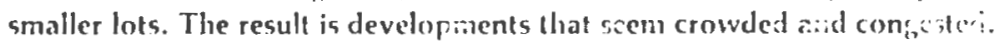
In addition, lower cost housing has been lorced out of the market place.

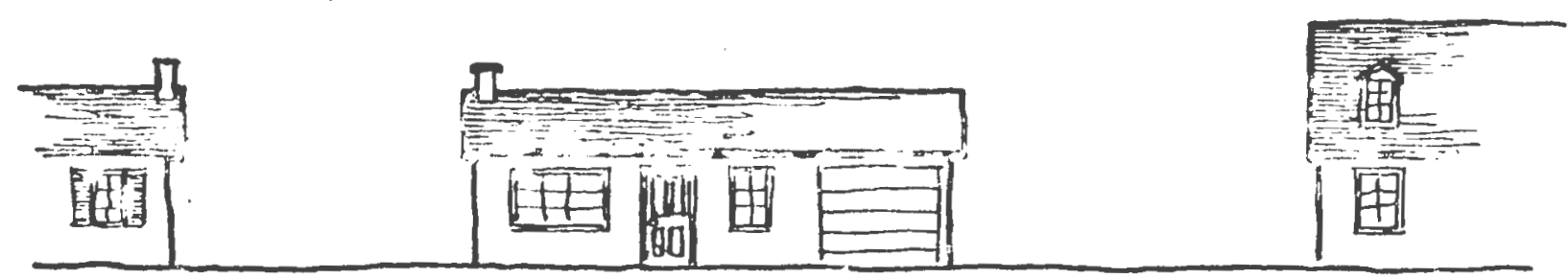

Homes on 70 foot lot 1950
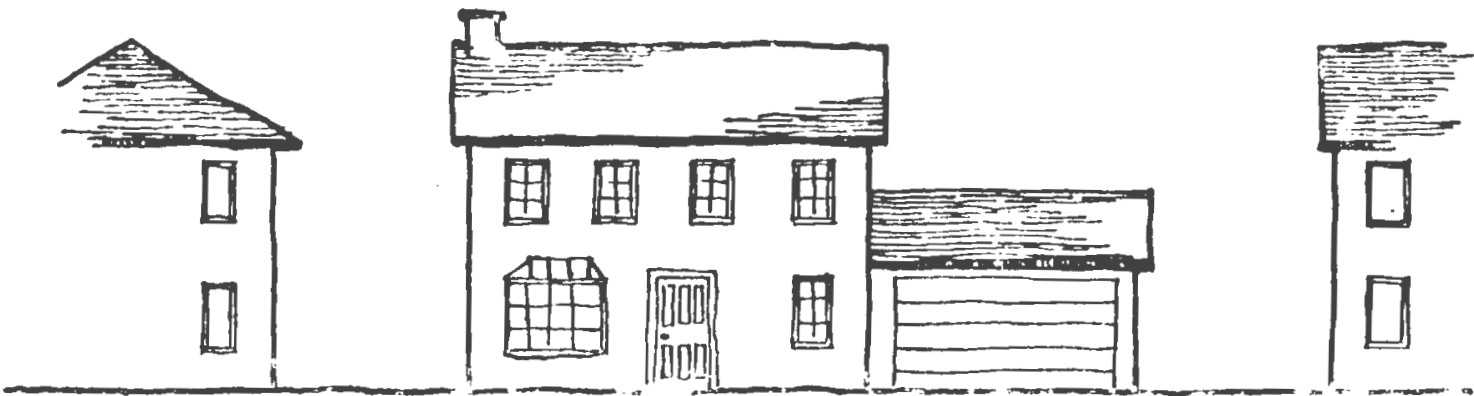

Fomes on 70 foot lot 1973 


\section{Variable Lots}

Ferformance zoning specifies floor area ratio and maximum on-lot inpervious surlace standards for each type of $d x$-lling unit. This means that larger dwellings require larger lols. The system thus maintains rcale by automatically adjusting site size to buildi:ig bulk. It also acts as a pricing riechanism, sirce density and therefore land costs are altered as the dwelling size incr"rses. This is an incentive to maintain a briader markel for homes.

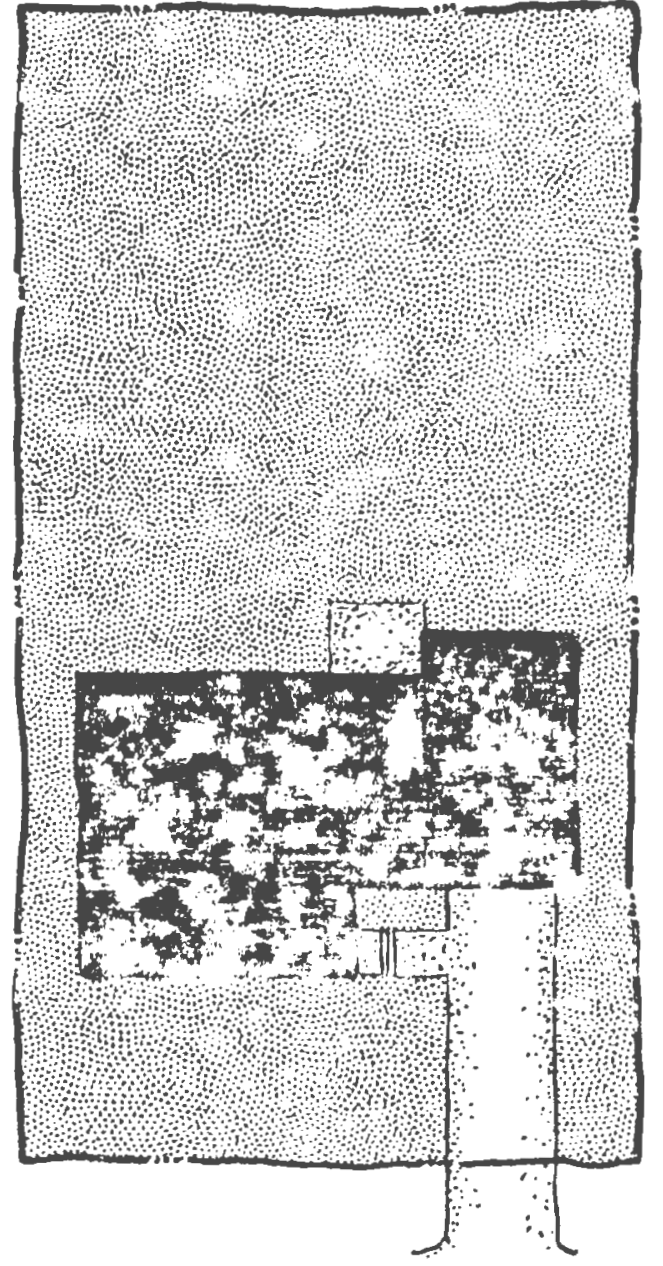

1800 sq. ft. house

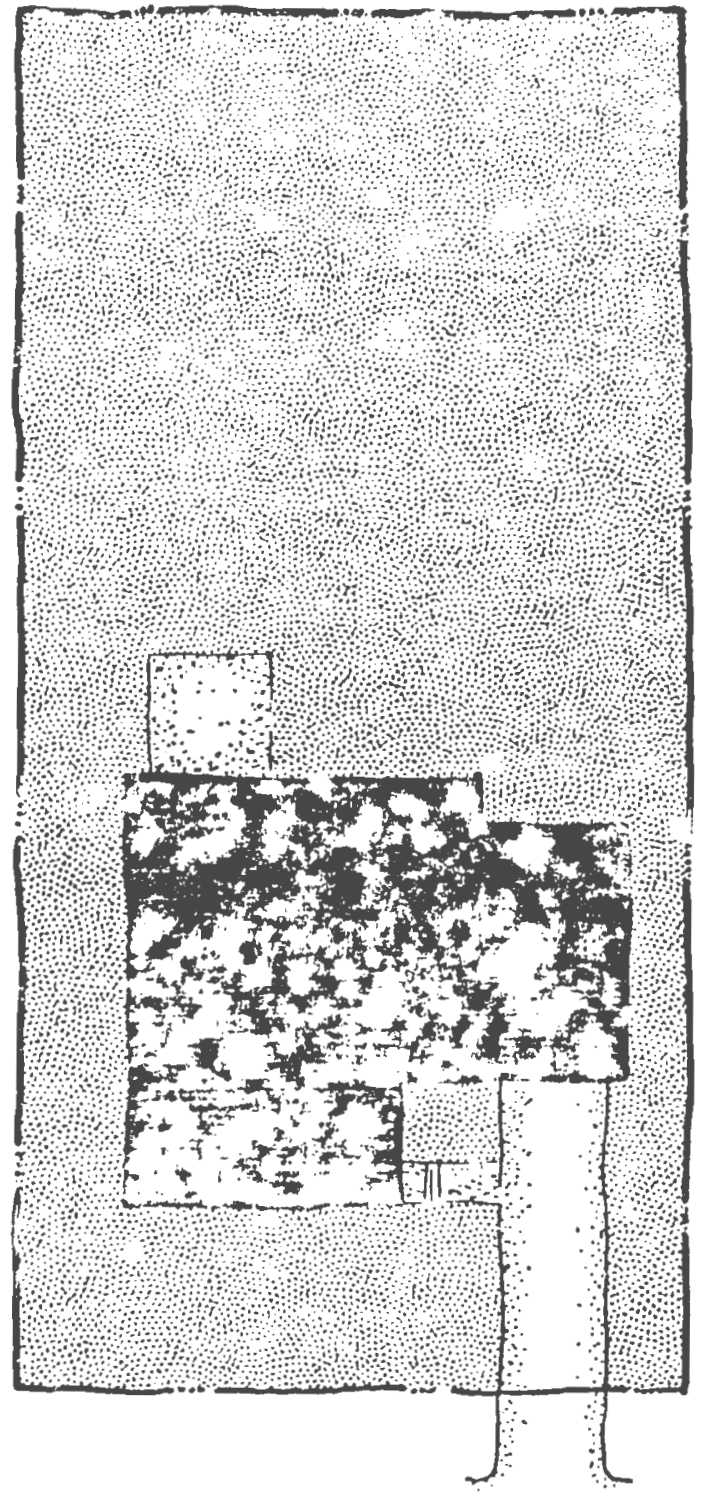

2400 sq. ft. house

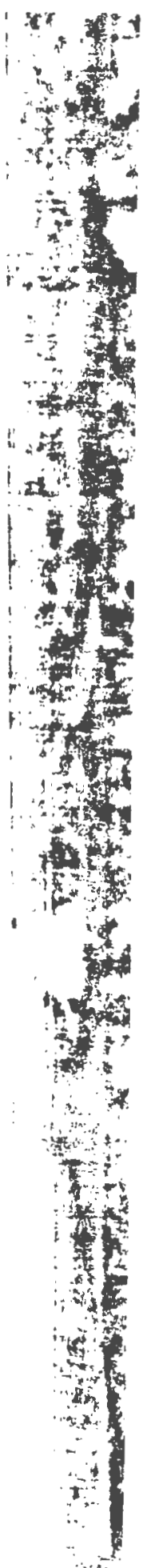




\section{Single-Family Detached}

This is the housing type to which most Americans aspire. Its principal feature is that the house is roughly centered on the lot and has large front and rear yards and narrow side yards. The large yards make it especially attractive to families with children.

DENSITY

OPEN SPACE RATIO

IMPERVIOUS SURFACE RATIO
1.55

.00

.16

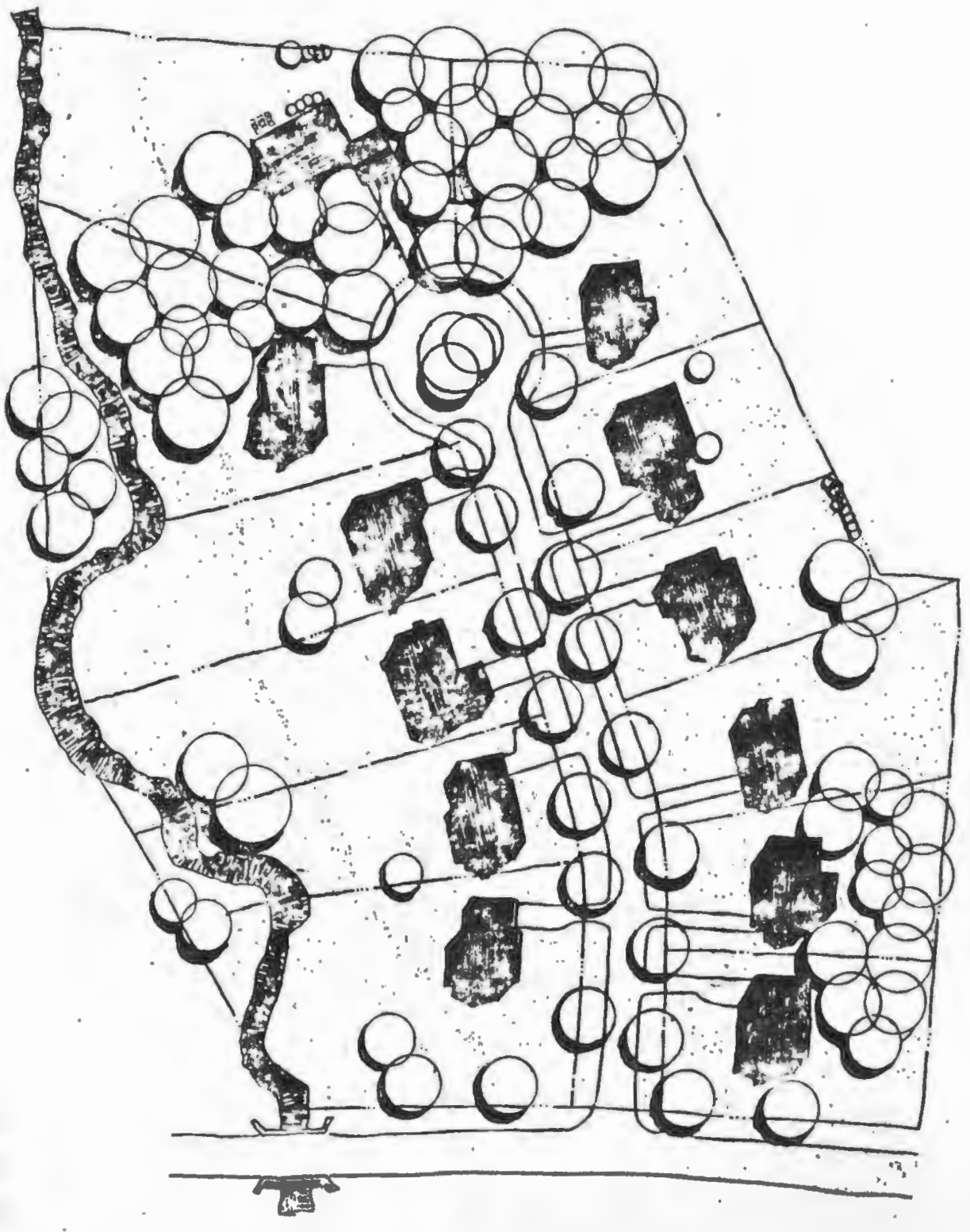




\section{Single-Family Detached}

This is the housing type to which most Americans aspire. Its principal feature is that the house is roughly centered on the lot and has large front and rear yards and narrow side yards. The large yards make it especially attractive to families with children.

\section{DENSITY}

OPEN SPACE RATIO

IMPERVIOUS SURFACE RATIO

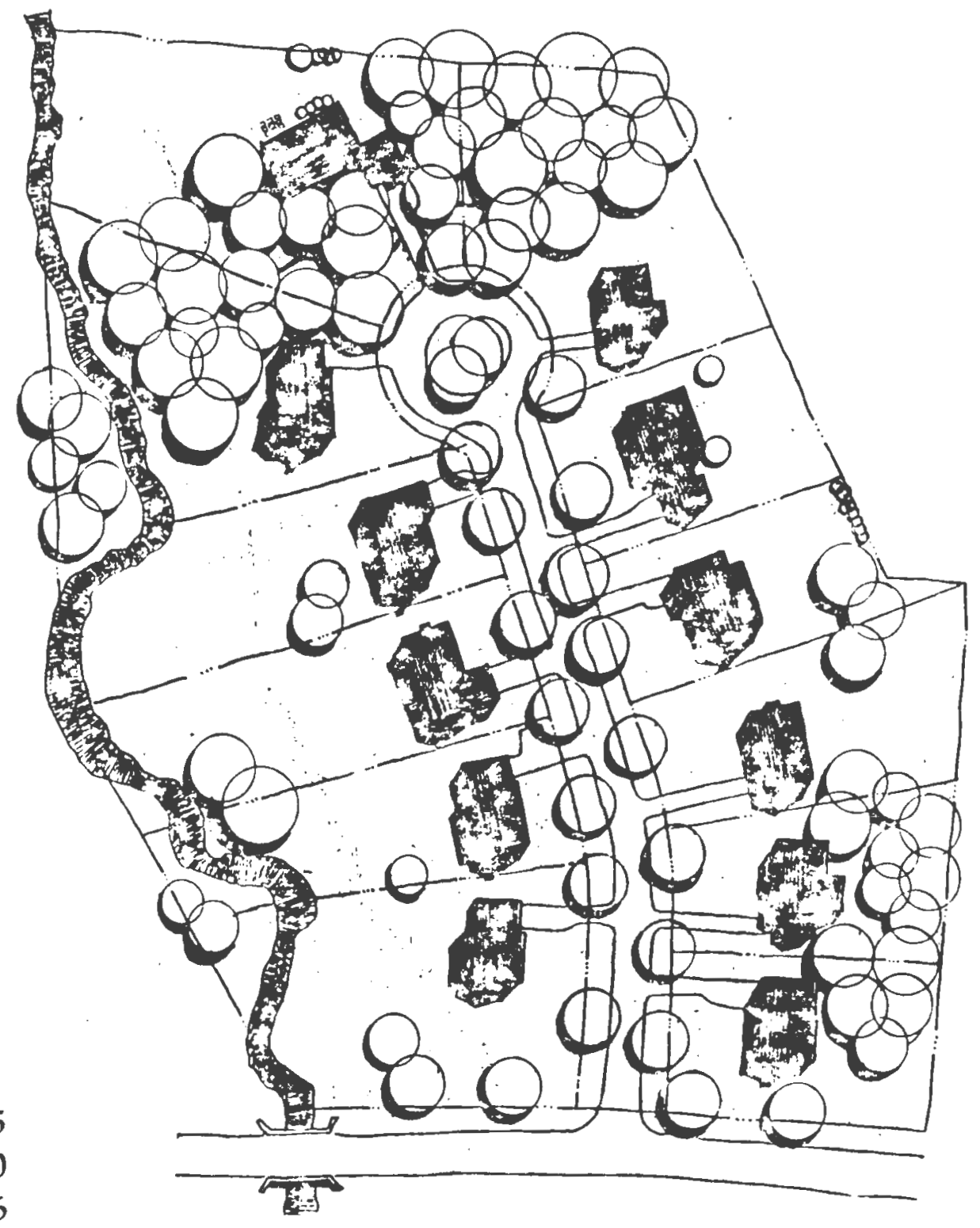




\section{Lot-Line House}

The lot-line house is a single-family detached unit which, instead of being centered on the lot, is placed against one of the side lot lines. This makes the side yard usable and requires less land than a house centered on its tot. The front yard, which is seldom used, may be substantially reduced.

DENSITY

OPEN SPACE RATIO

IMPERVIOUS SURFACE RATIO
1.55

.55

.14

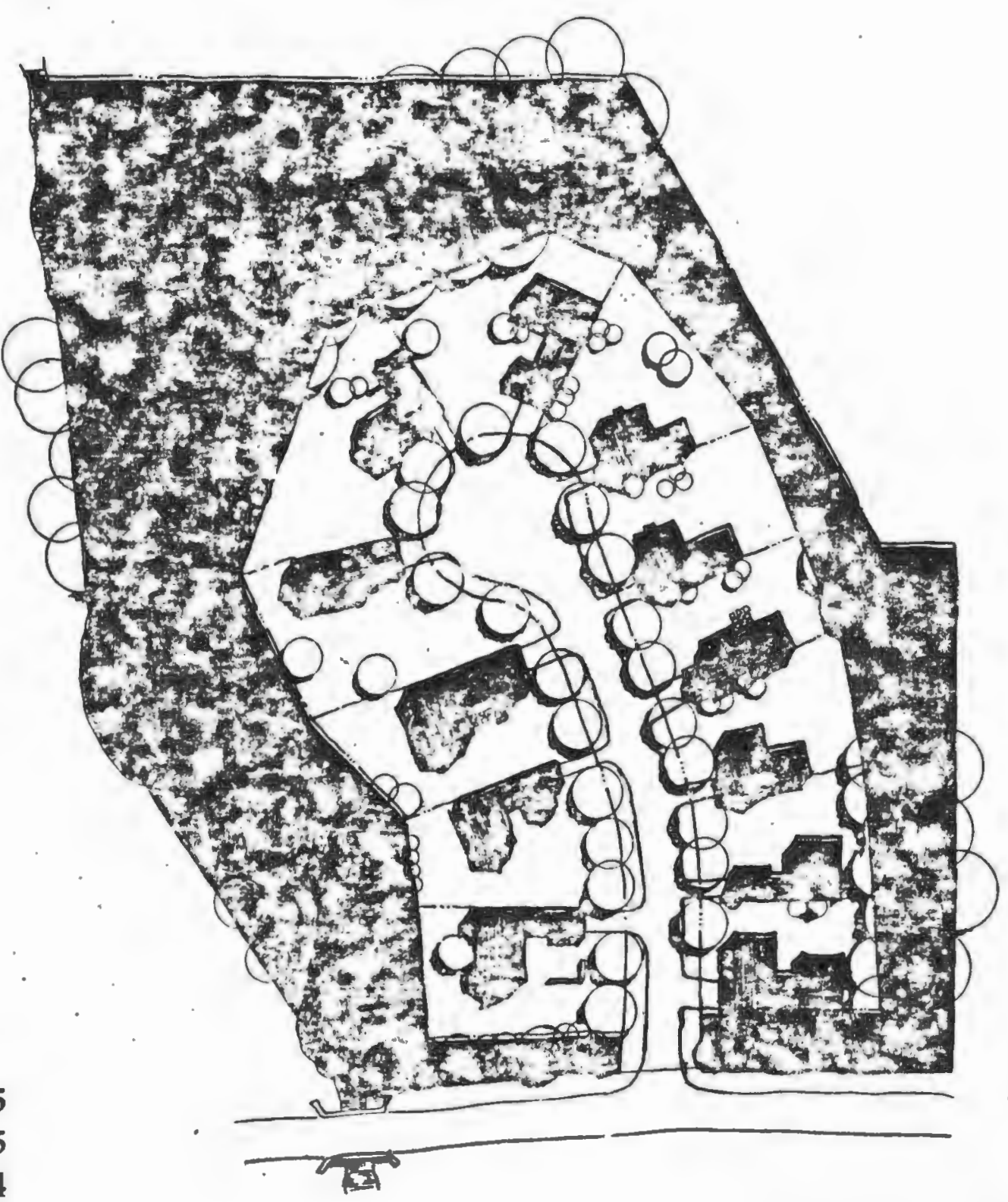




\section{Village House}

There are numerous old sing!e-family detached houses built on very small lots in the historic towns and villages New England and areas such as Bucks County, Pennsylvania. The village house is a modern descendant of there units. It is placed close to the street to maximize the rear yard; alleys are encouraged to reduce the visual inpact of the auto on streets. The result is a lot which is smaller than that of the lot-line house. Specific architectural or landscape standards are required for the street yardis) of the house. Research on historical houses of this type indicates that landscape features provide the charm, scale, and privacy that permits their location close to the street.

DENSITY

OPEN SPACE RATIO

IMPERVIOUS SURFACE RATIO

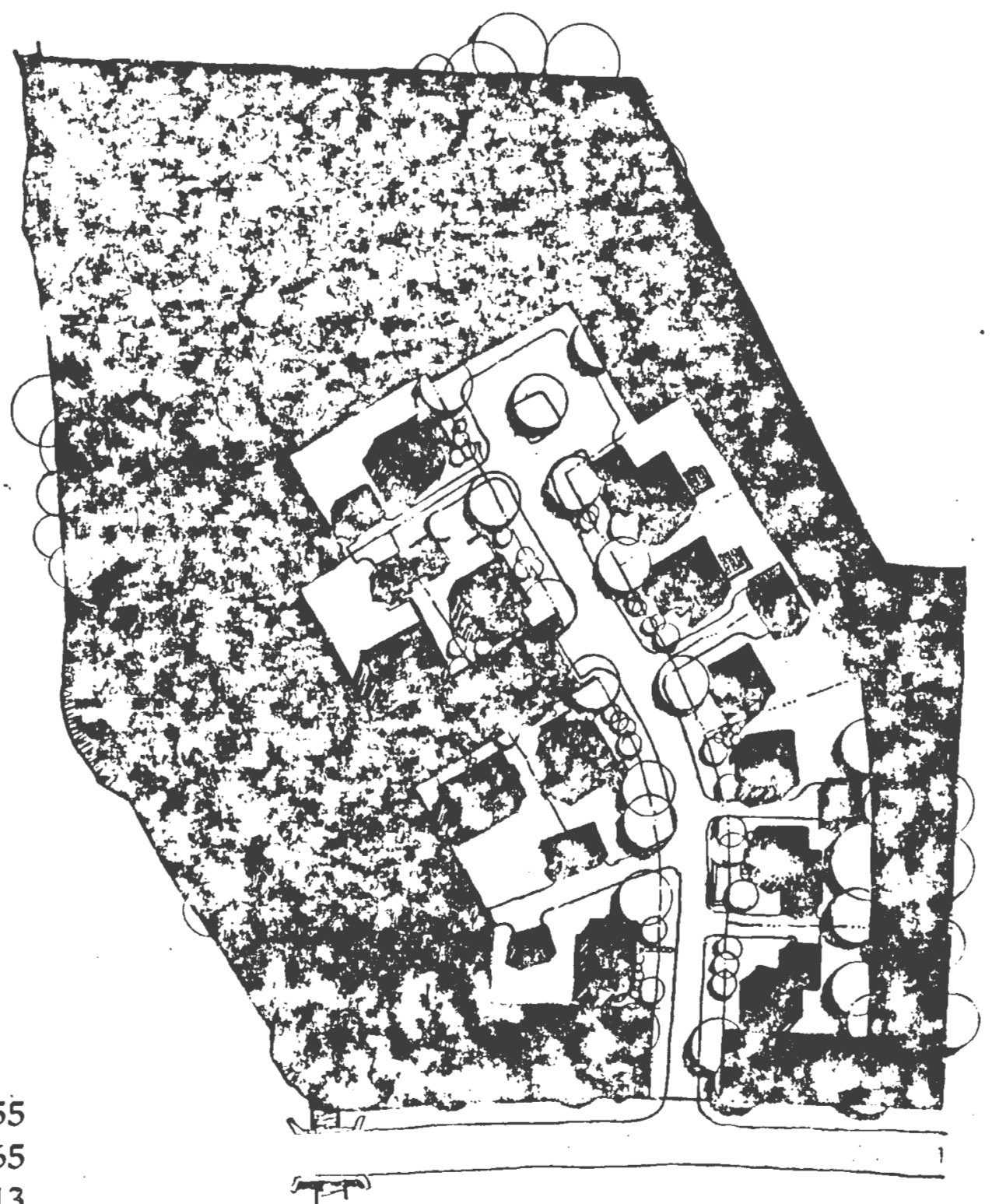




\section{Twin House}

The twin house is a semi-detached, single-family house, which is connected along a common party wall to a similar unit. Each structure has only two dwellings. Space is saved by eliminating two side yards.

DENSITY

OPEN SPACE RATIO

IMPERVIOUS SURFACE RATIO

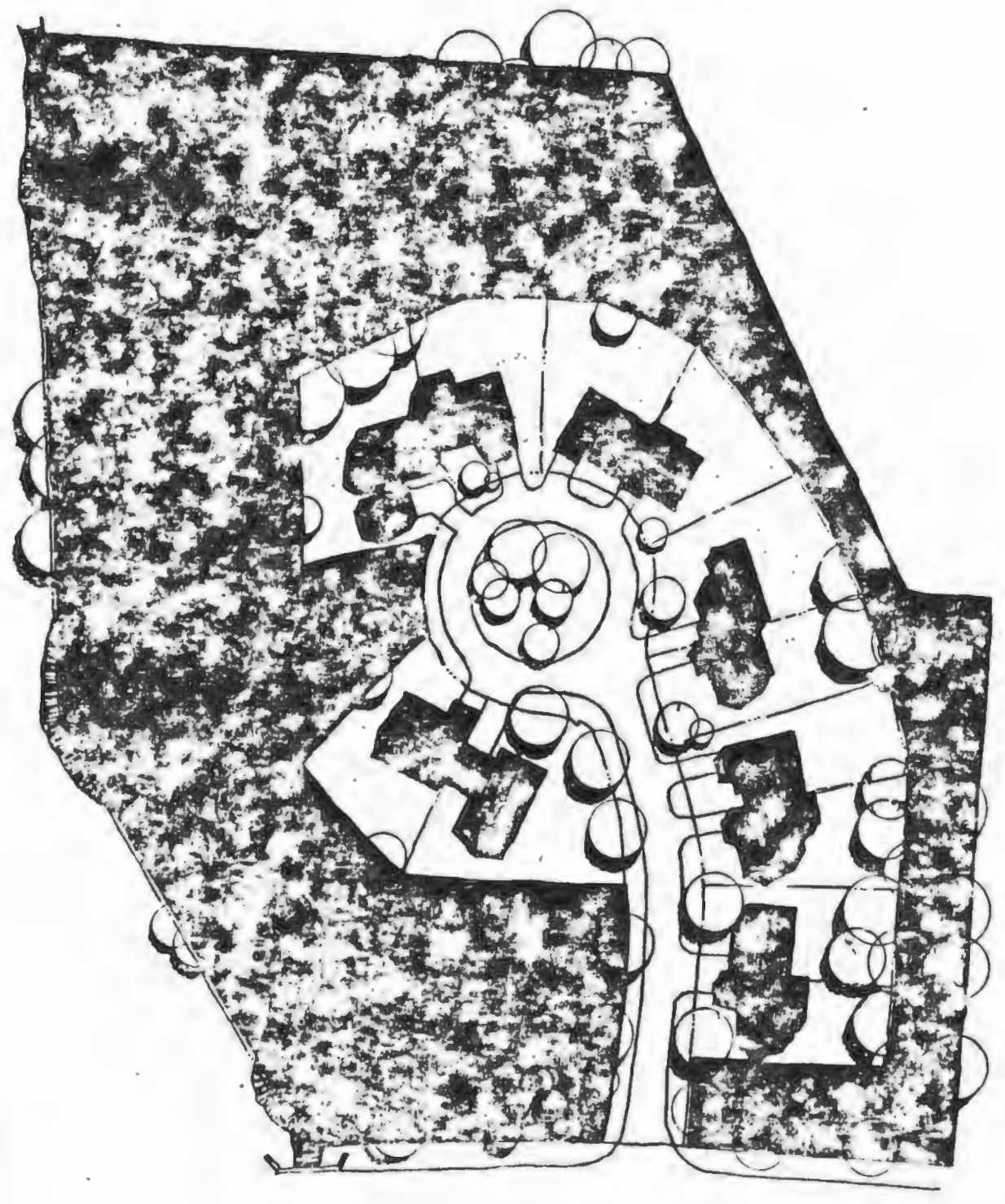

Ar 


\section{Patio House}

The patio house is a single-family detached or semiThe part. It is built on a small lot enclosed by walls which provide privacy. If the walls are ignored, its layout may be similar to either the lot-line or Iwin house thus, it may be built either as a detached or semidetached dwelling. The patio house appeals to those who want privacy without the maintenance of a larger yard.

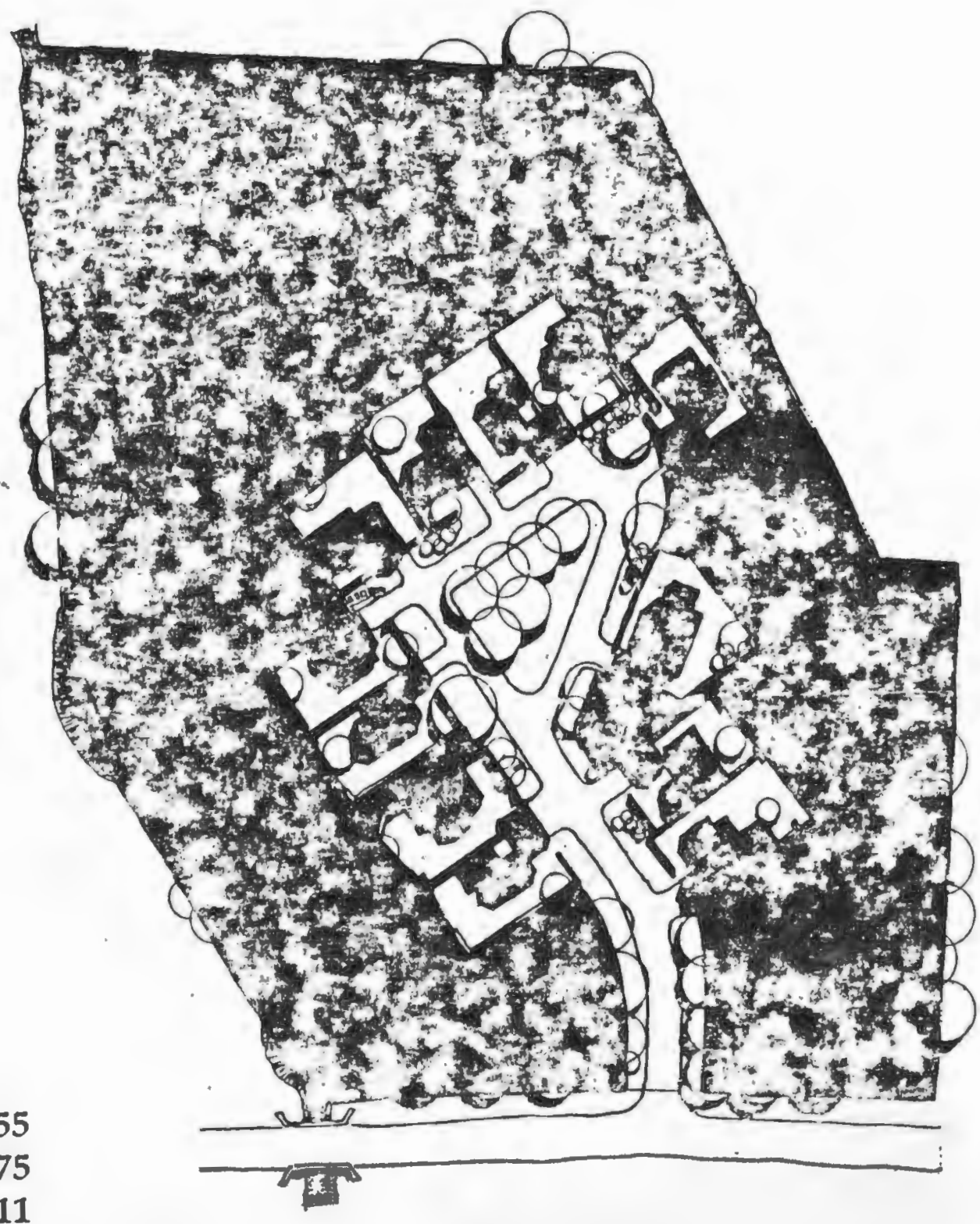




\section{Atrium House}

The atrium house is similar to, though distinct from, the patio house. It differs from the patio house in three respects: it has a smaller lot and yard, it is an attached unit, and it is a single-story unit. A small private yard is surrounded by the house and its walls; privacy is guaranteed. It appeals to persons without children who want privacy and do not want a maintenance responsibility. It is ideal for the elderly, because it is a singlestory home with minimal exterior maintenance responsibilities.

\section{DENSITY}

OPEN SPACE RATIO

IMF ERVIOUS SURFACE RATIO
1.55

.78

.13

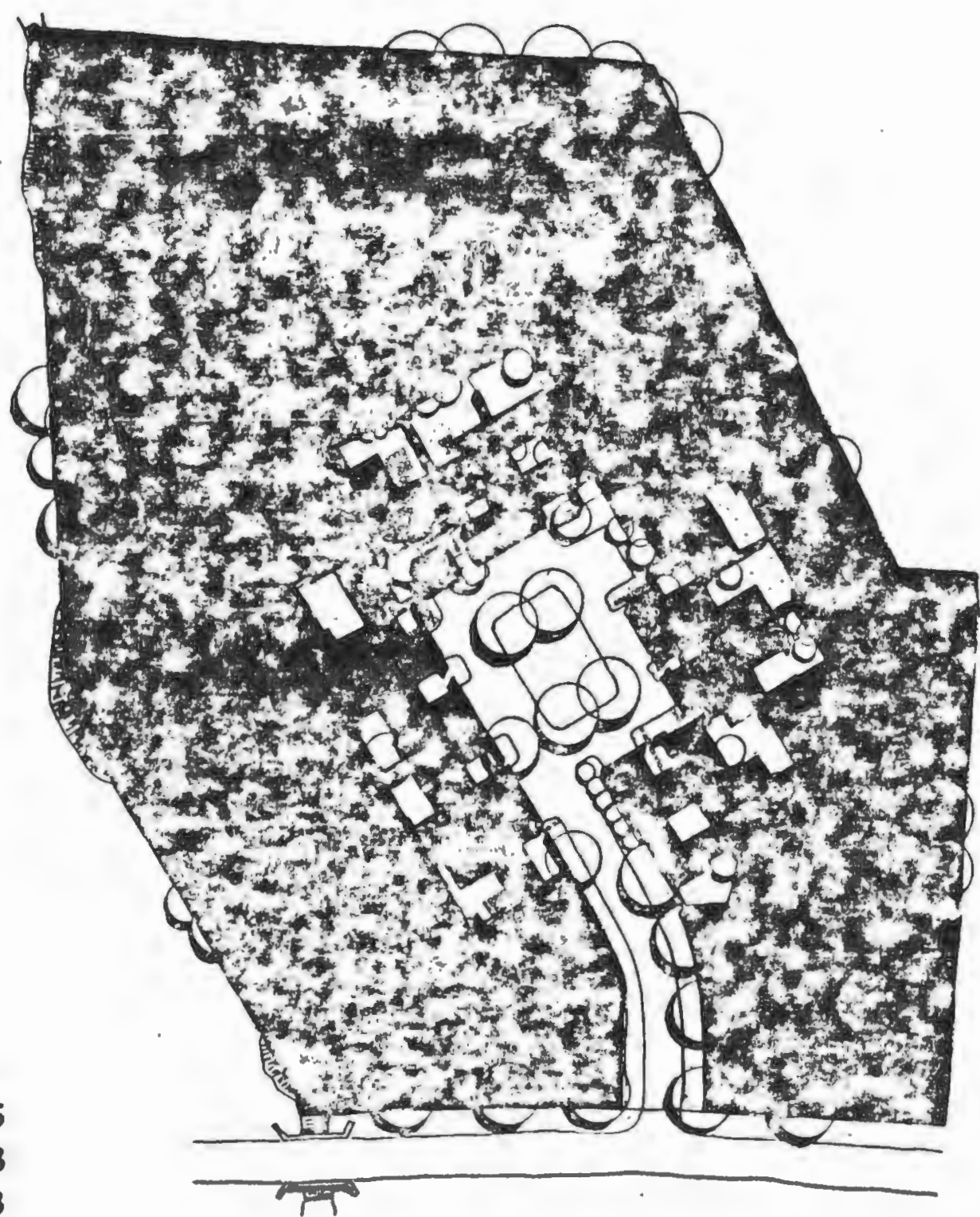




\section{Weak-Link Town House}

This single-family attached dwelling is a variation of the town house. It is distinguished by the fact that each unit has both a ore-story and a two-story portion. The units are wider than conventional town houses and are on larger lots. They present a facade resembling singlefamily detached homes and therefore provide a greater sense of the individual unit identity.

DENSITY

OPEN SPACE RATIO

IMPERVIOUS SURFACE RATIO

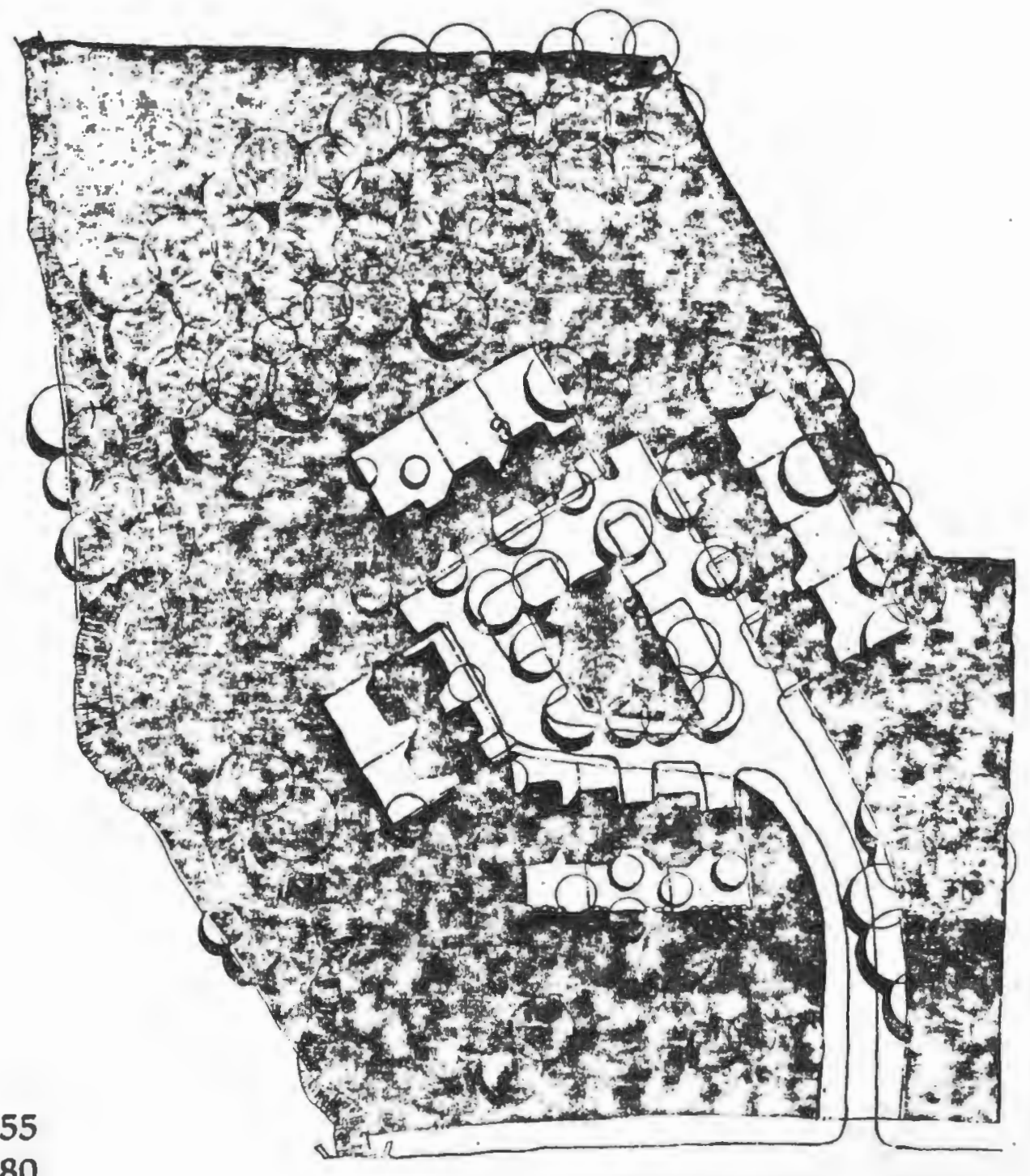

.80

.10 


\section{Town House}

The town house is a form of single-family attached dwelling in which units share common side walls and are often designed in rows (although good design attempts to deemphasize the "lined up" appearance). Yard areas are small, and privacy requires careful protection.

DENSITY

OPEN SPACE RATIO

IMPER VIOUS SURFACE RATIO
1.55

.85

.08

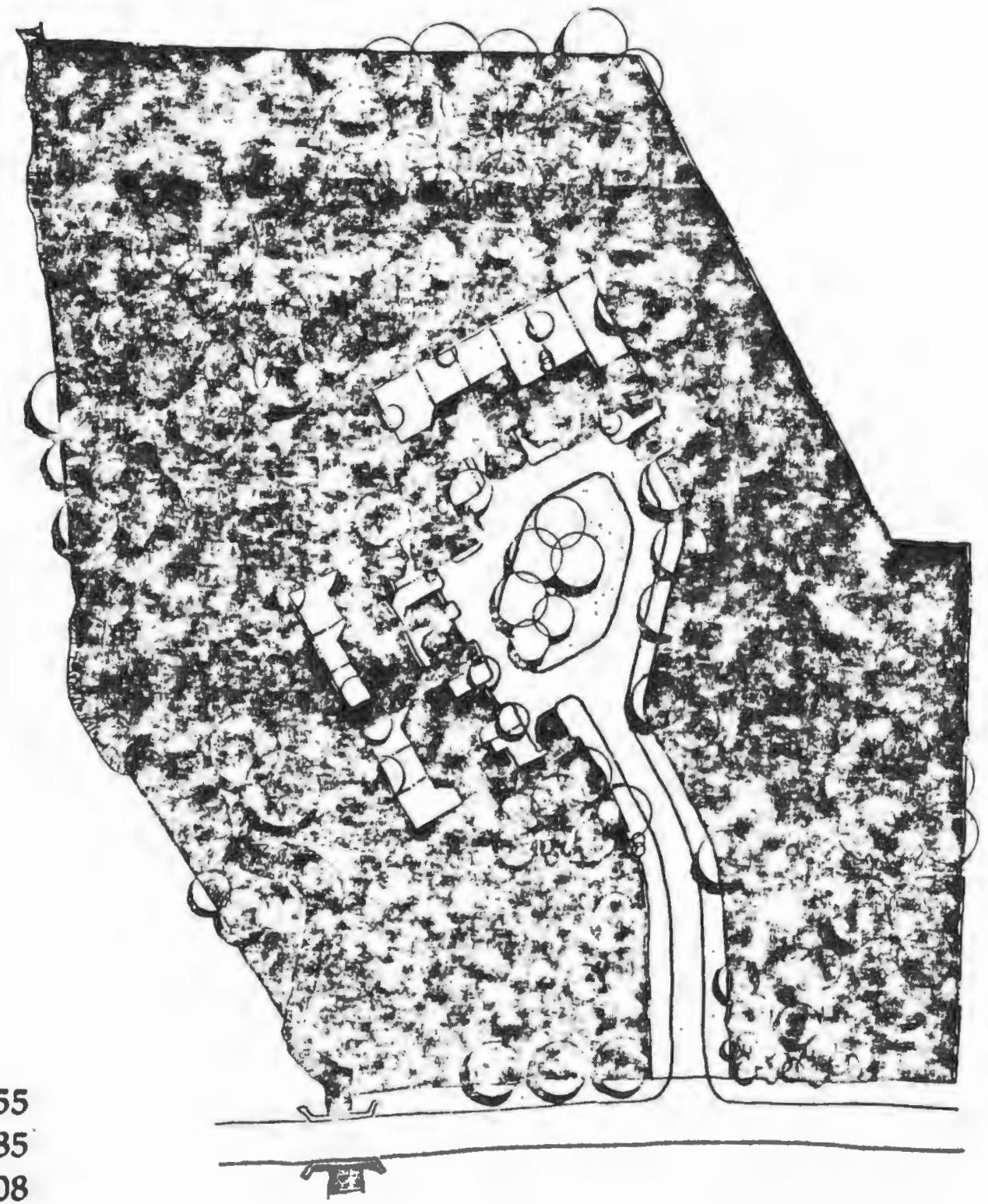

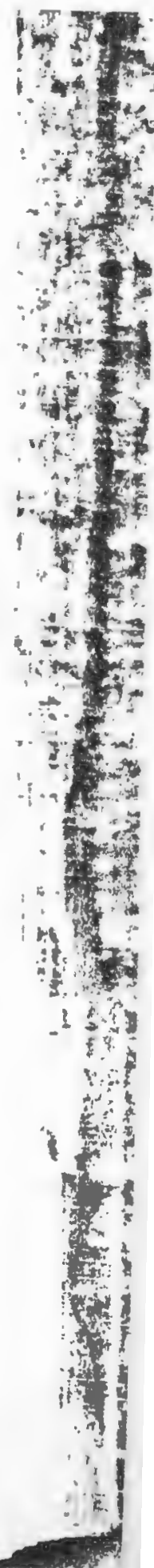




\section{Multiplex}

The multiplex is either a single-family attached unit or a multi-family unit. There are a variety of configurations: attached as a row, atlached back to back with each unit the corner of a square, or with some units on the first floor and others on the sscond. Dwelling units may have individual or shared outside access. Small patios or balconies provide outdoor living space. A well-designed multiplex may look like a large, single-family detached unit. Multiplexes can provide either individual unit ownership or rental units.

DENSITY

OPEN SPACE RATIO

IMPERVIOUS SURFACE RATIO

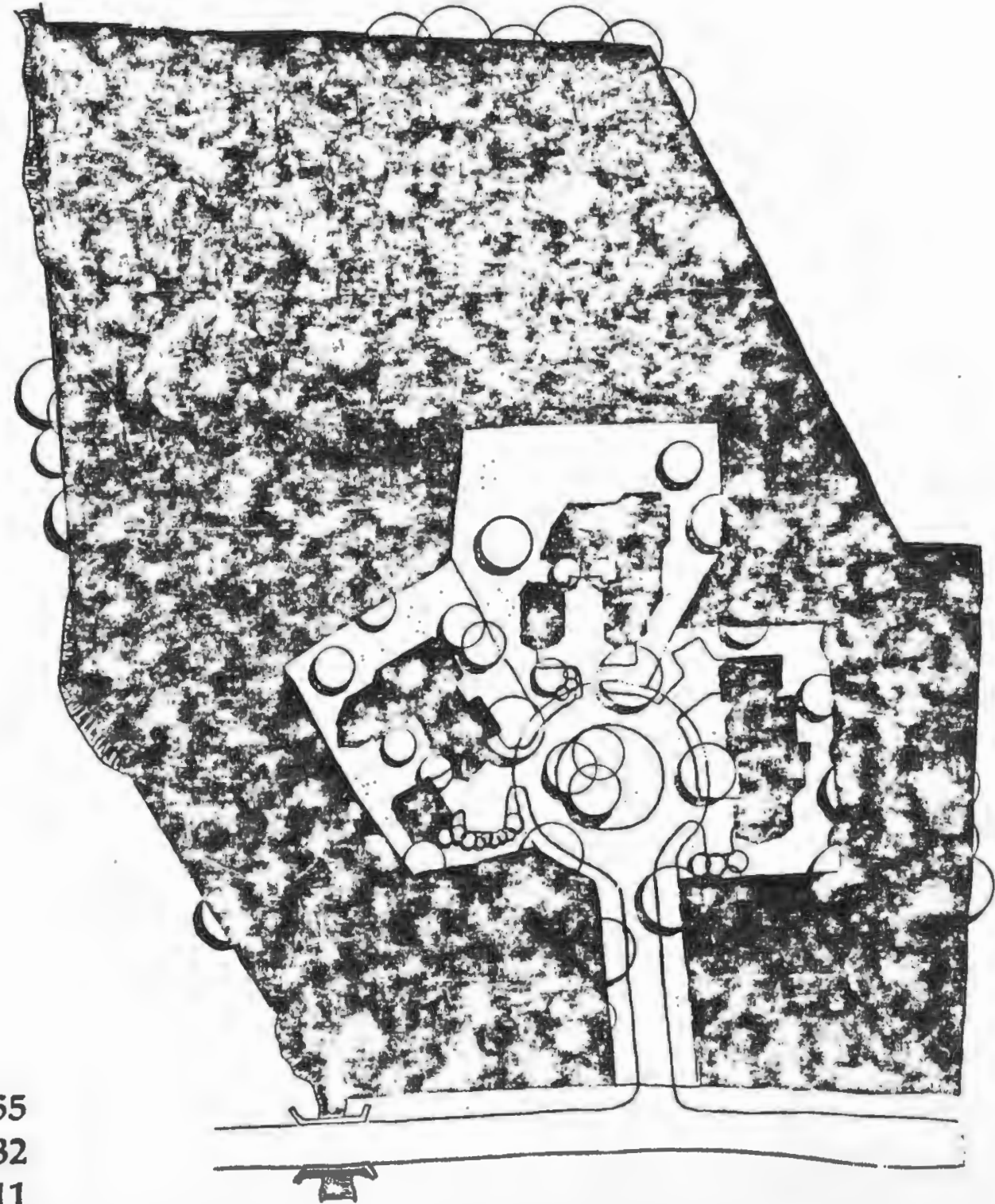




\section{Apartments}

Apartments are multi-family housing. Dwelling units share a common outside access. Ownership is not a factor in this type of unit, which may be either rental or condominium. Apartments appeal to single individuals and families without children.

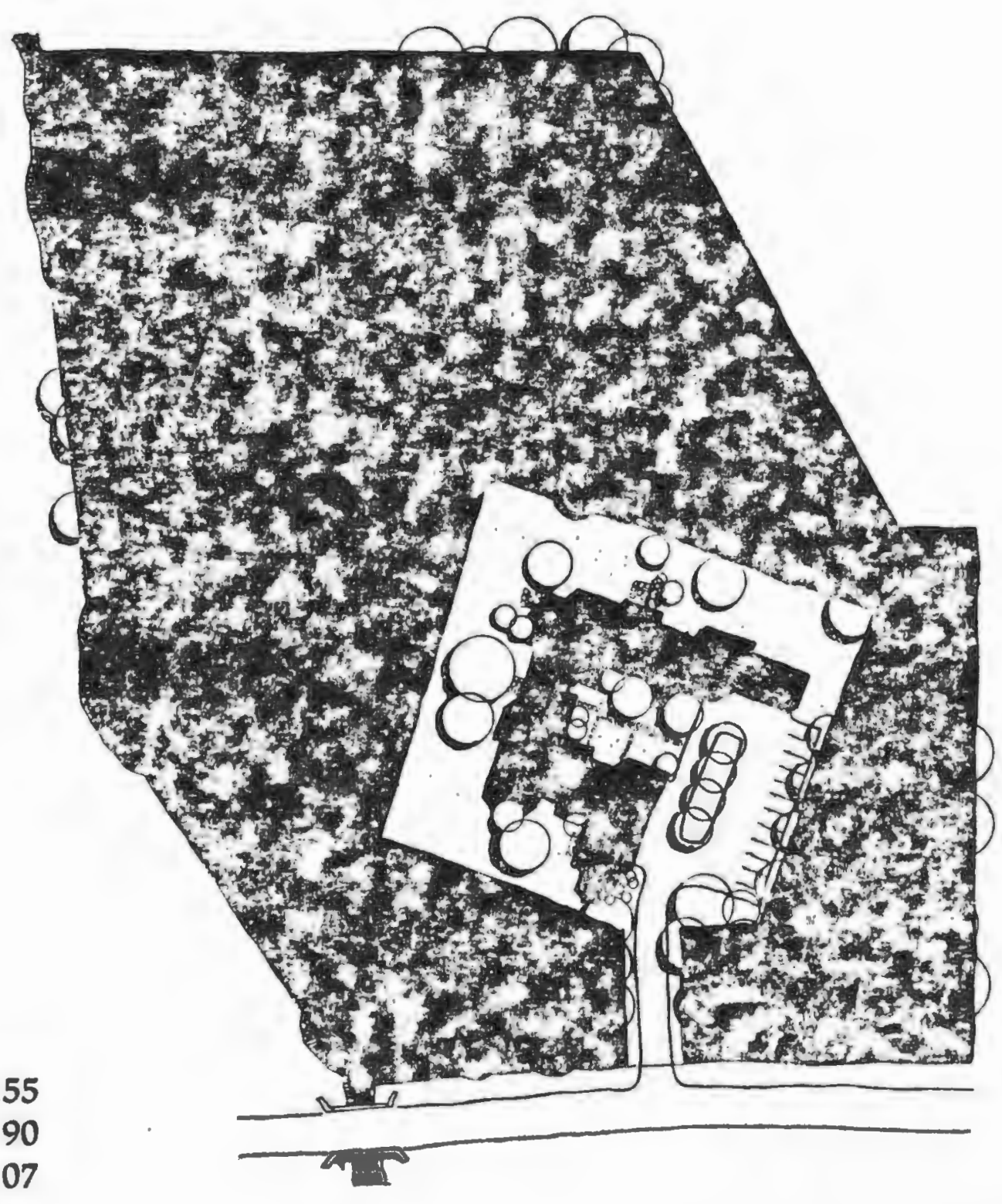

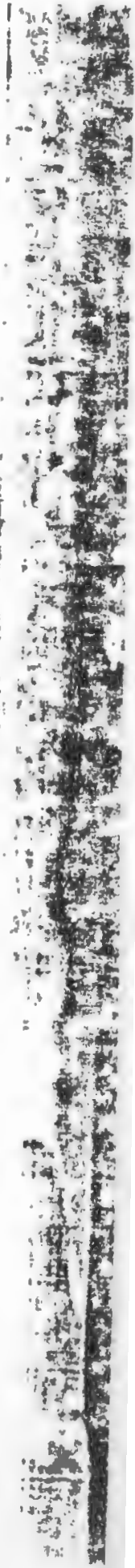


APPENDIX C. 2

VACANT LAND FILE

In the summer of 1985, utilizing Tax Assessor recorders a survey of vacant land in Marshfield was conducted. A file was created containing 11 categories of information about each parcel of land. This file contains only privately owned land that does rot contain any structures. Thus, Town owned land and parcels owned by conservation or preservation groups have not been included.

This file is interided to be used by the Planning Board as an information source in review processes. The designated categories were determined by the Planning Board. These categories demonstrate the suitalibity and development capabilities of each vacant parcel of 1 and.

The following is a delineation of the Vacant Land File categories;

As.Map-Lot: Assessor map lot number of each parcel. Location: Parcels street frontage.

Owner of Rec: Cwner of record as of 8-85.

Front: Frontage in feet on town accepted road.

Zon: Zoning as of 8-85

Sew: If property has sewer 1 ine access.

Wat: If property has water 1 ine access.

FPA: If property is within the flood Plain Area.

Access: The status of the road which the property has frontage on.

Area SF: Area of property in square feet. 
A!5-O1-05 URIJ: ETREET (OFF) HEAF HABSTENYES

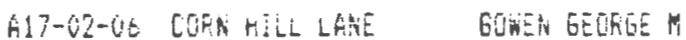

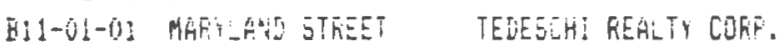

B:i-J1-62 MHFYLARI STREET TEDESCHI REALTY CDFF.

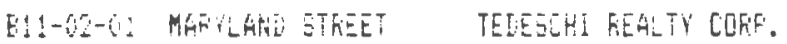

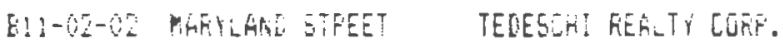

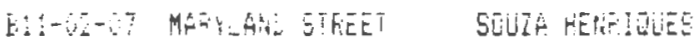

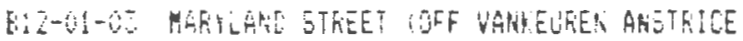

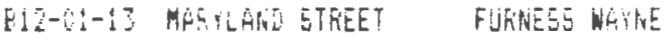

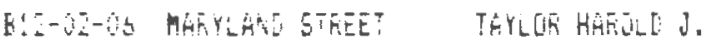

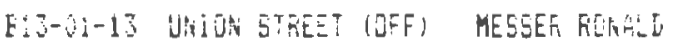

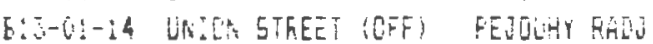

E:S-CO-CO UNIOR STREET NASH ROEERT

E14-6I-Z: UNIE, 5TREET

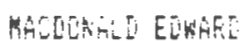

BI4-0Z-O: URIUN STREET

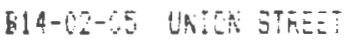

B:4-6Z-GE UWIUN STREET

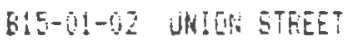

E:E-6:-10 URION STREET (OFF)

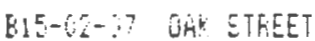

B:E-CZ-OIA BA STREET

EIL

B16-O1-2Z UHION STREET

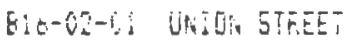

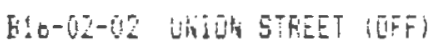

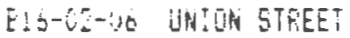

E:T-OI-CA COATR HILL LANE

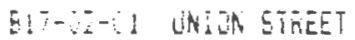

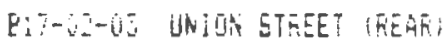

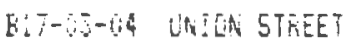

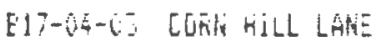

EIE-JI-JJ UNICE STREET (OFF)

Bi8-01-OG UNIJA STFEET

BEE- $11-10$ UAION STREET

EJE-SI-1! UKIUTH STREET

E!E-01-13 UNION STFEET

Eló-6!-14 URION STREET

H!8-01-15 UNIOR STFEET

BIE-OZ-OI LNTON ETEEET

E!E-6J-68 HURTER DFIVE

E! $9-0 Z-04$ HUNTEF DFIVE TREAR?

COY-OZ-O1 LONE STFEET

[10-01-01 LORE STEEET

C1G-01-O2 LQNE STREE

[i0-01-03 LONE STREET

C1O-G1-014 LONE 5TFEET

C10-03-02 5CHODL STREET

C10-05-03 FLAIN STFEET

CI01-0j-04 FiALIN STREET

C10-05-64 SEHELLL STREET

[11-01-01 UNDLN STREET

C11-01-11 UNIOH STHEET IREAF:
FERCOLU SALLATOÉE

MOAHLE LAWSENGE

MUUHEE LAWGERLE

FUTAEY IRE.

UAETÁÁ DTIE B

RUDETL RUSE MRTIE

STEFHFEKS GEFTLDIME

JAEULS REEALTY

OULTUN GEUREE

FEEE LMAR:EE

CAUCHILK RUEERT

Mifirir Eumitis

CULLJNE SAHIEL

FATH EETTEILE

COEOPNE RICHAKO

SFENLINHALEF ROLEFT

DELASTFŪ ALFFEE J

SESNEMICI RICHARD

DAvis RUMH:D

KOLUDEJ PAUL

DUDLEY AIEEL INE

DULIEY ANGEL INE

TME LIOHS MASTE TRUST

THE LIONS MAFI TRIJET

HAAK RAYMONE H

HHAK DOLORES J

STRIAFI DANIEL E.

LONE STREET RERLTY

LONE STREET REELTY

LOHE STREET REALTY

LONE STFEET REALTY

TRIANOLE CERTEK

HUDSTIN STREET REALTY TRUST

BAYBARK NJEFILLK

FLAINULLE CEAETAF́: HSS.

TEDESEHI REALTY COÁF.

LAUJERHILK GERALD
SOUTHGICH. KENNETH
NUTE F-I NE YES YES YES NS UIR 133290

207 R-1 NO YES NJ NO PUELIC 257004

15 R-1 NO YES YES NL̈ FUELIC 196620

336 R-1 NO YES NE NO FUELIC 4356!

$3 E 5 E+F-1$ NO YES YES NOO FUELIC 4350

32 R-1 NO YES YES NO FUELIC 45500

$5 E \quad R-1$ NO YES NO NO FUELIC 60554

RINE F-I WO NO YES YES RE UIF 47916 ?

50 R-1 NO YES NO NG PLELIC 43560

5J FI-L NI YES NJ NI FUELIC 75.5E

NULE F-I NG YES PUS NU NU EIF 297079

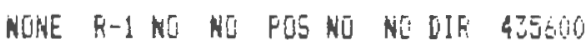

42 Fi-I NS YES NO HO FUELIC 25600

210 R-1 NE YES NO YES FUELIC 102306

550 R-1 NO YES NÜ HU FUÜLIC 217600

240 K-1 NL YES NU FUELIE 1611720

590 R-1 NI YES YES NIJ FUELIC 348480

2ZS R-I NJ YES FULS NU FUBLIL 3349764

NÜNE F-1 NJ NO POS NJ NO DIF 827640

150 F-I NO YES NI NJ PUELIC 43560

606 R-I NE YES YES NŨ FUELIL J1IETU

122 R-I NJ YES KI NG FLILLIC 4JÉ

125 R-I NJ YES YES YES FUELIC 882070

257 K-I NU YES NO NO FUELIC 43560

165 R-1 NO YES NE NU NIA 35000

202 R-j HO YES NÜ NO PUELII 56628

280 R-: HO YES HJ NO PUELIC 76230

226 Fi-1 NJ YES YES NO PLIELIC bígít

NE R-I NO NU NI NU RU DIE 197,00

391 Fi-1 NO YES NG NO PUELIC 392040

40 R-1 NO YES NO NO PLELIC 242143

125 R-1 NO YES YES NO N/A 151153

125 R-1 NO YES YES NO PUBLIC 434295

125 R-1 NU YES YES NU PUBLIC 442570

125 R-1 NO YES YES YES PUELIC 467395

260 R-1 NO YES YES NO FUELIC 32432

$260 \mathrm{R}-1$ NO YES YES NEI FUELIC 423839

260 F-1 NO YES YES NOS FUELIC 15246

150 R-1 NŌ YES YES NJ FUELIC 7840Ë

MUNE R-1 HE NG TES YES RU EIF 435S:

NONE F-I NO NŪ YES VES NO DIT́ 47416

$335+$ I-1 NO YES NO NU PUBLIC 287432

150 I-1 NO YES NO NO PUBLIC 45770

195 I-I NJ YES NO NO PLELIT 41215

15.5 I-1 NO YES NO NO PUELIC 56232

$1501-1$ NO YES NO NO PUE:IL 70655

420 B-2 NO YES NO NO PUBLIC $9690 \mathrm{~T}$

165 B-2 NO YES NO NO PUELIC 5U.48E

25E B-2 NO YES NO NO FUELIC 48122

25 E-2NO YES NO NO PUBLIC 69695

235 R-1 NJ YES YES NO PLIELIC 163786

55 K-I NU POS Ni NJ PUELIL 16EẼ 


\begin{tabular}{|c|c|c|c|c|c|c|c|c|c|}
\hline-12 & HON STREET IFEAE & EATES ALGN & $N$ & $\mathrm{R}-1 \mathrm{NO}$ & NDI & PC5 & ND & NENE & $5 t=28$ \\
\hline $1-0:-65$ & WOA STREE? KFELF & DARKLING ROLNEY & No & $\mathrm{R}-1 \mathrm{NO}$ & $\mathrm{NG}$ & Nú & nij & NO DIF & 148975 \\
\hline $11-02-27$ & FLAIII STREET (FEEFE) & MÁTSHFIELL RUI G GUN CLUE & NJNE & $\mathrm{F}-1 \mathrm{NO}$ & no & Fos & No & NU DIF & 97574 \\
\hline $2-01-65$ & NiLN STREET IFEAFE! & CáLLAHÂA LUCY & & $R-! N O$ & NO & F0S & NO & O DIK & 402930 \\
\hline $2-01-90$ & CIGOS FAETURE WUAD & KŨD \& GUN & ONE & $\mathrm{R}-1 \mathrm{NO}$ & N [ & YE5 & NO & DIF & 348480 \\
\hline $2-11-6 E$ & NULW STFEET IREAR & HILD & & E-1 NO & NU & No & ND & GNE & $14 i 797$ \\
\hline $3-0 i-36$ & FINE ET & 5\& MÁF́EÁRET & & $\mathrm{R}-1 \mathrm{NO}$ & PUS & HE & NO & JELIC & 45302 \\
\hline$=-62-1.0$ & INE & Juk, & & $\mathrm{R}-2 \mathrm{ND}$ & 05 & YES & NO & JELIC & 769265 \\
\hline $5-6-67$ & Whe 5 & Tonte & 5 & $k-1 N]$ & FUS & YES & No & JELIC & 550103 \\
\hline $4-0 i-6$ & ET (OFF) & $\operatorname{LDC}$ & NONE & $\mathrm{F}-1 \mathrm{NO}$ & No & POS & NO & DIf & 304920 \\
\hline & F) & A. & WE & $\mathrm{F}-1 \mathrm{NO}$ & 05 & Nū & $\mathrm{NO}$ & DIK & 261360 \\
\hline & ETT! & & INEE & $\mathrm{R}-1 \mathrm{NO}$ & ES & No & $\mathrm{NC}$ & & \\
\hline-15 & KEET $\quad\left(\mathrm{G}^{\mathrm{F} F \mathrm{~F}}\right.$ & & WE & $-1 * 0$ & $E 5$ & $\mathrm{NE}$ & No & UIth & 2330 \\
\hline-16 & Nit & & & & US & Noj & No & IESIC & 45646 \\
\hline-17 & $([D F)$ & & GNE & & & NG & & LIF & 11400 \\
\hline$-2 z$ & HE & & & & IES & $\mathrm{Ni}$ & Nã & ELIL & 63713 \\
\hline & FFEAT & & UNE & $\mathrm{F}-1 \mathrm{NO}$ & 05 & Kũ & $\mathrm{Nit}$ & DIF & 29551 \\
\hline & TOFF! & FEITLAd i It & RDNE & $1 N E$ & HES & YE & Nõ & UIF & 44431 \\
\hline & IKE & & 150 & & YES & YE & No & IELIT & 69696 \\
\hline & & & $15 i$ & & YES & YE & $\mathrm{Nij}$ & ELiC & 69696 \\
\hline & & MENT COKF. & 125 & & YES & IES & Nu & ELLIL & 63162 \\
\hline & & & 125 & & $P[15$ & YES & NE & IEL IC & 66211 \\
\hline & $(\mathrm{T}$ (OFF) & & NOKE & & 4I & No & $\mathrm{Mi}$ & UIK & 261300 \\
\hline & $T(\mathrm{JFF})$ & & ME & & No & $\mathrm{NO}$ & No & & 7552 \\
\hline & $\bar{T}$ TREAE! & & & & ii: & & NiI & & $3 E^{\circ}$ \\
\hline$-5 \bar{E}$ & ET lür: & & & & No & No & & IIF & 1360 \\
\hline-04 & Q $14 \mathrm{k}$ & & & & YES & & & ELIC & $4 \overline{79}$ \\
\hline-18 & $\bar{u}$ & & & & YES & & WO & ELIC & $878: E$ \\
\hline-11 & & & 242 & & YES & YE & AŨ & EIIC & 69552 \\
\hline 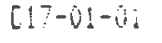 & HIE & & 405 & Fi-1 Ni & YES & NE: & KE & $\mathrm{jE}$ i iC & 218071 \\
\hline-65 & HIG & & 4004 & $\mathrm{~K}-1 \mathrm{~N}$ & YES & YES & YES & FUEEIC & 95030 \\
\hline-63 & & & 200 & $R-1 N \bar{J}$ & YES & YES & YES & FLEE:IC & 174240 \\
\hline-63 & $5 \cdot 5$ & & ij & $\mathrm{R}-\mathrm{I} N \mathrm{NE}$ & YES & YES & YES $i$ & FUE:IC & 174240 \\
\hline-019 & EET (KEAR) & EN & Nugive & R-1 Nu & NO & YES & YES 1 & Nú DIF & 9060.4 \\
\hline -i!! & iOFFi & Y Folj & NUNHE & -1 Nũ & Ni & YES & YES I & & 4356000 \\
\hline-01 & (FEEARI & & RUNE & $-1 \mathrm{NU}$ & Nĩ & YES & YES & NO DIR & 130680 \\
\hline-61 & KRELE & & 210 & $\mathrm{R}-1 \mathrm{NU}$ & YES & YES & YES & PLLELIC & 27600 \\
\hline & PLhi & & NONE & $-1 \mathrm{~A}[\mathrm{~J}$ & No & Ni & NG & FUELIC & 4356 \\
\hline & FLÁlA & & NUNE & $1 \mathrm{NJ}$ & Nũ & $\mathrm{NO}$ & Ni & iII L & $34 E 400$ \\
\hline & IFEFES & & NURE & $1-1 \mathrm{NO}$ & NO & NO & NO & IIF & 435600 \\
\hline & ET. IUFE & EFE C & NINE & $-1 \times 0$ & ND & NE & 100 & $101 \%$ & 304520 \\
\hline & I GEARI & & RUNE & $-1 \mathrm{NO}$ & NO & NO & NO & J DIF & 135030 \\
\hline & & & NCKE & & No & No & $\mathrm{NC}$ & FUELIC & 126324 \\
\hline & PLÁ & & RONE & & Hi & NO & Ni & Dif & 45532 \\
\hline & ET (REAR̂) & & & & $\mathrm{No}$ & Nõ & $\mathrm{N}[\mathrm{J}$ & & 74616 \\
\hline & PLÁ & & NONE & & No & F05 & $\mathrm{ND}$ & PUELIC & $2178 i j 0$ \\
\hline & FLA & & & & $\mathrm{NO}$ & Nó & Nij & UIK & 1655520 \\
\hline & PĹÁlíi & & NTEE & $1-1 N O$ & NJ & Fofs & $N \bar{N}$ & IBLIC & $174 \div 40$ \\
\hline & FLAIN & & NOWE & $1-1 \mathrm{NE}$ & Kü & Ní & $\mathrm{Mij}$ & DIF & 455202 \\
\hline & PLAIK STFEE SREAN" & & & & No & NC & NO & DIK & 15 Eegls \\
\hline & ENTERFFISE UKLE & VER̆DLTI REATLY TR̈LST & NONE & & Ni & NO & NO & U.IK & 447747 \\
\hline & SCHUOL ETFEET & LOGUE JAYES & 160 & $B-2 N=$ & & No & NO & FUSLIC & 3625 \\
\hline & & & 137 & $B-$ & & & & Fute. & \\
\hline
\end{tabular}




\begin{tabular}{|c|c|c|c|c|c|c|c|c|c|}
\hline AS. MAF-LUT & LESATIJ & UWHER OF FEL & Fhütit & TON 5EH & WAT & WET & $F F^{\prime} A$ & ACLESS & ARÉn 5 \\
\hline - & - & & & & & & & & \\
\hline$[1 j-01-10$ & TILOEK RUALI & KÜLANS LEAETY & 60 & $\mathrm{R}-\mathrm{i} \mathrm{NO}$ & P05 & No & No & PUELIL & \\
\hline $010-01-27$ & PLAIH ETREET (REGG) & FUIFIUGE AEE. & MUiNE & $\mathrm{B}-2 \mathrm{NO}$ & NO & $\mathrm{NE}$ & $\mathrm{Nit}$ & $N[D I K$ & \\
\hline $10-0 Z-08$ & PLAIH STREET & 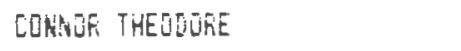 & & {$[-1 N 0$} & YE's & NO & wo & IIE I I & \\
\hline $010-02-10$ & PLAE STREET IFEAES & VERADLHE REALTY TRLLST & 375 & $1-1 \mathrm{N0}$ & YES & NO & No & C.D. & 5706 \\
\hline$[10-0]-01$ & FLAIH STFEET & EFFIOAH REALTY TFUST & $1140 \mathrm{C}$ & $1-1 \times 0$ & YES & No & No & UELIC & 6146 \\
\hline $10-03-11$ & FLAIN ETREET & ERDEHI REALTY TEUST & 189 & $I-1 N 0$ & YES & & NO & & \\
\hline $11-01-14$ & 5OHOS. STAEE & AGRSHFELE ROS \&UN & $41 E$ & $-1 N 5$ & YES & YES & No & UDLIL & 9888 \\
\hline$[01]-09$ & TI:LEK READ & GRAE:E WILLIAM & 57 & $-1 N \mathrm{~N}$ & YES & $\mathrm{HO}$ & NC & & \\
\hline$D: i-6 \hat{z}-2 \bar{i}$ & SHEFHAR'S WES IOFF: & LEELARE RUEEFT & NONE & $\mathrm{B}-2 \mathrm{NO}$ & $\mathrm{HL}$ & No & NU & Nó & \\
\hline $012-6 i-4 \overline{2}$ & SETUI STKEET & MAFEHEIELD REL \& GUN CLUE & 278 & $\mathrm{R}-1 \mathrm{NG}$ & YES & $N \bar{L}_{\mathrm{i}}$ & $\mathrm{Hu}$ & PUELIC & \\
\hline$-57 t$ & SOHER STREET & EPTYY TRUET & ZIE & $-1 N G$ & YES & $\mathrm{No}$ & $N[$ & IC & \\
\hline & SCHUD STREE? & E.T.H. BEALTY IFUST & Nü & -1 kJ & YEE & No & NO & FuE & \\
\hline $011-2-204$ & FLAIS EFEEET (OFF) & LOELE IREES & MÜNE & $\mathrm{E}-2 \mathrm{NC}$ & NO & NO & Nō & $\mathrm{NO}$ & 100 \\
\hline $012-0 !-0 i 2$ & SIMUI. STREET IOFF: & HELE KEE E G E H & NUENE & $\bar{K}-1 N \bar{U}$ & $\mathrm{Nit}$ & YES & No & NO DIR & \\
\hline $012-01-6 ?$ & FEFEET STHEET & ETrír INE. & $10 \mathrm{u} \mathrm{u}^{+}$ & $\mathrm{R}-1 \mathrm{~N}$ ) & TES & $\mathrm{Ni}$ & $\mathrm{NL}$ & PUELIL & \\
\hline$[12-01-11$ & SEMUUL STREET (OFF) & A.W. PEEFY INE. & NONE & $f_{i}-1 \mathrm{Nu}$ & No & VES & NE! & kil & 1353 \\
\hline & SEHOU SIREET (OFF) & MAREATELL KOU E GUN CLLE & NOKE & $-1 N \bar{U}$ & Nu & YES & Nĩ & Nū & $25 i$ \\
\hline-04 & ANDEEES AVETHE & KITSUR THOKAE 5. & 141 & $-1 N 0$ & YES & VES & NO & FUELIC & \\
\hline $015-111-22$ & ANDEAS AVENUE (OIFF) & A HETETY INC. & NONE & -1 No & No & Fus & NO & kij & 1481 \\
\hline & ARETERE AVENUE (CFF) & FOEDUF REMLTY TE & JNE & $-1 N 0$ & $\mathrm{Ne}$ & F05 & $N[\mathrm{i}$ & Ni & \\
\hline-14 & FUKEST STREET (KEAE) & LITTLEFIELU BKIAK E & CWE & -1 NO & No & YES & $\mathrm{Ni}$ & Hu & \\
\hline-15 & FÜEET STREET (FEAF) & MUEEAFIELE hÜ GUN ELUE INE. & NUNE & -1 NŨ & Nī & YE5 & No & Nú & 3484 \\
\hline$-\$ 6$ & FOHEET STFEET (OEF) & A.N. FEFFIY INE. & NULE & $-1 \mathrm{~kJ}$ & N5 & YES & No & & \\
\hline-07 & FUABET STREET & ELWAFI A. REAJT & INE & $-1 \times 0$ & NO & NU & NO & & \\
\hline-67 & FINE & EAILEY F. LEE & 150 & $-1 \mathrm{NO}$ & YES & No & No & & 479 \\
\hline $62-06$ & FIKE STREET & BAALEY F. LEE & 150 & $\mathrm{~K}-1 \mathrm{NO}$ & YES & NO & No & & 435 \\
\hline-69 & EARLDON LIRCLE & BÄILET F, LEE & $225+i$ & $R-1$ No & YES & $\mathrm{NG}$ & Mū & & \\
\hline-10 & EAF́LDERE CIFELLE & BAILEY . .LEE & 194 & F-1 NO & YES & NE & NJ & & \\
\hline$-6 . \overline{4}$ & h L GHE & EMIIE:F. LEE & 165 & $-1 N 0$ & $P 05$ & $\mathrm{NL}$ & No & & 435 \\
\hline-10 & 的 GSTSLE & BÁILEY F.LEE & 165 & $\mathrm{~F}-1 \mathrm{NU}$ & YES & YES & NE & & \\
\hline-11 & S CIFCLE & BAILY F, LEE & & Fi-1 No & YES & $Y E$ & Nî & & \\
\hline & EISEE & BAILEY F. LEE & 150 & $\mathrm{R}-1 \mathrm{NG}$ & YES & YE & kU & PRIVAT & 135 \\
\hline $3-13$ & If CIF:LE & EALLEY F. LEE & $220+[$ & K-1 NO & YES & YES & Nĩ & PR & 135 \\
\hline$-6 \bar{z}$ & FLREST STREET & PAGE ETHEL MARTY & 157 & Fi-1 No & YES & YES & NŨ & & \\
\hline & FUTE $=$ & FAGE ETHE: HA & & R-1 Wu & YES & YES & HO & & 5 \\
\hline-04 & ANDFEDS A & SULLIVSH MEAY & 170 & $R-1$ NO & YES & HO & NO & PUBLIC & 343 \\
\hline $01-0 \overline{0}$ & VELLEY FGTH & 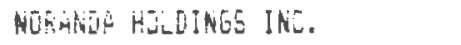 & NUNE & B-1 No & No & 805 & $N \cdot j$ & NOHE & 49222 \\
\hline $02-0 i$ & VALLEY FATH & RULRE FSAEEL & & $R-1$ NO & YES & No & NO & & 2047 \\
\hline $02-65$ & FUFEST STFEET & 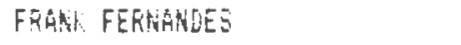 & & $R-1 N G$ & YES & No & No & & 223 \\
\hline $015-0.06$ & FUREET STREET & ERITT HEFKAH H. \& ANEELING & 108 & $\mathrm{E}-1 \mathrm{NO}$ & YES & NO & $\mathrm{Hi}$ & FUELIC & 1089 \\
\hline $015-i$ & RHDEES AVENUE & VEIGA MÁHLEL & 90 & & YES & Nin & $\mathrm{NC}$ & & \\
\hline $015-61-10$ & VÁLLEY PATH & JOHES LAWEEREE & & $R-1 N i$ & YES & $N$ & NO & & 522 \\
\hline $0: 0-11-1 !$ & VALLEY FHATH & JÜEES LAAFENEE & 174 & Fi-1 NO & YES & No & $\mathrm{Ni}$ & & 506 \\
\hline $01-12$ & VALLEY FHTH & PETEKSSON KILHAFI & & $\mathrm{K}-1 \mathrm{Ni}$ & YES & No & NO & & \\
\hline $016-02-112$ & VALLEY PATH & EUARIKL VICTOFIA & & $8-1 \mathrm{ke}$ & YES & N! & No] & & 635 \\
\hline $016-02-15$ & VALLEY FATH & JASON FEALTY TRUST & 50 & $R-1$ Nu & YES & Nú & No & & 053 \\
\hline $016-02-19$ & VRLLEY FHTH & JASTH REALTY TKIST & 50 & & YES & NO & No & & 200 \\
\hline $016-02-33$ & AROBREHE AVENLE (OFF) & CALLLAHAN LUEY H & NUNE & $\mathrm{R}-1 \mathrm{~N}[\mathrm{I}$ & YES & $\mathrm{NO}$ & NO & NII LIK & 3049 \\
\hline $016-0.2-38$ & ANGETEDSO AVERIE & STURY JAKES E. \& CLAUDIA H. & $200+5$ & $R-1 N O$ & N0 & NO & NG & PKIVAT & 301 \\
\hline $016-02-35$ & ARISRETS AYERUE & JHMES G. STURY & 120 & $\mathrm{k}-1 \mathrm{Nu}$ & PuS & HO & NO & FEIVAT & \\
\hline $017-01-62$ & HIGHAANI STKEET & ANDEFSOHS JEGHNETTE & 46 & $\mathrm{k}-1 \mathrm{k}$ & YES & $\mathrm{NO}$ & No & FUELIC & 435 \\
\hline $017-01-02$ & HIGHLSH: STREET & PROUIY EAEEAREA D. & 400 & F-1 Ní & YES & $\mathrm{NO}$ & No & FUELIC & 9713 \\
\hline $017-011-04$ & SFRINE STREET IOF & & NGTE & $\mathrm{R}-1 \mathrm{NG}$ & $\mathrm{Nu}$ & F05 & $k j$ & Nú $\mathrm{EIK}$ & \\
\hline
\end{tabular}




\begin{tabular}{|c|c|c|c|c|c|c|c|c|c|}
\hline AE. KET - LUT & LOCATIOH & OWREF OF FEL & FFUNT & ZUN SEH & WAT & WET & $F F$ & ALCES5 & AREH SF \\
\hline - & & & & & & & & & \\
\hline $017-02-68$ & HIGHLANES STREET & MARHIN: JUnh $\mathrm{J}$. & $160+5$ & $\mathrm{~B}-1 \mathrm{NO}$ & FUE & NO & NO & FUB:IC & $16: 172$ \\
\hline $18-01-02$ & SFRIGE STREET & ANLESSOK SEHIETTE & 420 & $R-1 N E$ & YES & YES & NE & PUJELIC & 044658 \\
\hline $15-62-61 i$ & MáIR STREET (OFF) & TRET JUEEFHE & NUNE & $\mathrm{K}-1 \mathrm{NO}$ & NO & YES & $\mathrm{Nu}$ & NÜ Q:K & $37 \div 05$ \\
\hline $15-62-67$ & SFRIRE STREET & HALE ALICE & 395 & $8-1 \mathrm{NO}$ & YES & Fos & No & PIJELIC & 1300000 \\
\hline $15-01-06$ & CGVE CREE LAHE & ORUIR MIL̈HÂEL & 53 & $-1 N C$ & 9015 & NE & NO & con of & $7710 ! 2$ \\
\hline$D ! \overline{1}-04-12$ & 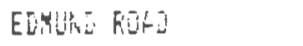 & TFIEELE JOSEFH L. & 80 & $\mathrm{~F}-1 \mathrm{NE}$ & YES & Ni & NG & FUELIC & 87120 \\
\hline$[15-(4-64)$ & ELHULD RUAE & HOUOFALL ROEERT & $260+5$ & $\bar{B}-1 N E$ & YES & Nū & $\mathrm{NE}$ & FUELLIL & 47222 \\
\hline $17-64-67$ & SFEINE STFEET & AES. AUDUEEM SALIETY & 14905 & $\mathrm{R}-1 \mathrm{KO}$ & YE5 & Nú & N5j & FUBLLic & 55750 \\
\hline $0 \div 5-04-60$ & SFRINO STREET & MAS5. ALIULELK 5EEIETY & 200 & Ri-1 NU & YE5 & NU & $\mathrm{NO}$ & UELIC & $14 \overline{5} 104$ \\
\hline$\square-05-3$ & MEIA STREET & COUFER JUHK & 260 & $1-1 \mathrm{NO}$ & YES & NŨ & Nō & FUELIC & 30.30 \\
\hline $15-65-69$ & FALNG STREET & CUMHINGS AFNOLO & $5 E 0$ & $\mathrm{R}-1 \mathrm{NO}$ & YES & & NO & FUELIE & 130080 \\
\hline $82(-1)-6$ & EUMLRE RTOA & TANGLEHGE CLUE TRUET & 55 & $B-1 N E$ & YES & YES & YES & FUELIC & 56628 \\
\hline $26-01-1 !$ & SFFING STREET (OFF) & TAYLOF FAMILY REALTIES & MULE & E-1 NE & Ni & VES & VES & No $[\ln$ & 544560 \\
\hline$(1-61-93$ & CAFÉTH EITELLE & 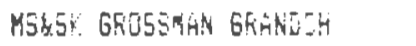 & $18 i$ & $R-1$ NG & YES & YES & NO & PKIVAT & 69690 \\
\hline $20-01-14$ & CAEOLYM CISLEEAEES & MELSL SFEESMAN ERAHDLH & NJWE & $\bar{F}-1 \mathrm{NI}$ & No & YES & YES & NË IIF & 560280 \\
\hline $60-61-15$ & CÁTIULS EIFCLE & H.S./5.K. ERESSMRN & 180 & $\mathrm{~K}-1 \mathrm{NJ}$ & YES & VES & No & PFivit & 67696 \\
\hline $60-61-16$ & ARCL HF LIFíLE & MSLSK GHUSEMAN GFGLJEH & $1 E 0$ & $R-1 N E$ & YES & YES & HO & FRIVAT & 7405 \\
\hline $126-0:-17$ & CAFE YIS CIFLEE & M.S./S.K. GFúsöHith & 155 & $\mathrm{R}-1 \mathrm{NO}$ & YES & YES & NO & & 113258 \\
\hline $20-01-23$ & LITTLE:S LAAKE & THUESTSN JUHA & 50 & $\mathrm{~F}-1 \mathrm{Ni}$ & NO & $N \bar{i}$ & NU & FERIVP̈T & 5272 \\
\hline $20-0:-24$ & LITTLE'S LAHE & HUFETER JUHN & 157 & $\mathrm{R}-1 \mathrm{NO}$ & NO & NO & NO & PEIVAT & 4356 \\
\hline $200-61-25$ & CARDLYH EIRELE & 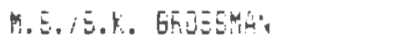 & 182 & Fi-1 NE & YES & $\mathrm{NL}$ & ME: & & $36: 70$ \\
\hline$(9-0)-23$ & CAFEL TH CIFELE & M.5./S.R. Grosstintu & 171 & $\mathrm{~K}-1 \mathrm{Nu}$ & YES & $\mathrm{No}$ & No & VATT & 42455 \\
\hline $26-0 !-27$ & EAREEIA CIFELE & M.5.i5.K. GE.055MAR & 103 & $\mathrm{~F}-1 \mathrm{~N}$ & YES & $\mathrm{Ni}$ & Nü & PEIVAT & $3 \overline{8} \div 7$ \\
\hline $201-01-25$ & CAFILYYK CIFILE & H.5.15.k.6Ressum & 120 & K-1 N J & YE5 & NO & NO & VAT & 20640 \\
\hline $20-61-54$ & 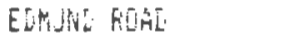 & 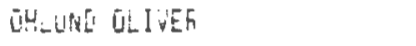 & NESLE & Fi-1 $\mathrm{NOS}$ & YES & IEL & YES & No Lifi & 8200 \\
\hline $02-6-03$ & CAEOL YK CIFEE & MSLS: GROSEMAR ERGNOLH & 215 & $\bar{H}-1 \mathrm{~N}$ & YES & Ni & $N$ & PEIVET & 31306 \\
\hline $270-62-64$ & CAEL YN CITLLE & 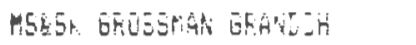 & 205 & $\mathrm{~F}-\mathrm{N} \mathrm{NE}$ & YES & $\mathrm{Ni}$ & NO & HT & 30130 \\
\hline$[26-6-65$ & CAFE YN CIKLLE & H.S.i5.R. 66155Mrk & 175 & Fi-1 HE & YES & Ni & NE & & 29956 \\
\hline$[00-6 z-6 t$ & ZAFEYYH EIRLLE & 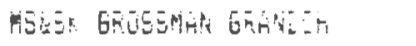 & $3(10+[$ & $\mathrm{R}-1 \mathrm{NO}$ & YES & YES & $\mathrm{Ni}$ & FHIVAT & 30590 \\
\hline 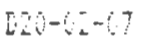 & LALELA CIALLE & 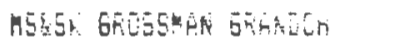 & $30+i$ & $h-1 \mathrm{Ni}$ & YES & YES & No & FFIVIT & 26.50 \\
\hline$[26-62-0]$ & LAFUL YA CIRELE & MELEY GRUESHA GRAVELH & 155 & $\bar{n}-1 \mathrm{NO}$ & YEE & Nĩ & & & $2889 i^{\circ}$ \\
\hline $026-02-69$ & CAFS YM EIFCIE & H.5./5.k. GRUEsmik & $12 i$ & Fil No & VES & No & \$O & FEIVAT & 20040 \\
\hline $020-02-10$ & CAEULYK CIROLE & . . S.K. G5UES4EN & 180 & Bi-1 Nu & YE5 & $\mathrm{NO}$ & NO & FFIVAT & 29450 \\
\hline $02-6 i-11$ & CAFT_ YH EIFLLE & K.5.15.t. GROSSMinit & 191 & $\mathrm{~B}-1 \mathrm{NO}$ & YES & $\mathrm{N}[\mathrm{j}$ & No & & 31530 \\
\hline E08-0i-0is & 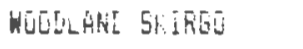 & STRLELE WILLIAH & No & $\mathrm{K}-1 \mathrm{NC}$ & YES & Noj & Nô & PUELIC & 479160 \\
\hline$E(j E-0) !-1)]$ & RUUNT SIIFGO (UFF) & SINUE ALGETIT & NONE & $\mathrm{K}-1 \mathrm{NCi}$ & NU & $\mathrm{Nit}$ & NO & HO UIK & 130680 \\
\hline$E O B-61-67 \dot{A}$ & HOUKRT SRIREU (OLF) & SIHLE A-BEET & NUNE & $R-1 \mathrm{NO}$ & NO & $\mathrm{No}$ & NG & NO OIF & 65340 \\
\hline$E 0 E-01-10$ & OLO MT. SKIRGOS ST. & VEALER BERAIARI & 50 & $\mathrm{~F}-1 \mathrm{NO}$ & YES & NO & NO & FUELIC & 174240 \\
\hline$E 08-01-11$ & 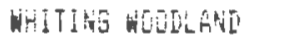 & ESTRIEY BUEEST & $\mathrm{Ni}$ & Fi- 2 HO & YES & YES & NO & FUELIC & 392040 \\
\hline$E 66-61-12$ & OLD MT.SHISEO (KEAR) & L.E.C. FEALTY THUST & NDHE & $I-1$ No & Nús & NŨ & NU & NE UIF & 522720 \\
\hline$E 05-01-02$ & FLAIA STREET (REAE) & VEFRACHI REALTY TRUST & NUNE & $I-1$ NO & NO & $N G$ & Ni & NO DIE & 1154340 \\
\hline$E 099-01-03$ & PLGIN STEEET (OFF) & SOULE ECHÁRD \& BESSIE & NEVEE & $1-1 N 0$ & $\mathrm{NO}$ & P05 & Nō & NŨ DIK & 217800 \\
\hline$E 64-01-05$ & SLHWYEILE PAFK & EMET SHIFPIASO CENTER & Ni & $I-1 \mathrm{NJ}$ & NO & $\mathrm{NG}$ & $\mathrm{No}$ & ND DIh & 755 \\
\hline$E(09-01-0) \varphi$ & PLAIN STREET (UAF) & SCANNELL ELILEF WOFKS & Pi]HE & $1-1 N G$ & HE & MU & No & Nü DIf & 8400 \\
\hline$E 0 T-0 i-10$ & PLAIN STREET (OFF) & COLE ELARETLP. & NOAE & $I-1 \mathrm{NO}$ & NO & No & Nū & NO DIF & 17424 \\
\hline$E 09-0 i-12$ & PLAIR STHEET (RELFS & EAST SHDFFING CENTER REALTH & NoTE & {$[-1 \mathrm{No}$} & Ni & P05 & $N_{i j}$ & NO DIF & 2976 \\
\hline Elu-01-04 & FLAIN STREET & CULLEN FRAHLIE & 157 & $\mathrm{I}-1 \mathrm{NO}$ & YES & NO & NO & PUELIL & 17150 \\
\hline$E ! 0-01-5$ & FLAIN STKEET & EAS S SKUFFING CENTEK REALTY & 845 & $1-1+\sqrt{3}$ & YES & NO & No & PUELIC & 1428.06 \\
\hline$E 10-0 !-12$ & PLAIK STFEET & BAI STATE GAS CU. & 640 & $I-1 \mathrm{~N} U$ & YES & YES & NO & PUELIE & 1130362 \\
\hline$E 10-0 Z-6 ?$ & PLAIN STREET & FALEUTA FEALTY TKUET & 50 & $B-2 \mathrm{WO}$ & YES & Ni & Nij & FUE:IL & 2570 \\
\hline$E 10-02-04$ & PLAIN STEEET & FALCË, REMLTY TELET & 96 & $B-\overline{N O}$ & YES & $\mathrm{NLI}$ & No & PUE:IL & 27160 \\
\hline$E 10-02-0.8$ & FLAIN STEEET & RUEEFTSUA CHESTEF & 100 & $\mathrm{~B}-2 \mathrm{Ni}$ & YES & NO & NO & PUE:IC & $609 \overline{4}$ \\
\hline$E: 0-62-16$ & PLAIR ETREET & EEVLÁNE KEALTH TKUET & $20 E$ & $\mathrm{E}-2 \mathrm{No}$ & YEE & $k_{i j}$ & No & FUELIC & 165015 \\
\hline
\end{tabular}




\begin{tabular}{|c|c|c|c|c|c|c|c|c|c|c|}
\hline AS.MEL-LET & LGGTIUN & OHKEF OF FEC & FFONT & ION & SE & WÁt & MET & $\mathrm{FPA}$ & ACCESS & AREA S \\
\hline$-\ldots \ldots$ & 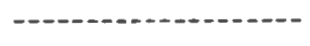 & $-0-1$ & --- & & & & & & & \\
\hline $16-03-05$ & FLAIN STFEET & DEWITT DLLEAAN \& DECASTKO INE. & 197 & OFO & NG & YES & No & No & PUELIC & \\
\hline $10-0 j-11$ & FUKEET STREET & JUNIDA ROBEF? A. L DERUTTHY A. & 125 & OF & No & YES & NE & $\mathrm{Nij}$ & & \\
\hline $10-04-014$ & ANGFERE AUENIE & MÉRSSHFIELE HED \& DENTAL CENTEF: & 167 & $5-2$ & NŌ & YES & NO & NO & FUELIC & \\
\hline $12-02-02$ & GIN STREET & BROLN MAFIAN $V$. & 282 & $k-1$ & N[1] & YES & NO & NO & & \\
\hline $15-0,3-0,4$ & CANIE TREE STREET & RUEGN: AKIHUF: & 150 & $\mathrm{~F}-1$ & No & YES & YES & $\mathrm{H}$ C & & \\
\hline $15-0.3-05$ & HÁIK STREET & FUEAHI AKTHUKR & 450 & $R-1$ & No & YES & NQ & $\mathrm{NQ}$ & & \\
\hline $16-\dot{b} \vec{b}-1 \hat{E}$ & GLE MAIN STFEET & NDETH FIVEK ARTS SULIETI INE. & 128 & $R-1$ & 10 & YES & NO & N0 & & \\
\hline$E i t-6 i 5-6 i$ & RUEGAN AVERIE & C ER̉IEN ELLEN RÁTHLEEN & NURE & Fi-1 & $\mathrm{NCO}$ & N5 & NO & NO & & \\
\hline $10-6-62$ & LUL:5 STREET & FLGÁALI AFTHUR F. & 123 & $R-1$ & NO & YES & NO & No & & \\
\hline $10-6 b-01$ & LQUIE STFEET & RUGANI AFTHUL F. & ZiE & $k-1$ & No & YES & YES & NE & PFIVAT & \\
\hline $8: 6-00-62$ & LUU:S STREET & RUGGNI AFIHUF $F$. & 252 & $\mathrm{~F}-1$ & NO & YES & NJ & YES & PEIVAT & \\
\hline $1 t-\hat{v} t-i j$ & KUSAT: AVEWE & RUGAHE! AFTHUF & $1 E J$ & $k-1$ & Nū & YES & YES & $\mathrm{NG}$ & & \\
\hline $26-66-60$ & RUSAR'S FUENE & 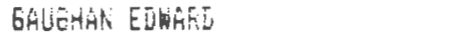 & 247 & $R-1$ & $\mathrm{NC}$ & YES & YES & $\mathrm{kij}$ & & \\
\hline $10-6 t-6 ?$ & FunO \& 5in-mir & FUEGH ARTHLE & NGHE & $\mathrm{F}-1$ & No & $\mathrm{NO}$ & YEE & Ho & MÜ DIF & \\
\hline$i t-5 j-6 j j$ & LUJIS ETKEET & RUGABI AETHLE F. & 250 & $k-1$ & $\mathrm{NiT}$ & YES & YES & No & & \\
\hline$E 16-07-02$ & CANDE TKEE STREET & RUGAHI AFTHIJ & 166 & $k-1$ & No & YES & YES & Ni & & \\
\hline $66-07-16$ & FEETSHRT STREE & CAFLSOA SIEFREL & 145 & $k-1$ & $\mathrm{Ni}$ & YE5 & N. & $\mathrm{NO}$ & FLELIE & \\
\hline $16-17-12$ & LULIS STFEET & RUGGHI AFTHJTI $F$. & 190 & $F-1$ & NO & YES & N5 & Nó & & \\
\hline$E: 0-07-12$ & LESE STREET & FUShW AETHUF $F$. & $148+C$ & $k-1$ & $\mathrm{NO}$ & NG & kiv & $\mathrm{Ku}$ & & \\
\hline$E 16-67-13$ & LUHIS STREET & 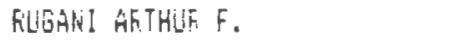 & 190 & $R-1$ & No & No & No & NO & FRICL & \\
\hline $1 b-1: T-14$ & LUUIS STREET & 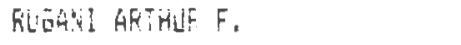 & 224 & K-1 & $N 0$ & $\$ 0$ & $N[$ & NO & PFI CL & \\
\hline$=i 6-0 B-01$ & CARELE TREE STREET & CARLSEN SEIGFAIED & 800 & $k-1$ & $\mathrm{NO}$ & POS & YES & No & & \\
\hline $517-02-03$ & OLD MAIR STKEET & KÜKCKEHUCA OAVID & 90 & $R-1$ & No & YES & No & NO & PUELIE & \\
\hline $17:-02-13$ & BIEHLSAU STFEET & MUEFH! PHILIF A. & 120 & $k-1$ & NO & YES & NO & NO & & \\
\hline$E[:-04-0]$ & FFUSFECT STFEET & KILLAR CONSTHAEE & 109 & $F-1$ & Nũ & YES & $?$ & No & & \\
\hline$E ! 7-0$ & PFEGFELT ST. (REFET) & HILLS A. ALII & NONE & $k-1$ & NO & NO & $N 0$ & kI & & \\
\hline$E 17-04-17$ & PRESFEUT STKEET IOFF & HLLLS h̆. ALLI & 30 & $F-1$ & ND & P05 & YES & $\mathrm{NE}$ & PFIVAT & 176 \\
\hline$E 17-04-26$ & PROSFECT STFEET & KILIAK CONETA & NOKE & $h-1$ & Nū & No & YES & NŨ & & \\
\hline$E 17-0$ & FLERSAKT STKETI & KELSELL WILLIÁK & 125 & $k-1$ & $N[]$ & YES & NU & NO & & \\
\hline$E 17-04-32$ & FLEFOAMT STREET (JFF) & HHÖKK UCANGEI & NINE & $k-1$ & NO & YES & YES & $\mathrm{NO}$ & No i & \\
\hline-34 & CAKILE TREE WAY (OFF) & HEEGAR DUNÁLD & HGKE & $k-1$ & No & NO & NO & NG & NO DIK & \\
\hline$E 18-0$ & OLD MÁLK STKEET & MuT jorik & 250 & $k-1$ & NC & YES & N[ & $\mathrm{KO}$ & & \\
\hline$E 18-03-10$ & ULU MALIN STREET & ANDERSON JEAR & 240 & $k-1$ & NO & YE5 & NO & No & PUELIC & \\
\hline$E ! 8-04-01$ & PROSPECT STFEET & WRIERT LIVINESTUN & 20 & $R-1$ & NO & YES & NŨ & $\mathrm{No}$ & PUBLIC & \\
\hline$E \perp 8-0$ & PROOSFECT STREET IOFF) & MURFHY RICHAKD & NDINE & $k-1$ & No & kio & YES & NO & NOI & \\
\hline$E 18-05-16$ & PRDSFECT STREET & DIFFEL HILLIAH & 230 & $k-1$ & NI & YES & NO & NO & PUBLIC & \\
\hline$E 19-01-01$ & SUHFER STREET & MASS AUDUELA SULIETY & $64 i+[$ & $R-1$ & No & YES & YES & YES & PUELIC & 1176 \\
\hline$E 19-01-07$ & NQSTH FIVEF LKIUE & LOHE AFTHLEF & 146 & $k-1$ & NO & YES & NO & Ho & PUESIC & \\
\hline$E: 9-02-0 i$ & SUKKEK STFEET & KAFNEF EDWAFE & $2 E 5$ & $R-1$ & $\mathrm{Ni}$ & YES & NO & NO & PUBELIC & \\
\hline$E 20-0.3-04$ & NGETH FIVEF UFIVE & FAFinulitia LUJIS & 50 & $F-1$ & No & YES & YES & YES & PUELIL & \\
\hline$E 20-63-65$ & NGFTH FIVER QREVE & BEALH MFX & 50 & $\mathrm{k}-1$ & $\mathrm{NO}$ & VES & HO & NO & PUELIC & \\
\hline$E 20-03-06$ & NUETH FIVER DFIVE & PFîT DCKR̃:D & 169 & Fi-1 & NO & YES & NE & NO & FUELIC & \\
\hline$F 07-01-63$ & OLI OCEFH STEEET & DPRIELL NILLIAM & 174 & $\mathrm{H}-1$ & $\mathrm{NG}$ & YES & YES & $\mathrm{NO}$ & FUELIC & \\
\hline$F 07-17-13$ & W_L OCEHA STREET & THE AFTHUF A. HILLS TFUST & 291 & k-1 & Ni & VES & YES & YES & FUEEIE & \\
\hline$F 08-62-10$ & GLI OCEAR STREET & ELLIS UATIL & $130 t$ & $k-1$ & Ni & YES & YES & YES & & 13024 \\
\hline$F Q E-02-13$ & OLD KUUNT SKIFGO & STAFLES UAHA A. & 127 & $\mathrm{R}-1$ & $\mathrm{Ha}$ & YES & NO & NO & FUELIC & \\
\hline$F \quad 0-05-05$ & CFUUSS STHEET & CAFEENTEK BLGNELE & 100 & $5-2$ & Nũ & YES & YES & YES & FUELIC & \\
\hline Fo8-00-12 & PLAIN STREET & THINERESL HOUSE REALTY & 720 & $n-2$ & Nil & YES & YES & YES & PUELIE & \\
\hline $504-61-05$ & PLHIN STREET & GASNUR ROEERT & 40 & $k-2$ & No & YES & No & N[ & PLIELIC & \\
\hline F09-01-10 & PLAIN STREET & SLHATI MATIE & 93 & $k-2$ & No & YES & No & ND & PUELIC & \\
\hline$F(15-011-10$ & FLFIN STREET & SCHÁTI MAREIE & 40 & $\mathrm{Fi}-2$ & No & YES & YES & NO & PUELIC & 11761 \\
\hline$F 09-03-17$ & PLAIR STKEET & BEFINICK JAHE & 695 & $R-2$ & NO & YES & NO & No & FLELIL & \\
\hline $709-0.3-51$ & PLKIN STREET (REAREI & FLGIN STREE; REALTY TRUST & MŨ & $8-2$ & NU & No & P05 & No & No DIF & 260 \\
\hline
\end{tabular}




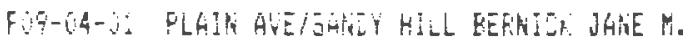

F!C-U2-63 F!AGGEF RGA: FHIHIEY ECHGST

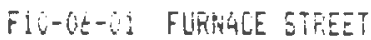

FIO-GE-OS FUFFHALE 5TREE]

FI1-05-14 EAMES WEY

Fi:-6b-iI EAHEE W?

F11-07-07 FLFHALE STAEET

F!I-TE-TE FUARTEE SThEET

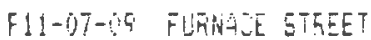

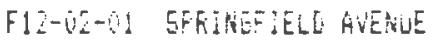

FIZ-OZLOCZ EARES WAY

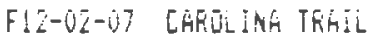

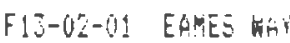

FIS-0Z-02 TILDES WOSE LARE

F14-v2-O EAHES WI

FI4-OZ-OZ EAKES WH: IUFF:

F14-01-O14 EAMES HAY (OFF)

F14-O2-OS EAMES W'-I

F14-02-06 AMES RUENIE

F!4-02-08 EAMES WAI:

F14-CO-CIS EAMEE HEY

FI4-12-10 ERHEE WAT

F14-02-11 EAMEE HA!

FI5-CZ-194 EAAES WAY

F!5i-0I-0L EAMES WAY

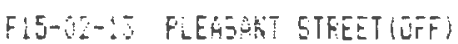

Flt-01-01 PLEASRET STFEET

FLE-CL-DS FLEAEHT STEET

FI6-U1-07 FLEREATT ETREET

FiE-UL-G PEATHE HILL FUA:

FI6-0:-10 HEATHEF HILL FEAO

FlO-O!-:E HESTHEF HILL RLAD

FiC-CZ-O4 FUERGART STFEET

Fio-CZ-OE FLEASART STREET

F1t-02-11 EAMES WAT

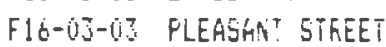

F16-03-11 EARES HAY

FI7-01-31 CAKIUE TFEE WAYY

F17-01-114 CAHUE ThEE HAY

F17-02-12 CANUE TREE WAY

F17-02-18G SLWMEF STREET IÜFF HAGAF DENALD

F17-62-19 PLEASFAT 5TREETIOFFI ALEKANLEFSON F'GUL

FIT-02-20 PLEASGIV STREETIOFF\} HAGER DONALD

F17-03-10 SUMFER STREET

FIE-OI-CI SUWHEF STREET

FIE-OI-OI SLHNER SIREET

F18-62-0Z MACUHEET'E HAY

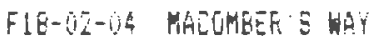

MLGFAGY RLEEFT

HELSOK FEEETIOH

AKUERSOL AFTHLS

FLACE BAREGARA E.

LAKE MYFTLE 3.

FI8-03-12 SUMMET STREET (FEAR) NICHOLEJA SHERMAG

FIB̈-CI-:5 SLWAER STREET (REAR) RELLY JOHK

F18-04-04 MACLMEEF IOFF;

F16-04-10 SUMMET STREET

JOHKSON MAFEARET

HIMES EDWAFO

F19-U1-OL DAMEN S ELINT RDAL
GHIES JANICE

\begin{tabular}{|c|c|c|c|c|c|c|}
\hline & & & & & & \\
\hline $1+L$ & $2 \mathrm{NO}$ & YES & $\mathrm{NG}$ & $\mathrm{Ni}$ & PUELIC & 16000 \\
\hline & $\mathrm{F}-2: \mathrm{NO}$ & NE & $N[1$ & NO & PEIVAT & 131907 \\
\hline & $F-1 N[j$ & YES & ND & NO & FUE & 125324 \\
\hline & $R-1 N G$ & YES & YES & YES & PUELIC & 139627 \\
\hline & $\bar{F}-1 \mathrm{~K} \overline{\mathrm{L}}$ & YES & & Mí & FUE:IC & $45746^{\prime}$ \\
\hline & $\mathrm{F}-1 \mathrm{ND}$ & YES & & No & FUELIC & 43638 \\
\hline & F-1 KU & YES & & Hi็ & FLELIC & \\
\hline & $\mathrm{F}-1 \mathrm{Nú}$ & YE'S & & No & FuELIC & 9405 \\
\hline & $F-1 N 0$ & YES & 0 & NO & FUELIE & 14700 \\
\hline & $\mathrm{F}-1 \mathrm{N0}$ & $\mathrm{NE}$ & ND & NO & PFIViaT & 352040 \\
\hline & $\mathrm{R}-1 \mathrm{Ni}$ & & $N$ & $N \bar{u}$ & $N / A$ & 522720 \\
\hline & $R-1 \mathrm{NE}$ & YES & ND & $\mathrm{No}$ & FFIVAT & 45707 \\
\hline & $\mathrm{F}-1 \mathrm{k}$ & NO & $N[$ & Nu & $N: A$ & 4635160 \\
\hline & B-1 No & $n$ & $\mathrm{NO}$ & 10 & NE OIK & 413829 \\
\hline & $\mathrm{F}-1 \mathrm{NU}$ & NO & $\mathrm{NS}$ & $\mathrm{NG}$ & $\mathrm{N} / \mathrm{H}$ & 254030 \\
\hline & $\mathrm{F}-1 \mathrm{ND}$ & NO & NO & NS & NE $J I R$ & \\
\hline & $\mathrm{R}-1 \mathrm{NO}$ & NI & $\mathrm{NLI}$ & $\mathrm{NU}$ & Nu Uif & 17424 \\
\hline & $\mathrm{R}-1 \mathrm{NG}$ & $\mathrm{NO}$ & ND & No & $N / A$ & 696960 \\
\hline & $\mathrm{F}-1 \mathrm{NE}$ & NŌ & No & $\mathrm{NO}$ & NiÁ & $174240^{\circ}$ \\
\hline NE & $\mathrm{F}-1 \mathrm{No}$ & Nõ & PJ5 & ต่อ & NO DIK & \\
\hline AE & $\mathrm{F}-1 \mathrm{NG}$ & NO & NO & NO & MU UIF & 15240 \\
\hline & $F-1 N \bar{J}$ & $\mathrm{HL}$ & $\mathrm{NO}$ & $\mathrm{NI}$ & $N / A$ & 33541 \\
\hline & $R-1 N[$ & $\mathrm{NO}$ & $\mathrm{H}[\mathrm{J}$ & Nō & $N / A$ & \\
\hline & $\mathrm{F}-1 \mathrm{ND}$ & NO & $\mathrm{NI}$ & No & $N / A$ & 47916 \\
\hline & $\mathrm{F}-1 \mathrm{NE}$ & YES & $N[$ & NO & PLELIC & $32 t 700$ \\
\hline iE & $\mathrm{F}-1 \mathrm{NJ}$ & $\mathrm{NG}$ & no & 10 & NO Dif & 235224 \\
\hline & $\mathrm{R}-1 \mathrm{NO}$ & YES & $\mathrm{NJ}$ & No & FLE:IC & 174240 \\
\hline & $\mathrm{F}-1 \mathrm{~N}]$ & YES & YES & $\mathrm{NO}$ & FUELIL & 217800 \\
\hline & $F-1 \quad N[]$ & YES & $\mathrm{No}$ & No & PUELIC & 40400 \\
\hline & $R-1 \mathrm{~N}[\mathrm{i}$ & YES & Nô & $\mathrm{NE}$ & FẼIVAT & \\
\hline & K-1 NU] & IES & $\mathrm{NI}$ & $\mathrm{NG}$ & FEIVAT & 5267 \\
\hline & $\mathrm{F}-1 \mathrm{k}$ & YES & N5 & NO & FEIVAT & 50628 \\
\hline & $\mathrm{F}-1 \mathrm{~N}[\mathrm{H}$ & YES & NË & $N 0$ & & \\
\hline & $R-1 \leqslant 0$ & YES & NO & NO & PUELIE & 43995 \\
\hline+[ & $\mathrm{K}-3 \mathrm{NI}$ & YES & Nū & $\mathrm{Nu}$ & PUELIC & $47 \overline{9}$ \\
\hline & $K-1$ NO & YES & $N[1$ & NO & $N[D I K$ & \\
\hline & $\mathrm{R}-1 \mathrm{~N}[\mathrm{~J}$ & YES & N] & NO & FLELIC & 43560 \\
\hline & $R- \pm N G$ & Nũ & YES & No & C.D. & 52272 \\
\hline & $\mathrm{F}-\mathrm{NE}$ & No & YES & $\mathrm{Ni}$ & [.]. & 74052 \\
\hline & Fi-1 N0 & $\mathrm{Nu}$ & NO & NO & C.V. & 44666 \\
\hline & $\mathrm{k}-1 \mathrm{k}$ & No & POS & $\mathrm{NO}$ & NO DIE & 901672 \\
\hline KE & $R-1 N 0$ & NO & PG5 & NO & NU DIF & 43560 \\
\hline & $\mathrm{F}-1 \mathrm{~N}[\mathrm{C}$ & $\mathrm{HO}$ & P05 & Nō & NO UIR & 21720 \\
\hline & $K-1$ Nĩ & POS & No & $N G$ & FUELIC & 4400 \\
\hline & $F-1$ kij & YES & N] & NO & FUELIC & $986 \overrightarrow{\mathrm{C}} \mathrm{l}$ \\
\hline & $\mathrm{F}-1 \mathrm{NO}$ & YES & YES & YES & PUELIC & 115800 \\
\hline $0+[$ & F-1 Nō & YES & YES & YES & FUE:IC & 182952 \\
\hline & $\mathrm{F}-1$ No & YES & YES & YES & FUELIC & 3102 \\
\hline & $\mathrm{R}-1 \mathrm{NO}$ & FOS & NO & Nō & RF FIOH & 23400 \\
\hline & $\mathrm{F}-1 \mathrm{kO}$ & No & NO & $\mathrm{His}$ & NO DIF & 2640 \\
\hline & F-1 NO & $N \bar{j}$ & NO & NG & ND DIF & 217000 \\
\hline & $\mathrm{R}-1 \mathrm{NO}$ & YES & NO & NO & FUE:IC & $24 \leq 114$ \\
\hline & $F-1 N_{i}$ & YFE & YFE & $N$ & PLELIS & 376972 \\
\hline
\end{tabular}


F19-0!-17 EAST AAEL LANE

FIC-01-09 EASTHARE LANE

FIG-UI-11 SURMER STREET (OFF)

F19-02-Z7 EAFILETT'S ISLAKS

F!9-62-33 DAMUN S FUINT RUAD

F200-01-18 BAOTLETT'S ISLARID

FQU-O1-19 MAOUHER IOFF)

FZO-CL-GI DAHOHE FUINT ROAR

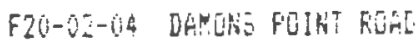

605-O1-01 ACOFN STHEET

50t-61-13 TEL FOOT. LANE

6Ut-01-13 TEA ROCK LAIE

GU6-6!-15 TEF ROSK LALE

Gub-01-17 DUFFERE LAIRE

E06-01-26 TES FECK LANE

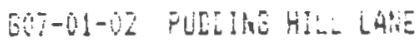

6.7-02-OJ ACOEA STREE

60i-6i-11 ACCHA ETFEET

607-62-29 CCEAR 5TREET

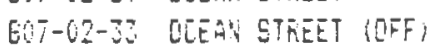

GOT-02-34 PUELAE HILL IEFI

67-A2-jo FUIEIHG HIL LN UJF

607-0Z-3E FULUINE HILL LARE

$507-02-40$ TEH FJTE LAIE

GUT-02-44 RELF MURATKE STREET

G08-03-13 PLAil 5TFEET

609-04-01 FUUDJAE HILL LALIE

GUB-0S-05 OCEAR STAEET

GQE-0J-15 SUUTH RIVEF STFEET

GE-67-11 SULTH RIVEF STKEET

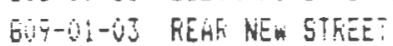

6015-01-16 NEH STREET

667-6!-16 NEI STREET

609-04-15 MEIN 5TREET IOFF?

609-04-1S MAIN STREET ICFF)

6!2-01-0: NURWIEH STREET

612-01-63 NOFWTEH STREET

612-01-06 NUSWICH STKEET

612-01-107 MUERTCH STKEET

E12-02-04 HCFHICH STREET

G12-0i-05 NOFWICH STREET

G12-03-01 5FERBEJELE AUENJE

612-03-02 NUEGLE STEEET

612-03-03 NOFWICH STFEET

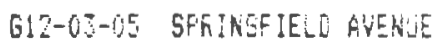

EI2-05-04 VEFMENT STFEET

Gi2-05-05 VEFHERT STFEET

612-0i-01 SFTINOEIELJ AVERUE

oli-bt-02 SFRINEFIELD AVENUE

612-05-03 SFKINGFIEID AVENUE

612-06-14 VERKITT STREET

612-06-13 NÜKITIS SIREET

6:2-66-14 NGFILM ETREET
CHÁPMÁN SUSAN

CHAFMAL SLSAHA L.

DAMENS POINT TRUST

AQGU-TEFF'́ FARTYS INE.

BNACKMAN WILLIAM

AUUA-TERTÍ FAFINS INE.

UAMKMÁT CTIS B.

CRUSSIEY WALTER E

BATLHELGS MUKES [

MARSKF IELD COUNTEY CLUE INL.

HARIVY RUEERT

HAEVEY RLEERT

Megfitio ANR

NEW GOROTHY

HAR' IEY RCEERT

TOF TRE SICHARE

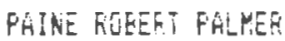

LEATHEREEE ROEEET \& FATEICIA

DAUENTSRT LOREN

SIHWDT CHABE:E

CUETELLE ESTHES

TOFHAM RICHAFE

IIFAY THUNAE

CONELL JCHKR \& $I$.

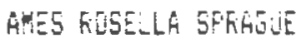

DSVIE PAIL \& HELEH

GRADFOFE ELIZAEETH

JÜHK DFIS

BLINETEUS HLLIAH

MUIIESG MATTHE

DAVIS CHATLES

LEMHY PERÉ

DAVIS CHARELS

GKIFFEN ELAIHE J

MAFJOR REALTY TKUST

LOMESEDI NICHULAS

CRÜKEY JOHR

NUSTON ANS

LEE F'FTEIISK

EVARE WILLIAH

KELLEY THOMAS

MCDSRIULH M. 3.

GREPTER SOUTHGHURE CAELEUISTON COKHELLY JAMES I.

CORHOLLY RICHAEL

FOFSMAR HARIOLD

FORSMAN HEFJUD

COtinil D.F.

LANG EIEAHELE

LANE ALEIËN

DOMHLLE FFEDETLI

MÁHLUNEY ANINÁ

KLEPINGER ELITH
$300+[F-1$ NO YES NO NO PRIVAT $1115: 3$

192 FI- N NO POS YES NO FFIVAT 77536

127 KI-1 NO YES NO NO N/A 117612

330 R-I NO YES YES YES PFIVAT 243936

73 R-1 NO YES YES YES PUBLIC 7300

NONE R-1 NO NO YES YES NO UIR 4112064

NUNE FI-I NO NO YES YES WU DIR 174240

58 R-I NO POS NO NO PRIVAT 2775

LOUTL RI-I NO POS NO NO FRIVAT 3774

17 F-1 NO YES NO NO PRIVAT 222156

NUNE F-1 NO NO NO NO NO DIF 36046

24: F-I NU FUS NO NO PFIVAT 36046

NENE R-I NO NO NO NO NE UIR J149720

NUNE R-1 NO NO NO NO N/A 177289

NURE R-I NO POS NO NO NU DIK 2178000

276 h-1 NIJ YES YES NI PFIVRT $16: 17$

NONE RII NJ NOJ YES RU PFIVAT 43560

33 K-1 NO YES YES NI FEIVAT 130660

175 E-2 NO NÜ NJ NJ PUELIC 435600

WOHE B-2 NO NO NO NO NO DIR 662983

NONE R-I NE NI NE NU NU DIE 291 ESTO

NUJE F-1 NO NE NO NO NO DIT 392040

140 R-I NO YES NO NO FFIVAT $2962 \mathrm{~V}$

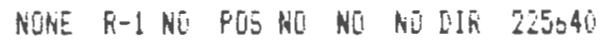

NUAE F-I NO NO NO NO NO DIR 91911

NUETE E-2 NU NO YES NO NG DIF 19800

NDAE R-I NU YES NO NO NU UIR 130680

160 E-2 NO YES YES YES FUELIC 56020

$155 \quad \hbar-2$ NO YES NO NO FUELIC 20448

RUME F-2 NL FOE NO NO FUELIS 34645

NJTEE R-Z NO NO YES YES NO LIK 5880 S

20 R-2 Ni YES NO NO PUELIL 2590

130 RI-2 NO YES YES RO FUELIC 17197

HONE F-2 NO NO YES NO NO DIR 87120

NONE R-2 NO NO YES HU NO DIK 261360

50 F-1 NO FES NJ NO FFIVAT 5000

50 R-1 NO FÚS NO RO FRIVAT 5090

50 RI-I NO FOS ND NO PEIVAT 5000

50 K-I NG FUE HE NO FRIVAT 5000

50 R-1 NO FOS HO NO FRIVAT 5000

50 F-1 NU FOS NÜ NI FEIVAT 5050

IEOOTE R-1 NG FOE NU NO PRIVAT 4000

250 R-1 NO FIS NO NO PRIVHT 22500

1900+C K-1 NE POS NJ NO FRIVÁ 4750

NORE FI- NI POE NE NE NO JIK 4500

$260+C$ E-1 NI FUS NO HO FEIVAT 3750

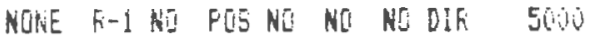

$165+i F-1$ NJ FUJ NO NO PKIVAT 5500

110 K-1 ND FUE NO NO PEIVAT 9500

$125+C h-1$ NLE POS NO NO PRIVAT $40 . \mathrm{JU}$

50 R-1 NU FUE NO NJ PEIVATT 5000

50 RIL NO POS NO NO FRIVAT 5000

50 R-1 NUE FUE NI NE FRILAT 5000 


\begin{tabular}{|c|c|c|c|c|c|c|c|c|c|}
\hline A5. NAGF-LUT & LECHIJN & UMLEF: UF REE & FFERT & ION SEH & HคT & & $F F A$ & ACCESS & AFEEA S \\
\hline -.......... & 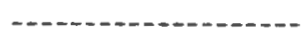 & -................... & -- & -.. - .. & $-\cdots$ & & --- & & \\
\hline $612-i b-15$ & NOREICH STREET & DEHEFTY JAMES & 50 & $\mathrm{R}-1 \mathrm{NO}$ & Fos & $\mathrm{kO}$ & NO & PEIVAT & \\
\hline $612-07-01$ & ESSEX AVENLE & MULLEFH JJSAK C. & $50+5$ & $\mathrm{~F}-1$ NI & VES & NO & No & PUELIC & \\
\hline $612-67-037$ & UTAH STEEET & RATHEA FICHAET & $200+C$ & F-1 NO & POS & NO & NO & PEIVAT & \\
\hline $612-07-66$ & WLITAH & DAFU FALL + DOSDTHI & $235+i$ & $\mathrm{~F}-1 \mathrm{No}$ & POS & Ko & Ko & PRIVAT & \\
\hline $612-0 E-016$ & UTAH STKEET & GILSOR RICHAED & 50 & $\mathrm{~F}-1 \mathrm{NO}$ & F05 & NO & No & PFIVATT & \\
\hline $6 ! 2-05-67$ & UTAR STPEET & WHITCHEF MERES. & 50 & R-1 $N 5$ & P0S & NO & No & FEIVGT & \\
\hline $612-08-116$ & ESEE AVENUE & TOEFEY JOHKANGA & $5 i+5$ & $\mathrm{Fi}-1 \mathrm{NO}$ & YES & No & $\mathrm{NO}$ & PUELIC & \\
\hline $612-08-13$ & ESSEX RUEHE & JONES CELELIF & 50 & R-1 $\mathrm{Ka}$ & YES & NO & Hī & PUELIC & \\
\hline $612-6 t-11$ & NEFWICH STERET & HILL]AVE GREFH & $125+C$ & $K-I N J$ & PES & NQ & No & PFIVAR & \\
\hline $612-0 z-12$ & NORIIS STEEET & CURHIFF DEDUAB & 50 & $R-1 N G$ & F05 & NO & NO & PRIVAT & \\
\hline $612-08-16$ & NUERICH STREET & FINLAYSON KENHETH & 50 & $\mathrm{R}-1 \mathrm{NO}$ & POS & NO & NO & FEIVAT & \\
\hline $012-0 \bar{\theta}-17$ & CUNAILEHAR MGIJFIE & 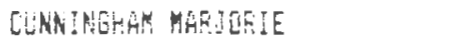 & 50 & $R-1 N 0$ & P05 & No & No & PFIVAT & \\
\hline $312-09-01$ & LYNH: STREET & MELVOER KENNETH & 125 & $R-1 N 0$ & YES & No & NO & FFIVHT & \\
\hline $612-09-64$ & LYNN STEEET & WIKIIE LASBIS & 40 & $\mathrm{~B}-1 \mathrm{NO}$ & YES & No & No & FRIVAT & \\
\hline $612-09-06$ & ESSEX AVEHIE & KUMIR EMIL & $50+5$ & $\mathrm{R}-1 \mathrm{~N}$ & YES & $\mathrm{NO}$ & NO & FUE_IC & \\
\hline $612-04-017$ & ESSEX AVENIE & MAKHIKE WIKR & 50 & $R-1 N G$ & YES & io & NO & PUE:IC & \\
\hline $612-09-09$ & UTAN STREET & HHITCHEF HARI & 50 & $\bar{R}-1 \mathrm{NE}$ & POS & NO & NO & PHIVAT & \\
\hline $612-09-10$ & UTHM STREET & 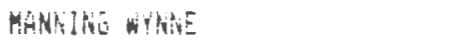 & 20 & $\mathrm{~F}-1 \mathrm{NU}$ & Fos & Nis & $\mathrm{Mij}$ & PRIVATT & 75 \\
\hline $615-05-11$ & UTAS: SIREET & VINIZE IGEZLO & 50 & $F-1 N O$ & Fos & No & $\mathrm{No}$ & PRIVAT & \\
\hline $612-17-12$ & UTAH STEEET & VINCIE LAEILO & 50 & $\mathrm{~F}-1 \mathrm{NO}$ & POS & No & 10 & FRIVAT & \\
\hline $612-05-13$ & UTAFH STKEET & DODES VEFLIE $A$ & 50 & $R-1 N 0$ & PCS & NO & NO & PFIVIT & \\
\hline $6: 2-38-16$ & UTRH STREET & MANINE WYKE & 50 & $R-1 \quad N]$ & FOS & NiE & No & FEIVAT & \\
\hline $612-10-11$ & ESSEX AUEN JE & FETET̄SUR JOHNANHA & $50+[$ & $\mathrm{K}-\mathrm{N} \mathrm{Ni}$ & YES & NO & KD & FUBLIC & \\
\hline $6: 2-10-610$ & HÉTHAT, AVE. & SKIFFINETUH FHUL & $2900+C$ & $R-1 N \bar{N}$ & Fos & No & NO & PRIVAT & 75 \\
\hline $612-10-0 E$ & WALTHAM AVE. & JEFOME KILIIA.T & 50 & $\mathrm{~F}-1 \mathrm{NO}$ & PDS & $\mathrm{Nu}$ & No & PRIVAT & \\
\hline $612-10-99$ & LYG STFEET & 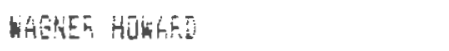 & 170 & $R-1 N 0$ & POS & NO & NO & PEIVHT & \\
\hline $612-11-04$ & SPFINGFIELD AVENLE & O LEARY AETHLE & 65 & $\mathrm{R}-1 \mathrm{NO}$ & P0S & NÕ & No & PRIVAT & \\
\hline $6: 2-11-05$ & HAL THÁ: AYERUE & [IEFIEK MAETHÁ & 25 & $\mathrm{R}-1 \mathrm{NO}$ & pos & ND & NO & PFIVAT & 22 \\
\hline $612-11-06$ & SFFINGFIELD GUENIE & MULLANEY MEFT'H & $2000+[$ & $F-1$ NE & PUS & No & No & PR̈IVAT & 40 \\
\hline $612-11-13$ & WALTHAN GUERLE & MECAFiH: FLDAERE & NONE & $R-1 N G$ & P0S & $\mathrm{No}$ & $\mathrm{No}$ & NU DIK & 31 \\
\hline $612-12-02$ & SFRINEEIELE AVENLE & ES5OH $\mathrm{d} . \mathrm{\&} \mathrm{J}$ & 100 & $E-1 N 0$ & Fo5 & No & No & FFIVÁ: & \\
\hline $6: 2-12-0: 3$ & SFRINGFIELD AVEME & BAhHE MAFTIR & $145+C$ & $\mathrm{~F}-1 \mathrm{NO}$ & P05 & NO & No & PFIVAT & \\
\hline $612-12-67$ & DELHAM HOHL & BUOTE ELIIAEETH & 25 & $h-1 N 0$ & Fus & $\mathrm{HS}$ & $\mathrm{NO}$ & FEIVAT & 65 \\
\hline $61 z-13-02$ & VEFMORT STREET & HAGMÂK TURE & 50 & $\mathrm{~F}-1 \mathrm{NJ}$ & PÜS & $\mathrm{Ni}$ & NO & FEIVIT & \\
\hline $612-14-65$ & CALIFORNIA STREET & MELALUGHLIN JARES & 50 & $\mathrm{R}-1 \mathrm{NO}$ & NU & ND & $\mathrm{NO}$ & PEIVAT & 50 \\
\hline $612-10-01$ & CALIFOKAIA STKEET & TEDESEHI DOHINIE & $160+C$ & $\mathrm{k}-1 \mathrm{No}$ & $\mathrm{NO}$ & NO & NO & PRIVGI & 76 \\
\hline $612-16-02$ & CALIFUENIS STREET & JOHES SANEEA & 60 & $\mathrm{~F}-1 \mathrm{NO}$ & $N \mathrm{~N}$ & No & Kũ & PRIVAT & 50 \\
\hline $612-16-03$ & CA_IFOERIA STREET & MATTS FUBER: W. & 90 & $R-1 \mathrm{NL}$ & $\mathrm{HO}$ & $\mathrm{NO}$ & NO & PEIVATT & \\
\hline $612-16-04$ & SFRINGFIELD AVENUE & MELUCAS CATHEK]NE & $300+5$ & $k-1$ No & P0S & ki & NO & PFIVAT & 220 \\
\hline $612-16-05$ & SFRINGFIELO AVENUE & QHEEREERGEF & 60 & $\mathrm{Fi}-1 \mathrm{NG}$ & POS & NO & No & PFIVAT & 75 \\
\hline $612-16-48$ & DEDHAMY KOAD & HEISHEF FRAMEES 6 & 50 & $\mathrm{R}-1 \mathrm{NO}$ & POS & NG & No & PFIUAT & \\
\hline $612-17-01$ & LAWFENCE ROGL & COLUNARA AELSTINEI & 125 & $\mathrm{R}-1 \mathrm{Ni}$ & NG & $\mathrm{NLI}$ & No & $\mathrm{FFICL}$ & 125 \\
\hline $6: 2-17-02$ & LAHEENCE ROAD & MELVOEN YEMHETH & 50 & F-1 NJ & $\mathrm{NU}$ & HO & NO & FRI CL & \\
\hline $6 ! 2-17-08$ & LYKK STKEET & 5COLLINS C. & 50 & $\mathrm{~F}-1 \mathrm{NE}$ & YES & $\mathrm{NO}$ & NO & FEIVITT & \\
\hline $6: 2-17-10$ & LYNG STREET & MEL VUEH RENGETH & $120+2$ & $\mathrm{~F}-1 \mathrm{NC}$ & YES & $\mathrm{NE}$ & N[ & PEIVAT & 32 \\
\hline $612-17-11$ & LYNS STREET & MELVOEN KENHETH & 70 & $\mathrm{R}-1 \mathrm{ND}$ & YES & No & NO & FEIVAT & 52 \\
\hline $612-17-12$ & LYNH STREET & DANAEET MAGS & 45 & $\mathrm{~B}-1 \mathrm{NO}$ & YES & $\mathrm{NJ}$ & NO & PRIVAT & 50 \\
\hline $612-17-13$ & LYAH STREET & MGIERIALL FAUL E. & 45 & $\mathrm{~F}-1 \mathrm{NS}$ & YES & No & NO & PRIVAT & \\
\hline $612-1 E-04$ & CALIFORISI ST STEET & HEALEY ELIILAEETH & 40 & $R-1 N E$ & No & NU & NO & FFIVAT & 50 \\
\hline $612-15-0.5$ & CFLIFORMIH STREET & HILL NUERS & 50 & $\mathrm{R}-1 \mathrm{NE}$ & NO & NU & No & FRIVAT & 50 \\
\hline $612-18-0 B$ & EALJFORKIÁ STFEET & COYLE JHMES & $125+[$ & $k-1 N 0$ & Nū & No & $N E$ & PFIVIAT & \\
\hline $612-18-13$ & LAHERENAE RJAE & TRAUTAES REFELL $F$. & 55 & $\mathrm{~K}-1 \mathrm{NO}$ & No & NO & No & PHI CL & \\
\hline $612-18-15$ & LAWTENEE RUAS & DULYE JAHESF。 & 60 & $\mathrm{~F}-1 \mathrm{NO}$ & No & $\mathrm{NO}$ & $\mathrm{NC}$ & $\mathrm{FK}: \mathrm{Cl}$ & \\
\hline
\end{tabular}




\begin{tabular}{|c|c|c|c|c|c|c|c|c|c|}
\hline $6: 2-18-16$ & LAMPENEE FOAD & BEHEE HELEN A. & 70 & $\mathrm{~F}-1 \mathrm{NO}$ & NO & NE & $\mathrm{Ni}$ & FFI CL & \\
\hline $612-18-17$ & ESSE AVENUE & TAYLOF FRANCIS W. & 23 & Fi-1 No & YES & Nó & Nū & FUEẼLIC: & \\
\hline $612-19-05$ & HALTHAA AYETHE & HOLKES FLORENCE H & 260 & $R-1 N E$ & YES & NO & Ho & PEIVAT & \\
\hline $312-19-05$ & WELTHAM AVE. & HUILAES FLORENICE & 260 & Fi-1 NO & PUS & NO & NO & PRIVAT & \\
\hline $6: 2-19-16$ & WHLTHAR GUENUE & MEEAKTHY CIKIL & 80 & $\mathrm{~K}-1 \mathrm{NO}$ & PU5 & NO & $\mathrm{HO}$ & FRIVAT & \\
\hline $6: 2-19-07$ & WALTHAR ALERULE & OLSEN ADEA MAY & 40 & $R-1 N$ & F0S & NO & NO & FRIVAT & \\
\hline $12-19-10$ & WOLTHEY AVE. & COLLIGAM THUMAS & 35 & $\mathrm{~F}-1 \mathrm{NU}$ & F05 & NO & $\mathrm{NGi}$ & PRIVÁT & \\
\hline $512-15-11$ & CALIFUFHIA STREET & COLLISEN THUAAE & $200+C$ & $\mathrm{~F}:-1 \mathrm{NO}$ & NON & NO & No & FEIVAT & \\
\hline $12-15-12$ & CALIFUERIH STKEET & DOKELARK MILDEED & 40 & $\mathrm{~F}-1 \mathrm{kO}$ & No & Hí & No & PEIVAT & \\
\hline $322-19-13$ & CALIFUKRIA STREET & TEDESELI DÜINIC & 100 & $R-1 N$ & NO & NO & NO & FEIVAT & \\
\hline $12-19-15$ & CALIFOFNIH STREET & DONELAN MILDRED & 40 & $\mathrm{~F}-1 \mathrm{NO}$ & NO & No & W0 & FRIVAT & \\
\hline $12-19-16$ & CALIFUFNIA STREET & IUJFFEE LEGH & 50 & F-1 NO & NI & $\mathrm{NO}$ & No & PFIVAT & \\
\hline $112-19-17$ & CALIFQENHÉ STEEET & DUSFEE MEATH & 145 & $\mathrm{~F}-1 \mathrm{NI}$ & NE & No & NO & FFIVAT & \\
\hline $12-15-1 E$ & CALIFUFHIL' STREET & BFIGES MASULFIE & 50 & $R-1 N 0$ & No & No & NG & FEIVAT & \\
\hline $27-19-19$ & CALIFURKIA STEEET & DLFFEE LENH & 100 & Ri-1 Ni & $\mathrm{N} \bar{j}$ & $\mathrm{NO}$ & No & PFIVHT & \\
\hline $6: 2-19-20$ & CALIFGSRIN STREET & HA.LETT FLDFENIE & 70 & $R-1 N E$ & NO & N: & Nu & FFIVAT & \\
\hline $2-19-5 h$ & WÁLTHAR AVE. & OLSEM MAYY & NEAE & $R-1 \mathrm{NJ}$ & $\mathrm{NS}$ & No & $N E$ & MO DIR & 130 \\
\hline $2-200-64$ & WALTHAM AUEMLE & CHAEIES MICHAEL & 60 & $R-1 N$ & FUS & NE & NO & FEIVAT & \\
\hline $612-211-36$ & WUARIVE STFEET & CHHFLES HICHAE & 40 & $\mathrm{~F}-1 \mathrm{NJ}$ & NS & $\mathrm{Ni}$ & k5 & $N / A$ & \\
\hline $12-20-06$ & WYLKING STREET & TEDESCh! DUMINIC $K$ & 75 & $\mathrm{~F}-1 \mathrm{NO}$ & $\mathrm{NE}$ & $\mathrm{No}$ & No & $N / A$ & \\
\hline $12-26-i, 5$ & RIOFIHE STFEET & MESTRIANBI GUY & $14 i+5$ & $R-1 N$ & No & No & N5 & $N / \hat{n}$ & \\
\hline $12-20-10$ & SFFINGFIELD AVEHIE & MAETKIANRI GJY & 40 & Fi-1 NE. & FUS & $\mathrm{ki}$ & NE & FEIVAT & \\
\hline $12-2 \hat{v}-12$ & CALIFEFHVH STEEET & MYLE FICHARDS & 65 & $\mathrm{~F}-1 \mathrm{NO}$ & No & NC & NI & PFIVAT & 118 \\
\hline $12-21-01$ & SFEINGFIELD AVELUE & WHITHEY DAVID & $150+i$ & $R-1 N \bar{i}$ & FUS & $\mathrm{hi}$ & Hit & FEIVAT & \\
\hline $612-21-32$ & 5ERINGFIEL ${ }^{n}$ AVEVUE & MELFETHY FITA & 50 & $R-1 \mathrm{NO}$ & P05 & NO & NO & FRIVAT & \\
\hline $612-21-613$ & STRINGTELD AVERJE & TEDESCHI UOHINIE & $215+t$ & $\mathrm{~B}-1 \mathrm{No}$ & Fús & No & No & PEIVAT & 117 \\
\hline $\mid 2-2 z-01$ & CALIFIFRIA STREET & FLAHECTY JARES & 45 & $k-1 N_{0}$ & NO & $N$ & ND & FFIVAT & \\
\hline $612-22-03$ & WYOHENO STFEET & KELLY DARIEL J & 80 & $R-1 N G$ & $\mathrm{Nu}$ & Nó & Nó & $N / \hat{H}$ & \\
\hline $12-2 j-62$ & WYEIHE STREET & LYQNE ESTHEF & 40 & $R-1$ Nü & $\mathrm{NI}$ & NO & No & $N i \hat{H}$ & \\
\hline $6: 2-23-65$ & HYUALE STREET & LEFEFA ALFFED & $225+5$ & h-1 No & $\mathrm{NI}$ & Hil & No & $N / A$ & 141 \\
\hline $612-23-0 E$ & HEDFOES STEEET & DUARINGRFA GEOREE & 40 & $F-1 N O$ & YES & ND & NO & PEIVAT & \\
\hline $612-23-09$ & MEDFOHE STREET & KAGR BAFGAFET & 35 & $\mathrm{~F}-\mathrm{INO}$ & YES & NO & NO & FFIVAT & \\
\hline $612-24-01$ & HIOMIKE STREET & MUQE THQMAS & $230+[$ & $k-1 N \bar{U}$ & $\mathrm{NO}$ & NO & NO & $N / A$ & 120 \\
\hline $12 \overline{2}-24-02$ & SFFINGSIELD AVENUE & FRANEE H.E. \& L. & 20 & $R-! N 0$ & P0S & NC & $\mathrm{No}$ & PFIVAT & \\
\hline $612-24-04$ & SERINGFIELD AVENLE & FEARICE H.E. \& L. & 120 & $\mathrm{~F}-1$ WO & POS & NG & $\mathrm{NO}$ & PRIVAT & \\
\hline $612-24-06$ & SFFINGF IELD AVENLE & TEUESCHI DOKINIC & $250+C$ & $R-1 N 0$ & pos & NG & No & FRIUPT & 104 \\
\hline $612-24-07$ & REDFUFD STREET & BEAULEAU RUEERT & $200+c$ & Fi-1 Na & YES & NO & NO & PEIVAT & 120 \\
\hline $612-2 F_{J}-01$ & MUNTANA STKEET & PALMEF RONFILD & $355+0^{\circ}$ & $\mathrm{F}-1 \mathrm{NO}$ & YES & NE & No & FRIVAT & \\
\hline $612-25-63$ & SFRINGEIELD AVERLE & TEDESEMI DOHIRIC & $360+i$ & $\mathrm{~K}-1 \mathrm{NO}$ & F05 & $\mathrm{NO}$ & NO & PEIVAT & 207 \\
\hline $6: 2-26-02$ & MUKTEKA STFEET & THE PATEKIS TRL'ST & 60 & $B-1 \mathrm{NO}$ & YES & No & NO & PFIVAT & \\
\hline $612-26-64$ & DOUEF STEEET & THEMFSOA DOKALE & 65 & $R-1 N$ & PO5 & No & No & PRIVAT & \\
\hline $612-26-05$ & DEVER STREET & TEDESEHI DOHINIC & 100 & $R-1 \mathrm{~N}$ & Fos & NQ & $\mathrm{NO}$ & PKIVAT & 82 \\
\hline $612-2 t-0 i$ & SFRINGFIELD AVEHIE & TELESEHS DOHIN:C & $255+[$ & $R-1 N D$ & Fus & Nu & NO & PRIVAT & \\
\hline $612-27-05$ & FEFRY STREET & GAREE FHILIF C. & 60 & $\mathrm{~F}-\mathrm{INO}$ & YES & Nó & no & PUBLIL & \\
\hline $612-29-63$ & FERE' STKEET (OFF) & SYLUESTEE A. RAY & NGRE & $R-1 N O$ & NO & No & No & No DIK & 3397 \\
\hline $61 \bar{i}-30-01$ & REÁR MEDFORI STREET & FEARL EVEFETT & $\mathrm{NO}$ & $8-1 N 0$ & Fus & NO & NOt & NUNE & 435 \\
\hline $612-j 0-0 j$ & FERRY STREET & THJUEFE F:CHARO & 40 & $R-1 N O$ & YES & NO & No & FUELIC & \\
\hline $614-01-02$ & FINEHUTET KŪAL & TEDESCHI DOMINIC & 110 & $R-1 N$ & YES & YES & No & FRIVAT & 1790 \\
\hline $614-01-09$ & CHLEREH STREET (REGA) & MLEEHI VICTORINA & NOHE & $\mathrm{F}-1 \mathrm{NO}$ & $\mathrm{No}$ & YES & NO & NO DIF & 9147 \\
\hline $6 i 4-01-i 1$ & CHLFCH STFEET & CRISAFULLI RICHARE C. & NGANE & $\mathrm{F}-1 \mathrm{NOT}$ & NO & VES & NO & PFIVAT & 3740 \\
\hline $614-01-19$ & CHUFICH STREET & GAFEEAL AFTTHUL $\mathrm{J}$ & 125 & $8-1 \mathrm{NS}$ & YES & YES & NO & PUBLIC & \\
\hline $614-0 !-20$ & CHLECH STKEET (KELE) & TEDESCH] DOHINIC & NLAE & $R-1 N O$ & NG & YES & $\mathrm{NO}$ & $\mathrm{N} Q \mathrm{DIF}$ & 2256 \\
\hline $14-6 !-24$ & CHUREH STREET IFEARI & AETHEFIÁ RESEGESH FQUNDRTICN & NLINE & $\mathrm{B}-1 \mathrm{NO}$ & Nu & YES & NO & NO DIR & 65 \\
\hline
\end{tabular}




\begin{tabular}{|c|c|c|c|c|c|c|c|c|c|}
\hline A5. MAP-LOT & LOATIDR & OUNEF OF REC & FRONT & ZON SEM & WAT & HET & FF'A & ACCESE & $A F E A S F$ \\
\hline $615-03-05$ & IDYL WILUE CIFLLE & BOUEKE FAUL D & 117 & $R-1 N[$ & YEE & NO & Nú & PUELIC & 31200 \\
\hline $6: 5-03-10$ & ILYL NILUE EIKCLE & NEE JOSEFH RILES & 118 & $\mathrm{R}-1 \mathrm{NO}$ & YES & No & Nū & PUELIC & 27300 \\
\hline $615-05-15$ & CHIJRCH STFEET & GARCEAU AFTHLI & 125 & $\mathrm{~F}-1 \mathrm{NQ}$ & YES & YES & NO & PUELIE & 297079 \\
\hline $615-05-16$ & CHLFLH ETFEET & GRUSS LESLIE & 125 & $R-1$ No & YES & YES & Ha & FUELIL & 215622 \\
\hline $615-0:-17$ & CHUREH STFEET & GREES LESLIE & 125 & F-1 NO & YES & YES & Ho & FUELIE & 242154 \\
\hline $615-05-19$ & CHUECH STKEET & 6F055 LESLIE & 125 & Fi-1 Nõ & YES & YES & $\mathrm{NO}$ & PUELIC & $31 \leq 60$ \\
\hline $615-05-20$ & CHIFE STREET & FÜLEAF: SARDFENA & 164 & R-! NO & YES & YES & NO & FUSLIC & $52: 7$ \\
\hline $615-0 \pm-21$ & SUPFER STEEET & O'OUNBE:L GEFTFÄH & 214 & $R-1 \mathrm{NJ}$ & YES & $N G$ & Ni & FUELIC & 10018 \\
\hline $6 \pm 5-05-22$ & SLMHEF STREET \{UFF\} & HE!KS OF LUTHEF LITTLE & Nülive & $\mathrm{F}-1 \mathrm{NO}$ & Ho & YE5 & $\mathrm{NE}$ & No 018 & 10454 \\
\hline $615-05-27$ & SLEREA STEEE (QFF) & DOOGKELL BERTFH & WEHE & $\mathrm{F}-1 \mathrm{ND}$ & NU & $\mathrm{NE}$ & Ni & Nu $\left[I F^{\prime}\right.$ & \\
\hline $616-01-02$ & DEEF HILL LANE & ANLEFESN JUHA $F$ & 134 & $\mathrm{~K}-1 \mathrm{NO}$ & YES & $N \bar{E}$ & NO & FLELIC & 3430 \\
\hline $612-65-10$ & FLEROART STKEET & RUEANI ARTHIJK & 120 & $\mathrm{~F}-1 \mathrm{ki}$ & YES & $\mathrm{NL}$ & NO & FLUELIC & $360 !$ \\
\hline $616-64-10$ & STATIGK STEEET & MELCHIONNE ALEEET & 280 & $F-1 \mathrm{NU}$ & YES & HE & Ni & FUELIE & 20010 \\
\hline $516-64-13$ & FLEGSKAT' STREET & Fígfill ABTHER & $520+C$ & $\mathrm{~F}-1 \mathrm{NO}$ & YES & $N[$ & N5 & FLELIC & 3510 \\
\hline $616-04-22$ & PLEAEFIT STREET & FLAHDERS HLAARE & 389 & h-1 Ni & YES & N5 & NO & FUE:IL & 17424 \\
\hline $616-07-10$ & SUPHEF STKEET & BANAEF EATL & $250+[$ & $F-1 N O$ & YES & Ni: & NO & FLLELIC & 1156 \\
\hline$E: 0-0 E-12$ & SURYEF STREET IOFF: & WAFEEN EGREALA & NONE & $\mathrm{F}-1 \mathrm{HJ}$ & $\mathrm{Ni}$ & YES & YES & NE OIF: & 520 \\
\hline $616-68-50$ & SHLI KEADLN & BEFETE DIARKE & HERE & $\mathrm{R}-1 \mathrm{NI}$ & No & YES & YES & No $4 I \pi$ & 65340 \\
\hline $617-01-01$ & SUMAER STKEET & WILLIAHS BRITHERE & - & $\mathrm{K}-1 \mathrm{NO}$ & YES & $\mathrm{NJ}$ & $\mathrm{N}[$ & PLELIL & 10505 \\
\hline $6 i j-02-17$ & FINE ISLANS & PEAFL EVEFETT & NOHE & F-1 NE & NO & YES & YEE & NO DIK & 17424 \\
\hline $617-02-15$ & FINE ISLAND & KAWA JEFEY & NGWE & $\mathrm{F}-1 \mathrm{NE}$ & NL & YES & YES & NO OIF. & 29620 \\
\hline $61 \bar{b}-i)-(01$ & TILUERS ISLARE & COHEAHNUN EFIAK & AUNE & $\mathrm{F}-1 \mathrm{NO}$ & NO & YES & YES & NO DIR & 39204 \\
\hline $6 ! 8-02-02$ & TILIEKS ISLANO & LYGNE GEURGE & HUNE & $\mathrm{k}-1 \mathrm{~kJ}$ & NO & YES & YES & 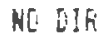 & 65340 \\
\hline $619-02-04$ & TRUUAKTS ISLAKR & SUNES LCUIS & NQRE & $\mathrm{F}-1 \mathrm{NJ}$ & YES & P05 & YES & NO DIK & 8706 \\
\hline Ho4-01-06 & MOFAIKE STREET & RAKSS SUE & 47 & $\mathrm{~F}-1 \mathrm{H} 5$ & YES & $\mathrm{NO}$ & NO & FUELIC & 45560 \\
\hline $404-01-0 \bar{c}$ & WIKGINE STREET (UFF) & CLIGEET JOHK & NONE & Fi- 1 No & NO & No & No & NO DIR & 241756 \\
\hline$H: 5-01-22$ & MDFF!HE STFEET & MERAINE REALIY TKUST & be & $\mathrm{R}-1 \mathrm{No}$ & YES & YES & NO & PLE:IC & 16E! \\
\hline $465-61-23$ & NOSAINE STREET & MUFAIAE REA TY TRUST & 300 & $\mathrm{R}-1 \mathrm{NO}$ & YES & YES & $N^{[j}$ & PUELIC & 818928 \\
\hline$H 6=-04-14$ & PARSUKAEE ETSEET & MCLLUSKEY GERALD & 50 & $k-1$ NG & YES & $\mathrm{NO}$ & NO & PULELIC & 161600 \\
\hline$h i t-02-20$ & FEVFIELL BOAS & SHAL:EY GEFALDIKE & 120 & $E-1 \quad A]$ & YES & $N E_{3}$ & NL & FLELIE & 2150 \\
\hline Hot-03-12 & HHIFFLETEEE LAKE & MULLEN LUMBEE COMFANY & $248+\bar{i}$ & $\mathrm{~F}-1 \mathrm{~N}$ & YES & YES & NO & FUELIS & 840 \\
\hline$H 66-04-01$ & PAESUNASE STKEET & HAREOESIDE REHLTY IHE. & 50 & $K-1$ NE & YES & Nu & NO & PUBLIC & $5: 272$ \\
\hline $\mathrm{Hut}-04-\mathrm{CZ}$ & PARSQHABDE STREET & HAREULSSIDE REÁLTY IKC. & 50 & F-1 NO & YES & No & NO & FUE:IC & 47916 \\
\hline$H 06-04-03$ & PARGORGSE STREET & HAFBOEEIDE REALTY INE. & 50 & Fi-1 N N & VES & Ni] & NG & PUELIC & 4791 \\
\hline Hot-04-04 & PAFSOHAEE STKEEI & NAZIAFIO FETEF & 210 & $\mathrm{~F}-1 \mathrm{Ne}$ & YES & NO & NO & PUELIC & 5227 \\
\hline Kob $-64-10$ & WHIFFLETFEE LAHE & MULLEN LUMEER COMFANY & 131 & R-1 Nu & YES & PES & NO & FUE:IC & 20817 \\
\hline HOt-04-11 & WHIFFLETFEE LAHE & MUJ!LEN LUAEER CO. & 131 & $R-1$ NI & YES & $\mathrm{F} 05$ & NO & FUELIC & 2107 \\
\hline$H 0 t-14-12$ & WHIFFLETREE LAKVE & MULLEN LUMEER CORFAN! & 127 & R-1 NE & YES & F05 & NO & PUBLIC & 1050 \\
\hline $1066-04-19$ & SUFFEY ROAD & MULLEN LUMBEF CORFAHY & 190 & $\mathrm{~K}-1 \mathrm{Ni}$ & YES & NG & $\mathrm{NO}$ & FUE:IL & 2005 \\
\hline$H(1)-05-04$ & WHIFFLETKEE LARE & MULLER LUMBER CCMFARI' & 120 & $5-1 \times 0$ & YES & YES & NE & FUELIS & 2480 \\
\hline Hoo $-05-12$ & FIDING CFOE LAKE & MUJLLEN LUMBEF' CO. & 120 & fi-1 No & YES & YES & NO & FUELIL & 2004 \\
\hline $466-65-13$ & FISINS CFOF LANE & MULLEK LUMEER CO. & 120 & $\mathrm{R}-1 \mathrm{Nu}$ & YES & YES & Nin & PUBLIC & 2004 \\
\hline$H 0 t-05-14$ & RIOINE CFOF LANE & MLLLEN LUMBER' CL. & 120 & $\mathrm{~F}-1 \mathrm{NO}$ & YES & YES & HO & FUÉ $L I C$ & 2004 \\
\hline$H 66-05-15$ & RIDING CRUY LANE & MULLEN LUMEEF' CO. & 120 & $\mathrm{~F}-1 \mathrm{~N} 0$ & YES & YES & $\mathrm{NL}$ & FUELIC & 2004 \\
\hline $406-05-16$ & RIDINE CFUF LANE & MULLEN LUMEET CO. & 120 & $\mathrm{~F}-1 \mathrm{NO}$ & YES & YES & NO & FUELIC & 2004 \\
\hline $\mathrm{H} 06-05-17$ & FICINS CRDF LAHE & MULLEN LUHBEF CO. & 120 & Fi-1 NO & YES & YE5 & No & FUELIC & 2108 \\
\hline Hot $-05-18$ & RIDING CFOF LAIIE & MULLEN LUMEEF? CO. & 110 & $R-1 N \bar{U}$ & YES & YES & NE & PUÉLIC & 2017 \\
\hline$H 06-05-19$ & RIDINS CKÜF LANE & MLLLEN LUMEEF CU. & 110 & $\mathrm{~F}-1 \mathrm{~N}[\mathrm{I}$ & YES & YES & No & FUELIC & 2000 \\
\hline$H 06-05-20$ & RIEING CKOF LANE & MULLEN LUMEEF' CO. & 110 & $\mathrm{R}-1 \mathrm{NO}$ & YES & YES & NO & PUELIC & 2496 \\
\hline $406-05-21$ & RIDING CFUF LANE & MULLEEN LUMEEF: CE. & 110 & $\mathrm{~B}-1 \mathrm{NU}$ & YES & YES & NO & PUELIE & 2142 \\
\hline $406-05-22$ & RIDINE CFDF LANE & MULLEK LLMEET̃ CO. & 130 & $5-1 N 5$ & YES & YES & NO & PUELIC & 2070 \\
\hline $60 t-05-23$ & MATINGSLE LANE & MÚLLEK LUMEER EO. INE. & $155+5$ & $R-z N 0$ & YES & No & NO & PEIVAT & 2003 \\
\hline$H 06-05-24$ & WHIFFLETKEE LÁHE & MULLEH LUMEEE COMFANY & 292 & $\mathrm{R}-1 \mathrm{NO}$ & YES & YES & NO & PUELIC & 2241 \\
\hline
\end{tabular}




\begin{tabular}{|c|c|c|c|c|c|c|c|c|}
\hline 5. Rin & LOCGTIER & URMER QIF FEL & FFiGkT & & & FF'ti & ACCESS & AGEA SF \\
\hline$t-65-2 t$ & HHIFFLETREE LANE & PLLLEN LUMEER CO. & 120 & $F-1 N D$ & YES FUS & $\mathrm{Ni}$ & FUELIC & 20640 \\
\hline $6-05-2$ & WHIFFLETEEE LANE & MLLEN LUMEET COMFANYY & 120 & $F-1 N E$ & YES YES & NO & FUE:IE & 20040 \\
\hline $0-65-28$ & WHIFFLETKEE LAKE & MULEEN LUEER COMPFAKY & 120 & $\mathrm{~B}-1 \mathrm{NO}$ & YES POS & No & PUELIC & 20040 \\
\hline $66-(65-3)$ & WHIFFLETREE LARE & MILLEN LUMEEF, COMEANY & 70 & $\mathrm{~B}-1 \mathrm{NO}$ & YES YES & NO & PUELIC & 87120 \\
\hline $6-(60-i)$ & RIDINE CFOF LANE & MULLER LUMEET Co. & 140 & $\mathrm{~K}-1 \mathrm{NU}$ & YES NO & NO & PUELIC & 20050 \\
\hline $6-0 t-0 z$ & RUINE CFO LAHE & MII_LEK LUKEEE CŨ. & 120 & F-INU & YES NO & NO & PUELIC & 20040 \\
\hline $6 t-0 t-03$ & RIOINE CFO LANE & MULLEN LUMËER CẼ. & 120 & $k-! N u$ & YES NE & Ho & PUELIC & 20040 \\
\hline $6 t-6 c-104$ & RIIING CRLE LARE & MULIEN LUMEEŔ LU. & 120 & $\mathrm{~F}-1 \mathrm{NiJ}$ & YES NU & NO & FLELIC & 20040 \\
\hline $4 t-i t-65$ & FIUINO ChI LANE & MULLEN LUMEER CO. & 120 & $\mathrm{~F}-1 \mathrm{NO}$ & YES NU & No & PUELIC & 20040 \\
\hline$H(6 b-16-60$ & RIJING CART LARE & MULLEN LiKGER CU. & 120 & $\mathrm{~F}-1 \mathrm{NO}$ & YES NJ & NO & PUELIC & 20760 \\
\hline $100-06-07$ & RIUIhG CRGP LANE & MULLEN LLMEEF: CO. & 127 & $\mathrm{~F}-1 \mathrm{No}$ & YES NO & No & PUELIC & 21390 \\
\hline Hot-jo-0E & RIDING CROF LGNE & MULLEN LUMEERE CO. & $14 \%$ & $\mathrm{~F}-1 \mathrm{NG}$ & YES NO & $\mathrm{NO}$ & FUELIC & 21922 \\
\hline$H u b-06-69$ & RIUINE CRGF LAME & MLIELEN LUMEER CU. & 142 & $\mathrm{~F}-1 \mathrm{NO}$ & VES NO & NO & FUELIC & 21922 \\
\hline$H 6 b-60-10$ & RIOINE CFIF LANE & MLLLER LUMEES CO. & 158 & F-1 NO & YES NO & No & FUELIC & $2034 t$ \\
\hline Hite-ib-11 & FITEAE CFIF LANE & MULLER LUMGEF CO. & 143 & $\mathrm{R}-1 \mathrm{No}$ & YES YES & No & FUELIC & 20177 \\
\hline hit $t-0 b-11$ & MAFTIKOGHEE LARE & MULLEN LUNEER IU. INC. & $200+c$ & $\mathrm{~F}-2 \mathrm{NO}$ & YES NU & N[I & PFIUET & 20204 \\
\hline Hog- $-t-12$ & MATTINESLE LANE & RLLLEN LUMEEF CO. ThE. & 169 & $\mathrm{~F}-\overline{2} \mathrm{~N}[\mathrm{I}$ & YES NO & No & FFIVAT & 20015 \\
\hline $6-05-13$ & RARTINGALE LANE & HULIEN LUM: & 120 & $5-2 \times 0$ & YES ND & Nü & IVAT & 23703 \\
\hline$t-0.06-15$ & METTINGAL & R CO. INC. & 127 & $\mathrm{~F}-2 \mathrm{NO}$ & YES NO & No & IVAT & 65340 \\
\hline $6-0 t-1 t$ & MAF IINGELL & I. INE. & 171 & $\mathrm{~F}-2 \mathrm{~N} \mathrm{Ni}$ & YES NO & NO & IVATT & 22568 \\
\hline $6-06-17$ & MAETLKGHLE LA'E & C. INE. & 1 है & $\mathrm{H}-2 \mathrm{NO}$ & YES NO & No & FRIVAT & 20097 \\
\hline $6-05-16$ & MARTINGALE LALE & Mo. & 135 & $\mathrm{~K}-2 \mathrm{NI}$ & YES NO & NO & FRIVAT & 20016 \\
\hline $6-06-15$ & MAETIKLA & Tir & 15 & $\mathrm{~F}-\mathrm{i} N \mathrm{NE}$ & YES NO & NI & PEIVHT & 20004 \\
\hline $0-0 \leq-20$ & KAETIIHOHL & . In:. & 132 & $\mathrm{~K}-2 \mathrm{HO}$ & YES NO & k5 & PFIVIAT & 20003 \\
\hline$t-6 t-21$ & HTIFFLETFEE LA'YE & HLLEN LUHE & 120 & $\mathrm{~F}-1 \mathrm{NL}$ & YES YES & $\mathrm{N} \cdot$ & PUELIC & 8400 \\
\hline Hin? $7-6:-617$ & GOEAN ETAEET & $\rightarrow 0$ & 75 & $B-1 N 5$ & YES NII & NO & BLIC & 15706 \\
\hline$H 07-0,3-02$ & STKATTON AVENEE & 61 & 50 & $E-1 N 0$ & YES $\mathrm{NE}$ & $\mathrm{NG}$ & FUE IC & 4750 \\
\hline $\mathrm{Hii}-64-14$ & WEEETER STREET & TFLST & 135 & $\mathrm{~B}-1 \mathrm{NO}$ & YES FUS & No & PUE:IC & 28150 \\
\hline $\mathrm{Hic7}-04-20$ & QLERI STREET & FETFUCELLI & 30 & $E-2 N[$ & YEE NO & $\mathrm{NO}$ & FUELIC & 3948 \\
\hline $607-64-35$ & MSTHINE & MLREEVEF GEUTEE & 99 & Fi-1 ki & YEE FOS & Ní & FUELIE & 20500 \\
\hline$H 017-05-68$ & WEESTER 5 & RAESHEIELD PLAD & NBME & E-1 FDE & $\mathrm{FOE} \mathrm{NO}$ & NO & NG UIF & $24: 15$ \\
\hline$H 07-05-16$ & WEESTER S & HOUEINE FOK II & NOWE & $\mathrm{B}-1 \mathrm{NO}$ & Ho NO & YES & NÓ DIK & 403801 \\
\hline $\mathrm{HOT}-0.5 \mathrm{5}-17$ & WEESTER S & ROCK REALTY T & 450 & $\mathrm{E}-1 \mathrm{NO}$ & YES NO & $N[$ & FUBLIC & 46600 \\
\hline$H 0 \bar{i}-6.5-18$ & WEEETER̈ 5 & FÜLK REALTH TFLST & NII & $B-1 N O$ & NO YES & NO & NI DIR & 106900 \\
\hline $406-62-05$ & SOITH RIVER STREET & FEATT & NUENE & Fi-1 NO & POS POS & Fus & NU DIR & 130680 \\
\hline$H 05-03-01$ & OCEAN STREET & BAKEA E & 71 & $\mathrm{~B}-1 \mathrm{NO}$ & YES YES & YES & FUELIC & 227000 \\
\hline$H(E-64-6)$ & QCERH STFEET (OFF) & PFATT MATHER \& MAEIA & NLNE & $\mathrm{E}-1 \mathrm{NO}$ & NU YES & YES & No UIR & 21850 \\
\hline $\mathrm{HCOB}-04-64$ & OCEAH STREET & RUGAV: AFT & 20 & B-1 NI & FOS YES & YES & PUELIC & 76230 \\
\hline$H(15-34-34$ & OCEAR STREET (KEARS) & WUOLLARE EN & NOAEE & E-1 NÜ & NO YES & YES & NO DIF & 78408 \\
\hline HGE-04-1i & QCEAN STREEI & NAGDURE CHAGRLES & NONE & $E-1 N D$ & NO YES & YES & NE BIR & 11028 \\
\hline$H 0 E-014-12$ & UEEAK STREET & BüL RonimLO & 110 & $B-1 N O$ & YES YES & YES & FUELIC & 47916 \\
\hline KOE-04-14 & CLEEAN STSEET & MOELLAND ENTEFFKISES & $2 \overline{8}$ & $\theta-1 N 0$ & PUS YES & YES & Hi DIR & 20000 \\
\hline$H(5-01-i):$ & S. RIVER ST. (REAGI) & EALE AFTHUA & NOKE & $R-1 N 0$ & NU NO & No & NO DIF & 87126 \\
\hline $109-02-0)_{2}$ & SOLTH RIVEF STREET & 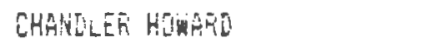 & 1100 & $k-1 N O$ & YES YES & YES & $N D D I K$ & $114 E 770$ \\
\hline$H 10-02-01$ & SOUTH RIVEF SREET & h. UEMHITES. CONETRUCTION CO. & NUNE & $R-1 \mathrm{NO}$ & YES YES & YES & No bif: & 1637950 \\
\hline$H 10-02-0.5$ & 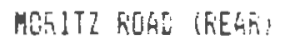 & SCHELZ JHEK & NULEE & $\mathrm{ki}-2 \mathrm{NO}$ & YES YES & NO & HU UIF & 93216 \\
\hline $110-01-07$ & METITI RLED & SELT WHNSS DEVELOFHENT CORE. & 300 & $k-\bar{z}$ NE & YES YES & NO & PUELIC & 27000 \\
\hline$h: 1-01-0 a$ & FHILIF STREET & ER A RÁY IHE. & 100 & $\mathrm{~K}-1 \mathrm{No}$ & POS NO & NO & PEIVAT & 65340 \\
\hline$H 11-6 i-013$ & PHILIF STKEET & SYLVESTEF: Á. FAY INE. & 100 & Fi-1 ND & FUS NE & NO & PRIVAT & 21780 \\
\hline $011-0:-04$ & PHILIF STEEET & & 100 & $R-1 k$ & $\mathrm{FOSNO}$ & No & PKIVAT & 18650 \\
\hline$H 11-02-01$ & FÄFK STREE & SILYEETEF A. FÁA & 406 & R-I NO & VES NO & $k[$ & PUELIC & $7405 \overline{5}$ \\
\hline $111-34-10$ & GRLVE STREET & TAGEAFT VALENTINE & 160 & Ri-1 NU & & NO & FUELIC & 19925 \\
\hline$H: 1-04-11$ & GRUUE STREET & FEFE CAE C CHAELES & $35+5$ & H-I NE & YES NE & $\mathrm{Ni}$ & FUE:IC & 4350 \\
\hline
\end{tabular}




\begin{tabular}{|c|c|c|c|c|c|c|c|c|c|}
\hline S. KAF-LET & LOEFIISN & OWHEE OF REC & FFGLIT & ZUN SEH & HAT & HET & FF'A & ACLESS & AREA \\
\hline & & & & & & & & & \\
\hline$H 11-04-17$ & PHILIF STAEET & MARSHFIELU SAME \& SRTAVEL & 500 & $\mathrm{~F}-1 \mathrm{NE}$ & FUS & NO & NO & FFIVAT & \\
\hline$H i 1-64-18$ & MYFTLE STEEET & STLUESTEF A. RÁY IRL. & 701 & R-1 Nō & YES & Nī & No & FEIVAT & \\
\hline$H 11-04-20$ & GROVE STREE & ANDEEWS LAURA & 20 & $h-1 N 0$ & YES & NG & NO & FiB:IC & \\
\hline$H 1 j-6 E_{-}-i j$ & ELAY FIT BLE (OEF) & SLYEETER R. RHE IRL. & NONE & $\bar{n}-1+1$ & $\mathrm{NS}$ & NO & No & & \\
\hline$H 1:-05-02$ & CLAS FIT KD/GFIUE ST & TAEGAFT VALLENTINE & 400 & $R-1$ NO & YES & No & NO & JELIC & \\
\hline$H i l-05-0 j$ & FIVE STREET & FHoE THumine $F$. & 360 & H-1 N5 & YES & NU & NO & UELIC & \\
\hline$H_{i} 1-0 E_{1}-1.4$ & CLAY FIT RUAL IDFF? & SYLVESIEF A. FIAY INL. & NUNE & $\mathrm{F}-1 \mathrm{Nu}$ & NO & NJ & $\mathrm{NO}$ & NOO DIF & \\
\hline$H ! 1-4 t-12$ & SHIYEFHL FILEE FJAE & MALEY LFHIL & $310+5$ & F-! NU & YES & NO & No & PUSLIC & \\
\hline$H 1:-6 e-15$ & GRUVE STEET & TEDESCH! REAL'Y CUEF. & 300 & $\mathrm{~F}-1 \mathrm{NO}$ & YES & $\mathrm{NO}$ & Nô & UHL & \\
\hline$H i j-0 b-14$ & SFJEERLL FIDGE RUHL & TELESCHI REHLIY CORF. & 130 & $R-1 N O$ & YES & No & NO & & \\
\hline$-0 \leq-22$ & SHCREHILL RIEGE FURE & 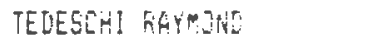 & 125 & $R-1 N$ & YES & $\mathrm{Ni}$ & $N 0$ & FUELIC & \\
\hline $06-24$ & HOEHICL RTSE RUAL & FITIEIEEUKS CHAR ES & 172 & $\mathrm{R}-1 \mathrm{NI}$ & YES & Ni & No & PUELIC & \\
\hline$-6 t-29$ & SPRERTLL RIDEE RGHE & TEDEETH REALY & 210 & $\mathrm{~K}-1 \mathrm{NO}$ & YES & $\mathrm{NG}$ & Hi & JELIL & \\
\hline$-16-32$ & HIEH BELCAN WLE & TELESEMI REETY COFF. & 50 & $5-1$ NO & YES & $N[:$ & Nuj & PEIVAT & \\
\hline$-6 t-33$ & HIGU BERCOU KS:E & TEIESLMI REALT COJEE. & 100 & R-1 NO & YES & NE & $\mathrm{M} 5$ & & \\
\hline $6 t-54$ & HOH BEALAS WAYE & TEIESLHI REALI' CURF. & $12 u+r$ & $F-1 N G$ & YE5 & NO & NO & IVAT & \\
\hline $0 t-35$ & 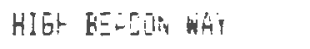 & TELESLHI REALAY LERE. & $100+[$ & $\mathrm{F}-1 \mathrm{NO}$ & YE5 & $\mathrm{No}$ & NO & PFIVHT & \\
\hline $06-30$ & HISH BEAELA WFYE & TEIESEHI REALIY CJFY. & 120 & $R-1 \mathrm{NO}$ & YES & $\mathrm{HO}$ & NO & & \\
\hline $0-37$ & HES EEREUN WRIE & TEDESTHI REALTY COFF. & 100 & $R-: N[i$ & YES & NO & $\mathrm{Nū}$ & & \\
\hline$-06-.38$ & HIGH BEA.UN WAY & TEDESCHI REALIY CORF. & 100 & $k-1 N$ & YES & NO & Noj & PKIVAT & \\
\hline$-06-39$ & HISH EEACOA HAYY & TEDEJCHI RAELTS CCRF. & $12 E$ & K-1 ND & YES & $\mathrm{NJ}$ & $\mathrm{Ni}$ & & \\
\hline$(66-40$ & SHJKEHILL RIGOE ROAAD & WHITCHURLH DKRKE & $305+C$ & R-1 NE & YES & $\mathrm{Nu}$ & No & & \\
\hline$H ! 1-06-43$ & GRTVE STFEET & FA6E THUMAE & 48 & F-1 NO & YES & $\mathrm{NL}$ & NE & & \\
\hline$-01-00$ & GRCUE STFEET & DUEJIS EDHASE A. & 236 & $\mathrm{~F}-1 \mathrm{NO}$ & YES & MŨ & Nü & & \\
\hline$-01-07$ & CLAY PIT RUÁ (CFF) & SHLVESTEF A.FAY INL. & NITHE & Fi-1 NO & $N \overline{0}$ & Hig & NE & & \\
\hline$H(25-62-0)$ & GLCVE STFEET & FLFGE JUHA R. & 106 & $R-1 \mathrm{NU}$ & YES & Ní & No & & \\
\hline $112-02-014$ & GPDVE STREET & FLAEG JUHN II. & 80 & Fi-1 NG & YES & $\mathrm{HC}$ & Nó & ELIC & 936 \\
\hline$H 12-02-16$ & GEEVE STFEET & HATHINE CATHERINE & 61 & $\mathrm{~F}-1 \mathrm{~N}$ & YES & ND & NO & & \\
\hline $2-17$ & SMIKEHILL FIDGE FOAS & TELES & 121 & $R-1 N J$ & YE & NO & No & & \\
\hline$H: 2-02-8$ & 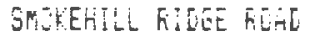 & ECHOINUITY FEHL' & 125 & $\mathrm{k}-1 \mathrm{~kL}$ & YE5 & NŨ & NO & FUELIC & \\
\hline$H 1 \bar{O}-0 \bar{Z}-0 \mathrm{i}$ & SILVEFEIRLT ROHL & FOETER COKETRJLT & 150 & $k-1 \mathrm{ki}$ & Fūs & $\mathrm{HO}$ & Nū & VAT & \\
\hline $02-3$ & HOL'Y FOAS & FQETEK CONSTFLET & 150 & $\mathrm{~F}-1 \mathrm{NO}$ & YES & Ho & NO & & \\
\hline $\mathrm{HiJ}-0 \mathrm{2}-0 \mathrm{j}$ & HELLY TELÁL & FOSTEF CONETEICT & 153 & Fi-1 No & YES & NJ & NO & & \\
\hline$H 15-0 i-08$ & CHURCH STREET & DAVIS BESSIE & 317 & $R-1 N 0$ & YES & NO & NO & PUELIC & 3092 \\
\hline $1,3-02-20$ & FEFKT STH & T.F. CABRELL CORF'. & 141 & $k-1$ NU & YES & NE & $\mathrm{NO}$ & & \\
\hline $6 i-25$ & FEREY STF & AEENA JQHN & 50 & $R-1 N[1$ & YES & NO & Nũ & & \\
\hline $113-03-04$ & FESTH STREET & MAEIUK FEALTH TFUST & $B 6$ & $R-1$ NO & YES & NO & ND & FUSLIL & 2553 \\
\hline $6-60$ & FEFE: STFEEI & KENKED IEA: & 120 & R-1 NO & YES & No & NO & FUELIC & 200 \\
\hline $0.3-09$ & ERUVE STEEET & TEDESCHI REALTY & NINE & Fi-1 NG & YES & $N 5$ & NE & & 24039 \\
\hline $0 \bar{j}-14$ & FERT STREET & CONLON RUEETT F. & 160 & F-1 NO & YES & No & $\mathrm{NO}$ & PUBLIC. & \\
\hline $03-15$ & FEFKT STKEET & HOREFICK GHENOLYK & 100 & R-1 ND & YES & NO & NO & FUELIC & \\
\hline $61-61$ & HGLLY GGS & FOSTEK CONSTFULTIOK CORF. & 157 & $R-1 \mathrm{Ni}$ & YES & NG & NO & FFIVAT & \\
\hline$H 14-01-02$ & HCLLY FJSAL & FESTER COHETRLITIOH CUFE. & $156+i$ & $\mathrm{~F}-1 \mathrm{Ni}$ & YES & NO & $\mathrm{HO}$ & FRiv & \\
\hline$H 14-02-01$ & SILYEFEISIZH RLAD & FOSTEF CONSTRLLTIDN COFE. & 150 & $\mathrm{~F}-1 \mathrm{NE}$ & YES & $\mathrm{Ni}$ & NO & PFIVAT & \\
\hline $\mathrm{H} 14-62-02$ & SILVEFEIRLH FÜAL & FUSTER CONSTRLCTION COFF. & 150 & $R-1 N \Gamma$ & YES & $N[$ & HO & & \\
\hline$H 14-(2-1) ?$ & SULVERTRCH RQAD & FOSTER CONSTRUCTION CERF. & 150 & $R-1$ No & P05 & Ni] & No & PRIVAT & \\
\hline$H: 4-02-04$ & SILVEFEIFEH RUÄI & FESTER CONSTRLTTIOUN CORF. & 150 & Fi-1 No & YES & NO & No & PRIVAT & \\
\hline$H 14-02-65.4$ & SILVEFETKCH FIAD & FOSTER CONSTRULTIOK COEF. & 150 & $\mathrm{~F}-1 \mathrm{ND}$ & F05 & $\mathrm{NJj}$ & NO & PRIVGT & \\
\hline$H 14-02-06 F^{2}$ & SILVERBIRLH ROAL & FESTER CONSTRULTIÜN COFF. & 150 & R-1 NO & POS & No & NO & PFIVAT & \\
\hline$H 14-132-077$ & SIIVEFEIR̃LH ROHO & FUETER CONSTFUCTION CORF. & 150 & $R-1 N E$ & YES & NO & NO & PFIVAT & \\
\hline$H 14-02-08$ & SILVEREIRUH ROHD & FQSTEF COHSTRLLTION CORF. & 150 & Fi-1 NO & YES & ND & NO & PFIVAT & \\
\hline$H 14-02-09$ & SILVEFEIS̃H RIJAD & FOSTEF CQNSTRULTIUR CORF. & 150 & $\mathrm{~F}-1 \mathrm{~N} 0$ & YES & No & No & PRIVAT & \\
\hline$H 14-0 ;-10$ & SILVEFEIRLO FUAD & FESTER COHETRULTILN COFF. & $453+C$ & $R-1 N u$ & YES & NÖ & No & PFIVAT & \\
\hline
\end{tabular}




\begin{tabular}{|c|c|c|c|c|c|c|c|c|c|}
\hline S. MnE-LOT & LOETISH & OWNEF: OF REC & FBLAT & Zof SEH & WAT & WET & FFH & ACEESS & AHEA $5 F$ \\
\hline & $\ldots \ldots$ & & & & --- & & & & \\
\hline $02-!:$ & BAYEFEI DFIVE & FOETER CURETRULTIOR CORF. & $360+c$ & $R-1 N$ & No & NO & NB & $\mathrm{N} / \mathrm{A}$ & 43500 \\
\hline $14-G \bar{Z}-: Z 2 A$ & HOLLLY ROEO & HoFiIILSUR UJHN & 150 & $\mathrm{~F}-1 \mathrm{NL}$ & YES & $\mathrm{Ni}$ & Ni & FEIVAT & $45=0$ \\
\hline $4-0 Z-17 \hat{H}$ & HüLL: RUGHi & FGSTEF CUNSTFUETIOK CJKF', & 150 & $R-1$ NJ & YES & NO & No & FEIVAT & 3500 \\
\hline $4-02-1 \bar{B} A$ & Hi:LY READ & FOSTEF CQNETRULTILN CORF. & 150 & $\mathrm{~F}-\mathrm{NE}$ & VES & Hiv & NG & FFIVHT & \\
\hline $4-\theta_{i}-19 \xi^{\prime}$ & HELL GOAC & FOSTER CURSTKUSTIION CORF. & 75 & $-1 \times 0$ & YES & No & NO & PFIVAT & \\
\hline $4-63-65$ & EHEERET InUE & FOETES CJNETRETIUN COSE. & 150 & $\mathrm{Fi}-1 \mathrm{No}$ & N! & $\mathrm{HL}$ & Nü & $N A$ & \\
\hline $4-09-6=$ & EAEERPY DEIVE & FUSTEF CEASTRUTTIOH COFF'. & 150 & Fi-1 NO & NO & No & NO & $N / A$ & 560 \\
\hline $4-8-87$ & EAEESFY DEIVE & FOSTEF CORETFOCTION COFF. & 150 & $\mathrm{Fi}-1 \mathrm{NO}$ & NO & NO & NO & NiA & \\
\hline $4-1 \bar{j}-\hat{E}$ & EAREESET DFILE & FUSTEK CONETKUEIOA COKF. & 150 & $\mathrm{~F}-\mathrm{NO}$ & No & NO & NO & $N / A$ & \\
\hline $4-6 j-65$ & GAREGET LEIVE & TRULTIUHA CORF. & 150 & $\mathrm{R}-1 \mathrm{NO}$ & NO & No & 10 & $\mathrm{~N} / \mathrm{H}$ & \\
\hline $4-6-10$ & AEERER DRIUE & FOSTER CONETRULTIOK CORF. & $300+i$ & $\mathrm{~F}-1 \mathrm{NO}$ & Nō & NO & $\mathrm{NO}$ & $\mathrm{N} / \mathrm{A}$ & \\
\hline $4-0-11$ & BIFERE FUAL & FOSTEF CONETFUCTIUN CUEF. & 150 & $R-1 N J$ & NJ & NO & $\mathrm{N}[$ & $N / A$ & \\
\hline $4-0 .-2$ & 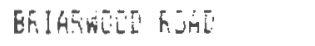 & FGSTEF CURETFULTIOK SUFF. & 108 & $\mathrm{Fi}-1 \mathrm{NO}$ & NE & Nō & Nū & N/h & \\
\hline $44-84-01$ & AYEETE LATIVE & CoRSTRULTICH COFF. & 162 & $\mathrm{~F}-1 \mathrm{NOI}$ & NO & NC & NO & NiA & \\
\hline $4-4-6$ & BALEERT DFIVE & GEFFULTIUU CÚF. & 162 & $R-1 N G$ & Nu & $\mathrm{Ni}$ & vo & & \\
\hline $4-(14-1) 3$ & BAABEEAY DEDV & FUSTES CORETRULTIOR COFF. & 162 & Fi-1 ND & NO & $\mathrm{Ni}$ & H. & & \\
\hline $4-4-4$ & 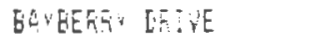 & FUSTER CUNEFTULTIUN CURF̆. & $14 \hat{v i t}$ & R-1 Nî & Nīj & $\mathrm{Ni}$ & NO & $N / A$ & 30 \\
\hline $4-64-65$ & BATEEFF, QREIVE & FESTER COKETRLU: & $145+C$ & $\bar{B}-1 \mathrm{~N}[\overline{\mathrm{L}}$ & NŨ & NS & No & & \\
\hline $4-014-06$ & BAHEERT LADE & FUSTER CQNSTKLL & 163 & $\mathrm{~F}-1 \mathrm{NO}$ & No & $\mathrm{N} L$ & KE & & \\
\hline $4-64-6 ?$ & BEYEEFF DR:VE & FUETEF CONSTRLLTILE CEFP. & $16 j$ & R-! NU & NO & NE & NO & $\hat{A}$ & 435 \\
\hline $14-34-65$ & SILVEALAR FUTA & FGETES CONETRLITINA CGEF. & $454+[$. & $\mathrm{B}-1 \mathrm{NG}$ & YES & No & No & FEIVET & \\
\hline $1: 4-04-07$ & SILUEEIFH RTAS & 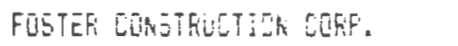 & 150 & $\mathrm{H}-1 \mathrm{~N} U$ & YES & $\mathrm{NL}$ & H. & PEIVAT & \\
\hline $4-04-10$ & SILVEFEIRTE FULD & FUSGER CGINGT & 150 & $R-1 N U$ & YES & $\mathrm{MI}$ & Nũ & & \\
\hline $14-54-11$ & SIUVAESREH RUAL & FUSTEF CUKETRULTIOK CORE. & 15 & $\mathrm{~F}-1 \mathrm{NO}$ & YES & NO & NÒ & FEIVIST & 435 \\
\hline $4-04-: 2$ & SLLVESEIÁLH RIHE & FUSIEP CUNST & 150 & $\mathrm{H}-1 \mathrm{NU}$ & YES & $\mathrm{No}$ & $\mathrm{NC}$ & PEIVET & \\
\hline $25-64-13$ & SiLVEATEST & FÜSTEK CUNETKU & $15 !$ & $F:-1 N O$ & Yes & $k_{-}^{\pi}$ & NO & & \\
\hline$H: 14-04-14$ & SILVEFEIREH FOLL & FOSIEK CÜRSTEUL & 150 & $\mathrm{R}-1 \mathrm{NO}$ & YES & Mij & No & FEIVAT & 4356 \\
\hline$H: 4-04-15$ & 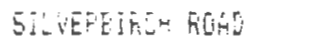 & FUSTEF CENET & 150 & $\mathrm{Fi}-\mathrm{I} N \mathrm{~N}$ & YES & $\mathrm{NL}$ & NO & PRIVAT & \\
\hline $514-04-15$ & SILVERSIRLH BEGL & FLSTEF CUASTI & $15:$ & $\mathrm{k}-1 \mathrm{NI}$ & FLi & NL & nit & & $4 j 5 t$ \\
\hline $144-6-17$ & SILVESDRCI RLA & FGSTER COKETRLETIU: LOFF. & $15 \overline{5}$ & $\mathrm{~F}-\mathrm{INO}$ & YES & $\mathrm{kit}^{-}$ & $\mathrm{NO}$ & Finluet & 4350 \\
\hline Hin $14-64-1 E$ & FEARY STAEET & 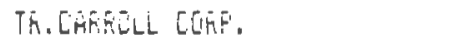 & $125+$ & $\mathrm{F}-1 \mathrm{NL}$ & YEj & HO & Nũ & Fuétic & 26700 \\
\hline H:J-0i-09 & CKLFCH STREET IFEAF: & SVLVESTEF FHIL & NONE & $\mathrm{R}-1 \mathrm{NO}$ & $\mathrm{NO}$ & YES & YES & N & 08 \\
\hline$h 15-61-10$ & CHUEH STREET (FEGE) & SYLUESTEF FrILIF & 60 & Fi-1 No & YES & YE5 & YES & NE DIK & \\
\hline$H 15-02-01$ & SUMMEF ETREET & POSNEE 5TELLA & 185 & E-1 NJ & YES & YES & YES & FUELIL & 1696 \\
\hline $1515-02-194$ & ELT STREET & HAKWAEDFS MAEEL & 46 & $k-1 \mathrm{NJ}$ & YES & $N E$ & $\mathrm{Mi}$ & PUELIE & \\
\hline H.5-04-05 & BIRCH RÜAL & MAKHELL JANET E & 270 & $\mathrm{~B}-2 \mathrm{NO}$ & NO & NO & $\mathrm{NO}$ & FFIVAT & 740 \\
\hline $\mathrm{Hi} \mathrm{F}_{\mathrm{i}}-25-11$ & WARUICK RÜHE & WALSH HUEERT & $294+[$ & $\mathrm{K}-\mathrm{S}$ NÓ & YES & NO & $\mathrm{kJ}$ & PETVHT & \\
\hline$H 15-06-64$ & BRIÁREULE FIATL & FUSTEF CUNSTKL & 267 & Fi-1 AL & Nō & NO & NO & $N / A$ & 4356 \\
\hline$H: \Sigma_{1}-07-01$ & THISTLE RUGL & FUSTEF CUERSTFULTISA CUEF. & 255 & $\mathrm{~F}-\mathrm{N} \mathrm{NE}$ & Fü & YES & $\mathrm{No}$ & FEIVATT & 435 \\
\hline$H 1 \bar{j}-0 \bar{i}-0 \bar{i}$ & THIETLE RUAL & FUSTEF CUNETEL & 150 & F-1 Hi & P015 & HES & NO & PFIVAT & \\
\hline $45_{5}-077-65$ & THISTLE REAE & FUSTEF CORETRULTIUN CQFF. & 150 & $F-1$ Nō & POS & YES & NO & FKIVAT & \\
\hline$H 15-67-6 E$ & EFIAREDED FUAD & FUSTER CQNSTHULTIUR CONFF. & 170 & $\mathrm{~F}-1 \mathrm{NO}$ & Nú & NO & No & $N / A$ & \\
\hline$H ! 5-07-099$ & ESTHFLUOD FGALE & FCSTEF CONETRLICTIUA CÖRŸ. & $2: 2$ & $\mathrm{~F}-1 \mathrm{~N} \mathbf{L}$ & NL & NO & NO & & \\
\hline$H 15-67-10$ & BRIAFIDIL FUAD & FUSTEF CONSTRISTIUN COAF'. & $16 i$ & $\mathrm{~K}-1 \mathrm{NO}$ & No & $\mathrm{Ni}_{\mathrm{i}}$ & $\mathrm{hO}$ & N/A & \\
\hline$H 15-07-11$ & AGIEEFEY DFIVE & FUSTER CONETFULTIUN COKF. & $300+[$ & Fi-1 Ni & NO & $\mathrm{Ni}$ & $\mathrm{NE}$ & $\mathrm{K} / \mathrm{A}$ & \\
\hline$H 15-6 T-12$ & BAIEEREI DSIVE & FUSTEK CONETRIETIUH CUREF. & & Fi-1 No & $N[i$ & NO & NO & & \\
\hline$H[5-07-13$ & EATERAY DFIVE & FÜSTER COKSTFLLTIOA: COFF. & 163 & Fi-1 NJ & Nô & No & $\mathrm{HO}$ & $N / A$ & \\
\hline$H: 5-67-14$ & BATEETRY DELIE & FOSTER CÜBSTRLSTIOH CLEFE. & 163 & $5-1 N O$ & HI & NE & No & $N / A$ & \\
\hline $4: 5-08-10$ & BQLLES ROAL (REAE) & NERGER GEOREE & 100 & Fi-1 ND & YES & Ho & NE & PRIVAT & \\
\hline$H I 5-6=-12$ & THISTLE REAAD & FUETER CUKSTAUCTIJA CORE. & 260 & Fi-1 NU & P05 & YES & NO & & \\
\hline$H E-6 E-15$ & HILLY ROER & FUETER CONETRELIG COAF. & 25 & E-: Kú & YES & NG & Wo & FRIVAT & \\
\hline$H ! 5-0 \div-j 5$ & CEDAR FEAT & NEFSER: GEOKJE E. & 85 & $\mathrm{R}-3 \mathrm{NE}$ & Ni & No & NO & PFIYAT & \\
\hline 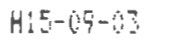 & EELATH FAH & NERGER GEOFGE E. & 65 & $5:-3 N 5$ & $\mathrm{Ni}$ & $N E$ & NO & PRIVAT & \\
\hline
\end{tabular}




\begin{tabular}{|c|c|c|c|c|c|c|c|c|c|}
\hline AS. MAF-LQT & LOCATIOH & OHNER OF REC & FFúlit & ZCN SEH & WAT & NET & FF' & ACCESS & AFEÁA SF \\
\hline -............. & $\ldots$ & - - & & & --- & $-\cdots$ & --- & & \\
\hline $\mathrm{HI} \mathrm{F}_{\mathrm{i}}-69-\mathrm{ij4}$ & CEDAF: RUAD & MŨDELLS CHAGLLES & 85 & $\mathrm{~F}-3 \mathrm{NO}$ & $N E$ & NO & NG & FEIVAT & 12550 \\
\hline$H ! 5-09-06$ & CEDAR RÜA & ARHETRONE JUAR F. & 85 & $R-3 N O$ & NO & NO & No & PFIVAT & 11250 \\
\hline$H 15-09-06$ & CELAF RÜAD & ENRIS JUHN $j$. & 85 & $\mathrm{Fi}-3 \mathrm{No}$ & $\mathrm{NGi}$ & $\mathrm{kg}$ & NO & FRIVAT & 11371 \\
\hline H:5-09-09 & CEQAE FOHD & NEFEEET GEURGE E. & 85 & $\mathrm{~F}-3 \mathrm{Ni}$ & NO & NO & NO & PRIVAT & 11290 \\
\hline$H 15-09-10$ & CEUAE RUAD & MEOJNJUSH HLLIAM & 85 & $\mathrm{R}-3 \mathrm{NJ}$ & HO & NO & HD & PFIVAT & 11200 \\
\hline$H 15-09-1 !$ & CEDAF 90140 & NEREEF MCDOHULEH & 130 & $R-3$ NO & Nô & NO & NO & PRIVAT & 10820 \\
\hline$H 15-10-65$ & BIFLH FIAE & CONHAYY ANHS M & 110 & $\mathrm{~F}-\overline{2} \mathrm{~N} \overline{\mathrm{u}}$ & NG & NO & No & FF!VAT & 21300 \\
\hline $415-12-02$ & HULLY RITE & KLEEES JCYCE H. & $205+[$ & $\mathrm{R}-3 \mathrm{NJ}$ & YES & Nô & $\mathrm{NO}$ & FUELIC & 13267 \\
\hline$H: 5-12-03$ & EHETYY RŨÁ: & TILEEN CHEISTOFHEF & 324 & $R-1 \mathrm{NO}$ & YES & NO & $\mathrm{Nu}_{\mathrm{S}}$ & PUELIC & 16580 \\
\hline$H i 5-1 \bar{i}-0 \bar{z}$ & ULA GHT RUAO & TUFFO FREDEFIICK & $150+[$ & $\mathrm{K}-3 \mathrm{NO}$ & YES & NO & $\mathrm{Ni}$ & FUELIC & 10505 \\
\hline$H: 5-12-39$ & DHIEHT KOAD & TUFFŨ FR̈ELER]CK' & $8 i$ & $\mathrm{R}-\mathrm{J}=0$ & YES & NO & NO & FUBLIC & 9675 \\
\hline$H 15-12-11$ & IHIEHT KLEL & FAHNEEY JAMES $F$. & E0 & $\mathrm{R}-3 \mathrm{NO}$ & YES & NG] & NO & FUELIC & 8624 \\
\hline$H 15-12-35$ & DHISHT RJA: & 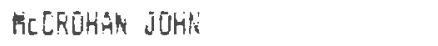 & $\overline{80}$ & $\mathrm{R}-\mathrm{j} \mathrm{NO}$ & YES & NO & $\mathrm{NO}$ & FUELIC & 9733 \\
\hline $\mathrm{H} 15-14-12$ & CEDAF REAL & GUEERTS FFARIL & 240 & $R-3 N O$ & No & NO & NJ & PFIVAT & 31500 \\
\hline$H: 5-14-03$ & CEEAF FEÄE: & FEFGLEUN UURLAN & 324 & $\mathrm{~F}-3 \mathrm{NO}$ & Nu & $\mathrm{kJ}$ & $N E$ & PFIVAT & $42: 53$ \\
\hline$H 15-14-i 14$ & EMEEH RQM & FICAFII ANGELO & 475 & $\mathrm{R}-\mathrm{i} \mathrm{Nu}$ & YES & $\mathrm{Nij}$ & ND & FUELIC & 52272 \\
\hline $115-14-12$ & HŨL Y RUUÁ & KILE: MARE E & Ei & $R-I N E$ & YEE & NO & $\mathrm{NO}$ & FFIVAT & 10400 \\
\hline$H i 5-15-36$ & EMEFY FIIAD & SARELLINE CQRETGRLE & 180 & $\mathrm{~K}-3 \mathrm{NC}$ & YE5 & No & NO & FuELIC & 22326 \\
\hline$H 15-16-64$ & HOLLY HILL CIRELE & HÂNIEY FÁLL & $206+[$ & $\mathrm{R}-\mathrm{J} \mathrm{ND}$ & YES & KO & $\mathrm{NO}$ & FFIVATI & 22737 \\
\hline$H_{1}: 5-10-00$ & HOL Y HILL CIREEE & LIGHTEOST ROY & 70 & $\mathrm{~B}-3 \mathrm{NO}$ & YE5 & NO & NO & PHIVAT & 12218 \\
\hline $\mathrm{H} 15-10-10$ & EMEFT ROAD & LIGHAFEUT REY & 45 & $\mathrm{~F}-3 \mathrm{~N}[\mathrm{I}$ & YES & $\mathrm{MO}$ & $N 9$ & FUELIL & 5060 \\
\hline$H 15-17-04$ & CHEISTMAS TREE LANE & GILL HILLIA: T. & 240 & $\mathrm{~F}-3 \mathrm{NO}$ & $\mathrm{N5}$ & NO & $\mathrm{HJ}$ & PRIVAT & 30200 \\
\hline$H(6-1)-3 j$ & GRAliLi:IE AVERUE & ALICE M. I BRIEN & 140 & $\mathrm{~F}-3 \mathrm{~N}[\mathrm{i}$ & YES & YES & YES & FEIVKT & 13700 \\
\hline $16-02-05$ & CEUAFE ACRES FUAD & SLITUÁTE CONLFETE FIFE COAF. & 129 & $\mathrm{~F}-1 \mathrm{NO}$ & YES & NO & NO & PUELIC & 19000 \\
\hline$H 16-03-06$ & UFLAND FOAT & MAUDEN STEFHEN & 80 & $\mathrm{R}-3 \mathrm{NO}$ & YES & No & NO & PUELIC & 11154 \\
\hline Kit-0j-ijy & UFLAND RUAL & ATLEAFII CLIFFOKI & $202+C$ & $\mathrm{~K}-\mathrm{J} \mathrm{NO}$ & YES & NO & NO & PUBLIC & 14234 \\
\hline $146-03-12$ & ELM STREET & WHELAN KERAKETH & 80 & $h-3 N 0$ & YES & NO & NO & FUELIC & 10800 \\
\hline$H 16-0 j-14$ & ELF, STREET & HEATIN RICHARD & 80 & $\mathrm{k}-3 \mathrm{NO}$ & YES & NO & Noj & PUELIC & 11367 \\
\hline$H 16-63-15$ & ELF STFEET & MUFEHY JEAINEVIE & 115 & $R-3 N O$ & YES & Nu & NO & PUELIL & 9825 \\
\hline $\mathrm{H} 16-03-16$ & ELM STIREET & HEATON EICHAED & 80 & $\mathrm{R}-3 \mathrm{NO}$ & YES & ND & NE & PlE:IC & 11478 \\
\hline$H 16-03-17$ & ELA STFEET & SALUEFE GEEGORY & 150 & $\mathrm{~F}-\mathrm{J}$ N $\mathrm{N}$ & YES & $\mathrm{NO}$ & NO & PUELIL & $1(1961$ \\
\hline $\mathrm{H} 16-04-0 \mathrm{~S}$ & ELM STFEET & GILL HILLIR̂H & 309 & $\mathrm{R}-3 \mathrm{NO}$ & YES & no & NO & PFIVAT & 26500 \\
\hline$H 16-04-07$ & UPLAND FŨAD & PLATT NGRTEAN & $400+i$ & $B-J N D$ & YES & $\mathrm{NO}$ & No & FUBLIC & 43500 \\
\hline$H 16-04-0.8$ & EMEFY' FÚAL & PLATT NOFMALI J. & 90 & $\mathrm{R}-3 \mathrm{NE}$ & YES & No & NO & PUBLIC & 9215 \\
\hline H16-06-03 & FEREO HILL FUAREOUF) & AESEESE JUEAN E. & NORE & $R-J N O$ & No & NO & Nū & Nü IIf & 11200 \\
\hline $416-06-104$ & ELH STREET & KALCATORE RICHGRC & 60 & $\mathrm{R}-3 \mathrm{NO}$ & YES & NO & No & FUELIC & 37300 \\
\hline $416-00-06$ & PEAEDEY RChL & TREVISANI JUAN & $396+C$ & $R-3 N D$ & YES & NO & NO & FUBLIC & 41947 \\
\hline$H: 6-06-01 ?$ & PEABODY RURE & TREVISANI JOAll & 120 & $R-3 \mathrm{NO}$ & YES & Nú & NO & FUELIC & 21175 \\
\hline$H: 6-06-11$ & GHAHSHIE \& FEFKY HL & KENHETH HC INTYRE & $14 !$ & $h-3 \mathrm{NO}$ & VES & Nō & NO & FFIVHT & 8400 \\
\hline$H 1 t-019-05$ & PALLINE FGAL & DUNKE DANIEL & 50 & $\mathrm{R}-3 \mathrm{NO}$ & YES & No & NO & PLEELIC & 5000 \\
\hline H16-05-016 & GRARDVIE AVERTIE & JAMES E. LALIGHE & $28:$ & Ki-jNE & YES & No & $\mathrm{HIJ}$ & FKIVAT & 1500 \\
\hline$H i t-16-0 E$ & CARELTUK REAS & ARJEFSER NILS & 100 & $5-3 N[t$ & No & Nu & $\mathrm{H}[\mathrm{I}$ & FFIVAT & 9626 \\
\hline H16-11-01 & PAULINE RŨAD & DYTEH ALBERT & $250+5$ & $\mathrm{~F}-\mathrm{J} \mathrm{NE}$ & YEE & NO & Nõ & FUBLIL & 15060 \\
\hline$H 16-15-0 !$ & GRARUVIE GVERUE & JAMES E. LALIERE & $100+[$ & $\mathrm{K}-3 \mathrm{NO}$ & YES & $\mathrm{NO}$ & ND & PEIVAT & 1500 \\
\hline $117-01-08$ & FEFEY STFEET & CULLEN BEFIIAERD & 171 & $\mathrm{R}-\mathrm{J} \mathrm{kL}$ & $\mathrm{NG}$ & lES & YEE & FUELIC & 16638 \\
\hline H17-01-07 & CAFELTER RÜALL & ANDEFSOAN RILS & 245 & $F_{i}-3 N O$ & NO & YES & YES & FRIV'T & 56628 \\
\hline $102-04-01$ & CARESTELL STREET & BKIGGS RICHÁẼ J. & $2001+L$ & $\bar{F}-\bar{z} \mathrm{Nu}$ & NO & NI & $N[$ & FUELIC & 26203 \\
\hline $105-01-01$ & MURAALE STEEET IOFF; & FFINCE DORIS J. & NGNE & $\mathrm{R}-1 \mathrm{NO}$ & No & YES & NO & ND DIK & 202554 \\
\hline $105-31-15$ & MURAINE STREET & DELANIU HERTMAN \& FLUFENEE & 200 & $k-1 N E$ & YES & YES & No & PUBLIC & 155123 \\
\hline $105-01-20$ & DUXELFI STSEET & FRINCE LEO E. & NGNE & $R-1 N i$ & $\mathrm{NO}$ & NO & Ni & No DIR & 6750 \\
\hline $104-01-01$ & MURAALE STREET & CHÁNDLE RUJSSELL & 125 & $\mathrm{R}-1 \mathrm{NO}$ & YES & NE & $\mathrm{NO}$ & FUELIC & 533610 \\
\hline $104-02-04$ & REAF: STAGE COACH DFI & NE EEDFURI GÁS \& ELECTKIS & 40 & $\mathrm{R}-1 \mathrm{Nu}$ & NO & PÜS & FOS & ND DIF & 213444 \\
\hline $105-01-09$ & KING FHILIFS PATHE-E & GARKETSIN JOHN H. JNE & NUKNE & $\mathrm{F}-2 \mathrm{KE}$ & No & YES & YES & WU DIF: & 50020 \\
\hline
\end{tabular}




\begin{tabular}{|c|c|c|c|c|c|c|c|c|}
\hline$A E . N K^{F}-L E T$ & LGiFin & OWNEF OF REC & FRUNT & ZON SEN & WAT HET & $F F A$ & ACCESS & AREA 5 \\
\hline - & & & & & $---\cdot$ & & & \\
\hline $1+2:-1 \varepsilon$ & MEETINGHESEE LARE IO & SEGLUNS CAROL & 146 & $\mathrm{~K}-2 \mathrm{NO}$ & YES NO & No & FUEiIC & \\
\hline$\therefore 5-6 !-02$ & HIS 5:KEET & ANIERSEN PGLIL & $300+[$ & $\mathrm{F}-2 \mathrm{kj}$ & YES NO & $N 5$ & & \\
\hline $0 e-62-01$ & CSTREOE STFEE & WILLIAHS GEOREE & 196 & $\mathrm{~B}-2 \mathrm{NO}$ & YES NO & NO & & \\
\hline $46-02-09$ & GEQHAEE STKEET & MCLRACKEN ROLEFT & 157 & $\mathrm{~F}-2 \mathrm{NO}$ & YES NO & NO & JE! IC & \\
\hline $9 t-6 i-11$ & RESRABE STREET & MULLEA LUMEES $[3$. & $380+5$ & $\mathrm{~K}-1 \mathrm{NO}$ & YES YES & YES & & \\
\hline$-02-12$ & ESTEF STFEET & DFURE 645 & 430 & $\mathrm{R}-2 \mathrm{NJ}$ & YES YES & & & \\
\hline$b-i 5-60$ & WOLE CEMETEFI RIO & ANIEL HEESTER & 120 & $\mathrm{~K}-\mathrm{Z}$ MŨ & YES YES & YES & & \\
\hline $7-61-62$ & IID STFEET & TREIN & 332 & $\mathrm{~B}-\mathrm{INO}$ & YES 140 & NÜ & & \\
\hline$-9-6 j$ & FISHME STFEET & CHAMULEF FUSSELL H. & 490 & $\mathrm{R}-2 \mathrm{NO}$ & YES YES & YES & & \\
\hline $8-(2-6)$ & EAN STREET & HAHTHRENE REALTY TRUST & 254 & $\mathrm{H}-2 \mathrm{AS}$ & YES YES & YES & FUELIC & \\
\hline$-0.9-07$ & TREE? & WR WILFEE & 100 & $\mathrm{E}-2 \mathrm{NO}$ & YES NO & HU & & \\
\hline$E-6 \overline{7}-10$ & EAN STREET & SUH NATALIE & 100 & $\mathrm{~B}-2 \mathrm{NL}$ & YES ND & No & c & \\
\hline $6 \bar{c}-10+64$ & STREET & VILLAGE II IKI.5:4 & $5: 4$ & $\mathrm{~B}-2 \mathrm{NO}$ & YES HO & NO & & \\
\hline $0 E-11-16$ & IE RDË & HTAL INVEETKEHT T & 130 & $\mathrm{R}-2 \mathrm{NI}$ & YES KII & NE & & \\
\hline$(1 E-11-: 7$ & ISETE RAEE & FL: INUESTMEAT TELST & 130 & $\mathrm{R}-2 \mathrm{~kL}$ & YES NE & No & & \\
\hline $1 E-11-16$ & ISEIE KÜAD & HTLL INWESTRENT TR:ST & 130 & $\mathrm{R}-2 \mathrm{NE}$ & YES HE: & No & PUE & \\
\hline & E_EEF STKEET & WORE NATLSAL SEIEN & 160 & $\mathrm{~K}-2 \mathrm{NG}$ & NÜ YES & NO & & \\
\hline$-6:-02$ & SOU'H R̈IVEA STREET & KIUEFTVIE HËHES IHE. & 100 & $\mathrm{R}-2 \mathrm{NU}$ & YES NIO & NŨ & PUE & \\
\hline $1(1-01-5$ & SOLTH & DUKEAE JOHK & 85 & $\mathrm{~F}-2 \mathrm{NC}$ & YES NI & NO & Fubil & 2013 \\
\hline$-0 i-07$ & 5ULTH RIVEF STREET & EN SAVINES BANU & 92 & $R-2$ No & YES NO & HO & FUS & \\
\hline$-(2-6) 4$ & HÜES ERUDK & ALEX & 120 & B-2 NO & YES NO & HO & PEIV & \\
\hline$-62-6 t$ & TEX LAKE & VALE & $200+\Gamma$ & Fis -2 & YES NO & NO & PUE:-1 & \\
\hline $10-08-01$ & WUEK STAEET & LEONGẼ & 1623 & $R-2 N E$ & YES NO & HO & FUE & 50311 \\
\hline$-03-04$ & HLIHES EHOLE RUAE & GAEL & $14 \mathrm{E}$ & $\mathrm{F}-2 \mathrm{NO}$ & YES YES & No & FRIVAT & \\
\hline $05-15$ & HOHES BROJ RETE & IEF ROEEFT & 120 & $\mathrm{~K}-2 \mathrm{NO}$ & YES YES & NG & & \\
\hline $10-07-13$ & HUHES EFSU FEOS & WHUAF FANkIEL & 50 & $\mathrm{R}-2 \mathrm{NO}$ & YES YES & $\mathrm{NO}$ & FRIVAT & 5227 \\
\hline$-03-26$ & SOLTH RIVEF STREET & FUS5ELL CHEL & 120 & $\mathrm{R}-2 \mathrm{NG}$ & YES YES & NO & PUE & \\
\hline-27 & ZLEE STEEET & SJUTH SHJFE KATTLFH' SCIENOE EE & 512 & $\mathrm{Fi}-2 \mathrm{~N}$ & NO YES & YES & $N / A$ & \\
\hline $110-05-25$ & SA_EY HVERLE & HEHLEY FFGRIIS & 200 & $\mathrm{k}-2 \mathrm{NJ}$ & FOS FUS & NO & PUE:IC & 1000 \\
\hline $116-6-30$ & TEASS CTEEET & SDL H SHOFE NAT.SEIENE CENTEF & RUNE & $\mathrm{K}-2 \mathrm{NJ}$ & P05 NO & $\mathrm{NC}$ & $\mathrm{NQ}$ & 784 \\
\hline & BSOR ATEPJE & & $2 u+5$ & $\mathrm{~K}-2 \mathrm{~kJ}$ & YES ND & No & & \\
\hline $3-72$ & TOK M NELLINSTON & FFANEES M. & 100 & $\mathrm{~F}-2 \mathrm{NO}$ & YES NO & NE & PFIVAT & 100 \\
\hline $8-35$ & TEK STEEET & TT STARKLEY & 220 & $\mathrm{R}-2 \mathrm{NO}$ & YES YES & YES & PFIVAT & 2200 \\
\hline & ETOHN STFEET & BUYUHT STANLEY & $B 0$ & $\mathrm{~K}-2 \mathrm{NJ}$ & YES YES & YES & & \\
\hline$-3 \bar{i}$ & ESTOWN STREET & HOME GUAFLIAR CO. & 40 & $\mathrm{Fi}-2 \mathrm{ND}$ & YES NO & NO & PRIVAT & \\
\hline $110-03-43$ & CHARLESTCHH STREET & SULL IVAN JERUME & 60 & R-2 NU & NO YES & YES & $N / A$ & \\
\hline & CHAFLESTOWH STREET & SULLIVAR JERTHE & 40 & $\mathrm{~F}-2 \mathrm{NO}$ & YES NO & NO & & \\
\hline-45 & CHARLLESTOHK STFEET & DLIVEF GUR TOR & 40 & $k-2$ NJ & YES NO & NO & & \\
\hline $110-0 j-40$ & CHAFELESTUWR STREET & EJKUNT STANLEY & 40 & $\mathrm{R}-2 \mathrm{NO}$ & YES ND & NO & VÂT & 100 \\
\hline-47 & CHAF:ESTUWN STKEET & & 60 & $\mathrm{R}-2 \mathrm{NO}$ & YES NÕ & $N 0$ & & ou \\
\hline & CHARLESTOK STKEET & & 80 & $R-2 N O$ & YES YES & YES & & \\
\hline & VILLE STREET & DALY FAFILY IFTEEVI & 80 & $\mathrm{~F}-2 \mathrm{NO}$ & FOS YES & POS & PFIVHT & 80 \\
\hline $110-03-51$ & SOREFULLE STREET & COOH JOHR w. & 100 & $\mathrm{~F}-2 \mathrm{Nu}$ & FOS NO & NO & PFIVAT & 1000 \\
\hline $110-03-54$ & SOHEFVILLE STTEET & GLINAN HALTEF & $200+C$ & Fi-2 NE & YES NU & NO & & \\
\hline $110-0.5-55$ & SOHEFIUILLE STREET & LEONAES FFAMVK 6 . & 200 & R-2 NO & POS NO & No & PFIVAT & \\
\hline $110-6 j-56$ & SOMEFVILLE STREET & LEHANE MARGGAET & 100 & $\mathrm{~F}-2 \mathrm{NO}$ & POS NO & HO & PRIVAT & 100 \\
\hline $110-03-57$ & SINEFVILLE STREET & DALY FAKILY IRKEVCLAELE TEUST & 80 & $R-2 N$ & POS YES & YES & $N / A$ & 80 \\
\hline $110-0 \overrightarrow{0}-5 E$ & SIMEETUILLE STREET & MURFIIY AENES & 40 & $\mathrm{R}-2 \mathrm{NO}$ & POS YES & YES & & 40 \\
\hline $116-04-02$ & SOHEFIVILLE STKEET & JEPEF WINIERED & 100 & $R-2 N C$ & YES NO & NO & PKIVAT & 100 \\
\hline $110-64-03$ & STMEVIILLE STREET & TEDESLH DUHINIC & 40 & $\mathrm{~K}-2 \mathrm{NO}$ & YES NU & No & PFIVAT & 40 \\
\hline $116-(4-14$ & SERETHILLE STREET & HOR.TE ALICE L. & 40 & $\mathrm{~F}-2 \mathrm{kj}$ & YES ND & No & & 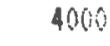 \\
\hline & SULEFUVILLE STFEET & HOREELL WLLIIAM & 40 & $R-2$ NO & YES NO & No & FFIVAT & \\
\hline $1: 0-04-66$ & CHERLESTUWE STREET & HELMES EDWARE & 60 & $\mathrm{R}-2 \mathrm{NO}$ & YES NE & No & PKIUAT & 1000 \\
\hline
\end{tabular}


110-04-07 50\%EFIILLE STREET

I10-04-08 HASHINSTOH RHEKUE

110-01-09 CHARLESTOWH STREET

110-04-10 CHASESTOWR 5TREET

110-04-12 CHAFIEETLAN ETREET

110-25-O: TEVEAE STEET

$110-05-02$ REVERE ETREET

I!C-OE-OI: REVEHE STREET

1!6-05-GE SOREFIILLE STFEET

110-05-OS SUREFILLE STEET

I1U-JS-OE NASTAEIET STFEE

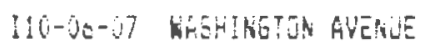

110-OO-OE REVEAE STREET

IIU-DS-i2 REVERE STFEET

111-OI-OI EAEIE RINAT:

I11-CI-U: EAELE R:

I11-0:-0J EAGLE FIAD

I1:-01-GA ERDIE FIJT.

I11-01-05 ERGLE FTOA

I11-OI-US EASLE RUTL

IIJ-Gi-G7 EFGLE Róni:

III-GI-UE EGOLE RGE:

$111-01-09$ EAGLE RGHE

II!-01-13 EABLE HEÁ

111-01-11 EAG_E RUAL

I11-01-12 EASEE RUSE

I11-0Z-0I! EAELE RQAI

I11- $02-02$ HAHES ETREET

I:1-02-0S HALEOR STREET

II!-0Z-OA HAREOK STKEET

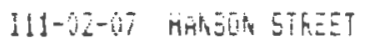

I11-0J-1:! SCITUAIE STFEE

II1-03-02 5LITJATE STAEET

I11-0.-OS SCITLARE STREET

I1!-05-04 SLITUATE STREET

I11-03-IG MINGHAY AVENUE

I11-0S-0T HIHSHAM AVERUE

111-03-0E HAHSOA STREET

I11-65-0T HANECH STREET

$111-03-10$ HANSIN STREET

IIi-04-01 COHAESET AUENLE

I!1-04-JG COHASSET RVENUE

111-04-03 COHAEEET STREET

II1-04-SE SLITURTE STREET

I11-04-06 CUHASEET STREET

111-04-05 HIRGrit HENUE

I11-O4-JO SEITUHTE STFEET

III-04-1! SIITLATE STFEET

211-05-0?

III-0t-01 SUTH RIVER CTREET

IH-6G-02 SLUAA RINEF STHEET

I11-06-A3 SDITH FIVEF STAEET

I11-07-01 LELIHGIEN AVE.
HOLMEE EOWGED 5.

KEEGAA RUSSELL

TEEESTHI DOMINIC

MOF.SELL HILLIAY

HOLLANEL THOHÁS

DAVIS JAMES

GḦLLE THEUSA

SAFBERTINO CATHERINE

MOFEAR MTEMAE:

OFMGAL: MESY E.

HEALEY FRANEIS

SIMHONS F'AUL

HEALEY FRHATIS

DEXILE WILIAM R.

TEDESCH: DUMHATC REATTY

IELLEY LEU A.

RELLEY LEQ A.

KELLEY LEU $h$.

BHEER EAFLE

MELLE! IEU A.

TELLE, LEU Á.

ERTIK HHESY $\mathrm{A}$.

FHISULI ARKE

TELESINI DQRBAC R.

FFISJL! ANHE

TEDESEHI OOHIKIL

TEDESCH: OOMIHIL

FFISEILI ARME F.

KELLEY LEE A.

COMHELLY THLKLE

GELIHE THEL DLTE

TEDESUHI DOWINIC

FRISULI AMVE F.

TEDESLIHI DCHINIS

FFISLI ANGE $F$.

RUSSELL GILDA

HAY 30 HiN $J$.

IAKTOSEF EEMGRE

ConLUE FALL B.

FRISEL! ANNE F.

U) NEF THCIRTTOH

MARSHFIELE ESTATES TRLET

GELIHAS THEUDORE

FFISEL! AHIVE F.

IAKTUECA ESWAT̃

GILLIS JUTH

TEDESEH: OOHIAIC

TEDESLAL DOKINIL

FLYNR JULN HILLIAM

FAIRHALN SHYINGE EAHH

FAIFTARER SAVIRES BAN:

FAIGHARER SRYVINGE ERHI

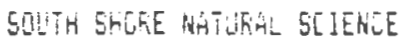

BO R-2 NQ YES NO NO PRIVAT GOOU $300+C R-2$ NO VES NO NO PUELIC 23958 6O R-2 NO YES NO NO PRIVAT 6000 60 R-2 NO YES ND NJ PRIVAT 6000

200 R-2 NU YES YES YES FRIVAT 10000

2 200 F-2 NG POS NO HO PFI 12000

60. FI-2 NU POS NO NO PRI 6000

60 R-2 HO POS NO NU PFI 6000

60 R-Z NU PUS ND NI FFIVAT 6000

60 R-Z NO POS NO NO PEIVAT 6060

$80 \quad K-2$ NO YES YES YES FFIVAAT 8000

$180+C R-Z$ NO YES WI NO PJBLIC 10003

BO R-2 NO FOS NO NO PRI BOBO

60 R-Z NU FOS NO NO FEI 2600

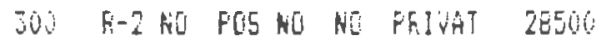

200 R-2 KE POS NO NO PRIVET 20060

100 K-I HU FES NI NE PRIVAT 10000

80 F-2 NI POS NE NO PRIVAT 6000

75 R-2 NU POSNO NU PFIVAT 8000

30 h-2 NO POE NO NO PRIVAT 200\%

40 R-2 HJ PLS NE NO FREVAT $460 \mathrm{O}$

50 R-2 NG PUS NJ NO PFIVAT 6000

50 FI-2 NO FOS NO NO FFIVAT 6000

5 5) R-2 NO POS NO NJ PFIVAT 6000

400: FI-2 NO POS NE NG FRIVAT 34600

2004 K R-2 NO POS YES NU FRIVAT 16800

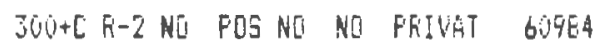

60 F-Z NO FOE NJ HO FEIVAT 6000

60 K-Z NE FOS HO NI FRIVIT 6600

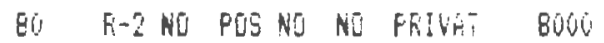

bi RI-2 NO POS NO NO PRIVAT 6000

250 R-2 NO PUS NO NO PRIVAT 24000

80 R-2 NO POS NO NI PRIVAT 8000

40 R-2 NO POS NE NO PAIVAT 4000

EO R-2 NO FUS NO NU PRIVAT 8000

8C+C K-2 NU YES NU NO PRIVAT 10000

1000 E FI-2 NO YES NO NO PFIVAT 12000

150 R-2 NJ FUS NI NO FRIVAT $1600 \mathrm{~J}$

150 R-2 NO FOS NO NO PKIVAT 16000

150 F-Z NE FOS NO NO FRIVAT 19000

BO R-2 NO YES NU HO PRIVAT 4200

40 R-2 ND YES NO NO PRIVET $200 \%$

100 R-2 NO YES ND NU FEIUHT 12000

43 F-2 NO POS NE NU PFIUAT 8006

160: R-2 HO YES NJ NO PEIVAT $550 \%$

$120+E R-2$ NO YES NO NO FRIVET $1000 \mathrm{O}$

120 F-2 NI FOS NJ NI FFIVAT $12 \mathrm{~B}$ W

260 R-2 NI POE NO NJ FRIVAT 28000

260 R-2 HO YES NO NI PUE!!C 24609

135 FI- 2 NO YES NE NO FUELIC 21200

$294+[R-2 N E$ YES NO NO FUELIC $2076 \%$

$279+\left[\begin{array}{ll}\mathrm{C}-2 \\ \mathrm{HO}\end{array}\right.$ $60 .+2 R-2 N I$ IES HO NO PFI LL 104549 
I!1-017-OE WRTHERF STEEET

I11-67-6O SAEE AVE.

111-67-07 DISTREF STEET

I11-07-0E HINTHRO ETREET

111-07-1.9 50:TH FIVER/RINTHEOF

11-07-10 SEGTH RIVEF. ETREET

M1-0T-11 SUITH RIVEF STFEET

I11-6T-12 SOUTH RIVER ETAEET

111-17-13 SELTH GIVEF 5THEET

I11-07-14 EDAT FIVEF ETREET

111-08-01 TEXHS ETFEET

111-66-04 TEXAS STREET

III-UE-G DELLINGTOK AVENJE

111-OE-OS MELLINETLN AUEMIE

I11-08-08 SALEM AVE.

11-05-OI LEXINGTOF, STREE:

111-09-04 FAFEniti

111-05-0J PARKISY

I11-09-60 LEXIEIZTOK ETEEET

111-Ú-0E LEXINGTUL: STFEET

I1!-05-OY LEX]MOTOR 5TREET

111-10-01 LEXIHSTON STREET

I11-10-03 LEXIKETLK ETREET

111-10-OA LELINETUN STHEET

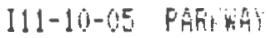

I11-10-06 PÂFíty

111-10-07 SOUTH FIVEF STREET

111-10-06 CHELSEA STREET

I11-10-09 CHELSEF STREE?

I11-:01-10 [HELSEH STHEET

$111-10-11$ CHELISEA STREET

III-10-12 SALES AUE.

II1-16-14 LEMINGTUN AVE.

I11-11-01 SALEM AUE.

111-11-02 CHELEEP STRFET

111-12-02 SOUTH RIVEF STFEET

111-12-03 COKFSSET AUENUE

111-12-05 SEUTH RIVEF STREET

111-12-09 FARTWRY \& CQTHESET

I11-12-10 COHASSET RVENUE

I11-12-11 COHASSET STREET

111-12-13 COHA5CET STFEET

111-12-14 COHFOEET STREET

111-12-15 HIKSKRA RUEHLE

1:1-12-16 COHASSET STREET

111-1j-01 COHG5SET STHEET

111-1j-02 COHAGSET STREET

111-13-03 COHASSET STFEET

I11-13-05 COHASSET STFEET

I11-13-06 COHASEET STREET

111-13-017 COHRSEET STKEET

111-13-UB COHASSET STREET

111-13-07 NOFSELL ROA.

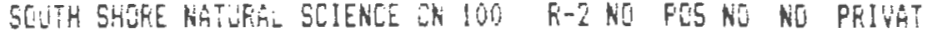
DAHISELLA

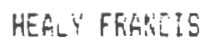

SALIE JUDITH

HEPLL FRARIS

SEIP MARTIA JEAS

EHLLE THESHF E.

MIRGat MichiE:

ATKINETA DORSTHY

Dwi Ghi GEFALI E. Ar. LINin

YUMKEF ELEARISR

YOMUEE ELEANG

SHITH ROEETT

MORGAN M?CHAEL

SOI'H SHJEE NHTURA: SCIENEE

SOLTIA SHIRE NHTURA SCIENE

SOLOMO: JUSEFH

VININE [HSELES

SOLIT SHOFE MATURA: SEIENCE

5DUTH SHISE NATURAL SCIENCE

GRESS JALE FYAETIE

O'CONIELL FRANCIS

SEUTH SHERE RATUFAL SEIEREE

ETHAON ALLAN ERTUN TRLST

ETHEN ALLGN BEOER TRLOST

PEFTETTA DUROTHI

ETHAB ALLA:I

BISCHDFF RAFL

EThGH ALLAN BEOLW

BIECHOFF RAB:

UAMIBELL'A ANH

SOUTH SHUTE NÁTUTÁL SLIEHLE

SULTTH SHORE NATURAL SEIEKLE

KELLY HILL!AḦ

EUCK COEIE E.

FRISULI ANKE

VARGA FATEICIA A

CHASE ROSEMAFYY

YOUNG MAUEEEN

FRISOL! RNAE

TELESCHI DOHINIS

TEDESEHI DOHINIC

TEOESEHI DOMINIC

SAMFSUN DDROTHY

VAGGA PATEISIA

REILLY TIMUTHY

HUEHES

HAREINGTUR A.E.

MEMUERACLS HENRY

MADDEN HAFETY $V$.

FFISSL: ANRE

STILLMÁN HAOYY

LAREENGE EMHE
HI-S YES FUS YES NU PFIVAT 3OOOO

10.) F-2 NO FOS ND NO PKIVAT DOUDO

250 F-2 NO PGS NO NU PRIVAT 26000

$290+$ CR-2 NO YES NO NO FUBLIC 8000

110 F-2 NO YES NII NO PUELIE 6500

20 R-2 MU YES NO NII FURLIC $200 \%$

20 R-2NU YES NO NO PUELIS 2000

IIE $k-2 N Q$ YES KI NO FUGLIE 10000

E1G+C R-2 NO YES NE NO FUELIC 216453

100 R-2 NO POS NA NO PRIVAT 16000

120 F-2 NE FOS NO NO FRIVAT 12000

$202+C$ R- 2 NU FOS YES PDS FFIVAT 10000

$210+C$ F-2 NO FOS YES PUS FRIVAT 6006

$360+C$ Fi-2 NOS YES YES PRIVAT 26000

$600+C F-2$ NÖ YES NO NO FRI CL 74052

$170+[$ Fi-2 NO FUS YES NO PFIVAT $1000 \%$

195 R-2 NO PQS YES NO PEIVHT 10000

80 R-2 NO YES NO NO FEI CL 8000

46. B-2 NO YES NO NO FEI CL 4000

40 RI-2 NO YEJ NO NO PFI CL $400 \%$

10. Fi-2 ND YES NO NO PRI CL 10000

40 FI-2 NO YESNO NO FEI CL 4090

15: R-2 NG YES NU NU FTI CL 12000

$200+C$ R-Z 20 POS YES NO PAIVAT 10000

$170+C$ R-2 HÕ FOS YES NÚ FRIYHT $120 \mathrm{UL}$

40 R-2 NO YES NO NO PUELIC 1200

40 R-2 NO NE YES NO FRIUAT 4000

40 F-2 NO NO YES NI FEIVET 4000

80 K-2 WE NO YEE NO FRIVAT 8000

200 K-2 NU RO YES NG PFIVHT 20000

$140+C$ RE- 2 NO FOS YES NG PRIVAT 400

$120+[R-2$ WD YES NS WO FFI CL 2000

$140+E$ F-2 NO POS YES NO FRIVAT 4000

70 Fi-2 NO YES NO NO FUELIC 6000

70 R-2 NO YES NI NO PUELIC 6500

20 R-2 NO YES NO NO FUELIC 6000

70 R-2 NO YES NE NO FUELIC BOUU

$200+$ L R-2 NO YES NO NO PEIVAT 10000

20 R-2 NE YES NO NO FEIVAT 2010

100 R-Z HZ YES NO NO PEIVAT BOWG

100 K-2 NO YES NG NO FFIYAT 10000

40 R-2 NI YES NO NO PEIVAT 4900

1001+E Fi- $\dot{C}$ NE YES NO NI FRIVGT 7200

20 R-2 NG YES NJ NO PFIVAT 6000

$200+C R-2$ NO YES NO NO PEIVAT 10000

60 R-2 NO YES NO NO PFIVAT 6010

60 R-2 NO YES NO NO PRIVAT 7125

220 R-2 NI YES NO NE PFIVAT 28000

40 FI- NE YES NO NO FRIVAT $600 \mathrm{~J}$

40 B-2 NO YES NO NO PFIVAT 4000

$200+[\hbar-2$ ND YES NO NO PRIVAT IWOGC

$220+[$ FI- 2 NO POS NO NO PFIVUT $1000 \mathrm{O}$ 
$11 !-13-10$ NURHELL ROAD

III-13-11 NOTHELL ROAE

111-13-13 NOROELL TUED

111-13-14 NISTEEL RUAO

I11-1j-15 HINGHAR AUENLE

II!-14-0! F'ÁEKUÁY

I11-14-02 FiEtifnt

111-14-3 PAFIGA

I11-14-04 PAFTEW:

II1-14-65 FAFKHÁ?

111-14-06 PAEKITGY

111-14-10 NGRHELL RLLL

111-14-11 NOSWELL FGAE

$111-14-12$ NGPUEL: ROAD

I11-14-13 PAFKMGI

III-14-14 HINGHA AHERE

II1-14-15 HINGHAM AUEHUE

[11-15-0\} DUREUFY STREET

I11-15-64 DUIELS! STKEET

I11-15-05 DUXELTY STEEET

I11-15-07 PACIIAY

I11-16-0Z EAOLE ROAL

111-1t-0J EAELE SOAL

111-16-14 DUXESFY STAEET

I11-16-05 DLLEJEY STREET

111-16-07 DLXELEY STPEET

111-17-01 COHAESET AUENUE

111-17-02 COHASSET AVENIE

I11-17-03 COMASSET AVE,

111-17-05 KINGSTOA STFEET

I11-17-06 KINESTUI STREET

II1-17-0? KING5TÜR STREET

IIj-17-08 KINESTEN STREET

111-17-16 NGFWELL FOAD

I11-17-11 NURHELL ROAD

$111-17-12$ NOFWELL ROAD

111-17-13 NUAOELL RÜAL

$111-17-15$ NOFFELL ROAE

I11-17-10 HURUELL FOAR

111-17-17 NOFHE_L ROÁL

I11-17-1E NOFAELL ROA:

111-17-17 EAGLE ROAD

111-17-20 KINGSTE: STREET

I11-17-21 KIAGSTOK STREET

IIj-19-0! EAELE ROAO

111-19-02 HANDVER STREET

111-19-04 HANDVES STAEET

111-19-65 KINGSTCN FLACE

I11-20-01 COHASSET RVENUE

I11-20-0G PEPBEURE STREET

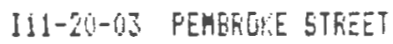

I11-20-004 HANUVER 5TREET

I11-20-05 HANOUES STREET

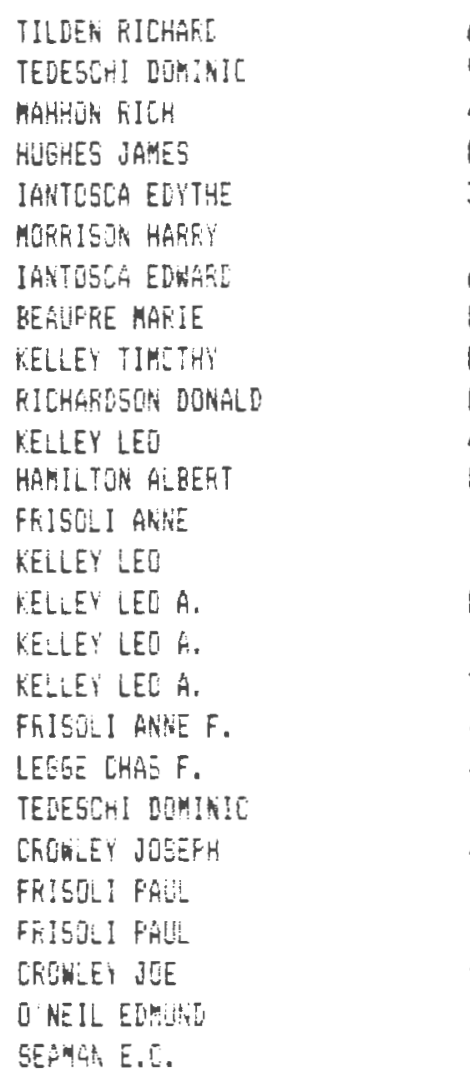

STILLMAK MAF'Y K. GURELTIS ALERGADER IANTUELA EUWATHD E. VIEIL DJK JPAES

FFISULI ANHE

RICHARES WILLIAM J.

FICHREDS HLL!AM J.

IAKTOSELED

TELESCH: DOMINIC

FICHAPRS HILLIAM

VIEIL DON JAKES

FRISUII ANNE

TEDESCHI DUMINIS

WIKBUULFE GAKBAR̃A

FRISOLI ANHE

IARTOSEA EOYTHE

IANTGSEA EDYTHES

ARIGGiN! DÁID C.

IANTCELA ELHATIE

ROEER WILL!AM

GREER DSRALD

TEDESCHI OQPUINIC F. IANTOSSA EDWGET E DUEFHT JULR A.

FEIELII ANHE

K'ELLEY IEO A.

MELGKJON RALFH

\begin{tabular}{|c|c|c|c|c|c|}
\hline 60 & $\mathrm{~F}-2 \mathrm{NO}$ & POS $\mathrm{NO}$ & NU & FEIVAT & 6000 \\
\hline & $\mathrm{R}-2 \mathrm{NF}$ & Fos NO & kĩ & PFIVAT & 12000 \\
\hline & $8-2 N 0$ & FOS NO & $\mathrm{NOI}$ & FEIVAT & 4000 \\
\hline & $\mathrm{B}-2 \mathrm{NO}$ & POS HO & No & PEIVAT & 7800 \\
\hline $0+[$ & Ki-2 ND & YES NO & NO & PEIVAT & 25000 \\
\hline 6 & $F-2 N E$ & FUS NJ & No & PRIVAT & 16150 \\
\hline & $\mathrm{R}-2 \mathrm{Nu}$ & FOS NG & NO & PRIVAT & 6000 \\
\hline & $R-2 N E$ & POS NO & NO & PRIVAT & 8000 \\
\hline & $5-2 N 0$ & POS NJ & $N 0$ & PEIVAT & 8000 \\
\hline & $R-2 \times[$ & PUS NO & NG & FRIVAT & 8000 \\
\hline & $\mathrm{R}-2 \mathrm{NO}$ & POS NO & NO & PEIVAT & 4000 \\
\hline & $R-2 N O$ & POS NO & NO & PRIVAT & 8000 \\
\hline 10 & $k-2 N O$ & POS NOS & $\mathrm{NI}$ & PFIVHT & 10000 \\
\hline 10 & $\mathrm{R}-2 \mathrm{NO}$ & PQS NO & NO & FRIVÁT & 10000 \\
\hline & $R-2 N O$ & POS NO & NI & PRIVAT & 10000 \\
\hline 70 & $R-1 N O$ & NO NO & No & PFIVAT & 10000 \\
\hline 75 & Fi-2 N[J & YES NO & NO & PKIVAT & 6000 \\
\hline & $\mathrm{R}-2 \mathrm{NO}$ & YES NO & $\mathrm{NO}$ & FRIVAT & 4000 \\
\hline & $\mathrm{R}-2 \mathrm{NI}$ & YES NE & No & FRIVAT & 4000 \\
\hline $100-$ & $\mathrm{B}-2 \mathrm{NJ}$ & YES NG & NO & PEIVATT & 10000 \\
\hline 40 & Fi-2 ki & FOS NJ & Ni & FEIVน́T & 400 \\
\hline $296+i$ & $F-2 N G$ & FUS YES & NO & PFIVAT & 20000 \\
\hline 120 & $\mathrm{~F}-\mathrm{NO}$ & FOE YES & $N[]$ & FEIVAT & 11000 \\
\hline ) & G-2 NO & YES NO & NJ & PFIVAT & 6000 \\
\hline i & F-2 NU & YES NG & $\mathrm{NO}$ & FEIVAT & 4000 \\
\hline 100 & $\mathrm{~F}-2 \mathrm{Nu}$ & YES NO & NO & PRIVAT & 8000 \\
\hline $220+i$ & $R-2 N O$ & YES YES & $\mathrm{NO}$ & PFIVAT & 12100 \\
\hline 00 & $\mathrm{~K}-2 \leqslant 0$ & YES YES & $\mathrm{NO}$ & PFIVAT & 10000 \\
\hline $100^{\circ}$ & $\mathrm{F}-2 \mathrm{k}$ & YES N! & Nỹ & FAIVAT & 10000 \\
\hline 60 & $k-\bar{i} N \bar{j}$ & PES YES & No & PRIVET & 5800 \\
\hline 60 & F $-2 \mathrm{NO}$ & PUS YES & NL & PRIVATT & 6100 \\
\hline 40 & $8-2$ No & PUS YES & NO & PRIVAT & 4000 \\
\hline 40 & $R-2$ NE & FUS YES & NO & PRIVAT & 4000 \\
\hline 90 & $R-z N 0$ & Fus NŌ & k! & PRIVAT & 8000 \\
\hline 100 & $\mathrm{R}-2 \mathrm{ND}$ & POS NO & No & PRIVAT & 13000 \\
\hline 40 & $\mathrm{k}-2 \mathrm{NO}$ & POS YES & NO & PEIVAT & 4000 \\
\hline 60 & $8-2 \mathrm{NI}$ & FOS NO & NO & PRIVAT & 6500 \\
\hline 60 & $\mathrm{~B}-2 \mathrm{NO}$ & FOS YES & Nú & PEIVAT & 7000 \\
\hline 40 & $\mathrm{E}-2 \mathrm{NC}$ & FOE NE & $N$ & PEIVAT & 4100 \\
\hline 40 & $R-2 N O$ & POS YES & No & PRIVAT & 4000 \\
\hline $195+i$ & $\mathrm{k}-2 \mathrm{H}[\mathrm{j}$ & FŨS YES & $\mathrm{NI}$ & FFIVAT & 9000 \\
\hline 0 & $\mathrm{k}-\mathrm{z} N \mathrm{NJ}$ & F'US YES & $\mathrm{N} 0$ & FRIVAT & 6000 \\
\hline $10+C$ & $\mathrm{~K}-2 \mathrm{NO}$ & FOS YES & $\mathrm{NO}$ & PRIVAT & 4500 \\
\hline 100 & $\mathrm{R}-2 \mathrm{NO}$ & F05 YES & $\mathrm{NO}$ & PFIVHT & 8900 \\
\hline $200+5$ & $\mathrm{k}-2 \mathrm{No}$ & FOS YES & $\mathrm{Ni}$ & FFIVAT & 33500 \\
\hline 60 & $\mathrm{~F}-2 \mathrm{NG}$ & PCS NOI & NG & FFIVAT & 6000 \\
\hline 80 & $\mathrm{~F}-2 \mathrm{NJ}$ & FOS NE & NO & PEIVAT & 8006 \\
\hline 80 & $5-2 \mathrm{NJ}$ & POS YES & NO & PRIVAT & 8000 \\
\hline $200+c$ & $\mathrm{~F}-2 \mathrm{NG}$ & YES NO & NO & PRIVAT & 4000 \\
\hline 60 & $5-2 k$ & FUS YES & NO & PEIVET & 6000 \\
\hline & $\mathrm{F}-2 \mathrm{kiJ}$ & PUS YES & NO & PEIVAT & 12000 \\
\hline & $\mathrm{F}-2 \mathrm{~N}$ & PUS YES & No & PEIVAT & 12000 \\
\hline & $\mathrm{Fi}-2 \mathrm{No}$ & POS $\mathrm{kO}$ & NO & PEIVAT & 8000 \\
\hline
\end{tabular}


FROMT IUN SEW WAT WET FFA ACLESS RREA SF

\begin{tabular}{|c|c|}
\hline $1: 1:-21-60$ & HARUVER STREET \\
\hline $111-21-07$ & HGNUYEX STREET \\
\hline $111-26-1.8$ & HAREVER STEEET \\
\hline $111-21-01$ & SUUTH RIVER STREET \\
\hline $111-21-03$ & CIHASSET STKEET \\
\hline $111-21-014$ & CURAESET STREET \\
\hline $11:-21-65$ & SOTH RIVEA STFEET \\
\hline $111-21-?$ & 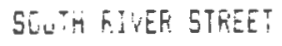 \\
\hline $1: 1-21-1 !$ & CPAASET STREET \\
\hline$j 1 j-22-01$ & SULTH FIVEF STFEET \\
\hline $31:-2 z-116$ & PAERTAS \\
\hline $11 i-2 i-0 j$ & FAFIHTI STREET \\
\hline $1: 1-2-10$ & CAHEFIESE STKEET \\
\hline $111-25-01$ & TEXAS STREET \\
\hline$i-2 i-02$ & TEXAS STKEE \\
\hline
\end{tabular}

III- $2 \mathrm{j}-1.4$ TEXA5 5TRET

D1-ZJ-0E WELHAETG ÁrE.

III-23-07 PAFIHAY

I11-23-6E WELLINETCH AVENLE

I11-2j-09 HELLIHGTULH RVERLE

I11-24-0! hELIINTOK GVERIE

I11-24-OS ASLINETCI STREET

II:-24-U4 AFEIATIN STREE?

RELAKSOA RELFH

IANTUSCA ELWANTL

MCCAEE JUSEFH E.

ETHANA ALLAH ERELH THUET

IANTOSCÁ EDIRTAO

MARLEY IAMES

STILLMES MAFF,

ENERG REALTY TRLST

TAEGHET FLEFIA

BRIHAX KELEN

SFINKNEY FIILL

FOEEIRS ALLER

CHFEELIE HILLIAKR.

DELAKS LIICT:LE

MARGIHE BUAR

FENBELLL MÁTY

MINCHIT C.H.

FOSTER JARET \& I.

FUEREY JOHW

RINLEIM CHAELES

SCONCE AHWG

CHEESMAL KRTHIEEK

BUCHÄRAN MÁSIE G.

I11-24-07 HSEHIHETEK GVE.

I:1-24-19 TETAS STREE?

II1-25-02 CHAFESTOWH STREET

I.J-25-OS CHMREETUWA ETKEET

I11-25-14 CHFF.ESTOWL STREET

111-25-J5 CHGRLEJTUA STREET

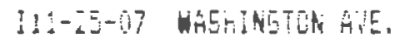

I:-25-O9 ARLINETIS STKEET

III-25-10 AFLINETON STREET

1:1-25-11 ABEINGTOR STREET

I11-25-13 AF:1NSTON 5TREET

I:1-25-16 CHAELESTUN STREET

I11-2t-02 CHAFRLEETOHN STREET

111-2E-0J CHARLESTCWN STREET

111-26-06 AFLINSTON STREET

I11-26-17 GFiNETON STREET

I11-27-03 AELINGTUN STREET

I11-27-14 AR:INGTUN 5TREET

311-27-05 AF:INGTON STREET

111-27-06 AFIINETER STREET

111-27-07 ARLINGTON 5TFEET

$111-28-32$ TENAS STREET

11-2E-0IS TEKAS STKEET

111-26-04 TEIAE STREET

I11-26-06 TEHAE STREET

111-20-07 TEXAS STKEET

II1-28-08 TEXAE STREET

111-2E-11 CAHERTIGE STREET

111-28-12 CAMERILE STREET

I11-26-13 CAHETIVE STREET
FAGL_ARZO LUCEECIS

LITTLE BAREGRT JEGR

CQREY DIAHE E.

DECASTRE JOSEF

ASCH CHEISTEPHES

ASCH FULARI

HSKLEA F. VIVIGH

CAYFEELL FHETHE

AECr RULGNI

5TORE ELIIABETH E.

DULLEA DENASE

CHEESRIA LAKFENEE

CRONIN FHILLIFS

VETRA THQNAS

SIMMUNS BETSEY

SIMMUNG HAFELD

DONOYART FICHAT̃O

DONBVAN FICHAEL

MURFHY MAFY

MURFIH MAEY

SIMUTins

SIMHONE ESTELLE

SIMMÖNE HAEOLD

SIMULNE HARSE

SIMADNS ESTELLE

SIRHONE HAETID

TEDESCHi OURGIL

GURECKIS ALEX.

GUFECIIS ALEK
MUEFHY MARY
40 K-2 NO POS NO NO PFIVAT 4000

46 FI-ZNO PDS NI NO FIRIVAT 4000

40 R-2 NU POS NO NO PRIVAT 4006

$205+C R-2$ NU YES NO ND PUELIC $1: 460$

80 FI-Z NO YES NU NO PFIVAT 10000

120 R-2 HO YES NO NO PRTVAT 20060

100 F- 2 NO YES NO NO PUELIC 20006

130 K-2 HO YES NJ NO FUESIC 16000

20 H-2 NU YES NI NU EFIVHT 2000

150 R-2 NU YES NO NO PUELIC 22506

42 F-2 NO POS YES NE PFIVAT 4000

$130+E$ F-2 NO PQS YES NE FEIVAT 2400

100 R-2 NO YES YES YES FEIVAT 4000

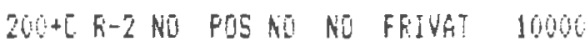

40 R-2 HE FUENE NO PFIVAT 4QOC

$275+E K-2$ NE PQE NU NO FEIVAT 10000

52 F-2 NG FOE NO NI FFIVAT 4000

$230+[$ F-2 NO FIS YES HO FRIVAT 12060

40 R-2 NO POS YES FES PFIVAT 4000

40 R-2 NO FOS YES FOS PKIVGT 4000

$200+C$ F-2 NI POS NU NO PRTVAT 10000

100 Fi-2 NU YES NU NJ FUEEIS 16060

4i. R-2 NO YES NO NO PUELIC 4060

$420+C$ K-2 NJ FOS NO NO PRIVAT 20000

120 BI-2 NU POS NE NO FRIVAT 12600

80 R-2 NO YES RI NJ PAIVGT EOTO

4. F-2 HO YES NO NO PEILAT 4000

40 R-2 NO YES NO NO PRIVAT 4000

85 G-ZNE YES NJ NE PFITAT 3000

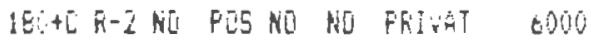

40 FI-ZNO YES NO NO FEIVAT 4000

60 R- 2 NU YES NŨ NO FEIVAT 6000

40 B-2 NO YES NÜ NO FUBLIC 4000

60 R-2 NO YES NO NO FUE LIC 6000

60 FI-2 NE YES NU NU FRIVAT 6000

200 FI-Z NO FOS NO NO FRIVAT 20000

lQG R-Z NO POS NU NO PRIVAT $1000 \mathrm{O}$

40 RI-2 NO YEE NJ KJ FUELIC 4060

4. R-2 NO YES HU NO PLELIC 8006

40 R- $Z$ HO YES NO NO FUELIC 4006

40 F-2 NG YES NL NO FUEDIC 4000

40 RI-2 NO VES NO NO PUELIC 4000

40 Bi-2 NO YES NO NO FUEDIC 4000

40 FI-2 NJ YES NO NO FFIVAT 4000

4.) R-2 HO FUJ NO AE FEIVHT 4000

60 R-2 NI POS NO NO PRIVAT OOJOG

40 K-2 NO PGE NE NO FFIVAT 4000

40 Ti-2 NG POS ND NO PRIVAT 4000

40 Fi-2 NJ POS NO NO PFIVAT 4000

60 K-2 NO POS NO NI PRIVAT 6000

$160 \quad \bar{R}-2$ NO YES YES YES N/A $1609 \mathrm{~A}$

100 R-2 ND YES NO NO PFIVAT 10600

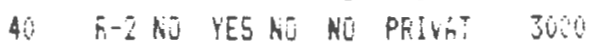




\begin{tabular}{|c|c|c|c|c|c|c|c|c|c|}
\hline & & & & & & & & & \\
\hline $111-28-15$ & CAMESTDGE STKEET & SLLLIVAN RAFËAKET & 40 & $\mathrm{R}-\mathrm{z} \mathrm{NO}$ & YE5 & No & NO & PRIVGT & 4060 \\
\hline $111-26-16$ & CAMETIDGE STFEET & STAFFOES EDWAGD & 160 & $R-2$ NO & YES & NO & NO & PEIVAT & 18006 \\
\hline $111-28-17$ & CAMERIUGE STKEET & MITTON FRAN!' & $240+C$ & $\mathrm{R}-2 \mathrm{NO}$ & YES & NO & no & PRIVAT & 10600 \\
\hline $118-01-01$ & SDLTH RIVEF ST. (OFF) & MAFION REALTY TRUST & NONE & $R-1$ Nó & NO & YES & No & HO DIR & 1078110 \\
\hline $112-01-02$ & PEMERTHE STREET & FRISULI ANKE & 100 & $\mathrm{R}-2 \mathrm{NO}$ & YES & NO & No & PRIVAT & 15500 \\
\hline $116-0 !-03$ & SOLTH RIVEF STKEET & GUY VINCENT & $95+C$ & $R-2$ NO & YES & No & No & PUELIC & 160000 \\
\hline $112-011-10$ & SEUTH FIVEF STREET & HILLIAMS BFOS.INC. OF MÁFSHELD & 101 & $\mathrm{R}-1 \mathrm{NO}$ & YEE & NO & No & PUELIC & 21400 \\
\hline $\mid 12-01-1]$ & SUITH RIVEF STHEET & WILLIAME BROS. INC. OF MAKSHFLD & 120 & $\mathrm{R}-1 \mathrm{NO}$ & YES & N0 & no & PUELIC & 21600 \\
\hline $112-01-12$ & SQLTH FIVEF STREET & HILLIAHS BROS. INE. OF MáRESHFLO & 103 & $\mathrm{R}-1 \mathrm{NO}$ & YES & $\mathrm{k} \amalg$ & $\mathrm{HIO}$ & PUELIC & 20700 \\
\hline $112-01-13$ & SELTH RIVEK STREET & WILLIAMS BRO5. INE. OF MARSHFLD & 98 & $\mathrm{~B}-1 \mathrm{NO}$ & YES & No & NO & PULIC & 20950 \\
\hline $112-01-16$ & SULTH FIUEE STKEET & HIILIAME BFOS. INC. & 80 & $\mathrm{R}-1 \mathrm{NO}$ & YES & YES & No & PUELIC & 8E5135 \\
\hline $112-02-05$ & 5UUTH RIVER STKEET & TAGGGEFT VALENTIHE & 350 & $R-1 N$ & YES & YES & No & PUELIC & 78406 \\
\hline $112-02-06$ & SOLTH RIVER STREET & ANEEREDR THEOEDTA N. & $145+[$ & $\mathrm{F}-1 \mathrm{NO}$ & YES & YES & NO & FUELIE & 152460 \\
\hline $112-03-03$ & OVERLEOKK RUAL & IEREGA ANAGA & 80 & $F-1 \times 3$ & Fũ & AJ & No & $N / A$ & 8000 \\
\hline $112-03-04$ & MINNESOTA STKEET & MEVEFE PGULL 100 & 100 & R-1 KI & YES & $\mathrm{NE}$ & Noi & FRIVAT & $80: 0$ \\
\hline $112-03-04$ & BINNESOTA SThEET & MEYEES FALUL & 100 & F-1 Nũ & YES & AS & No & PFIVAT & 8000 \\
\hline $1.2-0 j-0 j$ & INEIAHA S & VAREEHTINE & 40 & $\mathrm{~F}-1 \mathrm{NO}$ & NO & YES & ND & FEIVAT & 4000 \\
\hline$\| 12-04-01$ & SOUTH RIVEF STKEET & T FOUNEATICN & 120 & $\mathrm{~F}-1 \mathrm{NO}$ & YES & No & No & FUELIC & 10060 \\
\hline $11 z-04-02$ & IMDIAMA STFEET & EEY PÁlli E & 170 & $\mathrm{R}-1 \mathrm{NO}$ & NO & YES & No & PFIVAT & 12000 \\
\hline $112-(14-0\}$ & INIIA: & JUYCE $H$ & 180 & $\mathrm{R}-1 \mathrm{NO}$ & No & YES & No & PFIVHT & 22500 \\
\hline $11 z-04-05$ & RIFHEJ & [H] & 40 & R-1 Nu & YES & NI & no & FEIVAT & 4000 \\
\hline $112-04-06$ & MUNESOTE SThEET & BARES & 60 & $\mathrm{~F}-1 \mathrm{Nu}$ & YES & Nū & No & RIVAT & 6000 \\
\hline $112-04-07$ & SOUTH FIVEF STKEET & DOYCE H & 100 & $\mathrm{~F}-1 \mathrm{NU}$ & YES̄ & NO & NO & UELIC & 850 \\
\hline $112-05-61$ & PEFEGFINE WHITE DR. & ETHAN ALLAN ERTIHA TRUST & 300 & $\mathrm{~F}-1 \mathrm{~kJ}$ & YES & nu & No & GIVTT & 69656 \\
\hline $112-05-02$ & PEEREGLINE WHITE RK. & 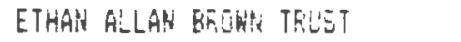 & 23 & & PQIS & NO & NO & IIVAT & 7370 \\
\hline $113-01-01$ & FEFGYY STREET & FICHARE & 246 & $k-1$ & YES & NO & NO & ELIC & 0533 \\
\hline $11 j-\hat{v} 1-64$ & FEŔRYY STREET & HILLIAMS BROS. ¿NE. & 102 & Fi-1 NO & YES & NS & 40 & FUELIC & 95632 \\
\hline $11 j-6 j-15$ & SUITH FIVEF STEEET & FALLOTTÁ JUSEFH & $700 \dot{0}$ & $\mathrm{k}-1 \mathrm{NU}$ & YES & YES & NO & PUELIC & $151414 t$ \\
\hline $113-04-01$ & SOLTH RIYEA STFEET & TOWNES MAATY & $340+[$ & $\mathrm{F}-1 \mathrm{NOI}$ & YES & YES & $\mathrm{NO}$ & FUELIC & $6534 i$ \\
\hline $11 j-05-0 j$ & Eutri: LGHE & DOW GEOROE L. & 150 & $\mathrm{~B}-1 \mathrm{NO}$ & Fos & kit & NO & PEIVAT & 45736 \\
\hline $113-06-02$ & MAIFLOHEE FUAD & SFENCEK NANEYY LEE & 45 & $\mathrm{k}-1 \mathrm{kO}$ & YES & YES & No & PUELIL & 87120 \\
\hline $113-06-06$ & BAYFL TULER Fún: & MILLER EVITH A & $48 . j$ & $\mathrm{~F}-1 \mathrm{~N}[\mathrm{I}$ & YES & No & NIJ & PUELIC & 32760 \\
\hline $113-07-03$ & FILGFIM RUAL & LUND RCEEFT & $2001+C$ & $\mathrm{~B}-1 \mathrm{NO}$ & P05 & FOS & No & FRIVAT & 24060 \\
\hline $113-08-02$ & SOITH RIVER ETREET & PALLUTTH JOSEPH & 169 & $\mathrm{k}-1 \mathrm{NO}$ & YES & POS & NO & FUELIC & 54014 \\
\hline $113-08-03$ & FILGRIM KOAD & FAGE MILTON 5. & $120+i$ & $h-1 N O$ & YES & YES & Nō & PEIVAT & 36000 \\
\hline $113-06-04$ & PILGKIM RUAL & HAMILTON BETTY JANE & $200+C$ & $R-1$ NO & POS & YES & No & PRIVAT & 104544 \\
\hline $113-0 E-10$ & PILGEIM RUKE & HJOL GEŨRGE A. JK. & 100 & $F-1 N 0$ & P05 & NO & NO & FEIVAT & 23000 \\
\hline $114-01-06$ & IKOIAK FOAD & KELLY KUBERT D & 182 & $\mathrm{~F}-1 \mathrm{NO}$ & YES & NO & No & PUELIC & 130680 \\
\hline $14-03-01$ & FERRY STREET & HILLIAHS BFOS. INC. & 101 & $\mathrm{R}-1 \mathrm{~N} U$ & YES & no & NU & FUELIC & 74052 \\
\hline $114-03-10$ & FEFEY STREET & REDONEELL MICHAEL & 121 & $R-1 N O$ & YES & YES & NO & PUELIC & 29320 \\
\hline $14-0 j-12$ & NAP JER FID. FERRH ST & BERNAFIDI KGTHLEEN & $300+E$ & $R-1 N O$ & YES & Nū & No & FUELIC & 25,70 \\
\hline $14-63-20$ & BEOGKK KUAL & RLRAE RICHARD & 201 & $5-1 \mathrm{NL}$ & YES & NO & No & PUELIC & 31800 \\
\hline $14-0.3-22$ & GROOK REH & NERGGEF GEORIGE & 200 & $\mathrm{R}-1 \mathrm{NI}$ & YES & NO & NO & PUBLIC & 52272 \\
\hline $14-04-03$ & ELM STREET & SHERMAK JOHN & $174+C$ & $R-3 N D$ & YES & $\mathrm{NJ}$ & $N a$ & FUBLIC & 23680 \\
\hline $14-05-011$ & FIUEE ROAE (FEERA) & CORRIGAN JHFES & No & $\mathrm{K}-\mathrm{J} N \mathrm{NO}$ & $\mathrm{NE}$ & YES & YES & HJ $\mathrm{NR}$ & $14 \overline{2}, 13$ \\
\hline$[14-05-12$ & EAYGERTY RUFI & PEPE CAFLOL C. & 92 & $R-3 \times U$ & NO & YES & YES & $N / A$ & 9594 \\
\hline $114-05-13$ & SHAEY LANE (OFF) & AEFBER GEORGE & NÜE & $8-3 N[$ & NO & YE5 & YES & NG DIF & 1000 \\
\hline$[14-05-14$ & SHAD: LAKEE & NERGEF GEOREE & 90 & $R-3 N$ NI & POS & YES & YES & FUELIC & 50629 \\
\hline $114-05-15$ & SHIFYAFI RDAD & NEFEER GEDKGE & 312 & $\mathrm{~F}-3 \mathrm{KL}$ & YES & NO & YES & $P L Q L L I C$ & 171151 \\
\hline $14-0.05-16$ & MHALEE PÜAR & NEFEEF EESLSEE & 155 & $R-3 \mathrm{NL}$ & YES & No & YES & FUELIC & 31204 \\
\hline $14-05-21$ & FEREY STKEET & EECHWTH OLIMEF & 101 & $\mathrm{~F}-\mathrm{j} k \mathrm{k}$ & YES & YES & NO & PLELIS & 171191 \\
\hline $4-06-01$ & F!DGE RCUE & CUFFISAA JAMES & AGNE & $\mathrm{F}-\mathrm{J} \mathrm{Ni}$ & NI & YES & YE5 & NU UIR & 23435 \\
\hline $14-66-14$ & FIUEE READ (UFF) & MOL ! HIEET & NWTHE & $\bar{R}-3 N E$ & Nä & YE5 & YES & NE dis & 90207 \\
\hline
\end{tabular}




\begin{tabular}{|c|c|c|c|c|c|c|c|c|c|}
\hline A5. Min $-1 \mathrm{~L}^{\circ}$ ? & LUEFIJUh & GWHER GIF REC & FRONT & 20N SEH & HAT I & WET & FPA & ACCESS & AREA SF \\
\hline 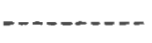 & - - & $-\ldots+\ldots$ & & 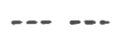 & -.. & -- & --- & $-\ldots-n$ & \\
\hline $115-62-05$ & EMEFI ROAL & QULIGLEY JACOE $\boldsymbol{~}$. & $220+i$ & $\mathrm{~K}-3 \mathrm{NO}$ & YES & NO & NO & PEIVAT & 18553 \\
\hline $115-6-i b$ & CEDSGF, RGQAD & SHEEHAN FAL: J. & 85 & $\mathrm{Ki}-3 \mathrm{NO}$ & NO & NO & $\mathrm{HO}$ & PEIVATT & 12229 \\
\hline $115-03-01$ & EREEYY FUEAD & RUCKLAKS TKUST CO. & $240+C$ & $\mathrm{k}-3 \mathrm{NO}$ & YES & $\mathrm{NO}$ & No & PEIVAT & 13085 \\
\hline $115-6 j-62$ & JUHFER RUÄ & CLAET MÁFiJOFIE & 85 & $\mathrm{k}-3 \mathrm{NO}$ & YES & NO & 1.0 & PRIVAT & 9480 \\
\hline $115-0 j-16$ & DHIEHT ROAD & ROMAR CATHCLIC AFCHEISHEF & $200+C$ & $\mathrm{E}-3 \mathrm{NO}$ & YES I & NO & NO & PULBLIC & 12000 \\
\hline I: $5-6 j-07$ & DHEHT ROAD & OHAFA HILLIAM F. & 85 & $\mathrm{~K}-\mathrm{j} \mathrm{NO}$ & YES & NO & No & PUELIC & 9770 \\
\hline $115-04-i 2$ & Eh SHA FCLI & HAMNEY FAUL & 87 & $R-3 N[$ & YES & NO & NO & PUBLIC & 14165 \\
\hline $1: 5-04-35$ & ELM STREET & RUḾ̈U CATHULIE AREHEIEHOF & $350+5$ & $\mathrm{~F}-3 \mathrm{ND}$ & YES & NO & No & PUELIC & 60984 \\
\hline $115-6 t-0 !$ & FEFEY STFEET & NEFGEF GEUREE & 344 & $\mathrm{~K}-3 \mathrm{No}$ & YES & YES & YES & PUELIC & 60984 \\
\hline $115-06-12$ & ELP ETREET & LANDERS JEARY & $200+[$ & $F-3 \times 5$ & YES & 10 & NJ & FUELIC & 20985 \\
\hline $115-07-61 \bar{y}$ & DOFHIK FOALE & WHLSH CHESTER RICHAE & 45 & $\mathrm{R}-3 \mathrm{NO}$ & YES & NO & NO & PRIVAT & 2824 \\
\hline $115-07-17$ & ELM STREET & KINGELLA EEHAFE & 60 & $\mathrm{~K}-3 \mathrm{NL}$ & YES & NO & No & PUE:IC & $900 \hat{0}$ \\
\hline $115-10-67$ & MEERE FIUAL & MUTHA ARTONIO $\mathrm{n}$. & 123 & $\mathrm{~K}-\mathrm{3} \mathrm{NO}$ & NC & NO & YES & FEIVAT & 7378 \\
\hline$i 15-j 1-6 j$ & TEEKE REA: & HOAF F: ÜFENCE & 6: & $\mathrm{K}-3 \mathrm{NE}$ & $N=1$ & HO & YES & PEIVAT & 2600 \\
\hline $115-11-21$ & FEFE, STEEET & O'BFEN EDWAER & 40 & $R-3 N 0$ & YES & NO & YES & PUELIC & $316:$ \\
\hline $11 \pm-11-2 z$ & FEFETI STREET & EHEER JOHRH. & $67+[$ & $\mathrm{R}-3 \mathrm{NO}$ & YES & $\mathrm{NLi}$ & YES & FUELIC & 71874 \\
\hline $115-11-25$ & NEF TLAE FOGE: & DAVIS HILLIAH & $163+5$ & $\bar{B}-\bar{J} \mathrm{~N} \overline{\mathrm{S}}$ & YES I & $\mathrm{NO}$ & YES & FRIVAT & 18602 \\
\hline $115-11-27$ & REERE FUART & REEERT RERE J. & 95 & $k-J N[$ & Nō & $\mathrm{HO}$ & YES & PEIVAT & 66211 \\
\hline $115-11-30$ & FEFFY STREET (CFF) & HUAT LOUISH & NONE & $\mathrm{F}-3 \mathrm{NL}$ & NC & YES & YES & NO DIR & 6400 \\
\hline $115-11-31$ & FEFFY STREET (OFF) & HUNT LOUEIA & NGJNE & $\mathrm{R}-3 \mathrm{NO}$ & NO & YES & YES & WJ DIK & 9365 \\
\hline $115-2: 2-02$ & FEFNY STREET & CARLTCH JCHR & $90+5$ & $R-3 N 0$ & YES & NO & YES & FUELIC & 11000 \\
\hline $1 ! c_{1}+14-02$ & BAYEEFT RUAE & KERK FRAHH， D. & 175 & $\mathrm{~K}-3 \mathrm{HE}$ & YES & No & YES & FUELIS & 7500 \\
\hline $115-14-67$ & FEFEYY STREET & HAFENKEY JOHK & 75 & $\mathrm{k}-\mathrm{J} \mathrm{NO}$ & YES I & NO & No & PUBLIC & 7625 \\
\hline $115-15-01$ & FEFFY STREET & MCDCNOLGH HILLIAM & $150+[$ & $\mathrm{Ki}-3 \mathrm{NO}$ & YES & NO & YES & PUELIC: & 17655 \\
\hline $115-16-0 ;$ & MALLÁFE REAR & LEOKE GEFBARC & 155 & $\mathrm{~K}-3 \mathrm{NO}$ & YES & NO & YES & FUELIC & 15000 \\
\hline $115-16-06$ & FEATEY STREET & FOLEY JAMES A. & 82 & $\mathrm{R}-3 \mathrm{NG}$ & YES & HO & YES & FUELIC & 10421 \\
\hline $115-17-61$ & MELLAKT FÜĹ: & RUSEI GRLANSO & $75+C$ & $\mathrm{R}-3 \mathrm{Ni}$ & YES & NO & YEE & PUELIC & 7500 \\
\hline $115-17-62$ & SHIFYASD RERE & VDGEL FAUL E. & 300 & $\mathrm{~K}-3 \mathrm{NO}$ & NO & YES & YES & $N / A$ & 22560 \\
\hline $115-17-34$ & MALLAKL RUALI & SIMHUNS MFEY LQUISE & 75 & $\mathrm{R}-\overline{3} \mathrm{Nu}$ & YES & NO & YES & PUBLIC & 7500 \\
\hline $115-18-2$ & EAYEERTE ROSA & LYUNE FHUL & 175 & $R-3 N 0$ & YES & ND & YES & FLELIC & 7500 \\
\hline $115-1 \bar{E}-60$ & 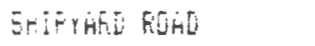 & HALEY JOHHA $F$. & $E: 5$ & $\mathrm{~K}-\mathrm{j} \mathrm{NO}$ & YES & NO & YES & FUELIC & 7452 \\
\hline $115-21-02$ & BAYEETEY RIJAL & NERËERT' GEUTRGE & $300+i$ & $R-J N O$ & YES & $\mathrm{No}$ & YES & FUELIC & 32390 \\
\hline $115-21-015$ & FIOGE RGLE & CKOSSPAA HENEYY & 75 & $\mathrm{R}-3 \mathrm{NJ}$ & YES & YES & YES & FUBLIC & BQEZ \\
\hline $115-21-06$ & MEALCW LAHE & CJURLEY JUHI & 124 & $\mathrm{~F}-3 \mathrm{NO}$ & YES & NO & YES & PFIVAT & 8000 \\
\hline $115-22-01$ & GAYEEREY RCED & NERG̈EFE GEQR'GE & 160 & $\mathrm{R}-\mathrm{J}$ NO & YES & NJ & YES & PUELIC & 126324 \\
\hline $115-24-01$ & BAYEEFFY RJHAL & NEFGEET EED. & 345 & $R-3 N O$ & YES & YES & YES & PUELIC & $56 t 28$ \\
\hline $115-24-02$ & RIDOE FEAT & NASEE ELHIN & 75 & $R-3 N:$ & YES & YES & YES & FUELIC & 7873 \\
\hline $115-24-10$ & BATEEFFY RDAD & NERSER GEORGE & NoLiE & $R-3 N u$ & NO & YES & YES & NO DIR & 557568 \\
\hline $115-24-15$ & FEFEY STKEET & KGF: OL GEJREE & 38 & $\mathrm{k}-3$ NO & YES & YES & YES & FUELIC & 4300 \\
\hline $1: 5-24-2 i$ & FEER STKEET & FAFELY RICHARE & 120 & $R-3 N C$ & YES & HO & YE5 & FUELIC & 5200 \\
\hline $115-24-2 z$ & FERKY STREET & WOWE JANICE & 40 & E-4 Nu & YES & $N \rrbracket$ & YES & PUBLIC & 1500 \\
\hline $115-24-24$ & FEFh, STREET & YEE KEARTH H.P. & $180-5$ & E-4 NE! & YES & NO & YE5 & FUBEIC & 5900 \\
\hline $115-24-25$ & FILGE REGÉ & MAESHFIELD YACHT CLUS INE. & 50 & $\mathrm{~K}-3 \mathrm{NO}$ & YE5 & YES & YES & PUBLIC & 10106 \\
\hline $115-24-26$ & BATEEFRT RUAL & FEAF: EVERTT H. & 145 & $R-j N G$ & YES & YES & YES & PLIELIC: & 11015 \\
\hline $11 t-02-02$ & FEESTCR TEFSHCE & RAYKEF FICKABR̃. & $129+i$ & $\mathrm{~K}-3 \mathrm{NJ}$ & YE5 & Nó & Nū & PUELIC & 11200 \\
\hline $116-12-64$ & FRESTOM TEREFEFFI ST & RÁYNEK MAKILEE & $209+C$ & $\mathrm{~K}-3 \mathrm{NO}$ & YE5 & NO & $\mathrm{NL}$ & PUELIC & 11600 \\
\hline $110-63-10$ & CAFITOH RGAL & DQROTHY M. TRUEE TKJST & 120 & $\mathrm{R}-3 \mathrm{NU}$ & YES & NO & NO & PUBLIC & 10740 \\
\hline $116-05-12$ & COLUMELA KUAJ & FULLER CAESOL JEAN & 60 & $\mathrm{R}-3 \mathrm{NO}$ & YES & HI & No & FUELIC & 7875 \\
\hline $116-67-03$ & CHAFThil WAY & MURFK' FhïL $H$. & 92 & $\mathrm{R}-3 \mathrm{NO}$ & P05 & NO & No & PRIVAT & $185: 2$ \\
\hline $116-07-66$ & ALLERTCH ROAD & CORNEL IUE FORDE & $6 ?$ & $\mathrm{R}-3 \mathrm{NO}$ & POS & NO & No & PRIVAT & 10010 \\
\hline $116-09-014$ & SEA STKEET & BUNLEF MABEE $\mathrm{F}$. & 86 & $\bar{R}-3 \times 0$ & YES & Nü & NO & PFIVAT & 5732 \\
\hline $116-12-05$ & SEA STFEET & CAFIIZOL! BEVEKLY & 60 & B-4 NE & YES & NO & NO & FFIVAT & 7565 \\
\hline $116-12-16$ & HYIE WAY & DALIELL WATANER & $80+C$ & $\mathrm{~K}-3 \mathrm{NO}$ & YES & No & No & PUBLIC & 4800 \\
\hline
\end{tabular}




\begin{tabular}{|c|c|c|c|c|c|c|c|c|c|}
\hline AS. PLF-LUT & LEIATION & UEREE JE REL & FFiUHT! & ZON EEH & WAT & HET & FFA & ACCESS & AR̃EA SF \\
\hline $16-i \bar{z}-1 \bar{i}$ & HYLE HEY & ERJBSE CERETARE & $80+C$ & $\mathrm{~F}-3 \mathrm{NJ}$ & YES & NO & $\mathrm{NO}$ & FUPLIE & \\
\hline $16-12-16$ & HYDE WAY & EF:J5E CONSTARIE H & 72 & $\mathrm{~K}-3 \mathrm{Na}$ & YES & Ni & No & FLE:IC & \\
\hline $16-i 2-19$ & IFELANI FUA口 & JFF NUTHEE RERLTY & NGRE & $-3 \mathrm{NO}$ & VES & $\mathrm{NL}$ & Nũ & & \\
\hline $16-12-20$ & 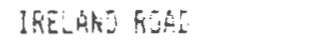 & JFE NUTHLEE REALTY TRIST & 127 & $\mathrm{~F}-3 \mathrm{NO}$ & YES & $\mathrm{NO}$ & N5] & UELIC & \\
\hline $1 t-13-07$ & ERE STREET & BRUAO AFTHUR & $180+\bar{i}$ & $\mathrm{~F}-3 \mathrm{NO}$ & YES & NO & NO & UELIC & \\
\hline$-15-014$ & EFFY STREET & WFi THOH is hi. & 70 & $\mathrm{R}-3 \mathrm{Ni}$ & YES & YES & YES & & \\
\hline $16-15-15$ & EFSY STEEET & ERULU ARTHLR & 275 & $\mathrm{~F}-3 \mathrm{NOS}$ & YES & $\mathrm{NO}$ & YES & FUELIL & \\
\hline $10-15-06$ & EFF' STREET & G'CUNATE PILHAEL & $12 i-5$ & $5-3 N 5$ & YE5 & NŨ & YE5 & & \\
\hline $16-15-6 E$ & RESTUN TEFHFEFEI ST & BSCWR FULAND & 40 & $\mathrm{R}-3 \mathrm{NS}$ & YES & Nu & $\mathrm{NL}$ & & \\
\hline $5-\sqrt{7}$ & FEFEV STFEET & VOUNEWUETH WILL LAM & 85 & $-3 \mathrm{Ni}$ & YES & YES & YES & FUELIC & \\
\hline $6-15-10$ & RESIU: TEFUEFRY ST & LOOMIS AAFIITH & 80 & $-3 N 0$ & YES & NO & $N 5$ & FUE & \\
\hline $\mid 6-\{5-1 !$ & EFF, SAFEET & EHEAETT UAREEL & 120 & $-3 \mathrm{NO}$ & YES & YES & VES & & \\
\hline $5-12$ & EFE STREET & SEEANA AETHUL & 45 & $-3 \mathrm{NO}$ & YE5 & $\mathrm{NO}$ & YES & PUE_IC & \\
\hline $10-15-13$ & FEFF, STFEET & FAELET RSEERT & 60 & $\mathrm{~F}-3 \mathrm{NO}$ & YES & YES & YES & FUE & \\
\hline $6-15-14$ & REETOH TEFGFE & TUGHEF AFTHULE & 83 & $R-j N$ & YES & $\mathrm{NJ}$ & $\mathrm{NE}$ & & \\
\hline $1-61$ & ARESNELI STREETIOFF & GAFSTUR IAHES U. & 200 & $\mathrm{~F}-2 \mathrm{~N}[\mathrm{~J}$ & YES & YES & No & IC & \\
\hline $1-6-14$ & AFEERE:LL STREET & HALL LINGSH & 70 & $R-1 \quad N E$ & $\mathrm{Ni}$ & YES & No & PUE & 252 \\
\hline $12-01-15$ & AFEESELL STFEET & PÚFE JO & $4: 5$ & $\mathrm{~F}-1 \mathrm{NO}$ & NS & YES & NE & & \\
\hline $4-01$ & DUCK HILL LARE (GFF) & HE:A5 A & No:iE & $\mathrm{F}-2 \mathrm{NO}$ & NO & YES & YES & NO & \\
\hline$=-04-05$ & CAEWELL STEET & RDEIAEJR RGFGARE? & 306 & $\mathrm{~F}-2 \mathrm{~N} \mathrm{NU}$ & Ni & Ni & N! & PUELIC & \\
\hline $32-04-6 i$ & CESTI HENTTT LAHE & HEATIT COLES JF. & 000 & $\mathrm{~F}-2 \mathrm{~N}$ & Nĩ & PES & VES & FEI & \\
\hline $4-10$ & DUER HIL LA:E fLFF\} & SUEETO DUEGAS A. & NuKE & $\mathrm{F}-2 \mathrm{NO}$ & No & YES & YES & Nõ & \\
\hline$-17-01$ & STEGMESAT DRIVE & NAFSURE CHAFEE & 125 & FI-1 NO & YES & No & $\mathrm{Nu}$ & PULELIC & \\
\hline$-02-04$ & STEHASTET DEIVE & HEEERT BLHAFIELE REALTY TRLET & 66 & Fi-1 Ni & YES & Nō & NO & & \\
\hline $2-i$ & CARESHELL ETREET & SWEET ROSER H. & NUKE & $\mathrm{FilNO}$ & $\mathrm{N}[\mathrm{j}$ & YES & YES & No & \\
\hline $04-0:-20$ & FLETCHEF IXILE & FUThE) IMC. & 178 & $\mathrm{~K}-\mathrm{i} \mathrm{NE}$ & YES & No & $\mathrm{ND}$ & PFIVATT & \\
\hline$(14-05-24$ & FEETCHEF DEIVE & FUTHEY IRT. & 17 & $R-2 N E$ & YES & NO & $\mathrm{No}$ & & \\
\hline-25 & AFFLETON WAYE & FUEET JURELE & $27 t$ & $\mathrm{~F}-2 \mathrm{AO}$ & YES & n & $\mathrm{Ni}$ & & \\
\hline $104-3.5-20$ & AFFLETUK 触E & PUTAEY IlYE. & 150 & $\bar{R}-2$ NE & YES & NO & NI & $A T$ & 22 \\
\hline $64-5 .-27$ & ACELTON ROE & KUEERT & 68 & $\mathrm{R}-2 \mathrm{NJ}$ & YES & Nu & $k \overline{0}$ & & \\
\hline & AFFLETER WAE & FUISEY INE. & $6 \bar{E}$ & $\mathrm{~F}-2 \mathrm{NO}$ & YES & No & $\mathrm{NO}$ & & \\
\hline$(14-03-29$ & ACFLETOR WAE & RUEERT A. JLHISTE & 117 & $\mathrm{k}-2 \mathrm{NO}$ & YE5 & NJ & $\mathrm{kit}$ & PRIVAT & 2126 \\
\hline $04-0.5-30$ & FLEETHEF DSIUE & FUTHEY IKC. & $500+5$ & $\mathrm{Fi}-2 \mathrm{NO}$ & YE5 & H.J & No & PEIVAT & 2265 \\
\hline & STEABEULT DRIVE & FUTNEY INE. & 123 & $\mathrm{k}-2 \mathrm{NG}$ & YES & NO & NO & & \\
\hline $04-03-30$ & CASHELL STREET (DFF) & ALEERT SCHSFIELO FEALTY & NükE & $\mathrm{Fi}-1 \mathrm{NO}$ & NO & YES & No & If & 76865 \\
\hline $04-03-46$ & WEBSTER STFEET (CFF) & FUEARI GINO & NURE & $\mathrm{R}-1 \mathrm{NO}$ & POS & HiJ & No & NO DIR & 261360 \\
\hline $104-03-50$ & PILGFIM TFAIL & IAIÁ GALE A. & 152 & Fi-1 NJ & P05 & NO & $\mathrm{NO}$ & IVAT & 4350 \\
\hline $3-5 ?$ & HESETER STREET (OFF) & MINELLI EFNEST III & 500 & R-1 NO & $P 05$ & No & NL & & 8642 \\
\hline $104-0 j-54$ & HEESTEF STREET (OFF) & ARCHEN' FILEETT & 90 & $R-1 N O$ & NO & $\mathrm{Nú}$ & No & NO DIR̆ & $1638=$ \\
\hline $05-06-05$ & OESEFVATOFYY WAY & OBSERVATOEY REHLTY TKUST & 125 & $k-2 \times 0$ & YES & kú & NO & PFIVAT & 2079 \\
\hline $05-6 E-0 ?$ & SIENGE HILI ROAJ & NGSEH REALTY TFULET & 120 & hi-i NO & YES & ND & No & & \\
\hline $05-09-16$ & OUTLOOR KUGD & OOVLE JAMESC. & 120 & $\mathrm{~K}-2 \mathrm{ND}$ & YES & NO & No & PUSLIC & 2071 \\
\hline $05-10-05$ & STATE5MAN TEREFÁLE & MC GOHEN ANRAM M. & $12 i$ & $\mathrm{~h}-3 \mathrm{KJ}$ & YES & NO & NO & FUELIE & 2004 \\
\hline $6 t-02-9 t$ & STAIESHAR TEKKÁEE & FESERTVIC HICHAEL & 120 & $\mathrm{~K}-2 \mathrm{NG}$ & YES & $\mathrm{No}$ & $N 0$ & PLELIC & 2024 \\
\hline $06-02-10$ & STATESHAR: TERTRACE & FESEFVIC MICHAEL & 120 & $R-2 N O$ & YES & NO & NO & FUELIC & 2037 \\
\hline $06-0 j-15$ & OFEHARE EUAD & LEAḦ JUHK JF. & 120 & $\mathrm{~K}-2 \mathrm{NO}$ & YES & No & NO & PUELIC & 3018 \\
\hline $100-(5-2)$ & HINGLOH CEM, RULOCFF) & HILLIAM ANDEFSUH & NONE & $5-2 \mathrm{Nu}$ & Nú & NO & NO & NO DIK & 1104 \\
\hline $106-63-27$ & HINSLOH CEMETEFY FI & THE DAR:EL HEESTEF RTY TFHST & NENE & $R-2 \mathrm{NJ}$ & Ne & YES & YES & NG DIF & 424 \\
\hline $366-05-01$ & FRESIDEN IR_- CIRCLE & DESHOND DHYIO \& JULIA & 126 & $\hbar-2 N O$ & YES & YES & NO & FUELIC & 307 \\
\hline $100-05-05$ & FHESIDERTIAL CIF & DESHOHE JAYVIS \& JULIA & 132 & $R-2 \mathrm{Al}$ & YES & $\mathrm{NO}$ & NO & PUBBLIE & 2240 \\
\hline $006-05-04$ & FREE:DEUIAL CIFGOFF & DESRIVIS DAVIS\& JULIA & NORE & $6-2 \mathrm{~kJ}$ & No & YES & YES & NO DIK & $24 \overline{25}$ \\
\hline $306-06-03$ & EMtRGE RUAD & EETTEF IOHK F. & 120 & $\mathrm{~F}-2 \mathrm{~N}[\mathrm{~J}$ & YES & k0 & No & PKIVAT & 2004 \\
\hline $106-99-03$ & LUREThHTIRE DRUVE & FICH LINIAA A & 120 & $\mathrm{~K}-2 \mathrm{NO}$ & YES & NŌ & $N[$ & FUELIC & \\
\hline
\end{tabular}




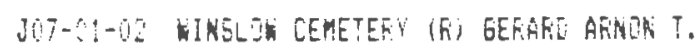

J07-01-05 WIGSLOH CEMETERT IRI MAESHFIELD ROD \& GUH LLUE

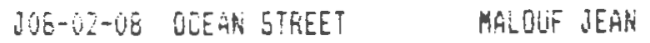

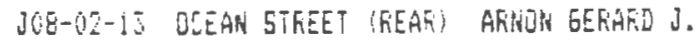

JUE-VZ-16 HLMELARI DFIIVE

JOE- $-22-23$ CQPELAKD STREET

JUE-AZ-ZT EATL AIENLE

JOQ-63-05 HLMELARIT DFIVE

JUE-64-01 EAS:L AVENUE

JUB-OLE- II EAFL AVENLE

JGE-TE-TE EAFL AVEENUE

JÜB-OL-UL COEAM STREET

JUS- DE-IZ MAIEF. TERTHEE

JOE-CES-15 OEERTE ETRETT

JOY-OI-OS QCESK STFEET

209-01-21 LIEESTY KÜAL

JCG-01-22 LHGRE EF DF. GEAE:

J09-02-03 OLEARI STEEE?

J $(67-07-15$ FHEAGART LARE

U10-OI-CO REVERE STREET

J16-OU-GE OUINLY ANERUE

J1G-01-6E SEMERSILLE STREET

J10-01-17 5EAERVILLE STREET

J10-01-10 SOMERVILLE STREET

J10-02-0? NANTASKET STREET

J11-GZ-U14 NANTAGIET STREET

J10-02-05 NANTASKRET STREET

Ji0-62-06 NANTAEKET STKEET

J10-0Z-07 NASTASKET STFEET

J10-02-16 RENERE ST. E EIIHCY

316-0Z-11 REVERE 5T. \& EUINCY

310-03-0j DLIRLY AYENUE

J10-03-04 NARTAERET STREET

J10-63-06 MARTAERET STAEET

J10-0.3-07 NANTÁSKET 5TREET

310-04-02 DAKOTA STFEET

$310-05-02$ ROCKFDFI STKEET

J10-05-0E DAYOTA STREET

310-0S-OB ROLKFIST STREET

D10-0O-OL ROCKYORT STREET

U1O-D6-OE RTCLFEFT STEEET

J10-07-014 DAKGTA ETREET

I110-67-0E DAKOTA STFEET

310-07-11 NAFTASEET STREET

J10-07-15 REVEFE ST. \& ESINCY

J10-0E-67 BOUFHE FAKK AVEWUE

JiO-C6-16 BOURNE FAFL AVERLE

J10-08-17 BUISTNE FARI AVENUE

310-6-46 OCEAS 5TREET COFF:

J11-01-V2 REVERE ST. \& QUINEY

311-01-03 KEVERE ST.\& QUINCY

311-01-05 SUMEFYILLE STFEET

II1-01-05 SOHEFGILLE STREET
DITLHMASES NICHOLAS Á

RUCK REALTY TRUST

RUCH. REALTY TRUST

DITUMHAEE HICHULLES A

FOCK REMLTY TRUET

RUCK REALTY TFUST

BOCK REALTY TRLST

COFELANE KENUETH

FOCL, REALTY TFUET

GEFÁE. AFENEN

OCEAR STKEET REALTH THLST

TINEEY HAFEY $\mathrm{A}$.

SULTHFLT LIVIE ASE. IKL.

RTELWED DURTS

CHASE RÜSEMAFY

SAREENTINO MAEY

DUUILLETIE EJGERE

TEUESCHI DUMIKIC F.

SRITH GESRTEE

memiller maíitie

FÁLINIO GERTAL

CONWELLY MICHAEL

LITTLE BAREARA

MLCARTHY ELGENE

SLAUIIN OWEK

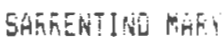

SARRENTINE RERI

CINTLE FFIANI.

MeajieY JakEe

MADEEN HAEEY

SULLIVAR FHILIF

FUTI ALFRED

IFHTEECA EDWERI E.

MÁLDEN HASEY

MLLALLLEY JAMES

DEEEAN WHLLIAMH

EEUELEF W. CHABMTHS

COFFIN JUSEFHINE

KLEEMIZ RIVOLIA M.

REYWDL LS THCYAE

MCMERUES MGEFER

DECAETFI ALFFEE J

ROEBNGOA LOFIS -

gOOSALE CHAFLES F

CHASE RUSEMATEY

CUUUGHLIN PATFICK

FÜNTE FITH

DUUIILLETTE LIONEL

DQUHLLETTE LIOKEL
NQ R-Z NO NU YES YES NI DIK 1064644

NO R-2 NO NO YES YES NO DIS EI:20

$160+[\mathrm{E}-2$ NÜ YES NO NJ PUELIC 10900

NONE F-2 NO NO YES YES NO DIK 191664

211 E-2 NO YES NO YES PFIVAT 20250

220 F-3 FUS $N$ Y YES YES PRIVAT 37000

277 F-2 NÜ YES NO POS PRIVAT SBEJE

120 E-2 NO YES NE YEE FR̃IVAT 27900

45OOC R-2 KL POS YES YES FFIVAT 83635

$3 G 0+\hat{L}$ ñ-2 NO FOS YES YES PRIVAT SUSO

128 R-2 NG POS NO HO FFIVAT 21560

$201+2$ E- 2 HO YEE NOS YES FUELIC 2060

$165+C$ F. -2 NE YES NO YES PLELIC 19856

248 E-2 ND YES YES YES FLEELIC 879912

$300+C$ E -2 NUL YES NÜ NO FUELIC 43795

12 F $2-2$ NO YES YES YEE FUE_LC 21000

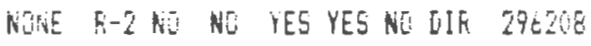

$28 \mathrm{O}+\mathrm{E} \mathrm{B}-2 \mathrm{NO}$ YES NO NO PUELIC 15509

8U R-3 NE YES NG NG PEIVAT 20041

100 R-2 NO YES NO NO PRIVAT 11200

100 FI-2 NO POS RE NO PRIVETT 10006

40 R-2 ND YES NE NO PEIVATT 4000

40 Fi-2 NE YES NI NO PEIVRT 4000

92 Fi-2 NO YES NO NO PRIVAT 9600

40 F-Z NL YES NIJ NO FRIVHT 4000

40 R-2 NO YES NO NU PRIVAT 40000

6O R-2 NUO YES HO NO PRIVAT $6000^{\circ}$

40 R-2 NO YES NO NO FEIVAT 4000

200 F-2 NO YES NO NO FFIVÁT 10000

40 Ri-2 HO YES NU NJ FRIVAT 4006

142 R-Z NO YES NO NO PRIVAT $14400^{\circ}$

100 F-2 NO POS NO NO PEIVAT 1006

4O TO-2 NO YES NO NO PRIVAT 4000

40 Fi-2 NÖ YES NI NO FRIVAT 4000

40 K-2 NO YES NO NO FRIVGT 4000

$300+[$ Fi-2 ND YES NO NU PRIVAT $315 \mathrm{O}$

80 R-2 NJ F'US YES YES $\mathrm{K} / \mathrm{A} \quad 800 \mathrm{C}$

Bi Ri-2 NO YES NG NE FRIVAT 8000

20 F-2 NE FOS VES YES N A 2006

40 F-2 NE FOS YES YES H/A 4UOC

$105 \quad R-2$ NO POS FOS FUS N/A 950 .

40 F-2 NO YES ND RE FHIVAT 4 SOL

40 F-2 NO YES HŨ NŨ PEIVÁT 4 UGG

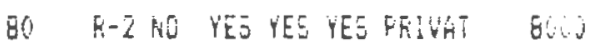

100 Fi-2 NO FŨE YES YES PRIVAT 10 UVO

$120 \quad \mathrm{R}-2 \mathrm{NL}$ YES YES YES FUELIC 31900

120 Fi-2 $\mathrm{kJ}$ YES YES YES FUELIC 1425

100 K-2 NÉ YES NGI NU FUELIC $13 E 07$

40 F-3 NE NO YES YES FRIVAT 1198771

40 Fi-Z NO YES NO NO PRIVAT 4 VGi

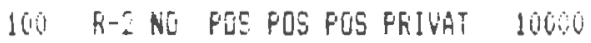

60 F-2 NO YES YES YES FKIVATT $6000 \mathrm{M}$

60 RI-2 NU FCS YES RE FRIVHT 6000 
J11-0:-UE SEYEFiILLE STFEET

311-01-199 CHARLESTOHA STREET

J1-01-10 CHAREESTUK STKEET

J1-01-11 CHAFLESTUUH ETHEET

J1-61-12 CHAFLESTOWN STREET

Ji1-01-14 CHAREESTERTS STREET

II-0I-15 QUINEY AUE.

W1-O1-20 ARLINETON STREET

J11-01-21 AFLINETSN STAEET

Ji1-U1-23 AFILINTOUR STREET

J11-01-25 ARILINOTCH STREET

$311-01-20$ ARLINGTON STREET

311-01-27 AFLINGTON STKEET

J11-01-3i AFIINETUL STREET

311-01-32 AFLINGTUK STFEET

JI1-O1-34 AFLINGTOA STREET

J11-01-35 ARLLINETUN STREET

J11-01-39 TEKGS STREET

J11-01-4\% TEXÁS 5TREET

JI1-01-41 TEX'SS STREET

J11-01-42 TEXAS STREET

J11-O1-43 TEXAS 5?REET

J11-0j-44 5ULUTH FIJUER STREET

J1-OI-45 TEIAE STRECT

J11-U1-4E TEXAS STREET

J11-01-47 TEXA5 ETREET

311-01-49 TEXAS STREET

J11-01-5: HWLEN RUENUE

JI1-01-54 TEXFS STREET

JUI-G1-E7 TEIAS STREET

U11-61-5E TEAAS STAEET

UL1-01-5T TEXÁ5 STAEET

J1j-0j-62 HALLEN GVENLE

?11-O2-O2 AFLINETOK STREET

J11-02-03 ARLINGTUN STSEET

J11-02-04 ARLINGTON STREET

J1-012-05 ARLINGTON STREET

J11-02-07 MALLEN GVENUE

J11-02-12 TEXAS STREET

J11-0.-6I NASHINGTÚR AUE.

J11-0J-03 SOKERVILLE STREET

J11-03-07 CHAFLESTONIS STREET

312-01-01 FEREGTINE WHITE DR.

JIZ-CI-0i FEFEGRINE WHITE DR.

J12-01-04 FEREGRINE HHIEE IR,

J12-0I-iJ FEREERINE WHITE DR.

J12-01-06 PEREOEILE HHITE OR.

J12-01-07 P'EREGRINE WITE OF.

ETHAN ALLAN BETHA TFUST

J12-01-19 FEREOKINE WHITE DR.

312-01-10 PEREGEINE HHITE OF. ROMAN ALEXANDER ANO EDITH

J12-0i-11 PEREGRINE HHITE DR. MOYAIHAK MAREJESTE

JI2-01-13 PEREGRINE WHIIE DK. ORMGHE MARGARET ANE ANN

LYONE HEEERT Fi.

JOHKSON EINAE G.

ULTSCH ARTHUÉ $W$.

FEREY ANTHONT T.

FARIINSON HAFITY

GUARIIAK COMFAN

MECUKDI FFÁNCIS

HAGAMN LOWELL

HAGAN LOHELL

HAUAN LUWELL \& CHEISTINE

MEDERMUTT FFEU

BFCICKTUN CUTTIKGS DIE

BiJfiE EDHIJNC M.

GISSUK ESTEF

JALTCN GEOKGE E.

GI0!OSH ARNGGYHAY

KENNEGLY HILLIAM

DEXTER NGITHARIEL

CFIHELY EDHATLD

PATKAXI KENAETH

FACKAGE RENMETH

PACKARE: KERAETH

EELCHER LELÁNE

PRGSSER GALL \& FRARLES

HYRES DHVID

LIKSKEY JUSEFH R.

ULTSEH ARTHJS W.

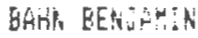

EES SARUE:

KULIKALSIAC IUSEFH

PACKARL KENMETH

DENMAH HAKR:ILT

BOOTH FOBEFT $H$.

TELESCHI DGEIAIC

ROCKLLANE INDUSTKIES INE.

LINJKEY JUSEFH R.

MLRPHY JOHN

COOL ARECHIBALE

RUNLEY EFNSETIN

CFONIA PHILLIP

ETHAN ALLAN BROHN TFUET

ETHAN ALLAN BFEHN TFUST

ETHAN ALLAN BRONN TFULS

ETHON ALLAN BFIUAN TRLOTT

ETHAN ALLAN BROtinN TFLIST

ETHAN RLLÁN BRONH TRUUST

BEOHIR HELEN

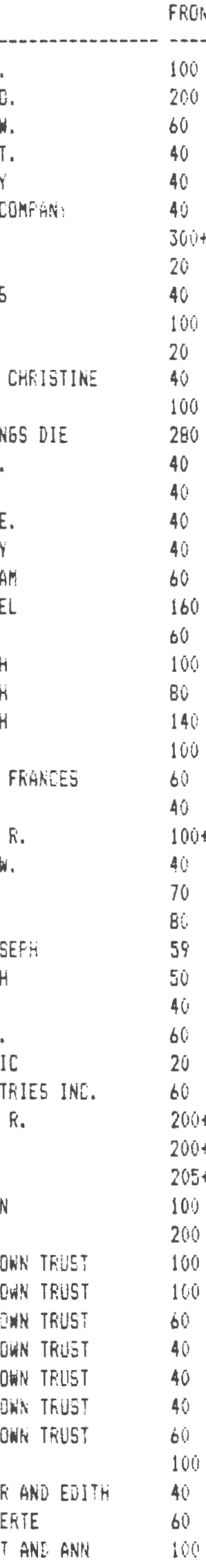


OWHES OF REC

J12-01-14 FETEEFIKE HHITE OR.

U12-01-15 SULTH RIVER STKEET

J!2-01-17 INUIAHF STSEET

J12-O1-1E INUIARA STHEET

JIZ-01-20 INETARH 5TKEET

JI2-0!-2i INUIANA STREET

J12-0!-ZO IKUANE EThEET

J2-01-24 IHETAR ETREZT

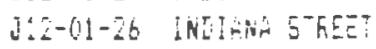

J12-01-27 IRLISPA STRET

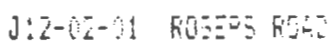

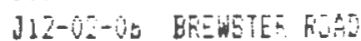

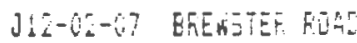

312-02-0E BREASTE RLAL

312-62-10 EREM

JIZ-0E-12 CHILTJH STREET

J12-62-15 GEEFEIF STEEET

JUT-CL-14 GEUREIA STFEET

J!Z-0Z-15 GEOGEIA STREET

J12-O2-17 GEOAEIH STREE

JI-C-1S GEOFIT STREET

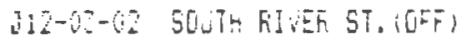

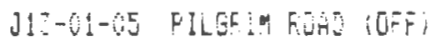

J1j-002-26 FAREER ETFEET

UDS-6Z-T2 PARLE STEET

Ji4-01-04 FIDEE RIAL

J:4-01-14 FIVEE REA (REFE

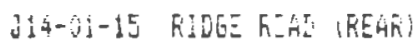

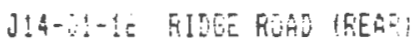

Ji4-Cj-17 RIJEE RiQH SFEHE:

J14-61-18 RIUEE FOA SRECF)

J14-01-19 FIOEE RLiñ (KEAF)

J14-0I-20 RIUEE RIIAE (EEAE)

J14-02-1E RIDEE FIUAD

J14-02-27 RIOGE RJAL

314-02-26 FIDEE RUAL (CFF)

JUS-02-0. STEAREGST DETHE

NOZ-01-04 COLEY HELITI LAHE

102-01-OS CULE HEHITT LIOIFF)

KOS-01-02 CAEAELL STREET IOFE,

ROS-01-04 CA5HELL STREET IOFF

RUS-GL-OS CAEESHELL STREET

KOE-6Z-OI COLET HEMIT LARE

KOL-02-02 CAFESBELI STREET

KOE-CZ-GJ CAFESELL STREET

1OOS-OZ-05 CARESHELL STAEE:

KOS-OZ-34 CHA HARHL EIRCLE

W0I-CZ-SE CARESHELL STREET

1OS-OZ-J7 FERFYY WH (OFF)

KOJ-OC-J9 CAFESWELL STREET ILFF

KO4-0!-05 HEEETES STHEET

KO4-OZZ-OE HEESTEF STREET

KO4-02-35 ENLTCUT STFEET
ORMOH ELIIAEETH

SMITH DAUIL A.

ORHÜD ELIZAEETH

BKU⿴囗十⺝木 HELEN A.

ETHAMN ALLAL BAJWN TRULST

MAFGLEJAR GLFFED $A$.

BEESAT: BILIJAF

MAHGLITIAN ELEN:

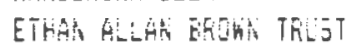

JUYCE NEEEITT MUEILYN

BFrinit HE EES

WLSOA MERT AlMUE

BRIDAN HELEF A.

Misirit IJURE.

MUREHT JUARE.

EFINA HELEN A.

HELEN H. GEETH

HELEN A. BFEHYY

CHAREES h. MCKEMVEY

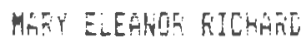

CRALFES H. METERE

FACTARE KERHETH J.

SEF FIVETS THUST

COEN LANGENCE R.

VISILA IAHET $M$.

BVIANI JOGEFH

CEREIGAM JAYES

CUKSIEAR JAHE

COFE IERK IAHES

COFPISAM JAMES

CORFISAR JAFES

COFFI OAAN JAFES

CUFFIGAR JAREE

FIDEE RUAD ASSECIATIEH

COFGIGAN JAHES

SEA FIIVER TFUET

ME NULTY RUEERT

FOE INSOL MAREARET

HEDITT COLEY C

CLFFIN JAHES

CAVANGUGH CHARLES

NAMASLEESET KEAL ESTATE

FÜLINGIE: MAFGARET

HALL LINILI'N

NAMASTEEEEST REAL ESTRTE

TAYLOR KAREA A.

GEVEHSF HINELCH

HISTURTL WISELUK HOLSE ASS.

MLLALG IN TAKEE

STAERATT CHARLES G.

HA: L INOOLH

DELGEY JOSH

HAVILART FGLHEIS
FFONT ION SEH HAT WET FF' ALCESS RREA SF

40 RII NO PUS NJ NO PFIVÁT 2000

NÜNE $\bar{H}-t$ NE WI NE NO NO DIF 100155

6. R-1 NU POS NO NO PRIVAT 6000

200 R-I NO POS NO NO PRIVAT 2003

72 K-I NO NO YES NO PRIVAT 4000

40 G-I NO FUS YES HO PRIVAT $40 \% 0$

20 FI- NO POS YES NG PFIVIRT 2060

60 Fi-1 NO FOS YES HU FFIVAT 6000

40 Fi-1 HO FUS NO NJ FHIVHT 4000

6) F-I NO FOS HO NO PFIYHT 6606

NU F-3 NJ ND YES YES NII DIF 12000

6) Fi-I WJ NT NL YES PRIVAT 6OUO

60 R-1 NE NE NU YEE FEIVAT 6000

115 R-! NO NE NE YES FFIVAT 10060

110 K-1 NO NI NO YES PFIVAT 12000

60 FI-J HO NE YES YES FFIVAT OUOO

40 F-J AJ NE YES YES FEIVAT 4000

100 R-1 NO NE YES YES FEIVAT 100\%;

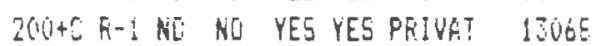

70 F-1 NL NO YEE YES FEIVAT 8010

50 FI NO NE YES YES FRIYAT $240 \mathrm{O}$

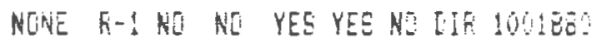

HOKE F-S WE NO YES YES NO OIK 1912294

50 Fi-3 YES YES NO NO FFI CL 5 USW

50 F-3 FOS FOS PJS PJS FRI CL 5355

75 Fi-3 NU YES YES YES FUELIC 10760

301 F-1 NO YES HO NO PUELIC 252648

NELE FI-Z NE NE YES YES NE DIR $222 ? 5$

NOLE $\mathrm{F}-3$ KI NL YES YES NO DIF 20306

NGLE Fi-3 NU NO YES YES NO DIF \$59T5

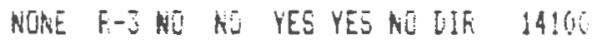

NENE R-J NO NO YES YES NO DIR 12475

171 K-3 NE POS YES YES N/A 12790

75 K-3 NU YES YES YES PUELIC 12625

NONE $R-3$ NO NO YES YES PUIE 498762

NONE $k-3$ HO NO YES YES NO DIR 313632

10i+l $h-1$ NO YES NO NO FULSLIC 43566

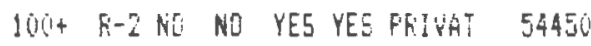

NOLE R-ZNI NO YES YES NO DIR 2134440

NJWE FI-I NO NO NO NU NO DIF 967032

NOAE R-1 NO NO NU NO NG DIF $436: 4$

571 R-2 HE NO YES YES PLELIC 77536

320 R 2 NO NE YES YES PFIVAT $10 E 720$

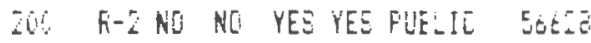

628 Fi-2 NO NG YES YES FUELIC 2400:6

100 RI-2 NU NU YES YES FUEIIC GEIOG

126 Fi-Z NO FOS NO NO FRIVAT 211266

NÜRE FI-2 RJ NO YES YES NU UIF JESE

RONE FI-2 NO HO YES YES NIJ DIF 87120

HIRE FI-2 NS NS YES YES NIT DIR 1176I:

420 FI- NO YES NO NO PUELIC 74052

110 Fi-Z HO YES NU NJ PUELIC $2050 \%$

16. F-2 NO NE NO NO K/A 1452\% 


\begin{tabular}{|c|c|c|c|c|c|c|c|c|c|}
\hline $604-02-54$ & MÁISURH AVE. & DUFFY NEIL & 90 & $\mathrm{R}-2 \mathrm{NO}$ & YES & NO & Ne & PRIVAT & 7200 \\
\hline$k 04-04-10$ & LEONAFS RUAL & INEIAN SFEINE TRUST & $200+C$ & $\mathrm{k}-2 \mathrm{ND}$ & No & No & NO & PFI CL & 45302 \\
\hline $604-04-11$ & LEGNAFE RUAE & INEIAN SFFINE TRUST & $200+C$ & $h_{i}-2 \mathrm{NO}$ & $\mathrm{NO}$ & NO & NO & F'RI CL & 33225 \\
\hline $604-65-01$ & LEQRAEE BDAR & INEIAA SFFINE TKUST & $160+i$ & $R-2 N C$ & Nij & NO & NO & PRI CL & 86245 \\
\hline$k 04-05-18$ & KAREN WAY & INDIAN SFRING TRUST & 300 & $\mathrm{k}-3 \mathrm{NO}$ & NO & NO & No & Pfi] CL & 34284 \\
\hline $104-65-15$ & UUSTIN WA & INEIAA SFRIHE THUST & $180+C$ & R- $2 \mathrm{NE}$ & YES & NO & No & PRIVAT & 17248 \\
\hline$k 04-05-20$ & LEGRIAETL ROALL & INUIAN SFTINE TRLET & $200+[$ & $h-2 N C$ & NO & NO & NO & PFI CL & 34456 \\
\hline$k 04-05-21$ & LEONAEE REAT & INETAA SFFING TRUST & $301+C$ & $5-2 N E$ & $\mathrm{No}$ & No & No & PKI CL & 33.22 \\
\hline$k 04-35-22$ & JUSTIN WSI & INDIAN SFFINO TEUST & $160+5$ & $\mathrm{~K}-2 \mathrm{NO}$ & YES & YES & YES & FRIVAT & 41254 \\
\hline$k_{6} E_{-}-6-6 / \hat{A}$ & JEFFEFSOR RVENLE & MOERISDH ROEEFT H & $80+C$ & R-2 NC & YES & NS & Hó & PRIVAT & 4257 \\
\hline K0I- $01-08$ & JEFFEFSCL AVENLLE & MOERISON ROEERT W & $80+C^{\circ}$ & $\mathrm{F}-2 \mathrm{~N}$ & YES & NO & NO & FEIUAT & 8320 \\
\hline$k 05-01-13$ & PUTAAY STREET & FINEALLT STEFHEN & 100 & $R-2 N a$ & P0S & $\mathrm{Ni}$ & no & PFIVAT & 25000 \\
\hline$k 05-01-18$ & EVERETT STREET & VENE AKTHIKT N. & 60 & $\mathrm{k}-2 \mathrm{NO}$ & NO & NO & NO & PFIVAT & 4800 \\
\hline $605-01-30$ & FohHAL STEEET & FITZGEGALD THOKAE & 40 & $\mathrm{~F}-2 \mathrm{NO}$ & POS & No & NO & PFIVAT & 30800 \\
\hline $105-01-3 j$ & CAFESWELL STREETIOFF & PLITAA FEALTY THUST & NESIE & $\mathrm{Fi}-2 \mathrm{No}$ & NO & YEE & YES & NG DIK & 130680 \\
\hline$k 1 r_{L}-01-35$ & JEFFERSIR AVENUE & DUIS JAMES & 80 & $\mathrm{Fi}-2 \mathrm{NO}$ & YES & NO & NO & FEIVAT & 3000 \\
\hline $605-03-01$ & RELAOII RUAL & MEFISLN R & 260 & $\mathrm{~F}-2 \mathrm{NO}$ & NO & no & Nu & FEIVAT & 14400 \\
\hline$k \cup 5-05-01$ & DAYIS STREET & PEJLEY RHARA M & 120 & $\mathrm{~F}-2 \mathrm{NO}$ & NO & NJ & N5 & PRIVAT & 9600 \\
\hline$\times 05-05-05$ & JEFFERSOHI AVEHLE & DOULEY ANRT' M & $16 \dot{0}+C$ & $\mathrm{Fi}-2 \mathrm{NG}$ & YES & NO & No & FFIVAT & 16800 \\
\hline $100_{1}-06-014$ & CAFVER ETREET & REALTY IMFROVEMENT TRLST & 30 & $\mathrm{~K}-2 \mathrm{NO}$ & NO & NO & NO & PRIVAT & 2400 \\
\hline $105-06-12$ & FUTHAM STREET & KAEEL REBEST H. & 30 & $B-2 N]$ & FOS & $\mathrm{NO}$ & $\mathrm{N}$ & PRIVAT & 2400 \\
\hline$k 05-06-13$ & PLINGH STKEET & HAEEL ROEERT W. & 60 & $\mathrm{R}-2 \mathrm{NG}$ & P05 & NG & NO & PRIVAT & 4800 \\
\hline $105-00-14$ & FUTNAY STREET & KEITH JAMES $H$. & 90 & $R-2 N O$ & P05 & NO & MC & PRIVAT & 7200 \\
\hline$k 05-07-69$ & EVERETS STFEET & MOETEESY TKREY & 140 & $\mathrm{~F}-2 \mathrm{NO}$ & nO & NO & No & PFIVHT & 5680 \\
\hline$K 05-07-10$ & CAFVEF STREET & HOFTEERE TRESY & 180 & $R-Z N]$ & No & No & NO & FRIVAT & 6400 \\
\hline$k 00-02-0 i$ & FRESIDERTIAL CIRCLE & SAMHER GEUREE & 105 & $\mathrm{R}-2 \mathrm{NO}$ & YES & NO & NI & PUEHLIC & 29273 \\
\hline $106-03-0 i$ & EUSTIS STKEET (OFF) & SINWETT NOEMAN W. & NONE & $\mathrm{R}-2 \mathrm{NO}$ & $\mathrm{NG}$ & YES & YES & NO DIR & 193642 \\
\hline $10 i-01-02$ & GREEN HAEETE MGSEH & MNGSHFIELD ROOU \& GUK CUUS & NONE & $\mathrm{K}-3 \mathrm{NJ}$ & HO & YES & YES & NO DIK & 182952 \\
\hline$k 06-03-01$ & DUYE BAESH & MASSACHIJSETTE ALOUESH SELIETY & NGINE & $R-3 N C$ & NO & $\mathrm{NO}$ & YEE & NO DIF & 575340 \\
\hline $105-6 j-6$ & GREEH HAFESF MAESH & EARLY BIGE REGLTY TFLST & NORE & $R-3 N 0$ & $\mathrm{Hi}$ & YES & YES & HO DIK & 1097712 \\
\hline$k 09-0.3-0.2$ & OLI CUIIQNY LARE & RINALILL FETEK & 236 & OF $\mathrm{NG}$ & YES & YES & $\mathrm{NO}$ & PUELIL & 304920 \\
\hline $109-03-06$ & REAF MUSHET RIAS & HYHES ELMEF & 40 & $R-3 N O$ & NO & YES & YES & Nu DIK & 178596 \\
\hline $109-03-08$ & RLSKET RULAD & JAE COERPSFATION & 110 & $k-j N 0$ & $\mathrm{No}$ & YES & YES & PEIVAT & $24 ! 95$ \\
\hline $699-03-09$ & COJFT STREET & JAE CORPLEATION & 190 & OF $\mathrm{NO}$ & No & YES & YES & PEIVAT & 25245 \\
\hline $109-04-01$ & MUSKET RUPA (UFF) & JÁE COEFEAATIUN & $430+[5$ & $\mathrm{K}-3 \mathrm{P} \times 05$ & P0S & YES & YES & $N / A$ & 31095 \\
\hline$k ! 0-01-09$ & HIKSIOR STREET & BUSAKE LEE & 108 & Ki-3 YES & YEE & NO & NO & FUBLIC & 65775 \\
\hline$k 10-0 !-15$ & WINS OH STREET & LALRERIEE FFEDE & 1450 & R-3 YES & YES & NO & $\mathrm{NO}$ & FUELIC & 1455260 \\
\hline $10-02-12$ & WINES GH STFEET & LAWEENCE FREDEFIS & $206 i+5$ & $F-j$ YES & TES & NO & Ho & FUELIC & 10460 \\
\hline $\mathrm{k} 10-03-05$ & GFASSKLEFER LANE & STUAET J.LANE & 50 & R-3 YEE & YES & $\mathrm{NOI}$ & W.J & FUELIE & 5000 \\
\hline$k 10-0.3-10$ & GFGSSHTFER LAKE & FFEDFICK C. LAWHERTE & $300+5$ & $R-3$ YES & YES & NE & NO & FUE:IC & 21150 \\
\hline $110-04-02$ & LONGVIEH TEFFECE & GUUE GEUREE 5. & $100+C$ & $R-3$ YES & YES & $\mathrm{HO}$ & NO & FUELIE & 5235 \\
\hline$(x 10-04-14$ & WINSLÜH STREET & SACFTHONH JAMES & $156+i$ & K-S YES & YES & NO & $\mathrm{NO}$ & FUELIC & 5727 \\
\hline$k 10-04-15$ & GRASSHEFFEF LANE & JOE SSLCM & $180+r^{2}$ & FI-3 YES & YES & No & Hü & PUELIC & 5000 \\
\hline $10-0.4-20$ & GRASSHLFPER LABE & MAFUIA C. YJIHE & 50 & $R-3$ YES & YES & NE & $\mathrm{NG}$ & PUELIC & 5000 \\
\hline $1010-04-22$ & GKASSHOEFEF LANE & FREDFICK T. YOUHEZLAUS & 50 & F-j YES & YES & $N Q$ & $\mathrm{NG}$ & PUELIC & 5000 \\
\hline $110-05-76$ & MAYFLOHEF LAKE & TUEIN RLEERT & 50 & R-J YES & YES & $\mathrm{Nu}$ & NO & FUELIC & 5000 \\
\hline $110-05-15$ & MAYFLOHE: LANE & CELIA GEORGE & $194+C$ & $5-3$ YES & YES & NO & NO & FUBLIC & 10583 \\
\hline$k 10-05-19$ & LOREVIEM TEFFHEE & AHEERSON JOHN H. & 50 & $\mathrm{~F}-3$ VES & YES & No & NO & PUELIC & 5000 \\
\hline$k 10-05-20$ & LONGUIEN TEFRACE & ANDEFSLLK JOHN H. & 50 & $R-3$ YES & YES & NO & NO & FUALIC & 5000 \\
\hline$k 10-05-25$ & LOKEVIEW TEPEACE & OADSAETIS AFHAKL & 50 & F-J YES & YES & NO & NO & PUE_IC & 5000 \\
\hline$k 10-0 t-02$ & RAYFLCWET' LANE & FFANEIS LUFILLE & $149+[$ & F-J VES & YES & NO & Nũ & PLELIC & 5155 \\
\hline$k 10-06-09$ & WINSL SW STREE? & ALAMS GEHEVIEVE & 100 & $R-3$ YES & YEE & NO & NO & FUELIL & 10274 \\
\hline$k: 0-07-05$ & ALEER RJAR & DRISCLLL JAHE F. & 100 & $R-3$ YES & YES & N: & NO & YES & 1004 \\
\hline
\end{tabular}




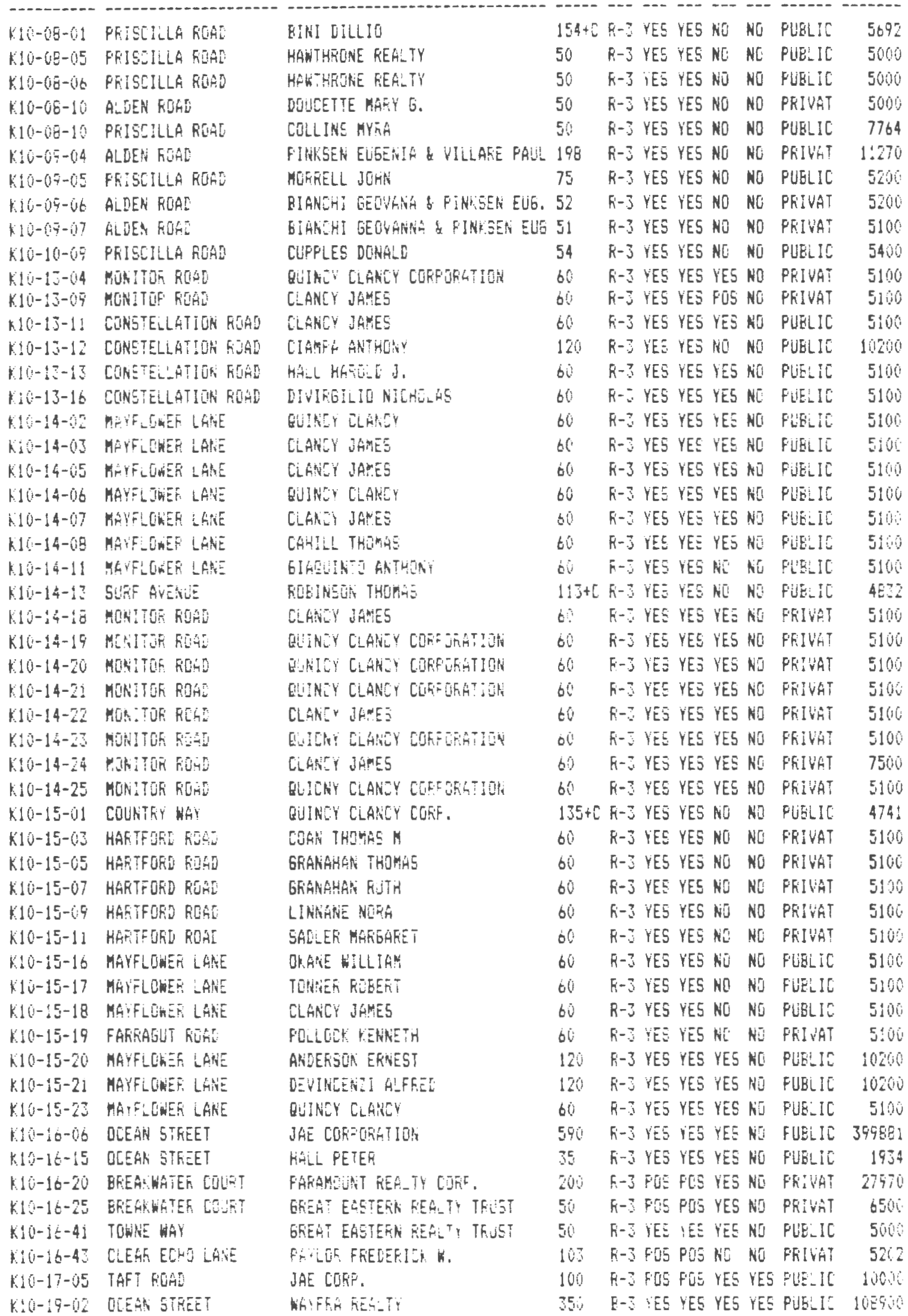




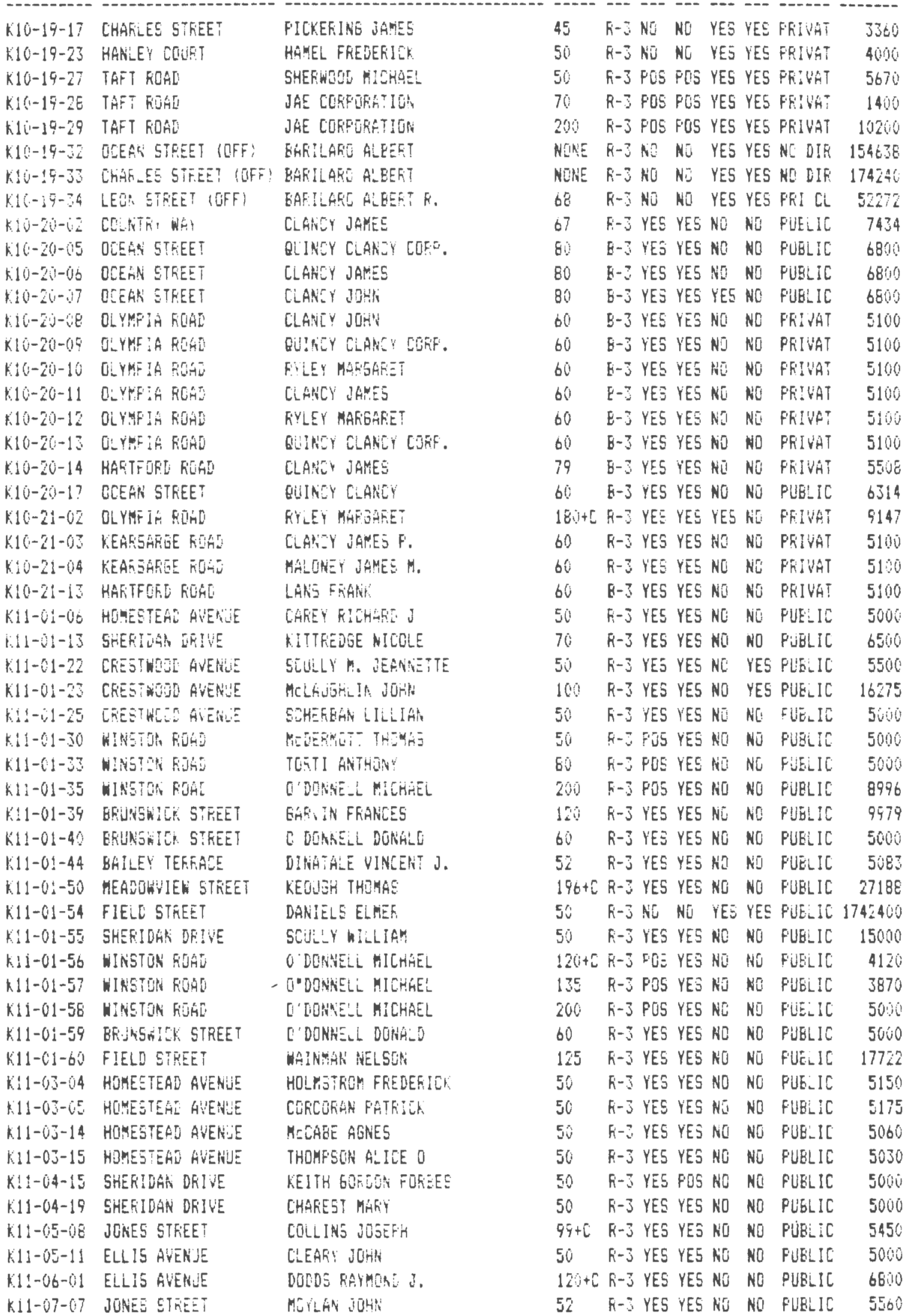




\begin{tabular}{|c|c|c|c|c|c|c|c|c|}
\hline A5. Nith-i LT? & LOLFTIUKR & CHAEE [EF FEC & FFü:T & 20K SE & WhI WET & FFA & ACCESS & AFEA 5 \\
\hline$\cdots+\infty-\infty$ & -.............. & & & & $\cdots$ & & & \\
\hline $1 ! !-07-1) E$ & JUNES STFEET & MUFPHY JAMES & $4 i$ & K-3 YES & YES NO & No & PIELIC & \\
\hline $1 i-C i-1 E$ & BRUHJWILI 5TEELT & FOUEOY RONA:D & 50 & $5-3$ YES & YES HC & NO & PUE:IC & \\
\hline$k 11-6 i-19$ & JOHES STREET & FANCIOCCO ARTHONI & 104 & R-3 YES & YES NO & NO & FUELIC & \\
\hline K11-0E-03 & EFIUHSWICK STREET & COCHFARE ROHEFT & 50 & F-3 YES & YES NU & NC & PUELIE & \\
\hline$k 11-0 e-17$ & CEICKE LANE & HAGEF AFTHLF A. & 60 & K-3 YES & YES NO & NO & PLBLIC & \\
\hline K11-0E-Z1 & CFICKET LARE & FEFK'ULLE JAMES W. & 116 & F-J YES & YES NO & $\mathrm{No}$ & FUE:IE & \\
\hline $111-0 \bar{y}-0.2$ & BÂE EF SFREET & SHQTT AETHUE F. & 56 & $\mathrm{R}-3$ YES & YES NO & $\mathrm{N}$ & PUEIIC & \\
\hline $1: 1 \pm-05-j 3$ & MEADCWIEA STREET & O'DOSNELL PHULA & 60 & R-J YES & YES ND & $\mathrm{NG}$ & FUELIC & \\
\hline $111-6 \overline{9}-15$ & GEUREE STREET & FRAK: W. DICFISTO & 50 & $R-3$ YES & YES RÜ & NO & FUELIS & \\
\hline $111-07-27$ & FIELD STFEET & WILLIS A. ALLISJN & $120+\varepsilon$ & F-j YES & YES NG & NG & FUELIE & \\
\hline $111-09-3 i$ & EARKEF 5TREE? & ALVES HENTY' & 50 & F-J Y YES & YES NO & NO & FubilC: & \\
\hline $111-10-6 j$ & CIRCUIT RVE, IWEET) & WHITE JUHW F. & 107 & $\mathrm{~F}-3 \mathrm{~J}: \mathrm{C}$ & NO NO & No & Príat & \\
\hline $111-11-62$ & WINELUW STREET & WASIL FAGL & 260 & $\mathrm{R}-3$ Y YES & YES NJ & No & PUBLIE & \\
\hline$k 11-11-03$ & STARISH ETEEET & 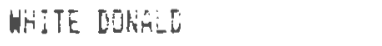 & 120 & R-J YES & YES NO & NO & FUB:IC & \\
\hline $1: 1:-11-0$ & STAROESH SIFEET & CHMFEELL CHIHY & 100 & R-3 YES & YES $N \Gamma_{i}$ & NE & PUELIC & \\
\hline$k, 1-12-10$ & HINE_JW STREET & FINE GR'JVE REALTY TFILJT & 70 & $5-3$ YE5 & YES NO & $\mathrm{NL}$ & FUELIC & \\
\hline$k i:-1:-04$ & VIREEAT DKIVE & CORIRUITY REALTP TFGST & 60 & R-3 YES & YES AN & $\mathrm{NO}$ & FEIVAT & \\
\hline$k 11-13-07$ & WINEENT DFIVE & ARTUINE REGEF & 75 & $F-j$ YES & YES Ni & Kü & FEIVHT & \\
\hline$k .11-1.3-60$ & VINEER: DRIVE & SHITH ALEXANDER & 100 & $F-3$ YES & YES HO & No & PEIVAT & \\
\hline $11-13-09$ & WINEENT DFIVE & SMITH MALL C. & 200 & FI-3 YES & YES NO & $\mathrm{NO}$ & PRIVAT & \\
\hline$k 11-13-13$ & FUARE STREET & ARTLTNE REA_TY & $R-3$ & 6: YES & YES NOT & Nú & PUELIC & \\
\hline$k: 1-1 . j-15$ & CONETELLAYION RÜHOD & SHITH JEFOKE & 60 & EI-Z YES & YES NG & No & PUELIC & \\
\hline $1 ! 1-14-67$ & WIREERT TEIVE & ARTOIAE RERLTY & 60 & Fi-J YES & YES NS & $\mathrm{NO}$ & FUELIC & \\
\hline$k 11-14-6.7$ & VINCENT DEIVE & ANTUIAE RELATY TRUES & 60 & K-J YES & YES NO & $\mathrm{No}$ & PEIVAT & \\
\hline $111-: 4-6 \overline{8}$ & WINUENT DFUE & WHITE LEE_IE & 60 & R-S YES & YES ND & ko & FhIVAT & \\
\hline$k 11-14-11$ & BINGEHT DEIVE & CILILA RIEHAFE & 61 & $R-j Y E S$ & YES NO & NO & FEIVAT & \\
\hline เ. $1-14-12$ & VINCE IF TEE & CILLLÁ R̈IEHATEL & $181+C$ & F-j YES & YES NU & Ni & FRIVAT & \\
\hline $111-14-13$ & CFAHE FITAL & MEDUh & $240+i$ & A-j YES & YES NO & $N E$ & FRIWAT & \\
\hline $1 ! 1-15-102$ & CFAALE RUAL & ENELEMAR RUEEFT & 66 & Ki-j YES & YES NE & NE & FUE:IC & \\
\hline$k 11-15-04$ & CFAARE RIIHL & PREMTISE SETOUE H & 120 & $\bar{h}-3$ YES & YES NE & $\mathrm{NO}$ & PUELIC & \\
\hline K.1 $1-19-01$ & COHSTELLATIOA ROHS & GFEAT ENSTEFR REALTH & $20 \bar{z}+\mathrm{C}$ & $F-3$ YES & YES YES & $\mathrm{Hi}$ & FUELIC & \\
\hline $111-19-07$ & COAEIITUTICN RUAO & SCUÁL ANTDRIA & 121 & R-3 YES & YES NO & NO & FlELIL & \\
\hline$k 11-19-0 \overline{7}$ & CONE:ITUTIOR FOAL & (6) DONHELL MICHAEL & 60 & E-J YES & YES IES & $\mathrm{No}$ & PUELIC & \\
\hline $111-15-10$ & CONSTITUION RGAD & O DORNELL MICHAEL & 60 & Fi-3 YES & YES YES & $\mathrm{NO}$ & PUBLIC & \\
\hline $111-19-12$ & CONETITUTIOH FOAE & LQUD THOKAS & 60 & RI-3 YES & YES YES & NO & PUBLIC & \\
\hline $111-19-15$ & COKSTITUTIOH FIGAD & VEFFTY GEORGE & 60 & R-J YES & YES YES & $\mathrm{NO}$ & FUELIC & \\
\hline $111-19-16$ & NEVATA STREET & GEORËE GECRËE & $174+C$ & R-3 YES & YES NO & NO & PFIVAT & \\
\hline $11-20-01$ & MORTTER FUAO & CLANCY JAMEE & 60 & R-J YES & YES $\mathrm{NG}$ & NE & PEIVAT & \\
\hline $11 \pm-200-02$ & HOHITOK RERE & WLINEY CLAKEY COREORATION & 60 & $R-3$ YES & YES NO & NO & PEIVAT & \\
\hline$k 11-20-03$ & MUNITUEK KOULE & GUINCY CLANCY CORFOGATION & 60 & $R-3$ YES & YEE NÚ & NJ & P'FIVATT & \\
\hline$k 11-20-04$ & MONITOE ROAL & CLAREY JGMES & 60 & $R-J$ YES & YES RJ & NO & FFIVET & \\
\hline$x 11-20-05$ & MUNITUK KLAL & MACAETHUEK FATFICJH'H & $139+C$ & R-3 VES & YEE NE & NO & PEIVAT & \\
\hline $111-2 i-j E$ & CONETELLATIORI RUAD & ERINLLEY EUGENE & 6.5 & K- 3 YES & YES MI & NO & PUSLIC & \\
\hline$k 11-2 i-10$ & CUNETELLATION EUAD & IYESJH MELVIR & 60 & $E-3$ YES & YES NE & NO & FUELIC & \\
\hline $\mathrm{KLi}-2 \mathrm{i}-0 \mathrm{i}$ & SURE AVERLE & SEPSLAEE KOMES & $145+5$ & $R-3$ YES & YES Nú & $\mathrm{NE}$ & FUELIC & \\
\hline$k 11-21-63$ & MONITUR KUAO & BECKMAK CAF:L & 60 & F-3 YES & YES ND & NO & PFIVAT & \\
\hline$k 11-21-04$ & MOHITUS FUAL & MAZZAEI IFIDH & 00 & $R-3$ YES & YES NE & No & PFIVAT & \\
\hline$k 1 j-22-03$ & CURETELLATIUER RUAEE & DEULLASIG NICHULAE & 60 & R-3 YES & VES NE & NO & PUE_IC & \\
\hline $111-22-614$ & COKSTELLATIJK ROAOD & 5ANBIRE RILUED & 60 & $R-3$ YES & YES NO & NC & PUELIS & \\
\hline$k 1 i-22-07$ & 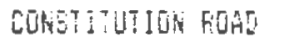 & WIINN THUMAS EG & to & FI-S YES & YES NE & NO & PUE'IE & \\
\hline $6: 1-3-61$ & CEASITUTIOA RJAL & GREFF FWEET & 125 & FI-J YES & YES NE & wo & FLEL & \\
\hline $111-2 \overline{5}-11$ & RERHAME RUAL & BAREEF DANIO & 60 & R- 3 YES & YES NE & No & FEIVAT & \\
\hline$k 11-2 i-12$ & RERTHER Fü & BEL MAFin & 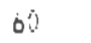 & $\mathrm{B}-3 \mathrm{YES}$ & YES NU & $\mathrm{kL}$ & FÁtín & \\
\hline
\end{tabular}


RI-24-02 CONETITLTIUA FELAL 11!-24-05 CORETIUTIOR FUR:

KI-24-J4 CUKSTITUTJUR RUEE

KII-24-0I SUFF GYVESE

K!1-25-64 CIRCUIT AUENUE

11-25-05 HETERMAR AVEADE

KII-25-GE WATERTHA BVE.

KII-2t-G EJEUUI AVE.IERST.

KII-27-GE KEN A'VEHL

K.11-27-0E KEKT AIERIIE

K!1-27-64 KENT AVERIE

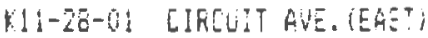

K11-24-02 WILSUIR GUENLE

K11-36-65 hAKLE!E: SUT:

KII-31-OL ARES ÁVENLE

K11-7i-63 CIFULIT REE. EAST!

111-32-014 EAMES WA

11-3J-6. CIECIT AVE

K11-35-0Z CIRLLIT AVE. LEAJT:

11-34-61 CIE-IT AVE.

K11-35-61 CIKEUIT AVE. (EAET)

KII-JE-CI CIATLUT AGE. SEAET?

KIZ-UI-OS MEALLUIE STEEET

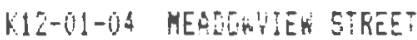

K12-0!-05 MERDJWHE 5TREET

KIZ-C2-OF HILLIJE STFEET

KD-6̈-40 FIELO STEEET

$12-0-44$ FIELI STREET

1.2-03-65 HILLSIDE STREET

KL-OS-ZT HILLSILE STREET

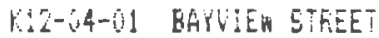

12-04-05 STAKD!SH STREET

K12-0E-23 NEWFJKT STREET

M12-05-30 CONCIND 5IREET

K.12-OE-OE JACKSUN STREET

K12-07-02 JACYSOA STKEET

K12-07-1I FICHAẼ STEEET

KIZ-OE-CI RICHAES STFEET

K12-0E-6A FICHASE STREET

KIC-AY-12 AEEEY STREET

KL-6G-3Z BÄEEF TERRALE

$K 1 \bar{i}-12-02$ JACKOSK STSEET

K1Z-1Z-DE RICHAEE STREET

KIT-1J-15 CONCOND STFEET (GFF)

K12-14-04 NEWFETT 5TREE?

KI2-14-10 CORCORŨ STFEET

12-16-12 MINUT STREET

K12-17-02 EAST STREET

K12-17-12 ATLANTIL STREET

K12-17-15 STANLISH STREET

K12-IB-ODS FORTEF STAEET

KIZ-18-09 PORTEF STREE

KIZ-15-13 PURTER ETREET
QUilít Clancy CEFF́.

DiLARIE ENEILIO $h$.

SMITH DUHALE H.

FILIOELIS JAHES

BUAKS R. EMERSOLA

DUTES REALTY TEUS

FICLEN RUEETT E.

RUEDEFIE JGHES

DULEE REALTY TRLET

MOSJHÁL J JOEFH

LITCHF IELC 3OSHA

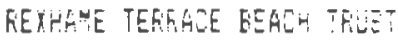

HULINE FAY $G$.

Cük JChil $L$.

Joun L. CLop III

SWETT MGSIDIE

LAWERENCE FREDEF]

EFELI EIF FERTIY TRLET

HUREIRG RATI 5 .

[ODA JGA': L

CE]N JUHA ].

SHETT MHEUUFIE

MEFIGSA THUMES

Q RCHRELL FAULLA

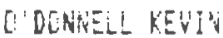

MASIX GLAN T.

OUSKHELL FALLA

WMTSEG IEHNETH

MELEN, EELEN

EFIULONI FUILIF

WELCH LuTRTGIAE

AKTERSER RUGER

LEONABR DIANE

MCGEE CLIFFORD

GLINSH I ANTHUNY T

FOSE FAYMRK E

JUHKEUN GLSTÄ̈

BUUZAR FATRICF

COTTES RESINHA

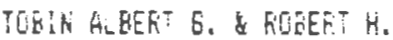

TCOKEY JUHiks E.

BUTDEIN CAROL A

SHLVESEF MILLKED

AEATE ANTHON:

FUEY TIMUTIR:

FEAT RUEEAT

CAMELIO RLEEST

EEDIE FISSELL H.

DTIIKAS WILLIAM

EETTEF IOHN

AEELLI LOBIS L.

AEELLI IEANRE

LEISHEF FLOYO
60 F-J YES YES NO NO FUE.IC $665 ?$

60 R-3 YES YES YES NO PUBLIC 6ES:

60 F-j YES YES NO NO PUELIC 6653

53 R-J YES YES NO NO PUBLIC 4505

300 F-3 YES YES YES NO PUELIL 30000

ZOORE F-3 YES YES NO NÜ FRI CL 10000

230 F-J YES YES NO NI FFI CL 23000

100 K-J HO NO HO NO FFIVAT 10000

$201+[\mathrm{L}$ K-J YES YES NO NI FFI CL $2000 \%$

125 F-3 YES YES NU NO FRI CL 12590

$100 \mathrm{R}-3$ YES YES NO NE FEI CL 1000

$200+E$ F-J 110 NO NO NO FFIVAT 119790

166 Fi-J YES YEE RO NE FUELIC 10000

10.2 R-3 YES YES NO NJ FRI CL 20006

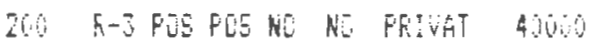

100 h-j NG WO NE NE FFITHAT 30090

100 Fi-j FOS FOS NJ NO FROVÁT 10060

10i RT-J NO NO NO NO PRIVAT 30000

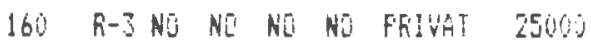

200 ET-J NO NO NO NO FRIVAT 50006

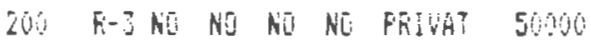

200 R-3 NO NO NO NO FRIVAT 50000

5O F-3 YES YES NC NO PLELIC 5000

50 Fi-3 YES YES NO NO PUELIL 5060

50 R-S YES YES NE N: FUELIC 5000

100 R-3 YES YES NO NO FUELIC 5000

40 F-J YES YES NE NU FUELIC 5002

54 R-3 YES YES NO NO FUELIC 5523

50 FI-J YES VES NO NO FUELIC 5000

100 F-J YES YES RJ HO FUSLIC 10000

239 R-3 YES YES NE RE FUELIE 4775

50 R-3 YES YES NO ND FUELIC 5000

50 R-3 YES YES NU NÜ FR: CL 5000

50 F-3 NG NJ NI NU PRI CL 5000

50 R-J YES YES HI YES PFIVAT 5000

50 R-3 YES YES NU YES PFIVAT 4220

$4 i$ Ti-3 YES YES NJ NE FRI 3615

$110+C$ L -3 YES YES NG NO FRI 10000

50 h-J YES YES NO ND PKI 5000

$5:$ Fi-3 YES YES NE YES FEIVHT 5006

100 H-3 NE NI NO NU FRIVGT 10931

$5 i$ R-J YES YES NO NE FRIVAT 5560

$250+5$ hi-j YES YES NE NO FI'LI 6200

Ni R-J FUS FOS Ni NE NO DIK 5225

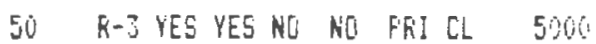

$50 \quad R-3 N O$ NO NO NO Ph!CL 5010

50 FI-J YES YES NÍ NO PUELIC 5000

50 R-J YES YES NO NO FRICLO 5000

50 R-3 FLIE F05 $\mathrm{kO}$ NO FFI CL 5000

$50 \quad \bar{R}-3$ YES YES NO NO FUELIC 5000

54 R-J YES YES NO NU PLE 4030

$1901+[\mathrm{CF}-3$ YES YES NO NO PUELIL $500 \mathrm{C}$

to RI-J YES YES NI NJ FUELIL 4790 
DANBEF QE FEE

SIPFSER MARGAEE:

KI3-03-0? PAEIEEF STREET

LUB-0:-OL CANÁL STREET (UFF)

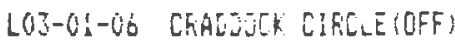

LO4-01-55 FLETCHEF DRTVE

LO4-01-57 FLETCHEF DFIVE

LO4-OI-5E CAEESHELL STREET

L04-01-59 CARESAELL STREET

LOU4-0)-64 BAFFIA FOLD

LO4-01-66 ELHUIEST STEEET

L04-01-76 CRADSSCR ROAD

LO4-6!-69 FLETCLIER STREET

L04-05-02 LINDEN GHE.

LO4-C5-04 FLETCHEF: LITIVE

L04-0E-05 LINLES AYE.

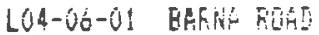

LQ4-07-0? CANG' 5TKEE:

LO4-OT-OIS CAKFE STKEET

L04-07-09 CANHL STREET

L04-07-10 CAMAL STREET

LO4-00-11 CAARL STREET

LO4-37-15 CÄAAL 5TREET

L04-607-1J CANÁL 5TREET

LO4-65-04 CANGL 5TKEET

LO14-05-24 CANÄ: STREET

LOU-GY-24 IUAHE STFEE?

LO4-16-02 CRARIDSI CIRCLE

L04-10-0T CFÁEJCR CIRILE

LOE-OM-OL ELSTIS STREET IOFF:

LC-:-A) EUTIS ETREET (OFF;

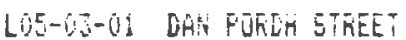

LOE-C4-0! SHIRLEY STEEET

LOE-04-02 LEVERETT STREET

LO5-05-0) SHIKLEY STREET

LO5-06-OI BEF'RAREL STREET

L05-007-0) WILSUR AUVENUE

L05-08-01 WILSUN AUENUE

L05-09-02 BEFNGEL STREET

L05-09-04 FLÜIDA STREET

LOE

LO5-11-OG LEVERETT STREET

L05-12-05 LEVERETT STREET

LO5-14-03 EVERETT STREET

LO5-15-09 LIKEOLN A'VE.

L05-16-06 LINEOLH AVE.

L05-17-05 SHIRLEY STREET

LO5-2OU-OS EUSTIS STKEET

LO5-20-04 LIRCELN AVE.

LO5-22-03 CAHAL STREET

LO5-2J-07 EDHAFI KOAE

LOE-23-68 EDWART KUAD

LOS-2J-11 EDhESD FuAD

LO5-23-14 EDHART RICAD

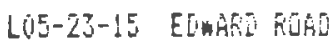

RQONEY EILEEN

LAFSEN HENR: C.

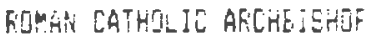

MCGRFIH EDHARSS

SARLEFLIR JAPES E.

BRTLWE MIKIAH

2ICK MAFTHA H.

DUFFY PATKILIA

RYERGJW HAGTEY

EQHAEI BSULHE

BRLLWHE ELHÁriD

BROWHE EULATIDS

GREANEY FRTHLIS

KEEFE TIRETHY $F$.

SAR CIEMENTE MAEY

BAEEETTI ALELIKE

VILLAGEE HOKEE INL.

VILLAOES HEMES IRE.

VILLGEE HOMES INE.

VILLFEE HOKES INS.

MECHETHY EUGEHE

BAFH TCLE EIUAFI U.

SABTATC GEUTEE

FLFTLEY JHAES O

BÁFIETTI ADELINA

BRERETII ADELIKE

REELTY INHOVENENT TEIEI

FEGT IMFE IEFEH TFUET

FEDETICU ALEEST J

REALTY IMFFOUVEERT TKLSI

VAEA GNHE F.

FERLITY IMFFEVEHENT TKUST

REALTY IMTHOUEMENT TRUSS

REALTY IMEFOUEMERT

REALTY IMFROUEMEWT

HEDONALD MICHAEL

REALTY IMFFOVEMENT TRJST

JORLAR GEOFIOE

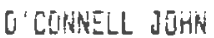

MATTIYELLO MARTIK

QUJFA KICHAGẼ M.

FISK BAREY H.

LUTKAFID EEOFEE J.

MURFHY GAYID

REALTY IMF REYEREST TRLET

FHILFUTT COLLETIE FAY

RÜMAL CATHIL IC ARCHE:SHLF

CAFFELLO MAEEJEEITO

HINES YIKUINIÁ

FAERIT RALFM F.

ACCAEE EDKHER J.

GiFFIR IREDEE.
Page 31

FROE ZOK SEL WAT HET FFA ACCESS AREA SF

50 R-J YES YES NG NO PRI CL 5425

NUAE BR-Z NO NO YES YES NO DIF 1135694

NJNE RIJ NO NO YES YES NO DIK 3147210

$200+[$ K -3 FUS FOS YES YES FFIVAT 2678 ?

$170 \mathrm{R}-3$ POS FOS YES YES N/A 21600

NUTE KI-S NI NO YES YES NO DIK 4EE7CS

NONE R- 3 NO NO YES YES NO DIK 568001

201 F-J YES YES NO NO PUELIC 10741

110 R-3 YES YES NO NO FULLIC 2.215

40 R-3 NU FOS NOI POS PRIVAT 1852

171 R-J POS POS YES YES N/A 21600

$100+C R-3$ YES YES NO NO FRIVAT BUTAO

10 RI-J FOS POS NO HO N/A 7350

SE R-3 YES YES NO NO FFIVATT 14300

169 R-3 YES YES NI NO PUELIC 8946

60 F-J YES YES NO NE PUELIC 10030

80 R-3 YES YES NO NO FLEL!C $\$$ WU10

155 F-3 YES YEE NE NE FUELIC 4365!

147 T-3 YES VES NJ NO FUELIC 10117

141 F-3 IEE YES NO NJ PUELIC 43606

129 F-3 YES YES NI WO FUELIC 10107

103 F-J YES YES YES NO FUELIC 6017E

90 R-3 YES YES NO NO PUELIC 9000

50 Ki-3 YES YES NE NO FULLIC 6250

45 R-J YES YES NO YES FLE!IC 4500

$110+i$ R-3 FUS YES HU NO FUELIC 5072

$116+C$ F-3 FOS YES YES NO FUELIC 9572

$160+C \bar{R}-2$ NE NO NO NO N/A 113256

NUNE Fi-2 NO NO YES YES NE DIK 91476

80 R-Z FUS FOS NL NS FEIUAT 14400

$445+C$ R-2 FOS FOS YES ND FRIVAT 42300

EO R-2 NG FUE NO NO FRIVAT 19166

206 R-2 FUS FUS YES NO FFIVAT 60584

JUGi+C R-2 NO NO YES NO FRIVAT 43000

$300+[$ R -2 PUS FUS YES NO N/A 21990

$500+[$ E-2 FUS PUS YES NO N/A TE40E

90 R-2 NU NO YES NO PRIVAT 7200

$2860+[$ h- 2 POS POS NO NO N:A 9600

60 R-2 POS PGS YES NO FRIVHT 4800

60 R-2 ME YES HEI NO PFI CL 5040

$20 .+C R-2$ NJ POS NO NO FRIVAT 96.10

260 R-2 NO YES NC NG FRIVAT 13200

90 R- 2 NO YES NO NO PRIVAT 4800

140+E R-Z NO YES NO NE FRIVAT 4 EUO

10: F-2 FOS FOS YES NU PRIVAT 5227

19 Ri-2 NJ NO NJ NO N/A 21075

BO+C. R-2 NO YES NO NO FFIVAT 9600

76 F-3 YES YES NO NO FUELIC 17667

50 R-3 YES YES NE NO FEIYAT 5000

50 KI-3 YES YES NO NU PFIVAT 5000

50 hi-3 YES YES NO NO PRIVAT 5000

50 R-3 IEE YES NO NO FRIVAT 5000

5. F-3 YES YES NO NO PFIVÁT 5000 


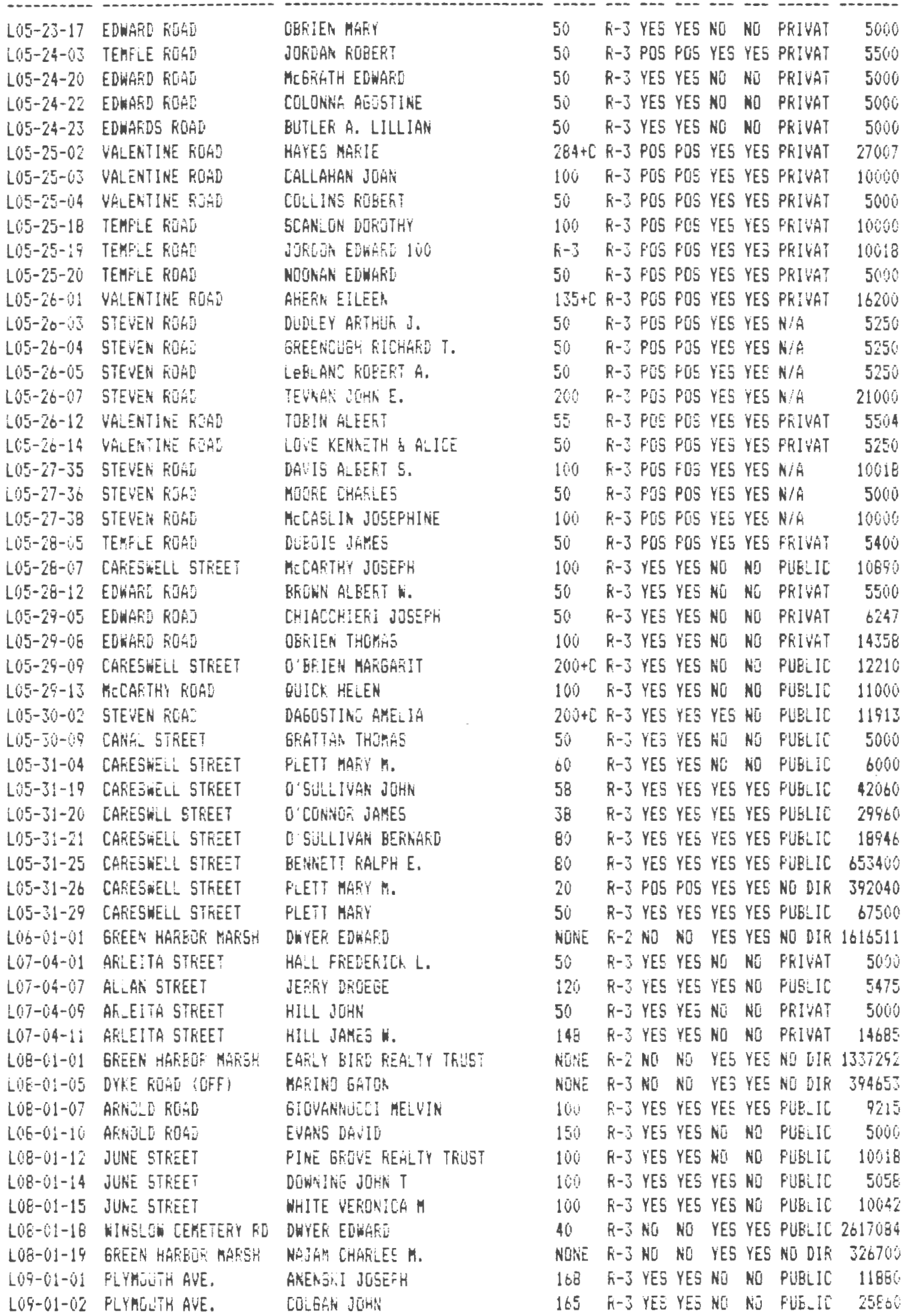




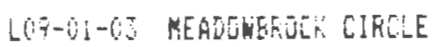

LGY-0:-6E FLYMUSTH AVE.

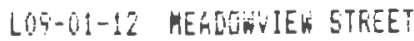

LOF-01-14 MEADOWHIE STEEET

LU9-0:-10 MEADÜVIEN STREET

LOG-6!-1E HEADOHIEH STREET

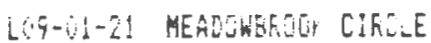

LOT-01-23 MEADOWUIEW STFEET

LOF-OT-2E MEALOHEFOUF. LIFCLE

LOS-0I-2t MEADOWHIEW STKEET

L09-0!-29 FLYMLUTH RiV.

LOS-CI-45 FLYMOLTH AVE. IREAR:

LO19-01-44 READOHBRTLE CIRCLE

L09-02-01 PLYMULTH AVE

LOG-02-02 AFKALSSS STKEET

LOF-OZ-04 AERAANOAS RUAL

LOA-0J-0S AERARSAS RIEAL

LOG-OA-OZZ HEATHEF FULD

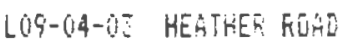

LOY-04-04 PLYMOUTH GVE.

L09-05-02 PLMUITH AVE.

LOS-05-QTS HEATHEF K[AL]

LOG-OE-OE HEPTHES FOCL

LOT-65-07 HEATHET RUAD

LO9-OE-CIG HEATHEF RLAG

LOF-05-14 AFKHHENE FICAD

L09-vo-0! FLYHULTH GVE.

LOG-00-02 MEAUJWYEW STREET

LOG-06-03 MEALLWERLIA EIFCLE

LiG-6t-6 HEMTHEF RUTH

LOS-OS-OQ HEATHEF FIER

L09-06-0E PLYKJiTH AUE.

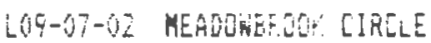

LOS-07-63 HEATHEF RLIGL

107-07-04 HEATHEF FOAD

LO5-07-OG MEATHER FOARD

LOS-07-07 HEATHER RIJÁ5

LOT-05-OI FLYHOLTH AVE.

L09-09-22 PLYMELTH AVE.

L09-04-23 PLYMUJTH AVE

L09-05-26 PLYMJLTH AVE.

L09-05-30 FLYHUITH AVE. (KEAF)

L09-09-3! PLYHOUTH AVE.

L09-10-12 RUUSEVELT FOAD

LOF-10-18 MEADOJWESOSK CIRLLE

LOG-10-22 MEADJLWIEW STREET

L09-11-0. HAMILTEN RUKD

LOG-11-0S HAMLLTON RUAO

L09-11-04 FLYMUuth ñve.

L69-11-21 FEFSHINE RUAD

L09-11-2Z RUOSEVELT RJAE

L019-12-0B FLYMUUTL AVE.

LOY-13-CA FirhouTH Rive.
MÁSGHFIELI FOD \& GUL CLUE

MAFSHFIELD RBD+DLLIH CLUE

ANEUEK DORUTHI

MARSHFIELD RLO \& GLN CLLE

ROEK REALTY TRLST

MAREHFIELD FLO \& GUUY CLUE

MÁRSTEIELO GOE \& GUN CLUU

DEMÁELLES DORIS

MAESHEIELD RÜD \& GLS C.UE

DONNELLY FICHAES

CQLEMAH ELIEN RAPPCLT

SOUTHWORTH ESTHEF

MAFEHEIELD ROD \& GULA CLUE

MÁSSHF IELD RULI+E NN CLIJE

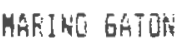

JÜHK VALGMán

ROEK REETLY TSUET

MUSSHFIELO ROE \& GLA CLUS

BREERER JAMES

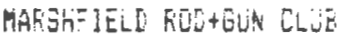

RAFSHF JELD RUL+GUS CLUE

DAILEY FFANEIE $\%$.

ALLEN WALTEK B.

MÁRLEETEL HAFULE

ThiADS THENAS

EDWARE FIOUX

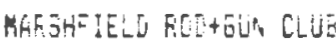

ROCK REÁLTY TRUE?

TRAB: THUMES

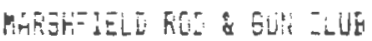

MUTI GERTFLDE

WHITE CATHEFINE

TFÄLL THUMAE

MESGUFIELD ROL \& GUN CLUB

GILMAN AFTHUK J.

MARSHEIELD ROL \& GUN CLUE

MARSHFIELO ROL \& GUN

KELLIHEF ANUFE

CAFEY FFAALIS

CAFEY FFÄHLIS

LAMUN REALTY TKUS?

MARSHF IELD RUJD+ELUN CLLLE

CONRELL FITA

GANTLEY FRANEIS

MERI_A ALFFED

MAT'SHFIELD FOC \& GUN CLUB

CATINÚ FALL E.

SCHUENEF RUEER $\mathrm{i}$

SCHUENER RIGEETT

MULLIN BEFTHEFI

EEAG JOHN J. CO.

DELIUFFE THOHAS

TANHEF CATHERINE
42 K-3 YES YES YES YES PFIVAT $7740^{\circ}$

5i R-J YES YES YES YES PUBLIC 958.2

$102 \pi-j$ YES YES YES YES PUERIC $784 i$

160 H-J YES YES YES YES FUELIC 39600

40 R-3 YES YES YES YES FUBLIC 4900

8O h-J YES YES YES YES FLELIC EZUO

40 F-3 YES YES YES YES FFIVAT BOOC

40 $\hbar-j$ YES YES YES YES PUELIC 108.0

40 R-3 YES VES YES YES FFIVAT 3716

40 K-3 YES YES YES YES FUELIC 3710

$1501+\left[\begin{array}{l}0 \\ 1\end{array}-3\right.$ YES YES YES YES PUELIC 3976

NURE R-J YES YES NO NO NO DIR 1230570

60 R-3 YES YES YES YES FFIVAT 5500

$151+C$ F-3 YES YES NO NO PUELIC 4632

80 R-3 YES YES NO NO FRIVHT 13790

4. R-J YES YES NO NO PKIVAT T5Z

$215+$ E R-3 YES YES NE NE PRIVAT 12375

60 F-J YES YES YES YES FKIVAT 8120

40 R-J FOS FUS YES YES FRIVAT 4060

$120+[R-3$ YES YES YES YES PUELIC 7500

60 Ri-3 YES YES HE NO FUELIC 228637

EO R-J FLS PUE RI NO PFIVAT 8120

80 R-3 YES YES NC NE PEIVAT 8000

40 R-J FUSFOS NO NU PEIVET 4000

40 R-J YES YES NO HO PRIVAT 406!

40 R-J YES YES NO NO FFIVRT 4UEO

$103+2 \mathrm{~K}-3$ YES YES NE NO PUELIC 1440

293 RI-3 YES YES YES YES FLELIC 17000

240 FI-3 YES YES YES YES FRIVAT 27895

15I RI-J YES VES NO NI PFIVAT 35E5

16) F-J FOS FIS YES YES FFIVHT 16117

58 R-3 YES YES ND NQI FUEEIC 3960

$224+5$ F-3 YES YES YES YES FFIVAT 14000

140 F-3 YES YES ND HO PUELIC 2000

40 F-3 YES YES NU NO PFIVAT 3985

40 R-3 YES YES YES YES PRIVAT 3985

Q0 R-3 FIS POS YES YES FFIVAT 7970

50 R-3 YEE YES NO NO FUBLIC 5000

50 R-3 YES YES YES YES FUULIC 5000

50 F-3 YES YES NO YES PUELIC 5000

$55+C \quad R-3$ YES YES NE YES PLELIC 13042

NULE Fi-3 YES YES NO NU NU DIR 376794

$100+[R-3$ YES YES NO NU FUDLIC 5366

QCi+C E-J YES VES FOS NO PRIVAT 2304

120 R-3 YES YES YES YES FRIVAT 11148

40 R-J YES YES YES YES FUBLIC $37 ! t$

$60 \quad R-3$ YES YES NO NO PKIVAT 5104

Ji RI-J YES YES NU NI PRIVAT 522 !

79 R-J YES YES NO NO FUELIC 7750

84 5-3 YES YES HO NO PFIVAT 6969

10it: Ri-J YES YES POS NO PFIVAT 3600

$5 S^{2} \quad R-J$ YES YES NJ NO FUELIC $540 \%$

5: Ri-J YEE YES NJ NU FUBLIC 5065 


\begin{tabular}{|c|c|c|c|c|c|c|c|c|}
\hline AE. MET-LOT & LOEGTIOK & OWNEE OF REC & FRONT & ION SEW & HAT NET & $F F H$ & ACEESS & AREA SF \\
\hline 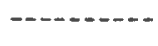 & - & -....-n & & --- & $--\cdots$ & $\cdots$ & & \\
\hline$\lfloor 09-16-01)$ & DCEARI STREET & JEREUANAE DUTOTHYY & $100+5$ & R-3 YES & YES NO & NO & FUELIC & 5671 \\
\hline$L 09-15-0.17$ & SECORO KCAO & BIANCHI DOMENICO & 45 & R-3 YES & YES NO & NO & PUELIC & $4050^{\circ}$ \\
\hline $105-1 E-10$ & FUSTEF AVEHIE & WILLIAH FLYNN & $90+5$ & R-J YES & YES NU & NO & FUBLIC & 365 \\
\hline$[19-19-0,5$ & THIFi RQAJ & STAKTON RICHART & 45 & F-J YES & YES NO & NO & PUELIL & 4050 \\
\hline $105-19-00$ & THIEL REAH & STANTSK JOHN & 45 & K-J YES & YES $\mathrm{NL}$ & NO & PUELIC & 4050 \\
\hline $467-19-12$ & THERL FïT & STANTUNN RATGARET & 45 & K-J YES & YES NO & NO & PUBLIL & 4050 \\
\hline $405-2 i-05$ & Füfin küb & EUSERE MCCARTHH & 40 & K-J Y YES & YES NO & No & PRIVAT & 3600 \\
\hline $167-21-0^{7}$ & FIFTH FEGE & HAFIHIS FELIX & 40 & Fi-3 YES & YES NO & NO & PUBLIC & 3600 \\
\hline $105-21-15$ & $\sin \operatorname{in} \overline{x i}$ & ROREIEAL THOHAS & 40 & R-J YES & YES NO & NO & PEIVET & 1986 \\
\hline $109-22-10$ & SEVERTH RIAH & FEOUT RICHAFEL & $100+i$ & K-J YES & YES NO & Ho & PRIVAT & 2745 \\
\hline $205-25-01$ & FUSTEF GVELHE & FÄULL S. KELSEY & 390 & R-3 YES & YES NO & NO & FUELIC & 37000 \\
\hline$L 10-(:-0:$ & FLIMELTH AVEADE & WH!TE CATHEGIHE A. & 270 & F-J YES & YES YES & YES & FUELIC & 261300 \\
\hline $110-02-01$ & OCEA' ETHEET & HAWTKOFRE REALTY TFUST & $806 j+[$ & E-3 YES & YES NO & $\mathrm{Nij}$ & FUELIC & 104544 \\
\hline $410-0 t-11$ & OLYMFIA FOAL & SUS: ELIZABETH G. & 85 & F-J YES & YES NO & $\mathrm{No}$ & FUELIL & 4868 \\
\hline $1 j 0-6 t-12$ & Q!YMFTA FUUALE & SUSI ELIZHEETH A. & 55 & E-J YES & VES NO & $\mathrm{No}$ & FUELIC & 4505 \\
\hline $1: 0-0 i-i 1$ & SIRF AVEKIE & CUELIEFA REALTY CIRE. & $300+c$ & $E-3$ YES & YES NO & NO & PFIVAT & 17449 \\
\hline$L:-\because-67$ & [AEEDK RUA: & FOFEL ALFFE $F$. & 52 & F-J YES & YES NC & NO & FUE:IS & 4505 \\
\hline$\lfloor(1,-0) \bar{L}-i \mid$ & ATALS RUAS & MEFEILL FICHAFEL H. & 76 & E-J YES & YES NO & YES & FGIVAT & $964^{5}$ \\
\hline LiV-iE-CiA & ALAME RORD & NDLGH FHU D. & 75 & $E-j$ YEJ & YES YES & $N[$ & FRIVAT & 6600 \\
\hline$L 1(1-68-1 !$ & FLYMJjTH AVENLE & C:Akti JüH & 99 & E-3 YES & YEE NO & Ni & PUELIC & $2316 t$ \\
\hline$\therefore 1 ;-6 E-12$ & 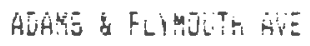 & DARE GERHEL F. A.T PO & 135 & E-J YES & YES YES & YES & FFIVAT & 1360 \\
\hline$L 10-6 E-14$ & PLYMOUTH AVENLE & CLPACI JUHN & 102 & E-S YES & YES HO & $\mathrm{N} \sqrt{5}$ & FUELIC & 23425 \\
\hline L16-0E-15 & BEAF FLYMOUTH AVERE & CLANEY JULH & NonE & E-J NO & ND NO & $\mathrm{Nis}$ & HE $[: 5$ & 3128 \\
\hline $110-08-16$ & OLEAR: STREET IREFES & CLFACY JUMin & NORE & $E-3 N O$ & NO NO & NO & NO DIE & 3281 \\
\hline$[10-50-01$ & HILEST: \& FLHELIH & LAME EETAREL F. & 25 & $R-3$ YES & YES NJ & No & FUELIC & 14620 \\
\hline$L 10-67-64$ & WLLSER AHERLE & NUIAN FAiL & 50 & E-J YES & YES NO & NO & PUELIC & 5000 \\
\hline $110-09-07$ & OCEAL STFEET & LAME GERÁTIO & 25 & F-J YES & YES NO & $\mathrm{NO}$ & FUELIC & 2500 \\
\hline $110-17-12$ & AIRYE ROAD & NINON ELWAS: \& FUTH & 108 & E-3 YES & YES NO & YES & PEIVAT & 15780 \\
\hline$[: 0-10-11$ & 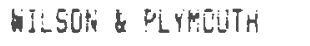 & LANE EERAEE $F$. & $15+i$ & R-J YES & YES NO & NE & FlELIL & 1920 \\
\hline$L 1 i-1:-67$ & EILLIRSE ROHE & SHER AERES H & 70 & R-j POS & FOS NO & NO & FEIVAT & 5455 \\
\hline $110-11-13$ & DCEAN STREET & FRINLESS FUUERICK TFLST & $3 i$ & $\bar{K}-3$ YES & YES ND & $\mathrm{kij}$ & FUELIE & 2633 \\
\hline$L 10-12-04$ & OCEAR STFEE: & PFINLESS TKUST & 31 & Fi-3 YES & YES HO & NO & PUGLIE & 2867 \\
\hline $110-14-04$ & OCEAN \& EIGHTH & BAFTR CHARLES & $120+C$ & $R-3$ YES & YES ND & $N[$ & F'UELIC & 3322 \\
\hline $10-14-16$ & NINTH REHU 25 & KETTENDJWF NATTHABIEL & 45 & R-j YES & YES NO & No & FUELIC & 4050 \\
\hline $410-j 5-03$ & DCEAN STREET & CASTIELIONI ALBERTA & 45 & R-J YES & YES NO & NO & PUBLIC & 3915 \\
\hline $410-15-18$ & FOSTEF AVENUE & ROSEFT F. BRÜHA & $80+[$ & F-? YES & YES NO & NO & PUBLIC & 3627 \\
\hline$[16-1 t-0]$ & OCEÂA STREET & NICOTFA DOMEHIL & 45 & F-J YES & YES ND & NO & FUELIL & $41: 6$ \\
\hline $410-16-15$ & ELEVERTH FUUH & REARDEN BICHARTE W. & 40 & K-J YES & YES NO & No & PFIVAT & 3600 \\
\hline$L: 0-200-06$ & CIL EEACH FISAD & COCLLERA REALTY INCUEF. & 160 & $E-3$ YES & YES NO & Nū & FEIVAT & 11200 \\
\hline$\lfloor 10-2\rfloor-05$ & OLD BEACH ROAD & COULLDEFE REALTY INCUFF, & 82 & B-3 YES & YES NO & NU & PUELI [ & 5500 \\
\hline $110-21-60$ & OLD BEACH ROAL & CUULDERA FEALTY INLORE. & 80 & E-J YES & YEE NO & N5j & PLELIC & 5651 \\
\hline$L 10-23-0 i$ & FOSTEF AVENLE & CHARLES FINUS & $40+i$ & F-3 YES & YES NŪ & NO & FU6!IE & 4393 \\
\hline$[11-02-03$ & CENETELLATION FOAE & CODOY FALLINE C. & 65 & F-J YES & YES NO & No & FUELIL & 4845 \\
\hline$L 11-0 \mathrm{~J}-10$ & CORETELLATILAN FOHE & SHNEUTR MILOFED & 60 & R-3 YES & YES NO & $\mathrm{Ni}$ & FUELIL & 5100 \\
\hline $111-04-13$ & MEN!TOE STEEET & HITLHELL ALEC. & 60 & R-J YES & YES NO & Nit & FLELIC & 5106 \\
\hline $111-04-\$ 17$ & FAFIKAGLT ROEJ & SABET FETER JOHK & 60 & K-J YES & YES NO & Hij & PEIVAT & 5106 \\
\hline 41$]-05-0 !$ & KANTFOSD RÜH & STRETTON CHAELEE H. & 60 & $h-j+E S$ & YES NO & NO & FFIVAT & 5100 \\
\hline $104-05-67$ & UGKIEL STREET & GREANEY FRAMISIS & 130 & $R-J P J S$ & Fos No & No & FRIVAT & 21500 \\
\hline $104-18-19$ & VIKEINIA STREET & DUFFY HEIL & 200 & $R-Z$ YES & YES NU & NO & PRIVAT & 7500 \\
\hline $404-09-6.6$ & VIREIMIF STKEET & BËUUI:5 JEAN & 100 & FI-3 YES & TES ND & NO & FEIVAT & 12800 \\
\hline$[04-09-07$ & VIFOINIA STREET & HHEF THUMAE & 100 & h-J YES & VES NO & Nú & PEIVAT & 750 \\
\hline $104-04-i b$ & WHOLYIF STFEET & HRLSH THJHAS & 45 & $K-3$ YES & YES NG & Nú & PFIVAT & 7500 \\
\hline $105-25-10$ & STEVEN RUAD & FAEIALEKI WÁLIER & $15 i+5$ & h-S YES & TES NO & $\mathrm{Ni}$ & FFIVAT & 5300 \\
\hline
\end{tabular}




\begin{tabular}{|c|c|c|c|c|c|c|c|c|}
\hline AJ. MGF-LOT & LoLATIK & GIMKES UF REC & FRONT & ZON SEV & HAT HET & $\mathrm{FF}_{\hat{H}}^{\prime}$ & ACCESS & AREF SF \\
\hline$\ldots$ & - & - non & & & -.. - - & --- & & \\
\hline $165-31-2 Z$ & CARESWELL STFEET & BENRETT GHALPR E. & 98 & $R-3$ YES & YES YES & NO & PUELIC & 17200 \\
\hline$m 04-01-01$ & 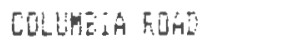 & FACE FIÄFLLHE. & 60 & R-3 YES & YES YES & YE5 & Plúbitis & 7500 \\
\hline $904-03-67$ & CANGL ETREET & WHITTY CGTHEFIHE DAY & 52 & R-3 YES & YES YES & YES & PUELIC & 5000 \\
\hline$M 04-05-0 E$ & CAKHE STAEET & EUHEFE WILLIAME & 52 & R-3 YES & YES YES & YES & FUBLIC & 5000 \\
\hline $104-05-09$ & CANAL STFEET & PIZZANG ANEELJ & 70 & R-J YES & YES YES & YE5 & PUBLIC & 5000 \\
\hline $404-03-10$ & ChATI SInEET & WHITT WIEEJE & 50 & R-J YES & YEE YES & YES & FUE:IC & 5000 \\
\hline$M i 4-0 j-1 E$ & CARP_ STREET & BROTHEFS FUUK INE. & 52 & $R-3$ YES & VES NO & YES & PUELIC & 5000 \\
\hline$M i 4-04-02$ & ALAEAYH STREET & MEEFAH DAVID E. \& SHEILA A. & 70 & $R-3$ YES & YES YES & YES & PRIVAT & 5800 \\
\hline$P \because 4-04-0 E$ & CAAAL STFEE & Mc BTFETH DAVID & $2000+[$ & FI-J YES & YES NO & $\mathrm{NIJ}$ & FUELIC & 6500 \\
\hline $1004-06-62$ & NEL YIFE 5TFEET & YURK DETEK & $200+C$ & F-j YES & YES YES & YES & PEIVAT & 14500 \\
\hline $504-05-18 ?$ & CAEEF FOAL & MATEEN EDKUN: & 100 & R-3 YES & YES NO & Nij & PRIVAT & 15000 \\
\hline$M 04-10-03$ & CFEE FOA & ZACCIGKINI: LANIEL & 50 & K-J YES & YES YES & YES & PRIVAT & 8400 \\
\hline $104-101-6=$ & AVUK STREET & BCWEFS GERTAGTL 6 . & 122 & F-3 Pü & FOS YES & YES & NiA & 19000 \\
\hline$n 04-11-10$ & AVOW STKEET & FALKLARE: FREIEFIL & 225 & $B-3$ P0S & FOS YES & YES & $N / A$ & 15200 \\
\hline $\operatorname{Mo} 4-1 j-i 5$ & SAY STREET & TELESCHI REALTY INL. & NUKE & R-3 NO & No NO & YES & NU DIR & 1875 \\
\hline $164-17-67$ & ERIEHTLY STFEET & JULNSOUN J. WILIIAM & 100 & $K-3$ YES & YES YES & YES & PUELIC & 1001 \\
\hline $104-16-101$ & PEAFiL STFEET & GOLDER MGEY & 250 & R-3 YES & YES YES & YES & PFIVAT & 250010 \\
\hline $\min 4-21-03$ & BAY AVE. & VILLAGE GREEN TKUSET & 60 & $R-3$ YES & YES NO & YES & FUELIC & 5000 \\
\hline $405-03-15$ & CARESWELL STREET & BOHK FGTEICIA M. & 105 & 6-3 YES & YES NO & NC & PLJBLIC & 10112 \\
\hline $105-05-01$ & ASSUSFTIUY RTAE & MCHUEH THJMAS $\mathrm{F}$. & 345 & R-J YES & YES YES & YES & PUE:IC & 100182 \\
\hline$M 05-65-14$ & STEVEN RLAL & Q'SULLIVAAY JOHN & 50 & $\pi-3$ FOS & FOS YES & YES & PF!VAT & 5000 \\
\hline$n 55-05-15$ & STEVEH RUAL & O'SJ!LIVAN EEFNARTI A. & 50 & $\mathrm{~F}-3$ FOS & POS VES & YES & F'IIVAT & 5000 \\
\hline $105-05-16$ & STEVERE ROAE & HQOAN JAMES & 50 & K-JPU5 & POS YES & YES & PRIVAT & 5000 \\
\hline Hos $-05-17$ & STEVENO RUAL & O'SULLIVGK JUHH & 104 & $\mathrm{H}-3 \mathrm{POS}$ & PES YES & YES & PFIVET & 5000 \\
\hline$H 05-05-18$ & STEYENS FLÁD & CHEFVE TE ALFSES & 100 & $R-3$ FOS & FOS YES & YES & FFIVAT & $10700^{\circ}$ \\
\hline mij $5-0.5-19$ & MIS5JULI ETFEET & HILEMÁli ILLIAG & 190 & $R-J$ YES & YES YES & $\mathrm{Nij}$ & FRIVAT & 10200 \\
\hline $105-05-21$ & MISEUDAT STREET & FILISUEZAR JGLOEE & 100 & $R-\bar{F}$ FOS & YES YES & ND & PRIVAT & 10000 \\
\hline $605-05-22$ & HISEDLEL STEEET & QLUER UILLIAH & 100 & Fi-j POS & YES NO & NO & PFIVAT & 10000 \\
\hline $105-05-23$ & KI5SDUARI STFEET & DUHK THOMES & 50 & $\mathrm{R}-\mathrm{J} \mathrm{F} 0 \mathrm{~S}$ & YEE NO & ND & PRIVAT & 5000 \\
\hline MOE-05-24 & MISSULE L STEEE & HUDAMLE CLYDE & 50 & F-3 FUS & IES NO & No: & PFIVAT & 5000 \\
\hline $605-05-27$ & MISSULE: SAREET & MALINA FFARISIS & $5 i$ & F-j Pis & YES NO & NQ & FEIVAT & 5000 \\
\hline Hot $5-05-47$ & BAY AYVE. & EUIKKES BEACH IRLST & $120+C$ & $R-3$ YES & YES YES & YES & FUELIL & 30006 \\
\hline $405-05-48$ & EEALH STREET & LOYELL EARY K. & 50 & R -3 YES & YES YES & YES & PUELIC & 3000 \\
\hline$n 05-05-51$ & NAOYI STEEET & BEADEUEY JESSE & 50 & Fi-j POS & YES NOS & VES & PFIVAT & 9100 \\
\hline$M 05-05-53$ & HACW STREET & RUEHOI AFTHLF & 50 & $R-j$ POS & YES NO & YES & PRIVAT & 5050 \\
\hline$M 05-05-54$ & NALAI STREET & RUGGMI AFTHUS & 60 & $R-3$ FOS & YES NO & YES & FEIVAT & 5405 \\
\hline $16.5-35-55$ & KAOF: STEEET & FUGRAI AFIHTUF & 60 & $\mathrm{R}-3 \mathrm{PLS}$ & YES NO & YES & PRIVAT & 5010 \\
\hline$M 05_{2}-05-50$ & NADFI STREET & RLEHNI AFTHHUF & 60 & $R-3 F[15$ & YES NOO & YES & PEIVAT & 5460 \\
\hline$M(15-05-5 i$ & NASE STFEET & RLEGNI ASTHUE & 60 & $R-3$ POS & YES NO & YES & PFIVAT & $5460^{\circ}$ \\
\hline $105-05-5 E$ & NGOMI STREE? & FUEAKI AFTHLE & 278 & Ki-j Fús & YES NS & VES & FRIVAT & 5267 \\
\hline $105-65-79$ & 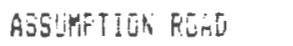 & FICKEFINS LOISE. & 365 & $K-3$ YES & YES YES & YES & PJELIC & 682440 \\
\hline$M 05-05-80$ & ASEUHFTION RSAE & DEERFIELD FRLFERTIES & 4E. $\bar{T}$ & R-J YES & YES YES & YES & PLEE'IC & 76408 \\
\hline $405-05-8 !$ & SULIFES AVEKLE & DEERFIE D FROFEFTIES INC. & 143 & R-3 YES & YES YES & YES & PUBLIC & $246 !$ \\
\hline 1.) $5-05-88$ & BEACH 5TKEET (UFF) & 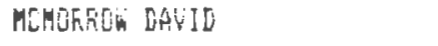 & NINEE & $R-j N D$ & NE YES & YES & NO IIF & 2500 \\
\hline $605-65-50$ & NAPCOL STFEET & FUEAMI AFTHUE & 60 & $\bar{R}-3$ FOS & YES NO & YES & PFIVAT & 5267 \\
\hline$M 05-05-51$ & NHOHI STFEET & FUGAME ASTHUK & 60 & $k i-3$ FOS & YES NO & YES & PFIVAT & 5267 \\
\hline $105-05-92$ & NADK STREET & FUEALI ARTTHUR & 60 & $8-3$ PQ5 & YES NŪ & YES & FRIVAT & 5267 \\
\hline $405-65-53$ & NAGHI ETEEET & RUGANI AFTHUF & 60 & R-j Füs & YES NE & YES & PEIVAT & 6353 \\
\hline $405-66-62$ & EAYY AVE. & SULLINAN JAMES JF. & 102 & R-Z YES & VES NO & YES & PUE:IL & 6000 \\
\hline núb-0i-ui & CARESHELL STFEET & HULGOHTON KELEN & 75 & $R-J$ YES & YES NO & NO & FUELIC & 76230 \\
\hline Mís-0 $1-02$ & CARESHELL STEEET & WHALEG LAWFENLE 3. & 50 & R-J YES & YES NO & NO & PUELIC & 15295 \\
\hline$M 0 t-62-01$ & FAFT STKEET & MLYR:LT EIWAFE & 90 & F-3 YES & YES NO & NO & $\mathrm{FFI} C \mathrm{CL}$ & 8106 \\
\hline$m s-0 z-10$ & LARING FinE & L+E FEARLTY TFUST & 81 & F -3 YES & YES NO & YES & FEIVAT & 10250 \\
\hline
\end{tabular}




\begin{tabular}{|c|c|c|c|c|c|c|c|}
\hline H5. MRF- LOT & LEET:OUK & GW OFE & FFORT & IUN SEH WGT & WET FFA & ACCESE & AREA SF \\
\hline $30 t-65-10$ & LAREIKÖ KÜÁ & BUEEE ULHN F. & 50 & K-J YES YES & YES & FRIVAT & 3450 \\
\hline Mit-04-io & MAFEIRAL STREET & MEEHAN F'ATSTEA & NONE & F-3 YES YES & YES YES & Nõ OIK & 28500 \\
\hline hub-je-jj & CARËSWELL STKEET & FLANDERE THEKIAS & 50 & E-4 IES YES & YEE YES & PUBLIE & 12000 \\
\hline Hot-0 $9-6$ & CHEEFE STEEET & KEHUSH JAKEE & 60 & R-3 Fü5 FOS & YES YES & FRIVHT & 12350 \\
\hline But $-05-67$ & CHEFFY STREET & RCHUEH ERIAR & 30 & F-3 FIS FOS & YES YES & FFIVAT & 7000 \\
\hline Mut-6j-6e & CHEFE STREE? & MctiväH ERIÁk & 60 & F-3 POS Füs & YES YES & PFIVAT & $1486 \%$ \\
\hline$n 07-01-01$ & ALLAA STREET & NEK EEUFEF GAS & 80 & 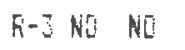 & YES YES & PUE!IC & 333234 \\
\hline$k_{i 7}-01-32$ & ALLFRI GTKEET & Jjok LFLUI & 50 & R-J YES YES & YES NÖ & FuELIC & 5060 \\
\hline$M i-0 i-2 E$ & HEESTER ANENGE & FERE THDHAE & 50 & K-J FUS IES & No YES & FUE IC & 5000 \\
\hline $4=-02-1: 1$ & IHE REAL (CEF) & BLFISE ERIL & NONE & $6-3 N Q N D$ & YES YES & NE DIF & 87120 \\
\hline$M: 7-65-04$ & DEEAH STREET & FEFRRAULT FETER & 30 & E-4 YES YES & YES YES & FUELIC & 4148 \\
\hline $4 \cdot 7-0.06$ & UUEAR STKEEL & WEHUS II ING. & 5. & E-4 YES YES & YES YEJ & FUELIC & 675 \\
\hline$M i-v-10$ & IKKE RIJH' & HAMHO FFH:IE & 102 & F-J YES YES & YES YES & FUELIC & 9905 \\
\hline$M 07-65-11$ & CLEHS STREET & VERSE II INE. & $5 j$ & B-4 YES YES & YES YES & PUELTC & 6075 \\
\hline $507-64-3)$ & DRALEYSTHES & SULLINAN JOHK T & $36+5$ & F-Z YEE YES & HO YES & FUE:IL & 4350 \\
\hline$n: 7-0-0 !$ & FLHEITA AVE. & SULLIVAR JuH & $606+i$ & $F-3$ YES YES & NO YEÖ & PUE & $20 \mathrm{wn}$ \\
\hline$=67-60-01$ & 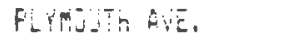 & SULLIVAN JOLE & $60+i$ & F-J YES YEE & YES & FUE_iL & 20001 \\
\hline$M i-0,-i=$ & HASOECK STFEET & HAE EIN CATHEFIRE Y. & 50 & F-: YES YES & NO & FHEVAT & 500 \\
\hline $107-87-32$ & LONHE ROR: & NELÁH LUEISE & 73 & K-3 YEE YE5 & YEE YES & FUELLIE & 7300 \\
\hline$m 6 i-67-90$ & HHLOU STEET & FHELAN FLSEF, L. & 50 & F- S YES YES & No Ni & FEIVAT & 400 \\
\hline $10-10-60$ & DHE FiJEL & WLALEA LAMFEHEE & 5 & F-J VES YES & Mi & FLELIC & 6157 \\
\hline $10 ;-16-12$ & LYVE FEL & 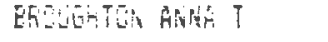 & $156+i$ & F-J YES YES & $\mathrm{Ni}$ & FUELIS & Jiets \\
\hline$M 7-16-24$ & FFAP LIS STFEET & 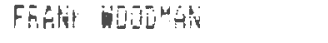 & 3 & $\bar{H}-3$ VES YEE & $\mathrm{Hi}$ & FLE'IC & 7560 \\
\hline$m i-10-26$ & ER:LE ETRE? & PHALETT RICHFS & 50 & R- Z YES YES & Ni Ni & FuELIS & 5500 \\
\hline $\operatorname{mot}-62-01$ & 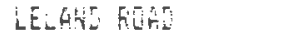 & KEFF DESUT' LEE & $156+i$ & F-3 YES YES & $\mathrm{H}[\mathrm{C}$ & FUELID & 500 \\
\hline$h 8-62-12$ & AKM-Z FUML & VAREMER MUVE ALEST & 50 & $R-3$ FES YES & $\mathrm{NJ}$ & FUELIC & 5000 \\
\hline $506-14-19$ & Elmílit Rúñ & WiLtLE JHES & 50 & F-J YES YES & $\mathrm{NII}$ & FUELIC & 500 \\
\hline het $-50-15$ & TEGES AUENHE & SLLLC FRÁR: & 50 & K-J YES YES & No NO & FUELIC & 5000 \\
\hline MUE- $-15-i c$ & TUKES AVENUE & 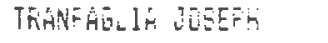 & 50 & F-J YEE YES & Hũ NO & FUELIE & 5000 \\
\hline $5 E-6 t-4 t$ & CULUKIAL RUÁ & 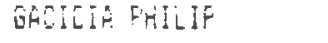 & 50 & F-S YES YES & NL NJ & FUELIC & 5000 \\
\hline MQE-68-07 & AESHAM STFEET & SHEA MULTEEN E. & 90 & $B-3$ YES YES & NO NO & FEIVAT & 6750 \\
\hline$M 05-09-05$ & SATLOEET AVENUE & FOND GKALE N. & 100 & K-J YES YES & NG & FUELIC & 12196 \\
\hline $508-1 !-60$ & OLEAN ETREEI & WHLSH FALL & $160+[$ & F-S YES YES & No & FUELIE & 11400 \\
\hline MUs-11-195 & SAE!HiR AGENHE & SHEFLOCL GOKODK A. & 60 & R-J YES YES & Nô & FLELIE & 7260 \\
\hline$M 0 E-11-16$ & CHICKATAHSO AHEHUE & GLEEFTI AMEE L. & 50 & R-3 YES YES & NO NŨ & FLELIE & 6000 \\
\hline $408-12-07$ & TECUMSEY AUERUE & RAKITALL GEGRTGE F. & $170+\mathrm{C}$ & F-3 YES YES & No & FUBLIC & 6000 \\
\hline $\operatorname{mog}-14-05$ & LUWEL: AVE. & DABLEY HENEYY E. & NontE & F-J FŨS FOS & NU & NODIR & 3651 \\
\hline Kog-: $4-18$ & CHICHATAREST AVENUE & FARICHER JOHK & 100 & P-J YES YES & NO & FUELIC & 10000 \\
\hline$M i 8-17-01$ & OLEER STREET & ALEXIE GEUTFGE & 116 & R-J YES YES & YES N $\mathrm{Ni}^{-}$ & FUELIE & JEEO \\
\hline$n 0 E-1 E-i n$ & GLEAS STREET & O'DAY HÁL & 30 & F-3 YES YES & NO NO & PUELIC & 3675 \\
\hline$M i E-15-01$ & AEHELTON BVEWIE & JEREY FREDEFICK W. & 50 & F-S YES YES & No NO & PLELIC & 5060 \\
\hline $108-2 i-12$ & FLYMDLTH AVEKUE & HBGEDLFN HUHER J. & 50 & KI-J YES YES & N3 NO & F'UbLIC & 50010 \\
\hline$M G 5-21-j t$ & SAMUSET AVENJE & METTIN JESEIE & 211 & F-J YES YES & NO NU & FUELIE & 16500 \\
\hline$M\left(1 e^{r}-r_{2} r_{-1}-10\right.$ & DORALE FLAD & SALIFAATE ALEXGRIEF & 50 & R-3 YES YES & Ní NO & PUELIC & 5060 \\
\hline HQE $-22-13$ & DEHAGLD REGT & DANIELS HJRATIS F & 59 & F-3 YES YES & NO NG & FLLELIC & 5900 \\
\hline Mine-3:-6! & BFIFET STFEE: & OMFiLLEY JOSEPH & $2001+c$ & F-J YES YES & NO & FUE:IL & 1000 \\
\hline$M 08-45-02$ & HAWOUL STEEET & SULLLIVAN JGHH T. & $360+\bar{c}$ & F-E YES YES & Nū & PFIVAT & 1000 \\
\hline$M 07-92-8 E$ & OCEANA STSEET & MCCOLGAK MEFY ETHEL & $5 j$ & R-J YES YES & No & PUELIC & 4380 \\
\hline M04-02 $2-69$ & DEEAEY STKEET & GFAIHGEE WLIA & 52 & K-: YEE YES & ND & FUELIC & 3559 \\
\hline Mō- $02-13$ & GEA STREE: & HOHALL ANBIE & 120 & F-J YEJ YES & so No & PLELIC & 1400 \\
\hline ho5-6j-03 & SERGGAE: & DONDHE IIT: & 50 & F-3 YES YES & NG NO & FUEE:IL & 4506 \\
\hline$N 15-0 j-62$ & CUVE STFEET & FALLON MGEESEET & 106 & F-S FOS YES & ND NE & FKIVRT & 7300 \\
\hline ME-6-0E & COUE STKEET & LOUELL LAMFENEE $\mathrm{r}$ & $36 \varepsilon$ & F-j FCE YES & NO NO & FRIVAT & 3632 \\
\hline
\end{tabular}




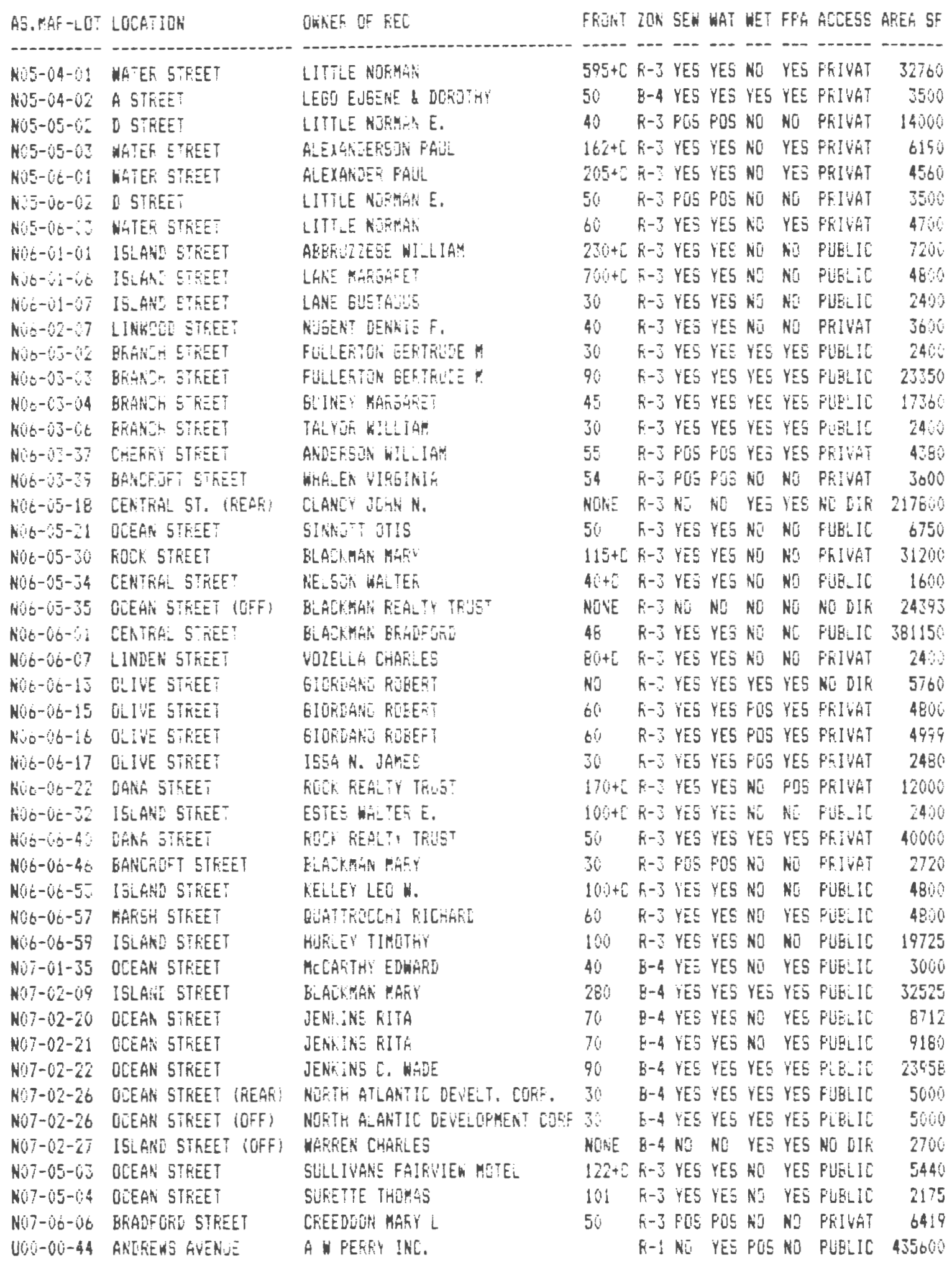

TUTALS:

AFEA 5F 203.673.263.93

frinted 1955 of the 1950 records. 
AFPENDIX 3.2

VACANT LAND FILE BY ZONE 


\begin{tabular}{|c|c|c|c|c|c|c|c|c|c|}
\hline S. MAE-LET & LOCATIOU: & OWHES OF FEC & FRCNT & $20 \mathrm{~N} 5 \mathrm{EH}$ & WHI & HET & FFÁ & ACCESS & AREÁ SF \\
\hline & & & & 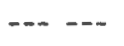 & & -- & -- & & \\
\hline $4-02-011$ & LOKE STEEET & STRIAR DARIEL E. & $33 \overline{5}+$ & $1-1 \mathrm{NO}$ & YES & Ho & HO & PUBLIC & 287932 \\
\hline$(j-0)-01$ & LUNE STFEET & LUKE STREE T REALTY & 150 & $1-1 N O$ & YES & $\mathrm{NO}$ & $N G$ & PUELIC & 9770 \\
\hline $6-61-62$ & LOHE ETREET & LORE STREET KEA & 195 & $1-1 \mathrm{NJ}$ & YES & NO & NO & $1 C$ & 41219 \\
\hline$(0-01-0)$ & LQRE STLEET & LONE STREET FIEALLTY & & $1-1 N G$ & YES & NO & $\mathrm{NO}$ & & 56232 \\
\hline$(2-01-0) 4$ & LDHE 5TREET & LE'IE STAEEET REALTY & & $I- \pm N 0$ & YES & No & NO & LIC & 70685 \\
\hline $2-01-61$ & FLAIR STREET & SOULE EUAHBD & NONE & $I-1 * 0$ & Nio 1 & NO & NO & LELIC & 43560 \\
\hline $8-01-62$ & PLATA STFEE IOFF; & ELLIS JGSEFHIRE & $M E$ & $1-1 N[1$ & NO & NO & $\mathrm{Nü}$ & If & 348480 \\
\hline$E-01-03$ & FLAIN 5TKEET IKEAEI & VEGROCHI REALTY IFGST & iURE & $\mathrm{I}-1 \mathrm{NC}$ & NE & NO & $\mathrm{HO}$ & IF & 435000 \\
\hline & MT, SIIRGE 5T. 10FF) & ANASTASI EROTHERE COFE. & NONE & $1-1 \mathrm{NO}$ & NO & NO & NO & & 1920 \\
\hline $19-0 !-02$ & FIAIN STFEET IFEAF: & EAY STATE GRS ES. & MUNE & & NO & No & No & NG DIH & 135036 \\
\hline $9-01-03$ & WLI PLAlN & COLE EQHAFE & IONE & $1-1 N 0$ & NO & NO & No & & 126324 \\
\hline $9-[1 !-64$ & FLAIN ETEET IREAES & CONHEF FGANE & INE & {$\left[\begin{array}{ll}-1 & k 5\end{array}\right.$} & HO & $\mathrm{No}$ & NE & & \\
\hline$-6 z^{2}$ & PLAIN STSEET IREAFI & VETTESEHI REAL & RONE & & $\mathrm{NG}$ & Nô & No & & 3746 \\
\hline $7-0:-0 t$ & FLÄ STREET & VERROCHI REALTY TKUET & NINEE & $I-1 N 0$ & No & FOS & NO & ic & 217800 \\
\hline-07 & FIAIN STREET (DFF) & VEFFUEAI REALTY TRUST & QNE & $I-1 N I$ & NO & NU & Nö & If: & 165520 \\
\hline-60 & PLA:A STFEET & EAEF MILISEI & NENE & $I-1 \mathrm{Wu}$ & NJ & P0S & $\mathrm{Ni}$ & PUELIC & \\
\hline $9-6:-65$ & PLAEN STAEET IREARI & TRUSTEES GF BUSTON UKIVERSITY & NOHE & $1-1 N 0$ & $\mathrm{NO}$ & NO & $\mathrm{NO}$ & If & $455 \%$ \\
\hline $7-6 !-16$ & FLARA STREET IFEAEI & VEFRUTH REALT! TEUST & NLERE & $1-1 \mathrm{k0}$ & $\mathrm{NO}$ & NO & $\mathrm{NG}$ & {$[D I K$} & 150 \\
\hline-11 & ERTEFFE:CE DRIUE & VERFELHI REATLY TRUST & 10:E & & Ni & NO & $N \Gamma_{j}$ & G DIR & \\
\hline $0-51-40$ & FLGIK STFEET & CQNAOF THEDOOR & 25 & $1-1 N$ & YES & NO & Nó & FUELIC & 33700 \\
\hline $0-02-10$ & PIAIN STREET IREAF! & VERFOEHI REALTH TRLST & 375 & $1-1 \mathrm{NL}$ & YES & No & NE & t. i. & 570636 \\
\hline & FHIG STFEET & VEFRELU: REALTY TRLLST & 11400 & & YES & No & NO & JELIC & \\
\hline$(6-03-1)$ & FLAIN STREET & VEFROLHI RERLLTY TFUST & 189 & $I-1 \mathrm{NJ}$ & YES & No & NO & FLIELIC & 3862 \\
\hline $6-01-12$ & [ZE MT.SK]GOE (REGA) & L.L.C. REALTY TFIUST & NGLE & $1-1 \mathrm{Nu}$ & No & Ni] & $\mathrm{NJ}$ & NO DIK & 522720 \\
\hline$(9-6)-02$ & FLAIH STFEET RREAE & VEREOCHI REALTY TKUST & NUNE & & $\mathrm{NO}$ & NO & $\mathrm{ND}$ & NO DIF & \\
\hline $15-011-10 ?$ & FLAIN STREET IOFF, & SOULE EDhAFT \& EESSIE & NONE & $I-1 \mathrm{NO}$ & $N[$ & Fos & NO & NO UIK & 217800 \\
\hline $507-01-05$ & SURHYYSIDE FÄEL & EAST SHŪFING CENTEK & NO & $1-1 N 0$ & 10 & NO & Ni & NO DIR & 7953 \\
\hline$E(5-01-019$ & FLAUI STREET (UFF) & SCANKE: BOILEF WJFKES & NDNE & $I-1 N[$ & $\mathrm{NO}$ & NO & No & No DIf & 8400 \\
\hline$(505-1) 1-10$ & PLAIN STEEET (OFF) & CDIE EDHARE F. & HOYE & $I-1 N \bar{I}$ & $\mathrm{~N}[\mathrm{I}$ & $\mathrm{NO}$ & No & NU DIK & 174240 \\
\hline $519-01-12$ & FLAIN STREET IREAEI & EAST SHLFFIHE CENTEF REALTY & NONE & $1-1$ Ni & NO & POS & $\mathrm{Ni}$ & NJ UIK & 2976 \\
\hline E: $:-01-04$ & PLAIR STFEET & CULEN FRAMUIE & 137 & $1-1 \mathrm{ND}$ & YES & No & NII & FUBLIE & 17130 \\
\hline$E(1)-61-65$ & PLAIN STEEET & EAST SHOFFING CENTER FEALTY & 845 & {$[-1 \times 5$} & YES & No & NI & PJELIC & \\
\hline$E: 0-0:-12$ & FLFIV STREET & EHY STHTE QHE CIS. & 640 & $1-1 \mathrm{~N}[$ & YES & VES & 10 & PUELIC & \\
\hline
\end{tabular}

TOTALS:

AKEP SF $9,875,126.00$

Frinted 30 of the 1950 recorde. 


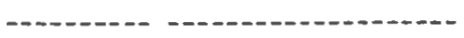

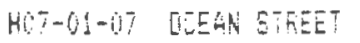

\section{LUEIEF ALEETT}

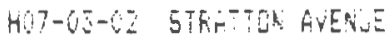

HO)-64-14 HEEE-EF STREET

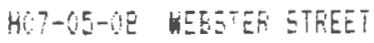

HO ?-05-16 WEEETEK STHEET

HGT-0E-17 HEEETES STREE

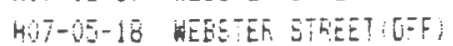

HOE-OS-OI UEEF ETHEET

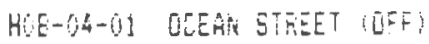

HOE-6A-OS DCEFL STSEET

HUE-04-OA UCEAR STHEET (F̈EÁS)

HE-?4-11 GLEAS STREET

H(E-04-12 QEEAH STHEET

HUE-04-14 OREA STFEET

JU-

THFE:

AFEF SF 950.048 .00

Frattes : E of the jgEs recorte.

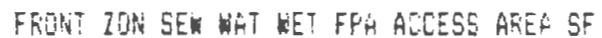

75 E-1 NG YES NO HO FUBELIC 15700

50 E-1 NO YES NO NO PUELIC 4750

139 B-I NO YES POS NO PUELIC 2E.EOJ

NONE B-! POS POS NI NO NO DIF 24215

NUNE F-I NU HO NO TES NÜ DIR 403801

45. B-1 NE YES NG NE PUELIC 46600

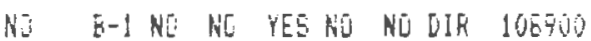

71 B-I NU YES VEE YES FUBLIC 2:700

HOHE E-I NJ NJ YES YES HL IIK 21850

$20 \quad B-1$ NO FOS YES YES FUB IIC 76230

NGNE B-I NO NG YES YES NO DIK 78496

NULE E-I NE NO YES YES NO DIF 11028

110 B-1 NG YES YES YES FUELIC 47916

28 E-I NO FOS YES YES NI DIR 20800

$3 . Z$ E-1 NO YES NU NJ FUELIC 19300 


\begin{tabular}{|c|c|c|c|c|c|c|c|c|c|}
\hline 5. MÁF-LET & LOCA:IUl: & OHARET QT REL & FEORT & 70N SEH & hî́ & MET & FF'i & ACCESS & AFEA SF \\
\hline 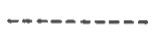 & - & 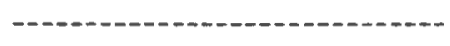 & 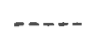 & ---- & --- & & --- & & \\
\hline $10-0]-02$ & SCHUELL STREET & TFIARELE CENTER & 426 & $B-2 N E$ & YES & Ni & $N E$ & FUBLIC & 96967 \\
\hline $10-05-03$ & FLAIA STFEET & HUDSOM STEEE' REMLTY TFLST & 165 & E-2 NO & YES & No & NU & UELIC & 50486 \\
\hline$(0-53-04$ & FLLAIN STEEET & BAYGANE NOEFDL: & 58 & $\mathrm{~B}-2 \mathrm{NO}$ & YES & NO & NO & & 8122 \\
\hline $0-05-614$ & CHUOL STKEE: & PLAINYILLE CEMETAFEY ASS. & & $5-2 \mathrm{NO}$ & YES & No & NO & & 9696 \\
\hline $6-0 !-r 1$ & SCHERL STREET & LDELEE JAHES & 160 & $\mathrm{~B}-2 \mathrm{NQ}$ & YES & ND & No & IBLIC & 6268 \\
\hline $6-0 !-65$ & AIR STFEET & CA:CAGH] THOKAE & 137 & $8-2 N O$ & YES & NO & No & UBLIC & 6626 \\
\hline & FLAIN STREET IREARI. & FUXFIDSE AES. & MKE & $\mathrm{B}-2 \mathrm{HC}$ & $\mathrm{NCi}$ & NO & No & & \\
\hline $1-i=23$ & SHEFMER'S HFY (OFF) & LEELÁRE FOEEST & JNE & $E-i$ & $N \sqrt{I}$ & No & No & & $65: 40$ \\
\hline $1-0_{-}^{2}-60 t$ & FLAIN STEEET IOFF; & LQEUE JAMES & Nüke & $\mathrm{E}-2 \mathrm{NU}$ & No & NO & NI & $0 \mathrm{DIF}$ & 10ISEE \\
\hline-6 & FLAIN STREET & FALCOA REALTY THLST & 50 & $E-2 N$ & YES & NO & $N i$ & BiIC & 25700 \\
\hline-04 & PLAIY STREET & FALCOA REALLTY TFUSET & 96 & $E-2$ & YES & $\mathrm{NO}$ & $\mathrm{HO}$ & & 27100 \\
\hline 09 & FLAIN STFEET & BUEETTSW LHESTEF & 100 & $\mathrm{E}-2$ & YES & NO & NO & & \\
\hline $2-10$ & PLAIK STEEET & DEVLARE FERLTY TFUET & $20 E$ & $\mathrm{E}-2 \mathrm{NJ}$ & YES & 10 & NO & UELIC & 169013 \\
\hline-29 & QSEAK STKEET & 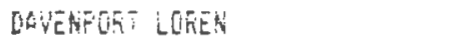 & 175 & $\mathrm{E}-\mathrm{NO}$ & Ni & No & $\mathrm{HO}$ & IC & 435600 \\
\hline-33 & DEEAN STEEET (GFF) & SEHATT CHARES & NOME & $\mathrm{E}-2 \mathrm{~N}$ & $\mathrm{NE}$ & $\mathrm{H}[\mathrm{C}$ & HO & NG DIR & \\
\hline $96-63-12$ & PLAIR STREET & DIVLE FG'L HELEN & MONE & $B-2 N \square$ & No & YES & Ho & ND DIF & 19800 \\
\hline $66-6 \overline{1}-05$ & OCEAK STEEET & 3Ot? DAt'S & 160 & $E-\overline{2} \mathrm{Nu}$ & YES & YES & YES & PLELIC & $56 t 2 E$ \\
\hline-20 & QCEHA STREET & FETROCELLI GLGKIA & 30 & $E-\overline{2}$ & YES & No & $\mathrm{Noj}$ & FUELIC & 3948 \\
\hline $08-62-0 !$ & DCEAH ETHEET & 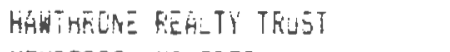 & 254 & $E-2 \mathrm{NL}$ & YES & YES & YES & PUE:IC & 130650 \\
\hline $0 E-0=-0 ?$ & OCEAK STEEE: & HENDEREDH WLFEL & 100 & $B-2 N G$ & YES & NO & $\mathrm{NO}$ & FUELIC & 11669 \\
\hline $05-09-10$ & OLEÄL STFEET & HENLERSGU MATALIE & 100 & $\mathrm{E}-2 \mathrm{NO}$ & YES & $\mathrm{NO}$ & NI & PUB_LC & 11669 \\
\hline $10 E-10-64$ & GUEAT STEEET & WIMSLLII VILLAGE II IKL. 514 & 514 & $\mathrm{E}-2 \mathrm{k}$ & YES & No & NL & FUE & 130630 \\
\hline$(U E-0)-0 E$ & QIEAAR STEEE? & 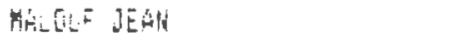 & $160+C$ & $\mathrm{E}-\overline{2} \mathrm{NO}$ & YES & $\mathrm{Not}$ & Nõ & FUE & 10900 \\
\hline $8-02-16$ & HEHELANE DETUE & DITURAES RICHULAE Á & $21 !$ & $E-2 N O$ & YES & NG & YES & FKIVAT & 20250 \\
\hline $6-05-09$ & HOSE ARE DFIVE & DITUMESE MLCHULAS A & 120 & $\mathrm{~B}-2 \mathrm{NO}$ & YES & $N 5$ & YES & & 27900 \\
\hline$(98-05-1.4$ & OLEAS STREET & COFELARKR KENHETH & $201+5$ & $B-2 \times 0$ & YES & Nü & YES & PUELIC. & 20600 \\
\hline $5-05-1 \varepsilon$ & DCEAN STREET & BEFARE AFING̈ & $24 E$ & $\mathrm{E}-2 \mathrm{NI}$ & YES & YES & YES & PLIBLIC & 879912 \\
\hline & CLEAN STREET & QIEEAR STREET REALTY TKUST & $306+5$ & $\mathrm{~B}-2 \mathrm{NJ}$ & YES & No & 100 & FUELIC & 43975 \\
\hline $67-02-65$ & COEAAP STEEET & RUEINSUK DOFIS & $280+i$ & $\mathrm{~B}-2 \mathrm{Ni}$ & YES & NO & NO & PUELIT & 15509 \\
\hline
\end{tabular}

TUTHE:

AREA SF 3,328,421,60

Printed 29 of the 1955 rezoros. 


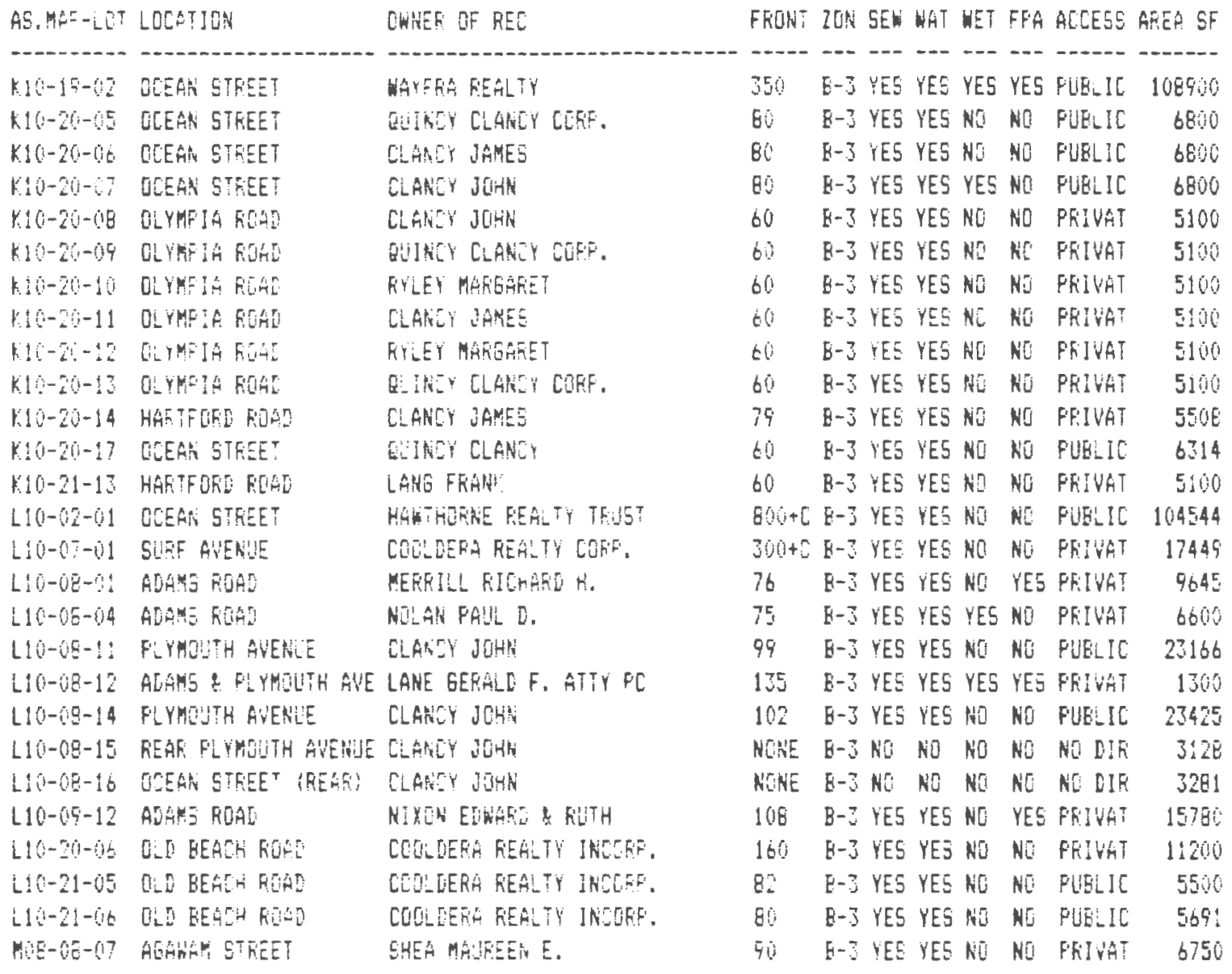

THY:E:

AEEA SF 414.281 .60

Frinted 27 of thie 1955 rearde. 


\begin{tabular}{|c|c|c|c|c|c|c|c|}
\hline AE. MAC-LOT & LE: In: & OH:HEF IF REL & FEOLNT & ZEN $5 E \mathrm{~W}$ & WFT HET & FFA ACCESS & AREA SF \\
\hline -............. & ......... & 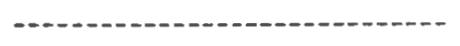 & $-\cdots$ & $\ldots \ldots$ & ---- & ------- & - \\
\hline $115-24-23$ & FEFFI STFEET & HEN BAHTEE & 40 & $\mathrm{~B}-4 \mathrm{NO}$ & YES $\mathrm{N}_{5}$ & YES PUELIC & 1500 \\
\hline $115-24-24$ & FEAFY STEEET & YEE YENRTH M.F. & $180-5$ & $\mathrm{E}-4 \mathrm{NE}$ & YES NL & YES FUBLIC & 5900 \\
\hline $116-12-3 t$ & SEA STREET & CAFOZIOLI EEVERLY & 60 & $\mathrm{~B}-4 \mathrm{NC}$ & YES NE & NE PRIVAT & $756 ?$ \\
\hline$M=-65-7$ & CAFESWELI STEET & FLANIEFS ThLHAS & 50 & $B-4$ YES & YES YEF & YES PLELIC & 12000 \\
\hline $47-03-614$ & QEEAN STFEET & PEFTARLT FETEF & 30 & B-4 YES & YES YES & YES FUELIC & 4140 \\
\hline$y=-0.01$ & DEEARI STFEET & VERIE II INE. & 50 & E-4 YES & YES YES & YES FUBLIC & 6750 \\
\hline $40-65-11$ & OEEPA ETEEE & WENSS II IHE. & 50 & $E-4$ YEE & YES YES & VES FLELIC & 6075 \\
\hline $5-14-2$ & G ETREET & LEEU EUGENE \& RERTTH & 50 & B-4 YES & YES YES & YES FEIVAT & 3506 \\
\hline $17-3-35$ & ELELA ETFEET & 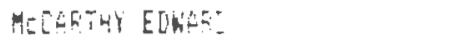 & 40 & E-4 IES & YES NI & IEE FUE_IC & 3000 \\
\hline $107-6-09$ & IS.ANE STREET & ELALKRAR MAFI & 280 & E-4 YES & YES YES & YES FiELIC & 32525 \\
\hline $\mathrm{N} T-1)-20$ & OEEAN STREET & JENKINE F:TH & 70 & $B-4$ YES & YES NE & YES PULLIL & 8712 \\
\hline$N O-32-2 i$ & OCEAR STEEE: & JEMITAS FiTA & 70 & E-4 YES & YES NO & YES FUSUIC & 9180 \\
\hline$N 17-02-2 i$ & QUESN STFEET & IENIINSC， HADE & 90 & B-4 YES & YES YES & YES FULLIC & 23558 \\
\hline Na?-02-26 & OLEPA ETFEET IREAF; & NETH ATLANTIC DEVELT. CTFE. & 30 & E-4 YEJ & YES YES & YES FUSLIC & 500 \\
\hline $40-07-2 t$ & QCEAR STEEET IOFF) & NETH AGATIL DEVE DFFENT COIE & 36 & E-4 YES & YES IEE & YES PUELTE & 5000 \\
\hline 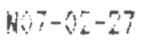 & IEZANS ETFEET IUFF) & HAFEER CHAFILE & NLKE & $\mathrm{B}-4 \mathrm{NG}$ & NU YES & YES NE DIF & 2700 \\
\hline
\end{tabular}

TOTALS:

AEE ELE

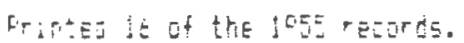




\begin{tabular}{|c|c|c|c|c|c|c|c|c|c|}
\hline E.PAF-LST & LUTETIJi & GHEEF OF REC & FRUENT & $20 \mathrm{~N}$ & SEH & WAT WET & FF'H & ACCES5 & GREA SF \\
\hline 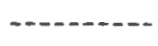 & & - & & & & $\cdots$ & & & \\
\hline & TEEET & DEWITT DLLEAN \& DECAETRE INC. & & Ofú & & YES NŨ & & & \\
\hline & QFEST ETREET & JUNIUF RUEEET A. \& DUECTHY A. & 125 & OF & & YES & & & \\
\hline & -E CO_CH: LAYE & RIHADES GETES & & & & YES YEE & & & \\
\hline$-6-0.09$ & CC:AT ETEEE? & JQE CUEFOAETIUA & 190 & of & Ho & Hij YEE & YES & FEIVAT & \\
\hline
\end{tabular}

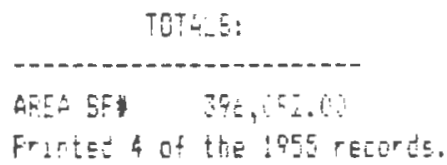




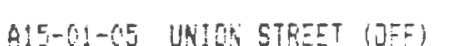

A17-01-06 COFA HILL LANE

E11-01-01 MAFIZANO STKEET

BI:-O!-O2 MAFHLAHE STEEET

E:1-02-01 MEFYLAND STFEET

E!1-CZ-IZ MAFYLART STFEET

E:1-OL-OT MAETLANE STSEET

BL2-0!-63 MAFILFNI STREET IOFF

EIZ-O1-13 MAFILANL 5TFEET

BIZ-0Z-06 MATEYLARE STFEET

BIS-0:-13 UNION STFEET IOFF;

BLS-OL-14 UAION STREE IOFF)

E13-02-03 UNIOK STFEE

E:4-01-10 URICN STFEET

BI4-OL-0I UHIOK EThEET

EI4-OA-OE UKIER STREET

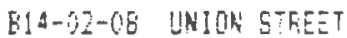

EL5-OL-02 UNIGH STEEET

B!S-O1-16 URIOS STKEET (GFF)

E:

BIC-UZ-12 OAE STREET

B!S-OS-OE UNOUN STREE

ELE-0:-22 UNIQN STFEET

BIE-0i-1 UNE GTFEE?

Bib-0i-62 UMIJW STKEE? (OFF)

EE-OT-SE UA:JK STREE?

Bi7-01-014 CUFN HILL LANE

E:T-52-01 UNIOH STFEET

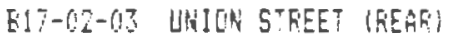

B!7-0?-CH URION SIFEET

817-040-63 COF' HILL LA'HE

B1E-OI-OE UN!SW STREET (OFF)

EIE-01-06 UNIOH STEEET

BI8-0i-10 URION STREE:

BIE-01-11 UR:ON STAEET

BIE-OI-13 URION STREET

E18-01-14 UNION STEEET

BIE-61-15 URIEN STREE?

FIE-02-0) UNIOH STREET

818-03-08 HUATEF DFIVE

EIF-07-OL HINTEE ORIVE IFEATS

[:1-01-01 UNBOH STREET

CI1-01-11 URICN STFEET (REATh)

C11-01-12 UNIOK STREET (REÁF)

C11-OI-UE UNIOA STFEET IKEAE:

[11-0Z-27 FLAIN STFEET IKEAFI

[12-0]-05 URION STFEET (KEAR)

[!2-01-06 BF16E5 FAETLEE WET

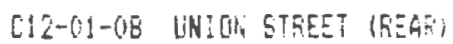

[II-U1-TIE FIALE STFEET

C15-0L-09 PINE STKEET

[14-01-02 LWIOH STREET IOFF.

CA4-01-A3 FIHE STRES (OFF)
HEAF HAFGGEAVES

GITER EEJEDE

TEAESCHI FEATT COFE.

TEDESCHI REALTY CORF.

TEDESSH TREATY COEF,

TEDESTHI REALTY COFF.

SEITS HENTIUUES

VANELEEN AKSTKIEE

FLLFEESE WATHE

TAYLOF HAROLD J.

MESEER RORALD

FEIDLIHY RAD:?

NASH ROEETT

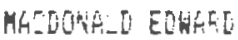

FERCOCU SÁ:V先T LIÁE

MOLIRLE LAREENE

MLUKEE LAHFERLE

Fi'TAEY IN.

OAG MAK OTISE

ROUERICK RUGE MAS!E

STEFHFENE GEFTLDINE

YAGUES RERT:

OU: TUN GEUTGE

REETi CHEFLES

CAJUOH RIEERT

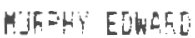

COILIINE SAMUJEL

PFGT EEATRICE

QSEOTHE RICHARD

SFERIUHALE KLBERT

DEGAGTEL HLFRED I

SESEERICL FICHAAT:

DAVIS ROKA:D

SDUTHATCK RENKETH

KOLODES PAII

DUULEY ANTEELINE

DUO_E: AHJELINE

THE LIOHE MAFK. THUST

THE LIONS MARE TFUES

HAÁt. REYMUKE

HAAT: DOLOGES J

TEDESCHI REGLTY CORP.

LAUREFYHIL GEFA:D

GATES ALGN

DAR:INE RUGUHEY

MÁGSHFIELD HUE \& EUN CLUE

CALLALFH LUCY

MATSHEIELD ROD \& EUAN

HILDUF EERET

HULDER JKRES \& REGGHET

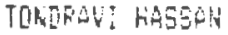

LEO REA TY TRLST

f. H. PEFTS INE.
NOHE R-1 NII YES YES VES NO DIf 1332936

207 R-1 NO YES NO NO PUELIC 257064

15 R-1 NO YES YES NO PUBLIE 196020

336 F-1 NO YES NG NO PUBLIC 43560

$355+C R-1$ NO YES YES NO PUBLIC 43566

324 R-I NO YES YES NO PUELIC 43560

55 K-1 NG YES NU NO FUELIL 60984

NOKE R-1 NO WO YES YES NO DIR 479160

50 F-1 NO YES NO NU FUELIC 43560

55 R-1 NE YES NO NO PUBLIC 75358

NONE R-1 NO YES POS NO ND DIF 297079

NGNE F-I N] NO POS NO NO DIE 435600

42 F-1 NO YES NO NO FUELIC 29600

210 F-1 NE YES NO YES PUELIC $1023 E t$

550 F-1 NG VES NO NG FUELIC 217800

240 R-1 NI YES NO FUELIC 1611720

590 R-1 RO YES YES NE PUBLIC 34E48:

2 RE R-1 NG YES FOS NE PUBLIC 3349704

NOUE Fi-1 NO WJ POS NO NO OIR B27640

150 Q -1 NO YES NO NO PUBLIC 43560

6UD Fi-1 NO YES VES NE FULELIC $311 E ?$

$12 i$ R-INO YES NO NO PUELIC 43562

12. $F-1$ NJ YES YES YES FUELIC BE

257 Fi-1 HO YES NU NO FLELIC 43500

1EI F-1 NG YES NU NÜ N/A 35060

202 R-1 NL YES NO NO FUBLIC 56228

$26:$ FI- NO YES NO NO FUELIC 76230

226 R-1 NUT YES YES NG FUELIC 69696

WU FI-1 NO NE NO NE NO DIK 19700

351 R-I KO YES WO NE FUELIC 39204 \%

40 Fi-1 NG YES NI NO PUBLIC 242193

125 R-1 NU YES YES NI N/A 151153

125 R-1 NU YES YES HE FUELIC 434293

125 Fi- 1 NO YES YES NO PUELIC 442570

125 R-1 NO YES YES YES FUELIC $467395^{\circ}$

$260 \quad \hbar-1$ NO YES YES NO PU3LIC 324322

260 R-1 NO YES YES NO FLULIC 423835

260 R-1 NQ YES YES NO FUELIC 152460

150 Fi-L NG YES YES NI FUELIC 78408

NONE R-I ND ND YES YES NO DIF 43560

NOHE R-I NII NO YES YES NO DIR 47936

235 FI- NO YES YES HO PLELIC 163786

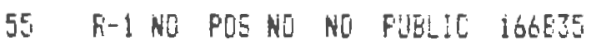

NG R-1 NL NO POS NO NUNE 56628

NO R-J NO ND NO NU NO DIF 148975

NORE R-1 NO NO FOE NO NO DIR 97574

NO R-1 NU NO PCS NO NO DIR 40293j

NINE R-! NO NO YES WO NT DIK 348430

NO Fi-1 NO NO NO NO NONE 140757

$125 \mathrm{~K}-1 \mathrm{NJ}$ FOS NO NU PUELIC 45302

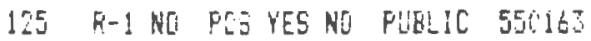

NONE H-1 NO NC FOS NO HUI DIF 304920

MUKE FI-1 NE FOS NO NE NE DIE 261360 
C14-Di-OI4 FINE STREET (OFF)

[14-O1-15 FINE STREET IDFF?

C14-01-10 FIKE STFEET

[14-01-17 PINE STFEET (GFF)

[14-01-22 PIHE STKEET

[I4-0!-23 PINE 5TFEET (REASE)

[14-012-01 FIKE ETREET (UFF)

C14-02-02 FHKE STHEE?

[14-02-0] FIAE ETREET

[:4-02-05 FINE STEEET

C!4-0)-0t FINE STREET

CIS-OI-JS UNION STKEET (UFF)

CIE-GI-G UNTON STPEET IOFF;

[:15-01-0E UHIGL STREET IFEAL;

CIS-O1-5E UNIOA STREET LGF:)

C16-02-04 OAK STFEET

[16-02-0IS OAL ETREET

[16-0 $2-1]$ CAL STREET

[17-01-01 HIBHLAND STREET

C17-0!-0? HIGLLAND STREET

[IE-01-0: SFRINE STREET

[16-0:-0? SFR]HE 5TFEET

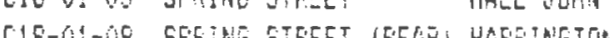

C19-02-01 HIVEFSIDE CIF (KEAR! HALL JOHW

C26-01-011 RIVEFIJIDE CJRCLE

Di6-01-16 TILEEN FGA

DI1-OI-14 SCHOOL STREET

DII-02-09 TILDEN FUAD

[II-62-42 SEHOUL STKEE?

DII-02-5TR SIHOOL 5TKEET

D!1-02-574 SCHODL STEEET

D:2-01-02 SCHOOL STREET (DFF)

D1:-01:-10] FCREST STFEET

D:2-01-11 SCHIUL STREET LOFF)

012-O1-12 SCHOOL STREET (OFF)

D:3-01-64 ANOKENS AVENUE

013-01-12 ANDEEUE AUENLE (OFF) A H FERRY INE.

D13-01-13 ANSGEUS AVENUE (OFF) ROEUUIT RER:TY TRULST

DIJ-OI-14 FOFEST STREET (FEAR) LITTLEFIELE ERIAN E

D3-0!-15 FOREST STAEET (KEARI MARG FFIELE ROD \& GUN CLUE INC

D15-01-16 FGREST STKEET (OFE) A. H. FERFY INE.

D1T-0I-07 FOKSET STRE:T

D14-02-0I FIHE STREET

D14-12-08 FINE STREET

Q14-02-09 EAFLDOF: CIFCLE

II $14-02-10$ EARLDOF CIRCLE

D14-03-09 RILKDN LAHE

D:4-0J-10 EARLDEF CIRCLE

D14-03-11 EARLDOR: CIRCLE

D14-0I-12 EAFiLOOH CIN̈CLE

[14-0.T-13 EARLIUE CIFCLE

D14-014-02 FOREST STREET
HALE JUSEFH D

LINE REPLTY TRLST

THS MILE LINE REALTY TWUIT

PLTTEY INC.

FDERES REALTY THLST

THE DELAHEY DEVELOFMENT COFE.

JURIOF RTEEFT \& DUROTHY

PERCOTU SALUATISE

EEROCO SALVVTGGE

DOWHS RTEEEFT

LEFES MAEY VINLENT

MEH ENGLANI FORESTFY FULLNDATIU 400

LS TKUST

RARSHFIELD RCO \& GUN

GRAELE WHLLIAM

MARGHFIELI ROD GUN CLUE

BTH REALLTY TEUST

B.T.H. REALTH TFLET

MARSHFIELD ROL ELIN

A.W. PEERT' INE.

A.N. FEEFYY INC.

MáFGHF IELD ROU \& GINN CLLUE

EIKAFC R. READT

BAILEY F. LEE

BAILEY F. LEE

BAILEY F. LEE

BAILEY T.LEE

BAILEY F. LEE

BALLEY F.LEE

BAILY F. LEE

BEILEY F. LEE

BAILEY F. LEE

FAGE ETHEL MGEY

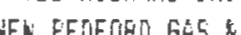

NONE Fi-1 NE YES NO NO NO DIK 392040

NGNE F-1 NO YES NO NÜ NÚ UIR 23304

125 R-1 NO FOS NO NO PUELTC 45646

NUNAE Fi-1 NO YES NO NO NO DIK 11400

544 R-1 ND YES NO NO PUELIC 63713

NONE Ri-1 NO POS NO NO NO DIR 29551

NONE R-1 NU YES YES ND HO DIF 4443

150 R-1 NO YES YES NO PUBLLE 69696

IET R-1 NO YES YES ND PUALIC 69696

125 R-1 ND YES YES NO PUE:IC 63162

125 K-1 NE POS YES NO FUBLIC B62:1

NONE R-1 WO NE NO NO NE DIR 261360

NUKE K-1 WD NO NO NO WE DIF 1707552

NO Fi-1 NO NO FOS NO NCHE 457380

NOHE F-1 ND ND NL NI NU DIK 261360

150 R-1 NO YES FOS HJ FLOLLL 104979

760 K-1 NO YES FES NS PUELIC 927828

242 F-1 NE YES YES NG PUELIC 1599523

465 R-1 WO YES NO NG PUELIC 218671

$400+$ R-1 NO YES YES YES PLIBLIC 958320

200 R-1 NO YES YES YES PUESIC 174240

200 R-I NO YES YES YES FLELIC 174740

NOHE $R-1$ NO NO YES YES WU UIE 90604

NONE F-1 NG ND YES YES N/A 4355000

NONE R-1 NE ND YES YES NO DIF 130680

$210 \quad \mathrm{~K}-1$ ND YES YES YES FLLELIC 27600

60 K-1 NJ FÚS NO NO PUELIS 103237

418 Fi-1 NO YES YES NO PUELIC 988812

57 Fi-1 NO YES NO NO FUELIC 47916

278 R-1 ND YES NG NO FUELIC 52272

$218 \mathrm{~K}-1$ NO YES NO NO FUELIC $474 i 2$

NO R-1 NU YES NU NO PUELIC $4742 \%$

WONE R-I NG NO YES NO ND DIR 12100

$1000+$ F-1 NE YES NO NO FUELIC 1176120

NONE R-1 NO NG YES NO NO DIR 1393920

NONE R-1 NO NO YES NO NO DIR 250470

141 R-1 NO YES YES NE PUBLIC 116305

NONE R-1 NO NO PGS NO NO DIR 1481040

NONE R-1 NO WG POS NE WO DIR 696960)

NONE Fi-1 NO NU YES NO NO DIR $34 \overline{8} 480$

NOHE R-I NO NO YES NI NG DIK 348480

NONE R-I NI NO YES NU NO DIR 306404

NONE R-I NO NE RU NO NU DIF 22700

150 F-1 NO YES NO MO PUBE!IC 47916

15! Fi-1 NO YES AB NO PUELIC 4356Ci

$229+C$ F-1 NII YES NO NO FRIVHT 43560

194 Fi-1 HO YEE HJ NI FRIVAT 43560

165 Fi-1 NO FOS NO NU PRIVAT 4356?

165 R-1 NC YES YES NO PRIVAT 43560

165 R-1 NG YES YES NO PATVAT $\$ 3560$

150 R-1 NO YES YES NO PEIVAT 43560

$220+[$ R-1 NO YES VES NC PFIVAT 43E60

157 F.-1 NO YES YES NO FUE:IC 43560 


\begin{tabular}{|c|c|}
\hline $014-04-63$ & FOREET STREET \\
\hline$[14-65-144$ & GWDFELE AUENUE \\
\hline$D 1 E_{1}-01-0 E$ & VALLEY FHTH \\
\hline $015-02-61$ & WEILEY FATH \\
\hline D: $5-02-05$ & FOFEST STREET \\
\hline $0: 5-02-06$ & FUFEST STFEET \\
\hline $0+5-02-09$ & ANDEEHS AVENLE \\
\hline $016-01-10$ & VÁLLEY FGTH \\
\hline$[16-(1 !-1)$ & VÁLLEY PATS \\
\hline $016-01-12$ & VALLET FHATH \\
\hline $016-02-02$ & VALLEY F'A'H \\
\hline $01 t-32-15$ & WGLLEY FATH \\
\hline $016-02-19$ & VALLEY FATH \\
\hline $16-62-73$ & ANJFELS AYERJE IOFF; \\
\hline$t-02-3 E$ & AKIFEWE AVENUE \\
\hline
\end{tabular}

$01 t-0 E-3 C$ ANLFEWE AVERIJE

FAGE ETHEL MAFY

SULLLIVAR MEFUE T

NDFANUA HOLDINGS INE.

MUTEE FSABEL

FRANK. FEFNANALES

BFITT HEFKAF: H. \& ANGELINA

VEIGA MAALELL

JJHES LAWFENLE

JCKES LARRENGE

FETERSOH FICHAGD

GUARINI VICTORIÁ

JASIN REGLTY TEUST

JHSOR REALTY TRUST

D17-01-02 HIGHLANI STFEET

DI7-01-02 HIGHLASE STHEET

DIT-0!-04 SFINE STEEET (DFF)

0:7-6Z-0S HIEHLANL STREET

DIE-O1-OL STKINE STREET

DIE-OZZ-OI MAIN STREET IOFF?

DIE-UZ-07 SFRINE STREET

[19-01-06 COUE CREE LAHE

D15-04-02 ELMIND RIJAJ

[15-04-14 EDUSW KSGL

D19-04-0? SFRING STREET

DIST-04-6E SFRINE STKEET

D!Q-45-6Z MEIN STEEET

D!9-05-09 SFFINE STFEET

$020-01-0 \bar{T}$ EDHLRE ROEL

D20-01-11 SFRING STREET (GFF)

D20-01-13 CARLLYN CBECLE

020-01-14 CARILYN CINCLEIKEAR'

Q20-01-15 CARULLN CIRCLE

D20-01-16 CAFSLYK CIFCLE

D20-01-17 CAFELYN CIRCLE

D20-01-23 LITILE'S LANE

D20-01-24 LITTLE'S LAKE

D20-01-2E CAFOLYN CIKCLE

[20-01-26 CARCLYH CIEC:E

020-0I-27 CAFDALUL CIFLLE

D20-01-29 CAKSILN IIECLE

DEO-0!-34 EDMHL KEAL

[20-02-OS CAROIS WIRC.E

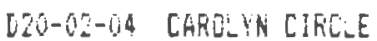

020-02-05 CARJUY CIRTEE

$020-02-06$ CAROLYH CIFELE

D2-02-07 CARELPH CIR⿴LE

D20-02-0E CAKCLPB CIFCLE

D2G-0Z-09 CASOZYN CTRLEE

D20-02-10 CARDL HE CIRZLE

DZT-OZ-11 CARLLW CIRCLE
CALLFHAR: LUCY H

STORT JAMES 6. \& CEALE?A M.

JAMES G. STOAT!

ANDESEOV JEARHETTE

FREUTY EAREAFA $D$.

A. W. FEFF' INE.

MAKAIRS JUH I.

ARTEFSEN JEGNETTE

TEET JISEFHS

HÁLE ALICE

GÜROM MCHIEL

TRIESLE JUEEFH L.

WOULFA'L FEEET

MáE5. AUJUESIN SDCIETY

MaSS. ALDESTS SDEIETY

COIFEF JGIH

CUMEINES AENED

TAHELEhOJI SLUE TFUST

TAYLOF FAMIL / REA TIES

MSLSE GROSSYHA GFIALDCH

HS.SK GROSSMAII GERNECH

M.5./S.K. GFIJSMAK

MSESK GRUSSMAEN GRÁNICH

H.S.15.K. GRUSSMAN

THUR5TUG JOHN

THISSTOK JOHN

n.5.15.k. 6Ressmint

H.5.15.K. GROSSMLN

M.5./5.K. GFGESHăk

M.E./S.K. ERCSOHAN

CIHLUND OLIVEK

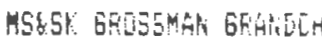

MGLSK EROSSTAP GR'ALULH

M.S./S.k. GREGEMAN

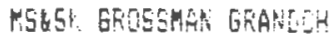

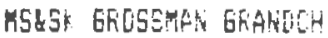

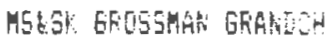

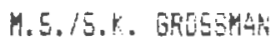

A.5.15.1. GRES5ntit

M. 5. /5.t. 65.5Smits
169 Fi-1 NO YES YES HO FUELIC 43560

120 F-1 NO YES NE NO FUBLIC 34302

NUNE R-I NO NI FOS NO NONE 4922280

GOU FI-1 NL YES NO NO PUBLIC 204732

100 F-1 HO YES NU NO PUSLIC 22563

108 R-1 NO YES NE NO PUELIC 108900

90 R-1 NU YES NJ NÚ FUELIC 8084

$155 \mathrm{~K}-1$ NU YES NII NO PUELIC 52272

$174 \quad \bar{R}-1$ NG YES NE NO FUELIC 56628

85? R-1 NO YES NO NO PUBLIC E2764

125 Fi-1 NO YES NO NO PUELIC 63597

50 R-1 NO YES NO NI PUELIC 65340

50 F-1 NG YES ND NO FUELIC 56628

MONE F-1 HO YES HI HO NO DIR 304520

Z00 +E R-1 NE NC NU NU FRIVATT 36124

120 R-1 NO FUE HO NO FRIVAT 36200

40 R-1 NO YES NG NE PUELIC 43560

400 R-1 NO YES NO NO PUBLIC 971388

NOkE $h-1$ NO NO FUES NO NO DIf 914760

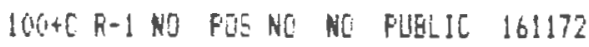

420 FI-1 NU YES YES NE FULELIC 644698

NOHE Fi-1 KJ NI YES WO NO DIF 370260

395 Fi-1 NE! VES PCS NO FUELIC 1306600

S3 R-1 NO POS NI RÚ COH OF: 771012

BO KI-1 NU YEE HO NO PUBLIC ET120

$200+E R-1$ NE YES NU NU PUBLIE 49222

$14905 \mathrm{E}$ KI NE YES NO NJ PUELIC 557568

200 H-1 NO YES NE NO PUELIC 148104

260 R-1 NO YES HI NO FUBLIC 36530

560 F-1 NO YEE YES NO FUELIC 130680

55 F-1 NO YES YES YES PUELIC 56628

MUNE R-1 NO NO YES YES HO DIF 544500

IBO FI-1 NO YES YES NO PFIVAT 65696

NCLEE R-1 NG NG YES YES NS DIF 566260

180 R-I NU YES YES NO PEIVAT 69696

180 R-1 NO YES YES NU PFIVAT 74052

155 R-I HO YES YES NO PKILAT 113256

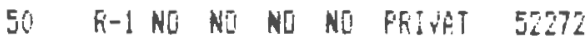

157 R-I NU NO KI NO PRIVAT 43560

182 FI-1 NO YES NO NO PRIVAT 36170

171 R-1 NO YES NO NO PRIVAT 42430

163 R-1 NO YES NO NO FFIVAT 38770

120 FI-1 NO VES KI NI PFIUAT $2004 \mathrm{I}^{\circ}$

RORE FI-I NO YES YES YES NO DIR 8200

213 FI-1 NO YES NO NO FFIVAT BLBOT

205 K-1 NO VES NO HS FFIVAT 3030

179 R-I NG YES NG NO PFIVAT 29950

30145 F-1 NE YES YES NJ PEIVAT 38790

$300+[R-1$ NO YES YES NO PFIVAT 26520

135 K-1 NO YES NO NO PFIVAT 28850

120 FI-1 NE YES NE NG PFIVAT 20640

18. R-: NO YES NE RS FFIVITT 2995

191 F-I NL YES NL HO PEIVAT BSBS 


\begin{tabular}{|c|c|c|c|c|c|c|c|c|c|}
\hline AE. RHE- DT & LELAT:OK & OHHEE OF REC & FRLNT & 70 SE SEh & HAT & HET & $F F A$ & ACSESS & AFEA SF \\
\hline - & 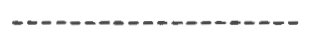 & ------1 & $-\cdots$ & & -- & & --- & & \\
\hline$E 0 E-01-0 \leq$ & HCJDLAHE SKIREL & STKUUBLE HILLIAM & $\mathrm{N}[$ & $\mathrm{F}-\mathrm{i} \mathrm{NO}$ & YES & NO & NO & FUE:IC & 475160 \\
\hline $56 e-0 \div-017$ & MUUसT SRIRED (DFF) & SINUL ALEEET & NUKE & $R-1 N i$ & $\mathrm{Na}$ & NO & N! & NE JIF & 130680 \\
\hline$E(8-01-07)$ & MUUR SKIFUO IOFF; & SINUS ALEEETi & MENE & $R-1 \mathrm{NI}$ & No & N] & No & No DIK & 65.540 \\
\hline EOE-61-16 & O:D MT, SKIFES ST. & VEADER BEFNARE & 50 & $\hbar-1 N$ & YES & $\mathrm{No}$ & NO & PUELIC & 174240 \\
\hline $512-02-02$ & PFiH STREET & BFOHIV NGEIAN V. & $2 e i$ & $\mathrm{R}-\mathrm{INO}$ & YES & NO & no & PUELIC & 54895 \\
\hline$E[5-\{\}-1)\}$ & CANEE TAEE STFEET & PUGANI AKTHUF & 150 & $\mathrm{~F}-1 \mathrm{~N}[$ & YES & YES & NO & UELIE & 44566 \\
\hline E:E- & MATS S-REE & FLEÁ:I AFTHLS & 450 & B-1 Ni & YES & NE & No & PUELIT: & 174240 \\
\hline$E: 0-0:-15$ & OLD MAIN STREET & NOETH RIVER ARTS SOCIETY INE. & 128 & $\mathrm{~F}-1 \mathrm{NO}$ & YES & No & No & FUELIL & 16890 \\
\hline Eit-vis-i!! & FIIAAR: AVEVIE & G'BAIE: ELLEN KATHLEEN & NEHE & $F-1 N !$ & $H[$ & N0 & HO & NG Dik & 47416 \\
\hline$E: E-C_{5}-6: 2$ & LU:IS STSEE' & FilLGÁNI AFITHUF $F$. & 12 & $\mathrm{R}-1 \mathrm{HO}$ & YES & No & NO & PEIVAT & 47916 \\
\hline$E 1 b-0 b-1 ; i$ & LOUIS STREET & RUEARI ARTHSF $F$. & 216 & $\mathrm{~F}-1 \mathrm{NE}$ & YES & YES & No & PFIVIT & 47916 \\
\hline E16-16-12 & LUIS GIFEET & Rugani $A F^{\top}$ HLIF $F$. & 252 & $R-1 N E$ & YES & No & YES & FRIVAT & 47916 \\
\hline$E ! t-06-05$ & RLEAT: AUENLE & FUSAR: ARTHLF & $18 ?$ & $\mathrm{R}-\mathrm{I} N \mathrm{~N}$ & YEE & YES & Wi & PULE:IC & 43560 \\
\hline$E 1 t-6 s-6 t$ & RUGFEI ALENSE & GAUDHAA EDWAD & 247 & $\mathrm{R}-1 \mathrm{NO}$ & YES & YES & $\mathrm{Nu}$ & PUE:IL & 47516 \\
\hline$E ! 6-16-17$ & FUK: C CHAME & FUGAEI AFTHLF & NUKE & $\mathrm{R}-1 \mathrm{NO}$ & NU & YES & NO & NE $D I K$ & 134372 \\
\hline$E: t-\{7-6 i)$ & LUL:J STRE:T & RUGANE AESTULF F. & 258 & $R-1 N 0$ & YES & YE5 & HO & FRIVAT & 47516 \\
\hline Ele-C?-TZ & EARTE THEE STREE? & FUEAL: AFTHLR & 166 & $\mathrm{R}-1 \mathrm{NO}$ & YES & YES & No & PLJEIC & 435.60 \\
\hline Eit- $-0-10$ & FLEASAH: ऽTKEET & CARLLÜH SIUFEIEO & 145 & $\mathrm{R}-1 \mathrm{Nu}$ & YES & $N[$ & $\mathrm{kL}$ & FuE IC & 43565 \\
\hline$E ! b-i \bar{i}-12$ & LO:IS STKEET & RJGGH AFTHLF $F$. & 190 & $\mathrm{Si}-1 \mathrm{NU}$ & YES & $\mathrm{Nō}$ & No & PFIVHT & 60964 \\
\hline$E i t-0:-12$ & LOU1S STREET & RUGAKI AFTHLLF $F$. & $145+C$ & $\mathrm{H}-1 \mathrm{NL}$ & NO & No & $\mathrm{HO}$ & FÉICL & 15500 \\
\hline$E 1=-67-15$ & LOUIS STFEET & FLGAR: AFTHUF F. & 150 & $\mathrm{H}-1 \mathrm{ND}$ & NE & Ni & $\mathrm{HI}$ & FFi CL & 47916 \\
\hline$E:-67-14$ & LOULS STREET & RUGANI ARTHIF. F. & 224 & $\mathrm{~F}-1 \mathrm{NO}$ & $\mathrm{Hic}$ & $\mathrm{Ni}$ & No & FFi $1[!$ & 5272 \\
\hline$E\lfloor t-0 \varepsilon-61$ & CATOE TKEE STAEET & CAKLSEN SEIEFADEL & 800 & $R-1$ NO & PUE & YES & NO & FUBLIC & 217800 \\
\hline$E 17-02-03$ & OLD MAII STREET & KULCKEHULK EAYID & 9 & $k-1$ Nì & YES & Ho & Mi & FUELIC & 38333 \\
\hline$[17-\{12-1\}$ & HIGHIAHE STKEET & MUEFHY PHILIF A. & 120 & $\mathrm{k}-1 \mathrm{NO}$ & YES & $\mathrm{NO}$ & $\mathrm{Ni}$ & FUELIC & 87120 \\
\hline E17-014-ij) & PRUS-ELT STEEET & KILLAY CCINSTARIJE & 109 & $\mathrm{~F}-1 \mathrm{NO}$ & YEE & $?$ & $\mathrm{HS}$ & FUE_IC & $11140^{\circ}$ \\
\hline$E 17-04-15$ & PFESFEET ST, IFEPF! & WILLS A. ALII5ON & MGKE & $R-1 \mathrm{NO}$ & $\mathrm{NO}$ & $\mathrm{HO}$ & no & nu UIK & 23375 \\
\hline$E 17-04-17$ & PRCSFECT STEEET (CFF) & WILLS A. ALLI5IN & 30 & $\mathrm{R}-1 \mathrm{NO}$ & P05 & YES & NO & FRIVAT & 174240 \\
\hline$E[7-34-26$ & FFUSDET STFEET & BILLAN CONETAREE & NGNE & $\mathrm{k}-1 \mathrm{ND}$ & No & YES & Ho & PLELIC & 272250 \\
\hline$E: 7-04-3 !$ & FLEGSANT STFETT & KRUSEL WILLIAM & 125 & $k-1 k i$ & YES & NO & No & FUE_IC & 9400 \\
\hline$E: 7-4-72$ & PLEAEATU STREET UAF) & HAÖBK LUNALD & MULE & (f-1 N & YES & YES & kiv & NU DIF & 261360 \\
\hline$E 17-04-34$ & CANDE TREE WAY (OFF) & HAGÁK DJHALD & NOKE & $R-1 N O$ & NE: & $N[1$ & NO & NO DIK & 54450 \\
\hline$E \mid E-01-10$ & DLD MFIN STREET & Moif Jorit & 250 & $R-1 N$ & YES & No & NO & FUE:IC & 87120 \\
\hline$E 18-05-10$ & OLD MAIN STREET & ANDEFEON JEANETTE & 240 & $\mathrm{R}-1 \mathrm{NL}$ & YEE & $\mathrm{N} J$ & No & FUELIC & 84070 \\
\hline$E[E-04-0]$ & FRGEFEUT STKEET & WhIEHT LIVINESTUR & 20 & $\mathrm{FinN}$ & YES & NO & NO & PUB:IL & 185130 \\
\hline$E 1 B-044-12$ & PFOSFECT STREET IOFF & NURPHY RICHARE & NENE & $\mathrm{R}-1 \mathrm{NO}$ & No & YES & No & NO DIR & 95396 \\
\hline$E \perp E-05-06$ & FROSFECT STEEET & DIFPEL KULLIAM & 230 & $R-1 N O$ & YES & NO & $\mathrm{Not}$ & PUELIC & 21870 \\
\hline E19-01-0! & SLMEEF STREET & MASS ALULUON SOEIETY & $640+i$ & $\mathrm{~F}-1 \mathrm{NO}$ & YES & YES & YES & PUELIC & 1176120 \\
\hline$E 19-01-017$ & WUFTH RIVEF, DKIVE & LULE AFTHITS & 146 & $R-1 N$ & YES & NO & $\mathrm{N}[\mathrm{j}$ & FUELIC & 43560 \\
\hline$E 19-02-012$ & SUHKEF STFEET & HAFNER EDWATID & $2 \mathrm{Es}^{2}$ & $\mathrm{R}-1 \mathrm{NO}$ & YE5 & $\mathrm{Ni}$ & NO & FUBLIC & 111078 \\
\hline$E 2,1-0.7-0.4$ & NOFTH RIVEF DRIVE & FARRIEIA LOUIS & 50 & $5-1 \times 0$ & YES & YES & YES & FUELIC & 235224 \\
\hline$E 20-05-05$ & NORTH FI'VER ORIVE & BEAEH MAY & 50 & $\mathrm{~F}-\mathrm{N} \mathrm{NO}$ & YES & $\mathrm{NO}$ & No & PLIE:IC & 43500 \\
\hline$E 20-0 j-0 j$ & NORTH BUEF DFEY & PFAY DORPED & 165 & $F-1$ Ni & YES & No & NL & PULELIC & 43560 \\
\hline$F 07-01-013$ & ULD OCEAN STFEET & DALIELL WILLIAM & 174 & Ki-1 Nu & YES & YES & NI & FUE:LE & 32790 \\
\hline $507-02-13$ & OLE GCEAII STFEET & THE AFTHUE A. WILLS TKULST & 291 & $\mathrm{~F}-1 \mathrm{Ni}$ & YES & YE5 & YES & FUELIC & $3276 ?$ \\
\hline$F(8-12-10$ & CLL OLEAH STREET & ELLIS CANIO & 1304 & $\mathrm{~F}-1 \mathrm{NE}$ & YES & YES & YES & FLELIC & 1302444 \\
\hline$F 0 E-02-13$ & TLD MGLNT SEIKGO & STAFLES DANA A. & 127 & R-j $N \mathbb{R}$ & YES & NO & N0 & FUELIC & 47480 \\
\hline$F_{10} 0-00-01$ & FUFFHEL STREET & LUEY W. CALLAHÂH & 330 & Fi-1 No & YES & $\mathrm{NE}$ & NO & PUELIC & 126324 \\
\hline$F 10-00-00$ & FURAHAE 5TREE? & LUEY H. CHLLAKAN & 280 & $R-1 N$ & YES & YES & YES & PUBLIC & 139827 \\
\hline$F: 1-05-14$ & EAMES WAY & SCUETI GUt M. & 150 & $\mathrm{R}-1 \mathrm{NO}$ & YES & NO 1 & NO & PUBLIC & 45746 \\
\hline$F ! 1-06-0 !$ & EARES WAY & FAFGGHEF JCLH: $F$. & 120 & $\mathrm{R}-1 \mathrm{NO}$ & YES & $k 0$ & No & FUE:IC & 43638 \\
\hline$F 11-07-07$ & FUSHACE STREET & ESTATE OF JOHN J. HALLISEY & 109 & $\mathrm{~K}-1 \mathrm{ND}$ & YEE & No & $\mathrm{No}$ & PHELIC & 72339 \\
\hline$F 11-67-60$ & FUFHACE STREET & ESTATE OF JOHN J. HALLISEY & 119 & $\mathrm{R}-1 \mathrm{NO}$ & YES & NE & ND & PLiELIE & 94085 \\
\hline
\end{tabular}




\begin{tabular}{|c|c|c|}
\hline$F 11-07-69$ & FUFNAEE STEEET & ELEN: C. FCẼD \\
\hline$F: 2-02-3 \mid$ & SFEINEFIELI ALEHUE & GFEATER SOLTHSHOFE CAE.EVISION \\
\hline $\mathrm{F} 12-02-012$ & EAMES WHY & BIAGIHI INC. \\
\hline$F \perp \bar{i}-(0 ;-6]$ & CABU!IHA TKKIL & HANLEY KEVIN \\
\hline$F 13-02-01$ & EAYES HAT & HAGAE ESTATE \\
\hline$F_{1} I_{1}-\mathrm{I}_{2}-\mathrm{CO}_{2}$ & THLDEN WOLS LAHE & BEUELL LET̃OY E. \\
\hline$F 14-02-01$ & EAYES HA: & BIAEINI INE. \\
\hline$F 14-02-62$ & EAMES WH IEFF! & HAGAF DSHALD \\
\hline$F: 4-(12-94$ & EATES LEY (TFF) & OALUZ MAGUE: \\
\hline$F 14-0,05$ & EATES WA & HAGGS DONALD \\
\hline$F: 4-02-06$ & AMES AMENUE & FHISILLA RI HALL \\
\hline$F 14-02-0 \overline{1}$ & EAMES WHY & HEIF C[I-GPEFGTIUE EANK \\
\hline$F 14-02-69$ & EAMES Hán! & DÁLUZ MANLLEL JUSE \\
\hline$F: 4-12-10$ & EAMES HE & HEIS COL-DFEFATIUE BANk' \\
\hline$F 14-0 i-1 !$ & EAMES WEY & GAULLEY ELIIAEETH \\
\hline$F 15-02-104$ & EARES WAV & BIASINI JUSEFH \\
\hline$F \perp 5-62-0 t$ & EAKES WAY & EIAGINI INC. \\
\hline$F 15-62-13$ & FLEASART STEEET (QEF) & CASTIGLIOHI ALEEFA \\
\hline$F 16-01-0 !$ & PLEASAMT STREET & 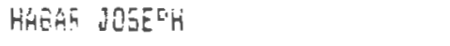 \\
\hline$F 10-01-03$ & PLEAEÁNT STREET & MUISE VINCERT \\
\hline$F 16-0:-07$ & PLEASAHT STEEET & EIAEIN: JJEEFH \\
\hline$F_{i}=-6 i-69$ & HEFTHEF HILL RUAD & RESA: MALAREMENT INIC. \\
\hline$F(6-0)-10$ & HEATHEF HILL ROL & FEEGA MAHAGEMENT INC. \\
\hline$F 10-11-18$ & HEATHEF HLL RUED & REGAL MAHAGEFENT INL. \\
\hline$F \$ 6-02-36$ & FLEFSAR STEEET & NECTOHE CHILDKEN BEALTY TRUST \\
\hline$F 16-92-1]$ & PLEASANT STREET & NECTOHS CHILOEEN FESTY TE:ST \\
\hline Fi $=-0]-9$ & FLEASGANT STKEEET & SALVETTI FETER \\
\hline$F \mid \leqslant-0 \leqslant-11$ & EARES HAS & HAEIN JUSEFH \\
\hline$F: 7-01-2 !$ & CANGE TREE WAYY & MITCHESL FATRTICIA \\
\hline $5: 7-0 !-1: 4$ & CAHIE TKEE WHY & 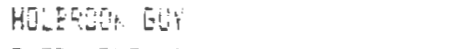 \\
\hline$F 17-5=-12$ & CANGE ThEE HAY & EMETR RUTTH Á. \\
\hline
\end{tabular}

F17-02-1EA SUMMEF STFEET (OFF) HAGGE DORALL

F17-02-19 FLEAEATI STKEETIOFF: ALEIAMLEGON PALI

F17-02-20 PLEASART STFEET (OFF) HAEEF OJMALL

FI7-03-10 SUMMER STFEET MUKRAY RUEEFT

FI8-0I-01 SUMMER STEEET NELSON RUEERTA

FIE-S1-02 SUMMEK STFEET GNDEFSTIN AFTHLF

F18-02-02 MACCMEEF 5 WÖY FLACE GAFBARAE.

FIE-02-04 MACONEEF 5 WÁY LAKE MYRTLE J.

FI8-0I-:2 SLHAES STREET (FEAR) NICHOLSON SHEFMAN

F1E-0J-15 SIJWFE STREET (REAF) KELLY IOTH

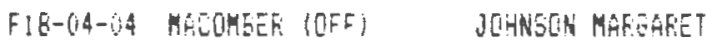

F18-04-10 SLMHER STREET HINES EQWARTO

Fl9-01-06 DARON'S FEINT BUAE GATES JANICE

F19-01-07 EASTHARD LANE CHAPMAL SUSAN

FI9-01-09 ERETHAFO LANE CHAFMAN SUSSTRL.

FIG-01-11 SUMAEF STFEET (OFF) DAFENE POINT TFUST

F:9-62-27 BAFTLETT'S ISLARE AEAU-TERSG FAFHS INE.

F19-02-33 DAMUNS PEINT RLAM BRACKMAHY HILLIAM

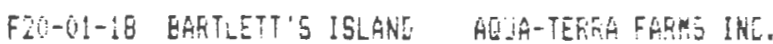

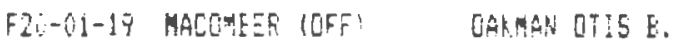

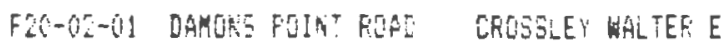

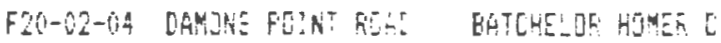

177 R-I NO YES NO NO FUELIC 14700

240 K-! NI WO NU NE PRIVAT 392640

500 F-1 NO NO NO NO N/A 522720

131 R-1 NO YES NO NO PEIVAT 4370 ?

2890 R-1 NO NO NO NO N/A 4835160

NONE R-1 NO NO HO NO NO DIF 413820

555 KI-1 NO NJ NG NO N/A 294030

NUWE R-1 NO NO HJ NO NO DIK 8.93

NERE FI-1 NO NO NU NO NE LIF 174240

NGRE B-I NO NO NO NO N/A 696960

740 R-1 ND NO NO NO N/A 174240

NENE R-1 NO NO PCS NO NO DIS 174240

NONE FI-1 NU NO NO NU NU DIR 152460

84ij R-1 NO NO NO NO $\mathrm{H} / \mathrm{A} \quad 335412$

NÜEE B-1 ND̃ HU NU NO N/A 65340

179 Fi-1 NU HO NO NO N/A 47916

335 Fi-1 NJ YES NG NO FUELIC 326700

NONE F-! ND NO NO HE HE DIF 235224

270 R-1 NU YES NO NO FUESIE 1742400

212 Fi-1 NO YES YES NO PUELIC 217800

150 R-1 NG YEE NG NO PLIELIC 40400

150 R-1 NO YES NG NE FEIVAT 43560

169 R-1 NO YES NG NO PFIVAT 52272

71 Fi-! NO YES NO NO PFIVAT 56028

124 KI-1 NO YES ND NO PUELIC 4617J

160 F-I NO YES NI NE FUELIC 43995

WJWE RI-1 NO YES NO NO NO DIF 200376

110 Fi-1 NO YES NE NO FUELIE 43560

220 KI-1 NO NO YES ND C.D. 52. 5272

300 Fi-1 NE HO YES NL C.D. 74052

442 Ri-1 NU NO NU NE E.D. 44Bsb

NGNE R-1 NO NO PES NG NO DIF 901692

NOKE $R-1 N E$ NO POS NÚ NO DIŔ 43560

NONE R-I NO HO FOS NJ NU DIK 21720

350 h-1 NO POS ND ND FUE:IC 4400

183 R-1 NO YES NO NO PUELIC 9888!

120 R-1 NO YES YES YES FUELIE 115870

$500+C$ R-I NS YES YES YES FUELIC 182952

50 R-1 NO YES YES YES PUELIC 3102

NO hi-1 NG POS NJ NO RF FOW 23490

NO $h-1$ NE NO NO NO NO DIK 2640

MURE FI-I NO NO NO NO NO DIF 217800

165 R-1 NO YES NO NO PUELIC 246114

$100+C R-1$ NO YES YES NO PUBLIC 378972

$306+C K-1$ NJ YES NOI NE PEIVAT 111513

192 FI-1 NO POS YES NO PEIVAT 77536

127 K-1 NU YES NU NC N/A 117612

$330 \quad R-1$ NO YES YES YES F'FIIVAT 243936

73 R-I NL YES YES YES PUELIC 7300

NONE R-1 NO ND YES YES NE DIR $4112 U 64$

NINE R-1 NO NO YES YES NO DIR 174240

58 FI-I NO PQ5 NO NO FFIVAT 2775

$100+C$ F-1 NO FOE $N$ NI FRIVAT 3774 


\begin{tabular}{|c|c|c|c|c|c|c|c|c|}
\hline 15.MUE-LOT & LAEFIOK & DUNEF CF REC & FEQRT & 20H SEH & WAT WET & FPA & ACCESS & AKEA SF \\
\hline & 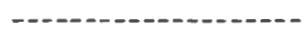 & & & & --. -.- & --- & & \\
\hline $5-0:-01$ & ALOFH STREET & MASSHF IELD COJNTFY CLLE INE. & 170 & $\mathrm{~F}-1 \mathrm{NO}$ & YES NO & N! & PFIVAT & 2156 \\
\hline $6-61-13$ & TEA RECK LANE & HAFVE TREEFT & NÜE & $\mathrm{Fi}-1 \mathrm{NO}$ & ND NL & HO & WD DIF & \\
\hline $6-61-13$ & TEA RUEK LAKE & HAFYEY ROEERT & 240 & $R-1 N O$ & Fos No & $\mathrm{NC}$ & PRIVAT & \\
\hline $6-01-15$ & TEA FIOAK LANE & MEGKAG ANN & NONE & $\mathrm{R}-1 \mathrm{NO}$ & NO NO & No & ND DIR & 304920 \\
\hline $6-31-17$ & DUFFEFS LARE & NEL DCFUTHY & RONE & R-1 NO & NO & $\mathrm{NO}$ & $N / A$ & 177285 \\
\hline$t-01-2 t$ & TEA RUEKL LANE & HARVE: RUEEFT & NOKE & $R-1 N E$ & FOS NO & NO & NO DIK & \\
\hline $7-(1 !-62$ & PUDSINE HI:S LAHE & TOFHAN FICHAFIJ & 230 & $\mathrm{~F}-1 \mathrm{NE}$ & YES YES & No & FRIVAT & 16117 \\
\hline $7-62-63$ & ACORN STKEET & FAINE ROEERT FALMES & NONE & $\mathrm{R}-\mathrm{I}$ NJ & NO YES & No & PFIVAT & 43560 \\
\hline $7-02-11$ & ACSFA STREET & LEATHEFEEE ROEERT \& PATRICIA & 33 & $\mathrm{R}-1 \mathrm{NJ}$ & YES YES & No & FKIVAT & 130680 \\
\hline $7-02-34$ & PUDDIHI HILL (DFF) & COSTELLO ESTHEK & ROREE & $\mathrm{R}-1 \mathrm{NE}$ & NO NO & NO & & \\
\hline $7-02-3 x$ & FUEUINE HILL LN IDFF & TUFHAW RICHAEE & HONE & $\mathrm{F}-1 \mathrm{NG}$ & NO No & Wo & NO DIK & 392040 \\
\hline $7-63-3 B$ & PULDING HILL LARE & ZIFA THCMES & 140 & $\mathrm{R}-1 \mathrm{NJ}$ & YES NG & $\mathrm{Ni}$ & FEIVAT & 296208 \\
\hline $17-02-40$ & TEF FOSY LANE & COHELL JOHH \& J. & NONE & $\mathrm{F}-1 \mathrm{NO}$ & POS NO & No & $\mathrm{NEI} D \mathrm{~K}$ & 225649 \\
\hline $7-02-44$ & FEAR MUTALINE STREET & AMES RGSE_LA SFTAGOUE & NONE & $f-1 N$ & NO NO & NO & NE DIF & 91511 \\
\hline $8-64-01$ & FLBOEIKE HILL LAKEE & BFELFOHS ELIZAEETH & NULE & $\mathrm{F}-1 \mathrm{H}=$ & YES KO & NO & NO DIF & 130680 \\
\hline $17-01-612$ & NOEKRICH STREET & LOMEAREI KICHE'AE & 5 & $\mathrm{~F}-1 \mathrm{NE}$ & POS NE & $\mathrm{NE}$ & RIVAT & \\
\hline $2-01-0 j$ & NGRTICH STREE & ChIWLEI JOHA & 5 & $R-i N E$ & POE NE & $\mathrm{NJ}$ & PFIVAT! & 5000 \\
\hline $2-01-06$ & HUFUICH STREET & NLETSN ALN & $5 i$ & $\mathrm{~F}-1 \mathrm{NO}$ & POS NL & NiE & FEIVAT & 5000 \\
\hline $2-01-07$ & NAEW:SH STREET & LEE FATEICK & 50 & $\mathrm{~B}-1 \mathrm{NO}$ & POS NE & No & PRIVAT & 5000 \\
\hline $2-62-04$ & WOEKICH STAEET & EVGHE WILLIA* & 50 & $R-1 N O$ & POS Nú & NO & VAT & 5000 \\
\hline $2-C_{-1}^{2}$ & NERGISH STRFE & BELLEY THEMAE & 50 & $F-1 N 5$ & Fos & His & FFIVAT & 5006 \\
\hline $2-03-01$ & SFFIHIGEIELD AVENUE & MELORALEH M.J. & $18 b+C$ & $\mathrm{~F}-1 \mathrm{NU}$ & FOS NO & Nis & PEIUAT & 4000 \\
\hline $2-6 .-02$ & NIFETCH STREET & GEEATEF SUUTHSHISE CABLEVISIOH & 250 & $\mathrm{R}-1 \mathrm{NO}$ & Fus NO & Not & VAT & 22500 \\
\hline $2-03-03$ & NEFH]CH ETFEET & COHRJLY JPEES J. & $15 i j+C$ & $\mathrm{~F}-\mathrm{i} N \mathrm{NO}$ & PÜS NO & NU & FEIVAT & \\
\hline $2-0 j-05$ & SFFIREE IELE AYERUE & CONAOLLY RICHÁEL & NINE & $\mathrm{K}-1 \mathrm{No}$ & POS NO & No & No DIF & 500 \\
\hline $5-04$ & VEFMOLT STFEET & FGREMAN HAFOD & $200+[$ & $\mathrm{F}-\mathrm{i} \mathrm{NE}$ & FUS NO & NO & PRIVITT & $375 i$ \\
\hline $2-0.5-0.5$ & VERHIKT STREET & FUTSWAK HARELD & NONE & R-1 NO & PUŚ N! & $\mathrm{NOH}$ & NODIR & \\
\hline $2-60-01$ & SPEINGFIELD AVENJE & COHAN D.F. & $165+5$ & $\mathrm{~h}-1 \mathrm{NE}$ & POS NO & no & FRIVAT & 5 \\
\hline-02 & SFRIMSFIELD AVENLE & LANG ELEANET̃ & 110 & $R-1 \mathrm{kO}$ & FUE NU & NO & PRIVAT & 9500 \\
\hline $2-16-03$ & SFFIKSEIELE AVENIJE & LANE ALEILH & $125+5$ & $\mathrm{~B}-1 \mathrm{Ni}$ & PUS NO & $\mathrm{HJ}_{\mathrm{i}}$ & IVAT & \\
\hline$t-64$ & VEFHDKT STREET & DOHARIJE FREDEEICK. & $5 i$ & $R-1$ No & POS NO & NO & PFIVAT & \\
\hline-13 & NOEWICH 5 & MAHONEY AHNA & 50 & $R-1 N i$ & POS NO & NO & PFIVAT & 5000 \\
\hline $612-0 t-14$ & WUFitiCF 5 & RLEFIREEF EOITH & 50 & $\mathrm{H}-\mathrm{i} \mathrm{NL}$ & FOS NO & NO & Frivit & 5000 \\
\hline $6-15$ & HORHICH STREET & DOHERTY JAMES & 50 & $k-1 N[$ & FOS NO & ND & PFIVAT & 500 \\
\hline-01 & ESSEX AVENUE & MULLEF JUHK C. & $50+C$ & Fi-1 No & YES NO & NO & PUELIC & 5250 \\
\hline-03 & UTAH STREET & MAFTFA RICHAFE & $201+C$ & $8-1 N 0$ & POS NO & NO & PFIVAT & 10000 \\
\hline $612-07-60$ & WE.LTHAM & DARCY FALL + DOSOTH: & $235+[$ & & POE NU & NO & PEIVAT & 9600 \\
\hline-16 & UTAH STKF & B]!SUN FICHARS & 50 & $R-1 N D$ & POS NO & Nĩ & PEIVAT & 5000 \\
\hline $8-67$ & ITAH STFEET & HHITCHES MAFK & 50 & $\mathrm{R}-\mathrm{i} \mathrm{NO}$ & POS NO & $\mathrm{Nu}$ & FFIVAT & 5000 \\
\hline $612-06-68$ & EESE: AVENLE & TUEFEY IUHARANGH & $50+i$ & R-1 NE & YES NEI & NC & FUE:IC & 4000 \\
\hline $612-08-10$ & ESSE: AVEFIE & JORES CECELIA & 50 & E-1 NO & YES NE & NO & PUE:IC & 4000 \\
\hline-11 & NDFHICH STHEET & HILIIAHE RÁLFH & $125+c$ & $R-! N O$ & POS NE & NO & PEIVARE & 3600 \\
\hline $612-08-12$ & NOFWICH STFEET & CUNA IFF DEBORinit & 50 & R-1 N & FOS Ni & NO & FFIVAT & $50 \% 0$ \\
\hline $6 ! 2-0 e-16$ & NOFWICH STSEET & FIN:AYSIN KENNETH & 50 & $\mathrm{~K}-1 \mathrm{kO}$ & $\mathrm{F}[S \mathrm{~N}$ & Hi & FEIVAT & 5000 \\
\hline $6: 2-08-17$ & CLHNINGHAK MASUORIE & CUANINGHAF MAEJUFIE & 50 & $R-1$ No & Fus :0 & $\mathrm{Ki}^{5}$ & FFIVAT & 5000 \\
\hline $612-05-01$ & LYHN STREET & MELVUEN YERHETH & 125 & Fil HE & YES NÕ & $N[$ & PF!VAT & $1250 \mathrm{i}$ \\
\hline $612-09-64$ & LWN STKEET & VINZZE LASEIU & $4 i$ & Fi-1 Ni & YES NO & no & PEIVAT & 506 \\
\hline $2-0.5-16$ & ESSEX AVENLE & KLHIN EYIL & $50+?$ & $\mathrm{R}-1 \mathrm{ND}$ & YES NE & NO & PUB:IE & 5460 \\
\hline $2-69-67$ & ESSEX AVENGE & 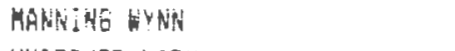 & 56 & $h-i N O$ & YES NO & NO & PUELIC & 4utue \\
\hline $2-69-05$ & UTAS' STKEET & HH:TCHEF MAEK & 50 & BI-1 NL & FuS NI & $\mathrm{HO}$ & FIVIVT & 500 \\
\hline $2-07-10$ & WTAH STEEET & MakNikg WHAE & 20 & $R-1 N C$ & FOS NO & NO & PRIVAT & 7500 \\
\hline $2-04-11$ & UTAH STFEET & VIHEIE LASLLO & 50 & $\mathrm{~F}-! \mathrm{NO}$ & fos nJ & $\mathrm{NO}$ & FRIVAT & J \\
\hline $12-09-12$ & LIÁR STREET & MRELE LASZLE & 50 & $\mathrm{~F}-1 \mathrm{NL}$ & FOE NE & NO & PEIVAT & $50 i$ \\
\hline
\end{tabular}


6IZ- 6 - IC UTAH STREET

E12-10-01 ESEEX AUEHUE

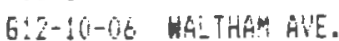

GIZ-jOOCE WALTHA GUE.

6: $10-10-19$ UTAH SIFEET

GI2-:1-14 SERIRETED AUENUE

Q:2-11-0E HHTHS AVERE

BI2-11-06 5FFINSEIELD AVENUE

Gi2-1:-15 HETHAH AVERUE

612-12-02 SFFINGFIELD AVENUE

G:Z-1Z-OZ SFRINETIE:D AUENUE

612-12-0? DEOHAW FUAL

612-13-02 VEFHOHT STREET

GI2-14-OE CA.IFOFHIA STEEET

G12-16-61 CHEIFGRRIA STFEET

DIL-16-02 CALIFOENIR STREET

G:Z-16-OJ CALIFUEN:A STKEET

612-16-04 5FRIKGFIELD AVEVIE

Gi2-ib-05 SEFINGFIELD AVEHEE

GI2-16-OE DELHAM RULA:

612-17-C1 LAWGENCE ROAD

6:2-17-02 LALGENLE BUAE

612-17-OE LYMN STEEET

612-17-10 LYKH STREET

612-17-11 LYMi 5TKEET

612-17-12 LYNN STREET

6:2-17-13 LYMN STREET

6:2-1E-TI4 CA:IFOFNIA STREET

612-18-05 CAEIFOFNAE STREET

GI2-1E-US EALIFURIIA STKEET

612-18-1? LAWKENLE FOBR

6:2-16-15 LAHEENLE RCAD

612-iQ-16 LAHEEHCE KOFD

612-15-17 ESSET AVENUE

6I:-19-105 NALTHAF AVENUE

612-19-05 HAITHAM AVE.

612-19-0) WALTHAH AUENUE

612-19-0? HA. THAM AVENUE

Gi2-19-16 WALTHAM AVE.

612-17-11 CALIFORWI STREET

612-19-12 CFIFOFNTH STFEET

612-19-13 CALIFDRWY STFEET

6:2-15-15 CALIFOFNIA STEEET

E12-19-16 CALIFOFNIA STREET

[:2-19-17 CALIFUKRIE STFEET

612-19-18 CALIFORMIA STAEET

6I2-19-19 CALIFURHIA STEEET

612-15-20 CALIFOSNIA STREET

6!2-19-5A HALTHAF AVE.

$612-20-04$ HAL THAY AVENLE

$612-20-06$ WTERINE STEEET

612-20-OB WUMINS STREET
QODDE VERDIE A

MÁNATSTS HYNAE

PETERSON IOHNGHHA

5UIFFIKSTOK FALL

JEFOYE RILLIAH.'

WASNEF HOHASO

O LEAEY ARTIUIF

O'BF:EN MAETHA

MLLLGEEY MAETHA

BCLAKTHY FLGBENLE

ESSEM J.\& 3 .

BAHE MAFTIN

BUETE ELILAEETH

HAGMAN TUAFE

MELALËHLIN JHES

TEEESSH: DOHIRIS

JONEE SARTITÁ

WATTS ROEEFT W.

MCLUCAS CATHERINE

OHEENEERGEF

HEISHER FRTANEE 6

COLOARA AESSTIN]

RELUIEN KENMETH.

SCULLINS C.

MELUOEN KENEETH

MELVEEA KENRETH

DABNEF MAEY

MATERALLL PAULL E.

HEALEY ELIZAEET

H:LL NOSMS

COYLE IHYS

TKAINAS REFELL F.

DI:YE JAMES F.

BEAKI HELEN A.

TAYLOF FFANEIS H.

HULMES FLUREREE HI

HOL HES FLOEEREE

MLCAFTHY CYRIL

QLSEN ADE MAY

CULLIGAR THLMAS

CULLIGARK THOMAS

DONELPN MILDKEL

TEDEEEHI DOHIVIL

DONELAN MILOKEE

DUFFEE LEAH

DUFFEE HEATH

BRIGGS MARJURIE

DUFFEE LEÁH H.

HALLLETT FLOFENCE

QLSEN MAYY

CHAREES MICHAEL

CHARLEE MICHAEL

TEDEEEK DUMINIS R 5i) FI-1 NO PUS NE HO PEIVIET 5000

50 R-1 NO FUS NU NU PRIVAT 5000

$5(i+C R-1$ NO YES HO NO FLUELIC 4350

$290+C$ F-1 NO POS NO NO FFIVATT 7590

50 E-I NO POS NO NO PRIVAT 5000

170 R-1 NO FOS NO NO PKIVGT 5000

65 R-I NE FOE NE NO FRIVAT 5000

25 R-1 NO FQS NI NO FEIVAT 2200

$200+[F-1$ NO PUS NO NO FEIVAT 4000

NONE R-I NO POS NO NO NO DIK 3125

100 R-I NI FUS NO NO PEIVAT $950 \mathrm{~J}$

$145+C F-1$ NO POS NE NO PEIWAT 5090

25 R-I NO PUS NO NO PEIVAT 6500

50 k-1 NO PO5 NO NO FRIVAT 5006

50 K-1 NO NO NO NO FGEVAT 5000

$160+C$ R-1 NE NO NE NE FFINAT 7600

60 K-1 NO NO ND NO PTIVAT 5000

90 R-1 NO NI NU NI PEIVAT 80!G

$300+[$ GI-1 NO POS WE NO FRIVAT 2200 '

60 R-1 NE POS NO NO FRIVAT 7500

50 R-I NO FOS NO NO PEIVAT 5000

125 Fi-1 NO NO NO NJ FFI CL 12500

50 F-INO NO NO NO FFI CL 5000

50 R-1 NO YES NO RU PEIYAT 5000

$120+C R-1$ NO YES NO NO PRIVAT 3200

70 Ri-: NU YES NE NJ PFIVAT 5,50

45 F-1 NO YES NO NJ FRIVAT 5000

45. FI-I NI YES NO NO PEIVAT 5000

40 F-1 NI NO NO NO FRIVAT 5000

50 FI-I NE NO NI NO PRIVAT 5060

$125+E$ R-I NO NO NO NO PEIIVAT 4000

5. R-1 NL NO NO NO FHI CL 5000

60 R-I NO NE NE NO FFI CL 5000

70 R-1 NO NO NO NO FEI CL 7500

23 BIN NO YES NO NO PUBLIL 2450

260 B-1 NL YES NO ND PFIVAT 13000

260 FI-1 NO FOS NO NO PFIVAT 13000

80 R-I NO POS NO NO FEIVAT 8000

40 FI-I NO FUS NII NO PEIVAT 4000

35. R-I NÜ POS NJ NO FGIVAT 3B50

$200+[$ RII NO NON NO NO GRIVAT 10000

40 Ri-1 NC HO NG NO PFIVAT 6000

100 R-1 NU NO NO NO PFIVET 13750

40 F-1 MI NO NO HO PFIVAT 4400

50 F-I NE NG NJ NO FRIVAT 5000

145 R-1 NG NE WJ ME PFIVAT 13750

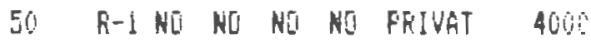

100 F-1 NO NO NO NO PRIVAT 7250

70 FI-1 NO NO NU NO PRIVAT 5000

HOBEE F-: NG NG NO NO NO OIS 13000

to R-I NO POE NO NO PRIVAT 6000

40 R-: NO $\$ O$ WO NO N/A 4009

75 R-1 NO NO NS HO NIA 10560 


\begin{tabular}{|c|c|c|c|c|c|c|c|c|c|}
\hline $612-20-19$ & WYOHINE STKEET & MASTEIANNI GUY & $140+C$ & $\mathrm{R}-1 \mathrm{NO}$ & Mó & NO & NG & $N / A$ & 5000 \\
\hline $12-2 i j-10$ & SFRINGFIELD AVENUE & MAETE?ANN! GUY & 40 & $5-1 N D$ & POS & NO & No & PHIVAT & 4010 \\
\hline$-20-12$ & CALIFORNIA STREET & MYLES RICHARIS & $b^{c}$ & $F-1 N i$ & $N D$ & NO & $\mathrm{No}$ & FRIVAT & 11800 \\
\hline$-21-01$ & SFRINGFIELE ALERUE & WHITNEY DAVIO & $15 i+c$ & $R-1 N O$ & Fos & NO & NO & PRivit & 4000 \\
\hline$-21-02$ & SFRIHAT IELD AVERSEE & MCCAFTHY RITA & 50 & $R-1 N[$ & P05 & NO & NO & PRIVAT & 5000 \\
\hline$-21-03$ & SPFINGFIELD AVERLE & TEDESEH: DOMINIC & $215+5$ & $R-1 N 0$ & POS & $\mathrm{NO}$ & NO & FKIVAT & 11700 \\
\hline $2-22-11$ & CALIFUFWT ST STKEET & FLAHERTY JAMES & 45 & h-1 NI & NO & NO & NO & PRIVAT & 5000 \\
\hline $2-22-63$ & WYOMHE STEEET & KELL DABRIELL J & 80 & $R-1 N G$ & N] & NO & NG & $N / A$ & $2453 !$ \\
\hline $2-23-02$ & WYON:HE STEEET & LYONS ESTHES & 40 & $R-\{N 0$ & NO & NE & No & NiA & $25(0)$ \\
\hline $2-23-05$ & SYOWING STEEET & LEFERAA ALFFED & $225+C$ & $h-1$ NO & NU & NO & NO & $N / A$ & 14160 \\
\hline $23-165$ & MEEFOROS STHEET & DUNRINETAN GEUROEE & 40 & $F_{i}-1 N \mathrm{NG}$ & YES & $\mathrm{HOH}$ & NO & PRIVAT & 4000 \\
\hline $23-09$ & HEDFORL STFEET & KAER MAEGAEET & 35 & $k^{\prime}-1 N 0$ & YES & NG & NE & FFIVAT & $4000^{\circ}$ \\
\hline $2-24-11 !$ & HOHING STEEET & WESO THEMAS & $230+6$ & $5-1$ NE & No & No & No & $N / A$ & 12100 \\
\hline $2-24-02$ & SPGINGFIELD AUENUE & FRAMLE H.E. L. & 20 & $\mathrm{~K}-\mathrm{I} N \mathrm{NI}$ & POS & NE: & NO & FRIVAT & 2400 \\
\hline $2-24-0.4$ & SFRINGFIELD AVENLE & FFAREE K. B.: L. & 120 & $R-1 N 0$ & P05 & $\mathrm{Ni}$ & NO & FEIVAT & 15240 \\
\hline $2-24-06$ & SFRINSEIELO AVEHE & TEGESCMD DOMINIL & $250+?$ & $\mathrm{a}-1 \mathrm{NL}$ & POE & $N E$ & No & FRIVAT & J040i \\
\hline $2-24-67$ & MEDFSET STREET & BEAULEA RUEES: & $200+\hat{c}$ & Ri-1 No & VES & $\mathrm{HU}$ & WI & FRIVAT & 1200 \\
\hline $25-91$ & HORTAHE STREET & FHE HEF RONALD & $355+C$ & $F-1 N E$ & YES & NO & Nú & FEIVAT & 17000 \\
\hline $25-03$ & SFFINGFIELD AVERLE & TEDESCHI DORIKIC & $3 E 0+C$ & $\mathrm{~F}-1 \mathrm{NG}$ & F05 & $\mathrm{NOI}$ & $\mathrm{NO}$ & PEIVAT & 20700 \\
\hline $2-20-0.2$ & MONIAHAS STREET & THE PABKIS TRUST & 60 & $R-1 \times n$ & YES & $\mathrm{NE}$ & NO & PFIVAT & 6000 \\
\hline $2-26-i 4$ & DOVEF STREET & THEMESON DOKALE & 65 & $F-1 N G$ & POS & NO & $\mathrm{NO}$ & FEIVAT & 6000 \\
\hline $2-26-1 i_{5}^{5}$ & DEVEF STREET & TERESTH DOHEIE & 100 & $R-1 N D$ & FEt & No & NO & FRIVAT & 8200 \\
\hline$-2 b-0$ & 5EFINGF IELO AVENIE & TEDESCHI DOMIGIL & $255+i$ & $\bar{x}-1$ No & Pot & NO & NO & PEIVÉT & $1650 ?$ \\
\hline $27-05$ & FEFFY STKEET & GAREEF OHILIF C. & 60 & $R-1 N i$ & YES & $\mathrm{Noi}$ & Nit & FUEEIL & 6000 \\
\hline $29-63$ & FEREY STFEET (BFF) & SYLUESTER A. BAY & NGKE & $R-1$ NO & N! & NO & No & NO DIR & 339768 \\
\hline $2-30-01$ & REAG MEIEDED STREET & FEAF:L EVEFETT & $\mathrm{NO}$ & $\mathrm{k}-1 \mathrm{NO}$ & POS & NO & NE & NLWE & 43560 \\
\hline $2-30-13$ & FEFFI STFEET & THERES FICHARS & 40 & $\mathrm{E}-1 \mathrm{NO}$ & YES & No & $\mathrm{Ni}$ & PUBLil: & 21780 \\
\hline $01-02$ & PINEHIRET FGAD & TEDEESH RUMINIC & 110 & $\mathrm{R}-\mathrm{INO}$ & YES & YEE & No & PFIKAT & 179032 \\
\hline $4-01-04$ & CHUKCH STFEET (KEAFI & WUFFYY VICTUEIHÉ & NDAE & $\mathrm{R}-1 \mathrm{NE}$ & No & YES & $\mathrm{NO}$ & No UIR & 914760 \\
\hline 4-01-ij & CHUKCH STREET & 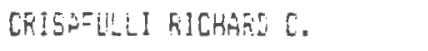 & MUNE & $R-i N 0$ & KC & YES & $\mathrm{NI}$ & FRIVAT & 374516 \\
\hline $1:-19$ & CHURCLE STREET & GAREETH GRTHUS I. & 126 & $k-1 \mathrm{ki}$ & YES & YES & $\mathrm{No}$ & PUBLIC & 47916 \\
\hline $14-01-20$ & CHUECH STFEET IREARTi & TEDESLHI DUHINIC & NJNE & h-1 NQ & NO & YES & NO & NOIIS & 228690 \\
\hline $14-0 !-24$ & CHUFCH STFEET SFEAS: & ASTHEGIT RESEARLH FOLAEATIOA & NORE & $\mathrm{F}-1 \mathrm{NU}$ & N! & YES & $\mathrm{NO}$ & NOS DIF & 65340 \\
\hline $5-013-69$ & IOYL WILEE CIKCLE & B]UTKEE PAUL O & 117 & $R-1 \mathrm{NO}$ & YES & NO & NL & FWELIC & 30200 \\
\hline $5-0,-10$ & IDYL HILIE CISUE & NEE 30SEFH MYLES & 118 & $\mathrm{R}-1 \mathrm{NE}$ & YE5 & $\mathrm{NiI}$ & ND & PliELIC & 27300 \\
\hline $615-05-15$ & CHUSCH STKEET & GARCEGU ARTHUT & 125 & R-1 NO & YES & YES & $\mathrm{NI}$ & FUELIC & 297079 \\
\hline $5-05-16$ & CHLACH STREET & 6ROSS LESLIE & 125 & $\mathrm{~K}-1 \mathrm{NE}$ & YES & YES & $\mathrm{Nu}$ & PUE:IC & 21562 \\
\hline $5-0.5-17$ & CHUARCH STFEET & 6FOSS LESLIE & 125 & $R-1 N 0$ & YES & YES & $\mathrm{Ni}$ & PUELIC & 242194 \\
\hline $5-65-19$ & CHJREH STREET & EROSS5 LESLIE & 125 & $\mathrm{R}-1 \mathrm{NO}$ & YES & YES & NO & PUELIC & $31668:$ \\
\hline$E 15-05-20$ & CHISCH STREET & FOLCARC SANDRINA & 164 & F-I NO & YES & YES & N3 & PUELIL & 52272 \\
\hline $615-05-21$ & SLIMAEF STFEET & O DUNAELL GEFTKRE & 214 & $A-1 \mathrm{kij}$ & YES & $\mathrm{Ni}$ & NO & PUBLIC & $100: 80$ \\
\hline $615-65-22$ & SUMAEF STKEET UOFE) & HEIFS OF LUTHEK LITTLE & NÜE & $\mathrm{R}-1 \mathrm{NO}$ & NO & YES & $N G$ & NE: DIF & $104=44$ \\
\hline $815-65-23$ & SUHHES STKEET (OFF) & O'DOHAELL EEFTFAM & NUNE & $R-1 N E$ & NG & NG & No & No UIK & $579: 34$ \\
\hline $616-01-02$ & DEEÉ HISL LANE & AHDEFSJR JJHE $\mathrm{F}$ & 134 & $5-1 \mathrm{NG}$ & YES & NO & $\mathrm{NE}$ & PUSLIC & $3430 \%$ \\
\hline $616-0.10$ & FLEAEART STREET & RUGANI ACTHLE & 120 & $R-1 N O$ & YES & $\mathrm{ki}$ & No & FUELIC & 36000 \\
\hline $61 t-04-10$ & STATIUN STREET & MELCHIUNMIS ALEERT & $280^{\circ}$ & $\mathrm{R}-1 \mathrm{NO}$ & YES & Ni: & NO & PUISLIC & 20000 \\
\hline $6 ! t-04-13$ & PLEASNAT STREET & RUEAN: AETHUK & $526+C$ & $F-1 \mathrm{~kJ}$ & YES & NE: & No & FUELIE: & 35000 \\
\hline $6 ! 6-04-22$ & FLEASANT STLEET & FLARLESS HBSAED & 389 & $\mathrm{Fi}-1 \mathrm{Ni}$ & VES & NS & NJ & FUELIE: & 174240 \\
\hline $616-07-10$ & S:MHER STREET & GANREF EAE_ & $250+C$ & $\mathrm{R}-1 \mathrm{NO}$ & YES & $\mathrm{Noj}$ & NO & PUSLIC & 11560 \\
\hline $616-08-12$ & SUHAEF STKEET (CIFF) & WAFEEN EAREATHA & NQRE & $k-1 N C$ & NE & YES & YEE & NE DIK & 5260 \\
\hline $610-6 \theta-70$ & SALT MEALCK & EAGTE DLARE & NOLE & $R-1 N$ & $\$ 0$ & YES & YES & WU EIF & 653400 \\
\hline $6 ! ?-01-01$ & SHMKER STREET & WILLIAME BRTTHETE & - & $F-1 N D$ & YES & $N D$ & Nú & FUBSLIC & 10585] \\
\hline $617-02-17$ & FINE ISIANE & FEARL EVERETT & NOEE & Fi-1 $\mathrm{N}$ & $N L^{i}$ & YES & YES & NE LIF & 174240 \\
\hline
\end{tabular}




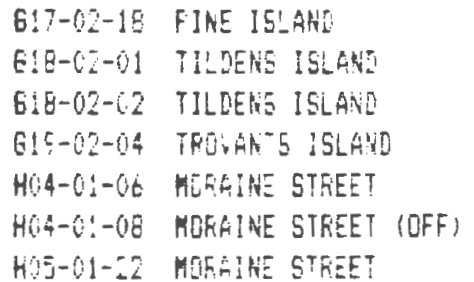

HIE

HOE-04-14 FARSIHAEE STREET

Ho6-02-10 FOVFIEL RLAL

HOL-0J-12 HUIFELETREE LANE

Hi)-0A-U1 FAFSENASE STREE:

HO6-04-12 PAFESHAEE STKEET

HO6-04-0J PAFSINASE STREET

HO6-04-04 FAFIONHEE STREET

HOb-O4-13 HHIFELETFEE LANE

HQt-(1L-11 NHIFFLETAEE LANE

HOE-0A-12 WHIFFLETREE LALE

HU6-64-19 SJJEAEY ROMLE

H(16-05-04 WHIFFLETKEE LANE

Hut-05-12 RIDINS ChIF LANE

HUt-C5-1: FILIKG CKOP IANE

HO6-05- I4 RIOING CRLF LAHE

HOt-05-15 FIOIHS CRJF LAME

HUt-05-16 RIOING ChOP LANE

HLS-35-17 RIOIKS CKUF LAHE

HO6-0E-1E fIDING CFUF LANE

HO6-05-19 RIOINE CFCF LANE

HO6-05-20 FIDING CFIF LAHE

HOt-05-21 RIDINE CFOE LARE

HOE-05-2Z RIDING EROE LANE

H16-05-24 WHIFFLETREE LANE

HOE-05-2b WHIFF_ETFEE LANE

HO6-05-27 HHIFFLETREE LARE

HO6-05-28 HHIFF ETAEE LANE

Hot-05-31 HHIFFLETREE LANE

HO6-0b-01 RIOING CFID LANE

HOD-06-02 FIUIHE CROF LANE

HJE-06-0J RIDINE RRIF LANE

Hit6-06-014 FIOINE CRUE LANE

H06-06-05 RIQ1KE CKIT LARE

HOb-OS-06 RIULHE CROF LAHE

HO6-06-01) FIOINO CROF LAME

HOb-0b-08 F!OIHE CFUE LANE

HO6-06-09 RIJING CFIE LAHE

HO-06-10 RIDISS CESO LARE

HO6-06-1: FIDING CROF LANE

HOE-06-2i WHIFFLETREE LARE

HOT-04-35 MOFAMINE STREET

HOE-02-6S SWITH RIYEN STREET

HO7-01-US S. FIVES ST. IFEASI

H:9-0Z-62 50:TH KISER STEEET

H10-0Z-01 5TUTH FIVEF STREET
KAVIA JERRY

CONEANASG GRIARK

LYENE GEOFJE

SUNES LOUIS

FAMRE SUE

CLIGEOTT JOH

MUEAIHE FEEATY TRUST

MURABNE REHLTY TELOTT

MCLLLSTEY GERALD

SHAM:EY GEFSLUINE

MULEN LUMEEK COMFANS

HAFEOASIDE REALTY INE.

HAESULSIDE REALTY INE.

KARBOESTDE RERLTY INC.

NAZZAFI FETEK

MULLEN LUMEEF COMPAYO

MULLEN LUMBER CO.

MULLEN LUMEER COMFANY

MULIEN LUMEE COMFARY

MULLEN LUMEEF COMFANY

MULLEN LUMEEF CO.

MULLERT LUMEEF CO.

HU: LEN LUMEER CD.

MULLES LLMEEF' CO.

HJLLEN LUMBER CO.

MLLLEN LLIMEET CE.

MULLEN LUAFEF CO.

MULLEK LUMGEF: CÕ.

HLLLEN LLUEEEK CO.

MULLEN LUMEEF CO.

MULLEN LUMEER CS.

MULLER LUMEEF COMTANYY

W.LEN LUMEEF CO.

RULLEN LUMBES COMFERYY

HLLEN LUEEA COKFANY

MULLEN LUMEES COMFANY

MULLEN LUMEEF CO.

RULLEN LUMEER CD.

MULLEN LUMGER [J.

MULLEN LUMEES CO.

HULLEN LUMEER CO.

HULLEN LUHEEF CO.

MULLEN LUMEER CJ̃.

MULLEN LUMBEF CE.

HULLEN LLMEEF CO.

MULLLEN LLMEEh CO.

MULLEN LUMEEF CO.

MULLEN LLMEET COMPANY

MCREEVEF GEGREE

FRATT MATTHE

BAKET APTHUS

CHARILLEF HOAPFO

H. DEMGTTER. CONSTRIETION CL.
NONE R-1 NO NO YES YES NO OIE 290203

NONE $R-1$ NÜ NO YES YES NOI DIR 392040

NÜHE R-1 NO NO YES YES NUE IIT 653403

NONE R-1 NO YES PDS YES NO OIF 87660

$47 \quad F-1$ NJ YES NO NS FUELIC 43560

NUNE F-I NO NE HO NO HO DIF $24: 758$

b6 R-1 NO YES YES NO FUBLIC $168 \%$

300 R-1 NU YES YES NO PUELIC 8189:0

50 FI-1 NO YES NU NO PUESIS 1616:5

120 R-1 NO YES NE NG FUELIE 21500

$248+C$ RI-1 NO YES YES NE FUEL!C 8400

50 F-I NE YES HO HO FUELIE 5272

5O F-1 NL VES NO NO FLELIC 473:6

50 R-1 NO YES NS NO FUELIC 474:j

210 R-1 NLI YEE NJ NO FLEL!C 52272

131 R-: NJ YES YES NO FUELIC 20817

131 R-1 HO YES POS NO PIJELIC 21074

127 R-1 NO YES POS KII PUELIC 10500

190 K-1 HO YES NI NO PUELIC 20050

$120 R-1$ NO YES YES NI PUELIC 24800

120 R-1 NI YES YES NI PUELIL 2004:

120 Fi-l NO YES YES WO PUBLIC $2004 \mathrm{i}$

$120 \quad \mathrm{~K}-1$ NO YES YES NO FUELIC 20040

120 R-1 NO YES YES NO PUBLIC $20040^{\circ}$

120 R-1 NU YES YES NO PUSLIC 26040

120 Fi-1 NO YES YES NO FUE'IC 2106

110 R-I NO YES YES NU FUELIC 20174

110 F-1 NO YES YES HE PUELIC 20006

110 F-1 NE YES YES NE FUELIC 2490

110 R-1 NO YES YES NE FUBLIC 21424

130 R-1 NO YES YES NO PULLIC 20700

292 Fi-l HO YES YES NO PUELIC 22410

120 R-1 NO YES PUS NO PUIELIC 20040

120 R-1 NU YES YES NO FUELIC 20040

$120 \quad R-1$ NO YES POS NO FUELIC 20040

70 R-1 NO YES YES NO PUEEIL 87120

140 R-I NU YES NE NO PUBLIC 20050

$120 \mathrm{R}-1$ NE YES NII HO PUELIC 20040

120 R-I NO YES NE NO FLELIC $2004 \mathrm{~V}$

120 B-1 NU YES NO NI PUBLIC 20040

120 R-1 NO YES NO NÜ FUULIC 201040

120 F-1 NO YES NJ HO PUBLIC 20760

127 R-1 NO YES NO NO PUBLIC 21390

142 Ki-1 NG VES NO HO PUELIC 21922

142 Fi-l NE YES NO NO PUELIC 21922

138 Fi-1 NO YES NO NO FUELIC 20346

143 R-1 NC YES YES NE PUELIC 2017?

120 F-1 NO YES YES NO FUELIC 8400

Q9 R-1 NU YES FOS NO PUELIC 20500

NINE R-I NO FDS POS POS NO DIR 133690

NOHE FI-J NO NO NO NE NO DIF 57120

1160 Fi-1 NU YES YES YES NO LIF $114 E 370$

NONE FI-1 NL YES YES YES AIE OIF 1E37ESE 


\begin{tabular}{|c|c|c|c|c|c|c|c|c|c|}
\hline 45. Mr $=-10 T$ & LEGATIDK & UWREF DF REL & FRIJKT & ZON SEH & WhT & WET & FF'A & ACCE5S & AREA SF \\
\hline ------- & $---10-1$ & & & & & & & & \\
\hline $111-0 !-22$ & FHTLIF STFEET & SVLVESTER A RAY INC. & 100 & $\mathrm{R}-1 \mathrm{NO}$ & POS & No & NC & PRIVAT & 65340 \\
\hline $11-01-13$ & PHILIF STREET & SYLVESTEF R. RAI INC. & 100 & $\mathrm{R}-1 \mathrm{No}$ & P05 & NO & $\mathrm{NO}$ & PRIVÁT & 2178 \\
\hline $11-01-6 \frac{4}{4}$ & PHILIP STREET & SUITHEF FRANH & 100 & $R-1 N L$ & $P 05$ & NO & ND & IVAT & \\
\hline $11-6-0 ;$ & FART STREET & SYLVESTEK A. FHA & 400 & $\mathrm{R}-1 \mathrm{NE}$ & YES & NO & NO & UELIC & 4052 \\
\hline $11-64-10$ & GRIVE STREET & TAGGART VALENTINE & $16 !$ & $R-1 N 0$ & YES & NO & HO & JELIC & \\
\hline $111-64-11$ & GFUVE STEEET & FEFE CAELLD CHÄKLES & $350+[$ & $\mathrm{R}-1 \mathrm{~N}[\mathrm{I}$ & YES & NO & NO & & \\
\hline $11-04-17$ & FHILIF STAEET & MOFSHFIELL SANE GFAUEL & 560 & $\mathrm{R}-1 \mathrm{~N}[\mathrm{I}$ & Fus & NO & HO & FFIVAT & 10208 \\
\hline $11-04-1 E$ & MVITLE STKEET & SYLVESTER A. RAY INE. & 701 & $\mathrm{~F}-1 \mathrm{NO}$ & YES & NO & No & PFIVAT & $J<45$ \\
\hline$\because i-04-Z i$ & GFQVE STEEET & ANRTEES LALKA & 20 & $\mathrm{R}-1 \mathrm{NG}$ & YES & NC & NO & & \\
\hline $1: 05-61$ & C_AY PIT KOAD IQEF) & SLYYESTER A. RAY INC. & NOKE & $\mathrm{Fi}-1 \mathrm{NO}$ & $\mathrm{NO}$ & HO & No & NO DIR & 6.5340 \\
\hline $1-05-2 z$ & CLAY FIT RDIEEOUE ST & TA56AFT VALENTINE & 400 & R-! NO & YES & NO & No & PUELIC & \\
\hline $11-05-05$ & GRSUE STREET & PAGE THIMAS $F$. & 360 & $\mathrm{Fi}-1 \mathrm{N0}$ & YES & NO & NG & & \\
\hline $1: 1-05-104$ & CIHF FIT FIAL (OFF) & SYLVESTEF A. RAY INE. & Nikite & $\mathrm{F}=! \mathrm{N}[\mathrm{I}$ & NO & No & NO & NE DIF & 21760 \\
\hline $11-00-12$ & SMEHEHILL KIDEE ROAD & MAEE DAVID & $310+C$ & $h-1 N$ & YES & NO & ND & PUSLIC & 4557 \\
\hline $11-0 t-13$ & EFTVE STREE & TEDESEHI SES_TY COPP. & 300 & $\mathrm{~F}-1 \mathrm{NEt}$ & YES & $\mathrm{NL}$ & $\mathrm{NO}$ & FUELIC & \\
\hline $11-06-14$ & SHOTEHILL RIJEE ROAJ & TEDESCHI REÁL'Y EOFF. & 130 & R-i NE: & YES & $N E$ & No & FUELIC & \\
\hline $11-60-22$ & SMEEHIL RUDE RLAD & TEDESCA GAVMUNE & 125 & F-1 NO & YE5 & nig & NE & USLIC & \\
\hline $11-i 2 t-24$ & SMIKEHILL RIDEE RLATD & FITZGIBEONS CHAFLES & 132 & $R-1 N O$ & YEE & $\mathrm{NE}$ & Nĩ & FLIBLIC & \\
\hline$H 11-0=-79$ & SMEREHILL RIDGE ROHE & TEDESCHI REALTY & 210 & $\mathrm{~F}-1 \mathrm{NO}$ & YES & NO & No & & \\
\hline$+1 !-06-72$ & HIEH BEARGAN HAYE & TEDESEHI REALTY COFP. & 50 & {$[i-1 \quad N]$} & YES & NO & No & & \\
\hline $4:-0 b-33$ & HTDH BEGOOA WATE & TEDESCHI REALTY OUFF. & 100 & $\mathrm{R}-1 \mathrm{NO}$ & YES & $N$ & $k E$ & PFIVAT & \\
\hline$H 11-60-34$ & HISH BEACEN HAYE & TEEESEHI REALTY CUOAF. & $1201+[$ & $\mathrm{k}-1 \mathrm{NO}$ & YES & $\mathrm{NE}$ & HE: & PEIVAT & \\
\hline $41 !-06-35$ & H]GH BEADEH WHY & TEDESCH] REALTY COEF. & $10+[$ & $\mathrm{F}-1 \mathrm{NO}$ & YES & No & NO & & \\
\hline$H 1 i-6 t-35$ & HISW SEHCON WAVIE & TEDESCHI REALTY COFF. & 120 & Fi-1 NLI & YES & No & $N[$ & FFIVAT & 5130 \\
\hline$H 11-60-3 i$ & H!GH BEAELW HAYE & TESESEHI FEALTY COFF. & $100^{\circ}$ & $R-1 N 0$ & YEZ & $\mathrm{No}$ & Nú & FFIVAT & \\
\hline $41 \mathrm{i}-0 \mathrm{~s}-38$ & HIGL SEACEN WAY & TELEECAI FERLT LUFE. & 100 & $\bar{B}-1 \mathrm{Ni}$ & YES & NO & NO & & \\
\hline$h: i-0 b-39$ & HIGH BEAEL̈N WASE & TELESLHI FGE TY COSF. & 128 & F-1 NE & YES & $N E$ & NO & PFIVAT & \\
\hline $4 i 1-06-40$ & SHUEEHLL RIGDE ROHD & HUITEHJREH DKAAE & $30^{5}+[$ & $\mathrm{F}-1 \mathrm{NL}$ & YES & $\mathrm{Nat}$ & NO & PUSL!C & \\
\hline $1911-46-43$ & EFUVE STFEET & FAEE THIRAS & 40 & $\mathrm{Bi}-1 \mathrm{NI}$ & YES & NJ & NO & If & \\
\hline $41-01-06$ & GRUUE STFEET & OUGO15 EUAHAL A. & 236 & F-1 NO & YES & HO & NI & PUELIE & 30326 \\
\hline $412-0 !-0 ?$ & CLAY FIT RULS (OFF) & SHLVEETER A. SAY INE. & NJNE & Fi-1 & NO & NO & H. & NG DIE & 18556 \\
\hline $412-02-01$ & GHLVE STREET & FLAGZ JDHK N. & 100 & $\bar{F}-1 \mathrm{NE}$ & YES & Nú & NO & FUSLIC & 20098 \\
\hline$h ! 2-(12-1) 4$ & EFDUE STREET & FLAGE JOHN N. & 80 & $R-1 N 0$ & YES & NO & NO & PUËLIC: & \\
\hline$H:-0-16$ & BRTUE STREE: & HACLINE CATHEF & 61 & $\mathrm{R}-1 \mathrm{NO}$ & YES & No & NO & PUBLIC & $4443 ! 2$ \\
\hline$H: 2-0,2-17$ & SMUKEHILL RIDGE ROAD & TELESCHI REFI & $12 !$ & $R-1 N j$ & YES & NO & NO & PUELIC & 66647 \\
\hline $412-02-18$ & SMDKEHILL FICGE RULE & CONTINUITY REË & 125 & R-1 NO & YES & $\mathrm{Noj}$ & NE & PUE! IC & \\
\hline $113-02-01$ & SILVEEEIFSH RIGD & FUSTEF COKSTRUETION COFF. & 150 & $R-1 \mathrm{No}$ & POS & $N G$ & NG & PRIVAT & \\
\hline $2-02$ & HULLY RLAD & FOSTEF CONSTRULTION CORF. & 150 & R-1 NO & YES & $N[$ & NG & FRIVAT & 4356 \\
\hline $115-02-63$ & HULLY RUAD & FOSTEF CONSTKL & 155 & $\mathrm{~F}-1 \mathrm{NO}$ & YES & NO & $\mathrm{NO}$ & PEIVAT & (2) \\
\hline $1 ! 3-0 \overline{2}-0 E$ & CHURCH STFE & DAVIS BESEIE & 317 & $\mathrm{~F}-1 \mathrm{ND}$ & YES & NO & NO & FUBLIC & 30927 \\
\hline $15-0,-20$ & FEREY STF & T.R. CARGOLL CERF. & 141 & $R-1$ NE & YES & 4 & NO & PUELIC & 4356 \\
\hline $13-02-25$ & FEREI STEE & AREVIA JOHI & 50 & Ri-1 No & YES & NÜ & HO & PUELIC & 2500 \\
\hline $115-03-04$ & FEFFYY STEEET & MARION REALTY TRUET & 80 & R-1 NI & YES & MU & NO & FUBLIC & 255305 \\
\hline $113-03-06$ & FERFY STKEET & KENKEOI JEAN & 120 & $\mathrm{~F}-1 \mathrm{NL}$ & YES & Nū & No & FLIELIC & 2004 \\
\hline $15-0.3-69$ & GEOVE STRE & TEDESENI REÁLYY & NONE & $\mathrm{R}-1 \mathrm{NB}$ & YES & NO & $\mathrm{NE}$ & NE DIK & 240395 \\
\hline $13-0.3-14$ & FEFF'Y STFEET & CUNLIN RUGEAT $F$. & 100 & $\mathrm{~F}-1 \mathrm{NO}$ & YES & NE: & NG & FLELIL & 2000 \\
\hline $115-0 . j-15$ & FERF STREET & MENOEICE GHENLES YG & $! 0 !$ & R-1 NO & YES & $N E$ & Nĩ & PUSLIC & $200 !$ \\
\hline $\mid 14-0 !-0 !$ & HJULY FIJAL & FOSTER CONSTRLETION CQRE. & 157 & $\bar{h}-1 \mathrm{NC}$ & YES & $N G$ & NO & PFIVAT & 435 \\
\hline$H 14-0 !-02$ & HELLLY ROAND & FOSTER CONSTRLCTION CUFF. & $156-5$ & Fi-1 Ni & YES & $N{ }_{L}$ & 10 & PFIVAT & 40.96 \\
\hline $414-02-01$ & SILVERERET REAL & FOETEF CONETFLETIOH CUEF. & 150 & $F-1 N E$ & YES & $\mathrm{NII}$ & NG & PFIVAT & 435 \\
\hline $114-02-02$ & SILVERERLH REHO & FQSTER CONSTRUTTION COEF. & 150 & $\mathrm{R}-1 \mathrm{NO}$ & YES & Nü & NJ & FFIVAT & \\
\hline $414-02-03$ & SILVEFEIATH ROAE & FOSTEF CONETRULTIOH CQRF. & 150 & $R-1 N$ & FOE & NO & NO & PFIVAT & 407 \\
\hline $114-62-114$ & SIVEREIFCH SOÁ & FOETER CENSTFUSTOA LUFF. & 15 & $F-1 N E$ & YES & N! & No & PEIVAT & 455 \\
\hline
\end{tabular}


A5. MSE-LOT LOCETIL,

QWNER OF RED

HI4-02-0EA SI_VEAEIFEH RLAD

HI4-02-C6A STLVEEEIS- FOHA

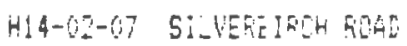

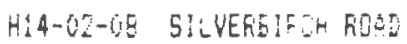

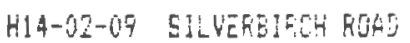

H14-0C-16 SILVERGIFI ROAE

HI4-02-1! BEYEEFFY DRT VE

HI4-012-12A HULL Fü

$H: 4-O 2-17 A$ HE L F FiA

HIT-O2-IEH HOLL RLAL

HIA-OL-19A HOLLY FIAD

H14-63-05 BEYBEFF: OTIVE

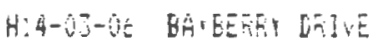

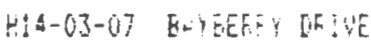

H:A-CO-GE BATEEAR' DFILE

H:4-0E-65 GE GELF: DFILE

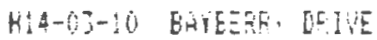

H14-03-!I ERTARWIS RUA?

H]4-03-:2 BFIARIDOE FUAL

H:4-04-C1 GAYGETSY DFIVE

HIA-04-OE EAYEEREY DFIVE

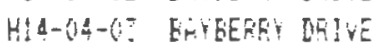

H:4-OU-OA BAYEEREY DETUE

HIA-64-CE BEYEERY DBIHE

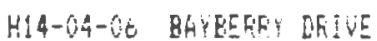

HI4-(i4-07 BFOEERGY DFIVE

H14-014-OE STLVEREFTH FOAT

H:4-04-05 SILUEREIRCH KLAT

HI4-04-10 SILVEREIFCH RUAL

H:4-14-11 SILUEGEIPTH FIFE

H:4-14-12 SILVESETFCH KRAL

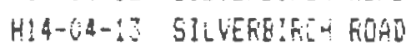

HAA-04-14 SILVEREIRCH ROAHD

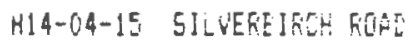

H14-06-10 SILVEREIACH FIALE

F14-14-17 SILVEGBIFICH ROAE

RI4-04-18 FEFTiY STFEET

HIS-01-019 CHLFCH STEEET IREAS SYLVESTER FHILIF

H15-01-10 CHISFEH STREET IFEAS SYLVESTEF FHILIF

H:5-02-01 SLIMEE STKEET

M15-02-014 ELM STREET

HI5-6L-04 BRIAFWCO FIAD

H:5-67-01 THIETIE FOAS

HLE- $97-02$ THISTLE ROAD

HL5-07-0? THISTLE RUAD

HIS-67-68 BRIAFHEOL ROAL

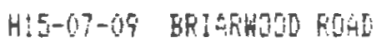

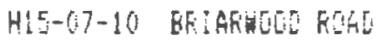

HIS-67-11 BAYYEERFY DRIUE

HLE-07-12 GAYBERF: ORILE

H15-07-13 BAYEEFF" [DTVE

H1E-17-14 EHYEEFFY DFIME

HILOE-TO BOLES FOAL IREAG:
FOSTER CONSTRLCTIOR CORF.

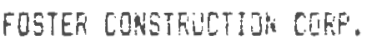

FESTEF CINSTRULTIO, CORF.

FOSTES CONSTRULTION COFF.

FOSTER CORSTRUSTIOH COFE.

FOSTEF CONETRUCTIOR COFE.

FOSTER IORETR:JLTION GOER'. HUFY:HED JOHN

FETTEF COHSTALT] IEN CORE.

Fuster CONETRLICTUUN LURF.

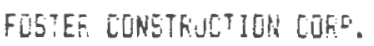

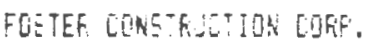

FOSTER CUKGTELTIDI CORE.

Fústé Cras? FurTIOA COR.

POSYẼ LINETR DCTIOA CORE.

FUSTEF CONSTFUCTION CQR:.

FUSTEF CONETFUCTIOK CERF.

FOSTEF CONSTFULTILA COFF.

FUSTEF CONSTR LCTION CORT.

FOETER CURETFUCTION CORE.

FUETER CONGTRULTIOH CORF.

FUSTER COASTEUCION CORP.

FGSTER CaKSFTUG IU: CORF.

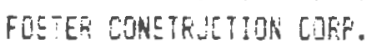

FDETER COHSTRUETIUN CÜF.

FLETER CONETEUTIOAN CORE.

FuETER CERETRICTIUN CLEFE.

FUSTEF ETRSTKUTIUEN EUPF.

FOSTER CONSTULTID LER.

FUETER CURE BSLTIOR CORF.

FOSTER COKSTRULTION CORE.

Fostef COKSTRUCTIOH CORF.

Fuster CONEThUCTION CORF.

FOSTEA CONSTRULTILN COFE'.

FOETEK CONETRUCTON CORF.

FOETER CONSTFUCTION CORE.

TF. CARFUUL CUKF.

FUSKER ETELIR

HÁt HAOELIRE RAEEL

FUSTES CONSTHLTIUN CULF.

FUSTER COENETKUETION CEFF.

FOSTER COKSTR ICTION COFE.

FOSTER CONSTHUETIOK COFC.

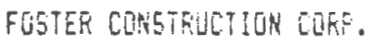

FUSTER CONETRUETJON CORF.

fuster CORETRLTIJA COFE.

FUSTER CUNSTEUCTIOL COFF.

FESTER CONETWU ION CLFF.

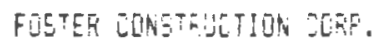

FISTER CONETRULTION CÜR.

NEFIEE GEGPEE
FRUNT ION SEM WOT WET FF'A ACCESS AREA SF

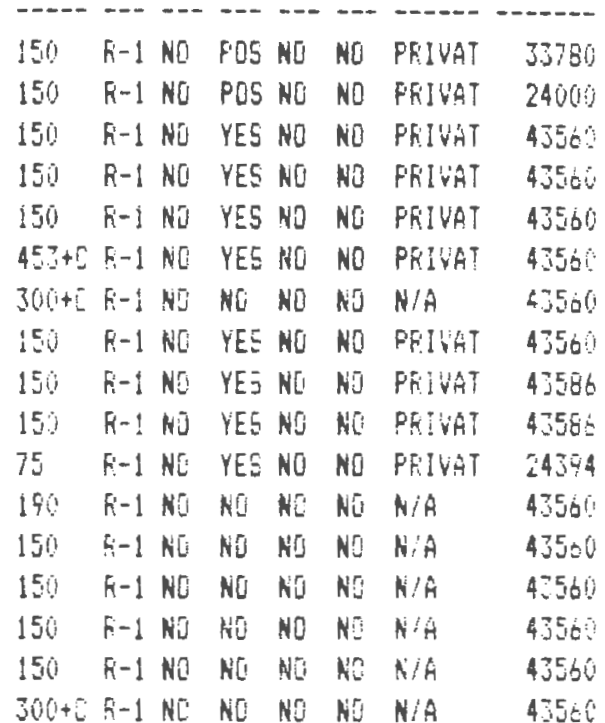

150 Fi-1 KS NO ND NO N/A 13566

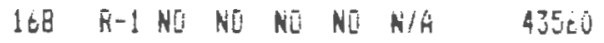

162 Fi-1 KO NO NO NE N/A 43560

162 R-1 NE NO NO NIS N/A $435 E$.

162 R-1 NO NO NE NO W/A 43560

$140+[$ Fi-1 NO NJ ND NII N/A 43560

$145+C$ F-1 NO NE NU NO N/A 47916

16.3 Ri-1 NO ND NJ NO N/A 43560

163 Fi-1 NO HO NG NO N/A 43560

$454+5$ Fi-1 ND YES NE NE PRIVAT 43560

15i F-1 NO YES NO NO PFIVAT 43560

.50 Ri-1 NO YEE NJ NE PRIVAT 4550

150 FI-1 NO YES WO NO FRIVAT 4356

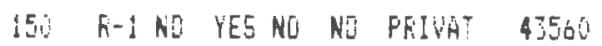

150 R-1 NO YeE nO RD PRIVAT 43560

150 R-1 NI YES NO NI PEIVAT 43560

15! Fi-1 NO YES NO ND PRIVAT 43560

15! Ri-1 NŨ FLS NO NE PRIVAT 435tí

153 R-1 NO YES NO NU PEIVRT 43550

$125+$ FI-1 NO YES NI NU PUELIC 3267600

NTHE Fi-1 NI HE YES YES KC UIR 51086

6) Fi-1 NO YES YES YES NE IIF 325EC

I8E R-1 NS YES YES YES FUELIC 16960

98 R-1 NC YES NO NO FUELIE 1000

267 R-1 NO NGI NII NO N/A 4350 ?

255 R-1 NO POS YES NJ FFIVRT 435 E?

150 R-! NU PUS YES NE FRIVAT 43560

150 F-I NO FLS YES NJ FRIJUAT 4J5G:

170 F-1 NG NO NO NO N/A 43560

212 B-! NDS NJ NO NO N/A 43565

161 R-1 NO WO NO NO N/A 43500

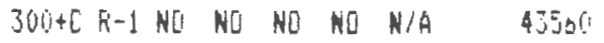

163 F-1 NO NO NO NO N/A 4356

163 F-1 NII NO NO NO N/A 43560

163 R-: NO NO NO NE N/A 43560

100 Fi-I NO YES NE NE FRIVRT 7840EE 


\begin{tabular}{|c|c|c|c|c|c|c|c|c|}
\hline 5. HAF-LDI & LOCHIIUN & Q UKKEF OF REC & FFDiti & & WHT KET & FFE. & ACCES5 A & AFEA SF \\
\hline & & & & & & & & \\
\hline $5-96-12$ & THISTLE FIAL: & FOSTER CORSTRMCTUON COFF. & 260 & $\mathrm{~F}-1 \mathrm{~kJ}$ & POS YES & Nĩ & & 21780 \\
\hline $5-69-13$ & HGLLY FGHE & FOSTER CONETRULTION COKE. & $2^{\mathrm{T}}$ & $\mathrm{F}-1 \mathrm{NO}$ & YES NU & N0 & FEIVUAT & 1580 \\
\hline $5-.2-63$ & EMEEY KIAL & TILLER CHRISTOFHEF & 324 & $\mathrm{R}-1 \mathrm{NO}$ & YES NU & No & FUELIC & 10580 \\
\hline $5-14-114$ & EMEKT ROAL & FICARDI ANEELU & 475 & $\mathrm{~F}-1 \mathrm{NG}$ & YES NŨ & NO & PUELIL & 52272 \\
\hline $5-14-12$ & HOLLY ROÁE & KILEY MERY E & & R-1 No & YES ND & NO & PFIVAT & 10400 \\
\hline $6-02-05$ & CEDAR ACRES ROAD & SCITUATE CQNCRETE FIPE CORF. & 129 & & YES NO & ND & PUELIC & 19000 \\
\hline$-01-01$ & PUFTHE STREET (OFF) & PFilWCE OÚFI5 J. & NCAE & $\mathrm{F}-1 \mathrm{NO}$ & WO YES & No & NU DIR & 202554 \\
\hline $5-01-15$ & MUSAINE STFEET & DELANO HERMÁRK \& FLUFERSE & 200 & Fi-1 NJ & YES YES & NO & PUELIC & 158123 \\
\hline$-61-20$ & KEUE: 5TREET & FFINCE LEE E. & NGLE & $\mathrm{F}-1 \mathrm{NO}$ & NO NE & NC & NU DIK & 6750 \\
\hline $104-01-01$ & MURAIHE STKEET & CHANELER RLSSELL & 125 & $R-1 N$ & YES NO & No & PUE_IC & 533610 \\
\hline $4-62-019$ & REǴR STAGE COAREH OSI & NEW BEDFUKL GAS \& ELECTKIC & 40 & $R-1 N G$ & NO POS & P05 & NO DIF & 213444 \\
\hline $6-02-11$ & FHESOUAEE STREET & MULLLEN LLURE & $380+[$ & $\mathrm{B}-1 \mathrm{NO}$ & YES YES & YEL & FUELIC & 740520 \\
\hline $1-14-14$ & HIAEHEQ A & KELLEY LEC $A$. & 170 & $\mathrm{~F}-1 \mathrm{~N}$ & NO NO & NO & PRIVAT & 10000 \\
\hline $112-01-01$ & SUITH REV & REALTY TRUST & NUNE & F-1 No & NI YES & NO & NO DIF & 1078110 \\
\hline $112-01-10$ & SULTH Fi? & WILLIAYE ERS & 101 & & YES ND & No & FUELIC & 21400 \\
\hline $112-01-11$ & SOLTH R!V & WILLIA & 120 & & YES ND & No & UELIC & 21600 \\
\hline $112-61+12 z$ & Sujth Fivi & WILLIAME BKIE & 103 & & YES $\mathrm{NOT}$ & NO & IELIC & 20700 \\
\hline $112-01-13$ & SOUTH FIVER & HILLIAME BROES.: & $9 \overline{8}$ & & YES NO & NO & ILIC & 20450 \\
\hline $112-01-10$ & Sollth RIV & WILLIAME ER: & 80 & $F-1+2$ & YES YES & $\mathrm{NI}$ & UELIC & 885137 \\
\hline $112-02-015$ & SELITH RIVE & TAGGE & $35 . j$ & $\mathrm{~F}-1 \mathrm{ND}$ & YES & NE & ELIi & 78498 \\
\hline $112-6 \bar{i}-6 i$ & SCUTH RIVEF STREET & ARDER & $145+[$ & Nis & YES YES & Hi & PUELIC & 152460 \\
\hline $112-03-03$ & QUEELCOK RLAE & 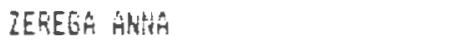 & 80 & ND & P0S No & NE & $N / A$ & 8000 \\
\hline $112-05-044$ & MIFNESOTA STFEET & MEYEFS FAJLL & 100 & & YES $\mathrm{NO}$ & No & FIVAT & 8000 \\
\hline $112-0.5-04$ & HJWHESOTÁ S & MEYERE FGUL & 100 & NS & YES NO & NO & PRIVAT & 8000 \\
\hline $112-0:-05$ & INDIAKS STFEE & TAGGGAT VALENTIH & 40 & $R-1 N O$ & NG YES & NO & PRIVAT & 4000 \\
\hline $1 ! 2-04-6 !$ & SOUTH FIVEF STKEET & FOESIEHT FOUKDATION & 120 & $\mathrm{R}-1 \mathrm{NO}$ & YES NO & NO & FUE IC & 10000 \\
\hline$z-014-02$ & INUIAKS STEEET & EEY PA!I_E & 170 & $\mathrm{R}-1 \mathrm{NO}$ & NO YES & No & FFIVAT & 12000 \\
\hline $2-42-63$ & INUIAN & JOYCE HELEN L & $18 ?$ & $\mathrm{~K}-1 \mathrm{Ni}$ & NE YES & NC & PFIVAT & 22500 \\
\hline $2-04-015$ & MISHES & CHURCh & 40 & & YES WJ & NO & PEIVAT & 4000 \\
\hline $11 ;-04-06$ & INHESOT & BAYER: & 60 & & YES ND & NE & FRIVAT & 6000 \\
\hline $2-04-67$ & RIVEF STREET & JGTCE & 100 & $R-1 N 0$ & YES Nó & NO & FLE:IC & 8500 \\
\hline $2-05-01$ & WHIIE DK. & ETHAN ALLAN BRT & 300 & $\mathrm{R}-1 \mathrm{NO}$ & YES NO & NO & PFIVAT & $6969 \mathrm{c}$ \\
\hline $2-05-10$ & PEFEEFINE WUITE Oh. & ETHAGL GLLAN BROLAS TRLLT & 230 & $\mathrm{~K}-1 \mathrm{NO}$ & POS NO & No & PEIVAT & 27370 \\
\hline $3-01-01$ & ERTYY & MAURAR: & 246 & $\mathrm{R}-1 \mathrm{NO}$ & YES NO & NO & PLiBLIC & 40533 \\
\hline $3-31-14$ & ERFY & 5 Ghos.1kt. & 102 & $R-1 N E$ & YES ND & NI & PUE:IC & 95832 \\
\hline $0.3-15$ & EF STREET & A JOSE & $700+C$ & $\mathrm{k}-1 \mathrm{NO}$ & YES YES & NO & PUELIC & 1514146 \\
\hline $3-04-01$ & SOUTH FIVEF STREET & TOHNE & $390+c$ & $\mathrm{~F}-1 \mathrm{ND}$ & YEE YES & No & FUB:IC & 65340 \\
\hline $3-05-63$ & BUNNY LANE & DEH E & $15 i$ & $\mathrm{R}-1 \mathrm{NO}$ & POS NO & NO & PRIVRT & 45738 \\
\hline $06-0 z$ & 60 & NANCY LEE & 45 & $\mathrm{R}-1 \mathrm{NO}$ & YES YES & No & PUELIC & 87120 \\
\hline & h & & $46 !$ & $\mathrm{R}-1 \mathrm{NO}$ & YES N! & $\mathrm{Mu}$ & PUELIC & 32760 \\
\hline & ILE & LUND & $200+[$ & $R-1 N 0$ & POS POS & No & PFIVAT & 24000 \\
\hline & F. STREET & FALLUTIÁ JOSEFH & 169 & $\mathrm{k}-1 \mathrm{Ni}$ & YES FUS & NO & PUELII & 54014 \\
\hline $113-08-0\}$ & FILGKIM & FAGE MILTQN 5. & $120+C$ & $\mathrm{R}-1 \mathrm{NO}$ & YES YES & Ni & PRIVAT & 36000 \\
\hline $113-08-04$ & FILGH & HAM:LLTON GETTY JARE & $200+c$ & $\mathrm{R}-1 \mathrm{No}$ & PUE YES & Nõ & PEIVAT & 104544 \\
\hline $113-68-10$ & PILGSTIM KÜÃO & NOOS GEOKGE A, JF. & 100 & $\mathrm{R}-1 \mathrm{NO}$ & POS NL & Ni & PRIVAT & 23000 \\
\hline $1-i j 6$ & INDIG & KELLY RUEEERT D & 182 & $\mathrm{R}-1 \mathrm{NO}$ & YES NO & NU & PUSLIC & 130680 \\
\hline $1: 4-0.5-61$ & FEFEY STE & WILLIAMS GKOSS. INE. & 101 & $\mathrm{R}-1 \mathrm{NO}$ & YES NO & NO & FUELIC & 74052 \\
\hline $114-65-10$ & FEHEI STREET & MEDONIEEL MICHAEL & 121 & $\mathrm{~F}-1 \mathrm{NO}$ & YES YES & NO & FUB:IC & 23320 \\
\hline $1: 4-63-12$ & NAFIEF RD.\& FEFFY $5 T$ & GEENGRDI KATHLEEN & $306+c$ & F-1 Na & YES NI & NO & PUELIC & 25230 \\
\hline & 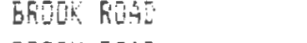 & MCFAE FICHADE & 201 & F-1 NG & YES NO & No & PUELIC & $316 \times 0$ \\
\hline $4-63-22$ & BRCTKK READ & NEREEF GEURËE & 200 & $\mathrm{R}-1 \mathrm{NO}$ & YES NI & WO & FUELIC & 52272 \\
\hline $4-61-2 i$ & FEFFY STREET & EELEFITH [LIVEF & 101 & $R-1 N E$ & YES YES & 100 & FLLELIC & 171191 \\
\hline $0-61-14$ & CAHESKELL STFEET & HALL LIMOUEA & 70 & F-1 NO & NG YES & $N_{5}$ & FLELIC & 252643 \\
\hline
\end{tabular}


JOL-OS-15 [AFESWELL STREET

JOS-CZZOI STEAMEOAT DFIVE

30T-02-04 STEAMECAT DRIVE

JOS-0 $3-07$ CAREJHELL STREET

J04-6J-36 CASWELL STREET (GFF) ALBEFT SCHOFIELD REALTY

JO4-03-4E WEQETEF STFEET (OFF) RUGAHI GINO

1O4-CS-5C PILEI TKAIS ZAIA GALE A.

JO4-0S-5. HEESTEC STREET (OFF) MINELLI ERNEST III

IO4-03-54 WEESTER STREET (CFF) ARTHES ROEETT

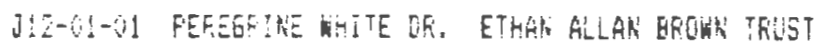

112-01-02 FEREGRINE HHITE DR. ETHAN ALLAN EFUUNA TFUST

312-01-04 FEREETINE WHTE OF. ETHAN ALLAN BEOWR TRUST

312-01-05 PEFEGFINE HHJTE DF. ETHAN ALLAN BF.JWH TKUET

J12-0!-OE PEREGRINE WHITE DF, ETHAN GLLAN BROHL TRUST

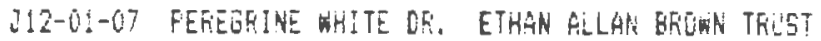

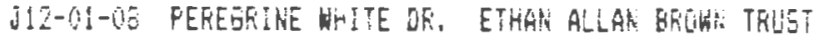

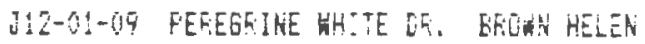

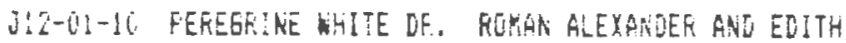

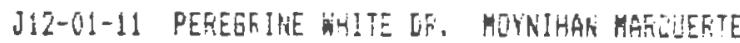

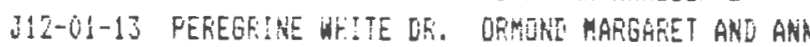

JIZ-0!-14 PEREGRIHE HHITE Dh. OEMOMD ELIZAEETH

II2-01-15 5ULTH RIVEF STREET SMITH DAVIOA.

J12-Ô1-17 INUIANA STREET

312-01-1E IND?AKS STFEET

J12-0I-20 INEJAHA STREET

J12-01-21 INGIAKA STEEET

J12-01-23 INIIAHE 5TFEET

J12-0:-24 INDIANA STREE:

J12-01-20 INWIAHA ETFEET

$312-01-27$ IND!ARA STREET

$J 12-v i-0$ GE EREETER RJAI

I:2-0I- 27 FEEHSTER RUALI

J1\%-0Z-08 GKEHEIEF ROAD

J12-02-1C HEELTEF ROCD

J12-02-13 GEOKGIA STREET

JI $Z-02-14$ GEORIGIA STREET

$J 12-0 Z-15$ GEOGRIA STEEET

1!2-02-17 GEOKG!H STREET

JI2-02-1B 6EOSEIA STREET

Ji2-0J-0I? SUITH FIVER ST. (CFF)

$313-0:-0 E$ FILGRIM ROAD (UFF)

J14-OI-14 RILGE ROAD (REAS!

JOS-0Z-02 STEAMEDÁ DFIVE

$105-0:-62$$$
\text { CASHELL STHEET (OFF) }
$$

(13-O:-04 CA5IIELL STFEET (OFF)

K04-0!-05 HEESTEF STFEE?

UOC-OO-44 AKLREGE AUENUE
UKMONE ELIIAEETH

BFUWN HELEN $A$.

ETHAN ALLAN EKTHN TE!JST

MGTSTSIÁR ALEREL A.

GEGGGAN HILLIAM

MGHGLIAIA GLEAN

ETHAN ALLAN EROAH TRUST

JOYOE MEESITT MASILYN

WILSUN MAEY GAME

BRUIR: HELEN A.

MUFFitY JUHA E.

MUEPHY JJIN E.

HELEN A. BFUHN

HELEN A. BFOHA

CHAX̃LLES H. MLKENKEY

MAET ELEANOK RICHARI

CHALEEES H. MEKENNEY

PACKARD KENKETH J.

SEÁ FIVESS TRUS

COKFIGEAT JAMES

MC HUSTY RLEEFT

COFFIN JAMES

CHVAGALISH CHÁLEE

A HEfiñ INC.
HALL LINEJUAN

\begin{tabular}{|c|c|c|c|c|c|c|}
\hline 415 & R-1 NU & NO & YES & NJ & FUELIS & 400752 \\
\hline 25 & $\mathrm{~F}-1 \mathrm{NO}$ & IES & $\mathrm{Nu}$ & NO & PUÉLIC & 43585 \\
\hline & $\mathrm{K}-1 \mathrm{NO}$ & YES & $\mathrm{NO}$ & NO & PUBLIC & 20041 \\
\hline NHE & $R-1 N 0$ & NO & YES & YES & No Dik & 703929 \\
\hline & $R-1$ NO & NO & YES & ND & NO DIK & 768834 \\
\hline & $\mathrm{k}-1 \mathrm{NO}$ & Pos & $\mathrm{NO}$ & NO & NO DIK & 261360 \\
\hline & $\mathrm{K}-1 \mathrm{NO}$ & PUS & NO & NO & FEIVAT & 43560 \\
\hline & $5-1 \times 0$ & FuS & NO & No & $k / A$ & 88426 \\
\hline & $\mathrm{K}-1 \mathrm{NO}$ & $\mathrm{NO}$ & NE & $\mathrm{Ni}$ & NE DIK & 1838232 \\
\hline & Fi-1 kis & POS & $N 5$ & Nis & PEIVAT & 10000 \\
\hline & $R-1 N O$ & POS & $\mathrm{NO}$ & NO & PRIVAT & 10000 \\
\hline & $6-1+5$ & F05 & YES & $N$ & PFIVAT & 6000 \\
\hline & $\mathrm{R}-1 \mathrm{~N} \overline{\mathrm{B}}$ & P05 & $\mathrm{NO}$ & No & F'FIVAT & 4000 \\
\hline & $k-1 N 0$ & $P 05$ & YES & NE & PFIVET & 4000 \\
\hline & $K-1 N E$ & 805 & YES & $\mathrm{HJ}$ & PEIVAT & 4010 \\
\hline & $R-1 \mathrm{NO}$ & P05 & YES & $\mathrm{No}$ & PKIVAT & 6000 \\
\hline & $F-1 N 5$ & POS & YES & $N \bar{~}$ & FFIVAT & 10000 \\
\hline & $\mathrm{R}-1 \mathrm{NO}$ & POS & YES & No & PFIVAT & 4000 \\
\hline & $\mathrm{k}-1 \mathrm{~N} \cdot \mathrm{j}$ & F0S & YES & $\mathrm{NO}$ & FFIVAT & 6090 \\
\hline & $\mathrm{k}-1 \mathrm{NO}$ & FOS & $N E$ & 150 & FFIVAT & 10018 \\
\hline & $\mathrm{R}-1 \mathrm{NO}$ & FOS & $\mathrm{No}$ & $\mathrm{NE}$ & PFIVÁT & 2000 \\
\hline $\mathbb{N}$ & $\mathrm{F}-1 \mathrm{NO}$ & $\mathrm{NO}$ & NO & NO & NU DIF & 100158 \\
\hline & $\mathrm{R}-1 \mathrm{NO}$ & POS & NE & $\mathrm{NO}$ & FEIVAT & 6000 \\
\hline & $\mathrm{B}-1 \mathrm{NO}$ & POS & No & No & FEIVAT & 20037 \\
\hline & $\mathrm{R}-\mathrm{NG}$ & NO & YES & HO & PRIVÁT & 4000 \\
\hline & $R-1 N 0$ & P05 & VES & $\mathrm{Nu}$ & FRIVAT: & 4000 \\
\hline & $R-1 N O$ & POS & YES & $\mathrm{NE}$ & FKIVAT & 2000 \\
\hline & F-INC & POS & YES & NO & PÉIVÁT & 6000 \\
\hline & $\mathrm{k}-1 \mathrm{NO}$ & FOS & NO & Nõ & FRIVAT & 4000 \\
\hline & $\mathrm{F}-1 \mathrm{NO}$ & POS & NO & N0 & FRIVAT & 6000 \\
\hline & F-: NU & $N 0$ & NO & YEE & FRIVAT & 6090 \\
\hline & $k-1 N 0$ & NO & No & YES & PKIVAT & 6000 \\
\hline & $\mathrm{K}-1 \mathrm{N0}$ & NO & Nô & YES & PFIVAT & 10000 \\
\hline & fi-1 $\mathrm{ka}$ & $W[i$ & $\mathrm{H}_{0}$ & YES & PEIVAT & 12000 \\
\hline & $R-1 \mathrm{NU}$ & No & YES & YES & FEIVAT & 4000 \\
\hline & $k-1$ No & NO & YES & YES & PRIVAT & 10000 \\
\hline $60+5$ & $h-1 \times 0$ & $\mathrm{No}$ & YES & YES & PFIVAT & 13006 \\
\hline & $R-1 N 0$ & $\mathrm{No}$ & YES & YES & FRIVAT & 8000 \\
\hline & $R-1 N E$ & No & YES & YES & FFIVET & 24000 \\
\hline & $R-1 N D$ & NO & YES & YES & Nú DIF & 1001880 \\
\hline & $\mathrm{F}-1 \mathrm{NG}$ & $\mathrm{No}$ & YES & YES & NO JIK & 1912284 \\
\hline & $\mathrm{R}-1 \mathrm{NC}$ & YES & No & No & PUE:IC & 252648 \\
\hline $0+\tilde{L}$ & K-1 NO & YES & NO & NO & PUELIC & 43566 \\
\hline & F-1 NO & NC & 10 & $N E$ & NE Dif & 967032 \\
\hline $\mathbb{N E}$ & $\mathrm{B}-1 \mathrm{NC}$ & $\mathrm{ND}$ & NO & $\mathrm{Nu}$ & NE DIF & 43654 \\
\hline \multirow[t]{2}{*}{420} & $\mathrm{~F}-1 \mathrm{ko}$ & YES & No & Ni & PUSLIC & 740520 \\
\hline & Ri-1 Ni & YES & 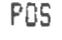 & NO & PUSLIC & 435606 \\
\hline
\end{tabular}

TUTALS:

AREA ST $13 ! 257.227 .93$

Frinted 685 of the 1955 records. 


\begin{tabular}{|c|c|c|c|c|c|c|c|c|c|}
\hline AS. MAF-LOT & LoLGi]Chi & OHNEF OF REC & FKOKNT & ION SEH & HAT & HET & $F F A$ & ACCESS & AREA SF \\
\hline & ------n-- & 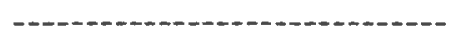 & & & & & -- & $-\cdots-.-$ & \\
\hline$[15-02-6 t$ & FINE STREET & JUNIOF RUEETT \& DRẼTH & 531 & $\mathrm{~K}-2 \mathrm{NO}$ & P05 & YES & NS & PUEL!C & $76926 ?$ \\
\hline $05-6 !-1 !$ & 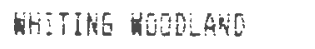 & EUNREY RIEEET & NO & $\mathrm{R}-2 \mathrm{NE}$ & YES & YES & NO & PUELIC & 392640 \\
\hline$: 10-64-04$ & AHOFENS AVERUE & MARSHFIELD MED \& DENTAL CEHTER & 167 & $\mathrm{Fi}-2 \mathrm{NO}$ & YES & NO & NO & PUELIE & 47044 \\
\hline $0 \bar{E}-05-63$ & CHEE STFEET & CAEFERTER ELANCHE & $100^{\circ}$ & Fi-2 NG & YES & YES & YES & PUELIC & 10650 \\
\hline $0 \bar{E}-602$ & FLAIN STREET & THINESOUDR HOLSE REALTY & 720 & $\mathrm{~K}-2 \mathrm{NG}$ & YES & YES & YES & FUELIC & 43560 \\
\hline $69-01-05$ & FLAIN STEEE' & EAEAGN FGEEFT & 40 & $R-2 N$ & YES & NG & $N[$ & PUELIC & 901692 \\
\hline $15-61-16$ & FLAII STREET & SEHATZ MAFIE & 53 & $\mathrm{~F}-2 \mathrm{~N}[\mathrm{I}$ & YES & NO & NO & PUELLIC & $121 . \mathrm{jE}$ \\
\hline$(4-19-16$ & FLALI SIREET & SCHATI MaEIE & 40 & $5-2 \mathrm{NO}$ & YES & YES & ND & PUBLIC & $1176 ! 20$ \\
\hline$F 05-[5-17$ & FLÁL STPEE & EEFNISA JAME & 695 & $\mathrm{~F}-2 \mathrm{NO}$ & YES & $N 0$ & No & FIIBL:L & 496598 \\
\hline $05-3 i-5 i$ & FLAIN STFEET IFEAEI & FLAIN STKEET REALTY TFUST & NE & $F i-2 N O$ & no & FOS & ND & NO 015 & 266152 \\
\hline $04-04-01$ & FLA:N RYEL/SAND: HILL & BEFNICK JANE H. & $967+i$ & $\mathrm{~B}-2 \mathrm{NC}$ & YES & $N G$ & NO & PUELIC & 16000 \\
\hline$F: 0-0 ;-6 j$ & FLAGEER RTA? & FHINNEY EDLAFD & 213 & $\mathrm{R}-\boldsymbol{i} \mathrm{NO}$ & NE & NO & NO & PRIVAT & $\$ 31967$ \\
\hline $668-45-15$ & SOUTH KIVEF STFEET & BLINSTKUE WILLIAM & 158 & $\mathrm{R}-2 \mathrm{~N} !$ & YES & $\mathrm{NG}$ & NO & PULELIC & 20448 \\
\hline ESE- $(7-: 1$ & SUUTH RIVER STREET & MULIEKS MATTHEH & NCINE & R-2 N! & $F 05$ & NO & NO & FUELIC & 34848 \\
\hline $604-01-05$ & REAF NEW STREET & DAYIS CHAELES & NONE & $\mathrm{R}-2 \mathrm{NO}$ & No & YES & YES & NO DIF & 5880 \\
\hline $609-0 !-16$ & NEH STREET & LEMEY PEFFY & 20 & $5-2 N 0$ & YES & $N 0$ & NO & FUELiC & 2590 \\
\hline $609-01-16$ & NEH STAEET & DÁVIS CHARTLES & 130 & $\mathrm{R}-2 \mathrm{NO}$ & YES & YES & NO & FUBLIC & 17167 \\
\hline $609-04-15$ & MEIN STREET (OFF) & GSIFFEN ELAINE J & NGLE & $\mathrm{F}-2 \mathrm{NO}$ & NO & YES & NO & MU IIF & $87 ! 20$ \\
\hline $609-04-16$ & MEIN STREET (QIEF) & MAFIOK REALTY TFUST & NONE & $\mathrm{B}-2 \mathrm{~N}[\mathrm{I}$ & $\mathrm{No}$ & YES & Nũ & No DIf & 261360 \\
\hline $40-05-25$ & METIKGHEE LARE & MULiER LUMEEF CO. IML. & $155+5$ & $\mathrm{~F}-2 \mathrm{NE}$ & YES & No & Noj & PFIVAT & 20032 \\
\hline $16 t-6 b-11$ & MAFTINGALE LARE & MULLEN LLMEET CI. INE. & $206+c$ & $\mathrm{R}-2 \mathrm{NE}$ & YES & HO & NO & FFIVATT & 20204 \\
\hline $\mathrm{Hin}-0 \mathrm{O}-12$ & MAGTINGALE LANE & RULLEN LUMEEF CO. INC. & 169 & $\mathrm{~F}-2 \mathrm{~N}$ & YES & No & No & PFIVAT & 20015 \\
\hline$H: t-0 b-15$ & MAETTHEALE LANE & MULLEH LUMEER CO. INE. & 120 & $\mathrm{~K}-2 \mathrm{NI}$ & YES & $\mathrm{No}$ & HO & FFIVAT & 23703 \\
\hline Hio-0b-15 & MGETINGËLE LANE & MULLEA LUMEER CO. IAL. & 127 & $\mathrm{R}-2 \mathrm{NO}$ & YES & NO & NO & FRIVAT & 65340 \\
\hline $196-0 b-16$ & MAFTIHEALE LAKE & MULEN LUMEET CII. INE. & 171 & $\mathrm{R}-2 \mathrm{~N}[$ & YES & NŨ & $\mathrm{NO}$ & FRIVAT & 27569 \\
\hline Hin- $0 t-17$ & MAFT IRIGALE LALE & MULLEN LUMEET CO. INC. & 138 & $\mathrm{~K}-2 \mathrm{AB}$ & YES & HO & NU & FFIVINT & 20097 \\
\hline Hot $-60-10$ & MARTINGALE LAME & MULLEN ULMEEK CE. INC. & 139 & $\mathrm{R}-2 \mathrm{NO}$ & YES & kO & No & PRIVAT & 20016 \\
\hline $40 t-6 \sin -19$ & MAETINSEA_E LAHE & MLLLEN LUMEE CO. IML. & 175 & $\mathrm{~B}-2 \mathrm{NO}$ & YES & NO & ND & PEIVAT & 20004 \\
\hline $406-0 t-20$ & MAFIINGALE LAKE & MULIEN LUMEEF CU. INL. & 132 & $\mathrm{R}-2 \mathrm{NO}$ & YES & $\mathrm{NI}$ & NC & FEIIAT & 20003 \\
\hline$H 16-0 i-15$ & MLF!TZ KOFL (FEAE! & SCHEI IHE & NOFE & $\mathrm{R}-2 \mathrm{NO}$ & YES & YES & NI & ND IIF & $9 J 218$ \\
\hline $110-62-07$ & MEETTZ ROAE & SH_T HIKE DEVELUFHEN COFF. & 300 & $\bar{B}-2 \mathrm{NC}$ & YES & YES & $N$ & PUE: !C & 27000 \\
\hline$H ! 5-004-0 \mathrm{n}$ & B!AER SEAL & MAXHELL JANETE & 270 & Ki-z Niv & Ni & NO & $N$ & FRIVHT & 74052 \\
\hline$H 15-10-09$ & EIECH RLAL & EGRÉ: ARH & 118 & $\mathrm{~B}-2 \mathrm{NO}$ & Nü & NO & NI & FEIVAT & $2136 !$ \\
\hline $102-14-6 !$ & CAFESWELL STKEET & BAIEES RICHAFO I. & $20 i+C$ & $8-2 N O$ & $\mathrm{NG}$ & Nu & kJ & FlišlC & 26203 \\
\hline $105-01-69$ & KIRE FHILIFS FATHE-K & GAFFETSUK JOHW H. JMK & NONE & $\mathrm{F}-2 \mathrm{NO}$ & NO & YES & YES & NE DIK & 566280 \\
\hline $105-51-18$ & MEETINGHELSE LANE 10 & 5EALLUND CAKEL & 146 & $\mathrm{R}-2 \mathrm{NO}$ & YES & $\mathrm{kL}$ & NO & FUE:IC & 20070 \\
\hline $100-01-02$ & OHIQ STREET & ANDEFSEN PAUL & $300+C$ & $\mathrm{~B}-2 \mathrm{NO}$ & YEE & $N[$ & $\mathrm{kij}$ & FUELIC & 23500 \\
\hline $106-02-07$ & PAFSUNAGE STFEET & WILLIAMS GEOREE & 196 & $\mathrm{~F}-2$ NO & YES & $N[1$ & N: & PUELIC & 43550 \\
\hline $10 t-02-09$ & PARSTHAEE STAEET & MCCEASTER ROEERT & 157 & $\mathrm{R}-2 \mathrm{NO}$ & YES & N! & $\mathrm{NO}$ & FLIELIC & $4 J 825$ \\
\hline $106-02-12$ & WEEETER STREET & NEW BEDFOF? GAS & 430 & $\mathrm{~F}-2 \mathrm{NO}$ & YES & YES & YES & PUBLIC & 25600 \\
\hline $10 \varepsilon-05-06$ & HIKGLLA CEME'ERY RL & THE DANIEL HEGSTEK & 120 & $\mathrm{H}-2 \mathrm{NO}$ & YES & YES & YES & FUEELIS & 2315214 \\
\hline $107-62-03$ & FAFSOMUEE STFEET & CHANDLEF FULSELLL $\|$ & 490 & $\mathrm{R}-2 \mathrm{~N}[\mathrm{~J}$ & YES & YES & YES & PUBLIC & 392040 \\
\hline $10 E-11-16$ & FHISEIE FUAD & CONTINENTAL INUESTHENT TKLST & 130 & $R-2 N$ & YES & N5 & HI & FUE & 5400 \\
\hline $10 E-11-1 ?$ & FEISEIE FIUA: & CENTINENTAL INUESTHENT TRULST & 130 & $R-2 N$ & YES & $\mathrm{HL}$ & ND & PljBLiC & 5400 \\
\hline $108-11-18$ & FFISEIE RIAL & CONTINENTAL INUESTMEN TRUST & 130 & $K-2 N E$ & YES & Nō & No & FUELIC & 5400 \\
\hline $11-07-62$ & CHELSEA STFEET & SULTH SHIRE NATUSAL SLIENCE CN & 160 & hi-2 No & No & YES & $N C$ & PRIVAT & 91476 \\
\hline $110-01-02$ & SOSTH FIVEF STEEET & RIVEFVIEL HOKES INE. & 108 & $\mathrm{R}-2 \mathrm{NO}$ & YES & NG & NO & 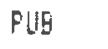 & $2004 \overline{8}$ \\
\hline $210-01-05$ & SE:TH STFEET & DUNESF JUHN & 86 & $\mathrm{R}-i \mathrm{NO}$ & YES & No & No & PUE:IC & 20132 \\
\hline $110-01-07$ & SOUTH RIVER STREET & FAIRNAVEK SAVINGS BALU & 92 & $\mathrm{R}-2 \mathrm{NC}$ & YES & NE & NO & PUE & 21500 \\
\hline $1 ! 1-12-04$ & HOLEE GROSK & ALEXAANLER & 120 & $\mathrm{~F}-2 \mathrm{NQ}$ & YES & NO & $N G$ & FEIVAT & 20040 \\
\hline $116-62-06$ & CAEFENTEF LANE & VAEEHTI MICHLE & $2000+L$ & $\mathrm{R}-2 \mathrm{NO}$ & YES & HO & NO & PULÉLIL & 20200 \\
\hline$I 1(1-0) .01$ & SOUIL RIVEF STEEET & IORDAA LEOHAFD & 1623 & $\mathrm{R}-2 \mathrm{NO}$ & YES & NO & $\mathrm{NG}$ & PUE & $50 ? 118$ \\
\hline $11:-6 j-04$ & HJWES BRELL: ROALE & GAFIUNEA LEQ & 145 & $\mathrm{~B}-\mathrm{Z}-\mathrm{NU}$ & YES & YEE & Nij & FRIVAT & 2060 \\
\hline
\end{tabular}




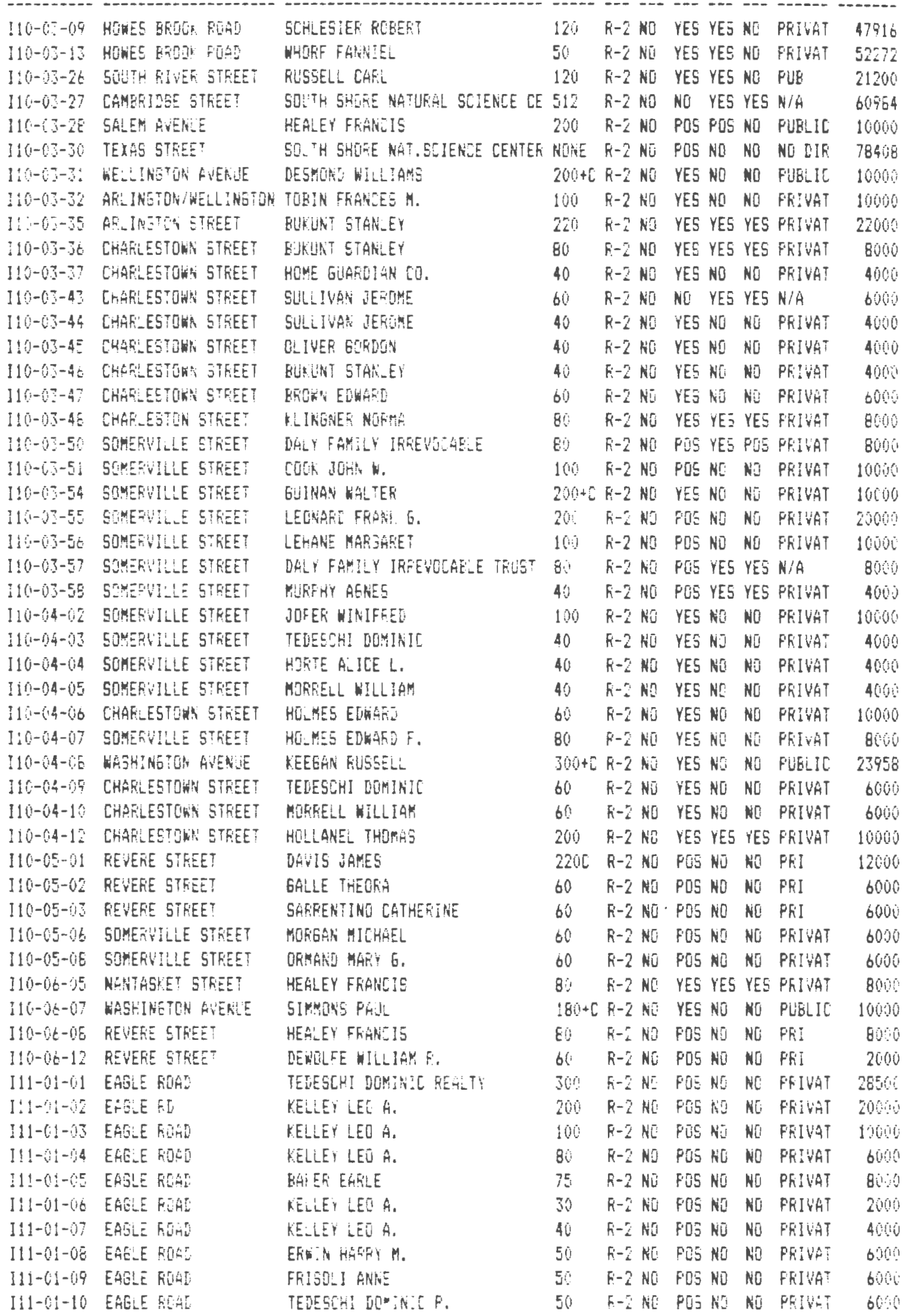




\begin{tabular}{|c|c|c|c|c|c|c|c|c|}
\hline & & & & & & & & \\
\hline $111-011-11$ & EASLE RUA & FFIES I ARE & 400 & Fi-2 NJ & POS ND & $N G$ & PFIVAT & 34600 \\
\hline $11-01-12$ & EAELE RTAL & TEDESCHA DERARA & $200+5$ & $\mathrm{~F}-2 \mathrm{NO}$ & FOS YES & $\mathrm{NJ}$ & FFIVAT & 16800 \\
\hline $11-\sqrt{12}-011$ & EAG:E FIUHE & TEDESCHI DOMIIT:C & $300+C$ & $\mathrm{R}-2 \mathrm{NO}$ & POS NO & NO & FFIVAT & 60984 \\
\hline $11-6-62$ & HAVOSR STREET & FRISELI ANSKE F. & 60 & $\mathrm{~F}-2 \times 5$ & POS NO & no & PRIVAT & 6000 \\
\hline I11-02-10 & HANSOR: STREET & KELLEY LED A. & 60 & $8-2 \times 0$ & POS NI & No & PRIVAT & 6000 \\
\hline $111-02-04$ & HANSOK ETKEET & CUKSELL TFjHES & 80 & $\mathrm{~F}-2 \mathrm{NO}$ & P05 No & HO & PEIVAT & 8000 \\
\hline $311-02-07$ & HALBOH STKEET & GELINAE THETDORE & 60 & $F-2 N$ & PDE NO & No & PFIVAT & 6000 \\
\hline $111-03-01$ & SCITUATE STEEET & TEDESEHI DOMINL & $25 i$ & $\mathrm{R}-2 \mathrm{NO}$ & POS NÓ & NO & PRIVAT & 240000 \\
\hline $111-60-02$ & SLITUA'E STFEET & FGISOLI ANKE F. & 80 & $\mathrm{~F}-2 \mathrm{Hi}$ & PUS NO & No & PEIVATI & $\bar{B} b \mathrm{~b}$ \\
\hline $11-03-63$ & SETTLATE STREE? & I Dethis & 40 & $\mathrm{~F}-2 \mathrm{NO}$ & P05 NI & NO & PRIVAT & 4000 \\
\hline $11-03-144$ & SEITUATE STKEET & GHEE F. & 80 & Gi-2 Ni & POS NO & Ni & PEIVAT & 8000 \\
\hline $11-03-06$ & HINGGAM AVENLE & ILAF & $80+C$ & $\mathrm{R}-2 \mathrm{NO}$ & YES NO & No & PKIVAT & 10000 \\
\hline $1-0.3-07$ & HINEHAR AUERIIE & HAY It & $100+[$ & $\mathrm{F}-2 \mathrm{NO}$ & YES NO & NE & FEIVAT & 12000 \\
\hline $1-0,3-0.5$ & HAHSOIV STREET & I AKSOSCA EDWGEL & $15 i$ & $8-2 \mathrm{NO}$ & ros 40 & $N 5$ & PRIVAT & 16000 \\
\hline $1-0:-09$ & HANEIN STKEET & CONDEN PRíl E. & 150 & $\mathrm{Fi}-2 \mathrm{ND}$ & PUE NO & NO & PFIVAT & 16000 \\
\hline $1-05-10$ & HAKSON STGEET & FFISULI ANIE F. & 150 & $\mathrm{R}-\mathrm{Z} \mathrm{NO}$ & PUS NO & No & PRIVAT & 19000 \\
\hline $1-04-01$ & COHAESET AVENUE & OKNER THOSWTON & 80 & Fi-2 NI & YES NU & NO & FRIVAT & 4200 \\
\hline $1-64-02$ & COHASSET AVENLE & MARSHFIELI ESTATES TKLST & 40 & Fi-2 No & YES & NO & PRIVAT & 2000 \\
\hline $11-04-01\}$ & COHAESET STREET & SELIHAS THEOUGKE & 100 & $\mathrm{k}-2 \mathrm{NO}$ & YES NO & NO & FFIVAT & 12000 \\
\hline $111-04-0 E_{1}$ & ELITUATE STREET & FFISOE I ANHE $F$. & 40 & $R-2 \times 10$ & POS NE & wo & PFIVAT & 8000 \\
\hline $111-04-02$ & COHAESET STEEET & IANTSS & 160 & $\mathrm{R}-2 \mathrm{Nu}$ & YEE NG & kU & FRIVAT & 9500 \\
\hline $111-04-05$ & HINGHAM AVERLE & GILLIS & $120+\mathrm{C}$ & $\mathrm{K}-2 \mathrm{NO}$ & YES NG & NO & PRTVAT & 10000 \\
\hline $111-04-10$ & SEITUATE STFEET & DGMINIC & 120 & $F^{\prime}-2 N 0$ & PDS ND & NO & PRIVAT & 12005 \\
\hline $111-04-11$ & SOITUPTE STFEET & TEDESCHI DOHINIC & 260 & $\mathrm{~B}-2 \mathrm{NO}$ & POS NO & Hi & PFIVAT & 28000 \\
\hline $111-05-03$ & SL. RIVEF \& GRQVE ST & FLYME JOHK WILLIAM & $2 t 0$ & $\mathrm{~F}-2 \mathrm{~N}[$ & VES NE & $\mathrm{Ba}$ & FUBLIC & 246,0 \\
\hline$[1-6 t-6]$ & SUTH FIVEF STFEET & 54VINSS BAHK & 135 & $B-2 N C$ & YES NO & NO & PUELIC & 21200 \\
\hline $111-06-02$ & SUITH FIVES STREET & 5AVINGS BAN & $294+C$ & $\mathrm{~F}-2 \mathrm{NL}$ & YES ND & Nü & PUELIC & 20700 \\
\hline $111-06-05$ & SOITH RIUEF STREET & AUINGS EÁKK & $279+c$ & $\mathrm{~F}-2 \mathrm{NO}$ & YES NO & ND & FUELIC & 20074 \\
\hline $111-07-01$ & LEXINGTUN AME. & E NGTILRAL SL̈IENEE & $600+c^{2}$ & $\mathrm{~B}-2 \mathrm{NO}$ & YES NO & NO & $P F I C L$ & 104544 \\
\hline $111-1$ & WITHFYP STFEE & GE NATURA SCIENCE CN & 160 & Fi-2 Ni & Po5 N5 & No & PKIVAT & 42060 \\
\hline $1: 1-07-07$ & HINTHESP STREET & HEÁY & 100 & $\mathrm{R}-2 \mathrm{NC}$ & POS NO & NE & PRIVAT & 10000 \\
\hline $111-07-08$ & HINTHKOFF STKEET & SACK5 & 250 & $B-2 \mathrm{NO}$ & FDS NL̄ & $\mathrm{RC}$ & PRIVAT & 26000 \\
\hline $111-07-09$ & SCULTH RIVEK/W:NTHFOF & HEALY & $290+z$ & $F_{1}-2 \mathrm{~N}$ & YES NO & NO & PUELIC & 8000 \\
\hline $111-07-10$ & SUITH FIVER STREET & JEA: & 110 & R $-2 \mathrm{NC}$ & YES NU & Nó & FLIBLIC & 6500 \\
\hline $11 !-[1]-11$ & SOUTH FIVEF STEEET & GALLE T & 20 & $\mathrm{~B}-2 \mathrm{NO}$ & YES NŪ & $\mathrm{NO}$ & PUELIC & 2000 \\
\hline $11-57-12$ & SOUTH RIVEK STREET & Mungen & 20 & $\mathrm{Fi}-2 \mathrm{NO}$ & YES NÚ & nis & PUBLIC & 2000 \\
\hline $11 !-07-13$ & SOLITH RIVER STREET & ATKIN5 & 115 & $\mathrm{~B}-2 \mathrm{NO}$ & YES $4 B$ & NO & PLELIC & 1000 \\
\hline $111-07-14$ & SOLTH RIVER STREET & DHIGHT GERALD E. Jr. \& LINDK & $810 \tilde{i}+[$ & $\mathrm{R}-2 \mathrm{NO}$ & YES ND & NC & PUBLIC & 216453 \\
\hline $111-08-01$ & TEXAS STKEET & YONKER & 100 & Fi-2 NO & FuS Ni & NO & FRIVAT & 16000 \\
\hline $111-08-64$ & TEXAE STKEET & YONEEF & 120 & $R-2 \mathrm{Nit}$ & Pas N: & NO & PFIVAT & 12000 \\
\hline 11$]-08-05$ & MELLINGTUN AUENUE & SMITH RO & $20^{\circ}+C$ & $\mathrm{~B}-2 \mathrm{NG}$ & FOS YES & FUE F & PRIVAT & 10000 \\
\hline $111-08-0 c$ & MELLINETOH AVENLE & MUKGAE & $210+C$ & $\mathrm{~F}-2 \mathrm{NO}$ & PCS YES & FUS F & PEIVAT & 6000 \\
\hline $111-0 E-0 E$ & SA:EM AVE. & SOUTH SHGFE HATURGL SCIERLE & $360+C$ & $R-2 N D$ & FUS YES & YES : & ERIVAT & 26000 \\
\hline $111-09-01$ & LEXINGT:JN STFEET & SOUTH SHCFE NATURF'L SEIENEE & $600+5$ & $\bar{R}-2 \mathrm{NO}$ & YES NO & No $\mathrm{F}$ & PEI CL & 74052 \\
\hline $1111-09-04$ & FARKGAY & SEFH & $170+c$ & $\mathrm{~F}-2 \mathrm{NO}$ & FUE YES & Nu & FEIVAT & 10000 \\
\hline $111-09-05$ & FAF'KEF! & VININE & 195 & $\mathrm{R}-2 \mathrm{NI}$ & FOS YES & W0 & PFIVAT & 10000 \\
\hline $11:-09-016$ & LEXINETCN STREET & E NATURALL SCIENCE & 80 & $\mathrm{~K}-2 \mathrm{NO}$ & YES NO & NO & $P$ fii CL & 8000 \\
\hline $111-09-013$ & LEXINGTUA STTEEET & EE NATULAAL SCIENEE & 40 & $\mathrm{~F}-2 \mathrm{NO}$ & YES NO & No & $\mathrm{PKI} C \mathrm{CL}$ & 4000 \\
\hline $111-09-09$ & LEXINGTON STREET & PYNETTE & 40 & $R-2 N 0$ & YES NO & NO & PFII CL & 4000 \\
\hline $111-10-01$ & LEXINETOK STHEET & FRAB:IS & 100 & $2 \mathrm{NO}$ & YES NO & NG & PFII CL & 1000 \\
\hline $111-10-03$ & LEXINETOH STKEET & SOLTH SHOFE NATLRF'- SCIEREE & 40 & $-2 \mathrm{NL}$ & YES NO & NO & PEI CL & 4000 \\
\hline $111-\div(1-04$ & LEXINGTUR STKEET & ETHAN ALLAK ERIGK TRLST & 150 & $2 N{ }^{2}$ & YES HO & We & F'RI CL & 12000 \\
\hline $111-10-65$ & FARK WAYY & ETHAN A'LAN BROLHN TRLST & $200+5$ & & POS YES & $\mathrm{NG}$ & FKLWAT & $100 \%$ \\
\hline
\end{tabular}




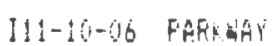

III-10-OT SULTH RIVEF STFEET

III-10-0E CHEGSE STREET

111-10-09 CHELSEA STREET

111-:0-10 CHELSEA STREET

111-16-11 CHELSEA STKEET

III-1O-1E SALE AVE.

II!-16-14 LEXINETOH ANE.

1!1-1!-U1 SALEY AVE.

I11-11-02 CHELSEA STFEET

II $1-1 r_{2}-02$ 5ITH RIVEF STREET

111-12-0Z COHAESE AUENUE

I11-12-05 5EUTH RIVEF STREET

11:-12-09 FAFkHAY \& CUHASSET

11-12-10 COHASSET RVEHLE

I11-12-11 COHASEET STAEET

111-12-13 COHASOET STREET

I11-13-14 CQHAEGET STAEE?

I11-12-1E HINGHA AVENLE

111-12-16 COHASEET STFEET

11:-13-C: COHEJET STEEET

111-13-UZ COHASSET STREET

II-1j-OS COHAESET STREET

111-13-05 COHASSET STREET

111-13-66 CQHASSET ETREET

I11-13-0? [EHASSET STAEET

I11-13-6E OOHASSET STEEET

111-13-19 NIFHEL! KCAR

111-13-10 NGTKELL ROAD

$1 ! 1-1 j-1 !$ NOEIHELL RLOAD

111-13-13 RIGWL: ROAEE

II1-15-14 NEFUELL RUAD

I11-13-15 HINEHAM AVENIE

111-14-01 PAFKHAY

$111-14-0:$ FAFBWE:

111-14-03 PAFKKAY

111-14-014 FGF!HAY

I11-14-05 PAFKWAY

1:1-14-06 PARKHA

I11-14-10 NURHELL ROAL

$11 !-14-11$ NGFKELL FOAD

111-14-12 NLFWELL ROAL

111-14-13 PATYHE

11:-14-15 HIREGAM AVENLE

$111-15-03$ OUHELEY STREET

I11-15-04 DUXEUEY STREET

I11-15-15 DUXELS: STREET

I11-15-0? PA5IWS

I11-16-02 EAGIE ROAL

III-16-0J EAEIE RUAD

111-16-i24 DUYSDS STREE?

1!1-16-65 DUTEUS! STREET

I11-16-0? [UJXESF? STEEET
PEFFITTTS DOFOTH!

ETHAM PILLAN

BISLHOFE KARL

ETHAH ALLAN BFOKH

BISCHOFF KAFIL

DAMIGELLÁ RNH

SULITH SHORE NATUFAL SCIENCE

SOLTH SHORE NATURAL SCIENEE

KELLY WILLIAW

BLOCK DJTIS E.

FRISLL] ARHE

VAREGA FATTICIA A

CHASE RGSEYHFI:

YJUNE MALUEEN

FEISULI AMRE

TEDESEHI DOMIRIT

TEDESCHI DOMINIC

TELESERI DOHINI

SAMFSON DOSOTHY

VAREÁ FATEIPIA

REILLY TIYITHY

HEGES

HRERTEOT A.E.

MEMERMAES HENEY

MALEE hEFF *

FRISJI! I ARNE

STILLMAN MEEY

LAWEENEE EMḾ́

TILDER BICHRES

TEDESCHI DCMILIC

Mutin BICH

HUGHES JHMES

IANTESEA EEYTHE

MOFEISUN HARFY

IANTOSEA EDKAFT

BEAUPFE MARIE

KELLEY TIMOTHI

FICHAROSON DONALE

KELLEY LEO

HAMILTOK ALBERT

FFISO! I ANHE

KE!LEY LES

KE!LEY LEO $A$.

KELIEY LEU A.

FEISÜL I ARTE $F$.

LEGEE CHAS F.

TEJESEH DOKINIE

CROHLY IOSEFH

FRI5CLI FALL

FFISUL I FAMLL

CROWLEY IUE

Q NEIL EOMJND

SEAMPR E.C.
1701C R-2 NO FOS YES RO PFIVAT 12000

40 F-2 NU YES NO NC PLELIC 1200

40 R-2 NE NO YES HI PRIVAT $40.5 \%$

40 R-2 NE: NO YES HO FEIUAT 4000

BO R-2 NO NO YES NO PRIVAT 8000

2010 R-2 NO NO YES NO FRIKAT 20000

$140+C$ R-2 NE POS YES NO FFIUAT 4000

$120+[$ K-2 NG YES NO NO Fí. CL $200 \%$

$140+C$ R-2 NE POS YEE RE PFIVAT 4000

70 Fi- 2 NI YES KOL NG FUELIC 6000

70 R-2 NO YES NO NE PUEAIC 6500

$2 \hat{V}$ R-2 NO YES ND NO FLLEIC 6000

70 Fi-2 NO YES ME NO PUELIC 8000

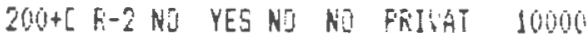

20 R-2 NE YES NI NO PEIVAT 2606

100 R-2 NO YES NG NE PRIVRT BOOL

100 R-2 NE YES NO RO PFIVAT 1000

40 F- 2 ND YES ND NO FiKIVAT 4900

100 +E RE- NE YES NI NE PFIVAT 720:

20 R-2 NO YES NE NO PFIUAT 6006

$200+$ FI-2 NO YES WE NO PAIVAT 1000

60 FI-2 NI YEENE NE FRIVAT 6000

60 F-E HO YES NO NO PRIVAT 7125

226 Fi-2 NO YES NO NE FRIVAT 28000

40 R-2 NI YESAD NE FFIVAT 6000

40 Fi- 2 NE YES NO RU FRIVGT 4000

$2001+E R-2 N D$ YES ND NO FFIUET 10000

$220+E$ K-2 NE POS NO NG FRIVAT 10000

60 RT-2 NO POS NO NO PRIVAT 6000

90 Ri-2 NF PUS NO NG FFIVA 12000

40 R-2 NU FUE NE NI FEIVAT 4000

80 R-2 NO POS NE NI FRIVAT 7810

$301+C$ FE-2 NL YES NO HO PFIVAT 25000

150 F-2 NG P05 NO NO FRIVAT 16150

60 Fi-2 AD PUS NC NO PRIVAT 6000

BO R-2 NI POS NO NI FFIVAT 8000

80 R-2 NO POS NE NO PFIVAT 8006

80 Fi-2 NO FOS NI NO PRIVAT 8000

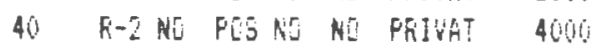

8O FI-2 NO POS NO RO FEIVAT BOT

I00 FI-2 NO FLES ND NO FEIVAT IOGOS

110 Fi-2 NO POS NO NO PRIVAT 10000

BO FI-2NO POS NE NÚ FEIVAT 10000

75 h-2 NE YES NO NO FRIVAT 6000

40 B-2 HO YES ND NO PFIVAT 4000

40 Ki-2 NO YES NO NO FRIVAT 4000

100 K-2 NO YES NO NO PRIVAT 10000

40 R-2 NO POS NB NO PRIVAT 4000

290 TE R-Z NU POS YES NO PFIVAT 2060 :

120 R-: NI PES YES NO FR!VAT 11000

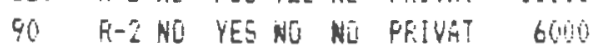

40 R-2 NO YES NO NO FEIVATT 4000

IOO F-2 NO YES NE NE PEIVAT BOOC 
111-17-01 COHASEET AVERLIE

111-17-02 CRHASSET AVENLE

I1:-17-03 COHASSET AVE.

111-17-05 KINESTON STEEET

111-17-06 KIHGSTOK 5TREET

11:-17-01 KIHESTON STFEET

I11-17-0S K1NGSTON STREET

111-17-10 NLFHELL ROAD

111-17-11 NOGHELL BLAMI

I!1-17-12 NCFWELL RSAI

111-17-13 NGTHELL ROAL

II1-17-15 NOFHELL ROAO

111-17-16 NORWE:L ROAO

I11-17-17 NJPNELL ROKE

111-17-18 NORHELL ROG

111-17-15 EFGLE ROAS

111-17-20 KNAETON STREET

11!-17-21 KINGSTOK STREET

111-19-11 EAG!E RO4D

111-15-02 HAHOVEF STREET

II1-19-04 HAWUVE STAEET

111-15-05 KINGSTON FLACE

$111-20-01$ COHAESET AUENIE

11i-2010Z PEMBSOYE STREET

I!1-20-03 FEMBFDEE STREET

1!1-2(1-0)4 HAHIVEL STREET

Ii1-2ij-05 HANEVEF ETREET

111-20-OS HAHLUEF STREET

III-20-07 HANWVES STKEET

II:-2i-06 HAMCVES STREE?

I11-21-01 SEUTH RIVEF ETREET

111-21-03 COHASSET STKEET

111-2i-04 COHASSET STFEET

111-21-05 5SUTH RIVEF STREET

II1-21-07 SUUTH RIVER STREET

$111-21-11$ CQHASSET STFEET

I11-22-01 50LTH RIVEF STREET

11i-22-06 FAFithíf

111-22-07 PARKHAY STREET

I1:-22-10 CAFEAIDGE ETREET

I11-23-1I TEXAS STREET

I11-2j-62 TEKAS STREET

I11-23-(14 TEXAS 5TKEET

III-23-05 HASHINGTON GUE.

$111-23-67$ PAKLAH

II1-23-08 WELLINGTOK AVENLE

111-23-(19 MELLINETJN AVENUE

111-24-111 RELLINETOH AVENLE

111-CA-0J AFLINETON STREET

II:-2A-04 AFLINGTOR STKEET

I11-24-07 HAEHINGSOA AVE.

111-24-69 TEXAS STREET

I11-2I-02 CHAFIESTOWK ETFEET
STILLFAN MARYY $X_{\text {. }}$

GLRECKIS ALEYARDEF

IARTOSCA ELWAED E.

VIGIL DOR JAMEE

FFISOLI ANHE

RICHALDS WILLIA. 3.

RICHAEDS HILLIARI J.

IANTOSEA EL

TEDEECHI DOMINIC

RICHAFIS WILLIAM

VIGIL DUN JAMES

FRISULI ANHE

TELESTHI DOHIMIC

HINEOUSAE BGREAFA

FKISDLI ANAE

IARTESEL ELTTHE

IANTSSEA EDITHEF

ACIGEMI DAVII $C$.

IAMTOSEA EDGARQZ E.

ROEES HILLIAF

GREET DORAD D

TEDESCHI DOMINIC R.

IANTOSEA EEHAED E

DUSGHT JOHE $A$.

FFISULI ARHE

KELLEY LEU f.

MELANSEN RP:FH

MELANSJR: FALFH

IANTOSTA ELAGED

MCCAEE JCSEFH E.

ETHAN ALLAN BFCWR TRELT

IANTOSCA EDHAFI

MÁFIEY TGMES

STILLMAN MEFW

EREREY REALTY TRUST

TAGGAFT FLOFA

BROWN HELEN

SFINAEY FHUL

ROEEINE ALIEN

CHAFFELLE WILLIAM K.

DELAHI LUCILLE

MARHINE JUHK

FENMELL MARY

MITIFIN L.H.

FOSTER JARET J.

ROUNEY JOH:

MINCHIN CHAFLLES

SCORIE ANHA

CHEESMGM KATHLEEN

BUCHGHAR MAFIE 6.

PAGLIAZZO LUCFEEIA

LITTLE BAREARA JEAN

CEFE DIANE E.
$22(1+C E-2$ NO YES YES NG FRIVAT 12100

100 R-2 NO YES YES HO FETYVAT 10000

100 R-2 NO YES NJ NO FEIVAT 10000

60 R-2 WO POS YES WO PFIVAT 5805

60 R-2 NG POS YES NO PRIVAT 6100

40 R-2 NO FOS YES NO PEIVAT 4000

40 R-2 NO POS YES NO PRIVAT 4006

90 R-2 NG POS NO NIO PEIUAT BOOO

100 KI-2 NO FOS NO NO FFIVAT 13000

40 R-2 NO FOS YES NO PEIHAT 4JOG

60 FI-2 NO FUS NU NO PRIVAT 6500

60 K-2 NU FSS YES NU PEIVAT 7000

40 FI-2 NO FOS NO NO FRIVAT 4100

40 F-2 NJ FOS YES NO PRIVAT 4000

$195+C$ F-2 NO FOS YES NO FRIYAT 9000

50 FI-2 HJ PUS YES NJ FIRUAT 6000

$50+C$ R.-2 NO POS YES NO PFIVIUT 4500

100 R-2 NO POS YES ND PFIVAT 8900

$200+C R-2$ NO PDS YES ND PRIVAT 33500

60 R-2 HO POS NO NO FRIVAT 6000

BO FI-2 NO POS NO NO PFIVAT 8OOQ

BO K-Z ND POS YES NO FFIVAT 8000

$200+[K F-2$ NO YES NO NO PKIVAT 4000

60 R-2 NO POS YES NO PRTVAT 6000

120 R-2 NO FUS YES NI PEIVAT 12000

80 R-2 NO FUS YES WO FRIVAT 12000

BO R-2 NO FUS NO NO PRIVAT BOUO

40 R-2 NO PGS HO NO PRIVAT 4000

40 R-2 NE POS NO NU PRIVAT 4000

40 R-2 WE POS NE NO PRIVAT 4000

$205+[$ F -2 NO YES NO NE PLELIC 11400

80 R-2 NO YES NO NO FRIVAT 10000

120 R-2 NO YES NO NO PFIVAT 20000

$100^{\circ}$ R-2 NU YES NO NO FUELIC 20000

130 R-2 NO YES NO NE FUBLIC 16000

20 R-2 NO YES NO NO PFIVAT 2000

150 FI-ZNO YES NI NE PUELIC 22500

42 R-2 NO FOS YES NŨ FRIVAT 4000

$130+[\mathrm{K}-2$ NE FUE YES NI FRIVAT 2400

100 H-2 NO YES YEE YES PFINAT 4000

$200+C$ R-2 NE FOS NE NO FRIVAT 10000

40 R-2 NE POS NO NO PFIVAT 4000

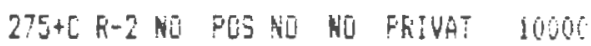

52 R-2 NO FOS NJ NO PRIVAT 4060

$230+E$ R-2 NO FES YES ND PFIVAT 12000

40 R-2 H3 PES YES POS PHIVAT 4000

40 R-2 NO FOS VES PUS PFIVAT 4000

$200+$ C R-Z ND POS NE NO PGIVAT 1030

101.) Fi-2 NE YES NO NO PUBLIC 10000

40 F-2 $N^{\circ}$ YES NL NO PUELIC 4060

$420+C$ R-2 NS POS NO NI PRIVAT ZOOOOO

120 R-2 NO PUS NU NO FEIVAT 12000

80 R-2 NO YES NI NO FFIVAT BOTO 
I11-25-GJ CHLESETOLH STREET

11!-25-64 CHAREESTIWH STEEET

III-25-OS CHFE ESTLD STREET

I11-25-67 WASHINETON AVE.

III-25-09 ARLINETEA STREET

I1:-25-10 ARLINGTON STFEET

1i1-25-11 AFLINETIR STREET

I1!-25-1? AF'INETUL STFEET

II!-25-16 CHARLESTOK STREET

I11-20-92 CHAELETLINAS STREET

I:1-26-03 CHAELESTOKA STREET

111-2E-0E ARLJHETOH STREET

I11-2s-67 AFLINGTUA STREET

I11-27-03 ARLINGTON STREET

I1:-27-14 ARLINETLI STREET

111-27-05 ALLIHSTUN 5TKEE

111-27-96 AF:IRGTUH, STREE?

II1-2:-07 ARLIHGTON ETEEET

I11-28-O2 TEYAE 5TEET

II1-28-03 TEXAS STREET

II!-2E-O4 TEXGS 5TFEE

I1!-2E-01E TEXEE STREET

$11 !-25-07$ TEXKS STEEET

1:1-2B-OE TEXAE STAEET

111-2E-11 CAHEIDGE STREET

11:-23-:2 CAMEFIUEE STREET

11!-2E-13 CAMESIOEE STEEET

III-26-1E CAMERIDEE STREET

III-ZE-1L CAMEIDGE STKEET

I11-ZE-17 CAMEFINGE STFEET

I1:-01-O2 FEHEFSUE STFEET

I:2-01-03 SUUTH RIVER STFEET

DEEASTRO JOSEFH

ASCH CHFISTOEHER

ASEH ROLAND

HAF: ON F. VIVIAN

CAMEBELL MASTHA

ASCH ROLANE

STOKE EL!ZABETHE 6.

DULLEA DENNIS

CHEESAAK LAKRENLE

CRONIN FUILLIFS

VETRA THOMAE

SIMRINS BETSEY

SIMPONS HARELI

DORGUAN FICHATL

DCNEVA: BICHAFI

MLFFH MAET

MUEPHY MASY

MULFHY MARY

SIMHüs

SIMYCNE ESTELLE

SIMAINS HAFILD

SIMULPS HAFILL

SIMMIN: ESTELLE

SI HIONE HAROLO

TEDESCHI DOHOAT:

GUFECR:S ALEA.

GUFESKIS ALEX

SULLIUAN PAFGGET

STAFEBKD EDLAER:

MITTOK FFIANU!

FFISELI PWNE

GLY VINEENT

J01-01-0: CANESHELL STREET IOFF EAFSTUR JARES J.

JOZ-04-01 DUCK HILL LANE IOFF) ROGERS DOUG:AS A

JO2-04-CS CASKELL STREET ROBIHSON MARGAEET

J0?-04-07 COLEY HEWITT LANE HENITT COLEY JK.

J02-04-10 DUCK HIIL LANE IJFF) ROBEFS JOUGLAS A.

JO4-03-20 FLETCHEF DSTVE

PUTNEY IMC.

JOA-03-24 FLETCHEF: DRTVE

FUTHEY ?NC.

J04-03-25 APF:ETELI HOYE

$304-03-26$ AFOLETUN HAVE

JO14-03-27 AFFLETON WAYE

J04-03-28 AFFLETON WYE

$304-0.3-29$ APPLETON WAYE

J(4-0)-30 FLETTHER OFIYE

304-03-32 STEGMESE: [EIUE

JUE-DE-OE OESEFVATORY WEY

JO5-OE-OJ SIGHAL HI:L ROAL

JUE-09-16 OUTLOGK RSTAD

JE-02-GS STATESMAN TERFACE

JUE-0Z-10 STGTESMAN TEFSACE

ROEEFT JURICE:

FUTNEY INC.

FOEEFT A. IUNIOR

FUTKEY INC.

FOEEFT A. JUNIOF

PUTKE! INC.

PUTREY INE.

OESEFVATOEY REA_TY TRUST

NASH REALTY TRUET

DQYLE JAMEE C.

RESEFVIC MICHAEL

KESEGVIT MICHAE:

LEMA JUHN JR.

$306-03-15$ BACHAST ROAD

nlli iar andergeri
40 RI-2 NO YES NI NO PRIVAT 4000

40 Ki-2 NE YES ND NO PKIVAT 4000

80 K-2 NO YES NO NO PRIYAT 8000

$180+C$ K-2 NO FOS NO NO PRIVAT 600

40 R-2 NO YES NO NO PRIVAT

60 R-2 NO YES NO NO FRIJAT 6000

40 R-2 NJ YES NO NO PUELIC 4000

60 Fi-2 NO YES NO NO PUELIL DOOO

60 Ri-2 NJ YES NO NO PEIVAT 6UOG:

200 R-2 NO FOS NO NO PFIVAT 20000

100 Ri-2 NO PUE NO NO PFIVAT 10000

40 R-2 NO YES NO NO FUELIC 4000

40 R-2 NI YES NJ NO PUELIC 8000

40 RI-2 NO YES $N O$ NO PUSLIC 4000

46 Fi-2 NO YES NO NO FUBLIE 4000

40 R-2 NG YES NE NO PUBLIC 4000

40 R-2 HO YES NI NJ PUELIS 4000

40 FI-2 NG YES NG NG FRIYATT 4000

40 hi-2 NJ POS NO WO FEIVAT 4000

60 5-2 NO POS NO NO PFIVAT 6000

40 Fi-2 NO FOS NO HE PEIVAT 4000

4( BO-2NO FUENO NE FRIVAT 4000

40 Ri-2NO FUS NO NO PRIHAT 4000

60 FI- NO FOS NO NO PFIVAT 6000

$160 \mathrm{~B}-2 \mathrm{R}$ [ YES YES YES $\mathrm{N} / \mathrm{A} \quad 16000$

100 R-2 NE YES NE NU PRIVAT 10000

40 Ri-2 NO YES NE NO PRIVAT 3000

40 R-2 NO YESNO NO FRIVAT 4000

160 R-2 HB YES NO NO PFIVGT 18000

$24 !+C R-2$ NL YES NE NE PEIVAT 10000

100 R-2 KO YES NO NJ PR!YAT 15500

$95+C$ Ri-2 NO YESNO NO PUELIC 16000

$200) R-2$ NE VES YES NG PUELIC 49222

NOHE R-2 NE NO YES YES NU DIR 196020

300 K-2 NO NO NO NO PUELIC 159865

600 Ri-2 NO NO YES YES PFIVAT 61288

NONE R-2 NO NO YES YES WO DIK 94525

178 RI-2 NO YES NO NO FRIVPT 20?19

171 R-2 NO YES NO NO PRIVAT 21980

276 Ri-2 NE YES NO NO PFIVAT 31326

158 K-2 NO YES NO NI PRIVAT 22225

65 FI-2 NO YES HO NO PRIVAT 25546

68 R-2 NU YES NJ WO PRIVAT 25684

117 FI-2 NO YES NU NO FRIVATT 2120 :

$300+C$ R -2 NO YES NI NO PRIVAT 2269!

123 K-2 NI YES HO NO FRIVAT $2210 \mathrm{E}$

125 Fi-2 NE NES NO FRIVAT 20798

120 R-2 NO YESNO NO PKI 20U4O

120 R-2 NO YES NG NO PUSLIC 20717

120 R-2 NO YES NO NO FUELIE 20245

126 Fi-2 NI YES HO NO FUELIC 20375

126 Fi-2 NO YES HE NO PUELIC $30: 84$

NINE Fi-2 NO NO NG WO NO DIF $1104:$ 


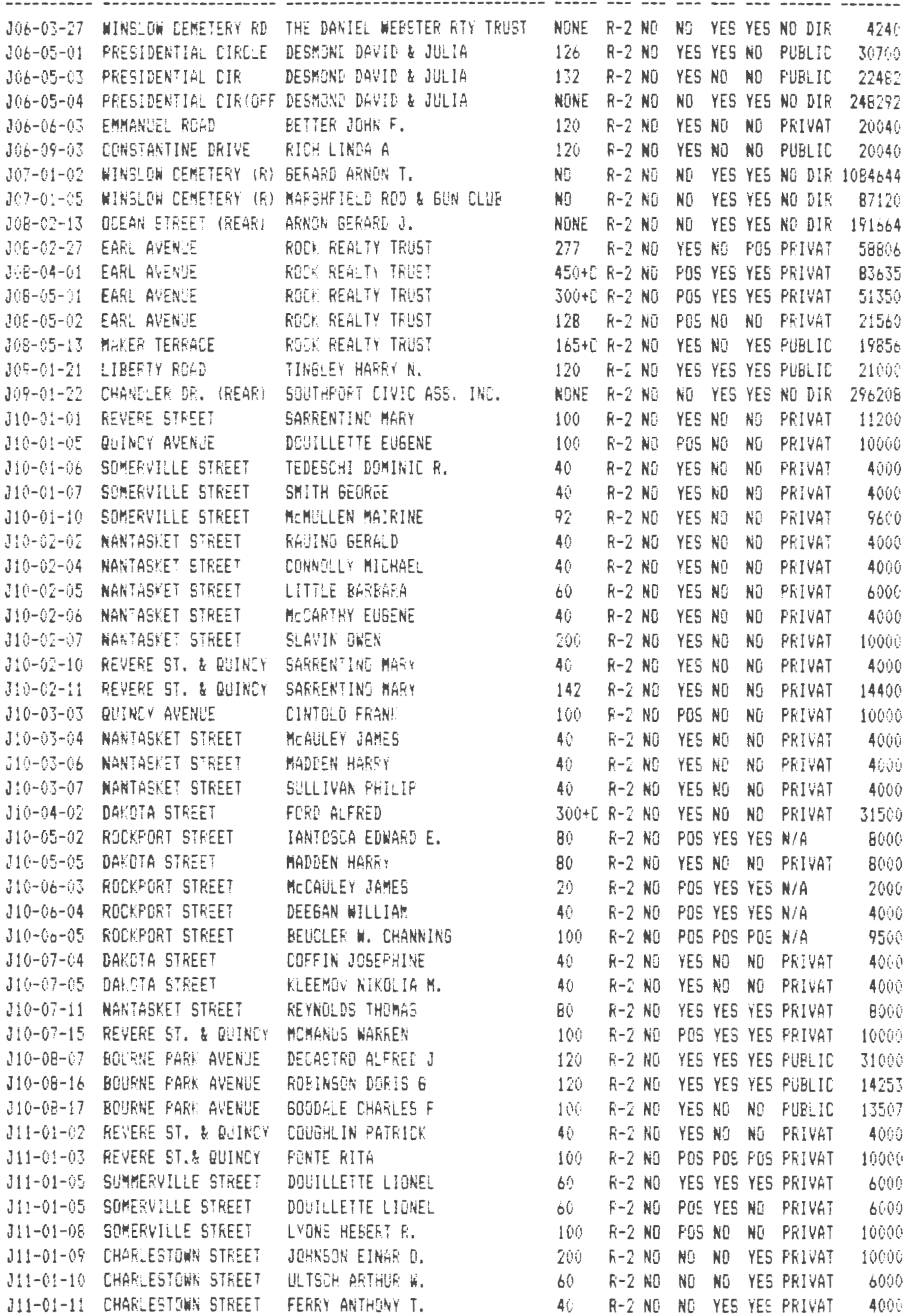




\begin{tabular}{|c|c|c|c|c|c|c|c|c|c|}
\hline AS. MAP-LC? & LOCATION & CWNEE IF REC & FFUNT & 2ON 5EK & WAT & MET & FPA & ACCESS & AREA SF \\
\hline 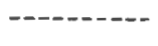 & n-n & & & & --- & & -- & & \\
\hline $3: 1-11-12$ & CHAR̃LESTIHA STREET & PAKK INSON HARE: & 40 & $\mathrm{R}-2 \mathrm{NO}$ & FOS & YES & YES & PRIVAT & 4000 \\
\hline $11-0 !-14$ & CHAFLESTOWH STREET & HOME GLAKDIAN COMEN & 40 & $\mathrm{~F}-2 \mathrm{NL}$ & NO & YES & YEE & PFIVAR: & 4000 \\
\hline $11:-01:-15$ & QSINEY AIE. & TWLHEi Hín T. & $306+C$ & $\mathrm{~F}-2 \mathrm{NO}$ & FOS & YE5 & YES & PUBLIE & 20000 \\
\hline $11-01-20$ & AELINETON STREET & WOUDS BAFIEAFA & 20 & $\mathrm{R}-2 \mathrm{NE}$ & YES & No & YES & PEIVAT & 2000 \\
\hline $11-01-2 i$ & AFLINGTOA STREET & MECUREY FRAREIS & 40 & $\mathrm{~B}-2 \mathrm{NO}$ & YES & NO & & FIVAT & \\
\hline $11-01-23$ & AFLINETON STREET & HAGAN LOHELL & 100 & $\mathrm{R}-2 \mathrm{NO}$ & YES & NO & YES & EIVAT & 1000 \\
\hline $11-0 !-25$ & AELING TH STREET & HAEAN LOHELL & 20 & $B-2$ NO & YEE & NO & YES & PEIVAT & 200 \\
\hline $11-01-26$ & AEL_INETOH STREE? & HAGAN LOHELL \& CHFIETINE & 40 & $R-2 \mathrm{NC}$ & YES & Nu & its & KIVAT & 405 \\
\hline $11-61-27$ & ARLINETEN STREET & MCDEFMITT FFED & 100 & $\mathrm{~F}-2 \mathrm{~N}$ & YES & NO & YES & SVAT & 1090 \\
\hline$\lfloor|-0|-3\rfloor$ & AFLINGTEL STREET & BROCKTON CUTTIHES DIE & 280 & $R-2$ NU & YES & NJ & YES & IVAT & $28: 0$ \\
\hline $11-01-32$ & ARLINGTUN STKEET & EUKKE EDKUND $M_{1}$ & 40 & $8-2$ HC & YES & NO & YES & IVAT & 4000 \\
\hline $11-01-34$ & AFLINGTOH STREET & GIESON ESTER & 40 & $k-2 N O$ & YE5 & NO & YES & IVHT & 400 \\
\hline $11-61-35$ & AF_INGIUAR STKEET & DHLTOK GEQRSE E. & 40 & $R-2$ NO & YES & NO & YES & VAT & 400 \\
\hline $11-0 !-35$ & TEXAS STFEET & G1010SE ALHAGMAY & 40 & $R-2$ NJ & P0s & NO & No & CIVAT & 4001 \\
\hline $11-0 !-4 !$ & TEKAS STREET & KENKEGLY HILLIAM & 60 & $\mathrm{R}-2 \mathrm{Ni}$ & POS & NO & YES & IVAT & 600 \\
\hline $\mid 1-0 !-4 !$ & TEXAS STREET & DEXTEF NLTHATIEL & 160 & $\mathrm{R}-2 \mathrm{NG}$ & F0S & NO & YES & IVAT & 1611 \\
\hline $11-01 !-42$ & TEXAS STKEET & CFGLELL EDHARIN & 60 & $R-2 \mathrm{kO}$ & FUS & NO & YES & IVAT & 600 \\
\hline $11-31-4 j$ & TEXAS STREET & PACKAFD KENNETH & 100 & Fi-z Ni & P05 & $\mathrm{No}$ & YES & VÁT & 1009 \\
\hline $11-01-44$ & 5.ITH FIVER STFEET & FACKARL KENKETH & 80 & $R-2 N O$ & YES & YES & YES & FUBLIC & 3043102 \\
\hline $01-45$ & TEYAS STKEET & (6) RERAETH & 140 & $\mathrm{R}-2 \mathrm{NE}$ & FOS & No & YES & PRIVAT & 1450 \\
\hline $311-01-46$ & TEXFES STREET & BELCHEF LELAND & 100 & $\mathrm{R}-2 \mathrm{NL}$ & P05 & N5j & YES & VPT & 1000 \\
\hline $311-01-47$ & TEXES STREET & FROSSER GAI' \& FFHALES & 60 & $\mathrm{R}-2 \mathrm{NO}$ & fios & No & YES & IVAT & 600 \\
\hline $311-1 !-49$ & TEXAS STREET & DAVID & 40: & $\mathrm{Fi}-2 \mathrm{NO}$ & Pis & $N Q$ & YES & FRIVAT & 400 \\
\hline$j|1-0|-51$ & ME:DEN AVESUE & LINGIEY JOSEPH Ŕ. & $1001+5$ & $5-2 \mathrm{NL}$ & YES & No & N5 & PUELIL & 10000 \\
\hline$-0 !-54$ & TEX'A5 ETREET & ULTSEH AKIHLF H. & 40 & $8-2 N_{3}$ & POS & N: & NO & PKIVAT & 4000 \\
\hline$(11-57$ & TEXASS STREET & ENJAMIR & 70 & $F-2$ NI & P05 & $N[j$ & $N E$ & PEIVAT & 6909 \\
\hline $311-0 !-55$ & TEXAS STREET & EBE SAMIEL & 80 & $\mathrm{~F}-2 \mathrm{NO}$ & Pus & Nó & NC & PEIVAT & 8000 \\
\hline$J 11-01-59$ & TEXAS STREET & SKAS JOSEEH & 59 & $\bar{k}-2 \mathrm{NE}$ & POS & MO & $\mathrm{No}$ & PEIVAT & 0096 \\
\hline $01-62$ & MǴLDEK ANENUE & 0 KEENKETH & 50 & $F-z=05$ & P05 & YES & YES & PEIVAT & 283140 \\
\hline $11-02-12$ & AR_INGTCH STFEET & HAFF,IDT & 40 & $\mathrm{R}-2 \mathrm{Nu}$ & YES & $\mathrm{NE}$ & YES & IVAT & $40 \mathrm{ij}$ \\
\hline$-02-63$ & AFLINGTEN STREET & BO:TH FUEET $\mathrm{H}$. & 60 & $8-2 N C$ & YES & No & YES & PEIVAT & 6000 \\
\hline $02-04$ & ARLINGTON $5 T$ & TEDESCHI DOMINIC & 20 & $\mathrm{ki}-2 \mathrm{NO}$ & YES & NO & YES & FEIVAT & 200 \\
\hline $11-02-015$ & AFELINGTON STREET & ARS INÜUSTRIES INE. & 60 & $\mathrm{~K}-2 \mathrm{NO}$ & YES & HO & YES & VAT & 600 \\
\hline $111-6 i-07$ & MALLDEH AVERIE & LINSEEY JOSEFH R. & $200+C$ & $\mathrm{~F}-2 \mathrm{NO}$ & YES & $\mathrm{ND}$ & YES & FUELIC & 2000 \\
\hline$-02-12$ & TEIAS STREET & MURPHY JOHN & $2000+[$ & $\mathrm{K}-2 \mathrm{~N}$ & POS & No & Ni & FRIVAT & 10000 \\
\hline $0 . j-0.1$ & WASHINGTON AVE. & COOL ARTHIBÁ: & $205+5$ & R-2 NO & POS & NO & NO & FRIVAT & 210 \\
\hline $11-03-63$ & SOREETIILLE STREET & HLNLEY EFNSETIN & 100 & $8-2$ NO & Pus & Nú & NO & FRIVAT & 10000 \\
\hline $11-6 j-07$ & CHAFILESTOHN STEEET & CFONIN PHLLIP & 200 & K̇-2 NŨ & No & No & YES & PRIVAT & 2000 \\
\hline $0 r_{i}-01-(14$ & COLBY HEHITT LANE & OH RAREARET & $100+$ & $F-2 \mathrm{NE}$ & 10 & YES & YES & PFIVAT & 5445 \\
\hline $62-01-05$ & COLEY REKITT LIOFF) & HEHITT COLBY C & NCNE & $\mathrm{F}-2 \mathrm{NO}$ & $N[$ & YES & YES & NO DIR & 213444 \\
\hline$(0.7-01-05$ & CARESHELL STREET & NAMASKEESET REAL ESTATE & 571 & $R-2$ NJ & NO & YES & YES & FUELIC & 775.3 \\
\hline $03-0 \%-01$ & COLEY HEHETT LANE & KDHIKSON MAFEARET & 320 & $5-2$ No & ND & YES & YES & FRIVAT & 10872 \\
\hline $03-02-02$ & CAFESHEL STREET & HALL LINCOLN & 200 & $\mathrm{Fi}-2 \mathrm{NJ}$ & N2 & YES & YES & FLELIC & 56628 \\
\hline $603-02-03$ & CARESHELL STREET & NAMASKEESET REAL ESTATE & $62 \overline{6}$ & $K-2 N E$ & Kú & YES & YES & PUELIC & 24001 \\
\hline $17-02-05$ & CARESWELL STREET & TAYLOA KAGEK A. & 100 & $\mathrm{~F}-2 \mathrm{NQ}$ & N] & YES & YES & FUBLIC & 6810 \\
\hline $6.6-6-34$ & CHAMAFA- CIFCLE & GCVENOF NINSLOK & 120 & $\mathrm{~F}-2 \mathrm{NO}$ & F'Ús & Nũ & NO & PFIVAT & $211: 0$ \\
\hline $603-02-35$ & CASESWELL STFEET & HISTUAIC HINSLOW HOLSE ASS. & NOKE & $\mathrm{F}-2 \mathrm{NO}$ & No & YES & YES & NDI DIK & 3862 \\
\hline$x 03-02-57$ & PERFYN WAY (OFF) & MLLAJGHIN JAMES & NGINE & $\mathrm{R}-2 \mathrm{NJ}$ & NO & YES & YE5 & NO DIK & 8712 \\
\hline $103-02-39$ & CAFESHELL STREETIOFF & STAREATT CHARLES 6. & KINE & $\mathrm{F}-2 \mathrm{NO}$ & No & YES & YES & NO DIF: & $1176 !$ \\
\hline $104-02-06$ & MEESTEF STREET & DELORY JDHH & 110 & F-2 N & YES & 10 & No & PUE_IL & 2050 \\
\hline $104-62-35$ & ENIICGT S STEEET & HGUILALC FEANEIS & 180 & $\mathrm{~F}-\mathrm{F}^{2} \mathrm{Nij}$ & NO & $\mathrm{Ni}$ & Ni] & $N / A$ & $145]$ \\
\hline $104-0=-54$ & MALISIN AVE. & DUFFY HE!L & 90 & $R-2 N L$ & YES & No & No & PEIVAT & 720 \\
\hline $04-04-! 0$ & LEOAFET ROAD & INLIAR SFFIHE THLLT & $200+[$ & $F-i N E$ & No & Nū & NE & FEI CL & 453 \\
\hline
\end{tabular}


KOL-CIA-I1 LEDNARD FUÁD

KO4-05-6! LEONAST ROAD

INDIANH SFRING TRLST

104-05-19 JUSTIA HAV

104-05-20 LEJKARO RISL

BO4-FE-21 LEONAKD KDAD

KOL-05-2Z JUSTIN HÁT

KOJ-01-0TA IEFFERSOH AUENIE

1)

KO5-01-13 PLTWAR STREET

TOE-OU-18 EVERETT STREET

HE-OI-30 POWHAL STFEET

INUIAN SFEING TRUST

INIIAN SFFINE TRLST

INDIAN SFRING TRUST

INDIAN SPEING TFLIST

INDIAR SFRINE TRUST

HISTSOSH REERT H

REREISON REEERT W

PINEAUIT STEFHEN

WEKE ALTHJNY N.

15-01-3: CAFESKELL STREET OIFF FUTHEM REALTY TRLIST

KOS-01-35 JEFFERSOH AVENIE DURN JAMES W

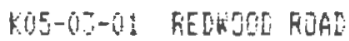

KO5-05-0I DAVIS ETFEET

KOS-T5-05 JEFFEFEJN AVENUE

MüFISUL F

PUIOEY ANWHA

QOE-6E-0IA CARUER STREET

RE- DE-12 PLTNAM STFEET

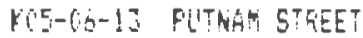

K.05-06-14 FUTHAT. STREET

KOS-07-(19 EUEFETT STREET

KOE-UT-10 CARIER STREET

DUILEY ANNS

REALTY IMFROVEHENT TELLST

HAEEL ROEEST $\mathbf{W}$.

HÁEEL RUEEFT H.

KEITH JAMES H.

MOSTEEFY TFACY

MUETEERE TFIFIYY

106-02-02 PRESIDENTIAL CIFCLE 5ANIEF GECEGE

KOE-OS-0! EUSTIS STFEE IOFFI SINRETT NOFMAN $h$.

LO3-01-02 CANA STSEET (OLF) FDOHEY EILEEN

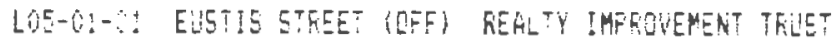

LOS-02-01 EUTIE STREET IOFF) REALTY IMFROUEMENT TRUST

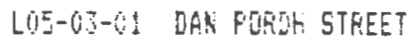

LQCE-O4-01 SHIELEY STFEET

LIS-१4-6I LEVERETT STEEET

LOS-OS-01 SHIRE STREET

LOS-OG-OL BEFRAFI STKEET

LOE-07-01 WILSOH AUENUE

LOE-OE-01 HILSOUY RUENUE

LOIE-09-012 BERNAET STEEET

LOC5-09-0) FLOFIDA STEEET

LOS-10-05 SHIRLEY STREET

LOE-11-09 LEVEFEYT STFEET

LOEL-12-05 LEVERETT STREET

LOS-14-05 EVEFETT STREET

LOL-15-09 LINCDIN AVE.

L05-16-0.6 LINEOLN AVE.

LO5-17-05 SHIREEY STKEET

LO5-20-93 EUSTIS STKEET

LO5-201-04 LINCOLN AVE.

LOG-01-01 GREEN HAEEJE MARSH

LOE-01-01 GFEER HAFEOF MARSH
FEDEFILO ALBEFT J

REÁTYY IMEROUERENT TEUET

VAFA ANNE F.

REALITY IHFROUEMENT THLST

REALTY IMFFOIEMENT TFUST

FEALTY IMFROUEMERT

REALTY IMFEOUEMENT

MCODNHLLI MICHAEL

REALTY IMFROUEMENT TKLST

JOROAN GETEEE

['CONBELL JOHN

MATTIVELLO MARTIN

BUITI. FICHARE $M$.

FISH EASTY H.

LUTFGEIO GESFGE J.

MURFH: DAUID

FEALTY IMFFEUEMENT TRUST

PHILFETT CDLLETIE RAY

DHEE EJWAFD

EAELY EIRE REALTY TRUST
$200+[\mathrm{K}-2$ NI NO NO NO PHI CL 33225

$160+C \mathrm{~F}-2$ NO NG NO NO PRI CL 86248

IBC+C R-2 NO YES NO NJ PRIVAT 17248

$2001+C \mathrm{~K}-2$ NO NO NU NU PEI CL 34496

$300+[K-2$ NO NO NO NO PRI CL 33322

$180+[C R-2$ NO YES YES YES PRIVAT 41254

$80+[\bar{K}-2$ NÜ YES NO NO FFIIVAT 4257

E0+[ Fi-2 NO YES NJ NO PEIVAT 8320

100 R-2 NO POS NO NO PRIVAT 25000

60 R-2 NO NO NO NO PRIVAT 4 BOO

40 R-2 NO FOS NO NO PRIVAT 36800

NONE R-2 NO NO YES YES NO DIR 13068 :

80 Fi-2 ND YES NO NO PRIVAT 3000

260 K-2 NO NO NO NO PEIVAT 14400

120 R-2 NO NE NE NO FRIVHT 9600

$160+2$ R-2 NO YES ND NL PRIVHT 16800

30 K-2 NU NE NU NO FGEVAT 2400

30 K-2 NO POS NU NE FFIVAT 2400

60) R-2 NO FOE HiL NI FEIVAT 4800

90 Fi-2 NO POS NO NO PRIVAT 7200

145. F-Z NO NE HE NO FEIVHT 5680

186 Fi-2 HO NO ND NI PRIVAT 6490

105 R-2 ND YES NO NO PUELIC 29273

NONE R-2 NO NI YES YES NE DIF 193342

NONE $K-2$ NU NO YES YES NO DIR 1139094

16 : ${ }^{-}$Fi-2 NJ NO NJ NO N/A 113255

NERE R-Z NO NE YES YES NO DIR 91476

EO $5-2$ FOS POS NO NO PEIVAT 14400

$445+[$ R-2 PUS FIS YES NU FRIVAT 42300

80 R-2 NO FOS NO NO PRIVAT 19166

200 R-2 FUS POS YES NO PFIVAT 66,9E4

$300+C R-2$ NIS NO YES NJ PRIVAT 43000

$300+[$ FI-2 FOS POS YES NU N/A 21990

$500+[$ Fi-2 FOS POS YES NO H/A 78408

90 R-2 NO NO YES NO PFIVAT 7200

$280+C$ K -2 POS FJS WD NO H/A 9600

60 R-2 POS FOS YES NO FFIVAT 4800

$60 \quad R-2 N O$ YES NO NO PRI CL 5040

$200+E R-2 N E$ PUS NO NO PEIVAT 9600

260 R-2 NO YES NO NO PFIVAT 13200

90 R-2 NO YES NO NO PRIVAT 4 EOO

$140+C$ FI-2 NE YES NE NI FRIVAT 4800

100 R-2 POS PUS YES NO FFIVAT 5227

190 R-2 NO NO NO NO N/4 21075

8O+5 R-2 NO YES NO NO FEIVAT 9600

NONE R-2 NO NO YES YES NO OIF 1616511

NUNE R-2 NO NO YES YES NO DIS 1337292

TOTGL5:

AREA SF $28,645,783.00$

Printed 471 of the 1955 records. 


\begin{tabular}{|c|c|c|c|c|c|c|c|c|c|}
\hline$F 16-02-11$ & EAMES WAL & LAMIGAN ELIIAEEETH & $3001+C$ & $R-3 N O$ & YES & No & $\mathrm{NII}$ & FUELII & 47916 \\
\hline$H: \Sigma_{1}-6 E_{2}-11$ & WeFiw Co hent & HQLSH HUEEFT & $294+C$ & $R-3 N O$ & YES & No & ND & PEIVGT & 1900 \\
\hline$H_{1} E_{1}-099-012$ & CEDAR RDAT & NEFGER GEOSGE E. & 85 & $\mathrm{~K}-3 \mathrm{NO}$ & NO & NO & $\mathrm{NC}$ & PRIVAT & 12300 \\
\hline $4.5-05-63$ & CEUAF RETE & NEKEEH GEGFGE E. & 85 & $\mathrm{k}-3 \mathrm{No}$ & NO & NO & NO & PRIVAT & 12300 \\
\hline$H 15-09-04$ & CELAEF RJAE & MUDELLS CHAFILES & 85 & $R-5 N O$ & NO & NO & NO & PFIVAT & 12350 \\
\hline$H: 5-6,5-06$ & CECAT REAS & ARMSTRONG JOHA R. & 65 & Fi-jNo & NO & NO & NO & PEIVAT & $1: 25 \mathrm{j}$ \\
\hline $415-05-68$ & 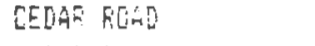 & ENN15 JOHF: נ. & 85 & $F-3 N[$ & $\mathrm{NE}$ & NO & $N[$ & PEIVGT & 11371 \\
\hline$H 15-89-69$ & CELAF RESE & NEFGER GEDFEE E. & 85 & $\mathrm{~F}-3 \mathrm{NO}$ & Ho & No & NO & PRIVET & 11296 \\
\hline$H 15-09-10$ & CEDAS FIAT & MCDONOUGH WLLIOY & 95 & $F-3 N:$ & NO & Nū & $\mathrm{Ho}$ & PR!VAT & 11200 \\
\hline$H 15-09-1 !$ & CEUAF $B \mathrm{HAT}$ & REFGEF MCDORJUGH & 130 & $\bar{K}-\bar{j} \mathrm{NO}$ & NO & Nõ & NO & PEIVAT & 10820 \\
\hline $4: 5-12-12$ & HOLLY RUAD & KLEBES JOYCE & $200+[$ & $8-3 N O$ & YES & No & NO & FUISLIL & 13207 \\
\hline $4 ! 5-12-05$ & IHEST Rori & TUFFU FRELERICK & $150+?$ & $5-3 N$ & YES & NO & No & PLIELIC & 10505 \\
\hline $415-12-09$ & DWIEHT RLAD & TUFFO FFEDEFICK & 80 & $R-3 N E$ & YES & ND & No & $F U I B \leq I C$ & 9675 \\
\hline$H 1 E_{1}-12-11$ & DHEHT REFD & FGHNLEY JAMES F. & $8 i j$ & $5-3 N 0$ & YES & $\mathrm{HI}$ & Ne & PLIBLIC & 8624 \\
\hline$H 15-12-13$ & DHIEUT RUAE & MCEROHAN JUHA & 80 & $5-3 N E$ & YES & NO & Nũ & FU: IC & 9733 \\
\hline$H+5-14-92$ & CEUAF FUAD & RDEEFTS FFANT: & 240 & $\mathrm{R}-3 \mathrm{NO}$ & NO & No & $\mathrm{NO}$ & PFIVAT & 31500 \\
\hline$H 15-14-0 j$ & CEUAG RLALI & FERG̈USDK DUREAR & 324 & $\mathrm{~K}-\overline{\mathrm{J} N \mathrm{NE}}$ & No & No & NO & PFIVAT & 42253 \\
\hline $4+5-15-16$ & EMEFY ROAD & SNELLING CORSTANCE & 180 & $\mathrm{~F}-3 \mathrm{ML}$ & YES & NO & NG & FLELIC & 22326 \\
\hline$H 15-16-04$ & HJLLY HISL CIFCLE & HANKEY FAIIL & $200+[$ & $5-3 N E$ & YEE & No & No & FEIUAT & 22737 \\
\hline $415-16-06$ & HOLIY HILL CIKCLE & LIGHTFELT KUIY & 70 & R-j ND & YES & NO & No & FEIVAT & 12218 \\
\hline$H 15-15-10$ & EFEFY ROAD & LIGHTFOUF FOY & 45 & $\mathrm{R}-\overline{\mathrm{J}} \mathrm{Ni}$ & YES & $N G$ & N0 & PUELIC & 5000 \\
\hline$H 15-17-64$ & CHAIETHAE TKEE LARE & GILL HILLIAH T. & 240 & $R-3$ NO & NO & NO & $\mathrm{AC}$ & PFIVAT & 30200 \\
\hline$H 16-01-33$ & GFAGIDIEH AUEVILE & ALICE M. I'EFIEN & 140 & $\bar{B}-3 \mathrm{NO}$ & YEE & YES & YES & PRIVAT & 13706 \\
\hline $1+6-05-06$ & UF:AKO KJAL & MAODEN STEPHEN & 80 & R-J NO & YES & NO & No & FUELIC & 11154 \\
\hline $316-1 j-09$ & LFLANO KOHL & ATLEAFN CLIFFOFL & $202+i$ & $F-5 N D$ & YES & NO & NO & PUELIC & 14234 \\
\hline$H 1=-0:-12$ & EL STSEET & WHE AN KENINETH & $8 \uparrow$ & Ki-3 NO & YES & NO & No & FUBLIC & 10800 \\
\hline$H: 6-03-14$ & ELM STREET & HEATOA FICHAED & 80 & $\mathrm{~K}-3 \mathrm{NJ}$ & YES & NO & No & FLELIC & 11367 \\
\hline $116-63-15$ & ELF STREET & MUGFHY JEABNENE & 115 & $\mathrm{R}-\mathrm{j} \mathrm{Ni}$ & YEE & $N G$ & $\mathrm{NO}$ & PUE:IC & $98: 5$ \\
\hline$H: t-03-j 6$ & ELM STAEET & HEATUN KILHASE & 80 & $\mathrm{~K}-\mathrm{J} \mathrm{NE}$ & YES & NC & Ni & Fustic & 11478 \\
\hline$H:=-63-17$ & ELW STREET & SGINEFS GFEGESY & 130 & $\mathrm{~F}-3 \mathrm{NJ}$ & YES & NO & NE & FUE_IC & 10901 \\
\hline $\mathrm{HE}-04-0 \mathrm{O}$ & EL STREET & G:LL HILLIAM & 309 & $\mathrm{R}-3 \mathrm{NL}$ & Yes & NO & $\mathrm{NU}$ & FRIVAT & 2650 \\
\hline$H: 6-04-07$ & UF_AND RUAL & PLATT NIKTYAAN & $4061+5$ & B-j $\mathrm{NO}$ & YES & No & No & PUBiIC & 43560 \\
\hline$H+t-04-08$ & EMEFY KUAAL & FEGTT NCFHÁN J. & 50 & $\mathrm{~F}-3 \mathrm{ND}$ & YES & $\mathrm{NLI}$ & $\mathrm{No}$ & FLELIC & 9215 \\
\hline$H: t-0 t-0 t$ & FERFY HILL KUADICFF) & ARCESE JOAK E. & NONE & $\mathrm{F}-\mathrm{J} \mathrm{NO}$ & $\mathrm{NO}$ & NJ & NQ & NO DIK & 11200 \\
\hline$H 16-06-0.14$ & ELH STKEET & RANCATOFE RICHAKD & 60 & $\mathrm{~F}-3 \mathrm{NO}$ & YES & NU & Ni & PUELIC & 37300 \\
\hline $416-06-06$ & PEAEODY KOAD & TREVISANI JOHK & $396+[$ & $R-3 N O$ & YES & $\mathrm{Ni}$ & Hi & PUELIL & 41447 \\
\hline $416-06-07$ & PEAEODY FGAD & TREVISAKI JUHH & 120 & $\mathrm{~K}-\mathrm{J} N[\mathrm{I}$ & YES & NO & $\mathrm{Ni}$ & FUELIC & 21175 \\
\hline$H 16-06-11$ & GRAMUVIEL FERFY HL & KENNETH HCINTYKE & 140 & $\mathrm{k}-3 \mathrm{NO}$ & YES & No & NG & PFIVAT & 8400 \\
\hline$H 16-09-195$ & PAULIINE ROÁE & DIJKREE DARIEL & 50 & $\mathrm{~K}-3 \mathrm{NJ}$ & YES & Ni & NEI & FUELIE & 5000 \\
\hline $4 ! 6-05-016$ & GFAHOVIEH AVENUE & JAMES E. LALIIGNE & 280 & H- INO & YES & $\mathrm{No}$ & No & PFIGAT & 1500 \\
\hline$H 16-10-60$ & CAFEITOK FOAD & ANDERSON NILS & 100 & $\mathrm{~K}-3 \mathrm{NC}$ & No & $N[$ & No & PEIYAT & 9620 \\
\hline$H \mid t-11-1$ & FGULIIHE RIAL & DYTCH ALEEKT & $25(i)+C$ & $\mathrm{R}-\mathrm{J}$ Nú & YES & $N E$ & HO & PUE:IC & 15000 \\
\hline $416-13-01$ & GSARDVIEW AVENUE & JAMES E. LAUIENE & $100+C$ & $R-3 N E$ & YEE & NO & No & FEIVAT & 1500 \\
\hline$H ! 7-01-0 E$ & FEREYY STREET & CULLEN BERIAREU & 171 & $R-3 N O$ & Wo & YES & YEE & FUELIC & 16638 \\
\hline $4 ! 7-01-09$ & CARELTON ROAO & ANDERSGK NILS & 245 & $\mathrm{~K}-3 \mathrm{NG}$ & NO & YES & YES & PAIVAT & 50628 \\
\hline $111-0 \bar{i}-06$ & SALEH ÄVE. & DAMIGELLA & $400+5$ & $F-3$ YES & F05 & YES & NO & FRIVAT & 30030 \\
\hline $114-04-63$ & ELM STREET & SHEFMAK IOHK & $174+[$ & $k-\div N 0$ & YES & $\mathrm{NU}$ & $N 5$ & PUE:IC & $236 E$ \\
\hline $114-05_{1}-1 ! 1$ & BIDEE RJAE (REAES) & COKKIGAK JAHES & NO & F-J NE & NO & YES & YES & NU DIK & 145104 \\
\hline $114-05-12$ & BAYEEFER ROAD & FEFE CARLOC. & 92 & B- $5 \mathrm{NO}$ & NO & YES & YES & $H / A$ & 9594 \\
\hline $114-05-13$ & SHAIY LAHE IOFF: & NEFGEF GEURGE & KONE & $R-3 N D$ & NO & YES & YES & NE UIK & 10000 \\
\hline $114-05-14$ & SHATY LAHE & NESGEF GEORISE & 96 & $R-5 \mathrm{~kJ}$ & PuS & YES & YES & FUELIC & $56 t 26$ \\
\hline $114-05-15$ & SHIFYAFE RORE & NEFGER GEOKGE & $3 ! 2$ & $R-3 N C$ & YES & NO & YES & FUE:IC & 171191 \\
\hline $114-05-16$ & MALLAFS FOAL & NERGER GEGRGE & 155 & $R-3 N E$ & YES & NE & YES & FIEE IC & 3120 \\
\hline
\end{tabular}




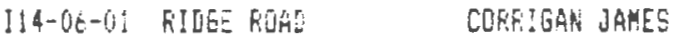

114-DE-14 RIDÓE REAHD (OFF) MOFI HIDEJ

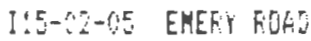

$115-0:-16$ CEDAT ROATD

IIE-OI-OI EMEFIY ROAL:

II5-03-12 JUNIPEF RIAE

II5-03-016 DHISHT RLAD

I15-0j-07 0HI6HT 6000

II5-S4-02 DH:SHT RUAJ

IIE-UA-03 ELM STREET

$115-60-04$ FERF'Y STREET

$115-U E-02$ ELM STREE:

115-67-09 DLEHIR ROHI

I15-07-17 EL STREE?

I15-1010-07 REENE ROAAD

II5-1!-0! REENE ROHL

IIE-11-21 FEFSY STKEET

I15-11-22 FERT' STREE?

115-11-25 HEFTURE ROAO

I15-11-27 KEENE ROAO

115-1!-30 FEFAY STREET LOFE,

115-11-31 FERTFY STFEET [OFE]

115-1Z-12 FEFE STFEET

IIS-14-02 BAYEEREY ROAL

I15-14-97 FERSY STREET

I:5-15-01 FEFinY STFEET

IIS-1S-O2 MALLAFO KOAD

$115-16-06$ FERFY STREET

I15-17-O1 MALERED ROAL

115-17-02 SHIFIARD FUAD

$115-17-14$ MALLAKL FOAL

$115-18-02$ BAYBEFFY RIJAD

115-18-06 SH!EVAFD ROAD

I15-21-02 BAYEERRY ROAD

$115-21-05$ RIJOE ROAD

115-21-06 MEADDE LAKE

I15-22-01 BFYGEERY ROAD

II5-24-01 BAYEEFFYY RLAL

II5-24-06 RIDGE ROALD

$115-24-10$ BAYBEREY KCLD

I15-24-15 FERFI STEEET

I15-24-22 FERTY STREET

115-24-25 RIDGE ROAT:

115-24-26 BAVEERFY KOAD

116-02-03 PRESTOM TEFhACE

$116-02-94$ PRESTOH TERKEEFSY 5T RAYNER MARILEE

116-0I-:0 CAFiTUN BOAGD

$116-05-12$ COLLMEISA KGAL

116-07-03 CHAFHAR HAY

116-07-06 ALLEFTON ROAD

$116-19-14$ SEA STREET

$116-12-16$ HYDE WAY

$116-\{2-17$ HYDE HAY
QLIIALEY JACOE H.

SHEEHAN FAULL J.

RUCKLAND TRUST CO.

CLAFE MAKIJURIE

KOAFN CATHOLIC AFEHEISHUE

OHAEA HILIIAM F.

HAMHEY FHUL

RGRAH CATHOLIC ARCHEISHOF

MEKGEF GEORGE

LASTERS JEAN

WHLSH CHESTER RICHAR:

KIASELLA EDEAEI

MOTTA ANTCLIS $M$.

HOAF FLDEERTE

[' GEIER EDKAFO

EATEF JOHK W.

DAVIS HILLIAM

HEEEKT FENE?

HUS $\mathrm{i}$ LOLISA

HUN LDUSIA

CARE TON JOHN

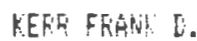

HAFENKEY JÜH

MCDUNUIGK HILLIAM:

LEONE GERGELI

FULEY JAMES A.

ROSSI CRLLANJC

VOGEL FALL E.

SIMMTS MARY LOUISE

LYONE FAUL $R$.

HALEY JUHN F.

MEREEF GEORGE

CHOSSTHA HENAY

CURLEY JOHW

NEFGER GEORSE

NERGER GED.

HASER EDHIN

MERGEF GEBRGE

HAELLOU GEOKGE

FAREL Y RICHARS

MAFSHFIELO YALHT CLUE INC.

FEARL EUERTT M.

RAINEF RICHAET

OOSETHY M. TRUEE TRUST

FULLEK CAEUL IEAN

NURFHY PAUL $H$.

COFNELIUS FGRUE

EUNEF, MAE:E $F$.

DALZELL WHERER'

BAIESE COKETARE
NOHE R-3 NO NO YES YES KO OIF 23939

NONE R-3 NJ NU YES YES NO DIF 96267

$220+C R-3$ NO YES NO NO PRIVAT 18593

85 R-3 NO NO NO NO PEIVAT 12229

$240+C R-3 N O$ YES NO NO PRIVAT 13085

E5 R-3 NO YES NG NO FRIVAT 9480

$200+C R-3 N O$ YES NO NO FUBIL 12000

85 R-JNO YES NO NO PUELIC 9770

87 R-J HE YES NO NG PUELIC 14165

$3500+[$ R-3 NO YES NO NO PUELIC 6.984

$344 \quad F-3$ NO YES YES YES PLELIC 60584

$206+C R-3 N O$ YES NO NO PUELIC 20985

45 R-3 NO YES NO NO PFIVAT 2824

60 R-3 NO YES NO NO PUBLIC 9060

123 K-3 NO HO NO YES PRIVAT 7378

60 R-J NO NO NO YES FFIVAT 2600

46 Fi-J HU YES NO YES FUBLIC ? 160

$67+C$ Fi-3 NE YES NJ YES FUELIC 71674

$163+C R-3 N J$ YES NO YES PRIYAT 1860,2

$95 R-3 N J$ NO NO YES FFIVAT 66211

NUAE $R-3$ NO NU YES YES WJ DIK 6400

NOHE $K-3$ HO NO YES YES NO DIR 9345

$90+C \quad R-3$ NO YES NO YES PUELIC 11000

$175 \quad R-3$ NO YES NO YES PUBLIC 7500

75 R-3 NO YES NO NO PUBLIC 7625

$150+[R$ R-3 NO YES NE YES PUBELIC 17655

$155 R-3 N D$ YES NO YES PUBLIC 15600

62 R-3 NG YES NU YES PUELLIC 10421

$75+C \quad R-3 N O$ YES NUT YES PLBLLIC $7500^{\circ}$

3019 R-3NO NO YES YES NIA 22500

$75 \quad R-3 N O$ YES NŨ YES PUJELIC 75 (IO)

$175 \quad 5-3$ NO YES NO YES PUELIC 7500

$85+5 \quad R-3 N O$ YES NE YES PUELIC 7452

$300+C R-3 N G$ YES NO YES FUELIC 32390

75 F-3 NO YES YES YES PLBLLIC 8082

124 HI-3 NO YES NO YES PRIVAT BOCO

160 R-J NO YES WO YES PUILLIC 126324

$345 \mathrm{R}-3$ NO YES YES YES PUELIC 56628

$75 \quad R-3$ NO YES YES YES FUBLIC 7873

NUHE R-3 NO NO YES YES NO DIF 557568

$38 R-3 N O$ YES YES YES PUEL!C 4310

$120 \mathrm{R}-3 \mathrm{NO}$ YES NO YES FIUELIC 5200

50 R-3 NE YES YES YES FUELIC 10100

145 $5-3$ NUI YES YES YES FUEDIC 11015

$12 \%+E-3$ NO YES NO NO FUELIC 11200

$205+\bar{L}-3$ NO HES NO NO FUEIIC 11600

120 F-3 NE YES ND NE FUELIC 10740

60 R-J NO YES NO NO PLIELIC 7875

92 R-3 NO PCS NO NLI PFIVAT 185,2

6j R-j NO POS NG NE FFIVAT 10010

E6 RIJNO YES NU HO FRIVAT 5732

$80+5$ R-J NO YES NO NJ FLELIC 4600

BOt $K-3$ NU YES NO NO PUELIS 12000 
OhHEF OF FEC

BRIGGS CONSTANCE H

I16-12-18 HYDE WAYY

116-12-19 IRELAND ROAO

$116-12-20$ IRELAND READ

$116-\{j-07$ FEFK' STREET

$116-15-04$ FEFFY STREET

II6-15-0E FEFIY STREET

116-15-16 FEREY STREET

IIE-15-OE FRESTOA TEK\&FEFGY ST BEOAK RILAND

I1E-:5-0Y FEFRY STKEET YOUNGHETIH BILLIAM

I16-\{5-10 PRESTUNN TERLFERGY ST LOOMIS AAEOH

I16-15-11 FEFFY STKEET BARKETT DAKIE!

116-15-12 FERFY 5TREET GÜRAR ARTHUS

116-15-13 FERFY STREET FARLEY ROEEFT

116-15-14 PFESTON TERLFEFFY ST TURNEF AFTHLE:

JÜL-10-03 STATESHAR TERRACE

JUQ-0Z-23 COEELANE STREET

JO9-07-15 PHEASALT TLANE

J10-08-46 OCEGN STREET (OFF)

J12-02-01 ROGERS ROHI

J!2-0Z-12 CHILTON STREET

J13-02-2t PARKER STKEET

J!J-02-32 PAFKEK STFEET

J14-O1-04 RIDGE ROAL

J14-01-15 RIDGE ROSL (FEAE)

114-01-16 RIDGE RUAD (REAE)

J14-U1-17 RIUEE FIOAN IFEAF'

J14-01-18 RIDEE ROAE (FEAF')

J14-01-19 FIDGE RDAD IREAFI

II4-II-20 RIDEE RJAE IFEAFI

J14-02-1E RINGE ROLL

J14-02-i7 RIDEE RUAO

Ji4-02-2G RIDGE ROAD (IITF)

K04-05-18 KAREN HAY

KOT-01-02 GKEEN HAFEOBK MAFSH

K0E-03-01 DKRE MARSH

KUB-0S-0J GREEN HAREOR MAESH

K.09-03-06 REAR MLISEET ROALI

KI9-03-08 MUSKET RGAD

KOS-04-0! MUSKET ROAD (JFF)

K10-01-09 HINSLOH STFEET

KIO-01-15 HINSLIH STREET

K10-02-12 HINSLOR STFEET

K10-03-05 GKAESHCFFER LANHE

R.19-0J-10 GRAESHIOFEF. LAHE

K.1U-04-02 LONGUIEW TEKFACE

K10-04-14 HINSLOH STREET

10-04-15 G5ASSHOFFEN LANE

K10-04-20 GRA55HEFPEF LALE

1.10-04-22 GRASSHJPFER LANE

KOO-05-06 MEYFLOTEE LAHE

1:10-05-15 MAYFLOHER LANE

110-05-15 LONGUIEH TERRMLE

K1j-05-20 LONEVIEH TERFGLE
KL GUHEN ARINA H.

RÜCK FEÁTYY TRUST

CHASE ROSEMAR'Y

CHASE RDSEMAF'Y

BROAN MELEN

BROHN HELEN A.

COEN LAUERESCE R.

VICLA JAMET H.

EIVIÁNO JUSEFH

COEEIGAN JAMES

CORGI GAH JAMES

COREIGAN JAMES

CORRIGAN JAMES

CORFIGAFI IAMES

CORR!GAN JAMES

BISGE ROEL ASSECIATION

CURERIGAFI JAMES

SEC RIVER TKLLST

IKIIIAN SFRINE TKLST

MARSFFIELD ROE \& ELN CLIJE

MASSACHUSETTS AULUEDH SOCIETY

EAFLYY BIFD REALTY TKUST

HYNES ELMER

JAE CORFORGTION

JAE CORPLRATION

BUBFEE LEG

LAWFENCE FREDEFIIC

LAHFERCE FREDEFIC

STUART J.LANE

FFERFICK C. LAWFEACE

GLVE GEJREE S.

SACFOMLNA JAMES

JOE SULOM

MAECIA C. YOUNE

FREDRICK T. YOLLESLLAUS

TUE:H ALEERT

CELIA GEORTE

ANDEFSOH JOHR H.

ANDEEEOR: JONR H.
FRONT ZON SEH WAT HET FFA ACCESS AREF SF

72 K-J NU YES NE NO PUELIS 9516

NDNE R-J NO YES NU NO NU DIR 18500

127 R-J ND YES ND NI FUELIC 13500

$180+C \mathrm{~F}-3$ HJ YES NO NO PUELIC 7600

$70 \quad K-3$ NO YES YES YES FUBLIC 7305

275 F-J NO YES NO YES FUBLIC 25016

127-5 F-3 NO YES NO YES FUBLIC 5300

40 K-3 NO YES NO NO PUELIC 1800

85 R-3 NO YES YES YES PUELIC 800

80 R-3 NJ YES NO NO PUELIC 9506

$120 \quad R-3$ NO YES YES YES PUBLIC $9200^{\circ}$

45 R-J NO YES NO YES FUELIC 7000

60 R-3 NE YES YES YES FUELIC 5100

83 R-3 NO YES NO NO FUELIC 1600

120 K-J $\mathrm{NG}$ YES $\mathrm{NC}$ ND FUBLIC $20040^{\circ}$

$22 !$ R-3 FOS NO YES YES FFIYHT 37600

80 Fi-3 NO YES NO NO PFIVAT 20041

40 R-J NO NO YES YES PFIVAT 1198771

NO R-3 HE NO YES YES NO DIR 12000

6O R-J NII NO YES YES PRIVAT 6000

50 R-3 YES YES NO NO FRI CL 5000

50 R-.3 FOS FUS POS POS FRI CL 5395

$75 \quad R-3$ NO YES YES YES PUELIL 10760

NONE R-J ND NO YES YES NJ DIK 22275

NUNE FI-S NE NE YES YES NO DIR 20000

NONE R-3 NO NE YES YES NO DIR 15975

NINE R-3 NO NO YES YES NU D!K 14100

NONE $R-3$ NO NO YES YES RO DIR 12975

171 R-3 NO POS YES YES N/H 12790

75 K -3 NO YES YES YES FUALIC 12875

WURE $\mathrm{K}-3$ NO WO YES YES FUL 498762

HUNE R-J NU NO YES YES NÜ DIF 313632

$30 \%$ Fi-J NO NO NO NI FFI CL 34284

NORE RT-J NO NO YES YES NO DIR 182952

NENE R-J NG NO NG YES NU DIR 579340

NONE R-3 NO NO YES YES NO DIR 1097712

40 R-J NU NU YES YES NO DIR 178596

110 R-J WO NO YES YES PFIVAT 24195

$430+C R-3$ FOS FOE YES VES N/A 31095

108 R-J YES YES NJ NO FULLIIC 65775

1430 R-3 YES YES HE NEI FUELIL 1459260

$200+2 R-j$ YES TES NO NO PUELIC 10460

50 R-3 YES YES NO NO PUBLIC 5000

$300+C E-3$ YES YES NO HO PUGLIC 21150

$100+C$ R-J YES YES NO KI FUELIC 5239

$150+[\mathrm{K}-3$ YES YES NO NO PUELIC 5727

$180+C R-J$ YES YES NL NE PUBLIC STOL

50 R-J YES YES NO NO PUELIC 5000

50 R-3 YES YES ND NO PUBLIC 5000

50 R-J YES YES NO NO FUBLIC 50010

$194+[\mathrm{F}-3$ YES YES NO NO PUB.IC $1055 \mathrm{~S}$

50 K-J YES YES NO NO PUELIC 5000

50 R-J YES IES NO NG PUE_IE $500 \%$ 


\begin{tabular}{|c|c|c|c|c|c|c|c|}
\hline A5. MAF-LET & LOCATION & GHNEF OF REC & FFUNT & ION SEH WAT WET & FFA & ACCESS A & AREA SF \\
\hline$k ! 0-0.5-23$ & LONGVIEK TERFACE & DADDARIO ARMAND & 50 & R-3 YES YES NJ & No & FUELIC & 5000 \\
\hline $1010-00-02$ & MAYFL CWER LAHE & FRAKCIS LUG:LLE & $14 \bar{y}+C$ & FI-J YES YES NC & No & FUELIC & 5155 \\
\hline $1010-06-09$ & HINSOON STREET & ADARS GENEVIEVE & 100 & F-J YES YES NO & NO & PUELIC & 10274 \\
\hline $110-07-05$ & ALDEN RUAD & DKISCOLL JANE $F$. & 100 & $F-j$ YES YES NO & NO & YE5 & 10600 \\
\hline$k ! 0-08-01$ & PRIERILLA ROAD & BINI DILLIO & $154+C$ & R-3 YES YES HD & No & PUELIC & 5692 \\
\hline$k 10-0 \varepsilon-0 E^{2}$ & PEISCILLA REAL & HALTHFUURE REALTY & 50 & R-J YES YES NO & NO & FUBLIC & $50 \mathrm{j0}$ \\
\hline$k ! 6-08-66$ & FFISCILLA RUA: & HAWTHRONE REALTY & 50 & R-3 YES YES NO & NO & PUELIC & 5060 \\
\hline$k 10-05-10$ & ALLEN F.ÜAD & DQUCETIE MÁF' $\overline{6}$. & 50 & R-J YES YES NE & NO & PKIVAT & 5000 \\
\hline $1.10-08-10$ & FRISEILAG ROAO & COLLINS MYKA'A & 50 & R-3 YES YES ND & NG & PUELIC & 7764 \\
\hline$(16-(19-1) 4$ & ALLEH FEAL & FINLGEN ELGENIA \& VILLARE FALL & 198 & $R-3$ YES YES NO & No & FFIVAT & 11270 \\
\hline$k 10-09-05$ & PFISEILLA RÜAE & MOFRELL JOHK & 75 & $R-3$ YES YES NDE & No & PUBLIC & 5200 \\
\hline$k 10-09-06$ & ALDEN FUAL & SIANEHI GEDVANA \& FIHESEN EUE. & 52 & $R-3$ YES YEE ND & No & PFIVAT & 5200 \\
\hline $110-09-67$ & ALDEF REAL & BIANCHI GEIVAANA FINKGEN EUE & 51 & R-S YES YES NDI & No & PRIVGT & 5100 \\
\hline$k 10-80-09$ & PFISEILLA FIAT & CUFFLES DQRAGL & 54 & R-J YES YES ND & NO & FUELIC & 5400 \\
\hline $1.10-15-04$ & MOHITOF RUAL & GUIKEY CLANCY COFFORATIOH & 60 & R-j YES YES YES & $\mathrm{Na}$ & PFIVAT & 5100 \\
\hline$k 10-13-09$ & MENITLF FEALE & CLANCY JAMES & 60 & F-3 YES YES POS & $\mathrm{Nu}$ & PFIVAT & 5100 \\
\hline $1 ! 10-15-11$ & COKSTELLATION ROELJ & CLANCY JAFES & 60 & R-3 YES YES YES & NU & FUELIC & 5100 \\
\hline $110-13-12$ & COHETELLATIOR REAL & CIAME'S ARTHC & 120 & R-3 YES YES NI & NU & FUELIC & 10200 \\
\hline $1.10-15-13$ & CONETELLATIUK RIAD & HALL HAFI:J 3. & 60 & R-3 YES YES YES & No & FUELIC & 5100 \\
\hline$k 0-13-16$ & CONSTELLATIOK ROAL & OJILIO NIEHDLAS & 60 & $R-3$ YES YES YES & No & PLELIE & 5100 \\
\hline $110-14-02$ & MAVFLOHEF LA:SE & GUIKEY CLAK & 60 & KI-3 YES YES YES & NO & FUELIC & 5100 \\
\hline$k 10-14-03$ & MAYCLOWEF LANE & CLAKEY JAMEE & 60 & R-3 YES YES YES & $\mathrm{NO}$ & PUELIC & 5100 \\
\hline$k 10-14-05$ & MÁNFLOHES LANE & CLANCY JKMES & 60 & R-3 YES YES YES & NO & PUELIC: & 5100 \\
\hline $100-14-06$ & MAYFLOHEF LAHE & Quik & 60 & F-J YEE YES YES & Ni & FUELIC & 5100 \\
\hline $1.10-14-07$ & METFLOLEF LARE & CLA & 60 & $\mathrm{~K}-3$ YES YES YES & NE & FUUELIC & 5100 \\
\hline$k: 0-14-0.6$ & MAYFLDUEF LA & CAH. & 60 & $R-3$ YES YES YES & No & FUELIC & 5106 \\
\hline$k 10-14-11$ & MAYFLOWER LAME & BIAUBTTE AN & 60 & FI-3 YES YES NO & No & PUELIC & 5100 \\
\hline$k ! 0-14-13$ & SISGF AUENUE & FOEINSON THO & $113+[$ & F-S YES YES NO & NO & PUELIC & 4832 \\
\hline$k 10-14-18$ & MONITOE FIAL & CLARCL JHHEE & 60 & Fi-3 YES YES YES & No & FRIVAT & 5100 \\
\hline $1019-14-17$ & MUNTOE REAL & QUINEY CLARYY CORFURETION & 60 & R-J YES YES YES & $\mathrm{N}$ & PRIVAT & 5100 \\
\hline $10-14-20$ & MONITOF: FEAL & QUHTCY CLAREY CURF & 60 & K-3 YES YES YES & $\mathrm{Ni}$ & PEIVAT & 5100 \\
\hline$k 10-14-21$ & MONITUE RLAE & QUIALY CLARCY COFFGRETION & 60 & F-J YES YES YES & No & FFIVAT & 5100 \\
\hline$k 101-14-22$ & MONITOF RDAD & CLANCY JAMES & 60 & K-J YES YES YES & No & PFIVAT & 5100 \\
\hline$k 10-14-2 j$ & MONITOR KLER: & EUICNY CLANCY CORFCRÁTIOH & 60 & $k-3$ YES YES YES & $\mathrm{Ni}$ & FRIVAT & 5105 \\
\hline$k 10-14-24$ & MONIIGE RLAD & CLANCY JAMES & 60 & R-3 YES YES YES & No & PRIVAT & 7500 \\
\hline$k 10-14-25$ & MULITOR RIASI & GUICNY CLARCY CORFOTATION & 60 & $K-3$ YES YES YES & NE & PRIVAT & 5160 \\
\hline $110-15-01$ & COUNTFY WAY & QUIACY CLANCY COFF. & $135+c$ & F-3 YES YES NO & No & PLELIE & 4741 \\
\hline$k 10-15-0 j$ & HăRTFUFI FJTÉ & COAN THOMAS M & 60 & K-3 YES YES NO & $\mathrm{No}$ & RIVAT & 5100 \\
\hline$k ! 10-15-0.15$ & HARTFORE ROAS & GKAAAAHAH THOMAS & 60 & R-J YES YES NJ & NO & PRIVAT & 5100 \\
\hline$k 10-15-0 ?$ & HARTEOAL RQAS & GRARABHANI FUTTH & 60 & $\mathrm{~K}-3$ YES YES $\mathrm{NOB}$ & NO & PEIVAT & 5100 \\
\hline$k 10-15-09$ & HFETFEKL KOFE & LINNRANE NDFA & 60 & H-3 YES YES WI & $N$ & PRIVAT & 5100 \\
\hline$k 10-15-11$ & HAFTFOFE REAL & SADLER MAGILAFET & 60 & Fi-J YES YES NQ & NŨ & PRIVAT & 5100 \\
\hline$k 16-15-16$ & HAYFLOWER LANE & OKARE WILLIAM & 60 & R-3 YES YES NG & ME & FUELIC & 5160 \\
\hline $10: 0-15-17$ & RAYFLDHEF LAME & TOHNEF ROGERT & 60 & FI- Y YES IES NO & No & FLELIIL & 5106 \\
\hline$k 11-15-1 E$ & BÁYFLUHEF LAME & CLANCY JAMES & 60 & R-3 YES YES NE & $\mathrm{kU}$ & FUELIC & 5100 \\
\hline $1: 10-15-19$ & 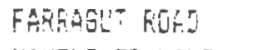 & POLLOKK KENAETH & 60 & R-J YES YES ND & ND & PRIVAT & 5100 \\
\hline $1.10-15-70$ & MAYFLUKEF LARE & ANDERSGL: EFNEST & 120 & F -3 YES YES YES & $\mathrm{NI}$ & F'UELIC & 1020 \\
\hline$k 10-15-21$ & MAYFLOHEF LARE & DEVINEEMII HEFFEL & 120 & F-J YES YES YES & $N[1$ & PUE:IC & 1000 \\
\hline$k 1(i-15-23$ & MAYFLOWEE LAKE & GUINCY CLANEY & 60 & R-J YES YES YES & Ni & PUELIC & 5100 \\
\hline $110-16-0 t$ & DCEAH STFEET & JAE CLFEQRFTUOA & 590 & F-J YES YES YES & No & PUELIC & $39965:$ \\
\hline$k: 0-16-15$ & QCEEARI STREET & HALLL FETEF & 35 & R-Z YES YES YES & ND & FUE:IC & 1934 \\
\hline$k 10-16-20$ & BFEAINHAET COIF! & FAFEMLUUK FEALTY CORE. & 200 & R-J FUS FOS YES & NU: & FEIVAT & 27976 \\
\hline$k 10-16-25$ & EFEAKHATEF CCLST & GKEAT EASTEFH: KEELTY TR:ST & 56 & R-3 PUS PDS YES & $\mathrm{NI}$ & FEIVAT & 6500 \\
\hline
\end{tabular}




\begin{tabular}{|c|c|c|c|c|c|c|c|c|c|}
\hline AE. MAF'-LJT & LOCATIOH & OHNER OF KEC & FRON: & $20 k$ SEW & WAT & HET & $F F \hat{H}$ & ACEESS & AIEER SF \\
\hline - & & 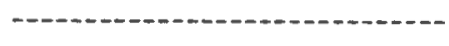 & -...- & $---\cdots$ & -- & --- & -- & & \\
\hline $11(i-16-41$ & TOHAE HAY & GREAT EASTEFN REALTY TRUST & 50 & KI-J YES & YES & YES & No & FUELIC: & 5010 \\
\hline $10-10-43$ & CLEFT ECHE LANE & FAYLOR FFEDERICK H. & 103 & $\mathrm{R}-3$ POS & pos & NO & NO & FEIVET & 5202 \\
\hline $110-17-05$ & TAFT FIñi & JAE COFP. & $10 i j$ & $R-3$ POS & Fus & YES & YES & PUE:IL & $100: 0$ \\
\hline $110-19-17$ & CHAFES STREET & FICKERINE JAMES & 45 & R-3 NE & No & YES & YES & PRIVAT & 3366 \\
\hline $119-19-23$ & HANEEY COUKT & HAMEL FREDERICY & 50 & $\mathrm{R}-3 \mathrm{NCI}$ & NU & YES & YES & PEIVAT & 40010 \\
\hline $616-19-27$ & TAFT KUED & SHEKWEJ MIEHAE: & 50 & $\mathrm{~F}-3 \mathrm{FOS}$ & F0S & YES & YES & PRIVAT & 5670 \\
\hline $1: 10-19-28$ & TAFT RUAL: & JAE CORFOKAT?DH & 70 & $R-3 F O S$ & plt & YES & YES & FFIVAT & 1400 \\
\hline $5: 3-19-29$ & TAFT RJAL & JAE COFFUAATIEH & 200 & $\mathrm{R}-3 \mathrm{FO}$ & Fllis & YE5 & YES & PEIVET & 10200 \\
\hline $110-15-32$ & DEEARY STREE： (UFF\} & BAFILAES ALEEET & NJWE & $\mathrm{R}-3 \mathrm{NO}$ & $N$ & YES & YES & He DIF & 1546.38 \\
\hline $110-17-7:$ & CHESES STFEET IUFF) & BAFELAET ALEEFT & NUSE & $\mathrm{K}-3 \mathrm{NO}$ & NO & YES & YES & NO UIF & 174240 \\
\hline $1.10-19-34$ & LEEN STREET (OFF) & BAFILASO ALBERT $\mathrm{K}$. & 68 & $\mathrm{R}-3 \mathrm{NO}$ & NO & YES & YES & Ffi $C L$ & 5272 \\
\hline $110-20-12$ & CSUUNTEY WEY & CLAKCY JAMES & 67 & R-3 YES & YE5 & $N !$ & NO & PLELIS & 7434 \\
\hline $110-21-02$ & OLYHFJA ROAP & FYLEY MAFGGAET & $18 i+c$ & R-3 YES & YES & YES & nO & PEIVAT & 9147 \\
\hline $110-21-03$ & KEGFSARSE FUAR & CLAKLCY JAAES F. & 60 & K-3 YES & YES & No & No & FRIVAT & 5100 \\
\hline $1(10-2 j-0.4$ & KEASSFAE ROAD & MALCREY JAMES $K$. & 60 & R-3 YES & YES & hIs & NO & FRIVAT & 5100 \\
\hline $1.11-01-06$ & HIMESTEAL FUENIJE & CAFEY FICHASD J & só & R-3 YES & YES & $N$ & NO & FUBLIC & 5000 \\
\hline$k 11-01-13$ & SHEFIDAH DFINE & KITTKEDEE HICULE & 70 & Fi-3 YES & YES & $\mathrm{Hi}$ & NE & PUE_IC & 6500 \\
\hline$k 11-01-22$ & CRESTHUOI AYEKJE & SCULLY M. JEANHETTE & 50 & R-j YES & YES & NO & YES & PUELIC & 5500 \\
\hline $111-01-23$ & CFESTWOOE AVERLE & MELAUGHLIN JOHN & 100 & F-3 YES & YES & Nĩ & YES & FUE:IC & 16275 \\
\hline$k: 1-01-25$ & CAESTHEOS RUENLE & SCHEREAM LILLIAAR & 50 & R-3 YES & YES & No & NO & PUBLIC & 5000 \\
\hline $111-01-3 i$ & WlWETH FEAL & MEDERMUTT THOHE & 50 & R-J FOS & YES & $\mathrm{Nu}$ & NG & FUSEL!C & 5000 \\
\hline$k: 1-01-33$ & HINSTEA RQE & TOETI ANTHOHY & 80 & $K-j F D S$ & YES & No & M & PUELIC & 5000 \\
\hline $111-61-35$ & HINSTQWH FOAL & O. DOHHELL MICHAEL & 200 & $R-5$ P0S & YES & NO & NO & PUE!IC & 8996 \\
\hline $111-0:-39$ & BRURJKIC STREET & GáfHIN FRGALES & 120 & R-j YES & YES & 15 & NO & FUELIC & 9979 \\
\hline$k 11-0 !-4 !$ & BR:KEWIEK STREET & O'OJNHELL DCNALD & 60 & R-J YES & YES & NJ & NE & FLLELIC & 5000 \\
\hline $\mid 1 i-01-41$ & BÁLLEY TEKGAGE & DIMATALE VIKEENT J. & 52 & $R-3$ YES & YES & NO & NO & PUELIC & 5083 \\
\hline$k 11-01-50$ & MECLUHSIEK STREET & KEDLGH THTIMÁS & $19 t+i$ & R-J YES & YES & NE & $\mathrm{NO}$ & FUELIC & $2716 \overline{8}$ \\
\hline$k 11-01-54$ & FIELE STREET & DRAIELL ELMES & 50 & $5-3 N 0$ & No & YES & YES & FUBLIC & 1742400 \\
\hline $111-61-55$ & SHERIDAK IRIVE & SEULIY WILLIAH & 50 & $B-3$ YES & YES & $\mathrm{Ni}$ & NO & FUE:IC & 15000 \\
\hline $11-01-5 t$ & HIHET RH FEL & G'DINRELL MICHAEL & $120+c$ & $R-3 F O E$ & YES & NC & No & PUELIC & $4 ! 20$ \\
\hline$k 11-0 !-57$ & HIRETUH FUATI & O"DONHELL MICHAEL & 135 & $\mathrm{R}-3 \mathrm{~F} 05$ & YES & $\mathrm{NLI}$ & $\mathrm{Ni}$ & FLELIL & 3870 \\
\hline$k 11-01-56$ & WINETJN RUGAO & O'DONKNELL MICHAEL & 200 & $R-3$ POS & YES & NO & 10 & PUELIC & 5000 \\
\hline $111-01-55$ & BFULEHICF STREET & G'DOWELL DONALD & 60 & B-3 YES & YES & NO & $k[$ & FUBLIE & 5000 \\
\hline $111-61-66$ & FIELD STREET & HAINHAN NELSOA & 125 & $R-j$ YES & YES & No & NO & PLELIC & 17722 \\
\hline$k ! 1-0.3-0.4$ & HOMESTEAD AVERLLE & HOLMSTROM FFEIEEICK & 50 & K-3 YES & YES & NO & No & PUELIC & 5150 \\
\hline$k 11-0.3-05$ & HOMESTESD AVENLE & CORCORAR PATEICK & 50 & R-3 YES & YES & NU & WO & FUBLIC & 5175 \\
\hline$k 11-0.3-14$ & HEMESTEAD AUEVUE & MCCAEE ASNES & 50 & R-3 YES & YES & $\sqrt{1}$ & NO & PUELIC & 5060 \\
\hline $111-03-15$ & HOMESTEAT GUENLE & THOMFEOL: ALICE O & 50 & R-J YES & YES & NG & NO & PUELIC & 5030 \\
\hline $111-04-15$ & SHEFIDAN DFIVE & REITH GOKOON FOFBES & 50 & R-J YES & F05 & $\mathrm{Ni}$ & NL & PUELIC & 5000 \\
\hline $111-04-19$ & SHEFIDAN ORIVE & CHAREST MAEY & 50 & R-3 YES & YES & $N$ & No & PUELIC & 5000 \\
\hline$k 11-05-68$ & JQNES STFEET & COLLINS JOSEFH & $95+C$ & F-J YES & YE5 & No & $N E$ & FUBLIC & 5450 \\
\hline$k 11-05-11$ & ELLIS AVENUE & CLEARYY JUHA & 50 & F-3 YES & YE5 & No & NO & PUELIC & 5000 \\
\hline $111-06-01$ & ELIIE AVENLE & DODDS RAYMONE J. & $120+[$ & R-3 YES & YES & NO & NO & PULELIC & 6800 \\
\hline$k 11-07-017$ & JONES STREET & MOYLAN JOHII & 52 & $\mathrm{~K}-3$ YES & YES & No & $N[$ & FUELIC & 5560 \\
\hline $111-07-18$ & IONES STFEET & MUFFHY JAMES & 42 & F-3 YEE & YES & Hö & NO & PUBLIC & 4760 \\
\hline$k: 1-17-18$ & BRUNSWICA STEEET & POUFUY ROKALD & 50 & R-J YES & YES & No & $\mathrm{NS}$ & FUELIC & 4750 \\
\hline$k 11-07-19$ & JUNES STREET & FANCIOCCG ANTHONY & 104 & Fi-j YES & YES & NO & No & PUBBLIC & $8 B 70$ \\
\hline $111-05-05$ & BFINSWICK STEEET & COCHRANE ROEEFT & 50 & R-3 YES & YES & $\mathrm{kr}$ & No & PLELIC & 560 \\
\hline $111-0 E-17$ & CRICKET LANE & HAGEK ARTHUS A. & 60 & $k-3$ YES & YES & $\mathrm{Ni}$ & No & PUE!IC & 7020 \\
\hline$k 1:-08-21$ & CEICRET LANE & FERFULLE JAMES $\mathrm{K}$. & 116 & R-3 YES & YES & No & NO & PUBLIC & 5165 \\
\hline $111-09-02$ & BAYER STFEET & SHOET AETHUEF F. & $5 t$ & $\bar{F}-\overline{3}$ Y $E S$ & YES & $\mathrm{NG}$ & $N 0$ & PUE'IC & 4440 \\
\hline$k 11-09-03$ & MEROOHVIEK STREET & O.DOKNE_L F'AULA & $6 \dot{0}$ & R-3 YES & YES & $\mathrm{NO}$ & NO & FUELIC & 5615 \\
\hline$k 11-07-19$ & GELASE STREET & EFARI W. DICEISTO & 50 & B-3 YEE & YEL & $\mathrm{H}^{5}$ & NO & PUELIL & 5600 \\
\hline
\end{tabular}




\begin{tabular}{|c|c|c|c|c|c|c|c|c|c|}
\hline$k 11-09-27$ & FIEL: STREE & WILII5 A. ALLISẼN & $126+[$ & $R-3$ YES & YES & Na & NO & PUELIC & 600 \\
\hline $111-64-32$ & BAEE STREET & ALYES HENRY & 50 & R-3 YES & YES & No & NO & PLBBLIC & 7009 \\
\hline $11-i n-01$ & CIKEUTT AVE. KWESTI & WHITE JUHN $F$. & 107 & $R-3=0$ & NO & NO & No & PFIVAT & $24300^{\circ}$ \\
\hline $\mid 11-11-02$ & HINSLJU STREET & VASIL FALL & 200 & $R-3$ YES & YES & ND & No & PUELIC & 1708 \\
\hline $1: 1-11-63$ & STANDISH STFEET & HHITE DOHFED & 120 & $\mathrm{R}-3$ YES & YES & NO & NO & PUE:IC & 135 \\
\hline $11-11-\{15$ & STANIIEL STEEET & CAMPEELL CATHA & 100 & $R-3$ YES & YES & NO & NO & PUEIIIC & 1412 \\
\hline$k 11-12-10$ & HINELOW STREE & FIRE GROVE REALTY TFLST & 70 & $\mathrm{R}-3$ YES & YES & NO & NO & PUELIC & \\
\hline $1: 11-13-04$ & VINEEK LFIVE & CONTINLITY REALTY TFULST & 60 & $R-J$ YES & YES & NO & NO & FRIVAT & \\
\hline $111-15-017$ & WIEERT UEIVE & ANTUIKE RCGEF & 75 & RI-3 YES & YES & NO & NO & PRIVAT & \\
\hline$(11-13-60$ & VINEEN LEIVE & SHITH ALEKAHDER & 100 & $k-j$ YES & YES & NU & NO & PEIVAT & \\
\hline $1 ! 1-13-09$ & VIKLEN' USIVE & SMITH MALUE. & 200 & $K-3$ YES & YES & NO & NO & FEIVAT & 128 \\
\hline$k 11-13-15$ & CONETELLATIJN FIAE & SHITH JEFOME & 60 & F-3 YES & YES & NO & Mi & PUE:IC & $=$ \\
\hline $111-14-07$ & VINCENT DRIVIE & ANTÚIRE KEALTY & 60 & $R-j$ YES & YES & $\mathrm{NE}$ & NO & PLIELIC & \\
\hline $11-14-17$ & VIHEENT DFIVE & ARTUINE RELATY TKUST & 60 & R-J YES & YES & NO & Ni & FRIVAT & \\
\hline $11-14-10$ & VIREERT DFIVE & WHITE LEELIE & 60 & R-j YES & YES & $\mathrm{Nu}$ & $\mathrm{No}$ & FFIVAT & 72 \\
\hline$k j i-14-1 ;$ & VINEEHT DFIVE & CIULIA FICHARD & 61 & $R-3 Y E_{L}^{C}$ & YEE & NO & NO & PREVHT & \\
\hline $11: 14-12$ & VIKEET DFIVE & CILELF FICHARE & $181+C$ & Fi-3 YES & YES & Nis & NO & PRIVAT & \\
\hline $111-14-13$ & CFANE FITAO & MCLTHEUSH COHSTRUCTION & $240+C$ & R-3 YES & YES & $\mathrm{NE}$ & NÚ & PFIVAT & 1031 \\
\hline$k ! 1-15-0 k$ & CFARE FGLE & EKGLEMAR FUEERT & 60 & R-3 YES & YES & Nū & NO & PUELIC & J3 \\
\hline $11:-1 \bar{\Sigma}-(44$ & CRALE RISTL & WRENTISE GEOFGE W & 120 & R-3 YES & YES & No & NE & PUELIC & 1177 \\
\hline $1: 1-1=-1$ & GGKETELIATIOR FUAD & BFEAT EFSTEEN REGLT: & $202+5$ & Fi-3 YES & YES & YES & $\mathrm{NO}$ & FUELIC & $5 \mathrm{dt}$ \\
\hline $111-15-07$ & 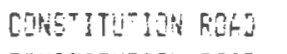 & SLOAL ANTCOIF & 121 & $F-3$ YES & YES & No & $N=$ & PLELIC & 56 \\
\hline $1: 1-: 5-69$ & CEHETITUTEK GOAD & G WOMSEL MIEHAE & 60 & R-j YES & YES & YES & NO & PUE: IC & 51 \\
\hline $11:-19-10$ & CONETITUILI ROAE & (C DOHELL MICHEEL & 60 & R-J YES & YES & YES & No & FUELIC & 510 \\
\hline $1: 1:-19-12$ & COASTTETLA ROAH & LOLS THCME & 60 & Ri-3 YES & YES & YES & $N !$ & Fug:16 & $5 \mathrm{ir}$ \\
\hline $11 !-15-15$ & COHET'TLTIOH FISU & VEFEY SERSSE & 00 & $\mathrm{~K}-3$ Y YES & YES & YES & NE. & PUELIC & 51 \\
\hline $11-1 \bar{\gamma}-1 i$ & NEVFI STSEE? & EESTEE GESRTE & $174+5$ & Ri-j YES & YES & NO & No & PFIVAT & 802 \\
\hline$(19-2)-0 !$ & MON'TE KOA: & CAARY IFMES & 60 & B-3 YEE & YES & Nú & Nis & FFIVAT & $5 !$ \\
\hline $111-20-02$ & MJATERE ROAE & GUINEY CLAHE COFFEFATDAN & 6.1 & R-S YES & YES & NÚ & NO & PRIVAT & \\
\hline $1.1-2-13$ & nakiton paib & 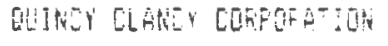 & 60 & F-S YEE & YES & $\mathrm{Ni}$ & $N i$ & PFIVAT & \\
\hline $11:-20-64$ & MUSITOF ROAS & CLATCY JAMES & 60 & F -3 Y YES & YES & No & Nü & PEIVAT & 510 \\
\hline$k 1:-20-05$ & MURITES RJAD & MAEAFTHUF FATEIEIA & $135+C$ & FH-3 YES & YES & $\mathrm{NO}$ & NI & PEIVAT & 48 \\
\hline $11-30-68$ & COHSTELLATIOH REAL & BSINDLEY ELSERE & 60 & $R-3$ YES & YES & NO & $\mathrm{NO}$ & FUELIC & $5:$ \\
\hline $11-20-10$ & COHETELLATIOH ROAL & IVESEN MELVIN & 60 & EI-3 YES & YES & $\mathrm{NO}$ & $\mathrm{NL}$ & PUELIC & \\
\hline$k 11-2 i-61$ & SURF AVENIE & SEASCAFE HDMES & $143+[$ & $\mathrm{R}-3$ YES & YES & NO & Nis & PUBLIC & 508 \\
\hline$k 11-2 i-63$ & MULITES ROAD & EEEKMEN CAFL & 60 & $\mathrm{~K}-3$ YES & YES & NO & NO & PFIVAT & 51 \\
\hline $111-21-014$ & MOLITUR RTAGD & MAZZAE! IFIDH & 60 & R-J YES & YES & $\mathrm{NL}$ & No & FRIVAT & 51 \\
\hline$k 11-22-03$ & CONETEL ATIOH REAL & DEELAEIO NICHULAS & 60 & F-J YES & YES & NU & No & PUELIC & \\
\hline $111-22-64$ & CONETELLATIOA ROAD & SANESRN MILDFES & 60 & $K-j$ YES & YES & $\mathrm{Ni \textrm {i }}$ & No & Putulí & $5 !$ \\
\hline $11-22-07$ & CONETITUTION RUAD & QUINA THOKAS EO & 60 & K-3 YES & YES & Nij & No & PUELIC & \\
\hline$k 11-2 j-01$ & CORETITUTIOR BOAL & GFAFF FCEERT & 125 & R-3 YES & YES & NO & Nit & PUELIC & \\
\hline $111-25-11$ & REXHAME RUAL & BAFBER DAMVD & 60 & $\mathrm{~K}-3$ YES & YES & NS & NO & PEIVAT & 766 \\
\hline $111-2-12$ & REXHOME RIAD & BEL MAR̂K & 60 & KI-3 YES & YE5 & No & NU & PRIVAT & 80 \\
\hline $111-24-02$ & COKSTITLTION RJAD & QLIREY CLANCY CERA. & 60 & $R-3$ YES & YES & Nõ & NO & PUE:IC & 00 \\
\hline$k 1:-24-12$ & CONETITLTION RJAL & DILANDE ENFILIS $R$. & 60 & $R-3$ YES & YES & YES & NS & PUBLIC & 665 \\
\hline $111-24-64$ & CONSTITUTION FIOAE & SMITH DONALE H. & 60 & R-3 YES & YES & NO & NO & PUELIL & $6 t^{2}$ \\
\hline $111-24-69$ & SLIRF AUENUIE & PILIUELIS JAKES & 55 & $F-3$ YES & YES & WJ & $\mathrm{NO}$ & PUELIC & \\
\hline $111-2 \mathrm{c}_{-}-014$ & CIFOUIT AVEN!E & EUFHS R. EMEFSDR & 300 & $R-3$ YES & YES & YES & $\mathrm{NLI}$ & PUE:IL & 300 \\
\hline$k 1:-25-6.5$ & WATEFMAN AUENLE & DUAES FEGLTY TFUST & $200+5$ & R-3 YES & YES & NO & NC & $P F I C L$ & 1000 \\
\hline$k 11-25-06$ & HATEFMAN AVE. & FTOEER ROEEGT E. & 230 & $\mathrm{~F}-3$ YES & YES & NO & NO & Fil Ll & 230 \\
\hline$\because 1-20-0 !$ & CIECYIT AVE, (EAET) & RODEEICK JAHES & 100 & R-jN $N$ & $\mathrm{NJ}$ & NL & NO & FFIVET & 100 \\
\hline $111-27-116$ & KENT GUENLE & DUNES KEALTY TSUET & $2001+C$ & Fi-J YES & YES & $\mathrm{NLI}$ & NO & FFI CL & \\
\hline $1: 1-27-00$ & KERT AVENUE & MEDCKA:E JUEEFH & 125 & R-3 VES & YES & NE & $R[$ & FF'I CL & 125 \\
\hline
\end{tabular}


K11-27-69 KERT HVENUE
KI1-28-01! C]RCII AUE (EAET)

KI1-29-02 WISSTS AVENLE

K11-30-015 RAHIE! GH ROAD

K11-31-04 AHES AVEN:JE

KI1-32-63 CIRCUIT AVE. (EAST)

111-32-04 EPMES WH:

K11-33-01 CIROLI? AVEHUE

K11-3j-02 CIRULIT AVE. (EAST)

1:1-34-01 [IECUIT AVE,

(11-35-01 CIRCUIT RUE. (EAST)

K11-36-0: CIROUI? AE. IEAST:

112-01-03 MEAT] WIEW STREET

K:2-01-014 HEALOWIEW 5TREET

K12-01-65 MEADTH:JEL STEEET

K12-02-09 HILLSIOE STFEET

K12-02-40 FIELD 5TFEET

112-02-44 FIELE 5TREET

K12-03-05 HILLSIDE STREET

K.12-0.3-27 HILLSIOE STKEET

K12-04-01 BAYUIEH STREET

K12-04-05 ETANEI5- STREET

K12-05-23 NEWFOST STREET

K.12-05-3E CONCORS STREET

112-06-06 JACKSJN STKEET

11Z-07-0Z JAFISON STEEET

112-07-11 RICHAED STEEET

KI2-0E-0! FICHAES STREET

I:2-08-OI4 RICHATE STREET

12-09-12 ABEEY STREET

K12-05-32 BAKER TERKAEE

KZ-12-02 JACISON STREET

K12-12-08 RICHAFI STREET

K12-13-13 CONCOFE STREET IOFF:

K12-14-014 NEWFOT STREET

K12-14-10 CONCORT: STREET

K12-16-12 HINOT STREET

K12-17-02 EAST STREET

K12-17-12 ATLAHTIC STREET

K12-17-15 STANDISH STFEET

K12-18-0! POFTEF: STFEET

K12-18-09 PJETEE STREET

12-15-13 FUFTEF 5TFEET

K13-03-OT PATHER STREET

LOS-01-06 CKADOUC: CIRCLE(JFF)

L $(14-0 !-55$ FLETLHEF DFIUE

LO4-0!-57 FLETCHEF DRIVE

L04-01-58 CARESHELL STFEET

L04-01-59 CAFESWELL STREET

L04-01-64 BAFNÁ KOAD

L04-01-66 ELMHEST STREET

L04-61-76 CRADDICK FOAD

LO4-01-8S F_ETCHEF STREET
UTSHFIELO JUHN

FEXKAME TEFFACE BEAEH TRIST

HULING RAY 6.

COOAN JEIH L.

JOHEN L. COSH III

SHETT RARJURIE

LAWEFENUE FREEESIL

EARLY EIFI REA!TY TRLST

HLRLINE RPA E.

CoOn JDrin!

Cogh JoH 3 .

SHETT MAEJORIE

MERIGUAl THOMHS

O OOREEL PGULA

O DORHELL REVIN

MABT ALHN T.

ODONHEL! PAULA

WETSON KENKETH

HELEN, BELEN

ERCELINI PHILIF

MELCH LORTAINE

ANDEFEDIF B PEEF

LEUNARE: DIAHE

MCGEE CLIFFUSD

6!IN5E: A ANTHOHY T

RUSS RAYMDER E

JUHRSER GUSTA:

BDITAN FATFICK

CQTTEF RESING

TOER ALEET G. G ROEEFT H.

TULEEY JJHN E.

BOTDEIHE CAEJL A

SYLVESTEK MILDFEL

AERTE GHTHOH:

FQLEY TIMUTHYY

FEAR ROBEF?

CAME_IO ALPEFT

BEIIG RUSSELL $H$.

UTTINAC WILLIAM

COTTER JUHN

AEE:LI LOIJIS L.

AEELLI JEALNE

LEISHEF FLOYE

SIMFSIN MAFGAFET

LATSEEY HENGYY $C$.

REMAN CATHOLIL AFCHEISHUF

MEGRATH EDUARES

SANDEF IN JAMES E.

BFOWWE MIKTAM

IICE MATTHA M.

DUFFS FATRIEIA

FYYERSÜ HAFEY

EDHARI BHOLHE
100 R-J YES YES NO NO PST CL 10000

$200+[$ R-S HO NO NO NO PFIVAT 119790

$100 \mathrm{k}-3$ YES YES NU NO PLELIC 10000

100 K-3 YES YES NO NO FRI CL 20000

200 R-J FOS FOS NO NO PRIVAT 40000

100 R-J NO NO NO NO PFIVAAT 30060

100 R-J PUSPOS NO NO PRIVAT 10060

100 R-3 NO NO NO NO PFIVAT 300U'

160 R-J NO NO NO NO PFIVAT 25000

$200 \mathrm{R}-3$ NO HO NO NIJ PRIVAT $5000 \mathrm{~L}$

200 R-3 NJ NG NO ND PRIVAT 50000

200 R-I NO NJ NO NJ FRIVAT 50000

50 R-3 YES YES NO NO FUELIC 5000

50 R-3 YES YES WL NO PUALIC 5000

50 FI-3 YES YES NU ND PLELIC 50 LUO

$100^{\circ} R-3$ YES YES NJ NO FUBLIC 5000

40 R-J YES YES NO NG PUBLIC 5002

54 R-J YES YES NO NII FUBLIC 5523

50 R-3 YES YES NO NŨ FUELIC 5000

100 R-j YES YES NJ WE PUELIC 10000

239 R-3 YES YES NO NO FUESIL 4775

50 R-3 YES YES NO NE FUBLIC 5000

50 R-3 YES YES NO NL PRI CL 5000

50 R-J NO NO NO NO FRI CL 5000

50 R-J YES YES ND YES PFIVATT 5000

SO R-J YES YES HJ YES FFIUAT 4220

42 R-3 YES YES NJ NE FRI 3615

$110+[$ K-3 YES YES WD NO FFI 10000

$50 \quad R-J$ YES YES NJ NI FFI 5000

50 FI-Z YES YES NO YES FFIVAT 5000

100 R-J NO NO NO HO FFIUHT 10931

51 K-j YES YES NO NO PRIVAT 5960

$250+C$ C R-3 YES YES NO NO FFI 68000

NO R-3 POS PQS NO NO NO DIR 5225

50 R-3 YEŚ YES NU NU PFI CL 5000

50 R-3 NO ND NO NO PRI CL 5000

50 R-J YES YES NI NU FUELIC 5000

50 RI-3 YES YES NO NO FFIILLO 5000

$50 \quad \mathrm{~K}-3 \mathrm{POS} F O S \mathrm{NU} N \mathrm{NC} \mathrm{PFl} \mathrm{Cl} \quad 5000$

50 RI-J YES YES NO NO PUELIC 500 ?

54 FE-3 YES YES NO NO FUIP 4630

$19 \%+[R-3$ YES YES NU NO FUELIC 5000

60 Fi-3 YES YES NO NO FUELIC $4: 90$

50 R-3 YES YES NII NII PFI CL 5425

NSNE RIJ NJ NO YES YES NO DIR 3147310

$200+C$ K-3 POS POS YES YES FFIYAT 2678 :

170 $R-j$ PUS PQS YES YES N/A 2:600

NOKE $R-3$ NO NO YES YES NO OIK 466705

HOHE R-J NO NÖ YES YES NO DIF 5686 GOI

201 R-3 YES YES NO NO FUELIC 1074:

110 F-J YES YES 10 NO FUB:IC 22215

40 R-3 NG POS NO POS PKIVAT 1852

171 F-J PUS PUS YES YES N/A 21600 


\begin{tabular}{|c|c|c|c|c|c|c|c|}
\hline$L(14-055-6) i$ & LIRIEN EVE. & BROKNE EDHATI & $100 i+C$ & $R-j$ YES YES NO & NO & PRIVAT & 8040 \\
\hline $\operatorname{Li4-(15-0)4}$ & FLETCHER DRIVE & BROLHE EIWAESO & 100 & R-J POS PUS NL & NO & $N / A$ & 7350 \\
\hline$(14-05-65$ & LINDER AVE. & GFEAREY FFAMILIS & 96 & R -3 YES YES NO & NE & PEIVAT & 14300 \\
\hline$\lfloor(j 4-0)-0]$ & EAATHA FIOAL & KEEFE TIMUTHI F. & 169 & R-J YES YES NO & NO & PLIBLIC & $8 \overline{4} 46$ \\
\hline $204-07-02$ & CAMGL STFEET & SÄK CLEMERTE MART & 60 & R-3 YES YES NO & NO & PUELIC & 10030 \\
\hline$[04-07-04$ & CANEL STREET & BARLETTI ALELLNE & 80 & Ri-3 YES YES NG & NO & FUE:IC & 10010 \\
\hline L04-07-015 & CARA_ STHEET & VILLAGES HLWES INE. & 155 & R-J YES YES NO & NO & PUBLIC: & $4 j 651$ \\
\hline$L 04-57-10$ & CANAL STREET & VILLAGES HOMES INC. & 145 & R-3 YES YES NO & NO & PUELIC & 10117 \\
\hline$(04-07-1 !$ & CAHAL STFEET & VILLAEE HUHES INT. & 141 & R-3 YES YES NO & NO & FUEIIC & 43006 \\
\hline $604-67-17$ & CANG: STREET & VILLAGE HOMES INC. & 129 & $K-J$ YES YES ND & Nō & PUELIC & 10107 \\
\hline$\lfloor 04-07-15$ & CABALL STREET & MECAFTHY EUEERE & 103 & K-3 YES YES YES & NE & FLIELIC & 60178 \\
\hline $604-65-04$ & CANA: STREE: & BARRICLE EDAGED J. & 90 & F-J YES YES NU & NO & PUELIC & 9000 \\
\hline $\operatorname{Lo4}-18-24$ & CAlHA STREET & SALINATI GEGGGE & 50 & R-3 YES YES NO & $N[$ & PUELLIC & 6250 \\
\hline$(04-09-24$ & IDAHO ETKEET & FLATLEY JAMES D & 45 & $\mathrm{~K}-3$ YES YES NU & YES : & FUELLIC & 4500 \\
\hline Lo4-101-02 & CFAGLUAK CIRULE & GARDETY: ADELING & $110+\varepsilon$ & K-3 POS YES NG & Na & PUELIC & 5072 \\
\hline$\lfloor 04-10-07$ & ChádDECL CIFELE & BAATETTI ALELINA & $110+[$ & F-J FOS YES YES & $N C$ & FUELIC & 9572 \\
\hline $405-3-05$ & CAHPLL STREET & BOMAN CATHOLIC ARLHEISHOF & 76 & PR-J YES YES NIJ & No & PUEAIC & 17887 \\
\hline $105-2 j-67$ & ELWAGD RIIA: & CAFFELLE MEADUESTTE & 50 & R-3 YES YES NO & $\mathrm{NQ}$ & FRIVAT & 5000 \\
\hline $405-20-92$ & EDWFE FIAL & HIALS VIFEINIA & 50 & R-J YES YES NO & No & PRIVAT & 5000 \\
\hline $\operatorname{LO} x_{2}-23-1 !$ & EDUARAD ROAD & FAENEA RAILH P. & 50 & R-J YES YES ND & Nu & PFILAT & 5000 \\
\hline $105-23-12$ & EDHAR̃ FUÁL & MELAEE EDHPFIL J. & 50 & R-J YES YES NI & NO & PFIVAT & 5000 \\
\hline $105-25-15$ & EDHFED RLIAL & GRIFFIN IRENE E. & 50 & R-3 YES YES NU & No & PEIVHT & 5000 \\
\hline$[15-2]-17$ & EUAGEI RUAL & CEFIEN MAEY & 50 & KR-3 YES YES NẼ & Wũ & PRIVAT & 5000 \\
\hline $105-24-67$ & TEAFE KOURE & JORDQW RUEERT & 50 & K-כ PIS PUS YES & YES & FRIVHT & 5500 \\
\hline $\log -24-26$ & EDAGE REGL & 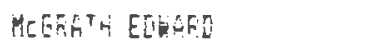 & 50 & F-S YES YES NE & No & PRIVAT & 5000 \\
\hline $25-24-22$ & 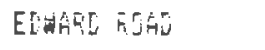 & CULCHAS AGUETINE & 50 & F-J YES YES NO & Nu & FRIVAT & 5000 \\
\hline $\operatorname{LUE}-24-2 j$ & EDHARES READ & BUTLEF A. LILLIAH & 5 & F-3 YES YES NO & WE & PEIVAT & 5000 \\
\hline $101_{2}-25-02$ & VALERTINE ROSO & HAVES MASIE & $284+i$ & R-3 PQS FOS YES & YES & TFINAT & $2700 ?$ \\
\hline $105-25-0 \overline{3}$ & VÁENTINE KEAE & CÁLLGEAT BUAR & 100 & R-3 FOS PQS YES & YES & PEIVAT & 10000 \\
\hline $605-25-0.4$ & WLEENTINE TUAE & CDLINE KUEETT & 50 & R-j DES FJS YES & YES & PFIVAT & 5000 \\
\hline$L 1 E^{5}-25-1 E$ & TEYFEE RDAJ & SLANLUR UOFJTH & 100 & R-3 FUS PQE YES & YES & PKIVAT & 10000 \\
\hline 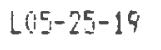 & TEMPLE FOASO & 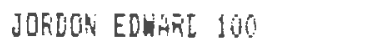 & $R-3$ & K-J PUS POS YES & YES & FRIVAT & $1001 E$ \\
\hline $405-25-20$ & TEMFEE FOAL & 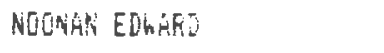 & 50 & R-3 P0S P05 YES & YES & PEIVAT & 5000 \\
\hline$(0,5-20-01$ & VALENTINE RIAE & AHERTI EILEEN & $135+c$ & R-3 POS FOS YES & YES & FKIVAT & 16200 \\
\hline $405-26-63$ & STEVER ROAD & DUDEE: AFTHUN J. & 50 & R-3 POS PUS YES & YES & $N / A$ & 5250 \\
\hline $105-26-04$ & STEVEN KUAL & GREENOUGH FICHAEL T. & 50 & K-3 PLS P0S YES & YES & $R / A$ & 5250 \\
\hline $405-2 t-05$ & STEVEN FUAD & LEELANE FOEERT A. & 50 & F-J POS POS YES & YES & $N / A$ & 5250 \\
\hline$\lfloor 05-20-07$ & STEVEN RÜAD & TEUNGN JUHN E. & 200 & R-3 FOS POS YES & YES & $N / A$ & 21000 \\
\hline $405-20-12$ & VALENTINE REAE: & TOEIN AI BEFT & 5 & R-3 PQS POS YES & YES & PEIVAT & 5504 \\
\hline $60 \mathrm{E}-2 t-14$ & VALENTINE RUAE & LOVE KENMETH \& ALICE & 50 & F-3 PUS FUS YES & YEE & FRIVAT & $5: 50$ \\
\hline L165-27-35 & STEVEN ROAGE & DAVIS ALEER $S$. & 100 & K-3 FUS FOS YES & YES & $W / A$ & 10018 \\
\hline $100,-27-36$ & STEVEN RDAE & MOQRE CHARLES & 50 & F-3 FUS FOS YES & YES & N/A & 5,500 \\
\hline$\lfloor 0 E-27-30$ & STEVEN FOH & MECASLIN JOSEFHINE & 100 & R-S PUS POS YES & YES & $N / A$ & $10\left(00^{\circ}\right)$ \\
\hline $405-2 B-05$ & TEMFLE RIIALL & DUEOES JAMES & 50 & KO-3 PUS FOS YES & IES & FRIVAT & 5400 \\
\hline$\left\lfloor 0 e^{2}-2 \bar{t}-0\right]$ & CAFESHELI STREET & MECARTHY BOSEPH & 100 & F-3 YES YES NO & No & PILELIC & 10890 \\
\hline $\operatorname{Lo5}-25-12$ & EDHAFD ROALE & BROHW ALBEFT W. & 50 & $R-3$ YES YES NG & NE: & PFIVAT & 55.0 \\
\hline$L(65-29-05$ & EUHAST FUEL & CHIACLHEE'] JOSEFH & 50 & R-3 YES YES NO & No & PEIVAT & 6247 \\
\hline$L 05-29-0 B$ & EDHAEC FUR & OBF!EN THOMÁE & $10 j$ & $\mathrm{R}-3$ YES YES NO & NO & PEIVRT & 14356 \\
\hline $105-29-015$ & CAFESHELL STTEET & O'BSIEN MAFGARIT & $2001+C$ & K-3 YES YES ND & NO & PUELIS & 12210 \\
\hline $405-29-13$ & MELARTAH RUAE & QUICK. HELEN & 100 & R-3 YES YES NO & NO & PUELIC & 11000 \\
\hline$(05-3)-2$ & STEVEN RIJAE & DAGOS IND AMELIA & $200+E$ & R-S YES YES YES & $\mathrm{N}[\mathrm{J}$ & FUE:IC & 11513 \\
\hline $205-30-19$ & CANAL STFEET & GRATTAL THUMAB & 5 & R-S YES YEE NO & NI & FUE: IC & 5000 \\
\hline $105-3:-64$ & CARESHELL STRE:T & FLETT MAEYY M. & & B- 3 YES YES NC: & nia & Eut in & \\
\hline
\end{tabular}


OHHEF OF REC

L05-31-19 CARESHELL STREET

LOS-3:-O CAFESTLL STREET

LOES-3:-21 CARESHELL STKEET

LOIE-3i-25 CARESWELL STREET

L05-3!-26 CARESHELI STREET

LOE-31-25 CARESHELL STFEET

LOT-0IA-OI ARLEITA STRET

L07-:4-67 A'LGN STREET

[6]-O4-09 ALEEITA STFEET

LOT-04-II ARLEITA 5TREET

LOS-CI-OS OYHE RUAD (OFF)

LO5-0!-07 AFHISO FOAL

LOE-01-10 ARHSLD FOAD

LOE-6I-12 JUHE STKEE?

LOE-OI-14 JLAME STREET

LOE-0!-I5 JUAE STFEET

LOE-OI-1E WINE_JW CETETEFY RD

LO8-0!-15 GFEEF HAFSOF HASSH

LIGT-0!-01 FLYMULTH ALIE.

L09-01-02 FLYMUUTH AVE.

LOG-01-0S MEADEHEDOOK CIFCLE

L09-0!-110 PLYMUUTH AVE.

[09-01!-12 MEADOWUIEU SIFEET

L09-01-14 REALSHUIEN STFEET

LO5-01-16 MEALEHIEH STKEET

LO9-01-18 MEADCHYIEW STREET

109-01-21 MEADOWEFJOT CIRCLE

L07-0!-2? HEADOWVIEN STFEET

L09-01-25 MEADJWGROOT CIRCLE

LOG-OI-ZE MEATUWIEN STREET

UG-C:-27 FLYMJUTH AVE.

LOG-01-45 FLYHLITH AUE. (REAR)

L09-01-44 MEADCHETLOK CIECLE

L09-0Z-01 FLYMUTTH AVE

L09-02-02 AEKANGAS STFEET

L69-0Z-014 ARK'AKSA5 RJGI

L09-003-03 AFKAKSPS RCAD

LO9-014-02 HEATHER FOAD

LO4-04-03 HEATHEK REAE

L09-04-014 FLYMULTH AVE.

L09-05-02 FLYMJULH AVE.

LO9-05-OE HEATHEF RILAE

LOS-05-06 HEATHER ROAL

L09-05-07 HEATHES FIOAD

LOS-05-09 MEATHES FUAE

LO9-15-14 AFIANEAS REGO

L09-0S-0) PLYMOLTH AVE.

LUS-Ob-OZ MEAOOWIIEN STREET

L09-06-03 MEADOHEFUISK CIKC:E

LOG-66-05 HEATHER KIOAS

LOC-VE-UE REATHEF RUGD

LGG-0E-0E FLYMOLTH AVE.

LOS-07-0I MESDOWEFOCL CIKLLE
O'SU!L IVAK JOH!

O CONHOR JAMES

O'SLLL IVAN BEFKAARD

BENKETT RIALPHE.

FLETT MAEY $H$.

FLETT MAFY

HALL FFEDEFICK $L$.

JEREY DRUEGE

HILL IIINK

HILL JAMES $H$.

MAPRINUE GATON

GIOUAAKWULCI MELVIR

EVARS DAVID

PINE GEOLE REGLIY THUST

DOHANG JOLNT

HHITE VEFONICA

DhYTE EDHÁtio

NajAM CHGELES M.

ANENSKI JOSEFH

COLGAY JOHS

HAESHEITLD RIOR \& EUN CLIJE

MARENEIELD RJJU +OUN CLUS

AHEUST: DOFOTHY

MARSHFIELD ROI \& GLN CLUE

ROCK REA:TY TRUST

MARSHE IELO ROI \& ELH CLUS

MAFSHFIELD FUD \& EULN CLLIE

DERABK:ES DORIS

MASEHFIELD ROL \& GUN CLUE

DONKELLY RICHAF:

CULEMÁN ELLEN RAFFOLT

SOLTHHORTH ESTHER

MARSHFIELD FEE \&UN CLUE

HASSHFIELI RUSTEUK CLUE

MALIND GATON

JOHW VAUGHAN

ROCK REATLY TFLST

MARSSTFIELD ROD \& GLN CLUE

BREENEF JAMES

MAREHFIELD RONOGUR CLUE

MARSHFIELD ROD+EUN CLUE

DGILEY FRAKLIS $M$.

ALLEN WALTEF $B$.

MACRLEETTS HEROLO

TEAAUL THOMHES

EDRAROS BIOLX

MAFSHFIELO ROUL+GUN CLUE

RECI REALTY TRUST

TRADD THOMAS

MGFSHFIELD FJO \& GUR CLLE

RATI GEFTRLLUE

WHITE CATHEFINE

TRALE THDGAE
FRONT ZON SEW WAT WET FPA ACCESS AREA SF

58 R-3 YES YES YES YES PUBLIC 42060

$38 \quad K-3$ YES YES YES YES FJELIC 29960

80 R-3 YES YES YES YES PUELIC 19940

$80 \quad R-3$ YES YES YES YES PUELIC 653400

20 R-3 FIJS POS YES YES NO DIR $39204 \%$

50 R-3 YES YES YES YES PURLIC 67500

50 R-J YES YES NOI NC PRIVAT 5000

120 F-3 YES YES YES NO PUSLIC 5475

50 R-3 YES YES NU NE PEIULT 5000

$14 E$ R-Z YES YES NO NO PEIVAT 14685

NONE R-J NE NO YES YES NO $E I R$ TS 34653

100 R-j YES YES YES YES PUELIC 9215

150 R-3 YES YES NU NO PUELIC 5000

100 R-3 YES YES NI HO PLELIC 10018

100 R-J YES YES YES NE QUELIC 5058

106 F-J YES YES YES NS PUE

40 R-3 NE NO YES YES FUELIC $26: 7084$

NUNE R-INI NI YES YES NJ DIR 326700

168 R-3 YES YES NO NI PLELIC 11880

165 KR-J YES YES NO NO PLELIC 25860

42 R-J YES YES YES YES FKIVAT 7740

$50 \quad k-3$ YES YES YES YES FUELIC 95832

$102 \quad F-3$ YES YES YES YES FUELIC 7840

$180 \quad K-3$ YES YES YES YES PUELIC 39610

40 F-J YES YES YES YES FUELIL 4900

80 R- 3 YES YES YES YES FUELIC 8200

40 R- 3 YES YES YES YES FRIVAT BOUO

40 R-3 YES YES YES YES PUBLIC 10800

40 K-3 YES YES YES YES FFIVAT 3716

40 R-3 YES YES YES YES FUELIC 3716

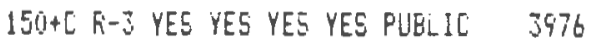

NONE R-3 YES YES ND NO NO DIF: 1230570

60 K-J YES YES YES YES FRIVAT 5500

$151+C$ R $R-3$ YES YES NO NOS PUBLIC 4632

80 R-3 YES YES NO NO PRIIVAT 13790

40 K-3 YES YES NO NO PRIVAT 6526

$215+C R-3$ YES YES NO HO PRIVAT 12875

60 H-j YES YES YES YES PFIVAT 8120

40 FI-3 FUE POS YES YES PRIVAT 4060

$120+C$ R-3 YES YES YES YES PLELIC 750

60 R-J YES YES NO NO PUBLIC 228677

80 KI-J FOS PUE WI NO PFIVIT 8120

80 R-J YES YES NO NO PRIVAT 8000

40 FI-3 POS POS NO NO PFIUA 4006

40 KR-3 YES YES NO NO PRIVAT 4060

40 R-3 VES YES NO NO PFIVART 4060

$103+[R-3$ YES YES NO NO PLIBLIC 1440

29.3 R-3 YES YES YES YES FUELIC 17000

240 K-J YES YES YES YES PFIVAT 27895

150 KR-3 YES YES NO NO PFIYAT 3985

100 K-3 PEE POS YES YES PFIVAT 16117

SE FI-3 YES YES NO NO PUELIC 3560

$224+$ E R-3 YES YES YEE YEE FEIVAT 1400 


\begin{tabular}{|c|c|c|c|c|c|c|c|}
\hline$[09-07-6]$ & HEGTHEF RÜALI & MAFSHFIELD ROO \& GLN CLUE & 140 & R-3 YES YES NO & Non 1 & FUELIC & 2000 \\
\hline$L 49-07-94$ & HESTHEF FOAD & GILMAN AFTHLIK J. & 40 & $R-3$ YES YES NO & $\mathrm{N}[\mathrm{I}$ & PRIVAT & 398 \\
\hline $205-07-66$ & HEATKEF RLAD & MASSHFIELI RUL \& GLL CLUE & 40 & FI- 3 YES YES YES & YES & PKLVAT & \\
\hline $404-07-617$ & HEATHER RIAD & MARSTHFIELD KOI \& GIN & 80 & K-3 PUS PUS YES & YES & FRIVAT & \\
\hline$\lfloor 99-69-2 !$ & PLYMJiTH AVE. & KELLIHEF ANDREW & 50 & R-3 YES YES NO & No & PUELIC & \\
\hline $209-05-22$ & FEVAROTH AVE. & CAKEYY FRANLIS & 50 & $K-3$ YES YES YES & YES : & PUELIC & \\
\hline $\operatorname{L0} 5-07-23$ & FLMULTH AIE & CAFEY FRGHCIE & 50 & R-J YES YES NO & YES I & FUELIC & \\
\hline$L 09-05-2 t$ & FLIMUJTH AVE. & DARON REA_TY TKUST & $55_{i+C}+C$ & $\mathrm{~K}-3$ YES YES NL & YES & FUELIC & 13042 \\
\hline $105-94-30$ & PLYME TH AIE, (KEMRI & MAFSSTF IELD RGII+GLA CLUE & RINE & F-S YES YES NO & NE 1 & NO OIR & 376734 \\
\hline$(09-69-3)$ & FLYYOLIH AME. & CONNELL RITA & $100+c$ & K-3 YES YES NU & No & PUELIC & \\
\hline$[(19-10-12$ & ROSSEVELT RUGD & GANTLEY FRGARIS & $90+C$ & R-3 YES YES FUS & No 1 & PKIVAT & \\
\hline $107-10-1 E$ & MEADOWEFOU: CIRLLE & REROLA ALFRED & 120 & R-3 YES YES YES & YES & PKIVAT & \\
\hline $109-10-22$ & MEAUOWVIEV STKEET & MARSTFIELI ROL \& ELLN CLLE & 40 & R-S YES YES YES & YES & PUBLIC & \\
\hline $205-11-02$ & HAH]LTON RUAB & CATINO FAUL E. & 60 & R-3 YES YES NO & No & PRIVAT & \\
\hline$\lfloor 09-11-0)$ & HAEILTON FEAO & SCHQEREF RUEEFT & 52 & R-J YES YES NO & NE & PFIVHT & \\
\hline $109-1:-04$ & PLYMUTH GVE. & SLHOENEF RCGERT & 79 & R-J YES YES NO & No & PUELIL & \\
\hline $169-11-21$ & PERSHIFG ROAD & MULLIR BEFNARI & 84 & R-j YES YES RU & Nij 1 & PEIVAT & \\
\hline $109-11-22$ & RUUSEVELT RUAT & EGAN JUHN J. CO. & $100+c$ & R-3 YES YES FOS & Aid & PRIVAT & \\
\hline $109-12-00$ & FLYMEUTH AVE. & DELIOFFO THETHÁs & 55 & R-3 YES YES NO & N] & PUELIC & \\
\hline L09-13-014 & FLYGOLTh AVE. & TAHNER CATHERINE & 50 & R-3 YES YES ND & 80 & PUELIC & \\
\hline$L(99-16-1)$ & OEEAS STFEET & JENCLINAS DORLTHY & $100+C$ & R-Z YES YEE NEI & Nü & FUELIC & \\
\hline $104-18-01) 7$ & SECUNO FIOATI & EIANLHE DUMENICŨ & 45 & K-J YES YES NTJ & NOI : & PLUELIC & \\
\hline $167-18-10$ & FOSTER ANENUIE & WLLIGH FLYHN & $90+C$ & R-3 YES YES NU & Mo & PUELIC & \\
\hline $409-j 9-05$ & THIRO RTAE & STANTOK RICHALE & 45 & K-J YES YES NO & Ne & PUELIC & \\
\hline$L(19-19-06$ & THIRU RUAS & STARTUR JGHA & 45 & R-J YES YES NO & no & FUSLIC & 85 \\
\hline L0G-19-0E & THIRL FUAL & MAFGARET & 45 & R-S YES YES NI & Ní & PLLBLIC & \\
\hline $109-2(1-05$ & FQUKTH ROAL & MECAETH & 40 & R-3 YES YES NO & kO & PRIVAT & \\
\hline$\lfloor 09-21-97$ & FIFTK ROUAD & HFELIX & 40 & $R-3$ YES YES NO & NO & PUELIC & \\
\hline$\lfloor 09-21-13$ & SIXTH FI & THETAS & 40 & E:-3 YES YES NO & no & PRIVAT & \\
\hline $205-2 \hat{i}-10$ & SEVERTH REAAL & PROLT RICHARI & $100+C$ & R-3 YES YES NO & $\mathrm{NLI}$ & FFIVAT & 27 \\
\hline$\lfloor(9-2]-6)$ & FUETER AYELLE & FAUL 5, KELSEY & 390 & R-J YES YES NI & Hit & PUELIC & 370 \\
\hline$\lfloor 10-0 !-01$ & FLYMDUTH AHENUE & WHITE CATHERINE A. & 270 & R-J YEE YES YES & YES & FUELIC & 26130 \\
\hline $110-66-11$ & OLYMFIF FGAD & .2ZAEETHA. & $B 5$ & R-3 YES YES NE & No & FLLE:!C & 4868 \\
\hline $110-06-12$ & DLYMEIS RUED & SUSI ELIIAEETH A. & 53 & R-3 YES YES NE & wo 1 & PUELIC & \\
\hline $400-67-07$ & OREGUN REAL & FOKFO RLFFED F. & 52 & K-J YES YES NO & No 1 & FUELIC & \\
\hline $10-09-01$ & MILSON \& FLYMGITH & LANE GEKAEE F. & 250 & $R-3$ YES YES NII & NO 1 & FUELIC & 14620 \\
\hline L16-19-944 & WILSON AVENUE & NOLAN PAUL & 50 & R-J YES YES NI & No & FULELIC & 5000 \\
\hline$[10-0 \overline{4}-[1] 7$ & OCEAN STREET & LANE GERÁRO & 25 & R-J YES YES NU & NO! & PUELIIC & \\
\hline $410-10-11$ & WILSTH \& FLYPOUTH & LANE GERFRD $F$. & $150+[$ & R-J YES YES NE & No & PUELIC & 920 \\
\hline$\lfloor 10-11-07$ & BILLINES RIOAD & SHEA AGKES M & 70 & R-3 FGS FOS NII & ND & FKIVAT & 455 \\
\hline $110-11-13$ & OCEAN STREET & FRINLESS RODEFICK TFUUST & 32 & R-3 YES YES NE & No & PugLIC & 263 \\
\hline $110-1 \bar{i}-04$ & OLEAH STKEET & PRINLESE TKUST & 31 & R-3 YES YES Ni & Ne 1 & FliE & 283 \\
\hline$L 10-14-044$ & OCEAN \& E!GHTH & BHETH CHAELES & $120+\bar{c}$ & R-3 YES YES NO & No & FUE:IC & 3322 \\
\hline $110-14-16$ & NINTH FOAD 25 & KETTENDJFF NATHANIEL & 45 & R-j YES YES ND & NO & PLELIC & \\
\hline$L 16-15-63$ & OCEAN STKEET & CAETIGLIONI GLEERTA & 45 & $\mathrm{~K}-3$ YES YES NO & NO & FUELIC & \\
\hline$L 10-15-1 B$ & FOSTER AVENUE & ROEERT F, BREGHR & $80+c$ & R-J YES YES NO & no & Flisili: & 629 \\
\hline $410-16-03$ & UCEAN STREET & NICOTFA OGKENIC & 45 & R-3 YES YES NO & No & PLeLIC & \\
\hline $110-16-15$ & E_EYENTH FUAL & FEARSON RICHAEE W. & 4) & R-3 YES YES NE & no & PRIVAT & \\
\hline$\lfloor 10-2 j-01$ & FUSTEK AVENUE & CHAFLES RIKDS & $40+[$ & R-3 YES YES NO & NO & PUELIC & \\
\hline$L 11-02-03$ & CDEETELLATICH FUAD & CODY FALLINE C. & $8^{5}$ & R-J YES YES NO & NJ & PUEL!C & \\
\hline$\lfloor 11-0.3-10$ & CONSTELLATION ROAE & SANEOHA MILDEE! & 60 & KI-Z YES YES NE & NO & PUE:IC & \\
\hline L11-04-15 & MDTITEF STREET & MITCHELL ALEC, & 60 & $\mathrm{~K}-3$ YES YES NO & No & PUEEIL & \\
\hline$L 11-04-17$ & FARREROLI KÜAD & SAEES FEIEF 20 OHE & 60 & K- 3 YES YES NI & Nu & FRIVAT & \\
\hline
\end{tabular}


LI:-0E-OI HOFTFDED KOLS

LOG-05-07 LANIEL STREET

104-6.5-1Y VIKGIYIT STREET

LO4-6G-06 VIFGIHIA STKEET

LO4-04-07 VIRGINIA STFEET

LG4-04-26 VIFEINIA STFEET

LOS-2E-10 STEVER RUT:

GE-T!-22 CAFESRELL STREET

MO4-01-0! CULUMEZA ROE

MOA-OS-07 [AKRE- STFEET

MO4-0J-OE EAHEL STREET

MU4-0j-OA CANA STREET

MO4-DJ-10 CAOH:L STFEET

MO4-0S-18 CANAL STHEET

MG-04-02 ALAEATHA STREET

MO4-OA-TE CANHE STFEET

MO4-06-02 NEH YORT: STKEET

44-07-03 CFEE REAT

BOA-1C-GS CKEER KOAD

MU-10-0S AVEI STREET

PO4-11-10 AVUK STREET

M-1j-CS BÁY STREET

M4-17-07 EFIGUTLE 5TEEET

M(14-1B-OI PEAL: STEEET

MUA-21-03 BAY AUE.

MOS-0J-15 CARESWELL STREET

MOS-JE-OL ASSUKRTISH FSAD

MUL-OL-14 STEVEN REAT

MOL-05-15 STEVEN ROAL

HOT-65-16 STEYENE REAT

HOS-0J-17 STEVEHS RUA

MOE-05-18 STEVERE ROAL

MOS-OS-1Y MISEZURT STREET

MUE-05-2! MISSUIFI STFEET

MUS-05-22 MIS5QURI STHEET

MULS-05-23 MI5SOLFI STREET

MOS-015-24 MISSOUEI STREET

MOS-05-27 MIS5ULFI STEEET

M05-05-47 EAY AIE.

MC5-05-4E BEACH STEEET

MOJJ-05-5I NASHI STREET

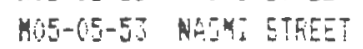

MO5-05-54 NAJHI STREET

NOS-OS-EE NATUY STREET

MIS-05-5E NAORI STREET

ME-05-57 NADMI STFEET

KUIE-05-5B NAJKI STREET

MOE-05-79 A55LLETIE FOR

MOE-0J-80 ASSLHFTION RULAL

MUS- $15-5 !$ SEUIRES AVENUE

MOE-CS-8B BEACH STREET (OFF)

MOL-05-40 KAJUI STREET

MOE-CL-QI NAIHI STREET
STRETTON CHARIES H.

GREANEY FFANEIS K

DUFFY NEIL

BTUOYS JEAN

HALSH THOMAS

WALSH THOHAS

FAEIARESI WALTES

BENHETT RALFHE.

FACE RAFLH E.

WHITTY CATHERINE DRY

BONEKS HILLIAMS

PITLARI: ANEELO

WHITTY HILEUTF

BROTHESS FQIST IKL.

MCGËTHK DAVIL $B$. I SHEILA A. MEGETTH DARTS

YORE PETEK

BRLDER EDMLON

ZALCIEHINI DANDEL

EUREST BEFNATS 6 .

FE:KLAND FEEDERIL

TEUESEHI REALTY INE.

JUHFSN J. HILLIAH

GULDEN HAR:

VILLAEE GREER TELST

BEUR FATEICIA $M$.

ROHIOH THOMAS F.

G' SLLLLIVARE JLIHN

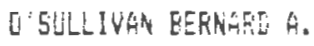

HUEHH JAMES

E SULLINGN JURK

CHEFVETTE ALFEED

HILEHAY WILLIAM

FILIBUSIAN JACOE

QUIRE HILLIAK

DUNK THCHAS

HLDHA: CLYDE

MALIWI FEAKE'S

BLFKES BEALH TRUST

LGVELL GAF' $K$.

BRADELEY JESEE

FLSANE AFTHUF:

FUESH: ARTHUE

RUGGNI AFHTUE

FUGARI AETHUF:

RUGARI GETHEL:

RUGRTI ARTHUE

FICHEFING LUISE.

DEERFIE: P FUFEFTIES

DEERFIELD FROFERTIES INC.

MCWUGRES DAUID

BULATIN ARTHUE.

RUGALI AFTHUE:

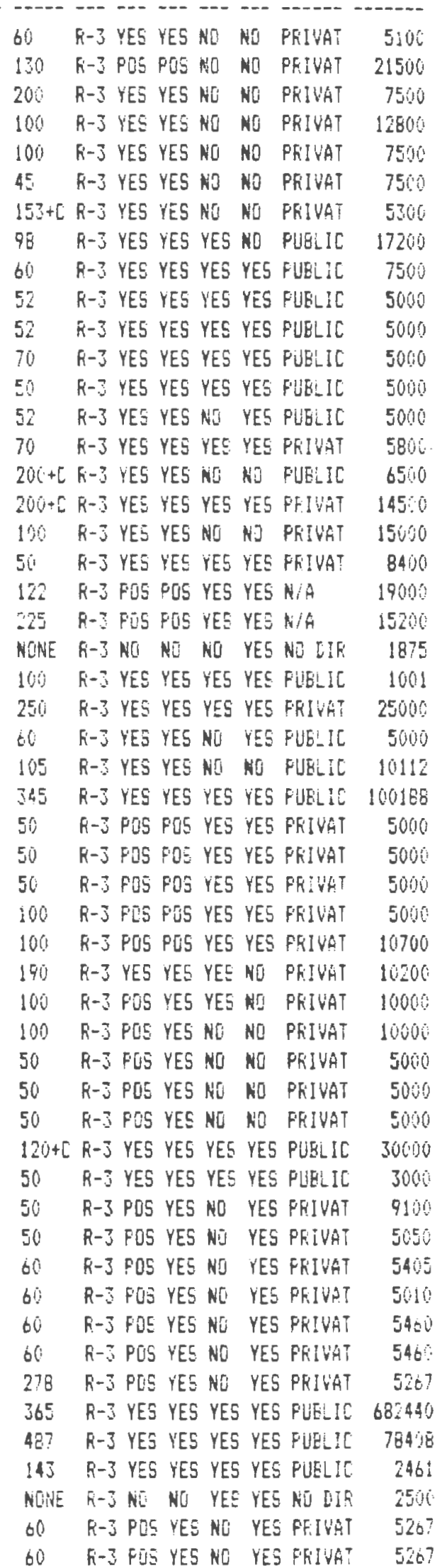




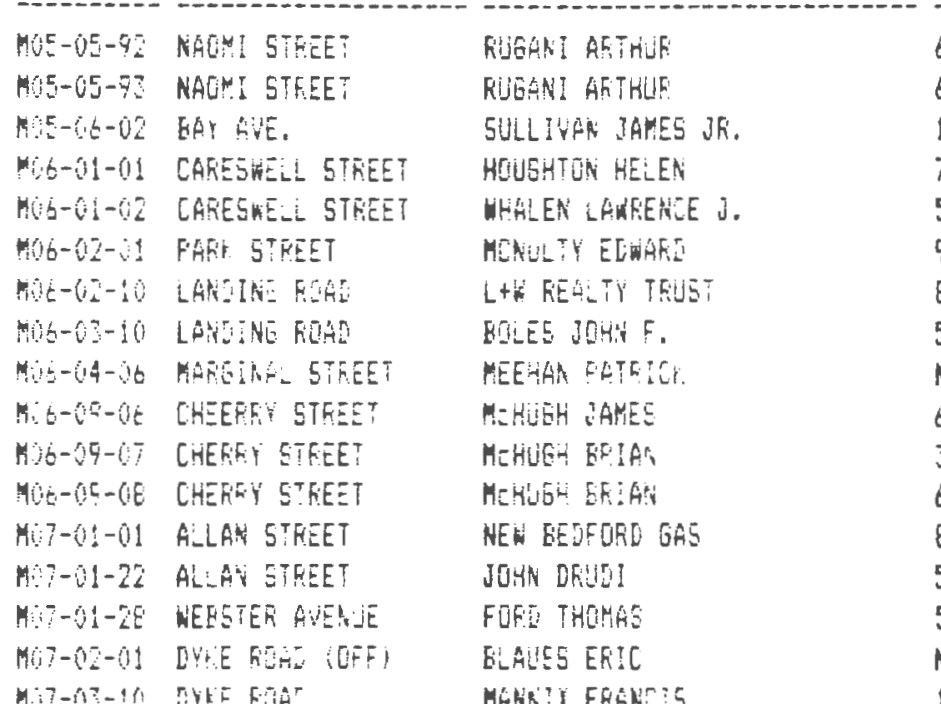

MIT-OA-0: ESHEEV ETAEET

SLLLIVAR JUHK T

MOT-05-0I FLYMUTH GUE.

SULLIVAR IE:HK

KOT-66-01 FLYMEDIH AIE.

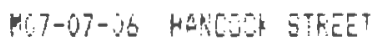

SULCIVHAT JSHW

MO7-07-35 DONG:D ROAL

MUT-67-33 HAFICULE STEET

HEFEST CKTHEFIRE P.

NU:AN DUTIS E

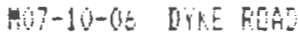

MOT-10-12 DYKE RUAL

HOT-10-24 FEAH IN STEEET

FHELAR GUEEF: L.

HWAEA LARTEREE

ERJULUTJR ARNG T

MOT-1O-2S BEIFA STEEET

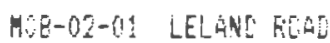

ME-OZ-IE ARRET

MOE-O4-15 LELAME FELI

MUE-05-15 TUEE RUEALE

ME-D-1O TUHER AVENE

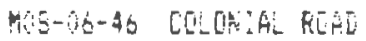

MO3-05-OS SATULKET ANENLE

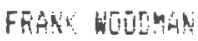

PHELETT FICHAFE

KERE URTIHY LEE

VGRNEAER HEVEN AHOLOT

6O R-3 FOS YES ND YES PEIVAT

60 R-3 PUS YES NO YES PEIVAT

5267

102 R-3 YES YES NU YES FUELIC 6.00:

75 R-3 YES YES NO NO PUELIC 76 SOU

50 F-3 YES YES NO ND PUELIC 15275

90 $5-3$ YES YES NO NO PFI CL 8100

E! R-3 YES VES NO YES PEIVAT 10250

50 F-J YES YES NO YES FRIVAT 3450

NUNE R-3 YES YEE YES YES NI DIR 2850

60 R-J PUS FOS YES YES FFIVAT 12300

30 R-3 POS PES YES YES FFIVAT 7000

60 R-J FUS FLS YES YES FFILATT 14800

$80 \quad k-3 N]$ NE YES YES FJE:IC 333234

$50 \quad k-3$ YES YES YES NO FUE:IC 5000

50 R-J POS YES NO YES FUELIS 5000

NINE FI-J NO HO YES TEE NU DIR 87120

102 5-3 YES YES YES YES FLLEIO 9905

$360+C$ R -3 YES YES N] YES PUBLIC 43560

600 $+C R-3$ YES YES NO YES FLELLIC 20000

$60(j)+[R-3$ YES YES NO YES PLELIC 20000

50 K-3 YES YES NG NO FEIVHT 5000

$73 \quad K-J$ YES YES YES YES FUELIC 7300

50 R-3 YES YES NO NO PRIVAT $\mathbf{4 0 0 0}$

50 R-3 VES YES NO NJ FUE!IC 8157

ME-I!- GE QEAR JTREET

NOCHES IAUES

SULLE FFANY

ThAREAGIIA DUEEFH

SAEICIA FHILIF

POHO ERAE N.

MOE-11-09 SAGIKA: ŔVENIJE

MOE-11-16 CHICIATFHEST AUENIL

MOE-12-09 TECUMEEY AUEHULE

WALEH F'HUL'

SHERLOCI GEFIEIA A.

YUV-14-09 LOHELL RIE.

GIEERTI AMIEU L.

RÁNJÁLL GEGFE \%.

MOE-1E-70 DCEAK STEEET

MOE-19-01 ABHEIRTOA GVENE

MOE-20-12 FLYMULTH AUENGE

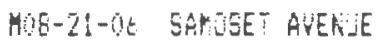

MOE-22-10 DENAED READ

MUE-ZL-Z DOSHE RIAD

MUE-31-OI BRYANT STREET

MUD-45-02 HANOBLK STFEET

POY-OL-C1E ULEAN STFEE

MS-02-19 OCEAT STFEET

MT-GO-13 OCEAS STAEET

MUS-OS-IJS SEHLNAET

OSULEY HENFY E.

A.EXXIS GEOFGE

O DAY HAL

DEFEY FFELEFILK *

HAGEDGRN HOMER I.

MGETIX JESEIE

SALIPAITE ALEXAUTER

DARIELS HUATAIO $F$

O MALLEY MOSEF.

SULLIVPA JOHN T.

MCCOLGAN MACY ETHEL

ERFINGEF JLLIA

HOWAET GHAIE

$150+C R-3$ YES YES NO NŨ FUBLIC $10 E 13$

73 B-j YES YES NJ NO FUELIC 7500

50 R-3 YES YES NO NI FULLIC 5500

IEOHE Ri-J YES YES NJ NE FUDLIE 5000

50 R-J FOS YES NO NO PUBLIL 5000

5. Fi-3 YES YES NII Ni. FUELIC SOUO

50 R-J YES YES NO NE FUELIC 50.0

50 R-3 YES YES NO NE PUBLIC 5000

50 Fi-S YES YES NE NE PUELIC 5000

100 R-J YES YES NÕ NO FUELIC 12196

$160+C$ Fi-3 YES YES NU NO PUBLIC 11400

60 Fi-J YES YES NO NO FUELIC 7200

50 R-J VES YES NG NO FUELIS 6000

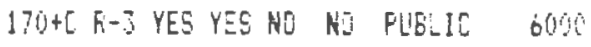

HONE R-3 FUS FUS NO NO NO DIF JE

100 KT-3 YES YES NU NO FLELIC IOAOC

116 RI-3 YES YES YES NE PUELIC 3830

30 FI-J YES YES NO NO FUELIC 3E 75

50 FI-3 YES YES NO NO FUELIC 500

50 Fi-J YES YES NO NL FUELIC FIOI?

211 F-3 YES YES NC NU PiE:IE 1820

50 ET-Z YES YES NO NO FULLIC 5000

59 Fi-3 YES YES NO NO FUBLIC 5900

$200+[$ E -3 YES YES NE NO FUELIC 10000

$300+[R-J$ YES YES NO NO PRIVAT 10000

53 R-J YES YES NE NO FULELIL $430 \mathrm{U}$

52 R-3 YES YES NO WO FUELIC 3958

126 FI-3 YES VES NO NE FUELIC $140 \%$

50 F-3 YES YES NO NG FUELIC 4500 


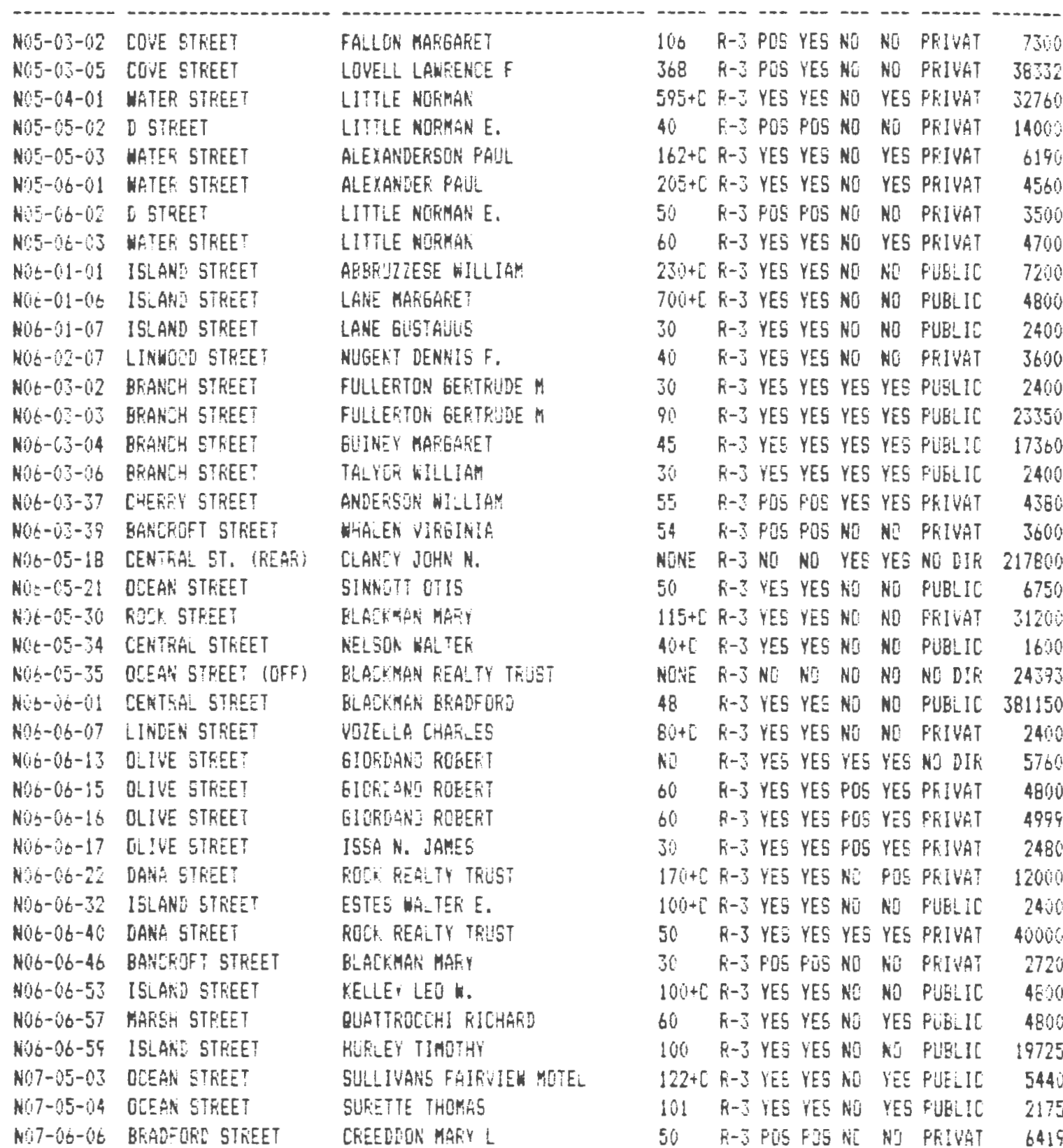

TUTALS:

AEEA SF 29,67E.16\%.00

Frinted 675 of the 1950 recerss. 
APPENDIX D. I

POPULATION 
The Cohort survival method of population projection, seperates population dynamics into three component parts; births. deaths and net migration. cohorts.

The population is separated by sex into five year age

1980 pop, is 1980 population figures obtained from the U.S. Census of Population for 1980 .

1 Yr Sr. is a factor used to determine the number of persons who will survive to the next year.

$10 \mathrm{Yr} \mathrm{Sr}$. is the I Yr Sr raised to the tenth power.

$1990 \mathrm{Sr}$, is the number of people (in a given cohort) expected to survive from 1980 to 1990.

Mig Rate, is a factor which, when multiplied by the 1990 population, will determine the population, taking migration into account. It is determined by estimating the population expected to survive between 1970 and 1980, and comparing that estimate with the actual increase in population that occurred.

The analysis was then repeated in the same fashion to obtain a projection for the year 2000 .

For further explanation of the Cohort Survival Methodology see, Krueckebera. Donald A.. and Silvers, Arthur L.. Urban Planning Analysis: Methods and Models. New York: John Wiley and Sons, 1972, Pp. 274-282 


\section{APPENDIX D. 2}

POPULATION FORECASTS, M.A.P.C. 


\section{MARSHFIELD}

POPULATION

YEAR

POPULATION

1950

3267

1960

6748

1970

15223

1980

20916

1990

2000

23700

24300

SOURCE: Massachuetts Area Planning Commission Population Projection Report. 
APPENDIX E

PUBLIC SERVICES 
The following chart was supplied by Dr. Paul McDonnell. Marshfield's Assistant superintendent of Schools. The top section of the chart projects the number of students expected to be enrolled in the school system, by grade level, starting with the 1985-1986 school year through to the 1994-1995 school year. The projections are based on the number of births which occurred or are expected to occur between 1980 and 1989.

The bottom half of the chart shows available classroom space, by school, from 1985-1986 school year through to the 1995-1996 school year. 


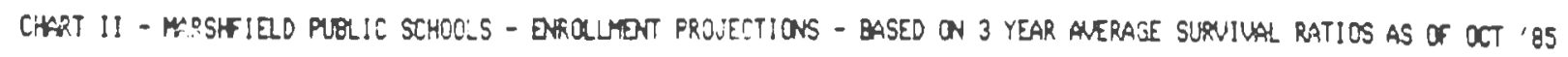
BIRTH YERR BIRTHS SCHL YR KIND GR 1 GR 2 GR 3 GR 4 GR 5 GR 6 GR 7 GR 8 GR 9 GR 10 GR 11 GR 12 TOT

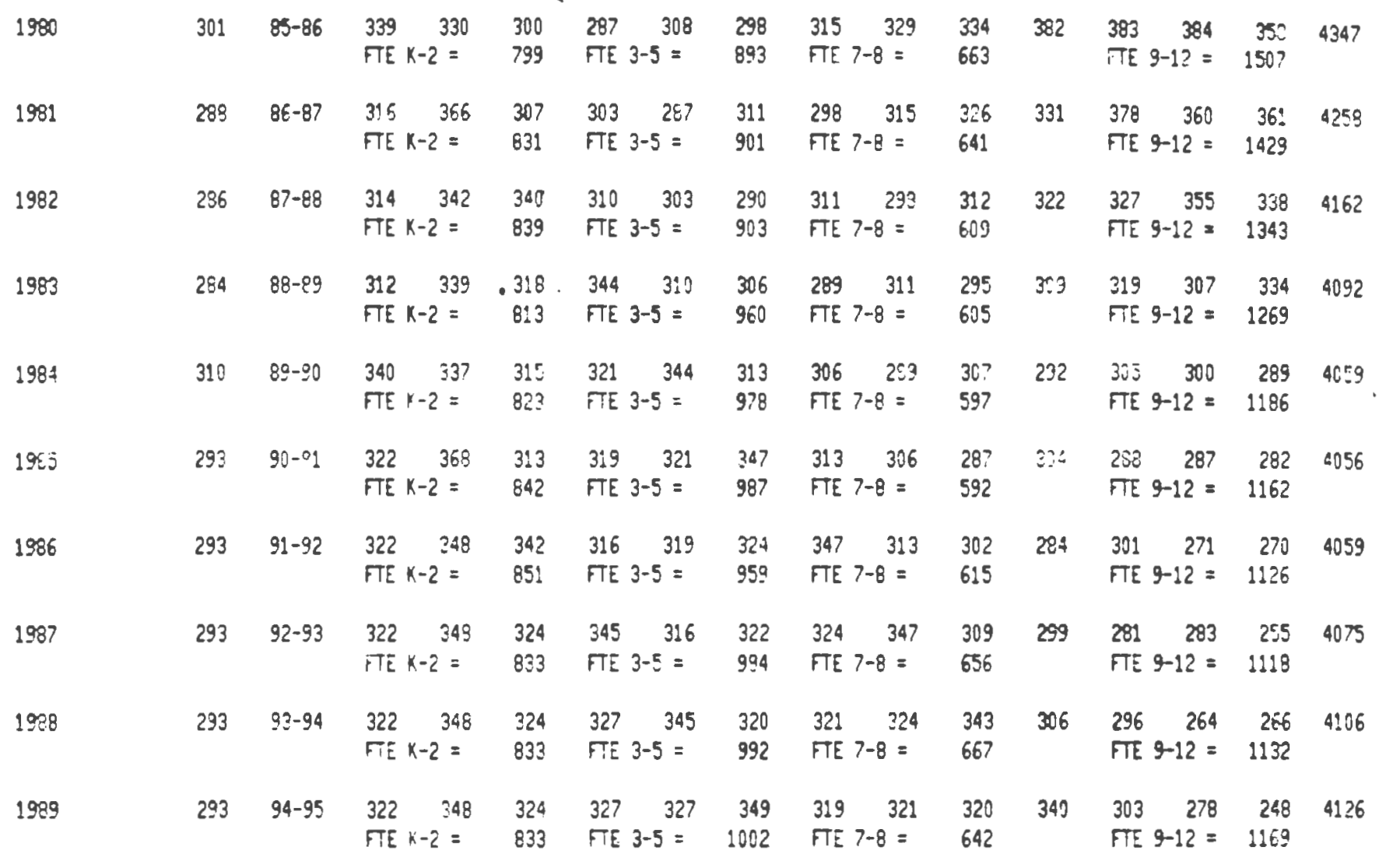

\begin{tabular}{|c|c|c|c|c|c|c|}
\hline$x-5$ RODS & $0 . W$ & E.W & E.N. & S.R. & ALAT? & TUTRL \\
\hline TOTAL & 25 & 16 & 27 & 25 & 8 & 101 \\
\hline LEASED - FY CS & 6 & 0 & 3 & 1 & 8 & 18 \\
\hline NET AMAILABLE & 15 & 16 & 24 & 24 & 0 & 83 \\
\hline
\end{tabular}

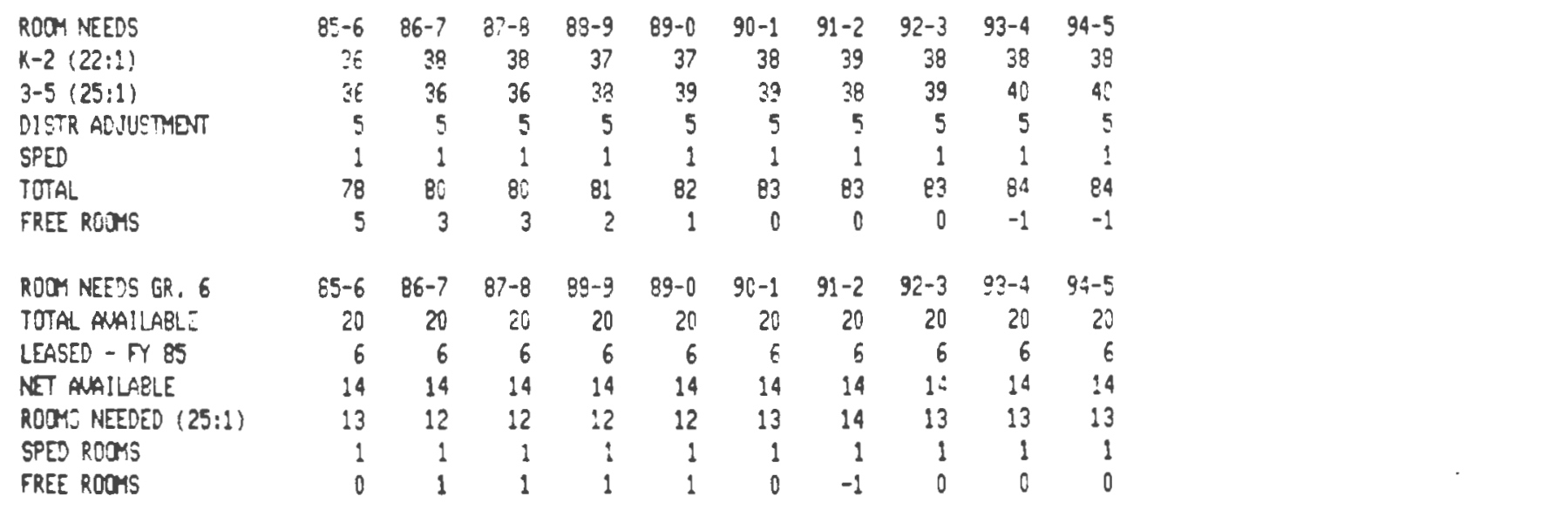

HIGH SCHOCL CAPK::TV IS ESTIMATED AT 1750

JUIOR HIGH CAFACITY IS ESTIMATED AT 800 
APPENDIX F

CONSERVATION/RECREATION 
Marshfield's inventory of land for Open Space and Recreation includes public and private parcels that may be used for a great variety of uses. The inventory lists parcels in the following categories:

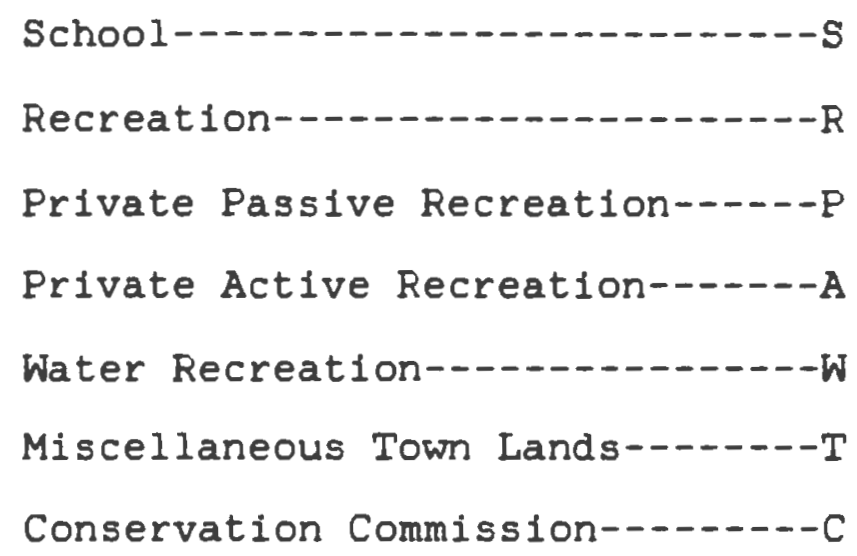

The listing gives ownership using the following symbols:

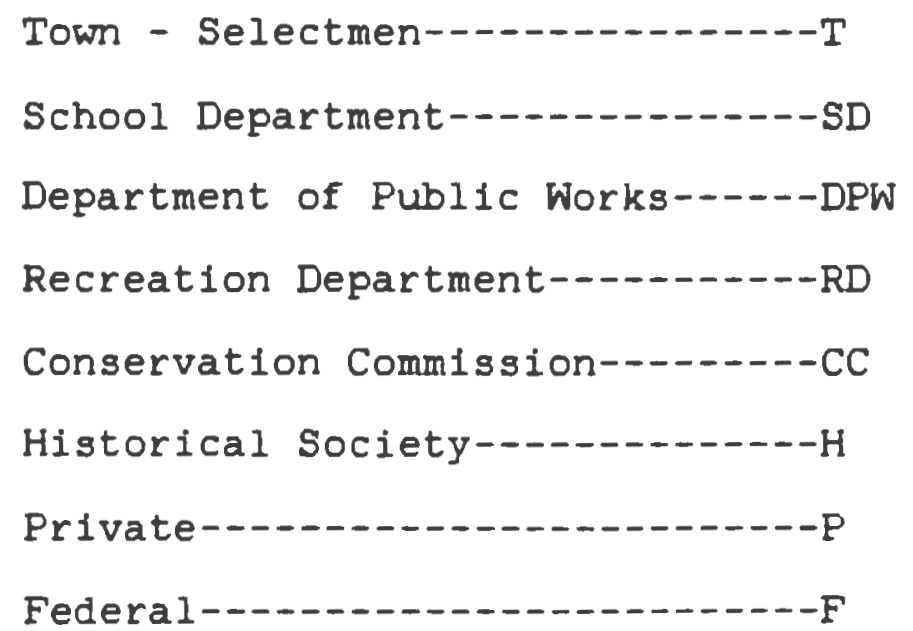




\begin{tabular}{|c|c|c|c|c|c|c|c|c|c|c|c|c|c|c|c|c|c|c|c|c|c|c|c|}
\hline \multirow[b]{4}{*}{$71-$} & \multirow[b]{4}{*}{ NAME } & \multirow{4}{*}{$\begin{array}{l}\frac{\Omega}{I} \\
\Omega \\
\alpha \\
U \\
z \\
3 \\
0\end{array}$} & \multirow[b]{4}{*}{ ACRES } & \multirow[b]{3}{*}{$\begin{array}{l}0 \\
z \\
\bar{\alpha} \\
\alpha \\
\alpha \\
\alpha\end{array}$} & \multirow{3}{*}{ 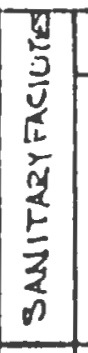 } & \multicolumn{6}{|c|}{$A C T \mid V E$} & \multicolumn{11}{|c|}{ PASSIVE } & \\
\hline & & & & & & \multirow{2}{*}{\begin{tabular}{|l|}
0 \\
$z$ \\
5 \\
9 \\
0 \\
0 \\
7 \\
3 \\
0 \\
\end{tabular}} & \multirow{2}{*}{ 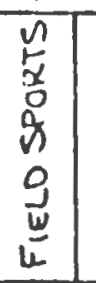 } & \multirow[b]{2}{*}{$\begin{array}{l}n \\
\leftarrow \\
\alpha \\
J \\
0 \\
u\end{array}$} & \multirow[b]{2}{*}{ 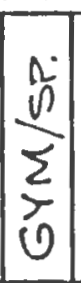 } & \multirow[b]{2}{*}{$\begin{array}{l}\Sigma \\
\Sigma \\
\dot{\Sigma} \\
\frac{5}{\Sigma}\end{array}$} & \multirow[b]{2}{*}{$\begin{array}{l}4 \\
\overrightarrow{0} \\
0 \\
0\end{array}$} & \multicolumn{4}{|c|}{ WATER } & \multicolumn{2}{|c|}{ Winter } & \multirow{2}{*}{\begin{tabular}{|l|}
$\underline{y}$ \\
$\frac{y}{y}$ \\
$\underline{u}$ \\
$\frac{z}{u}$ \\
$\underline{\alpha}$ \\
\end{tabular}} & \multirow{2}{*}{$\frac{-2}{\Delta}$} & \multirow[b]{2}{*}{\begin{tabular}{|l}
0 \\
$z$ \\
$\underline{1}$ \\
$z$ \\
$z$ \\
1 \\
\end{tabular}} & \multirow[b]{2}{*}{\begin{tabular}{|l|} 
\\
0 \\
2 \\
5 \\
$w$ \\
$w$ \\
8 \\
5 \\
$z$ \\
$z$ \\
\end{tabular}} & \multirow[b]{2}{*}{$\begin{array}{l}n \\
0 \\
0\end{array}$} & \\
\hline & & & & & & & & & & & & 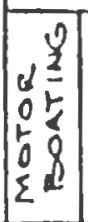 & \begin{tabular}{|l|}
$\frac{2}{2}$ \\
$\frac{g}{z}$ \\
$\frac{3}{3}$
\end{tabular} & $\frac{n}{\sum}$ & $\frac{\mathfrak{D}}{2}$ & $\begin{array}{l}0 \\
z \\
\frac{2}{5} \\
\frac{8}{n}\end{array}$ & \begin{tabular}{|c}
$\frac{0}{z}$ \\
5 \\
$g$ \\
$j$ \\
$j$
\end{tabular} & & & & & & \\
\hline & & & & & & & & & & & & & & & & & & & & & & & \\
\hline & SCHOOL & & & & & & & & & & & & & & & & & & & & & & \\
\hline $5-1$ & High, Martinson \& FB & SD & 80.0 & $x$ & $x$ & & $x$ & $x$ & $x$ & $x$ & & & & & & & & & & & & & \\
\hline $3-2$ & Eames Way & SD & 18.6 & $x$ & $x$ & $x$ & $x$ & $x$ & $x$ & $x$ & & & & & & & & & & & & & \\
\hline$j-3$ & Daniel Wobster & SD & 25.5 & $x$ & $x$ & $x$ & $\times$ & & $x$ & $x$ & & & & & & & & & & & & & \\
\hline $3-1$ & Governor Winslow & SD & 21.1 & $x$ & $x$ & $x$ & $\mathrm{X}$ & & $x$ & $x$ & & & & & & & & & & & & & $\Gamma$ \\
\hline $3-5$ & South River & SD & 13.6 & $x$ & $x$ & $x$ & $x$ & & X & $x$ & & & & & & & & & & & & & $\frac{\Gamma}{n}$ \\
\hline $3-6$ & Grace Ryder & $T$ & 10.0 & $x$ & $x$ & $x$ & x & $x$ & & $x$ & & & & & & & & & & & & & $\stackrel{s}{0}$ \\
\hline $3-7$ & Oak Street & $T$ & 250 & & & & & & & & & & & & & & & & & & & & o \\
\hline & & & & & & & & $\therefore$ & & & & & & & & & & & & & & & $\stackrel{0}{\stackrel{\leftrightarrow}{n}}$ \\
\hline & RECREATION & & & & & & & & & & & & & & & & & & & & & & $\Leftrightarrow$ \\
\hline $2-1$ & Recreation Center & $T$ & 17.0 & $x$ & $\bar{x}$ & $x$ & $x$ & $x$ & $x$ & $x$ & & & & & & & & & & & & $\bar{x}$ & 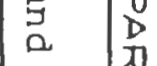 \\
\hline $2-2$ & Peter Igo Park & $R$ & 17.3 & $x$ & $x$ & $x$ & $x$ & $x$ & & & & & $x$ & & $x$ & & & $x$ & & & $x$ & X & $\underset{0}{7}$ \\
\hline $2-3$ & Tower Avenue & $R$ & 1.6 & & & $x$ & $\mathrm{X}$ & $\times$ & & & & & & & & & & $x$ & & & & & $\begin{array}{l}1 \\
0 \\
3 \\
3\end{array}$ \\
\hline $2-4$ & South River Cranberry $B$. & $P$ & 2.0 & $x$ & & & & & & & & & & & & $x$ & & & & & & & $\begin{array}{ll}0 \\
0 \\
0\end{array}$ \\
\hline $3-5$ & GAR Hall & $T$ & 0.2 & $x$ & $x$ & & & & & X & & & & & & & & & & & & & 常. \\
\hline $12-6$ & Veterans Memorial Park & $T$ & 0.8 & & & & & & & & & & & & $x$ & & & $x$ & & & $x$ & & $\begin{array}{l}0 \\
b\end{array}$ \\
\hline$Q-7$ & Everson Memorial Park & $T$ & 0.3 & & & & & & & & & & & & & & & & & & & & $1-1$ \\
\hline $2-\theta$ & Bridle Trall & $T$ & 45.0 & & & & & & & & & & & & & & & & & $x$ & $x$ & $x$ & 3 \\
\hline $2-9$ & Town Green & $T$ & 1,0 & $x$ & $x$ & & & & & & & & & & & & & $x$ & & & & & 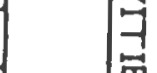 \\
\hline $2-10$ & Library & $T$ & 3.8 & $x$ & X & & & & & $x$ & & & & & & & & & & & & & \\
\hline $2-11$ & Marshfield Hills Park & $T$ & 1.1 & $x$ & $x$ & $x$ & $\times$ & $x$ & & & & & & & & & & $x$ & & & & & \\
\hline & & & & & & & & & & & & & & & & & & & & & & & \\
\hline & & & . & & & & & & & & & & & & & & & & & & & & \\
\hline & & & & & & & & & & & & & & & & & & & & & & & \\
\hline & & & & & & & & & & & & & & & & & & & & & & & \\
\hline
\end{tabular}




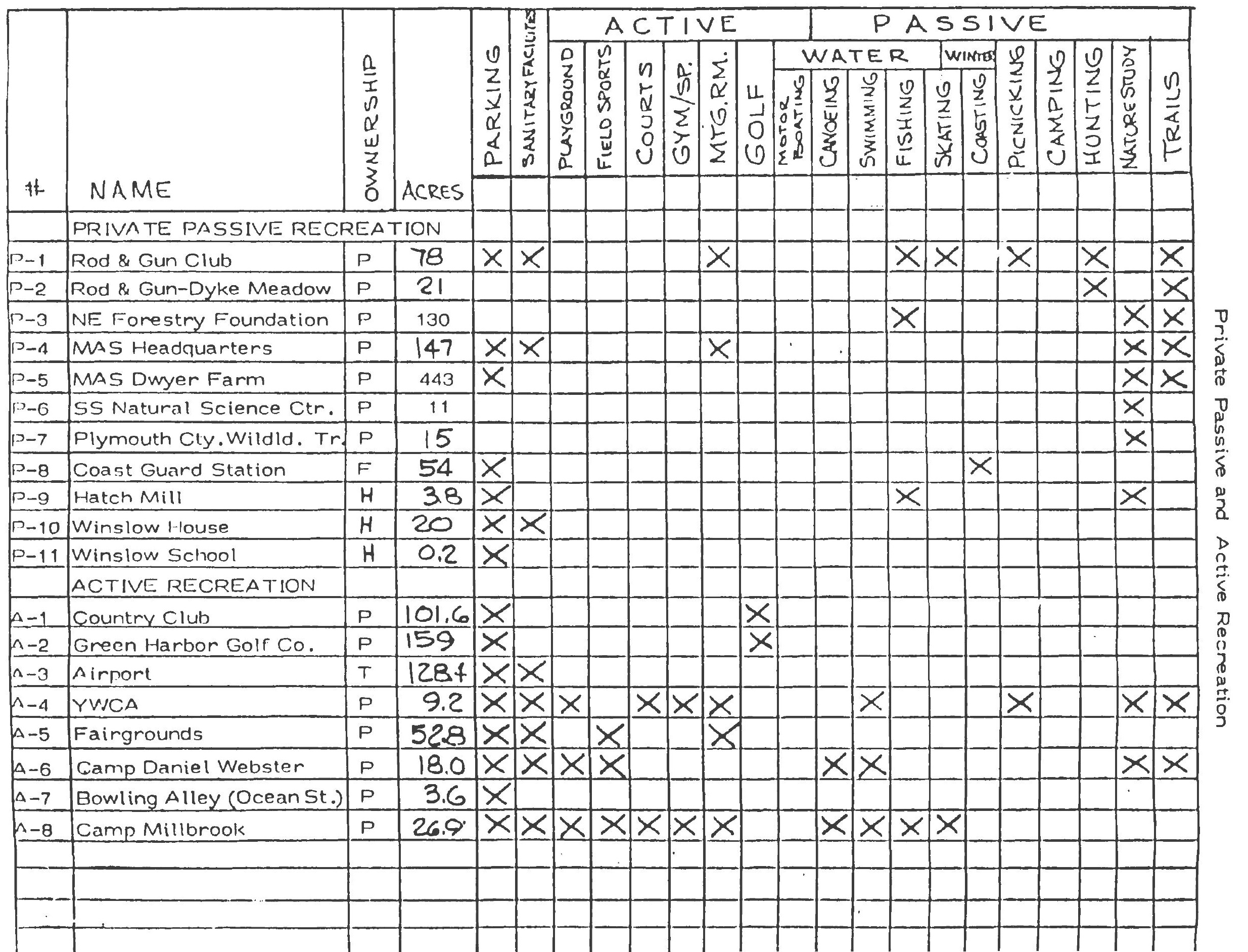




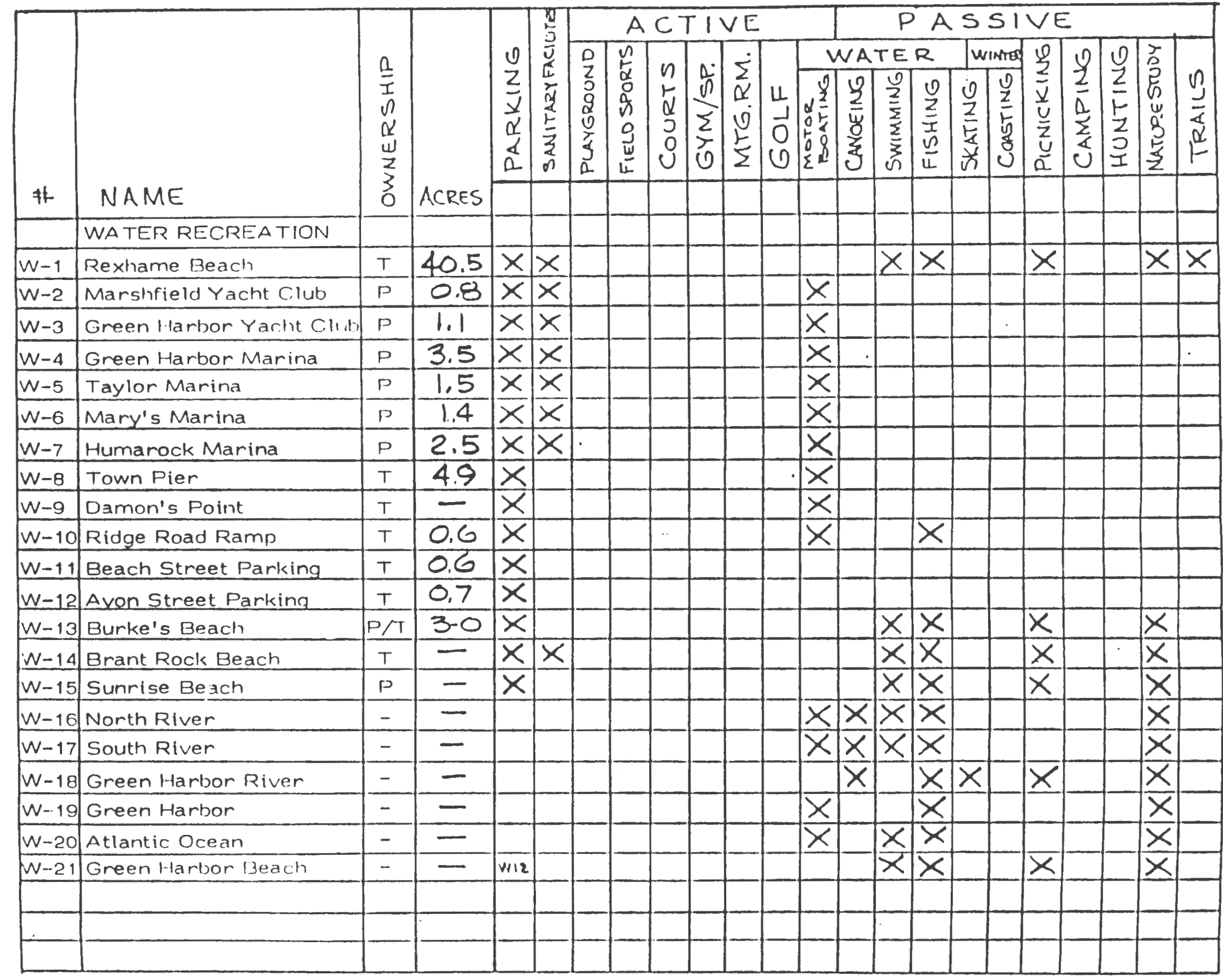




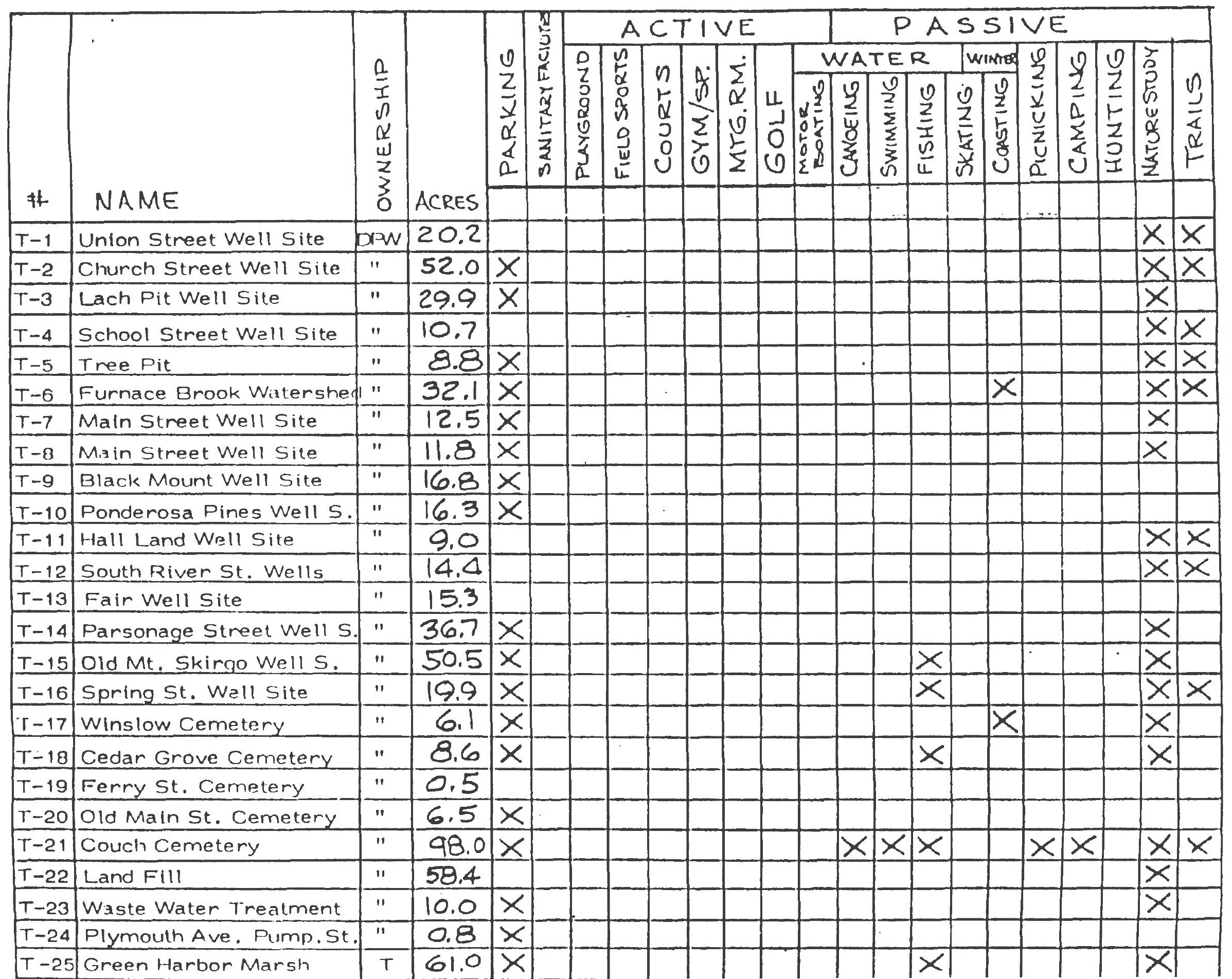




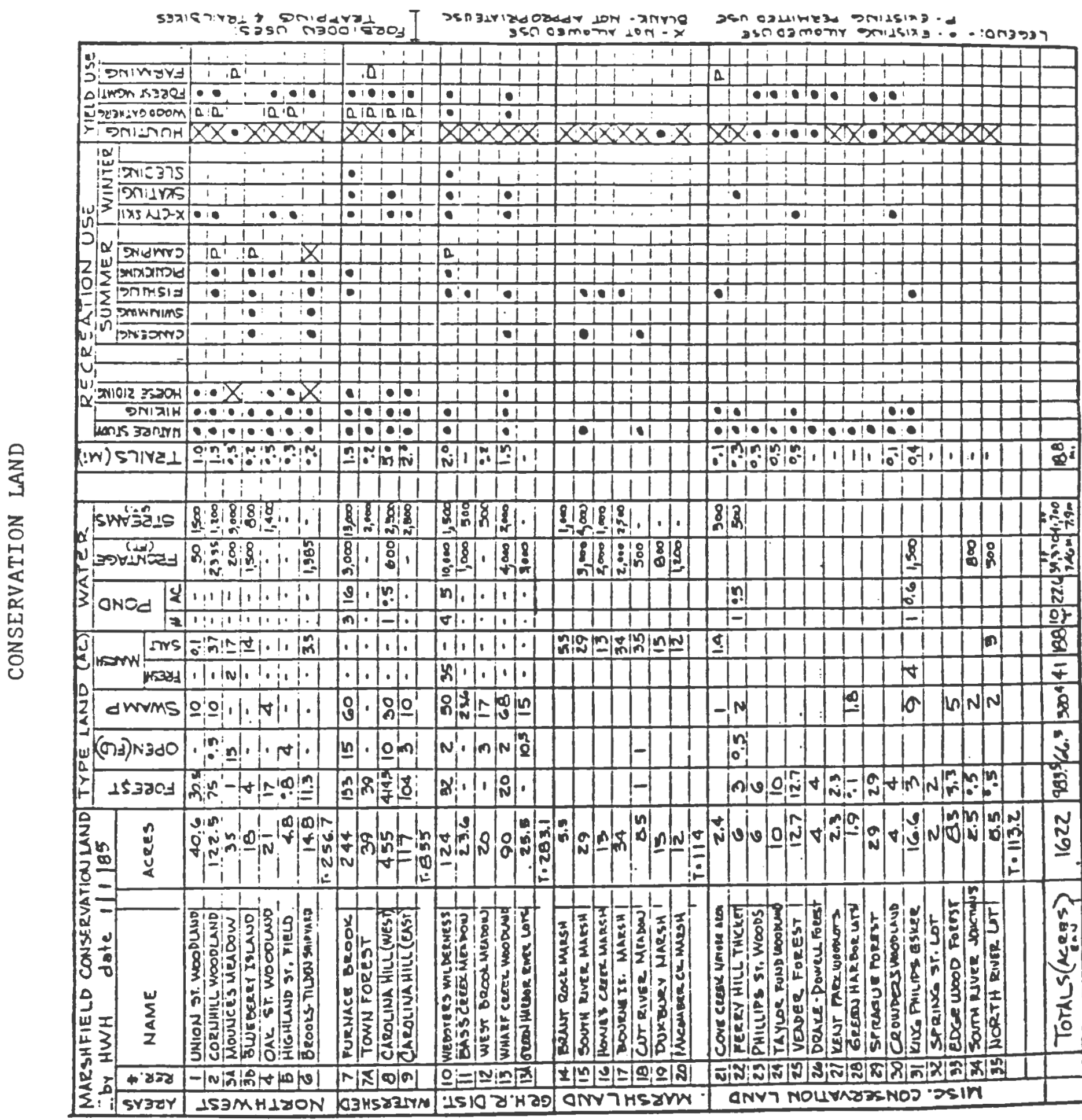




\section{OUDOOR-RECREATIONAL EQUIPMENT INVENTORY}

\begin{tabular}{|c|c|c|c|c|c|c|c|c|c|c|c|c|c|c|c|c|c|c|c|c|}
\hline \multicolumn{13}{|c|}{ PLAY EQUDMENT } & \multicolumn{4}{|c|}{ DLANFIELD } & \multicolumn{2}{|c|}{ covers } & \multirow[b]{2}{*}{$\begin{array}{l}d \\
w \\
d \\
\sum \\
z \\
z\end{array}$} & \multirow[b]{2}{*}{$\begin{array}{l}\text { FACILITY } \\
\text { NAMES }\end{array}$} \\
\hline$\frac{y}{2}$ & 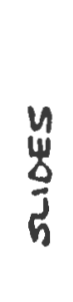 & \begin{tabular}{l}
5 \\
\multirow{3}{3}{} \\
$y$ \\
3 \\
3 \\
5 \\
5
\end{tabular} & $\begin{array}{l}3 \\
3 \\
1 \\
5 \\
5\end{array}$ & 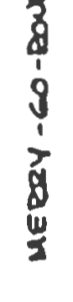 & $\begin{array}{l}y \\
z \\
d \\
\frac{1}{j} \\
z \\
z \\
z\end{array}$ & 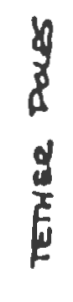 & $\begin{array}{l}0 \\
0 \\
0 \\
\frac{y}{0} \\
0\end{array}$ & 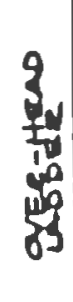 & 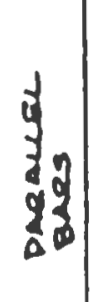 & $\begin{array}{l}6 \\
1 \\
1 \\
\vdots \\
1\end{array}$ & 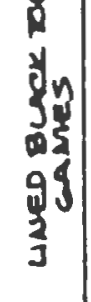 & 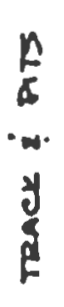 & 8 & $\frac{\$}{\$} \frac{1}{8}$ & 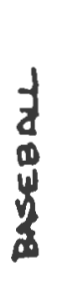 & $\begin{array}{l}1 \\
\frac{1}{2} \\
0 \\
5 \\
8 \\
0\end{array}$ & $\begin{array}{l}7 \\
3 \\
3 \\
3 \\
3\end{array}$ & \begin{tabular}{l}
$\frac{n}{2}$ \\
2 \\
\multirow{2}{*}{}
\end{tabular} & & \\
\hline & & & & & - & & & & & & & & - & - & - & $\bullet$ & & - & s-1 & MARSHFIELO HIGH SCHOOL \\
\hline & & & & & & & & & & & & - & & & & & & & s-1 & MARTINSON SCHOOL \\
\hline & & & & & & & & & & & & & & - & & & & - & s.1 & FURNACE BROOK SCHOOL \\
\hline - & - & - & - & - & & - & & & & & & & & - & & & - & & S-2 & EAMES WAY SCHOOL \\
\hline - & - & - & & - & - & - & - & - & & & - & & - & - & & & - & & s.3 & DANIEL WEBSTER SCHOOL \\
\hline - & - & - & & - & & - & & - & & & - & & - & - & - & & - & & $5 \cdot 4$ & GOV.WINSLOW SCHOOL \\
\hline - & - & - & & - & - & & - & - & & - & - & & - & - & & & - & & $5 \cdot 5$ & SOUTH RIVER SCHOOL \\
\hline - & & & - & & & & & & & & - & & - & - & - & & - & & $5-6$ & GRACE RYDER SCHOOL \\
\hline & & & & & & & & & & & & & & & & & & & & \\
\hline & & & & & & & & & & & & & & & & & & & & \\
\hline - & - & - & & & & - & & & & & & & & & - & & - & & R.1 & HARUBIN RECREATION CTR. \\
\hline & & & & & & & & & & & & & & & & & - & - & $R-2$ & PETER IGO PARK \\
\hline - & & - & & - & & - & & & & - & & & & - & & & - & & $R \cdot 3$ & Tower Ave. PARK \\
\hline - & & - & & & & - & - & & & - & & & - & - & & - & - & & $R \cdot 11$ & MARS HFIELD HIUS PARK \\
\hline & & & & & & & & & & & & & & & & & & & & \\
\hline
\end{tabular}




\section{INVENTORY OF OTHER PUBLIC AND PRIATE FACILITIES}

\begin{tabular}{|c|c|c|c|c|}
\hline No. & Facility and Name & Classification & Acres & Features \\
\hline$P-1$ & $\begin{array}{l}\text { Marshfield Rod and } \\
\text { Gun Club }\end{array}$ & Gun Club & 78 & $\begin{array}{l}\text { Clubhouse, indoor } \\
\text { range, toilet } \\
\text { facility, outdoor } \\
\text { range }\end{array}$ \\
\hline$A-1$ & Marshfield Country Club & Golf Course & 100 & $\begin{array}{l}\text { Privately owned } \\
\text { by corporation } \\
\text { and members - } \\
18 \text { hole course }\end{array}$ \\
\hline$A-2$ & Green Harbor Golf Course & Golf Course & 157 & $\begin{array}{l}\text { Privately owned } \\
\text { open to public } \\
18 \text { hole course }\end{array}$ \\
\hline$w-2$ & Marshfield Yacht Club & Yacht Club & 1 & $\begin{array}{l}\text { Available to } \\
\text { members - sailing } \\
\text { instruction }\end{array}$ \\
\hline$w-3$ & Green Harbor Yacht Club & Yacht Club & 1 & $\begin{array}{l}\text { Available to } \\
\text { members - } \\
\text { sailing instruction }\end{array}$ \\
\hline$A-4$ & Y.W.C.A. & Camp & 6 & $\begin{array}{l}\text { Day camping } \\
\text { facilities } \\
\text { privately oumed }\end{array}$ \\
\hline$W-4$ & Green Harbor Marina & Marina & 6.5 & $\begin{array}{l}\text { Showroom, Dock } \\
\text { Moorings, Slips } \\
\text { Repair facilities }\end{array}$ \\
\hline$w-5$ & Taylor Marina & Marina & 4.5 & Slips, storage \\
\hline$W-\varepsilon$ & Miary's Marina & Marina & 3 & $\begin{array}{l}\text { Boat rental, } \\
\text { boat ramp, slips, } \\
\text { mooring }\end{array}$ \\
\hline$W-7$ & Humarock Marina & Marina & 5 & $\begin{array}{l}\text { Storage capacity, } \\
\text { moorings, repair } \\
\text { facilities }\end{array}$ \\
\hline$A-5$ & Marshfield Fair Grounds & Country Fair & 50 & $\begin{array}{l}\text { Stables, track, } \\
\text { grandstand, } \\
\text { storage }\end{array}$ \\
\hline$w-8$ & Town Pier & Pier & 3 & $\begin{array}{l}\text { Parking, boat } \\
\text { launching ramp, } \\
\text { dock }\end{array}$ \\
\hline
\end{tabular}




\section{TYPES OF RECREATIONAL FACILITIES}

The following are definitions of recreational facilities, many of which can found in Marshfield.

\section{Outdoor Facilities}

Playlot - An active nelghborhood play area intended for children of pre-school age. They are essentially a substitute for home yard areas and are normally provided in high population density areas. In rural areas, it may be desirable to include the playlot function within a recreational facility such as a neighborhood playground.

Playground - An active nelghborhood play area for recreation needs of the 5 to 12 year age group. It serves as a major center of outdoor play for children, and is often developed in conjunction with nelghborhood schools. Features include: apparatus areas; field area for games and informal play; passive areas; and areas for court games.

Playfield - An active recreation area which usually serves more than one neighborhood and provides for varied forms of activities for people of all ages. A portion of the playfield is usually developed as an athletic field for highly organized team sports. Features of the playfield include: area for court games such as tennis, volleyball, and basketball; sports fields for games such as softball, baseball. soccer and football; and areas including picnic sites. Playfields may also include a field-house and running track.

Minor Park - A neighborhood park which is primarily an area for sitting and quiet relaxation. When practical, it should be in confunction with a playground or playfield.

Major Park for Recreation - Major recreational parks are generally considered to be large city parks which are recreational complexes combining all types of recreational facilities.

Conservation Area - The unique natural resources which a community possesses. There is no quantitative measure which can be used as a guide.

Speclal Areas - Areas developed for a special use such as a municipal beach, golf course, etc.

Greenbelts - Iinear parks emphasizing movement, including such facilities as pedestrian paths, bridle trails and bicycle paths. Greenbelts may follow natural features such as a stream. 
Open Space - Conservation, and natural areas whose primary purpose is the protection of flora and fauna, water management, flood protection and the preservation of the landscape.

\section{Indoor Facilities}

Gymnasium - Usually found in a public school. Can be used outside school hours.

Recreation Center - For family groups and individuals of all ages. Can include such facilities as gymnasium, auditorium and specialized library. Provision can be made for participation in arts and crafts, indoor games, movies, etc.

Swimming Pool - For family groups and individuals of all ages, including such facilities as a bath house, or locker rooms. $A$ pool suitable for competition swimming and diving is desirable. because it would then fit into the high school physical education program, and make swimming events and exhibitions possible yearround, as well as being used for recreational swimming. 
A land trust can be an effective tool to help manage and guide growth as well as retain open space and preserve agricultural lands. A Community Land Trust (CLT) is an organization created to hold land for the benefit of a community and of individuals within the community. The Trust is a democratically structured, non-profit corporation with an open membership and a board of trustees elected by the members.

A CLT acquires land through purchase or donation with the intention to retain the title in perpetuity - removing property from the speculative market. Appropriate uses are determined by members, then the land is leased for public purposes. The leaseholder must use the land in an environmentally and socially responsible manner. Leaseholders pay a lease-based use value price and not full market value, making this an attractive alternative to ownership. 
BIBLIOGRAPHY 
Bibliograchy

All About Marshfield: Green Harbor League of Women Voters of Marshfield; First Edition, 1976

Appeals Board Reviews Cluster Development Plans, Marshifield Mariner, 31 July 1985, page 23

Arnold, David S. ed.; Practices In Local Government Planning; Intemational City Management Association; Washington, D.C.; 1979

The Balanced Growth Planning Manual; M.A.P.C.; Septenber 1980

Barrier Beaches, Salt Marshes and Tidal Flats An Inventory Of The Coastal Resources Of The Commonwealth Of Massachusetts; Lloyd Center Of Environmental Studies - Massachusetts Coastal Zone Management Program; The U.S. Dept. of the Interior, Fish and Wildlife Service Region 5; January 1985

Blizzard Of 1978, Coastal Storm Damage Study: New England Division Army Corps Of Engineers; Waltham, Massachusetts; February 1979

Bluefish Cove Eliminated From Green Harbor Plan, Marshfield Mariner, 4 September 1985, page 14 Changing Tide and Times Of Brant Rock, The, Marshfield Mariner, 17 Aprll 1985, page 32

Clean Water Our Cormon Concern; M.A.C.P.; September 1976

Coastal Barrier Resources System; Draft Report To Congress; U.S. Dept. of the Interior; April 1985

Collier; Building Construction On Shoreline Property; Sponsored by the Florida Dept. of Natural Resources; Bureau of Beaches and Shores; 1978

Commonweal th Of Massachusetts, 301 Code Of Massachusetts Regulations 50-19; Fair Housing Quidelines; July 1, 1979 
Commercial Area Revitalization District (CARD) Plan; Town of Marshifield Planning Board:

September 1981

Delaney and Maevsky; Distribution Of Aauifers, Liquid-Waste Imorovements And Municipal Water

Sudoly Sources: U.S. Geological Survey; Boston, Massachusetts; 1980

Duxbury Massachusetts Comprehensive Plan 1969; The Planning Services Group, Inc,; Cambridge. Massachusetts; July 1969

Economic Feasibility Of Floodprooting Analysis Of Small Commarcial Buildings: The Federal Emergency Mariagemerit Agericy Federal Insurance And Hazard Mitigation; 1977

Erosion \& Sedimerit Control In Site Develooment Massachusetts Conservation Guide Volume II; U.S. Dept. of Agrioulture; Antierst, Massactiusetts

Fay, Spofford and Throndike, Inc.: Report Or Proposed Develooment Of Green Harbor River Basin; May 1982

Federal Emergency Managemerit Agency National Flood Insurance Program; 1982

Federal Insurance Administration National Fload Inisurance Programi Guide For Ordinarice Development Commurity Development Service; No. 1; U.S. Dept. of H.U.D; 1978

Final Environment Statement Undevelooed Coastal Barriers; U.S. Dept. of the Interior; May 1983

Flood Insurance Study - Town of Marshfield, Plymouth County Massachusetts; U.S. Dent. of H.U.D. Federal Insisance Administration; October 1977

Floodway: A Guide For Community Permit Officials. The; No. 4; Federal Emergency Manazement Agency Federal Insurance Administration; 1977

Gilney, Fred; Marshfield Monograph; Massachusetts Department of Commerce; Bostor. Massachusetts; October 1984

Goldberg, Zoino, Duncliffe and Assuciates. Iric.; Marshfield Groundwater Resources Inventory; Marshfield, Massathusetts; January 1978 
All About Marshfield: Green Harbor League of Women Voters of Marshfield; First Edition, 1976

Appeals Board Reviews Cluster Development Plans, Marshtield Mariner, 31 July 1985, page 23

Arnold, David S. ed.; Practices In Local Government Planning; International City Management Association; Wastington, D.C.; 1979

The Balanced Growth Planning Manual; M.A.P.C.; September 1980

Barrier Beaches, Salt Marshes and Tidal Flats An Inventory Of The Coastal Resources Of The Commonmealth Of Massachusetts; Lloyd Center of Environmental Studies - Massachusetts Coastal Zone Management Program; The U.S. Dept. of the Interior, Fish and Wildlife Service Region 5; January 1985

Blizzard Of 1978, Coastal Storm Damage Study: New England Division Army Corps Of Engineers; Waltham, Massachusetts; February 1979

Bluefish Cove El iminated From Green Hartor Plan, Marshfield Mariner, 4 September 1985, page 14 Changing Tide and Times Of Brant Rock, The, Marshfield Mariner, 17 April 1985, page 32

Clean Water ar Common Concern; M.A.C.P.; September 1976

Coastal Barrier Resources System; Draft Report To Congress; U.S. Dept. of the Interior; April 1985

Collier; Bullding Construction On Shoreline Property; Sponsored by the Florida Dept. of Natural Resources; Bureau of Beaches and Shores; 1978

Commonwealth Of Massachusetts, 301 Code Of Massachusetts Regulations 50-19; Fair Housing Gidel ines; July 1, 1979 
Commercial Area Revitalization District (CARD) Plan; Town of Marshfield Planning Board;

September 1981

Delaney and Maevsky; Distribution Of Aquifers, Liquid-Waste Improvements And Municipal Water Supply Sources; U.S. Geological Survey; Boston, Massachusetts; 1980

Duxbury Massachusetts Comprehensive Plan 1969; The Planning Services Group, Inc, Cambridge, Massachusetts; July 1969

Economic Feasibility Of Floodprooting Analysis Of Small Commercial Buildings; The Federal Emergency Management Agency Federal Insurance And Hazard Mitigation; 1977

Erosion \& Sediment Control In Site Development Massachusetts Conservation Guide Volume II; U.S. Dept. of Agrioulture; Anherst, Massachusetts

Fay, Spotford and Throndike, Inc.; Report On Proposed Development Of Green Harbor River Basin; May 1982

Federal Emergency Management Agency National Flood Insurance Program; 1982

Federal Insurance Adninistration National Flood Insurance Program Guide For Ordinance Development Community Development Service; No. 1; U.S. Dept. of H.U.D; 1978

Final Environment Statement Undeveloped Coastal Barriers; U.S. Dept. of the Interior; May 1983

Flood Insurance Study - Town of Marshfield, Plymouth County Massachusetts; U.S. Dept. of H.U.D. Federal Insurance Administration; October 1977

Floodway: A Guide For Community Permit Officials, The; No. 4; Federal Emergency Management Agency Federal Insurance Administration; 1977

Gilney, Fred; Marshfield Monograph; Massachusetts Department of Commerce; Boston, Massachusetts; October 1984

Golcberg, Zoino, Duncliffe and Associates, Inc.; Marshilield Groundwater Resources Inventory; Marshifield, Massachusetts; January 1978 
Harrington and Reynolds; Town of Marshfield Massachusetts Conservation/Recreation - Open Space Plan - 1985; Conservation Commission, Recreation Commission; 1985

Harrington, H.W.; Polder Flooding Report In Marshfield, Massachusetts; Marshfield Conservation Comission; February 1982

Home Prices Increase Dramatically, Marshfield Mariner, 26 June 1985, pages 1,5

Housing In Marshfield: Affordability Study And Development Control Ootions; Abt Associates Inc.; Boston, Massachusetts; September 1985

How To Judge ENIRONMENTAL PLANING for SLBOIVISIONS A Citizens Guide; Inform, Inc.; New York, N.Y.; 1981

Huse, Kramer and Kalauskas; Route 139 Corridor Planning Study Final Report; Massachusetts Department Of Public Works - U.S. Deptartment Of Transportation Federal Highway Administration - Massachusetts Transportation Administration; July 1981

Impact 2 1/2 Case Study Marshfield: Impacts On Individual Budgets; M.I.T., Dept. of Urban Studies and Planning; Cambridge, Massachusetts; June 1981

Interim.Population Forecast 1980-2010 Data Analysis Program Technical Report 2; M.A.P.C.; Boston, Massachusetts; July 1981

Krusell, Cynthia; Of Tea And Tories; Presented By The Marshfield Bicentennial Committee; 1976

Landtill Site Has 25 Truck Limit, Marshtield Mariner, 31 July 1985, page 26

Low Cost Shore Protection; U.S. Army Corps of Engineers; Washington, D.C.

Machmier, Roger; On Site Sewage Disposal In Flood Plain Areas; A Report Prepared For The Dept. Of Natural Resources, State Of Minnesota; 1974

Marshall, John E.; School Building Needs Marshfield Massachusetts; Belmont, Massachusetts; 1980 
Marshilield Master Plan; Metcalf and Eddy Inc.; Boston, Massachusetts; Novenber 1973

Marshtield's Changing Tides A History Of Marshfield By The U.S. History/Bicentennial Class; June 1976

Marshtield's Building Boom Continues, Marshfleld Mariner, 26 June 1985, page 26

Marshfield The Autobiography Of A Pilgrim Toun; Marshfield Tercentenary Comittee;

Marshifield, Massachusetts; 1940

Master Plan For Marstifield, Massachusetts; Technical Planning Associates, Inc.;

New Haven, Connecticut; September 1950

Me Keever; UI Tectnical Bulletin 65 Dusiness Parks, Office Parks, Plazas And Centers: A Case Study of Development Practices And Producers; 1970

Metcalf and Eddy, Inc.; Report To The Board Of Water Commissioners Marshfield, Massachusetts on Additions And Improvements To The Water System; April 1971

Meshenberg, Michael J.; The Language Of Zoning A Glossary Of Words And Phrases; Planning Advisory Service Report No. 322; November 1976

Metropolitan Area Planning Council Final Draft: Open Space And Recreation Plan And Program For Metro - Boston; Volume 1, M.A.P.C.; September 1975

New England River Basins Commission; December 1975

North And South Rivers Basin Plymouth County Massachusetts Massachusetts River Basin Planning Program; U.S. Dept. Of Agriculture Soll Conservation Service, Economic Research Service, Forest Service; Massachusetts Water Resources Commission 1982

North And South River Basin Report Action Handoook; M.A.P.C.; May 1977

North River Management Plan; Massachusetts Department Of Environmental Management Scenic Rivers Program; March 1978 
North Fiver Follution Study Gats More Complicated, Marghfield Mariner, 31 July 1995, page 23

Open Space Plan For Marshfield, Massachusetts; Revised By Marshfield Conservation Comission; April 1977

Penbroke Plans More Development On Route 139, Marshtield Mariner, 4 September 1985, pages 1,2

Philips Trustees Are Receptive To Spending Money For Recreation Center, Marshfield Mariner, January 29, 1986; page 1,2

PLANIING STUDIES, 1983; Neecham Planning Board; April 6, 1983

Plate 2 Southeastern Massachusetts Development Capabilities Map; New England River

Basins Commission; January 1975

Pilot Plan; Technical Planning Associates, Inc.; New Haven, Connectiaut; November 1959

PROTECTIVE BY-LAW TOWN OF DUXBURY, MASSACHUSETTS; March 1982

Regional Open Space Plan, The Open Space And Recreation Program For Metro - Boston, The 1976;

M.A.P.C. ; 1976

Regulation Of Assessory Apartments In The Metropolitan Boston Region; M.A.P.C.; July 1978

Report Of Qurrent Practices: Develoment Of Design And Construction Standards For Residential Building In Coastal High Hazard Area; Washington, D.C.; February 1979

Report Of The Southeastern New England Study Area A Strategy For Balanced Development And Protection Of Water And Related Land Resources In Eastern Massachusetts and Rhode Island;

Regional Report, 1975

Report to Marshfield Planning Board Second Phase Of Planning Program; Technical Planning Associates, Inc.; New Haven, Connecticut; September 1960 
Report To The Marshfield Planning Board On Coastal Zone Management Feasibility Studies Related

To Channel Shoaling Town Pier Facilities And Town Pier Access; Massachusetts Coastal Zone Management Agency; Boston, Massachusetts; 1980

Report To The Marshtield Planning Board Upon The Green Harbor Basin Master Plan; Metcalf and Eddy, Inc.; Boston, Massachusetts; March 29, 1976

Residents Oppose Rezoning Of Some Streets, Marshfield Mariner, 3 July 1985, page 12

Route 139 Corridor Planning Study; S.S.C. Draft Report; January 1981

Route 3A Corridor. Traffic Safety Analysis; Central Transportation Planning Staft;

September 1979

RULS AND REGULATIONS OF THE PLANING BOARD OF THE TOWN OF MARSFFIELD, MASSACHUSETTS UNDER THE SUBOIVISION CONTRQ LAW; October 4, 1977

School Enrollment Continues Decline, Marshtield Mariner, 17 April 1985, page 1

Small Water Systems Alternative Systems for Small Communitles and Rural Areas;

United States Environmental Proctective Agency, Office of Water Program Dperations;

Wastington D.C.; January 1980

Soil Survey: Plymouth County Massachusetts; U.S. Dept. Of Agrioulture Soil Conservation Service Massachusetts Agriculture Experiment Station; July 1976

Solls And Their Interpretation For Varlous Land Uses, Toun of Marshifield; U.S. Dept. of Agrialture Soll Conservation; July 1969

South Shore Planning Area Report; 1975

Stotts Associates; GENRAL PLAN FOR THE TOWN OF PEMROKE AND DEPARTMENT OF COMERCE; 1959

Tedeschi Realty Corp. Warehouse Request Underscores Marshtield - Pentorcke Clash, Marshtield Mariner, 4 September 1985, page 2 
Thomas, Marcia A.; Memorials of Marshfield And Quide Book To Its Localities At Green Harbor;

Dutton and Wentworth; Boston 1854

Three Major Building Projects Win Approval, Marshtield Mariner, 26 June 1985, pages 1,6

Town Of Marshfield Street Listing; 1955, 1959, 1965, 1969, 1975, 1979

TOWN OF MARSHFIELD ZONING BY-LAWS; AORIl 30, 1984

Town Meeting Debuts Monday, Marstifield Mariner, 17 Apr $¥ 1$ 1985, page 1

TRANSPORTATION FACTS For The Metropolitan Boston Region; Central Transportation Planning Staft; 1983

TRANSPORTATION IMPROVENENT PROGRAM 1980-1984 BOSTON REGION; October 1979

VEGETATIVE PRACTICES In Site Development, Massachusetts Conservation Gide Volume II; U.S. Dept.

Of Agriculture; Amherst, Massachusetts

Wrenn, Douglas M. with Casazza, J.A. and Smart, J.E.; Urban Waterfront Development; Urtan Land Institute; Washington, D.C.; 1983

Whitman and Howard; Report Relative To Water Systems Study, Marshfield, Massachusetts; June 1978

Williams, Willey and Tasker; Massachusetts Hydrol ic Data Report No. 16 Hydrolic Data

Of The Coastal Drainage Basins Of Southeastem Massachusetts; Commonweal th of Massachusetts Water Resources Cormission; 1975

ZONING BYLLAWS of the TOUN OF PEMBROKE, MASSACHSETTS; 1985 